UNIVERSIDADE DE SÃO PAULO

INSTITUTO DE GEOCIÊNCIAS

\title{
O Leucogranito Inhandjara: um exemplo de diferenciação magmato-hidrotermal na província granítica Itu, SP (Brasil)
}

\section{FERNANDO PRADO ARAUJO}

Orientadora: Profa. Dra. Lucelene Martins

Dissertação de Mestrado

No 801

COMISSÃO JULGADORA

Dra. Lucelene Martins

Dra. Lena Virginia Soares Monteiro

Dr. Washington Barbosa Leite Junior

SÃO PAULO

2018 
Autorizo a reprodução e divulgação total ou parcial deste trabalho, por qualquer meio convencional ou eletrônico, para fins de estudo e pesquisa, desde que citada a fonte.

Serviço de Biblioteca e Documentaçäo do IGc/USP

Ficha catalográfica gerada automaticamente com dados fornecidos pelo(a) autor(a) via programa desenvolvido pela Seçäo Técnica de Informática do ICMC/USP

Bibliotecários responsáveis pela estrutura de catalogação da publicação: Sonia Regina Yole Guerra - CRB-8/4208 | Anderson de Santana - CRB-8/6858

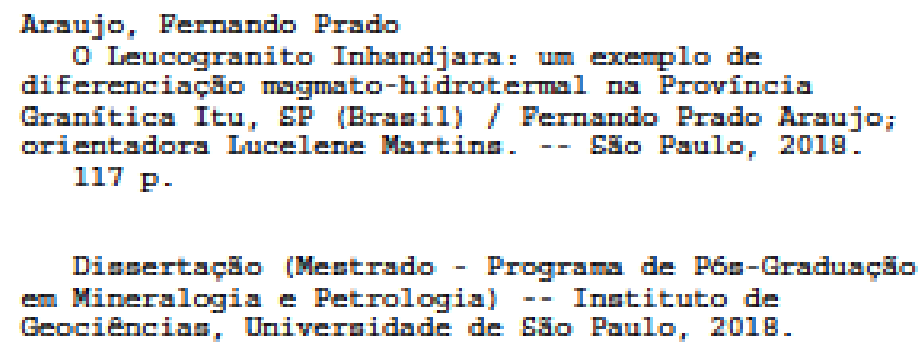

1. Provincia Granitica Itu. 2. Diferenciação Magmbtica. 3. Leucogranito com topbzio. 4. Aiteraçäo Greiaen. 5. Granito a Netaia Raros. I. Martina, Lucelene, orient. II. Titulo. 
Ao tempo, o verdadeiro grande alquimista.

Aquele que realmente transforma tudo e todos.

"Hic est totius fortitudinis fortitudo fortis, qa vincet omnem rem subtilem, omnemque solidam penetrabit.

Sic mundus creatus est. Hinc erunt adaptationes mirabiles, quarum modus hic est." Tabvla Smaragdina

"Nem todo trajeto é reto Nem o mar é regular" Metá Metá - Cobra Rasteira 



\section{AGRADECIMENTOS}

Deixo aqui meus sinceros agradecimentos a todas as pessoas e entidades que tornaram este trabalho possível, me apoiando, ajudando e incentivando das formas mais sutis e diretas de qual modo fosse necessário.

Agradeço à Universidade de São Paulo e ao Instituto de Geociências por ter me recebido de forma acolhedora ao longo da graduação e mestrado. E por toda infraestrutura que tive acesso para desenvolver minha pesquisa. Ao CNPq pela bolsa de mestrado (149342/2016-0) que possibilitou minha dedicação exclusiva ao projeto e à FAPESP (2015/01817-6) pelo auxílio financeiro relativo aos custos analíticos da pesquisa. Também agradeço ao Programa de Mineralogia e Petrologia e seus coordenadores (Prof. Renato Moraes e Profa. Eliane Del Lama) por todo suporte dado.

À Profa. Lucelene Martins tenho muito a agradecer, pela paciência que teve e por compartilhar seus conhecimentos comigo. Com sua ajuda me iniciei na pesquisa acadêmica e cresci muito como pessoa ao longo dos 6 anos que convivemos. A partir dos seus ensinamentos sobre as geociências, acho que consegui desenvolver uma pesquisa interessante e de qualidade.

Aos Profs. Valdecir Janasi e Adriana Alves pelas aulas de petrologia, dentro e fora das salas, pelas conversas que me iluminaram e por compartilharem seus trabalhos e dados comigo. Isto também vale para a Giovanna Pereira, que me acompanhou no mundo dos granitos de Itu e me ajudou durante todo o mestrado.

Aos Profs. Miguel Basei, Paulo Roberto dos Santos, Patrício Munoz e Frederico Faleiros pelos ensinamentos e vivência de campo durante meu estágio na disciplina de Mapeamento Geológico. Ao Frederico também agradeço pelos conhecimentos compartilhados sobre inclusões fluidas, que espero aplicar logo.

Agradeço aos membros da Comissão de Pós-Graduação pelas informações que me passaram quando fui representante discente e por todo apoio ao meu processo de defesa. Também ao Prof. Washington Leite e à Profa. Lena Monteiro por aceitarem participar da minha banca de mestrado, mesmo nas condições excepcionais do momento, e pelas dicas e contribuições ao trabalho.

Aos funcionários do IGc-USP pelo suporte em todas as etapas: Samuca (onipotente e onipresente da geo); Alexandre e Katherine (Seção de Pós-Graduação); aos técnicos dos laboratórios do NAP-Geoanalítica (Roger, Leandro, Marcos, José Paulo, Audrey e Vinícius) e do CPGeo (Vasco, Kei, Silvana); e também ao pessoal da seção de transportes (Bira, Adriano, Marciano e Michele), da gráfica (Henrique e Claudionor) e ao Renato da seção de laminação; além de muitos outros que não tive contato direto, mas foram de grande importância para tudo funcionar.

Aos funcionários da Pedreira Viracopos (especialmente o Leonardo Motta), do condomínio Colinas de Inhandjara, da Prefeitura de Itupeva e os moradores do Bairro da Mina. Por me possibilitarem estudar essa região tão intrigante e maravilhosa e os projetos que se desenvolveram pelo interesse comum.

Aos Profs. Washington Leite e Márcia Moura, por compartilharem um pouco do conhecimento sobre granitos estaníferos, pelas ideias e discussões sobre as amostras de Inhandjara, que influenciaram muito este trabalho. 
Aos amigos da geo: Fernanda, Natasha, Funga, Adrianna, Grega, Fofona, Thiago, Sebastian, Frota, Christian, Ney, José Renato e tantos outros que não tenho espaço para citar todos, mas agradeço da mesma forma.

À galera do bosque Thomas Akabane, Nicholas Machado, Julio Lopes, Stephani Somekawa, Raquel Romão e John Barré por todas as fogueiras e momentos de ajuda, descontração e de crescimento. Foram parte decisiva desse mestrado.

Ao pessoal de casa, Satoshi, Gui, Lucas, Gab e Marx pelo convívio diário e todas aventuras que passamos por todos esses anos.

Os amigos da vida e do mundo, Lucas Gonçalves e família; todos os membros da família AÚ, antigos e novos, perto e longe: Vitória, Antônio, Isabela, Marina, Renata, Gisele, Danilo, Gustavo, João, Bernardo, Ricardo e Coco. Por toda alegria compartilhada nessa e outras vidas e tantas histórias para levar sempre na memória. O mundo nos uniu e vai ser muito difícil separar.

Ao Sabino, Ângela e Gabriel, pelas vezes que me receberam, todas conversas, momentos bons e todo carinho que me deram. Aqui estendo meus agradecimentos à Geosistema e à MS Minérios pela possibilidade de desenvolver meu lado profissional em um ambiente tão bom e diversificado.

À minha família: avós, tios, tias, primos, primas e afins, especialmente meus pais Cely e Silvio e meu irmão Victor, pela base sólida que me deram, todo apoio e compreensão que depositaram em mim. Sem eles não teria chegado até aqui.

$\mathrm{E}$ agradeço imensamente à Luiza, por ter estado sempre ao meu lado. Me encorajado a seguir em frente e sempre fazer mais. Por todo amor e conforto que me deu, nas horas boas e nas ruins. Pelo apoio nos momentos de necessidade e pelas comemorações nos momentos devidos. Este trabalho é tanto seu, quanto meu!

Peço perdão caso tenha esquecido de nomear alguém. A falta da indicação não foi por desgosto ou descaso, mas por estes momentos finais serem sempre carregados de emoção e adrenalina, atrapalhando o funcionamento da memória.

Enfim, serei eternamente grato por todos momentos vividos, todos caminhos trilhados e histórias cruzadas. Aqui se apresenta o resultado dessa alquimia maluca de sentimentos e ações que compõem minha história. Assim toda obscuridade fugirá de ti. 


\section{ABSTRACT}

The Inhandjara Leucogranite is a small and differentiated Ediacaran stock (ca $570 \mathrm{Ma}$ ) that constitutes the northeaster border of the Itu Batholith (São Paulo state, SE Brazil), an A-type rapakivi body, composed of four main intrusions (Indaiatuba, Salto, Itupeva and Cabreúva). The stock outcrops as hololeucocratic granites, with distinguished radiometric contents (more enriched in Th and $U$ than the surrounding units). It presents the highest altitudes of the region, occurring separated from the other granitic plutons by a belt of basement gneisses. It is made of two main units: (1) inequigranular to porphyritic biotite-bearing monzogranite, with potassium feldspar megacrysts in a medium to coarse-grained matrix; and (2) medium to finegrained equigranular alkali feldspar granite, defined as the most evolved facies, consisted of subhedral albite and anhedral quartz, potassium feldspar and Li-bearing siderophyllite. As accessory magmatic phases, it shows fluorite, topaz, zircon, ilmenite and columbite-tantalite. The Leucogranite is metaluminous of A-type (A2 subtype), with alkali-calcic to alkalic character, from the ferroan series. It presents reduced nature and is classified into the ilmenite series. The facies show progressive increase of $\mathrm{SiO}_{2}, \mathrm{Al}_{2} \mathrm{O}_{3}, \mathrm{Na}_{2} \mathrm{O}, \mathrm{F}, \mathrm{Cs}, \mathrm{Rb}, \mathrm{Nb}$, $\mathrm{Ta}$ e $\mathrm{Y}$, while contents of $\mathrm{TiO}_{2}, \mathrm{Fe}_{2} \mathrm{O}_{3}, \mathrm{MgO}, \mathrm{CaO}, \mathrm{Sr}, \mathrm{Ba}$ e $\mathrm{Zr}$ tend to decrease to the alkali-feldspar granite. For the rare earth elements (REE), the evolved facies shows slight enrichment in the heavy elements, with $\mathrm{REE}_{\mathrm{TOTAL}}$ content around $150 \mathrm{ppm}$ and $(\mathrm{La} / \mathrm{Yb})_{\mathrm{N}}$ ratio of 0.6 . It displays an almost flat pattern in chondrite-normalized plots, with strong negative Eu anomaly (Eu/Eu* = 0.003), highlighting itself from the other units from the Itu Batholith. Zircon chemical analyses directly corroborate to the differentiation model, presenting composition enriched in $\mathrm{Hf}, \mathrm{Y}, \mathrm{Nb}$, Th and $U$ at the crystal borders in biotite granite and throughout the crystals of the alkalifeldspar granite, what may indicate late crystallization in the presence of fluid phase. The stock shows evidences of intensive metasomatism, mainly as pervasive albitisation and fissure to pervasive greisenisation, where the paragenesis of Li-bearing muscovite, quartz and chlorite ( \pm fluorite) occurs associated with disseminate sulphides (pyrite, sphalerite and galena, \pm chalcopyrite and molybdenite). The alteration process also affected the gneissic country rocks, transforming them to topaz-Li-bearing micas-quartz greisen bodies, associated with quartztopaz veins mineralised with hübnerite (Mn-rich wolframite) and cassiterite. Therefore, the Inhandjara Leucogranite presents mineralogical and chemical evidences of strong differentiation, resulting from the crystallization of a late magma, enriched in volatile phases and incompatible elements, and enhanced by interaction with exsolved F-rich hydrothermal fluids. Those characteristics place the stock in the most evolved spectrum inside the Itu Batholith, relating it with the rare-metal ( $\mathrm{Nb}-\mathrm{Ta}-\mathrm{W}-\mathrm{Sn}$ ) mineralization processes which occur in the area from the old Inhandjara Mine.

Keywords: Itu Granite Province, Magmatic Differentiation, Topaz-bearing Leucogranite, Greisen Alteration, Rare-Metal Granite. 


\section{RESUMO}

O Leucogranito Inhandjara é um pequeno e diferenciado stock Ediacarano ( 570 M.a.) que constitui a borda nordeste do Batólito de Itu (estado de São Paulo, SE Brasil), um corpo rapakivi tipo A, composto principalmente por quatro intrusões (Indaiatuba, Salto, Itupeva e Cabreúva). O stock aflora como granitos hololeucocráticos, com teores radiométricos diferenciados (mais enriquecidos em Th e $U$ do que as unidades vizinhas). Ele apresenta as maiores altitudes da região, sendo separado das outras unidades graníticas por um cinturão de gnaisses do embasamento. É constituído por dois litotipos: (1) monzogranito inequigranular a porfirítico com biotita, apresenta megacristais de feldspato potássico em uma matriz de granulação média a grossa; e (2) álcali-feldspato granito equigranular médio a fino, definido como a fácies mais evoluída, consistindo de albita subédrica $\left(A n_{<5}\right)$ e quartzo, feldspato potássio e Li-siderofilita anédricos. Como fases magmáticas acessórias, apresenta fluorita, topázio, zircão, ilmenita e columbita-tantalita. O Leucogranito é metaluminoso do tipo A (subtipo A2), com caráter alcali-cálcico a alcalino, da série ferroana. Ele apresenta natureza reduzida, sendo classificado como da série ilmenita. As fácies apresentam enriquecimento progressivo em $\mathrm{SiO}_{2}, \mathrm{Al}_{2} \mathrm{O}_{3}, \mathrm{Na}_{2} \mathrm{O}, \mathrm{F}$, Cs, $\mathrm{Rb}, \mathrm{Nb}$, Ta e $\mathrm{Y}$, enquanto os teores de $\mathrm{TiO}_{2}, \mathrm{Fe}_{2} \mathrm{O}_{3}$, $\mathrm{MgO}, \mathrm{CaO}, \mathrm{Sr}$, Ba e Zr tendem a diminuir em direção ao Topázio Granito. Para os elementos terras raras (ETR), a fácies evoluída apresenta ligeiro enriquecimento nos elementos pesados,

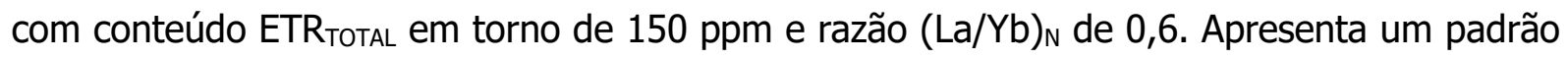
quase retilíneo quando normalizada por condrito, com forte anomalia negativa de Eu (Eu/Eu* $=0,003)$, se destacando das demais unidades do Batólito Itu. Análises químicas de zircão corroboram diretamente com o modelo de diferenciação, apresentando composição enriquecida em Hf, Y, Nb, Th e U nas bordas de cristais no Biotita Granito e por todos cristais do Topázio Granito, o que pode indicar cristalização tardia em presença de fase fluida. O stock apresenta evidências de intenso metassomatismo, principalmente albitização pervasiva e greisenização fissural, onde a paragênese de muscovita com Li, quartzo e clorita ( \pm fluorita) ocorre associada a sulfetos disseminados (pirita, esfalerita e galena, \pm calcopirita e molibdenita). O processo de alteração também afetou as rochas gnáissicas encaixantes, transformando-as em corpos de topázio-Li micas-quartzo greisen, associados a veios de quartzo-topázio mineralizados com hübnerita (wolframita rica em $\mathrm{Mn}$ ) e cassiterita. Portanto, o Leucogranito de Inhandjara apresenta evidências mineralógicas e químicas de forte diferenciação, resultante da cristalização de um magma tardio, enriquecido em fases voláteis e elementos incompatíveis e acentuada pela interação com fluidos hidrotermais ricos em $\mathrm{F}$ exsolvidos do magma. Essas características colocam o stock no espectro mais evoluído dentro do Batólito Itu, relacionando-o com os processos de mineralização em metais raros (Nb-TaW-Sn) presentes na área da antiga Mina de Inhandjara.

Palavras-chave: Província Granítica Itu, Diferenciação Magmática, Leucogranito com Topázio, Alteração Greisen, Granito a Metais-Raros. 


\section{Sumário}

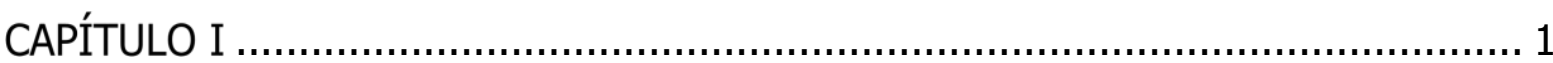

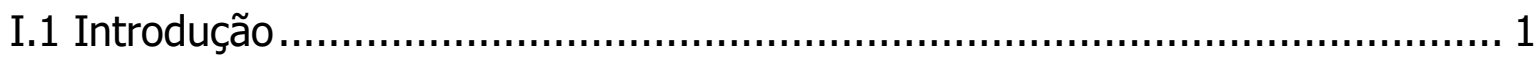

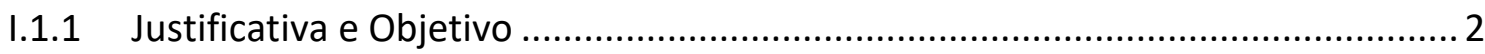

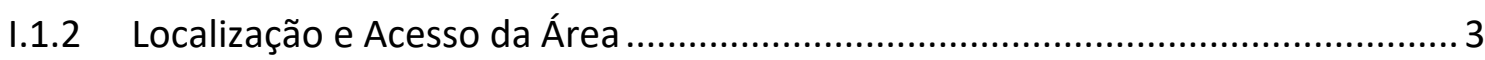

I.2 Metodologia ......................................................................... 4

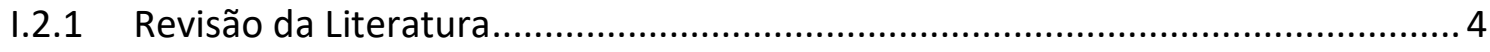

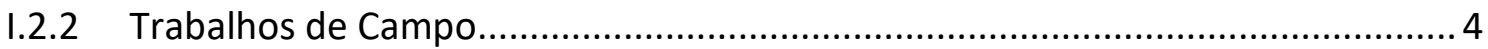

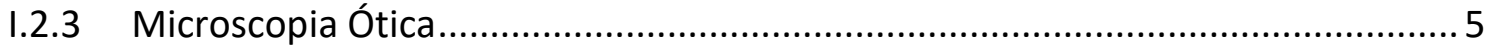

I.2.4 Microscopia Eletrônica de Varredura (MEV) …................................................. 6

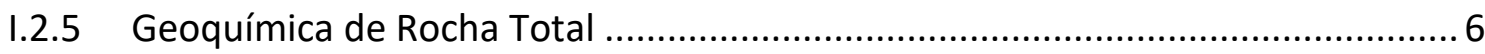

I.2.6 Química Mineral de elementos maiores por Microssonda Eletrônica (EPMA) .... 7

I.2.7 Química Mineral de elementos menores e traços por LA-ICP-MS ......................9

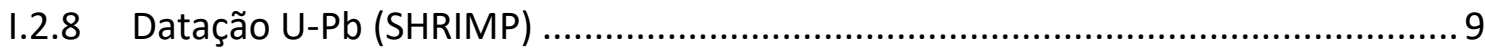

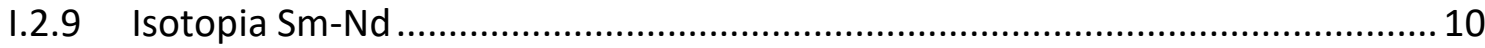

I.3 Geologia Regional ......................................................................

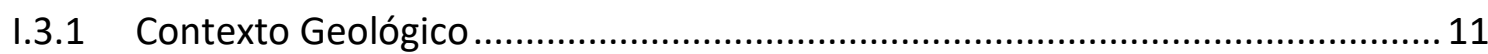

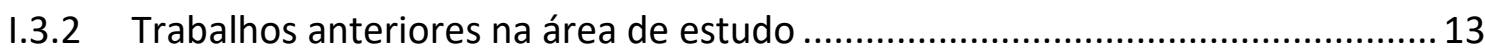

CAPÍTULO II - O LEUCOGRANITO INHANDJARA .....................................19

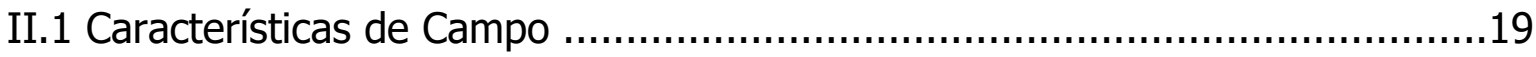

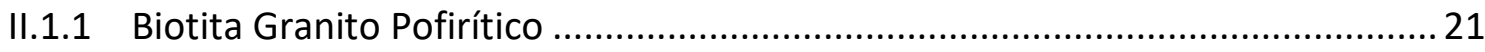

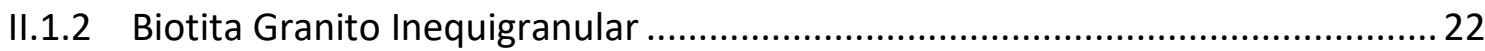

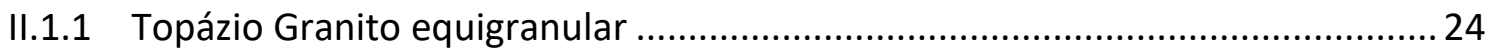

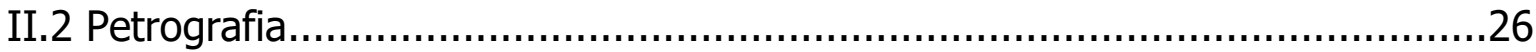

II.2.1 Biotita Monzogranito com fluorita e apatita (BG Porfirítico) ........................... 28

II.2.1 Biotita Monzogranito com fluorita (BG Inequigranular).................................. 29

II.2.1 Topázio Granito com biotita, topázio e fluorita (TAG - Equigranular) ................ 41

II.3 Alteração Hidrotermal no Leucogranito Inhandjara e Gnaisses Associados ....50

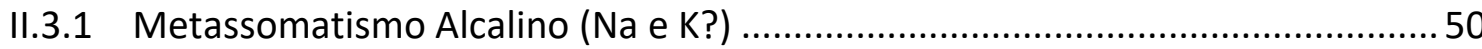

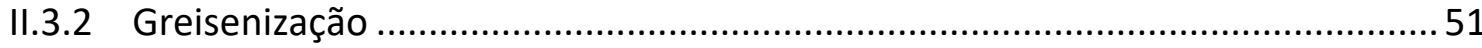

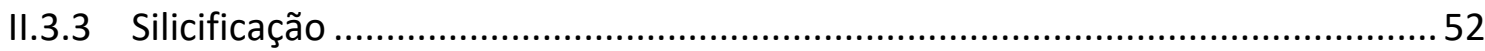

II.3.4 Cloritização e outras alterações subordinadas ................................................... 52 


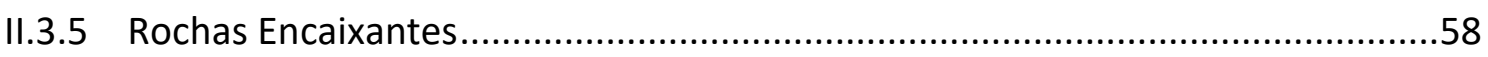

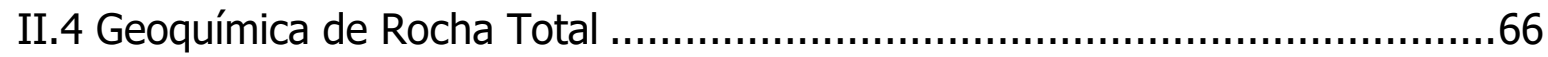

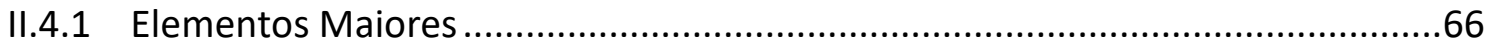

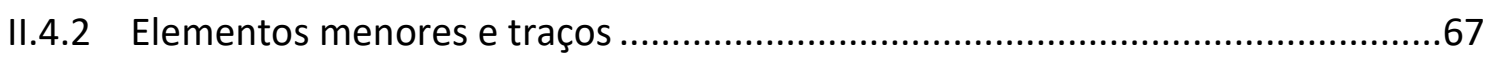

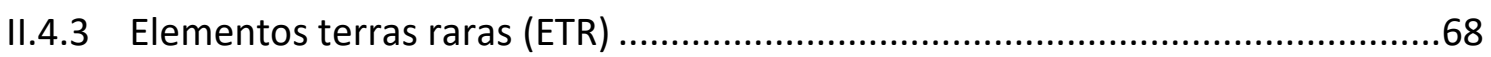

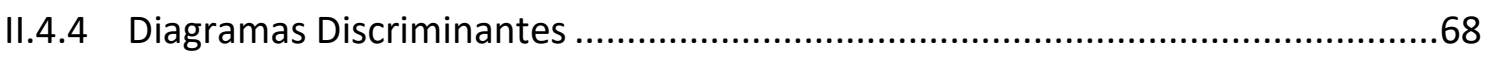

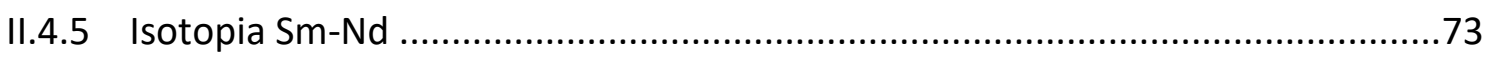

II.4.6 Variação química do processo hidrotermal....................................................75

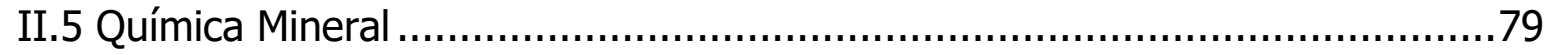

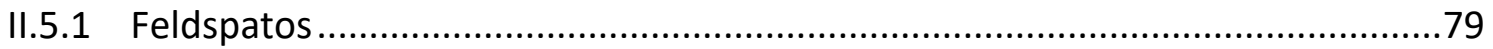

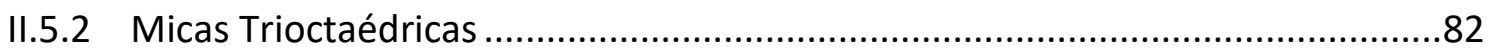

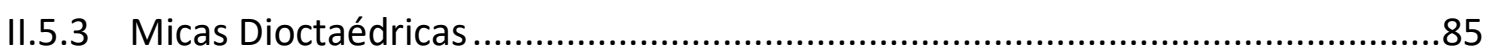

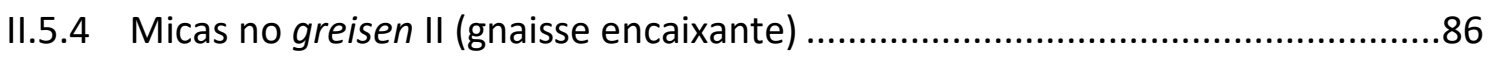

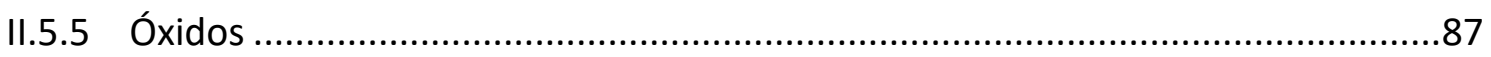

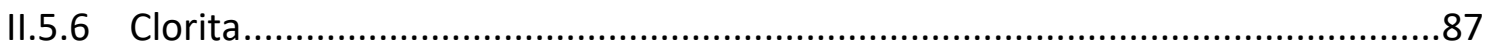

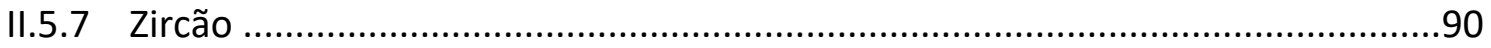

II.6 Datação U/Pb em zircão ......................................................95

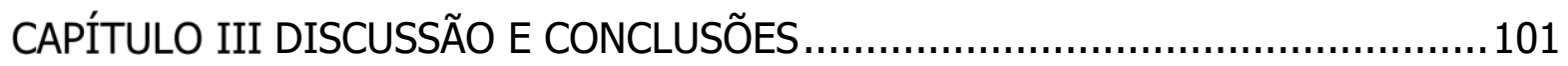

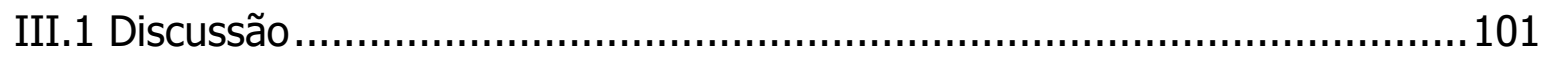

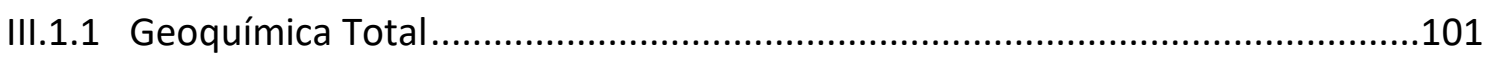

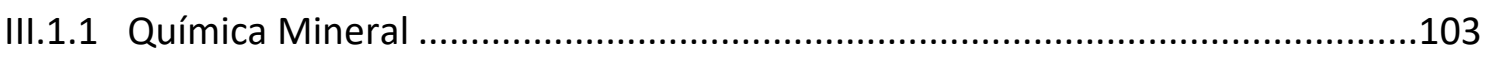

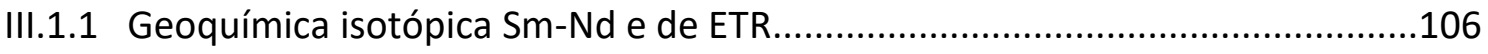

III.1.2 Associação com Mineralizações de Metais Raros ...........................................107

III.1.3 Evolução Magmato-Hidrotermal do Sistema .................................................110

III.2 Conclusões ................................................................... 111

CAPÍTULO IV REFERÊNCIAS Citadas..................................................... 112

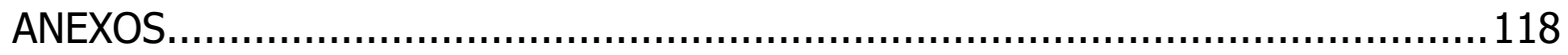




\section{Lista de Tabelas}

Tabela 1: Padrões utilizados para análises WDS pontuais em cristais de feldspatos..........7

Tabela 2: Padrões utilizados para análises WDS pontuais em cristais de micas. ..............8

Tabela 3: Padrões utilizados para análises WDS pontuais em cristais de zircão................8

Tabela 4: Padrões utilizados para análises WDS pontuais em cristais de óxidos. ..............9

Tabela 5: Análises químicas de elementos maiores em rocha total representativas das fácies do Stock de Inhandjara. 69

Tabela 6: Dados isotópicos Sm/Nd em rocha total das amostras de Inhandjara. 73

Tabela 7: Dados químicos comparando amostras frescas e hidrotermalizadas das fácies de Inhandjara. 76

Tabela 8: Dados químicos relacionando a variação na intensidade do metassomatismo na Pedreira Viracopos. 77

Tabela 9: Análises químicas representativas de feldspato potássico do Leucogranito Inhandjara. 79

Tabela 10: Análises químicas representativas de albita do Leucogranito Inhandjara....... 80

Tabela 11: Análises químicas representativas de plagioclásio do Leucogranito Inhandjara. 80

Tabela 12: Fórmula estrutural calculado para os feldspatos de Inhandjara a partir de análises in situ

Tabela 13: Análises químicas in situ representativas de micas trioctaédricas de Inhandjara

Tabela 14: Análises químicas in situ representativas de micas dioctaédricas de Inhandjara 86

Tabela 15: Análises químicas in situ representativas de cloritas de Inhandjara 89

Tabela 16: Análises químicas in situ representativas dos zircões de Inhandjara 92

Tabela 17: Dados geocronológicos U/Pb obtidos em cristais de zircão de Inhandjara por SHRIMP 97 


\section{Lista de Figuras}

Figura 1: Instalações da antiga Mina de Inhandjara.......................................... 3

Figura 2: Localização da área de estudo ................................................... 4

Figura 3: Mapas Geológicos Regional e Local .......................................................13

Figura 4: Mapa geológico para o Batólito Itu....................................................16

Figura 5: Mapas de gamaespectrometria Regional ............................................17

Figura 6: Imagem de Satélite da região de estudo ...........................................20

Figura 7: Mapa de Análise de Terreno (dados SRTM) ........................................20

Figura 8: Diagramas binários para gamaespectrometria de campo............................21

Figura 9: Aspecto de campo do Biotita Granito Porfirítico .......................................22

Figura 10: Aspecto de campo do Biotita Granito Inequiranular ...............................23

Figura 11: Aspecto de campo do Topázio Granito..............................................25

Figura 12: Diagrama modal QAP para amostras de Inhandjara ................................26

Figura 13: Variação textural e tabela paragenética para o Leucogranito Inhandjara .......27

Figura 14: Fotomicrografias dos feldspatos presentes no Biotita Granito Porfirítico.........32

Figura 15: Fotomicrografias dos filossilicatos e minerais acessórios presentes no Biotita

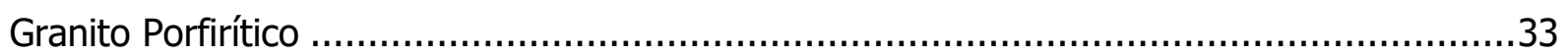

Figura 16: Imagens de elétrons retro-espalhados para o Biotita Granito Porfirítico .........34

Figura 17: Fotomicrografias dos feldspatos presentes no Biotita Granito Inequigranular .35

Figura 18: Fotomicrografias dos filossilicatos presentes no Biotita Granito Inequigranular .36

Figura 19: Fotomicrografias das feições secundárias presentes no Biotita Granito Inequigranular. 37

Figura 20: Imagens de elétrons retro-espalhados (BSE) do Biotita Granito Inequigranular .38

Figura 21: Mapas composicionais de EDS obtidos em MEV para inclusões em pseudomorfo de biotita, amostra IPV-30C do BG Inequigranular. .39

Figura 22: Mapas composicionais de EDS obtidos em MEV para cristal de zircão zonado,

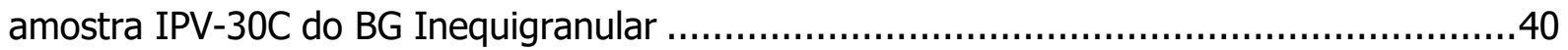

Figura 23: Fotomicrografias dos feldspatos presentes no Topázio Granito ....................43

Figura 24: Fotomicrografias das micas presentes no Topázio Granito ...........................44

Figura 25: Fotomicrografias das fases acessórias presentes no Topázio Granito .............45

Figura 26: Prancha de imagens BSE para o Topázio Granito ....................................46

Figura 27: Mapas composicionais de EDS obtidos em MEV para cristal de fluorita zonada e com inclusões, amostra IPV-35A do TAG 
Figura 28: Mapas composicionais de EDS obtidos em FE-EPMA para cristal de fluorita zonada com inclusão de fluoreto de $Y$, amostra IPV-35A do TAG

Figura 29: Mapas composicionais de EDS obtidos em MEV para cristal de zircão parcialmente substituído, amostra IPV-35A do TAG 49

Figura 30: Aspecto macroscópico das amostras hidrotermalizadas do Biotita Granito ..... 54

Figura 31: Aspecto macroscópico das amostras hidrotermalizadas do Topázio Granito ... 55

Figura 32: Fotomicrografias dos greisens presentes no Topázio Granito (greisen I) ....... 56

Figura 33: Mapas composicionais de EDS obtidos em MEV para sulfetos de greisen I, amostra IPV-35H do TAG. 57

Figura 34: Mapas composicionais de EDS obtidos em MEV para matriz de greisen I, amostra IPV-35H do TAG. 58

Figura 35: Aspecto de campo dos Gnaisses Encaixantes Greisenizados (greisen II)........ 61

Figura 36: Fotomicrografias dos Gnaisses Encaixantes Greisenizados (greisen II) .......... 62

Figura 37: Fotomicrografias das veios de topázio-quartzo mineralizados em W-Sn........ 63

Figura 38: Prancha de imagens BSE dos greisen II e veio de topazito mineralizados ...... 64

Figura 39: Mapas composicionais de EDS obtidos em MEV para veios de topazito

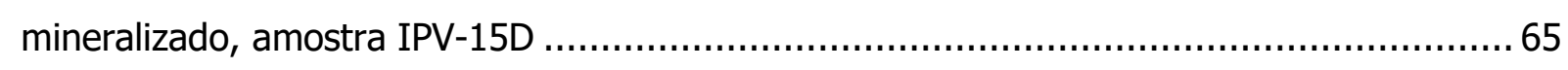

Figura 40: Diagramas Harker de elementos maiores para as amostras de Inhandjara .... 70

Figura 41: Diagramas Harker de elementos menores e traços para amostras de Inhandjara. 71

Figura 42: Diagramas Harker de razões geoquímicas de interesse para as amostras de Inhandjara 72

Figura 43: Diagrama de elementos terras-rara (ETR) e elementos traços normalizados pelo

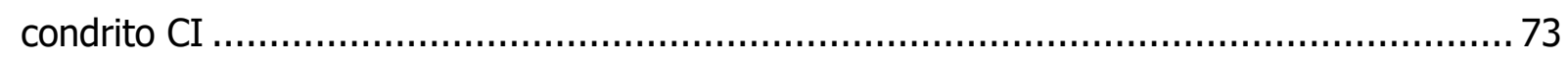

Figura 44: Diagramas geoquímicas discriminantes para amostras de Inhandjara ........... 74

Figura 45: Diagramas de geoquímica isotópica $\mathrm{Sm-Nd} \mathrm{\ldots \ldots \ldots \ldots \ldots \ldots \ldots \ldots \ldots \ldots \ldots \ldots \ldots \ldots \ldots \ldots \ldots \ldots \ldots \ldots \ldots \ldots \ldots}$

Figura 46: Diagrama linear da variação química para elementos maiores durante progressão do processo hidrotermal no Topázio Granito da Pedreira Viracopos 78

Figura 47: Diagrama linear da variação química para elementos meores e traços durante progressão do processo hidrotermal no Topázio Granito da Pedreira Viracopos. 78

Figura 48: Diagrama linear da variação química para razões geoquímicas durante progressão do processo hidrotermal no Topázio Granito da Pedreira Viracopos. 78

Figura 49: Diagramas de classificação e binários para análises in situ de feldspatos do Leucogranito Inhandjara. 79

Figura 50: Diagramas de classificação para análises in situ de micas do Leucogranito Inhandjara 84 
Figura 51: Diagramas binários para análises in situ de micas do Leucogranito Inhandjara 84

Figura 52: Diagramas de classificação para análises in situ de micas do Gnaisse Encaixante Greisenizado (greisen II) .88

Figura 53: Diagramas binários para análises in situ de micas do Gnaisse Encaixante Greisenizado (greisen II) .88

Figura 54: Diagramas de classificação e binários para análises in situ de cloritas do Leucogranito Inhandjara 90

Figura 55: Diagramas binários e diagramas de ETR normalizados pelo condrito para análises in situ de zircões do Leucogranito Inhandjara .93

Figura 56: Imagens BSE para cristais de zircão do Biotita Granito. .94

Figura 57: Imagens BSE para cristais de zircão do Topázio Granito .95

Figura 58: Imagem de catodoluminêscencia dos cristais de zircão do Topázio Granito ....96

Figura 59: Imagem de catodoluminêscencia dos cristais de zircão datados do Biotita Granito Porfirítico com posição dos spots e idade pontuais ${ }^{206} \mathrm{~Pb} /{ }^{238} \mathrm{U}$ por SHRIMP. .98

Figura 60: Diagrama concordia obtido para dados do Biotita Granito Porfirítico. .98

Figura 61: Imagem de catodoluminêscencia dos cristais de zircão datados do Biotita Granito Inequigranular com posição dos spots e idade pontuais ${ }^{206} \mathrm{~Pb} / 238 \mathrm{U}$ por SHRIMP. .99

Figura 62: Diagrama concordia obtido para dados do Biotita Granito Inequigranular. .....99

Figura 63: (A) Diagrama Hf vs. Zr para as amostras rocha total de Inhandjara. (B) Diagrama $\mathrm{Nb} / \mathrm{Ta}$ vs. Zr/Hf com linhas de referência conforme Wu et al. (2017) e campos para granitos mineralizados de Ballouard et al. (2016). 103

Figura 64: Diagramas para dados de química in situ para zircões de Inhandjara (A) Diagrama Yb vs. Th/U com os campos definidos por Breiter et al. (2014). (B) Diagrama Yb vs. $\mathrm{Zr} / \mathrm{Hf}$ com os campos de Breiter et al. (2014). (C) Diagrama Zr/Hf vs. Hf com os domínios delimitados por Raimbault et al., (1995) e Wang et al. (2000) (D) Diagrama Zr/Hf vs. $\mathrm{HF}+\mathrm{Y}+\mathrm{Th}+\mathrm{U}$ com os campos definidos por Lamarão et al. (2018). 105

Figura 65: Diagrama ternário com composições normativas de Q-Ab-Or para amostras de Inhandjara mostrando posição do mínimo haplogranítico para diferentes concentrações de $\mathrm{F}$ (conforme Manning, 1981). 106

Figura 66: Modelo esquemático para o Stock Inhandjara, com os litotipos e alterações hidrotermais definidos. 110 


\section{CAPÍTULO I}

\section{I.1 INTRODUÇÃO}

Rochas granitoides estão entre os componentes fundamentais da crosta continental terrestre e seus processos de geração e diferenciação representam os principais meios para a evolução crustal (Gill, 2010). Os produtos finais desta evolução enriquecem quimicamente as camadas mais externas do planeta em minerais de interesse para a sociedade e tem grande importância para o avanço tecnológico atual e futuro.

Processos hidrotermais tardi- a pós-magmáticos associados às rochas granitoides também são importantes mecanismos de evolução crustal e formação de depósitos metálicos (Hannah e Stein, 1990; Saad et al., 1996; Candela, 1997; Pereira et al., 2008). Parte destes depósitos magmático-hidrotermais compreendem ocorrências de minerais de metais raros (e.g. wolframita - $(\mathrm{Fe}, \mathrm{Mn}) \mathrm{WO}_{4}$, cassiterita - $\mathrm{SnO}_{2}$, molibdenita - $\mathrm{MoS}_{2}$ e columbita-tantalita - $\left.(\mathrm{Fe}, \mathrm{Mn})(\mathrm{Nb}, \mathrm{Ta})_{2} \mathrm{O}_{6}\right)$. Estes normalmente estão hospedados em cavidades miarolíticas e corpos pegmatíticos nas zonas de cúpula das intrusões graníticas (Suwimonprecha et al., 1995; Pollard, 1995), assim como em zonas hidrotermalizadas (e.g., greisen) e sistemas de veios nas bordas das intrusões e em suas rochas encaixantes (Derre et al., 1986; Pitfield et al., 1990; Haapala, 1995; Moura et al., 2007).

Os depósitos de metais raros costumam estar associadas a magmas evoluídos, com assinaturas geoquímicas de granitos tipo $\mathrm{A}$ ou $\mathrm{S}$ e enriquecimento em álcalis, voláteis e elementos incompatíveis, incluindo os de natureza radioativa (Bowden, 1981; Manning, 1986; Lehmann, 1990; Sawka et al., 1990; Audétat et al., 2000; Ishihara e Murakami, 2006; Moura et al., 2014). Com considerável parte das ocorrências relacionadas a granitos peraluminosos com topázio (Raimbault et al., 1995).

A presença destas rochas altamente evoluídas em corpos graníticos do tipo A é comum em diversas províncias pós-orogênicas e anorogênicas pelo mundo (Exley, 1958; Moura e Botelho, 2000; Audétat et al., 2000; Štemprok et al., 2005; Haapala et al., 2007; Lukkari et al., 2009; Gu et al., 2011). A Província Granítica Itu é um desses exemplos (Bettencourt et al., 2005; Janasi et al., 2009), onde aflora o Leucogranito Inhandjara, um corpo altamente fracionado e especializado em metais raros, localizado no município de Itupeva (SP). Nessa localidade, durante as décadas de 40 e 60, foi explotada wolframita na Mina de Inhandjara. 
Os depósitos metálicos de Inhandjara já foram descritos na literatura (e.g. Abreu, 1945; Saldanha, 1946; Amaral e Pascholati, 1990; Ribeiro et al., 1994; Pereira et al., 2008). Estes compreendem ocorrências de wolframita e cassiterita, hospedadas em veios de quartzo e topázio diretamente associados a corpos de topázio-mica-quartzo greisen nas rochas encaixantes. Quando nos granitos, os depósitos metálicos se dão na forma de sulfetos disseminados (Amaral e Pascholati, 1990).

No entanto a evolução magmático-hidrotermal do Leucogranito e sua correlação com a ocorrência de wolframita e cassiterita na área, seja como fonte primária dos metais ou apenas como motor termal do sistema, ainda não foi bem estabelecida, por isso foi alvo deste estudo.

\section{I.1.1 Justificativa e Objetivo}

A área de estudo abrange a borda nordeste do batólito Itu, onde aflora o stock Inhandjara, composto por leucogranitos evoluídos com evidências de intenso processo hidrotermal e associados a anomalias geofísicas regionais (Pascholati, 1990; Pascholati et al., 1997), e também suas rochas gnáissicas encaixantes. Estas ocorrem mineralizadas em W e Sn e abrigam a antiga Mina de Inhandjara, desativada atualmente. Depósitos metálicos desse tipo são raros no estado de São Paulo e, devido à grande demanda que tiveram durante a segunda guerra mundial, foram intensamente explotadas pela Sociedade Mineração Inhandjara (Figura 1), representando uma das principais produções de tungstênio do país no período (Saldanha, 1946; White, 1974).

Desta forma, a região de Inhandjara apresenta características petrológicas, radiogênicas e estruturais muito favoráveis ao estudo do processo de diferenciação magmática, com formação de granitos evoluídos e suas relações com mineralizações de metais raros.

Neste panorama a proposta deste trabalho é fornecer dados sobre a petrologia do Leucogranito Inhandjara buscando compreender os processos evolutivos associados aos granitos diferenciados e especializados em metais raros, considerando suas variações geoquímicas e mineralógicas durante os processos magmáticos e hidrotermais. Para isto foram utilizados diversos métodos, como caracterização de campo, petrográfica, química (minerais e rochas) e geocronológica, a fim de estabelecer correlações com a mineralização descrita na literatura. 


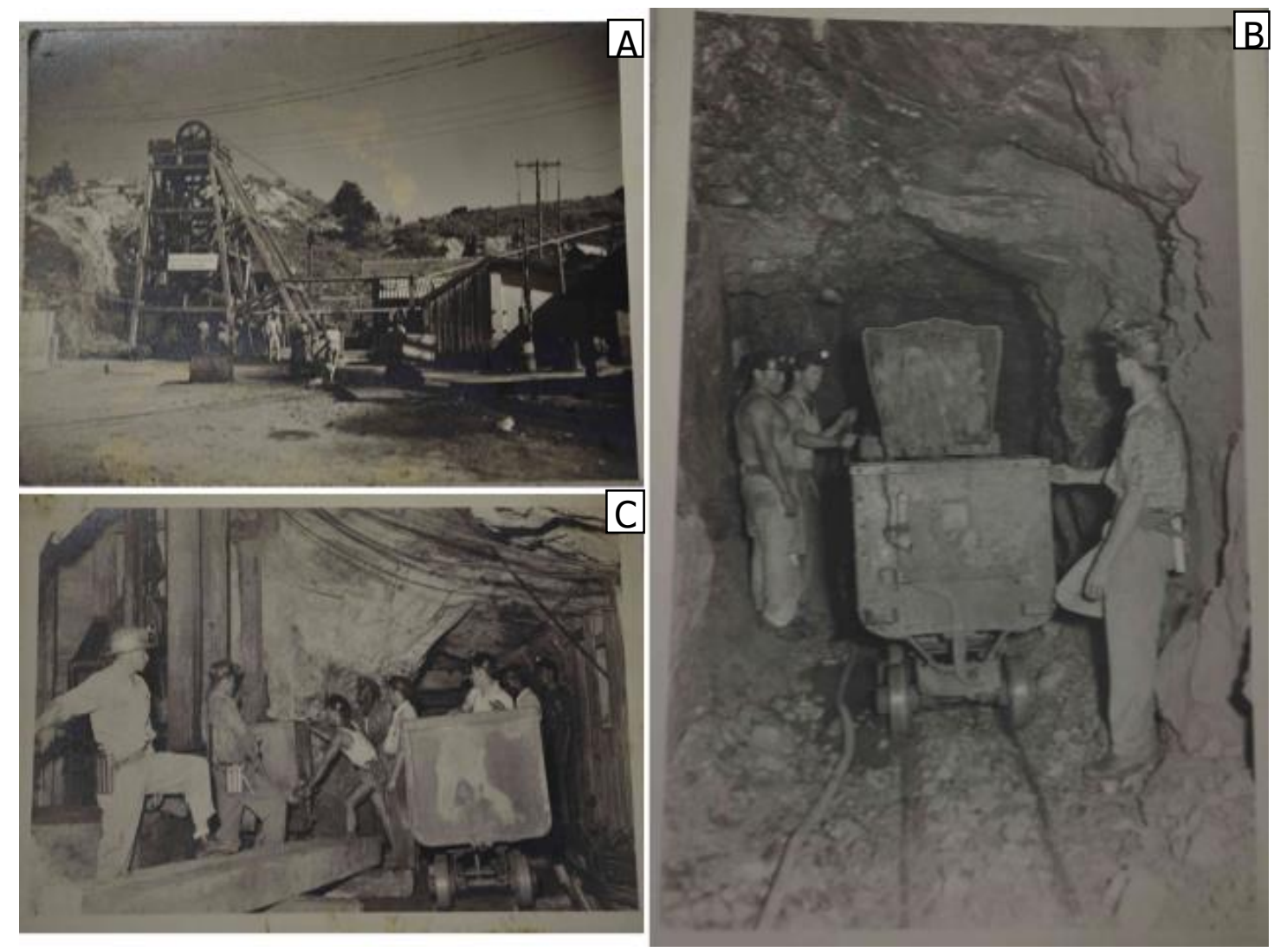

Figura 1: Instalações da antiga Mina de Inhandjara. (A) Estruturas de beneficiamento na superfície. (B) e (C) Galerias subterrâneas com trabalhadores extraindo e transportando o minério. Fotografias do acervo pessoal do Sr. Luiz Carlos Izzo, do Jornal de Itupeva.

\section{I.1.2 Localização e Acesso da Área}

A área de estudo é localizada no estado de São Paulo, a cerca de $75 \mathrm{~km}$ da capital, a norte da cidade de Itupeva, entre as cidades de Jundiaí, Indaiatuba e Itu (Figura 2). Faz parte do município de Itupeva e engloba a porção norte da mancha urbana, além das regiões do Bairro da Mina, do condomínio Colinas de Inhandjara e a Pedreira Viracopos. No passado toda a área de estudo fazia parte da antiga Fazenda Inhandjara, a qual cunhou o nome da região e serviu como inspiração para todas as utilizações posteriores.

O acesso ao local é feito, a partir da capital estadual (a $80 \mathrm{~km}$ de distância), pela Rodovia dos Bandeirantes (SP-348) ou Rodovia Anhanguera (BR-050), sentido Campinas (norte), tomando a saída para a Rodovia Dom Gabriel Paulino Bueno Couto (SP-300), sentido Itu (oeste), e em seguida a Rodovia Prefeito Hermenegildo Tonoli (SPA-66/300) até a cidade de Itupeva. 


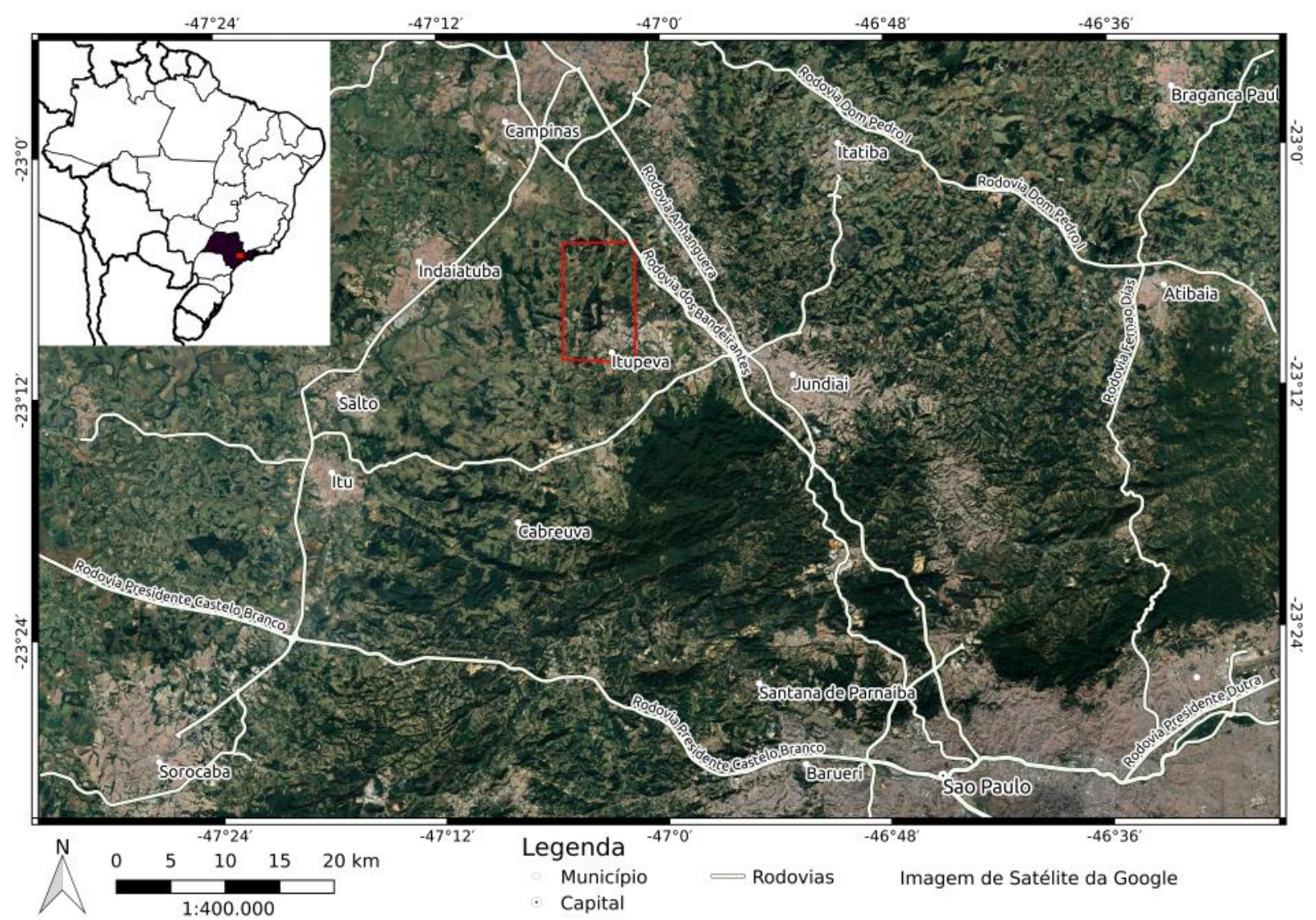

Figura 2: Localização da área de estudo a norte do município de Itupeva, com malha rodoviária regional.

\section{I.2 METODOLOGIA}

\section{I.2.1 Revisão da Literatura}

Exemplos análogos de ocorrência de granitos evoluídos e especializados em metais raros, em especial, associados a províncias magmáticas do tipo A e pós-colisionais, foram buscados em plataformas digitais de periódicos (periodicos.capes.gov.br, sciencedirect.com; scielo.br, scopus.com). Essa busca possibilitou a comparação do Leucogranito Inhandjara e os modelos da literatura, dando subsídio para a caracterização dos litotipos e dos processos evolutivos magmáticos e hidrotermais registrados na área de estudo.

\section{I.2.2 Trabalhos de Campo}

Quatro etapas de campo, em um total de 7 dias, foram realizadas para se definir o contexto geológico da área de estudo, coletar dados estruturais e gamaespectrométricos, além de amostras para análises laboratoriais. Essas etapas não tiveram por objetivo o mapeamento de detalhe do stock granítico, por isso se concentraram nas principais exposições. A localização e descrição dos pontos se encontra no Anexo I. 
Para a obtenção de medidas gamaespectrométricas ( $K, U$ e Th) foi utilizado um aparelho portátil Satisgeo GS-512, posicionando o detector diretamente sobre a superfície fresca das rochas (tempo de leitura de 5 minutos). Por não haver calibração dos resultados os dados obtidos (disponíveis no Anexo II) devem ser considerados apenas qualitativamente para relacionar as análises realizadas, sem fornecer teores precisos.

Os amostras coletadas foram processadas e armazenadas no Laboratório de Tratamento de Amostras (LTA), parte do Núcleo de Apoio à Pesquisa (NAP) Geoanalítica do IGc-USP.

Dados de campo georreferenciados foram analisados em Sistemas de Informações Geográficas (SIG) utilizando o programa QGIS, versão 2.18, e correlacionados com imagens de satélite, mapas geológicos, geofísicos e modelos de relevo para análises espaciais, utilizando a projeção Universal Tranversa de Mercator (UTM), com datum de referência WGS 84, zona 23K. Os bancos de dados consultados foram: CPRM geosgb.cprm.gov.br (dados geológicos e geofísicos); USGS - earthexplorer.usgs.gov (dados SRTM com resolução espacial de $30 \mathrm{~m}$ ); Google Earth (imagens de satélite); além de teses realizadas na região (dados geológicos e geofísicos).

\subsubsection{Microscopia Ótica}

Foram confeccionadas 40 seções delgadas com espessura de $45 \mu \mathrm{m}$ na Seção de Laminação do IGc-USP, além de 12 seções delgadas polidas, confeccionadas no Setor de Preparação de Amostras para Microssonda Eletrônica.

As análises petrográficas foram realizadas em luz transmitida e refletida no Laboratório de Microscopia Petrográfica (LMP) do NAP-Geoanalítica, utilizando microscópios petrográficos da marca Zeiss, modelos Axioplan e Axio imager.A2M, este último acoplado com câmera Zeiss AxioCam MRc, utilizada para obtenção das fotomicrografias, e na sala de microscopia do IGc-USP utilizando microscópio Olympus, BX40.

Análises modais por contagem foram feitas em seis amostras, representativas dos litotipos estudados, utilizando um charriot acoplado a platina do microscópio, com malha de $1 \mathrm{~mm} \times 1 \mathrm{~mm}$, totalizando 700 pontos contados por amostra. No restante das amostras a estimativa da moda foi visual.

As abreviações de nomes de minerais, quando utilizadas, seguiram o padrão definido por Whitney e Evans (2010). 


\section{I.2.4 Microscopia Eletrônica de Varredura (MEV)}

Duas sessões de MEV foram realizadas em lâminas delgadas polidas recobertas por película de carbono, no Laboratório de Caracterização Tecnológica (LCT) do Departamento de Engenharia de Minas da Escola Politécnica-USP, em equipamento da marca FEI, modelo Quanta 650FEG, equipado com detector EDS Quantax, da Bruker. As análises foram realizadas em alto vácuo, com voltagem de aceleração em 20 kV, corrente de $100 \mathrm{nA}$ e spot com $6 \mu \mathrm{m}$.

\section{I.2.5 Geoquímica de Rocha Total}

Quatorze análises químicas de rocha total foram obtidas por Fluorescência de raios $X(F R X)$ em pastilhas fundidas (elementos maiores e menores) e prensadas (traços) e seis análises por espectrometria de massa com plasma acoplado indutivamente (ICPMS) para determinação de elementos traço e terras raras.

As análises foram realizadas nos Laboratórios de Fluorescência de Raios $X$, em equipamento da PANalytical, modelo AXIOS MAX Advanced; e de Química e ICP, em aparelho da Thermo Scientific, modelo iCAP Q, ambos parte do NAP Geoanalítica do IGc-USP e seguindo os procedimentos descritos em Mori et al. (1999) e Navarro et al. (2008), respectivamente. Dados completos são disponibilizados no Anexo III.

A preparação das amostras foi feita no Laboratório de Tratamento de Amostras (LTA), onde as amostras foram cortadas em serra diamantada para diminuição do tamanho, com descarte das bordas e porções intemperizadas. Foi feita em seguida a fragmentação em prensa hidráulica manual, homogeneização e quarteamento do material prensado. Por fim, os fragmentos passaram por moinho planetário de ágata até atingir uma granulometria menor que 200 mesh.

$7 \mathrm{~g}$ de pó de rocha, micronizado por cerca de 15 minutos em solução com etanol, e posteriormente deixado para secar por 48 horas em uma estufa, foi misturado com cera ligante $\left(\mathrm{C}_{6} \mathrm{H}_{8} \mathrm{O}_{3} \mathrm{~N}_{2}\right)$ na proporção de $20 \%$ em massa do pó total $(\sim 1,4 \mathrm{~g})$. A mistura foi colocada em prensa de carbeto de tungstênio, que produziu 14 pastilhas de cerca de $40 \mathrm{~mm}$ de diâmetro a uma pressão de $30 \mathrm{kPa}$. Essas pastilhas foram utilizadas para obtenção de elementos traço em FRX.

Pastilhas fundidas (14) foram confeccionadas misturando $1 \mathrm{~g}$ da amostra pulverizada com $9 \mathrm{~g}$ de material fundente (metaborato de lítio com tetraborato de lítio). A mistura foi fundida em forno elétrico da marca Ox, sendo o material fundido solidificado como pastilha vítrea de cerca de $40 \mathrm{~mm}$ em suportes de platina. 
O programa Excel ${ }^{\circledR} 2013$ foi utilizado para tratar os dados de geoquímica e combinado com o programa Inkscape (v. 0.91) para tratamento dos gráficos e figuras.

\section{I.2.6 Química Mineral de elementos maiores por Microssonda Eletrônica (EPMA)}

Foram realizadas duas sessões de EPMA, totalizando três dias, no Laboratório de Microssonda Eletrônica (ME) do NAP Geoanalítica, IGc-USP, para a determinação de elementos maiores em cristais de micas, feldspatos, zircão e alguns óxidos. As análises químicas in situ foram feitas por dispersão de comprimento de ondas (WDS), em equipamento da marca JEOL, modelo JXA-8530F, equipado com canhão eletrônico tipo Field Emission (FE). Resultados completos estão disponíveis no anexo IV.

As condições de operação foram: corrente em 20 nA, aceleração de $15 \mathrm{kV}$ e diâmetro de $10 \mu \mathrm{m}$ para feldspatos e 5 um para micas e óxidos. Para análises de zircão condições foram: corrente em 100 nA, aceleração de 15 kV e feixe com $5 \mu \mathrm{m}$. O método utilizado para corrigir as análises pelos padrões foi o PRZ-Armstrong.

O recálculo catiônico das fases minerais foi realizado em planilhas de Excel $^{\circledR}$ seguindo o procedimento descrito em Deer et al. (1992), exceto no caso dos filossilicatos (micas e clorita), onde foi utilizada uma planilha disponibilizada online pelo Prof. Andrew Tindle em sua página no site da Open University, Reino Unido. (http://www.open.ac.uk/earth-research/tindle/AGTWebPages/AGTSoft.html).

O conteúdo de Li das micas foi calculado a partir da estequiometria com o teores analisados por EPMA, conforme equações de Tischendorf et al. (1997): $\mathrm{LiO}_{2}=(0,289$ $* \mathrm{SiO} 2)$ - 9,658, para as micas trioctaédricas ou como $\mathrm{LiO}_{2}=\left(0,3935 * \mathrm{~F}^{1,326}\right)$, para micas dioctaédricas. O teor de água foi calculado considerando ocupação total no sítio $(\mathrm{OH}, \mathrm{F})$, conforme procedimento descrito por Tindle e Webb (1990).

Os padrões utilizados, fornecidos pelos Laboratórios Geller e Museu Smithsonian, são conforme Tabela 1, 2 e, onde também estão listadas as condições analíticas.

Tabela 1: Padrões utilizados para análises WDS pontuais em cristais de feldspatos.

\begin{tabular}{|c|c|c|c|c|c|}
\hline Elemento & Linha raio X & Cristal & Pos. Pico $(\mathrm{mm})$ & Padrão & Tempo Pico (s) \\
\hline $\mathrm{Si}$ & $\mathrm{Ka}$ & TAP & 77.288 & Anortoclasio & 10 \\
\hline $\mathrm{Al}$ & $\mathrm{Ka}$ & TAP & 90.485 & Anortoclasio & 15 \\
\hline $\mathrm{Fe}$ & $\mathrm{Ka}$ & LIFL & 134.629 & Faialita & 10 \\
\hline $\mathrm{Mn}$ & $\mathrm{Ka}$ & LIFL & 146.161 & Faialita & 40 \\
\hline $\mathrm{K}$ & $\mathrm{Ka}$ & PETJ & 119.655 & Ortoclasio & 10 \\
\hline $\mathrm{Ca}$ & $\mathrm{Ka}$ & PETJ & 107.485 & Wollastonita & 10 \\
\hline $\mathrm{Sr}$ & $\mathrm{La}$ & PETJ & 219.470 & Estroncianita & 40 \\
\hline $\mathrm{Ti}$ & $\mathrm{Ka}$ & LIFL & 190.861 & Rutilo & 10 \\
\hline $\mathrm{Ba}$ & $\mathrm{La}$ & LIFL & 192.945 & Benitoita & 20 \\
\hline $\mathrm{Na}$ & $\mathrm{Ka}$ & TAPH & 129.599 & Albita & 5 \\
\hline $\mathrm{Mg}$ & $\mathrm{Ka}$ & TAPH & 107.591 & Diopsidio & 10 \\
\hline
\end{tabular}


Tabela 2: Padrões utilizados para análises WDS pontuais em cristais de micas.

\begin{tabular}{|c|c|c|c|c|c|}
\hline Elemento & Linha raio $\mathrm{X}$ & Cristal & Pos. Pico $(\mathrm{mm})$ & Padrão & Tempo Pico (s) \\
\hline $\mathrm{Si}$ & $\mathrm{Ka}$ & TAP & 77.288 & Diopsidio & 10 \\
\hline $\mathrm{Al}$ & $\mathrm{Ka}$ & TAP & 90.784 & Anortoclasio & 15 \\
\hline $\mathrm{Sr}$ & $\mathrm{La}$ & $\mathrm{TAP}$ & 74.443 & Stroncianita & 30 \\
\hline $\mathrm{Fe}$ & $\mathrm{Ka}$ & LIFL & 134.629 & Faialita & 10 \\
\hline $\mathrm{Mn}$ & $\mathrm{Ka}$ & LIFL & 146.161 & Faialita & 20 \\
\hline $\mathrm{Zn}$ & $\mathrm{Ka}$ & LIFL & 99.842 & Willemita & 30 \\
\hline $\mathrm{Cl}$ & $\mathrm{Ka}$ & PETJ & 151.193 & Sodalita & 10 \\
\hline $\mathrm{K}$ & $\mathrm{Ka}$ & PETJ & 119.655 & Ortoclasio & 10 \\
\hline $\mathrm{Ca}$ & $\mathrm{Ka}$ & PETJ & 107.485 & Wollastonita & 10 \\
\hline $\mathrm{Nb}$ & $\mathrm{La}$ & PETJ & 183.055 & Ilmenita & 40 \\
\hline $\mathrm{Ti}$ & $\mathrm{Ka}$ & LIFL & 191.117 & Rutilo & 10 \\
\hline $\mathrm{Ba}$ & $\mathrm{La}$ & LIFL & 192.945 & Benitoita & 30 \\
\hline $\mathrm{Cr}$ & $\mathrm{Ka}$ & LIFL & 158.977 & Cromita & 10 \\
\hline $\mathrm{F}$ & $\mathrm{Ka}$ & TAPH & 200.648 & Fluorapatita & 10 \\
\hline $\mathrm{Na}$ & $\mathrm{Ka}$ & TAPH & 129.599 & Albita & 10 \\
\hline $\mathrm{Mg}$ & $\mathrm{Ka}$ & TAPH & 107.579 & Diopsidio & 10 \\
\hline
\end{tabular}

Tabela 3: Padrões utilizados para análises WDS pontuais em cristais de zircão.

\begin{tabular}{|c|c|c|c|c|c|}
\hline Elemento & Linha raio $X$ & Cristal & Pos. Pico (mm) & Padrão & Tempo Pico (s) \\
\hline $\mathrm{Si}$ & $\mathrm{Ka}$ & TAP & 77.378 & Zircão & 10 \\
\hline $\mathrm{Al}$ & $\mathrm{Ka}$ & TAP & 90.574 & Anortoclasio & 20 \\
\hline $\mathrm{Fe}$ & $\mathrm{Ka}$ & LIFL & 134.640 & Faialita & 10 \\
\hline $\mathrm{Gd}$ & $\mathrm{Lb}$ & LIFL & 128.433 & Gd-fosfato & 20 \\
\hline Dy & $\mathrm{Lb}$ & LIFL & 118.965 & Dy-fosfato & 20 \\
\hline $\mathrm{Hf}$ & La & LIFL & 109.144 & Zircão & 30 \\
\hline $\mathrm{Yb}$ & La & LIFL & 116.272 & Yb-fosfato & 20 \\
\hline K & $\mathrm{Ka}$ & PETJ & 119.965 & Ortoclasio & 10 \\
\hline $\mathrm{Ca}$ & $\mathrm{Ka}$ & PETJ & 107.715 & Wollastonita & 10 \\
\hline $\mathrm{P}$ & $\mathrm{Ka}$ & PETJ & 197.325 & Fluorapatita & 10 \\
\hline $\mathrm{Ti}$ & $\mathrm{Ka}$ & PETJ & 88.150 & Rutilo & 20 \\
\hline$U$ & $\mathrm{Mb}$ & PETJ & 119.085 & Vidro Riolitico & 20 \\
\hline $\mathrm{Zr}$ & La & PETL & 194.159 & Zircão & 10 \\
\hline$Y$ & $\mathrm{La}$ & PETL & 206.270 & Y-fosfato & 20 \\
\hline $\mathrm{Nb}$ & $\mathrm{La}$ & PETL & 183.083 & Ilmenita & 20 \\
\hline Th & $\mathrm{Ma}$ & PETL & 132.284 & Vidro Riolitico & 30 \\
\hline $\mathrm{F}$ & $\mathrm{Ka}$ & TAPH & 199.471 & Fluorapatita & 5 \\
\hline $\mathrm{Na}$ & $\mathrm{Ka}$ & TAPH & 129.623 & Albita & 10 \\
\hline
\end{tabular}


Tabela 4: Padrões utilizados para análises WDS pontuais em cristais de óxidos.

\begin{tabular}{|c|c|c|c|c|c|}
\hline Elemento & Linha raio $\mathrm{X}$ & Cristal & Pos. Pico $(\mathrm{mm})$ & Padrão & Tempo Pico $(\mathrm{s})$ \\
\hline $\mathrm{Si}$ & $\mathrm{Ka}$ & TAP & 77.288 & Diopsídio & 20 \\
\hline $\mathrm{Al}$ & $\mathrm{Ka}$ & $\mathrm{TAP}$ & 90.485 & Anortita & 20 \\
\hline $\mathrm{Fe}$ & $\mathrm{Ka}$ & LIFL & 134.651 & Ilmenita & 10 \\
\hline $\mathrm{Mn}$ & $\mathrm{Ka}$ & LIFL & 146.118 & Ilmenita & 40 \\
\hline $\mathrm{K}$ & $\mathrm{Ka}$ & $\mathrm{PETJ}$ & 119.655 & Ortoclasio & 20 \\
\hline $\mathrm{Ca}$ & $\mathrm{Ka}$ & PETJ & 107.460 & Wollastonita & 20 \\
\hline $\mathrm{Nb}$ & $\mathrm{La}$ & $\mathrm{PETJ}$ & 183.055 & Ilmenita & 40 \\
\hline $\mathrm{Ti}$ & $\mathrm{Ka}$ & LIFL & 190.857 & IImenita & 5 \\
\hline $\mathrm{Cr}$ & $\mathrm{Ka}$ & LIFL & 158.977 & Cromita & 40 \\
\hline $\mathrm{Zn}$ & $\mathrm{Ka}$ & LIFL & 99.864 & Willemita & 40 \\
\hline $\mathrm{Na}$ & $\mathrm{Ka}$ & TAPH & 129.491 & Albita & 40 \\
\hline $\mathrm{Mg}$ & $\mathrm{Ka}$ & TAPH & 107.579 & Diopsídio & 40 \\
\hline
\end{tabular}

\section{I.2.7 Química Mineral de elementos menores e traços por LA-ICP-MS}

As microanálises por laser ablation (LA) ICP-MS, utilizadas para quantificar a composição de elementos menores e traço de zircão, foram realizadas no Laboratório de Química e ICP, parte do NAP Geoanalítica do IGc-USP.

Análises foram obtidas com amostrador laser ablation New Wave 213 A/F (Nd:YAG deep UV - 213nm) acoplado a espectrômetro de massa quadrupolo Thermo Scientific iCAP, controlado pelo software Qtegra. A amostragem foi realizada em modo raster de $60 \mu \mathrm{m}$, com spot de $30 \mu \mathrm{m}$ e o passo do raster de $1 \mu \mathrm{m} / \mathrm{s}$.

Os resultados obtidos foram tratados em tempo real pelo software Glitter ${ }^{\circledR}$ (Van Achterbergh et al., 2001). Para correção do drift instrumental foi utilizado o valor de $\mathrm{ZrO}_{2}$ obtido por WDS como padrão interno e para a padronização externa o vidro silicático NIST SRM-610. A qualidade das análises foi conferida com o zircão Zr91500, padrão de referência internacional (Wiedenbeck et al., 1995).

\section{I.2.8 Datação U-Pb (SHRIMP)}

Análises geocronológicas utilizando o sistema U-Pb em cristais de zircão de duas amostras de interesse foram obtidas por espectrometria de massa de íons secundários (SIMS) em Microssonda Iônica Sensitiva de Alta Precisão (SHRIMP) modelo IIe, no Laboratório de Geocronologia de Alta Resolução, do Centro de Pesquisas Geocronológicas (CPGEO), IGc-USP. As condições de operação são descritas por Sato et al. (2014). Resultados completos das datações U-Pb por SHRIMP estão disponíveis no Anexo V e pontos de análise no Anexo VI. 
Cristais de zircão foram concentrados no Laboratório de Separação do CPGEO, seguindo o procedimento descrito por Loios (2009). A primeira etapa foi a fragmentação das amostras em britador de mandíbulas de aço até cerca de $1 \mathrm{~cm}$, passando em seguida para o moinho de disco para redução gradual da granulação do material até aspecto de areia fina. Em seguida o material passou por um conjunto de peneiras vibratórias, separando em níveis de granulação: maior que 0,250 mm; entre 0,250 e 0,100 mm; e menores que 0,100 mm. Frações menores que 0,250 mm, foram colocadas na Mesa Vibratória de Wiffley, para separação por densidade em meio aquoso em dois grupos: os pesados, concentrados na caneca 1, e os leves, que são carreados pela água ou se depositam na caneca 2 . Após este processo o material foi secado sob lâmpadas térmicas. O material da caneca 1 foi submetido ao imã de mão para extração de minerais fortemente magnéticos (i.e. magnetita e ilmenita). Posteriormente esse material passou por um separador eletromagnético, tipo FRANTZ, com inclinação frontal de $10^{\circ}$, que dividiu o material em porções magnéticas e não magnéticas ao campo elétrico submetido, primeiramente de $0.5 \mathrm{~A}$. Em seguida a fração não magnética foi separada por líquidos densos, primeiro com Bromofórmio ( $\mathrm{d}=2.89$ $\left.\mathrm{g} / \mathrm{cm}^{3}\right)$ e depois com Iodeto de Metileno $\left(\mathrm{d}=3.325 \mathrm{~g} / \mathrm{cm}^{3}\right)$. Nestes processos a fração densa, que afunda nos líquidos, é o material de interesse, que ao fim voltou para o separador FRANTZ, desta vez com intensidades de $0.75 \mathrm{~A}$ e $1.0 \mathrm{~A}$. A porção não magnética a $1.0 \mathrm{~A}$, que concentra o zircão, foi separada. Por fim, os cristais de zircão foram catados com auxílio de lupa e pinça fina. Os cristais mais límpidos e sem fraturas ou inclusões foram montados em resina epoxi. Este mount foi então lixado até os cristais estarem na superfície, sendo em seguida polido e recoberto com uma fina camada de ouro (6.4 nm) antes de entrar na microssonda iônica para análise isotópica.

\section{I.2.9 Isotopia Sm-Nd}

Três amostras, as mais representativas de cada fácies granítica, foram analisadas a partir do material pulverizado de rocha total para concentrações de isótopos de Sm e Nd. A abertura das amostras e concentração dos elementos foi feita pelos técnicos do Laboratório Químico (CPGeo-USP). Análises foram realizadas por MC-ICP-MS em espectrômetro da marca Thermo Scientific, modelo Neptune Plus, no Laboratório de Espectrometria do CPGeo-USP, conforme procedimentos descritos por Petronilho (2009) e Souza (2009). Cálculos de $\varepsilon N d$ e idade TDM foram realizados a partir de planilhas fornecidas pelo próprio CPGeo-USP. 


\section{I.3 GEOLOGIA REGIONAL}

\section{I.3.1 Contexto Geológico}

O Leucogranito Inhandjara está inserido na Província Granítica Itu (Janasi et al., 2009), também chamada de Cinturão Itu (Vlach et al., 1991) e Província Rapakivi Itu (Wernick, 1992). A Província é composta por diversos batólitos graníticos póscolisionais alcali-cálcicos a calcio-alcalinos de alto K, com afinidades do tipo-A a do tipo-I Caledoniano (Vlach et al., 1991; Wernick, 2000; Janasi et al., 2009). Esses granitos são majoritariamente oxidados e intrudem rochas metamórficas supracrustais de médio a alto grau e granitoides sintectônicos correspondentes ao Terreno Apiaí-Guaxupé, que agrupa dois grandes segmentos tectônicos, a Nappe SocorroGuaxupé a norte (Figura 3A) e o domínio Apiaí-São Roque a sul (Janasi et al., 2009).

O Batólito Itu (Pascholati, 1990; Galembeck, 1997) compreende o maior volume granítico da Província Itu. É um corpo multicentrado, composto por quatro plutons graníticos principais (Itupeva, Salto, Indaiatuba e Cabreúva) do tipo-A. O Batólito é Ediacarano (590-580 M.a - Tassinari, 1988; Janasi et al., 2009), sendo localmente rapakivi e com rochas básicas subordinadas (Wernick, 2000). Apresenta forma irregular, de eixo maior NE-SW, com $30 \mathrm{~km}$ de extensão e em média $15 \mathrm{~km}$ de espessura no eixo menor, abrangendo um total de $300 \mathrm{~km}^{2}$ de exposição.

O Pluton Itupeva, aflorante na região mais ao norte, é composto majoritariamente por biotita monzogranitos de afinidade calcio-alcalina de alto- $K$, que variam em granulação. Comumente apresenta evidências de interação com magmas máficos, como aumento local na proporção de minerais máficos próximo a enclaves máficos de diversos tamanhos e com formação de corpos híbridos na região central da intrusão (Janasi et al. 2009). Foi dividido em oito fácies internas por Galembeck (1997). O Pluton Salto, que aflora à oeste do Batólito, é separado em três fácies (Pereira, 2013; Alves et al., 2015), e compreende anfibólio-biotita granitos rapakivi grossos, com ocorrências de pórfiro e rochas hololeucocráticas. Enclaves microgranulares félsicos são comuns, com enclaves máficos menos frequentes (Alves et al., 2015). O Pluton Indaiatuba, que ocorre na região central do Batólito, é descrito com uma única fácies de anfibólio-biotita sienogranito rapakivi porfirítico (Galembeck, 1997). O Pluton Cabreúva, presente na porção sul do Batólito, abrange onze fácies (Galembeck, 1997), e é o pluton mais volumoso do Batólito. É composto principalmente por ( \pm anfibólio) biotita granitos grossos, também apresentando rochas com textura rapakivi e alguns 
enclaves máficos e félsicos. Galembeck (1997) interpretou o Pluton Itupeva como o mais antigo, sendo localmente cortado por unidades pertencentes aos Plutons Indaiatuba e Cabreúva.

Os contatos intrusivos entre as rochas granitoides do Batólito Itu e suas unidades encaixantes são bruscos e cortam estruturas metamórficas principais, ocasionalmente com xenólitos angulosos (Pascholati, 1990). Não há evidências de metamorfismo de contato ou margens de resfriamento nas bordas dos corpos (Alves et al., 2015). Localmente, também são observados contatos tectônicos em zonas de cisalhamento (Galembeck, 1997), onde granitos e suas rochas encaixantes são deformados em diversos graus, desde cataclasitos a ultramilonitos.

Conforme os mapas geológicos da CPRM (Perrotta et al., 2005) o Batólito Itu (Figura 3) é intrusivo nos migmatitos que compõem a Nappe Socorro-Guaxupé (NSG), um terreno alóctone de rochas de alto grau metamórfico, definido por três unidades (Granulítica Basal, Diatexítica Intermediária e Migmatítica Superior - Campos Neto e Caby, 2000), colocadas sobre rochas supra-crustais de menor grau, durante o evento Brasiliano (Neves et al., 2014). A sul, o Batólito é delimitado pelos gnaisses metatexíticos a diatexíticos associados a rochas anfibolíticas da Unidade Migmatítica Intermediária da Nappe. A norte e leste, é delimitado pela Unidade Migmatítica Superior da NSG, composta majoritariamente por paragnaisses metatexíticos (Campos Neto et al., 2004), localmente intercalados com ortognaisses (Heilbron et al., 2008). A oeste, o Batólito ocorre parcialmente recoberto pela Bacia do Paraná, em inconformidade com as rochas sedimentares do Grupo Itararé (Perrotta et al., 2005).

No contexto tectônico, o Batólito Itu se insere na porção sul da Província Tocantins, na zona de confluência entre as faixas Brasília e Ribeira (Trouw et al., 2013; Heilbron et al., 2008), representada pela Nappe Socorro-Guaxupé.

Neste cenário temos o Leucogranito Inhandjara, que perfaz a borda nordeste do Batólito Itu, adjacente aos Plutons Itupeva a leste e Cabreúva a sul (Figura 3B). 

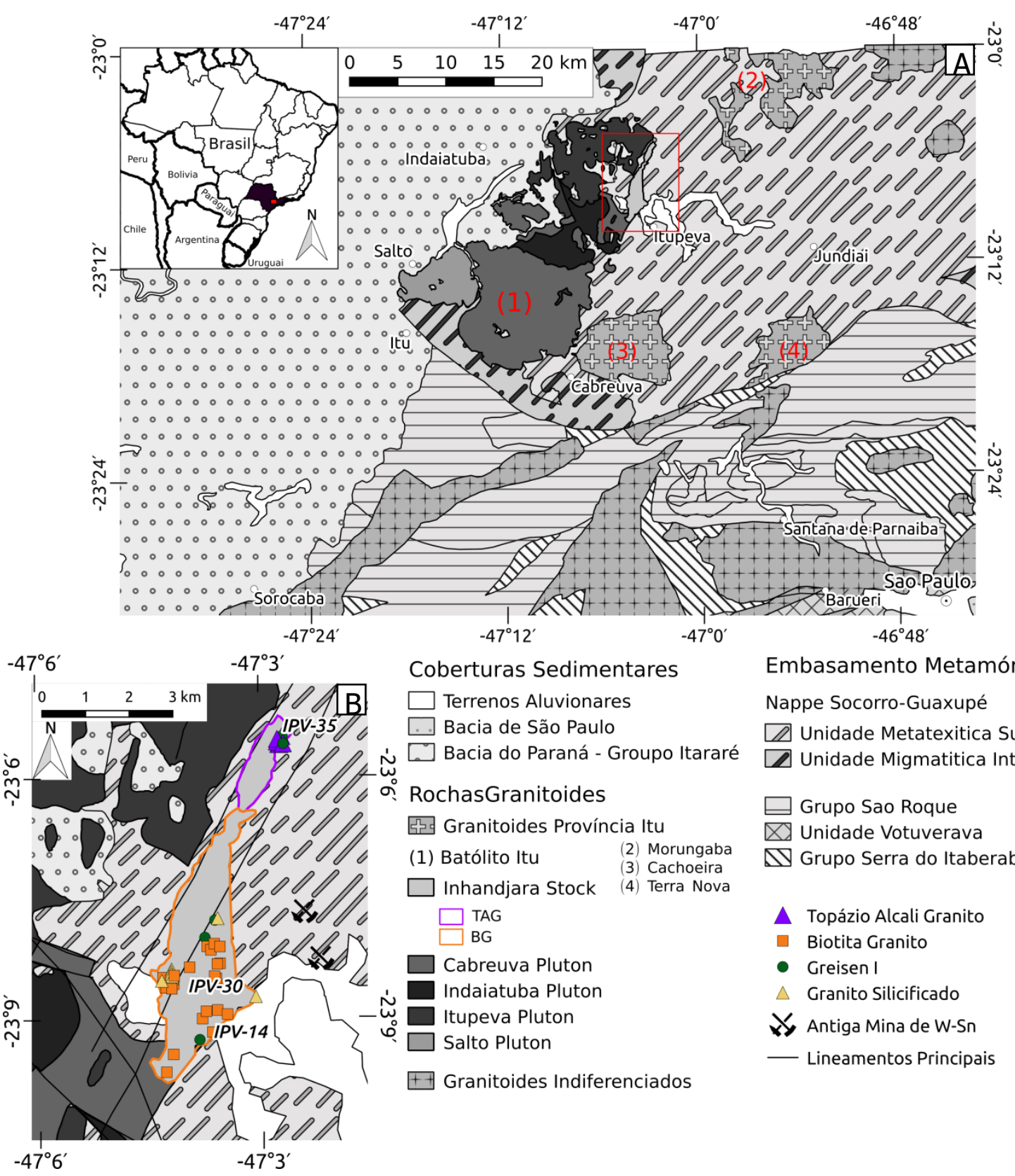

Coberturas Sedimentares

Embasamento Metamórfico

$\square$ Terrenos Aluvionares

Nappe Socorro-Guaxupé

. Bacia de São Paulo

C. Bacia do Paraná - Groupo Itararé

D Unidade Metatexitica Superior

RochasGranitoides

臣 Granitoides Província Itu

$\begin{array}{ll}\text { (1) Batólito Itu Morungaba } & \text { (2) }\end{array}$

(3) Cachoeira

Unidade Migmatitica Intermediaria

$\square$ Inhandjara Stock (4) Terra Nova

$\square$ Grupo Sao Roque

$\square$ Unidade Votuverava

$\triangle$ Grupo Serra do Itaberaba

$\square$ TAG
$\square$ BG
Cabreuva Pluton
Indaiatuba Pluton
$\square$ Itupeva Pluton
$\square$ Salto Pluton
$\square$ Granitoides Indiferenciados

A Topázio Alcali Granito

- Biotita Granito

- Greisen I

$\triangle$ Granito Silicificado

Xý Antiga Mina de W-Sn

— Lineamentos Principais

Figura 3: (A) Mapa litoestratigráfico regional com localização da área de estudo (polígono vermelho). (B) Mapa local da área de estudo, mostrando pontos visitados em campo (com rótulo nos afloramentos-chave) e localização da antiga mina. Conforme Galembeck (1997); Janasi et al. (2009); e Perrota et al. (2005).

\section{I.3.2 Trabalhos anteriores na área de estudo}

Trabalhos anteriores realizados no Batólito Itu consideram a área deste estudo como parte dos Plutons Itupeva e Cabreúva (e.g. Pascholati, 1990; Galembeck, 1997; Janasi et al., 2009).

Reynaldo Saldanha, em 1946, realizou trabalhos pioneiros na área da antiga Fazenda Inhandjara, região de contato do Batólito Itu com seu embasamento gnáissico onde aflora o Leucogranito alvo deste trabalho. $O$ trabalho de Saldanha é único, pois caracteriza detalhadamente a mineralização de wolframita, seus greisens e veios hospedeiros, o gnaisse encaixante e um biotita quartzo-pórfiro microgranito, que tem 
evolução diretamente relacionada ao granito local. O autor identificou três estágios evolutivos na região de Inhandjara: colocação dos corpos graníticos, seguida pela segregação de magmas tardios evoluídos e depois pela exsolução dos voláteis, que alteram hidrotermalmente os granitos e gnaisses encaixantes, onde ocorreu a precipitação dos metais. $\mathrm{O}$ autor constatou que o enriquecimento em topázio se correlaciona com o aumento da proporção de wolframita e cassiterita, sendo oposta à ocorrência de quartzo, atingindo ausência completa nas porções silicificadas.

Pascholati (1990) separou o Batólito Itu em dois grupos distintos. O primeiro, aflorante na porção sul do batólito, é dominado por hornblenda-biotita granitos inequigranulares, de textura seriada a porfirítica, localmente com texturas rapakivi, denominados Salto, Fazenda Japão e Fazenda Cruz Alta. O segundo grupo ocorre na porção norte do batólito e compreende biotita granitos equigranulares de granulação média a grossa, hololeucocráticos a leucocráticos, denominados Itupeva (Figura 4A).

A autora define o granito Itupeva como a intrusão de maior teor radioativo e de caráter mais evoluído, garantindo a categoria de maior produtor de calor ou corpo "mais quente" dentro da Província Itu. Ela ressalta ainda que as características estruturais (representa o topo de intrusão e possui uma profusão de fraturas preenchidas), petrológicas (intensa alteração hidrotermal e caráter oxidado) e radioativas (alto teor de elementos radiogênicos e elevada razão Th/U) do Granito Itupeva, o colocam em uma posição de grande destaque para estudos de processos metalogenéticos.

Leite e Zanardo (1994), definem a ocorrência do albita granito de Inhandjara na região de estudo, que corresponde à borda leste do Pluton Itupeva. O granito caracterizado pelos autores foi coletado pelo Prof. Heinz Ebert na antiga mina de wolframita, e corresponde a um álcali-feldspato granito equigranular fino a médio. Como fases acessórias de interesse apresenta mica litinífera, possível protolitionita a zinnwaldita, topázio, fluorita e cassiterita. De acordo com os autores o albita granito possui origem magmática, sendo a albita e o topázio formados em um estágio inicial, seguidos pelas fases intersticiais mica litinífera e fluorita. Assim de acordo com Leite e Zanardo (1994) o albita granito Inhandjara se relaciona diretamente com a mineralização de metais raros. 
Ribeiro (1994), analisando dados geofísicos e imagens de satélite, delimitou regiões dentro do Batólito Itu que podem representar fácies magmáticas mais evoluídas, relacionadas com processos metalogenéticos. $\mathrm{O}$ autor utilizou como critérios, alta resposta radiométrica, o decréscimo do conteúdo de $\mathrm{CaO}$, aumento na razão $\mathrm{Na}_{2} \mathrm{O} / \mathrm{K}_{2} \mathrm{O}$, e aumento do teor de $\mathrm{SiO}_{2}$. Uma destas regiões delimitadas corresponde à porção nordeste do Pluton Itupeva, na área da Pedreira Tocantins (atual Pedreira Viracopos), localizada a norte do município de Itupeva.

O autor indica que o granito equigranular fino a médio, com biotita, topázio e arfvedsonita, que aflora na Pedreira Tocantins, é um foco de alteração hidrotermal dentro do Batólito de Itu. Na pedreira ocorre grande profusão de fraturas, localmente mineralizadas com sulfetos (pirita, calcopirita, pirrotita, esfalerita e galena) e raros veios de quartzo puro. $O$ autor afirma que este processo mineralizante é distinto do que gerou a mineralização de wolframita na Mina de Inhandjara. Ele caracteriza dois processos distintos: um primeiro relacionado com eventos magmáticos, formando depósitos de tungstênio; e um segundo relacionado com a remobilização de fluidos e metais a partir de grandes falhamentos regionais, formando sulfetos.

De acordo com Galembeck (1997) ocorrem quatro diferentes litologias na área de estudo (Figura 4C), três pertencentes ao Pluton Itupeva (IP2, 4 e 6) e uma ao Pluton Cabreúva (CB7). A fácies IP2 é caracterizada por biotita sienogranitos porfiríticos de matriz média a grossa, cinza rosado, com IC entre 11 e 14\%. A fácies IP4 é um biotita monzogranito róseo inequigranular médio a grosso, de IC entre 3\% e 7\%. A fácies IP6 são sieno- a monzogranitos rosados a avermelhados equigranulares média, com IC entre $1.5 \%$ e $3 \%$. Uma característica própria dessa fácies é presença de microclínio pertítico (com lamelas de albita chessboard), oligoclásio zonado (com bordas albíticas e alteração diferencial) e biotita acastanhada. Essas três fácies apresentam em comum titanita, opacos, apatita, zircão e "pseudomorfos" de allanita como acessórios. E por fim, a fácies CB7 do Pluton Cabreúva é definida como quartzo sienito a sienogranito com biotita e raro anfibólio, rosado a avermelhado, equigranular médio a grosso, com IC entre $2 \%$ e $5 \%$ e fluorita como fase acessória intersticial.

Ferreira (1991) e Pascholati et al. (1997) apresentam dados geofísicos regionais (Figura 5), que possibilitam delimitar o contorno dos corpos graníticos e ressalta as anomalias radioativas, gravimétricas e magnetométricas, possivelmente relacionadas à atividade hidrotermal. Estas anomalias se associam à processos mineralizantes 
(Pascholati, 1990). A área de Inhandjara possui destaque para estudos metalogenéticos, pois é interpretada por esta autora como um High Heat Producing Granite, com altos teores de K, U e Th, se destacando das unidades ao redor (Figura 5). Essas anomalias correspondem a zonas de intensa atividade magmato-hidrotermal, que leva à concentração destes elementos radioativos nas unidades mais evoluídas.

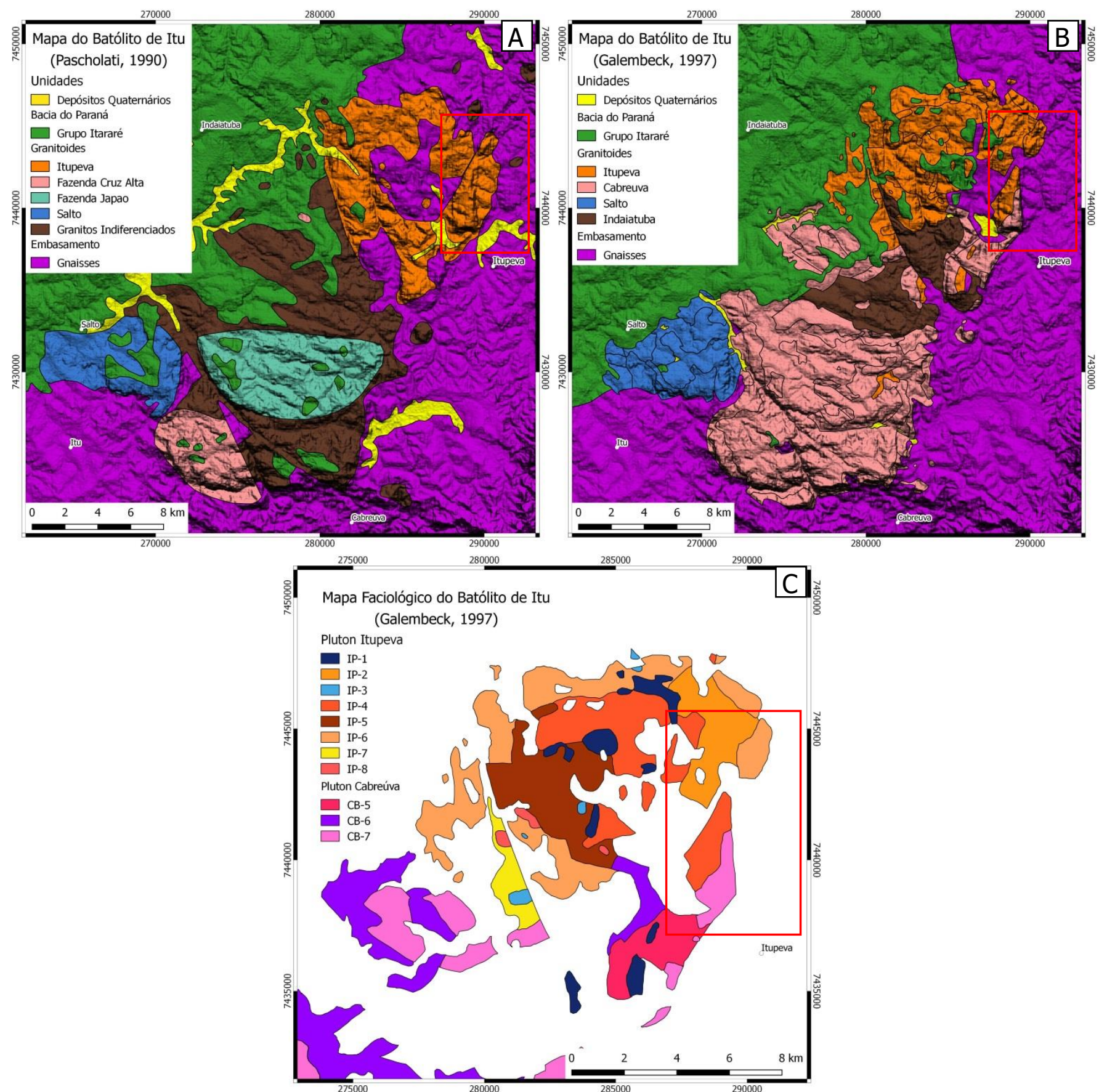

Figura 4: Mapa geológico para o Batólito Itu, conforme apresentados por Pascholati (1990) (A) e Galembeck (1997) (B) com destaque para a área de estudo (polígono vermelho). (C) Mapa faciológico da porção norte do Batólito de Itu, conforme definido por Galembeck (1997). 


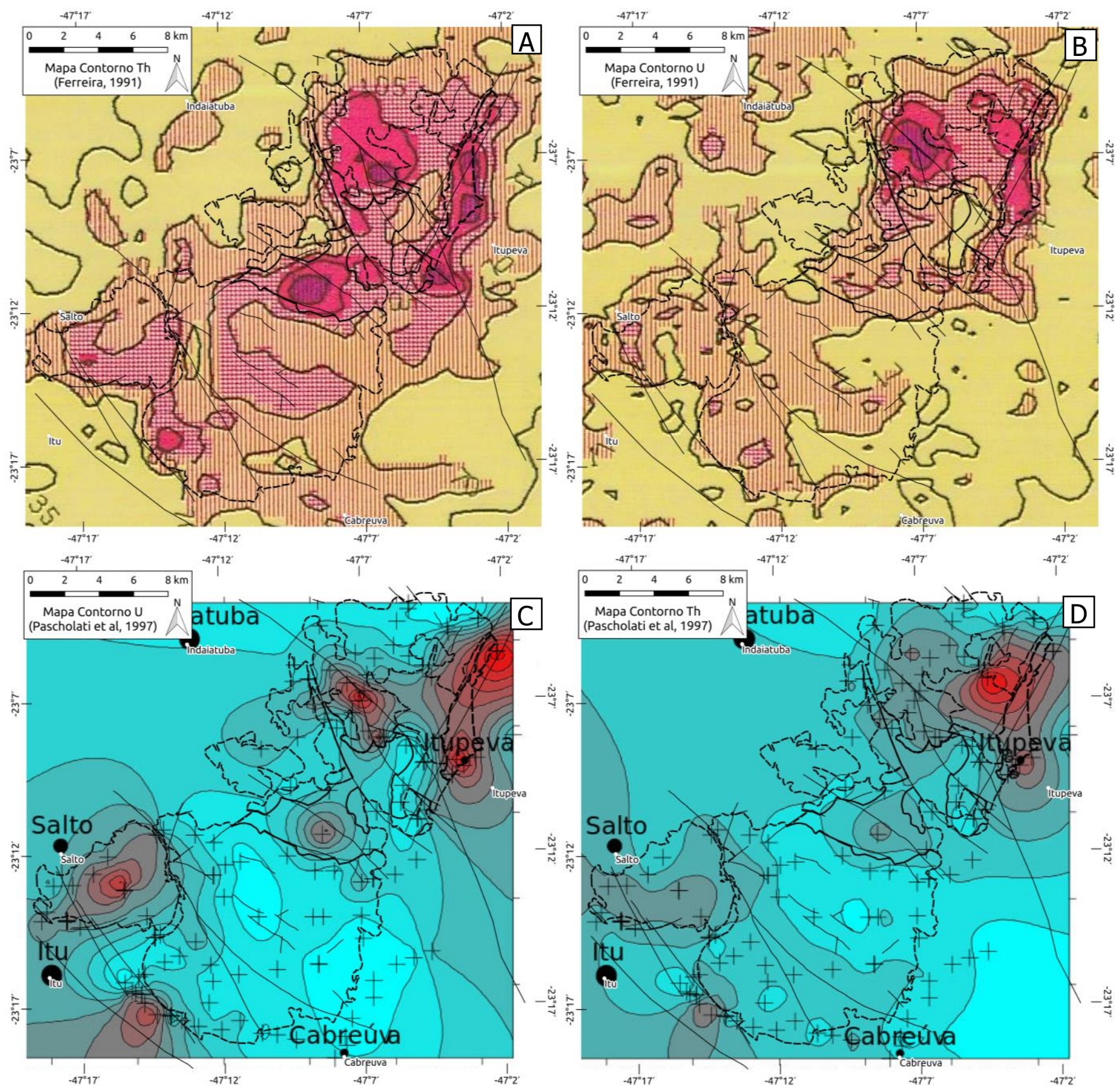

Figura 5: Mapas de gamaespectrometria aérea (A e C), produzidos por Ferreira (1991), e de campo (B e D), produzidos por Pascholati et al. (1997), para os canais de Th (A e B) e U (C e D), juntamente com o contorno do batólito de Itu (linha preta tracejada). 


\section{CAPÍTULO II - O LEUCOGRANITO INHANDJARA}

\section{II.1 CARACTERÍSTICAS DE CAMPO}

Chapter 1 Os locais amostrados se concentram na porção norte do município de Itupeva (Figura 6), em quatro localidades principais, correspondentes às unidades descritas abaixo: (1) parte norte da cidade (IPV-14); (2) área do Condomínio Colinas de Inhandjara (IPV-30); (3) área da Pedreira Viracopos (IPV-35); (4) região do Bairro da Mina, local da antiga Mina de Inhandjara, que hospeda os veios de quartzo e topázio mineralizados (Saldanha, 1946).

Os pontos visitados durante as etapas de campo foram divididos, segundo características composicionais e texturais, em quatro fácies petrográficas: Três foram identificadas como granitos hololeucocráticos isotrópicos, sendo relacionadas ao Leucogranito Inhandjara (Biotita Granito porfirítico, Biotita Granito inequigranular e Topázio Granito equigranular); e uma correspondente aos gnaisses encaixantes.

Os locais visitados mostram evidência de intensa alteração hidrotermal, com a coloração avermelhada típica do Batólito Itu. Essa alteração tardi- a pós magmática é caracterizada pela substituição das fases primárias, aumento da granulação, coloração dos feldspatos até tons vermelhos e formação de matriz filossilicática fina de cor esverdeada. Com a progressão da alteração, há aumento na proporção matriz/cristais.

Geomorfologicamente, o Leucogranito Inhandjara ocorre na forma de dois morros arredondados e alinhados que se destacam na topografia (Figura 7A), além de pequenos morrotes à volta. $O$ corpo do Leucogranito forma um stock satélite ao Batólito Itu e é separado dos plutons adjacentes (Itupeva a leste e Cabreúva a sul) por regiões mais erodidas e intemperizadas, que correspondem ao gnaisse encaixante alterado. $\mathrm{O}$ stock comumente aflora como pequenos blocos esparsos (medindo entre 10 e $60 \mathrm{~cm}$, que às vezes alcançam cerca de 1,5 m de diâmetro) ou como lajedos rochosos nas regiões de maior altitude. Essa feição contrasta com os chamados "mar de blocos" típicos do Batólito Itu, caracterizado por afloramentos de diversos matacões arredondados aglomerados. A área de estudo alcança as maiores altitudes da região (Figura 7B), dando mais um destaque para o Leucogranito Inhandjara.

A Pedreira Viracopos (IPV-35) é o único local onde o contato intrusivo do Leucogranito com o gnaisse encaixante pode ser observado (Figura 11G), onde localmente forma xenólitos angulares métricos do gnaisse dentro do granito. 


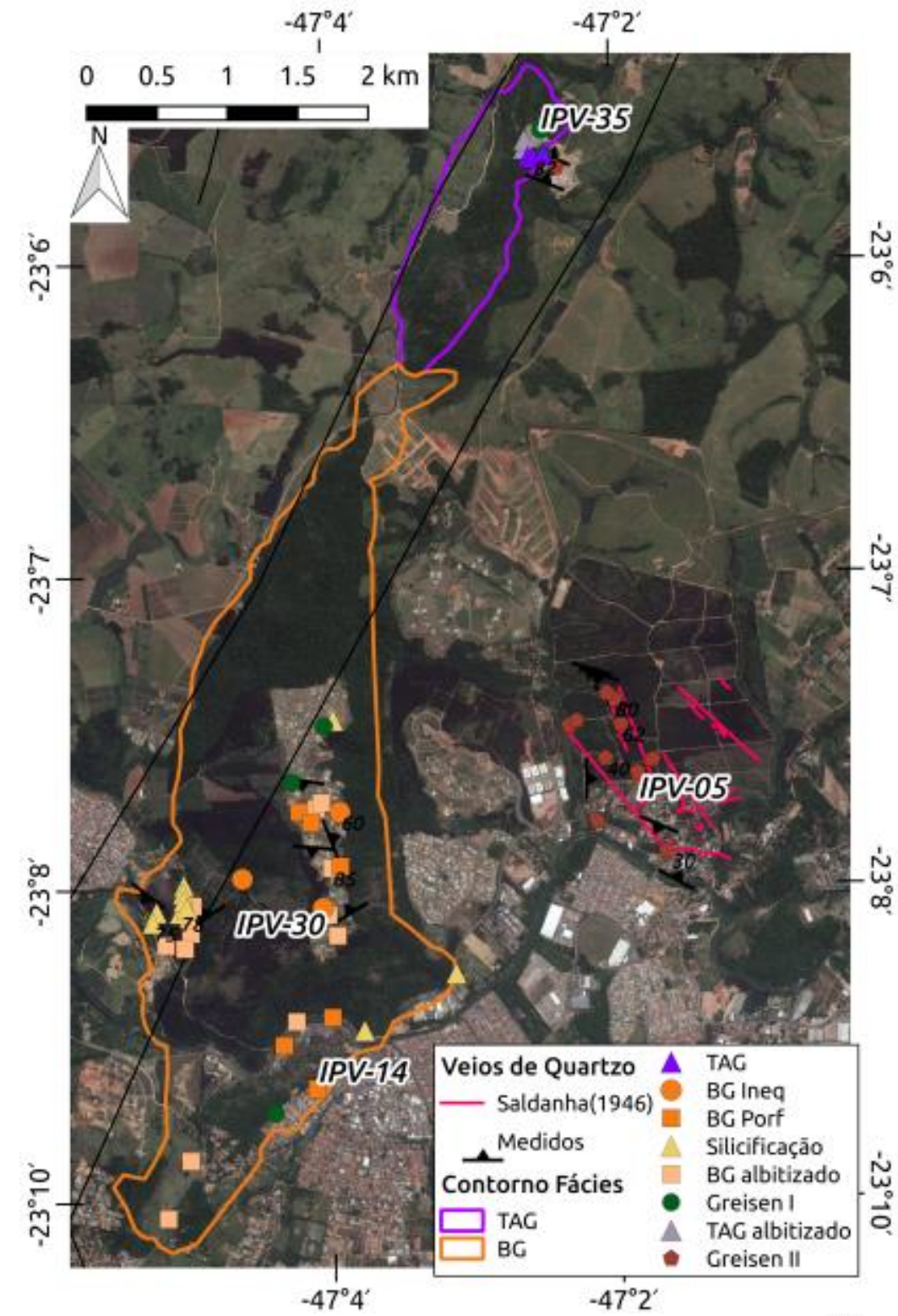

Figura 6: Imagem de Satélite do Google Earth mostrando a região de estudo com os pontos visitados em campo, os limites inferidos para as fácies locais e comparando os veios de quartzo encontrados em campo com os descritos por Saldanha (1946). $\underset{0}{\tilde{\omega}}$
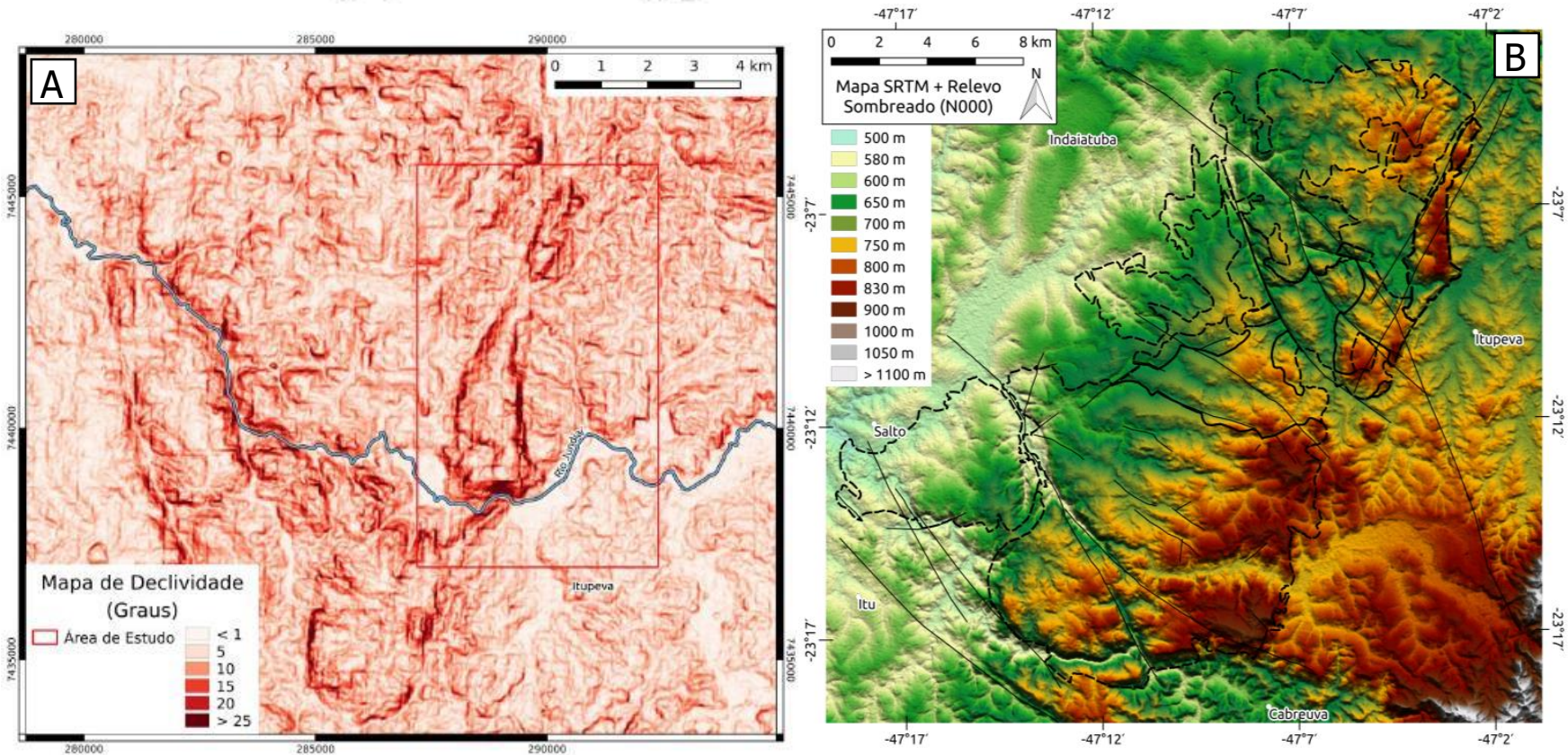

Figura 7: (A) Mapa local de declividade em graus, obtido a partir de imagem SRTM. Destaque para área de estudo (polígono vermelho). (B) Mapa de elevação regional (dados de SRTM), com o limite do Batólito Itu (linha preta tracejada). 
Medidas radiométricas obtidas a partir da gamaespectrometria de campo demonstram que a fácies porfirítica apresenta a maior emissão no canal de K (Figura $8 \mathrm{~A})$, sendo superada apenas por bolsões sieníticos presentes entre essa fácies e 0 Biotita Granito inequigranular. Comparando a relação entre amostras muito e pouco alteradas, temos que a concentração de $\mathrm{K}$ tende a diminuir com o hidrotermalismo, exceto na fácies equigranular onde ocorre inversão deste comportamento.

Considerando os valores de Th e $U$, há uma sobreposição nos teores de Th entre as fácies; enquanto a fácies equigranular se mostra mais enriquecida em $U$ que as demais (Figura 8B). As amostras mais hidrotermalizadas tendem a aumentar a concentração de Th. As fácies porfirítica e inequigranular apresentam comportamento similar na razão Th/U, enquanto a fácies equigranular apresenta menores razões.

As análises realizadas em xenólitos gnáissicos dentro da fácies equigranular, mostram que a encaixante neste contexto possui valores radiométricos próximos aos fornecidos pelo granito desta fácies.
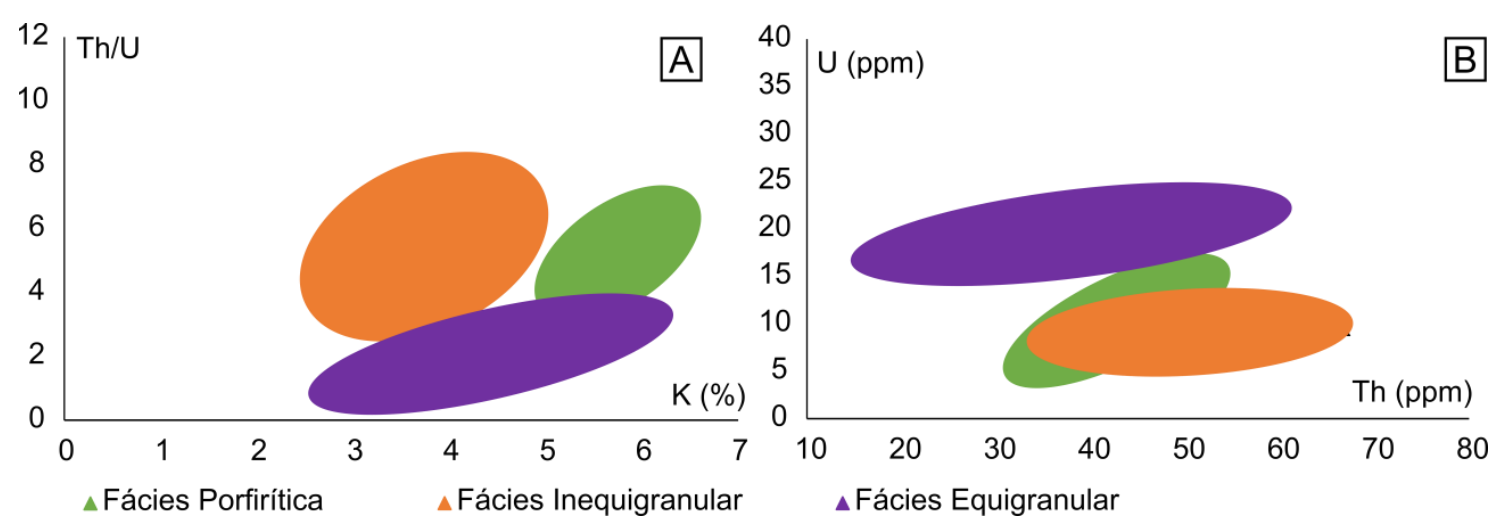

Figura 8: Diagramas binários para dados gamaespectrométricos de campo, separando as fácies identificadas neste trabalho. (A) Th/U vs. K (\%). (B) U vs. Th (ppm).

\section{II.1.1 Biotita Granito Pofirítico}

O Biotita Granito porfirítico ocorre na porção sul do stock Inhandjara. Sua principal exposição se dá no ponto IPV-14 (Figura 9A), localizado dentro da cidade de Itupeva (Figura 6). Em campo apresenta coloração bege a rosada, podendo chegar a termos avermelhados, devido à progressiva coloração dos feldspatos, e esverdeados, por substituição das fases primárias por fases hidrotermais (e.g., sericita e clorita).

A estrutura desse granito é homogênea e maciça, com textura porfirítica definida por megacristais bege de feldspato potássico subédrico (variando de 1 a $2 \mathrm{~cm}$ ) em matriz inequigranular média a grossa (Figura 9B e C). Este apresenta composição monzogranítica, mas com proporção considerável de feldspato alcalino na forma de 
megacristais ( $8 \%)$. 0 índice de cor $\left(\mathrm{M}^{\prime}\right)$ varia de 3 a $4 \%$, sendo a biotita a principal fase máfica presente (porém já bastante cloritizada, se tornando esverdeada).

Localmente ocorrem cristais esparsos de feldspato alcalino sub-arredondado manteado por plagioclásio (Figura 9D), sendo uma feição rara e que não corre nos megacristais. Portanto o uso do termo rapakivi foi evitado, ficando apenas como uma característica textural distintiva das demais fácies.

Quando essa fácies ocorre na borda do corpo apresenta-se fortemente silicificada, sendo, por vezes, totalmente transformada em rocha quartzosa maciça. Veios de quartzo são comuns nessa região, e ocasionalmente apresentam cavidades com formação de pequenos cristais de quartzo prismático facetado.
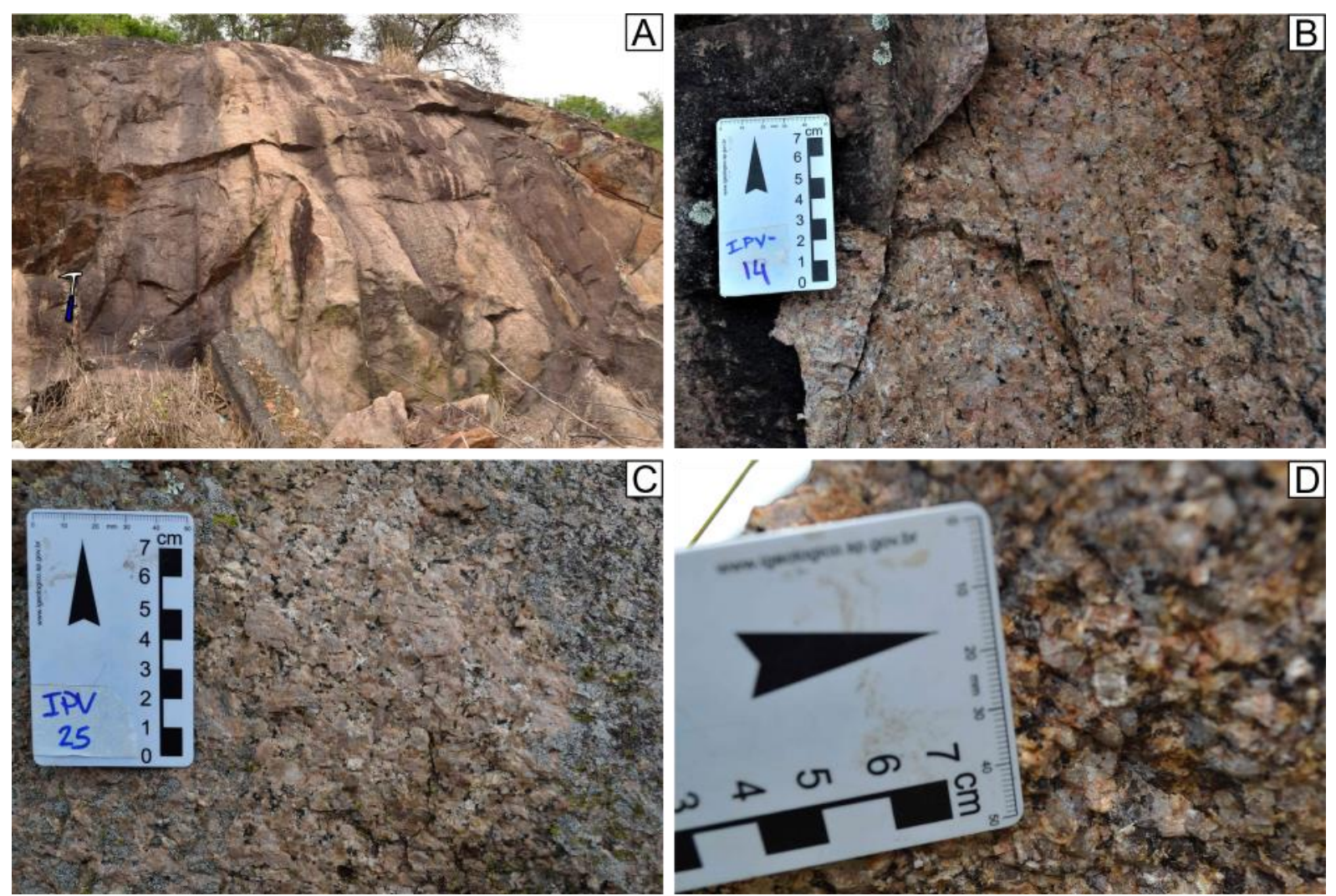

Figura 9: (A) Afloramento da localidade-tipo da fácies porfirítica (IPV-14) mostrando ocorrência na forma de morrotes de rocha. (B) Aspecto de campo do granito da fácies porfirítica com coloração bege e megacristais de feldspato potássico. (C) Aspecto da fácies em afloramento dentro do condomínio Colinas de Inhandjara, destacando megacristais de feldspato potássico em meio a matriz de granulação média-grossa. (D) Ocorrência local de cristais de feldspato alcalino bege manteado por plagioclásio branco, IPV-24.

\section{II.1.2 Biotita Granito Inequigranular}

A principal exposição desta fácies ocorre no centro do stock, correspondendo ao Condomínio Colinas de Inhandjara. Seu afloramento-tipo se localiza na região da portaria do residencial (ponto IPV-30 - Figura 6). Esta fácies ocorre variando em coloração de rosada a avermelhada, podendo tornar-se bem vermelha e bem esverdeada quando com maior grau de alteração hidrotermal. 
Sua estrutura é predominantemente maciça, mas exibe variações locais para porções mais brechadas e foliadas quando o grau de metassomatismo é muito alto. Possui textura inequigranular média a fina (Figura 10A e B), e raramente alcança termos grossos (Figura 10C). Apresenta composição monzogranítica, é hololeucocrático, com índice de cor ( $\left.\mathrm{M}^{\prime}\right)$ variando de 2 a 4\%, e tem biotita como única fase máfica primária.

A presença de stockworks de quartzo é comum no granito (Figura 10D). Alguns afloramentos mostram grande profusão de vênulas milimétricas de quartzo puro ou com clorita, que podem gradar para veios mais espessos, atingindo até cerca de 50 $\mathrm{cm}$. A porção sudoeste da fácies, região de contato do corpo com as rochas encaixantes, é caracterizada por alta densidade destes veios de quartzo puro, formando enxames de veios com cristais euédricos que substituem totalmente a rocha original.
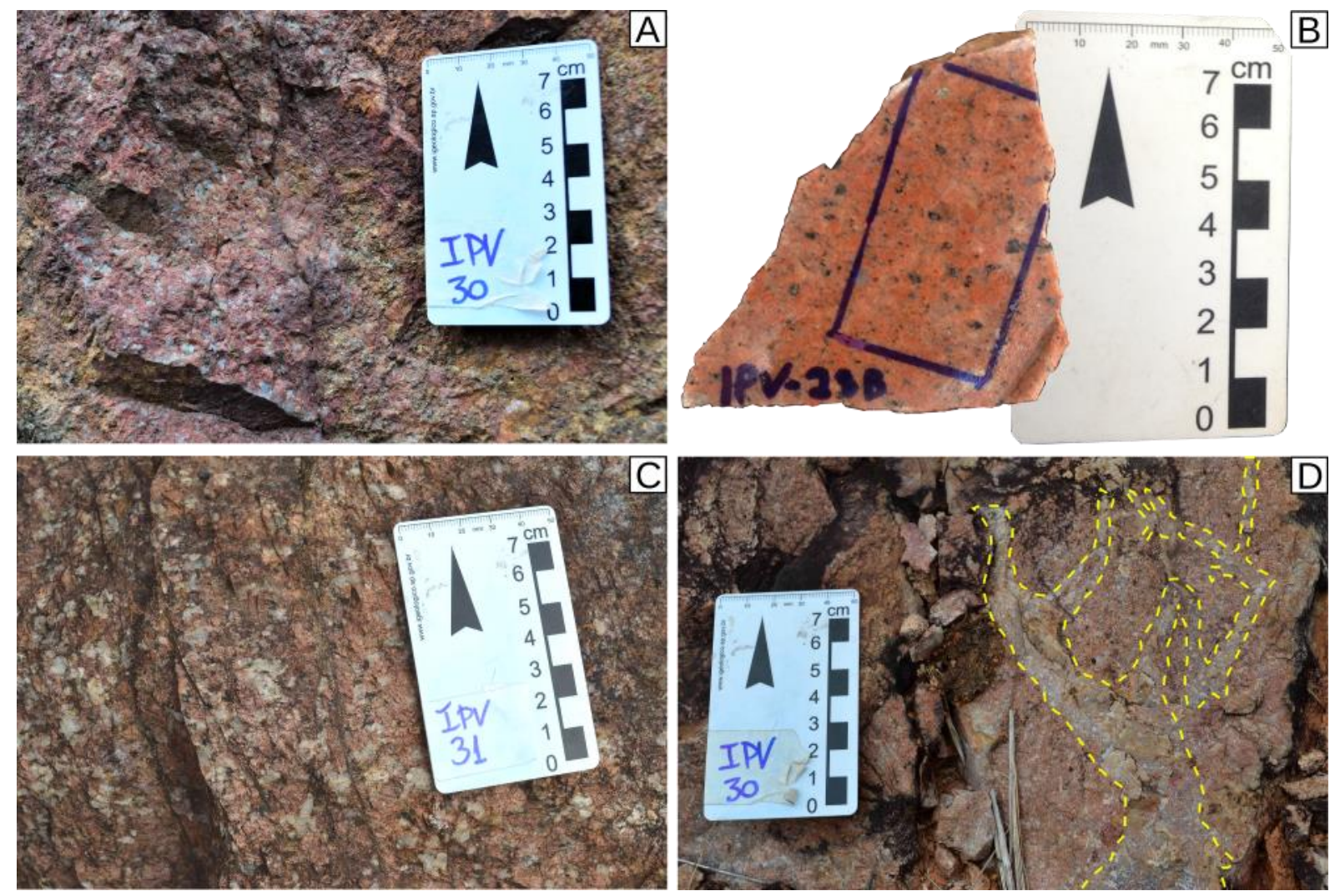

Figura 10: (A) Aspecto de campo do biotita monzgogranito (BG) inequigranular médio bem hidrotermalizado no afloramento-tipo da fácies, IPV-30. (B) Amostra do BG inequigranular apresentando granulação mais fina, IPV28. (C) Aspecto do BG inequigranular apresentando granulação mais grossa, IPV-31 (D) Amostra do BG inequigranular cortado por stockwork centimétrico de quartzo e silicificado, IPV-30. 
Há ocorrência rara de rocha sienítica muito grossa (episienito? - ver item II.3), composta apenas por cristais de feldspato alcalino euédrico e de cor vermelha intensa (ver Figura 30A, item II.3). Esta rocha aparece na região central do Stock, no Biotita Granito, entre afloramentos das fácies Inequigranular e Porfirítica. Aparece como blocos esparsos, sem relações claras na transição para os granitos, ou como bolsões métricos dentro dos granitos. Apresenta estrutura maciça a localmente brechada.

\section{II.1.1 Topázio Granito equigranular}

Esta fácies se localiza no extremo norte do Stock formando um morro ligeiramente isolado. Sua principal exposição é a Pedreira Viracopos (ponto IPV-35, Figura 6), administrada pela companhia Embu S.A. A cava (Figura 11A) registra toda a transição hidrotermal do Leucogranito, desde porções com textura equigranular média, coloração branca a cinzenta e preservando as fases ígneas (Figura 11B), até termos bem avermelhados de granulação mais grossa e fases ígneas bastante substituídas (Figura 11C). Ocorre também a greisenização fissural substituindo o granito original para associações de Li-muscovita, clorita, quartzo, fluorita e sulfetos. Em geral, a intensidade da alteração hidrotermal na cava tende a aumentar na direção noroeste.

Também está presente um leucogranito com textura equigranular fina, presente na forma de enclaves arredondados (5 - $10 \mathrm{~cm}$ de diâmetro) e corpos irregulares interdigitados com as porções de granulação média (Figura 11D). Apresenta contatos sinuosos, transicionais a bruscos, com o granito principal e possui mineralogia idêntica a este. Essas rochas variam de cor cinzenta até avermelhada (Figura 11E).

Litologicamente a pedreira é bastante homogênea, sendo caracterizada como álcalifeldspato ( $K f s+A b)$ granito maciço e hololeucocrático ( $M^{\prime}$ variando entre 2 e $3 \%$ ), tendo biotita como única fase máfica. Porém diversas feições locais podem ser encontradas, como a presença irregular de bolsões aplíticos e pegmatíticos centimétricos (Figura 11F). Estes são compostos por feldspatos alcalinos, quartzo e massas de sericita e clorita (às vezes apresentam molibdenita e galena nos contatos com granito hospedeiro). Alguns planos de fraturas são preenchidos com fluorita roxa ou massas estriadas de sericita; além de raras vênulas carbonáticas. 

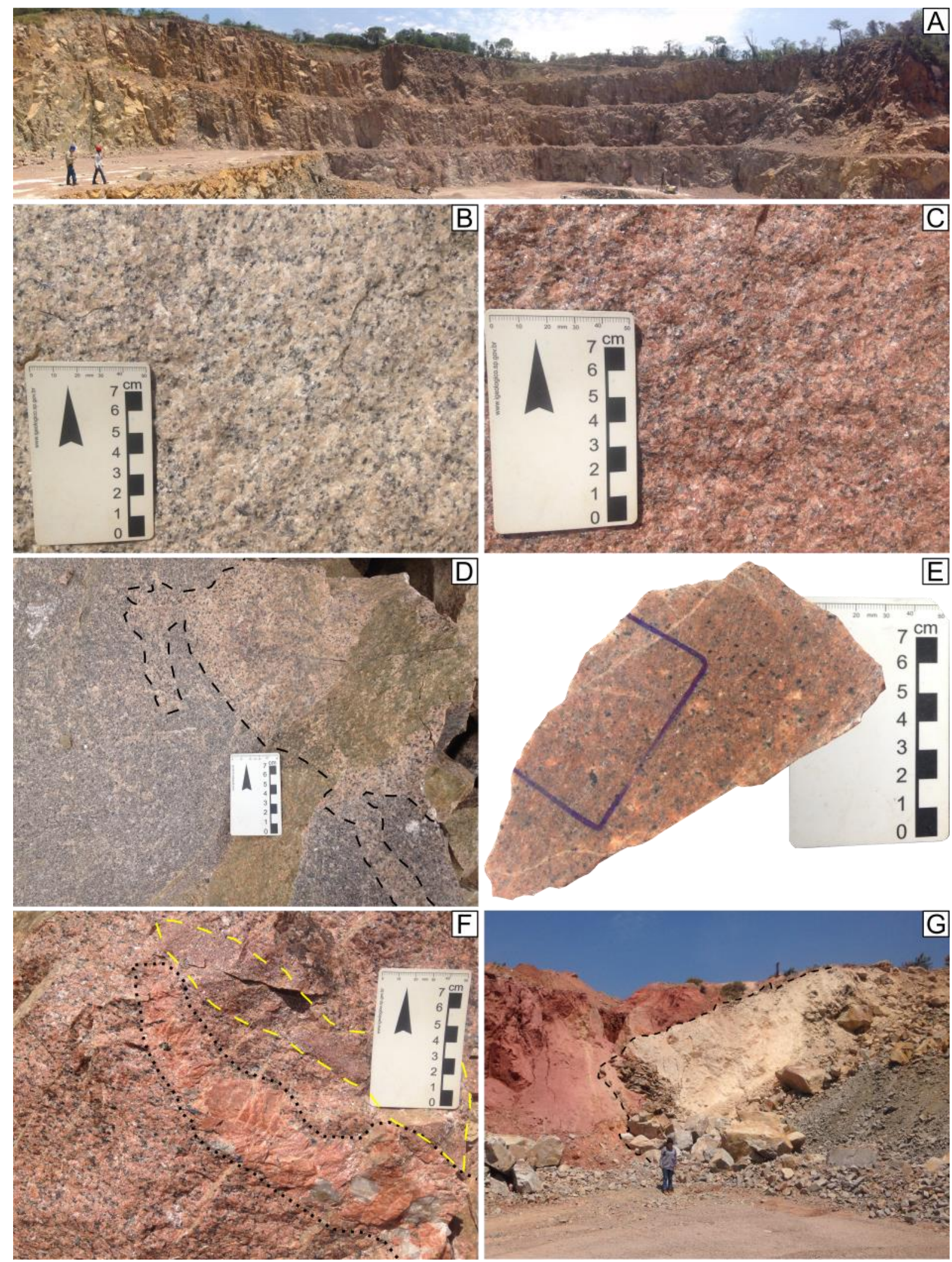

Figura 11: (A) Vista panorâmica da Pedreira Viracopos, (IPV-35) afloramento-tipo da fácies equigranular, campo de visão WSW-ENE, com o centro da imagem aproximadamente para noroeste. (B) Aspecto de campo da rocha esbranquiçada que preserva fases ígneas. (C) Aspecto de campo da rocha vermelha com fases primárias substituídas e recristalizadas. (D) Relação de contato (linhas preta tracejada) entre o leucogranito principal, lado direito superior, e porção cinzenta de granulação fina, maior área da imagem. (E) Aspecto de amostra do leucogranito fino quando ocorre avermelhado. (F) Bolsão pegmatítico (linha preta pontilhada) com borda aplítica (linha amarela tracejada) em meio ao leucogranito. (G) Afloramento no lado leste da Pedreira Viracopos mostrando o contato (linha tracejda) entre o granito, saprólito esbranquiçado, com gnaisse encaixante, saprólito avermelhado. 
Também há alta densidade de veios hidrotermais com muscovita verde-clara e clorita verde-escura associadas a sulfetos disseminados. Esses veios podem formar halos centimétricos de greisen e envoltos por região de consumo dos minerais máficos do granito. É comum a ocorrência de brechas em associação aos greisens, tendo matriz micácea esverdeada que envolve clastos do granito.

$\mathrm{Na}$ borda leste da cava aflora o gnaisse encaixante, muito intemperizado na forma de saprólito vermelho e refletindo contato intrusivo do Leucogranito (Figura 11G). Alguns xenólitos angulares de gnaisse, mais bem preservados, ocorrem com variado grau de alteração hidrotermal, sendo a cloritização das micas e granadas o processo principal.

\section{II.1 PETROGRAFIA}

O Stock Inhandjara é constituído por pelo menos dois tipos dominantes de leucogranitos (Figura 12): um biotita monzogranito (BG), que engloba as fácies porfirítica e inequigranular, e um álcali-feldspato granito (TAG), que corresponde à fácies equigranular. Ambos apresentam variação no tamanho dos grãos, porém o BG ocorre em um intervalo maior, com o TAG sempre próximo a equigranularidade. Mineralogicamente (Figura 13) é composto majoritariamente por quartzo anedral, feldspato potássico pertítico e plagioclásio sódico ou albita euédrica, tendo biotita com Li, fluorita, muscovita, ilmenita e zircão recorrentes, além de fases mais restritas (e.g. topázio). A análise petrográfica das fácies foi complementada por MEV, que possibilitou a distinção das fases acessórias (e.g., bastnasita-parisita, columbita-tantalita).

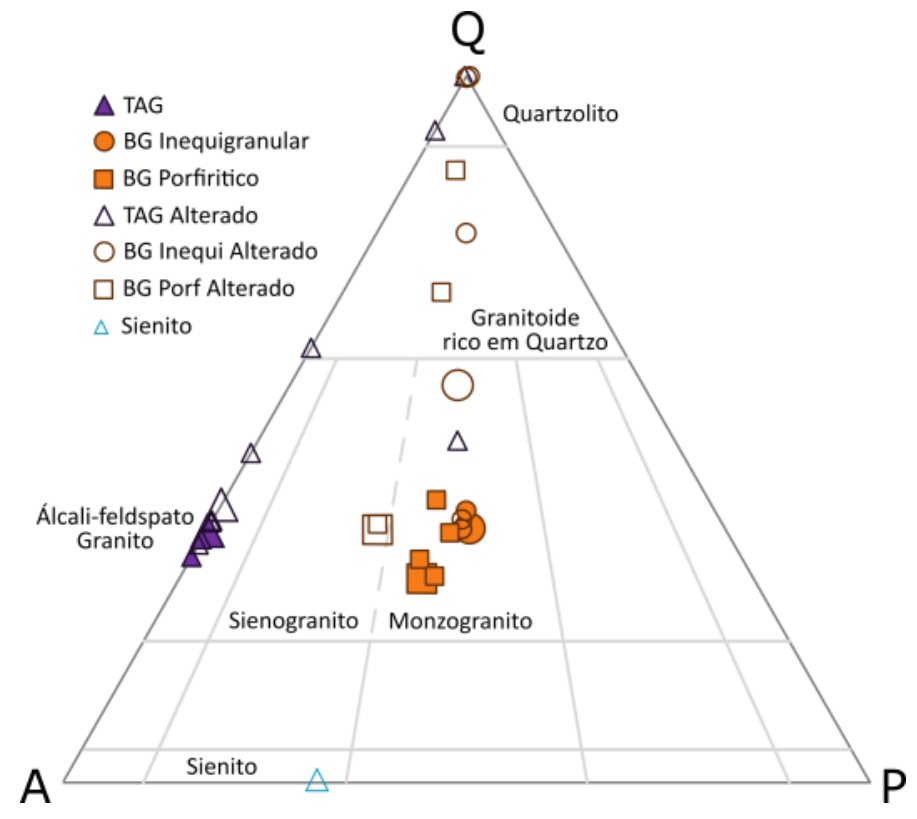

Figura 12: Análises modais das fácies do granito Inhandjara em diagrama QAP (Le Maitre et al., 2002). Símbolos maiores representam amostras tipo de cada fácies, com contagem de pontos. 

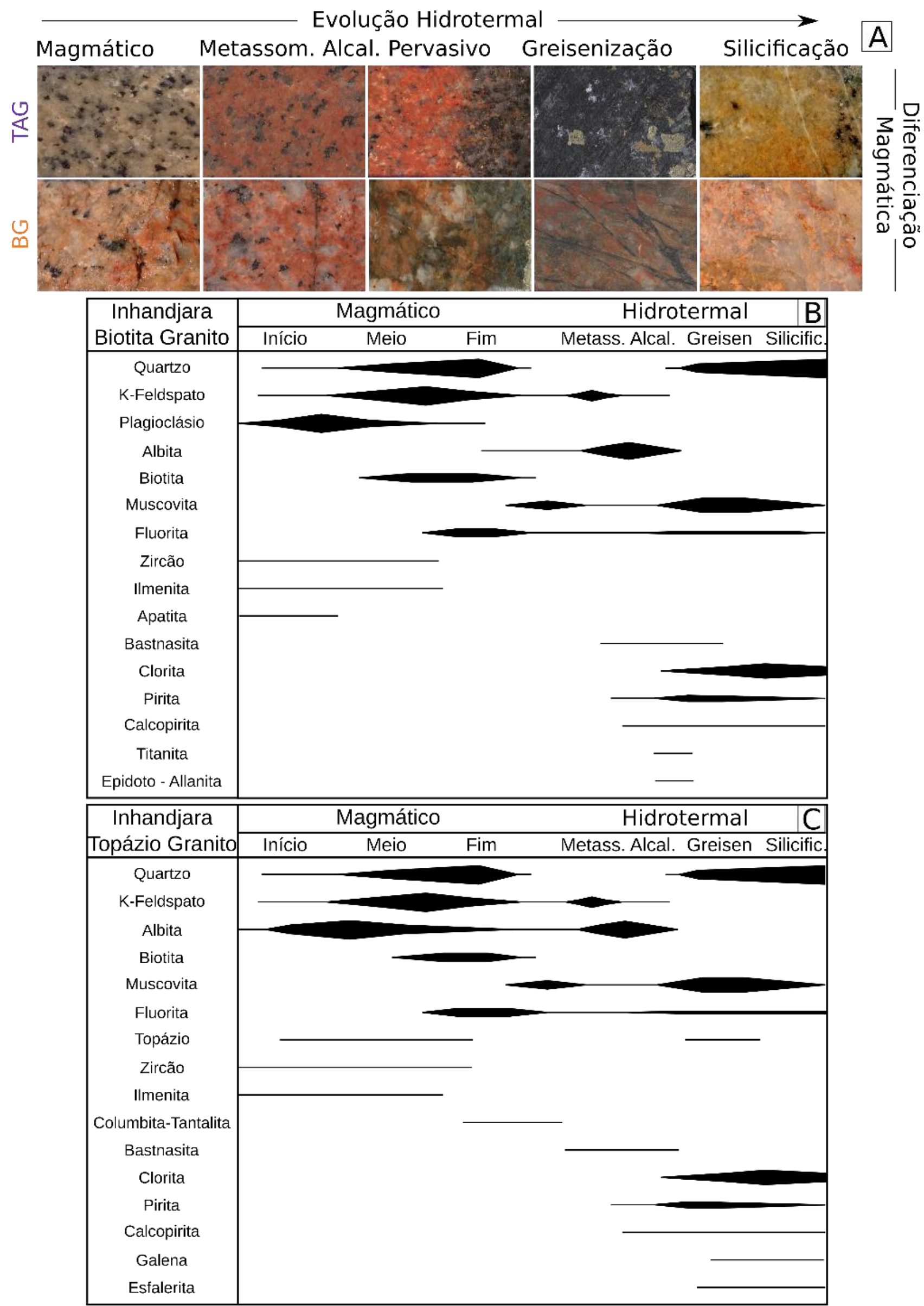

Figura 13: (A) Variação textural no Stock Inhandjara conforme grau de diferenciação magmática e de metassomatismo. (B) Tabela paragenética para o Biotita Granito mostrando a distribuição mineral conforme o estágio magmato-hidrotermal. (C) Tabela paragenética para o Topázio Granito. 


\section{II.1.1 Biotita Monzogranito com fluorita e apatita (BG Porfirítico)}

Este grupo apresenta microestrutura isotrópica e textura hipidiomórfica inequigranular porfirítica de matriz média a grossa, e com presença de alguns ( 8\%) megacristais centimétricos de feldspato potássico. Apresenta coloração bege a avermelhada.

Feldspato potássico (35-40\%) ocorre como a fase de maior tamanho das amostras, comumente formando megacristais euédricos, que localmente envolvem cristais e aglomerados de plagioclásio (Figura 14A), ou como grãos subédricos a anédricos na mesostase. Frequentemente são pertíticos (lamelas albíticas irregulares - Figura 14E algumas com albita geminada e orientada), sem geminação aparente ou com inclusões de plagioclásio e quartzo (Figura 16A). É comum se apresentarem alterados, quando passam a ter aspecto turvo e manchado. Os megacristais podem apresentar zonalidade nessa alteração (coloração vermelha, turbidez e manchas), com núcleos subédricos a euédricos moderadamente alterados sobrecrescidos por bordas anedrais de intensa turbidez (Figura 14B). O contato entre essas zonas normalmente é marcado por intercrescimentos com quartzo arredondado e vermicular (Figura 14A e B).

Os cristais de quartzo (27-35\%) são anédricos, de contatos irregulares a lobados, e intersticiais. Também aparecem como inclusões arredondadas e/ou intercrescidos com os feldspatos (Figura 14B). Quando mais grosso pode exibir leve extinção ondulante. Quartzo também ocorre como fase secundária juntamente com clorita em vênulas hidrotermais tardias e stockworks.

O plagioclásio (25-30\%) ocorre como cristais euédricos a subédricos com geminação polissintética e baixos teores da molécula de anortita ( $\left(\mathrm{An}_{0-15}\right)$. Usualmente apresenta-se zonado, com núcleo turvo bem formado envolto por borda anedral límpida (Figura 14C). Estas bordas são albíticas e ocorrem bem desenvolvidas nos contatos com feldspato potássico, mas ausentes quando em contato com quartzo. Parte dessa albita também ocorre de forma intergranular entre os cristais de feldspatos (Figura 14D), com indicativos de migração das lamelas no feldspato potássico para as bordas (Figura 14E). É comum o plagioclásio ocorrer manchado, sendo parcialmente substituído por feldspato potássico (Figura 14F). 
Biotita (0-2\%) é o mineral máfico primário principal. Os cristais são subédricos a anédricos, localmente intersticiais. Apresenta inclusões de feldspatos e minerais opacos alinhados na clivagem (Figura 15A). Possui forte pleocroísmo, com coloração variando desde castanho "enferrujado" até verde escuro.

Em quase todas as amostras analisadas, a biotita se encontra completamente substituída por clorita (3-5\%). Esta possui coloração esverdeada escura e pleocroísmo leve a moderado (Figura 15C). Comumente ocorre sobre as fases magmáticas (Figura 15D) em associação com opacos, muscovita e quartzo (Figura 16F), e localmente aparece junto com fluorita, titanita e epidoto (Figura 15E). Também está presente na forma de pequenos cristais euédricos junto com quartzo em vênulas hidrotermais tardias que cortam toda a estrutura da rocha.

Localmente, ocorre muscovita (1-2\%) levemente pleocróica, variando de incolor a castanho claro sem hábito definido. Por vezes é intersticial às fases primárias, com contatos retos para estas; ou aparentemente preenchendo bolsões na mesostase (Figura 15B) intercrescida com clorita (e escassa ilmenita - Figura 16B).

Minerais acessórios são caracterizados como: fluorita, subédrica a anédrica, com aspecto intersticial em relação às fases ígneas (Figura 15F), comumente apresenta zonalidade de cor e diversas inclusões; Minerais opacos, ilmenita (Figura 16E) e sulfetos (pirita e calcopirita) subédricos a euédricos; Apatita, presente como cristais euédricos, normalmente inclusos em quartzo, fluorita e nos pseudomorfos de biotita cloritizada (Figura 16C); Zircão ocorre como pequenos cristais subédricos a euédricos incolores, alguns sendo fraturados (Figura 16D); e Rutilo aparece como cristais anédricos associados às bordas de ilmenita.

\section{II.1.1 Biotita Monzogranito com fluorita (BG Inequigranular)}

O biotita monzogranito inequigranular apresenta microestrutura isotrópica e textura hipidiomórfica inequigranular seriada fina a grossa, predominando granulação média. Sua coloração é majoritariamente avermelhada, às vezes chegando a termos róseos.

Quartzo (30-35\%) é cinzento e anédrico, ocorre intersticialmente, com contatos lobados para outras fases. Raramente aparece como inclusões arredondadas nos feldspatos ou em biotita. Cristais mais grossos apresentam leve extinção ondulante. Também ocorre juntamente com clorita em vênulas hidrotermais tardias (Figura 17A), sendo que algumas amostras muito silicificadas apresentam completa substituição do granito original formando rochas de puro quartzo (Figura 19F.) 
Feldspato potássico (28-32\%) ocorre como cristais anédricos a subédricos, às vezes de forma intersticial, sem geminação aparente e moderadamente turvos. Frequentemente são pertíticos (com lamelas albíticas na forma de patches irregulares - Figura 17A), com aspecto manchado e moderadamente turvos. Apresentam inclusões de quartzo arredondado, plagioclásio euédrico e micas. Localmente ocorre a formação de bordas albíticas trocadas nos contatos entre cristais de feldspato potássico (Figura 17D). Estas são marcadas por albita subédrica nas bordas de um cristal, mas em continuidade ótica com o grão adjacente e nas bordas do grão adjacente, em continuidade ótica com o primeiro cristal.

Plagioclásio (28-31\%) ocorre como cristais euédricos a subédricos com geminação polissintética, levemente turvos e com baixos teores de anortita ( $\left(A n_{0-15}\right)$. Usualmente apresentam-se zonados, com núcleo turvo bem formado, envolto por borda albítica límpida irregular Figura 17B). Estas bordas se desenvolvem apenas nos contatos com cristais de feldspato alcalino, sendo ausentes contra o quartzo (Figura 17C). Localmente aparecem raros cristais intersticiais de albita, onde alguns destes podem ocorrer com geminação do tipo tabuleiro de xadrez (Figura 17E).

Biotita (0-1\%) é o mineral máfico primário principal e se apresenta subédrica a anédrica. Possui forte pleocroísmo, com coloração esverdeada de tonalidades escuras (Figura 18A). Pode se relacionar com cristais mais grossos de fluorita zonada, apresentando contatos retilíneos, de aspecto estável. Apresenta inclusões de quartzo, ilmenita, além de zircão e monazita (rara).

Em grande parte das amostras desta unidade, a biotita se encontra totalmente substituída por clorita (Figura 18C, D e E) em associação com feldspato potássico, fluorita, minerais opacos e argilominerais (possivelmente caulinita), muscovita (Figura 20A) e aglomerados fibro-radiados de bastnasita. A clorita (2-5\%) tem coloração esverdeada e pleocroísmo moderado. Além de preencher os pseudomorfos de biotita, também ocorre intercrescida com muscovita pleocróica e ilmenita em cristais isolados na mesostase (Figura 19A) ou como pequenos cristais euédricos junto com quartzo e rara fluorita (Figura 19C) em vênulas hidrotermais tardias na forma de stockworks (Figura 19D) que cortam outras fases magmáticas e hidrotermais (Figura 19E). 
Localmente, aparecem cristais euédricos a anédricos intersticiais de muscovita levemente pleocróica (1-2\%), apresentando contatos retilíneos com feldspatos e fluoritas na mesostase (Figura 18B) ou então anédrica nas bordas dos pseudomorfos de biotita cloritizados (Figura 20B) e minerais opacos nas bordas e fraturas de pseudomorfos de biotita. Raramente ocorre como cristais subédricos inclusos em quartzo, dentro de zonas ricas em inclusões fluidas próximas às vênulas hidrotermais (Figura 18F).

Minerais acessórios são: fluorita, anédrica a subédrica, de aspecto intersticial com contatos retos para plagioclásio e lobados com quartzo e feldspato potássico (Figura 17F). Comumente possui zoneamento de cor e químico, com zonas ricas em inclusões de cor roxa de composição normal $\left(\mathrm{CaF}_{2}\right)$ e zonas límpidas incolores com presença de Y na estrutura (Figura 20C); Minerais opacos, como ilmenita e raros sulfetos, são subédricos a euédricos; Zircão, ocorre como pequenos cristais subédricos a euédricos (Figura 20D) incolores a levemente acastanhados. O zircão se apresenta bastante zonado com zonas ricas em $\mathrm{Th}$ e $\mathrm{Nb}$, que raramente envolvem núcleos de rutilo portador de Nb (Figura 22); Rutilo, aparece na forma cristais bem escuros e anédricos, comumente manteando cristais de ilmenita (Figura 20E); Minerais de ETR (Figura 21 - bastnasita-parisita?) presentes como aglomerados de cristais aciculares fibroradiados inclusos nas micas cloritizada e fluoritas (Figura 20F). 

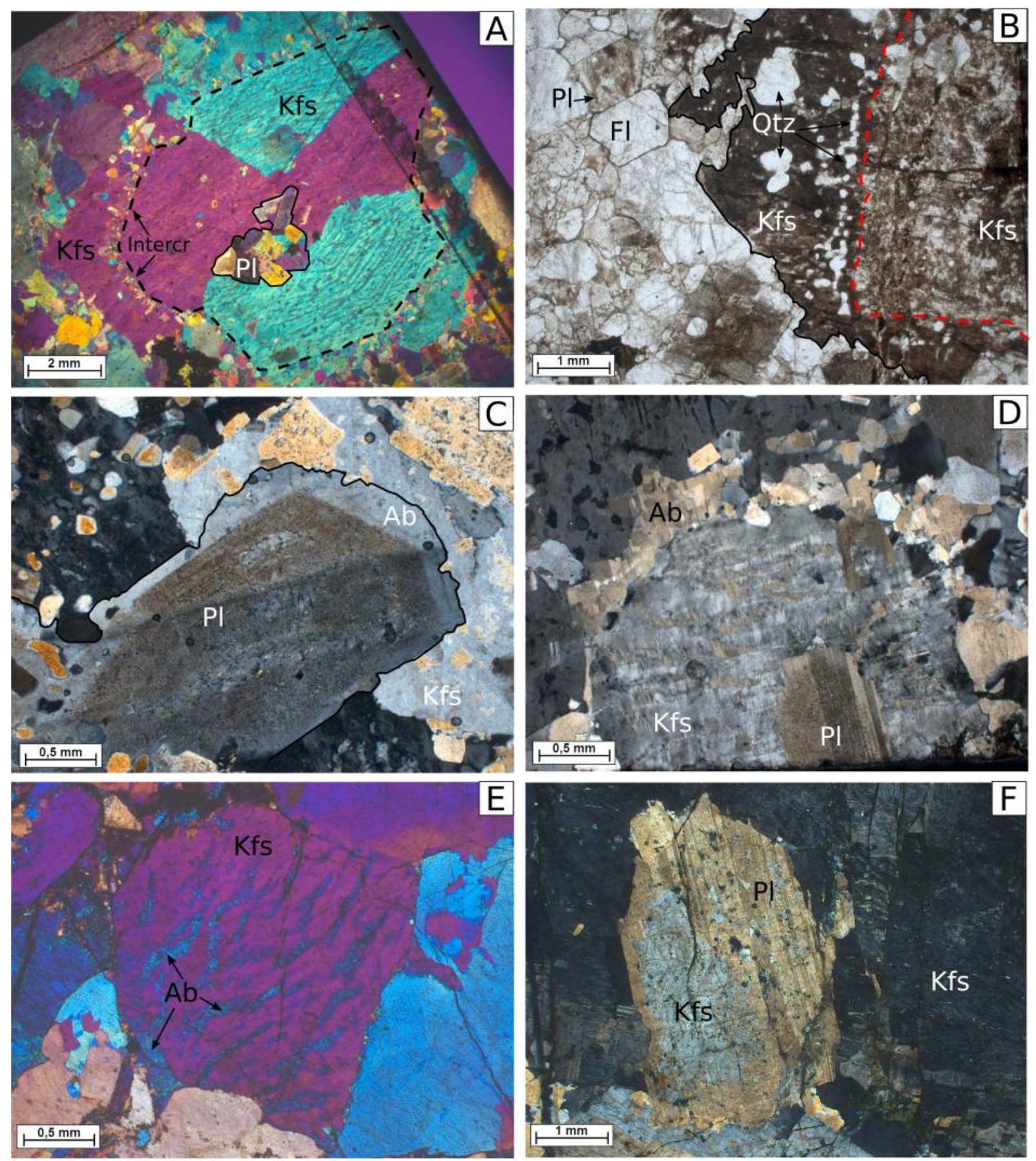

Figura 14: Fotomicrografias dos feldspatos presentes no Biotita Granito Porfirítico. (A) IPV-14 - Megacristal de feldspato potássico mostrando geminação setorial, tipo ampulheta. Apresenta núcleo subédrico (linha preta tracejada), e sobrecrescimento anédrico marcado por região de intercrescimento com quartzo vermiforme e arredondado. O megacristal também envolve um aglomerado de cristais de plagioclásio euédricos (linha contínua). Polarizadores cruzados e com placa de gipso (B) IPV-28A - Megacristal de feldspato alcalino de núcleo subédrico (linha tracejada vermelha) com borda sobrecrescida anédrica e mais turva (linha preta contínua) envolvendo cristais arredondados a subédricos de quartzo. Ao lado ocorre cristal de fluorita de contatos retos com fases magmáticas. Polarizadores paralelos (C) IPV-14 - Plagioclásio de núcleo euédrico fortemente sericitizado e turvo sobrecrescido por borda albítica límpida e irregular. Notar que a forma do sobrecrescimento varia a conforme o contato passa de um cristal para outro, e que esta tende a envolver os cristais de albita inclusos no feldspato potássico ao lado. Polarizadores cruzados. (D) IPV-14 - Megacristal de feldspato potássico com lamelas albíticas irregulares e formação de albita intergranular em seu contato externo. Também envolve cristal de plagioclásio sericitizado, que desenvolve borda albíticas límpida com geminação paralela à geminação das lamelas e albita intergranular. Polarizados cruzados (E) IPV-06A - Cristal de feldspato potássico com lamelas albíticas irregulares que tendem a migrar para a borda do cristal e se acumular no contato com outro feldspato. Polarizadores cruzados e com placa de gipso. (F) IPV-16A - Cristal subédrico de plagioclásio com mancha irregular de feldspato potássico sem geminação aparente. Polarizadores cruzados. Siglas utilizadas: Kfs - feldspato potássico, PI - plagioclásio, Qtz quartzo, Fl - fluorita, Ab - albita. 

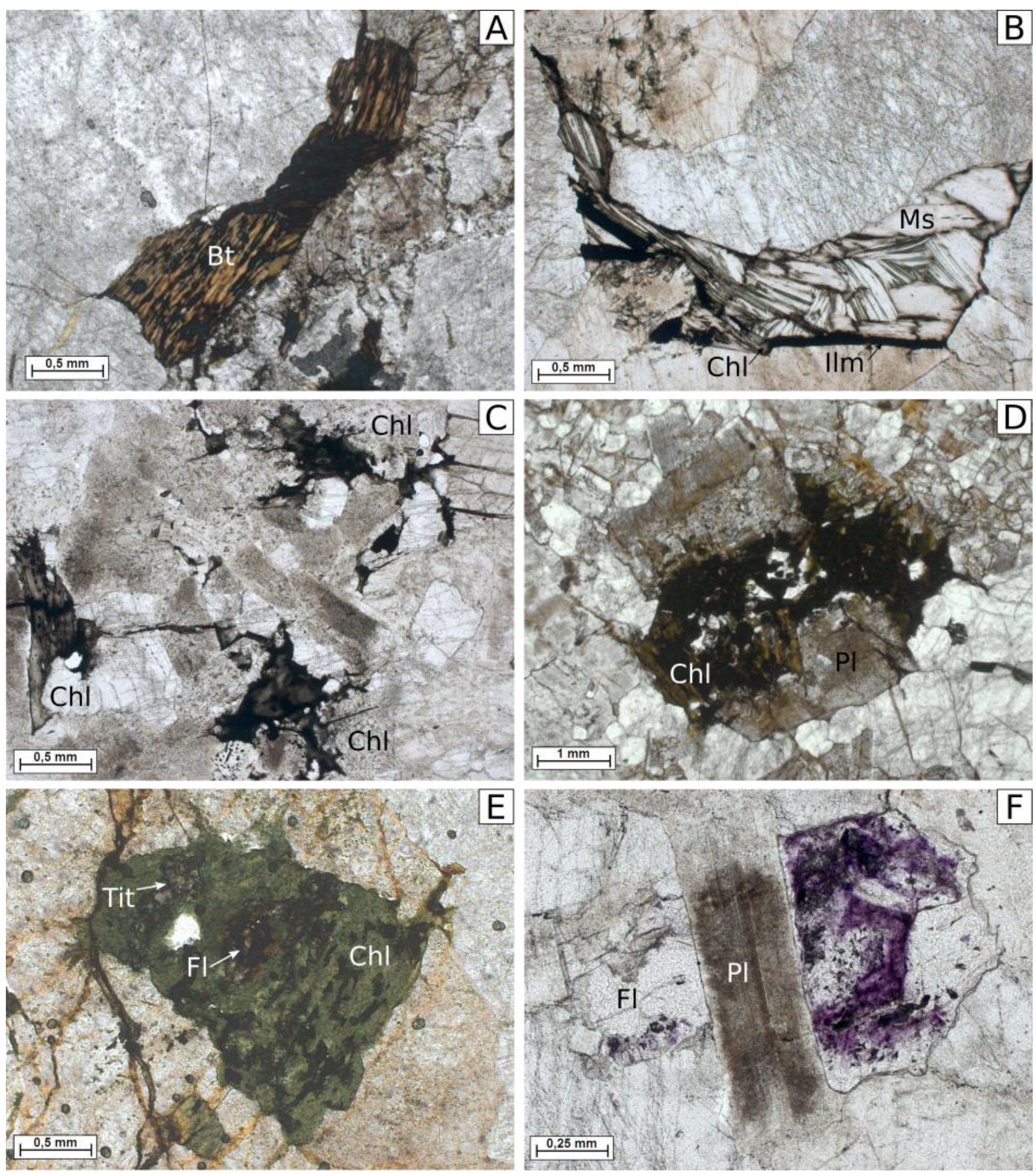

Figura 15: Fotomicrografias dos filossilicatos e minerais acessórios presentes no Biotita Granito Porfirítico. (A) IPV-06A - cristal de biotita oxidada mostrando diversas inclusões de minerais opacos. Polarizadores paralelos. (B) IPV-14 - Bolsão preenchida por muscovita pleocróica euédrica intercrescida com clorita e associada a ilmenita nas bordas do bolsão. Polarizadores paralelos. (C) IPV-14 - Cristais anédricos de clorita cinzenta associados a minerais opacos e interpretados como pseudomorfos de biotita. Polarizadores paralelos. (D) IPV-28A - Cristal anédrico de clorita intercrescida com minerais opacos e quartzo crescendo sobre núcleo de plagioclásio turvo e fraturado. Polarizadores paralelos. (E) IPV-16A - Cristal de clorita associado com cristais anedrais de titanita e fluorita. Interpretada como pseudomorfo de biotita. Polarizadores paralelos. (F) IPV-14 - Cristal intersticial de fluorita zonada, mostrando porções arroxeadas cheias de inclusão e áreas incolores límpidas, em contato reto com plagioclásio euédrico com núcleo turvo e borda albítica. Polarizadores paralelos. Siglas utilizadas: Bt - biotita, Ms muscovita, Chl - clorita, Ilm - ilmenita, PI - plagioclásio, FI - fluorita, Tit - titanita. 

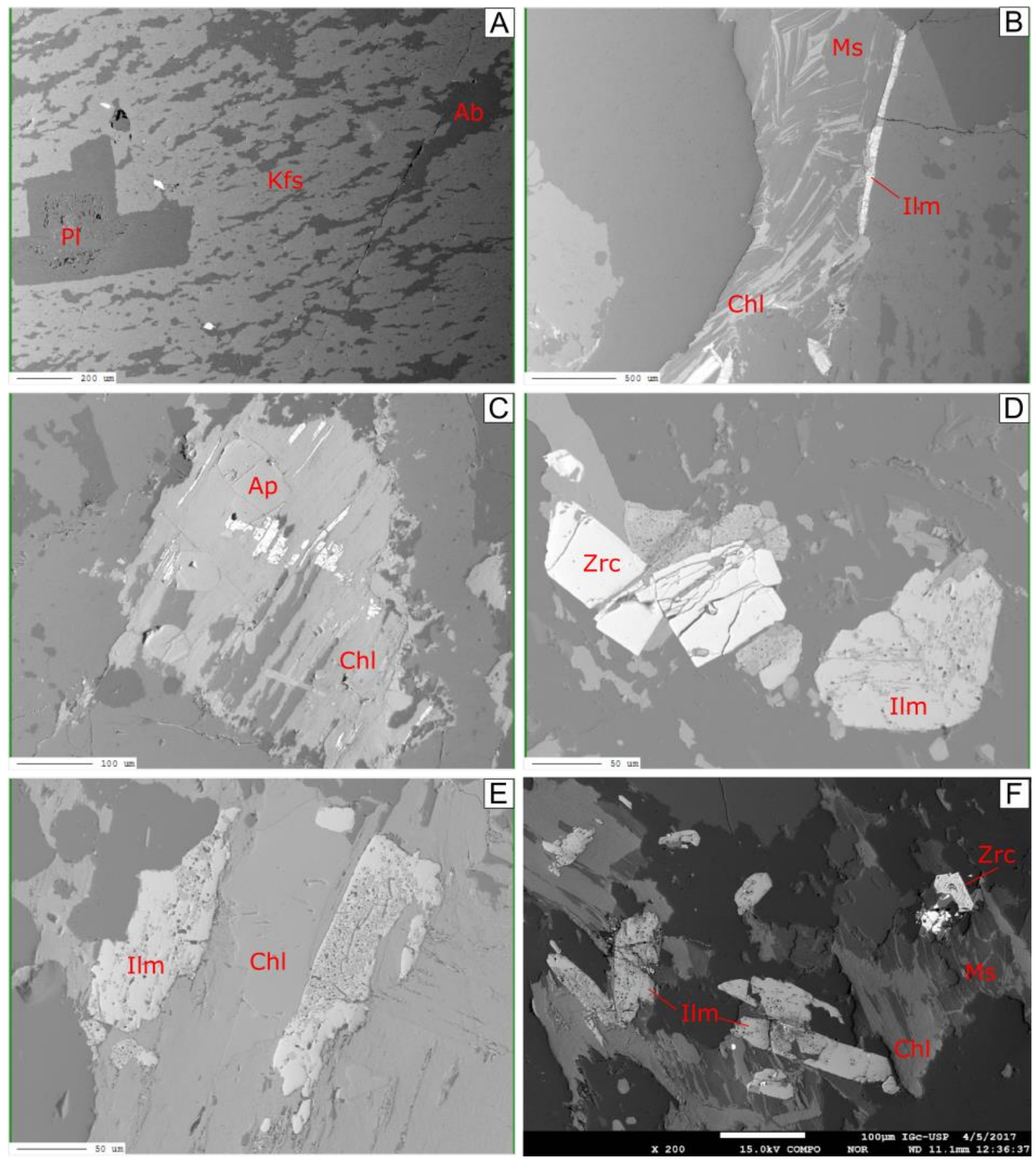

Figura 16: Imagens de elétrons retro-espalhados para o Biotita Granito Porfirítico. (A) Megacristal de feldspato potássico pertítico, com lamela irregulares de albita e envolvendo cristais euédricos de plagioclásio. Notar que a resposta na imagem BSE é idêntica para as lamelas e os cristais inclusos. (B) Bolsão preenchido por muscovita euédrica intercrescida com clorita e bordejada por ilmenita. Mesmo local da Figura 15B. (C) Cristal anédrico de clorita associada a ilmenita e muscovita (pseudomorfo de biotita) com inclusões de apatita subédrica. (D) Cristal de zircão fraturado sendo manteado por ilmenita. (E) Cristais subédricos de ilmenita associados a clorita. (F) Aglomerado de minerais acessórios em volta de pseudomorfos de biotita. Ilmenita zonada com bordas de rutilo e muscovita intercrescida com clorita. Siglas utilizadas: Kfs - feldspato potássico, Ab - albita, Pl - plagioclásio, Chl clorita, Ms - muscovita, Ilm - ilmenita, Ap - apatita, Zrc - zircão. 

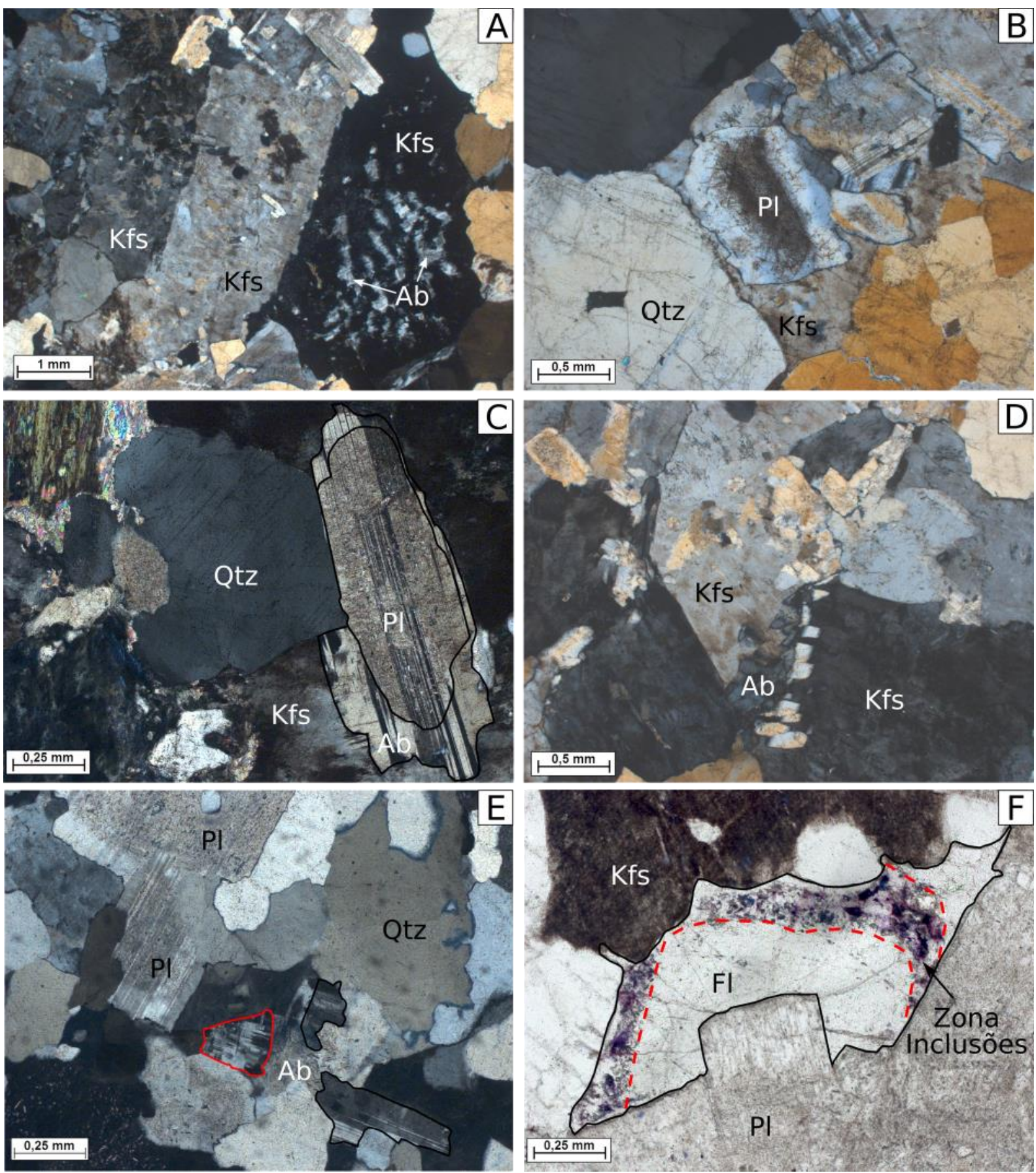

Figura 17: Fotomicrografias dos feldspatos presentes no Biotita Granito Inequigranular. (A) IPV-30C - Cristais anedrais de feldspato potássico com manchas turvas e lamelas irregulares de albita. Polarizadores cruzados. (B) IPV-30C - Cristal de plagioclásio subédrico, com núcleo fortemente turvo e borda albítica límpida, sendo envolto por feldspato potássico moderadamente turvo e intersticial. Polarizadores cruzados. (C) IPV-30C - Cristal de plagioclásio com núcleo subédrico turvo e borda albítica límpida. Notar que aborda se desenvolve apenas no contato com feldspato alcalino, mas não com quartzo. Polarizadores cruzados. (D) IPV-30C - Cristais de feldspato potássico com bordas albíticas trocadas. Polarizadores cruzados. (E) IPV-28B - Cristais homogêneos de albita intersticial (linha preta), com um grão apresentando geminação tipo tabuleiro de xadrez (linha vermelha), em meio a mesostase. Polarizadores cruzados. (F) IPV-30C - Fluorita zonada com núcleo subédrico incolor e límpido, seguido por zona rica em inclusões e coloração arroxeada no entorno destas, tornando a ser incolor e límpida nas bordas. O cristal possui aspecto intersticial e contatos retos para as fases magmáticas ao redor. Notar a presença de fraturas radiais na fluorita ao redor do plagioclásio parcialmente incluso. Polarizadores paralelos. Siglas utilizadas: Kfs feldspato potássico, Ab - albita, PI - plagioclásio, Qtz - quartzo, FI - fluorita, Chl - clorita. 

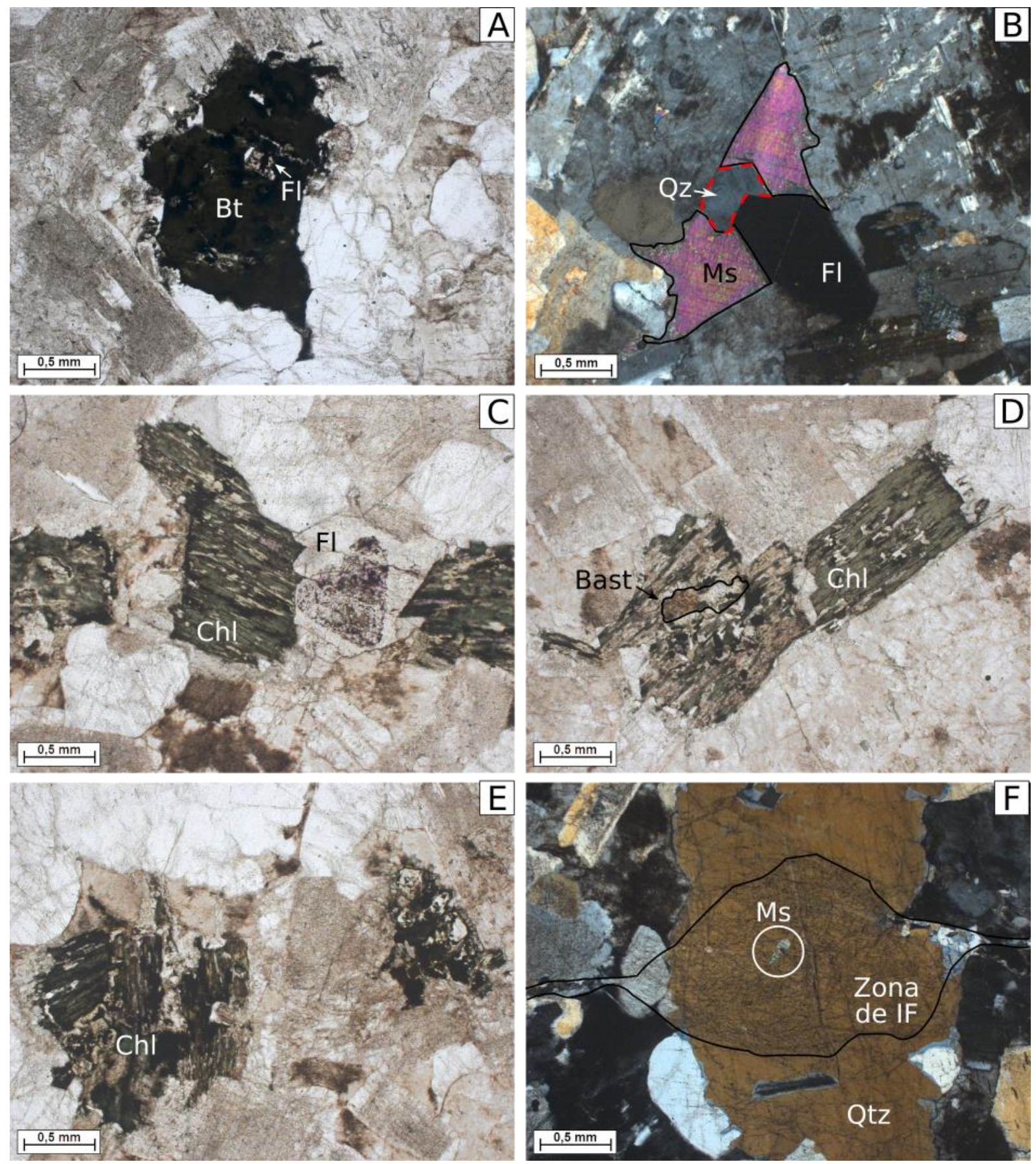

Figura 18: Fotomicrografias dos filossilicatos presentes no Biotita Granito Inequigranular. (A) IPV-30C - Cristal subédrico de biotita com diversas inclusões de zircão, monazita, ilmenita e fluorita. Suas bordas são marcadas por sericita pleocróica. Polarizadores paralelos. (B) IPV-30C - Muscovita pleocróica com aspecto intersticial, em contato com Qtz e Fl euédricos e de contatos retos com as fases magmáticas ao redor. Polarizadores cruzados. (C) IPV30C - Associação entre pseudomorfo de biotita cloritizada, com ilmenita e argilominerais, e fluorita zonada, com muitas inclusões no núcleo. Polarizadores paralelos. Polarizadores paralelos. (D) IPV-30C - Pseudomorfo de biotita cloritizada com inclusões de argilominerais, fluorita, minerais opacos, sericita e bastnasita-parisita (linha preta). Polarizadores paralelos. (E) IPV-30C - Pseudomorfos de biotita totalmente substituídos por clorita em associação com minerais opacos, argilominerais e sericita. Polarizadores paralelos. (F) IPV-30C - Cristal de muscovita euédrica inclusa em quartzo, bem em meio a região cheia de inclusões fluidas (linha contínua), dando aspecto turvo ao quartzo. Polarizadores cruzados. Siglas utilizadas: Bt - biotita, Fl - fluorita, Qtz - quartzo, Ms - muscovita, Chl clorita, Bast - bastnasita-parisita. 

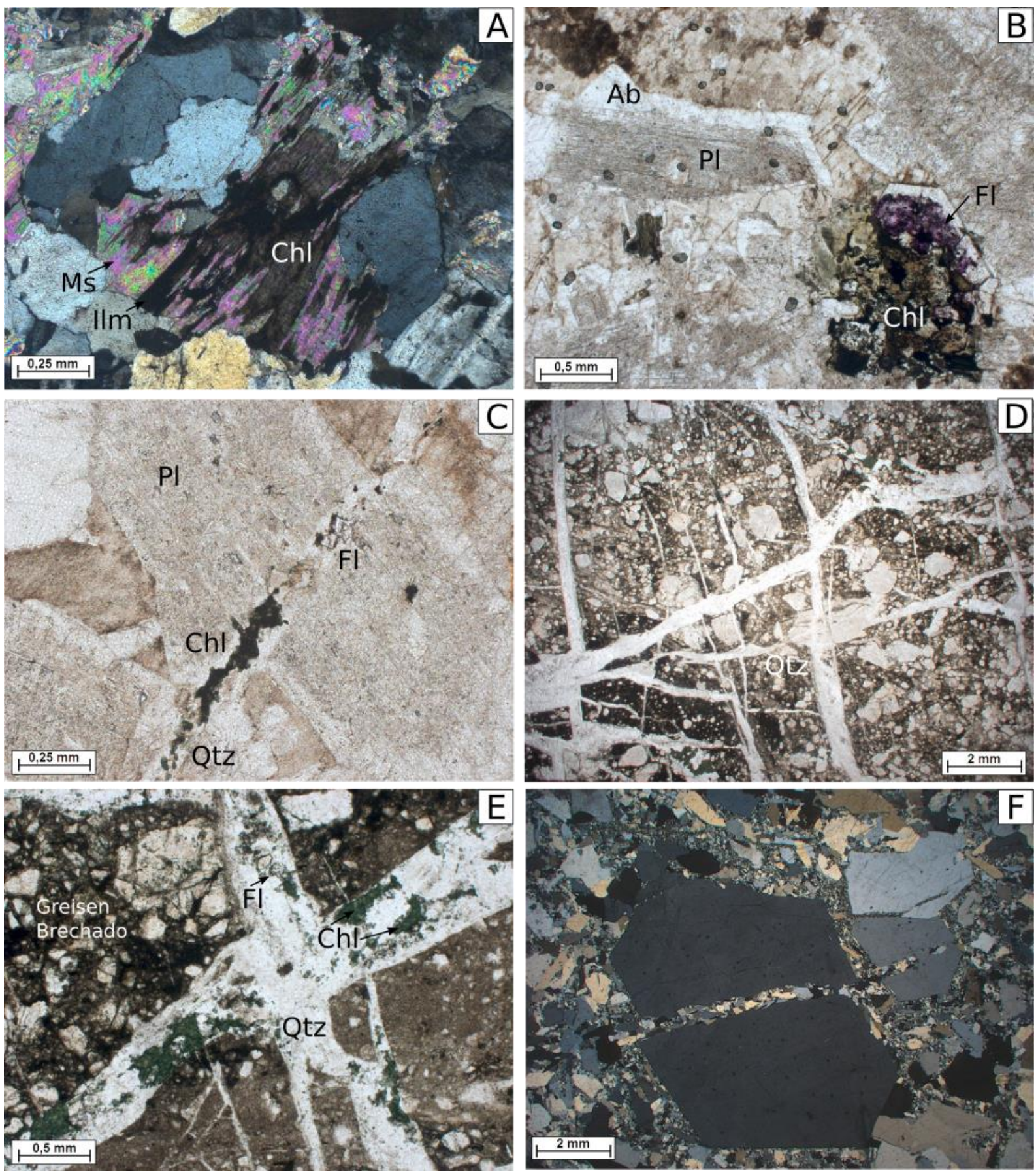

Figura 19: Fotomicrografias das feições secundárias presentes no Biotita Granito Inequigranular. (A) IPV-28B - Cristal de clorita intercrescido com muscovita pleocróica e ilmenita. Polarizadores cruzados. (B) IPV-30C Plagioclásio zonado (núcleo turvo e borda albítica límpida) ao lado de cristal anedral de clorita associada a opacos e argilominerais e fluorita zonada (núcleo roxo com inclusões e borda incolor límpida). Polarizadores paralelos. (C) IPV-30C - Vênula de quartzo e clorita deslocando cristal de plagioclásio zonado. Polarizadores paralelos. (D) IPV22B - Stockwork de quartzo cortando porção de granito brechado. Polarizadores paralelos. (E) IPV-22B - Vênulas de quartzo com acúmulos de clorita fina, principalmente nas bordas dos veios e presença de fluorita, cortando porção de granito brechado. Polarizadores paralelos. (F) IPV-18 - Cristal euédrico de quartzo sendo cortado por vênula de quartzo fino anédrico em amostra de enxame de veios. Polarizadores cruzados. Ms - muscovita, Chl clorita, Ilm - ilmenita, FI - fluorita, Qtz - quartzo, PI - plagioclásio. 

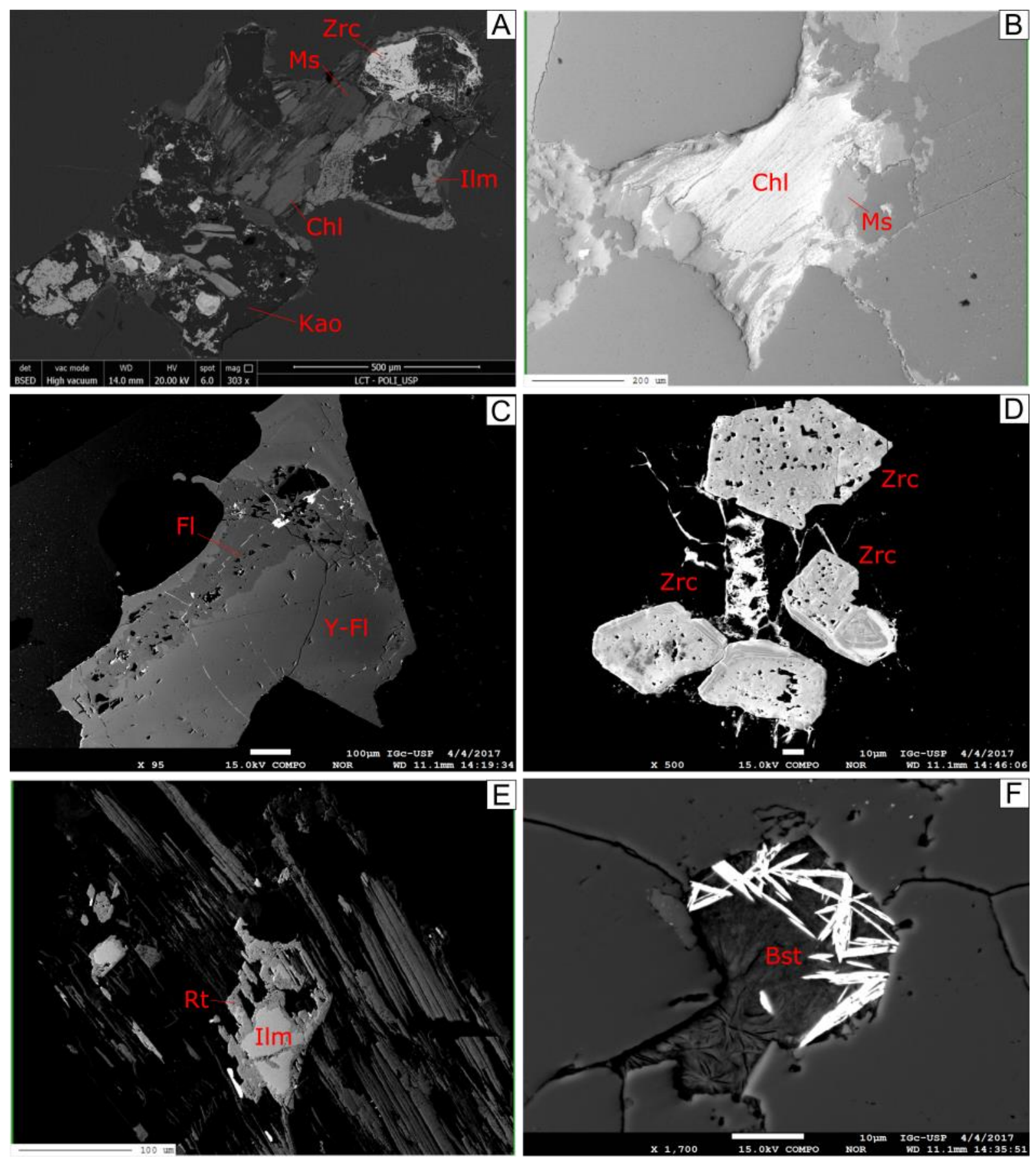

Figura 20: Imagens de elétrons retro-espalhados (BSE) do Biotita Granito Inequigranular. (A) Pseudomorfo de biotita substituído para aglomerado de clorita intercrescida com muscovita, ilmenita zonada e kaolinita. Notar que cristal de zircão também ocorre bem alterado e já devia estar incluso na mica ígnea. (B) Cristal anédrico de clorita manteado por muscovita. (C) Cristal zonado de fluorita mostrando região límpida com Y (mais clara na imagem BSE) e região rica em inclusões com menor peso atômico médio (mais escura na imagem BSE). (D) Cristais subédricos de zircão alterados e porosos, alguns cristais com forte zoneamento na imagem BSE, indicando grande variação composicional. (E) Cristal de ilmenita manteado por rutilo anédrico e corroído. (F) Cristais aciculares de bastnasita inclusos em plagioclásio sódico e formando aglomerados fibro-radiados. Siglas utilizadas: Chl - clorita, Ms - muscovita, Ilm - ilmenita, Zrc - zircão, Kao - caulinita, FI - fluorita, Y-FI - fluorita com ítrio, Rt - rutilo, Bst bastnasita. 


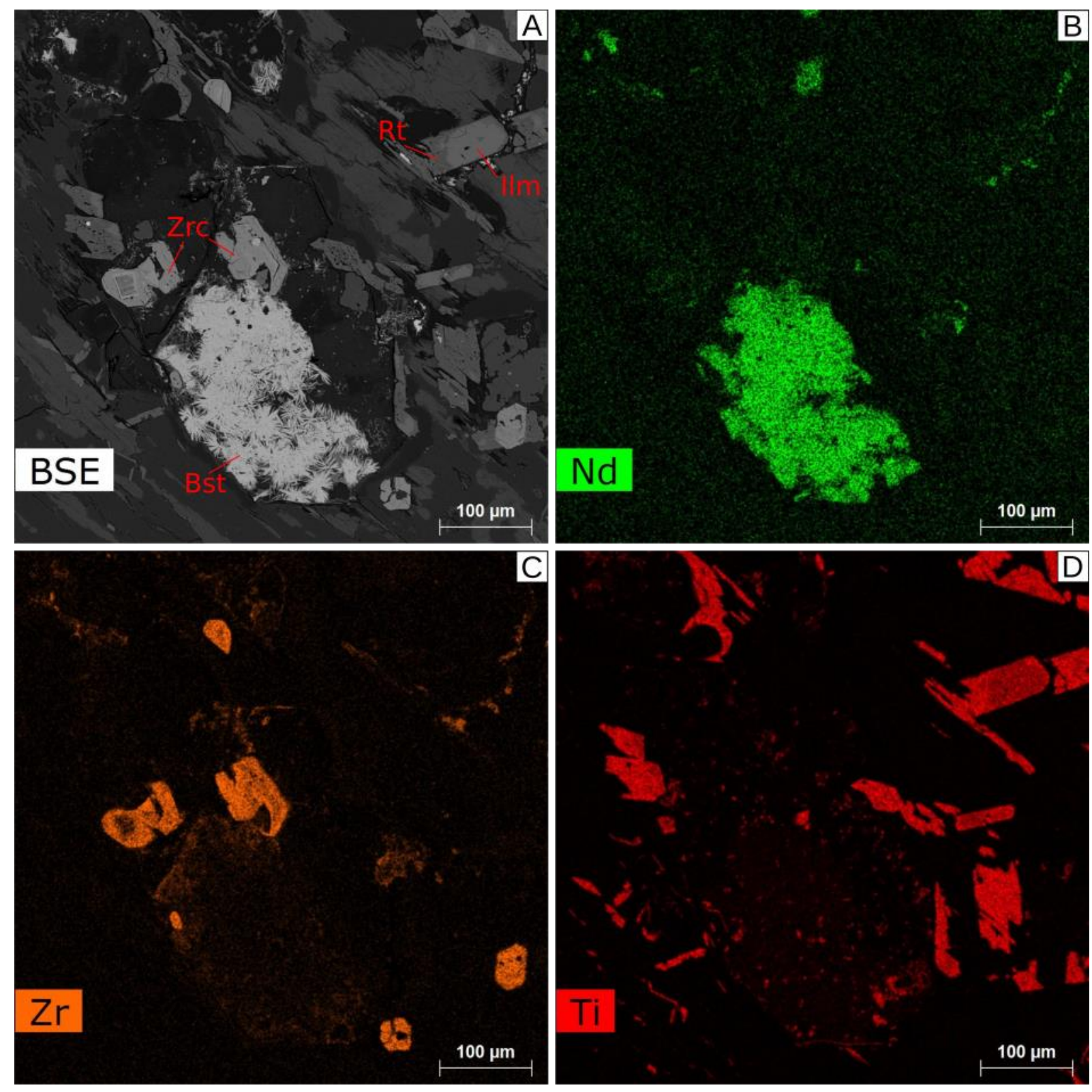

Figura 21: Mapas composicionais de EDS obtidos em MEV para inclusões em pseudomorfo de biotita, amostra IPV-30C do BG Inequigranular. (A) Imagem de elétrons retro-espalhados (BSE) correspondente à área dos mapas. (B) Mapa de distribuição de Nd. (C) Mapa de distribuição de Zr. (D) Mapa de distribuição de Ti. Siglas utilizadas: Ilm - ilmenita, Zrc - zircão, Rt - rutilo, Bst - bastnasita. 

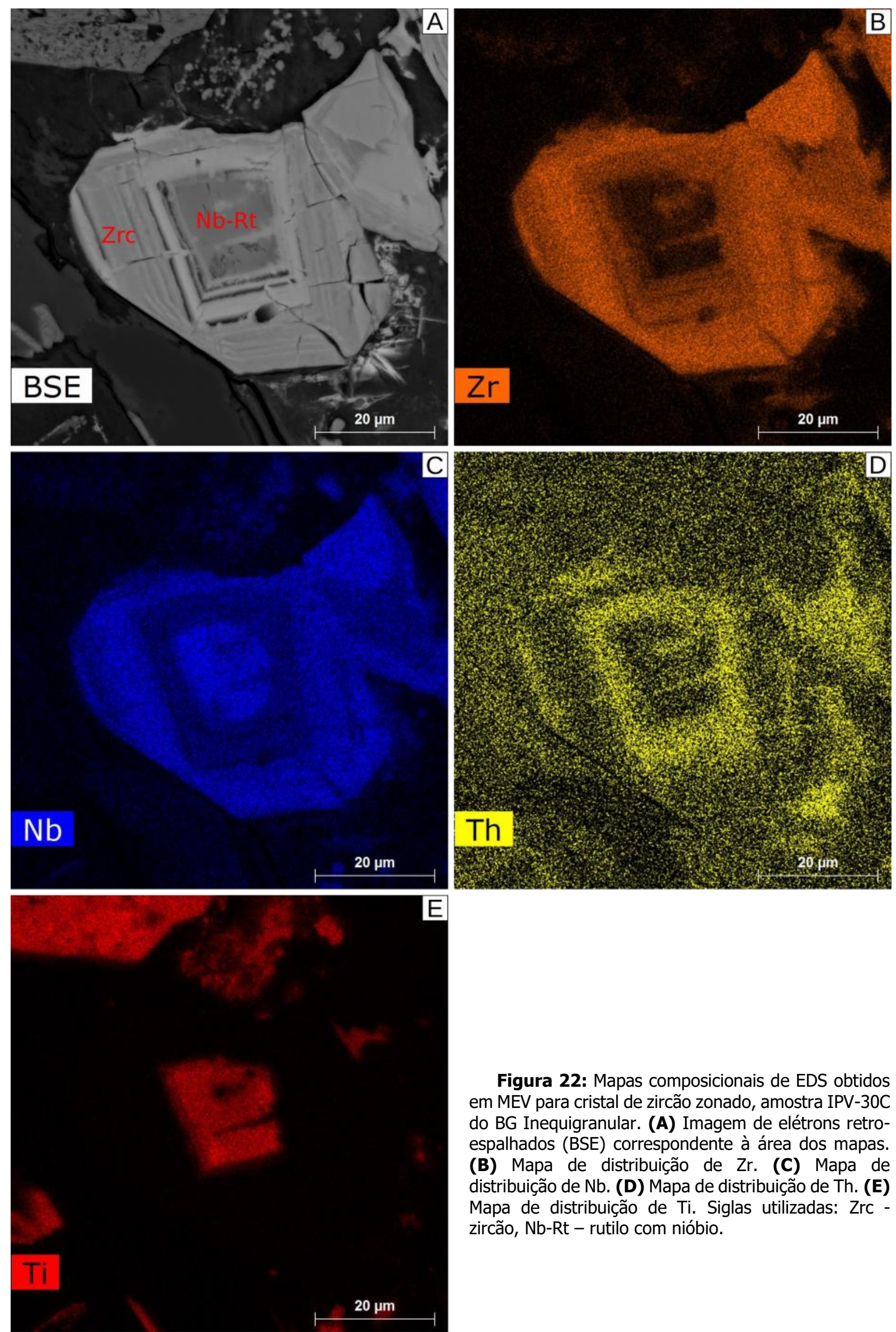

Figura 22: Mapas composicionais de EDS obtidos em MEV para cristal de zircão zonado, amostra IPV-30C do BG Inequigranular. (A) Imagem de elétrons retroespalhados (BSE) correspondente à área dos mapas. (B) Mapa de distribuição de Zr. (C) Mapa de distribuição de Nb. (D) Mapa de distribuição de Th. (E) Mapa de distribuição de Ti. Siglas utilizadas: Zrc zircão, Nb-Rt - rutilo com nióbio. 


\section{II.1.1 Álcali-feldspato granito com biotita, topázio e fluorita (TAG - Equigranular)}

Esta fácies apresenta microestrutura isotrópica e textura equigranular xenomórfica, de granulação fina a média. Variando em coloração desde esbranquiçada até fortemente avermelhada.

Feldspato potássico (30-35\%) ocorre como cristais anédricos, habitualmente se apresenta sem geminação, pertítico (lamelas finas de albita ou patches irregulares mais grossos - Figura 23A) e ligeiramente turvo e manchado. Localmente apresenta bordas albíticas trocadas (Figura 23C) e também leve extinção zonada. Possui inclusões de albita euédrica geminada e orientada discordantemente das pertitas (Figura 23D).

Quartzo (30-34\%) é anédrico, comumente intersticial, de aspecto ameboide e contatos serrilhados a lobados. Também ocorre intercrescido com feldspatos (Figura 23B). Cristais mais grossos podem apresentar leve extinção ondulante.

Albita (28-32\%) se apresenta subédrica a anédrica na mesostase (Figura 23A), com geminação múltipla $\left(A n_{0-5}\right)$, às vezes internamente terminada ou truncada ortogonalmente. Pode exibir manchas irregulares de feldspato potássico em seu interior (Figura 23F), e ocorre parcialmente substituída por fluorita e muscovita. Alguns cristais bem finos ocorrem intersticialmente, de aspecto límpido e geminação tabuleiro de xadrez. Porções albitizadas do granito podem desenvolver textura zonada, com núcleos turvos manteados por borda límpida. Ou como finos cristais límpidos que despontam de vênulas hidrotermais e substituem parcialmente os feldspatos potássicos ao lado (Figura 23E).

Como fases acessórias, ocorrem:

Biotita (2-4\%) é o mineral máfico principal e se apresenta sempre anédrica (Figura 24). Tem forte pleocroísmo, variando de bege a marrom escuro acinzentado, e cor de interferência alta (Figura 24D). Comumente se relaciona com cristais de fluorita zonada e de topázio (Figura 24A, C e F) e apresenta inclusões de minerais opacos (Figura 24B) e zircão, formando halos pleocróicos. Pode exibir um manteamento e manchas internas de muscovita pleocróica (Figura 24E), comumente se desenvolvendo nos contatos com albita, quando em contato com feldspato potássico, a muscovita ocorre intercrescida com quartzo vermiforme (Figura 26A). Nas amostras de granito com forte hidrotermalismo, a biotita se encontra cloritizada ocorrendo apenas como pseudomorfos substituídos por clorita, muscovita e opacos (Figura 25B). 
Muscovita (1 a 2\%) ocorre como cristais bem finos e anedrais de aspecto intersticial na mesostase, ou manteando e preenchendo fraturas da biotita, dos feldspatos e também do topázio. Possui pleocroísmo leve a moderado, variando de incolor a verde claro, que se torna mais intenso e evidente nos cristais mais grossos. Também ocorre como massas finas em veios hidrotermais intersticiais, que contornam as fases primárias, normalmente associada a minerais opacos e fluorita.

Fluorita $(\sim 1 \%)$ é anédrica de aspecto intersticial (Figura 24F). Comumente apresenta zonalidade de cor e química (Figura 25C e D), onde zonas ricas em inclusões de fases acessórias apresentam coloração roxa e composição normal $\left(\mathrm{CaF}_{2}\right)$ e zonas incolores e límpidas apresentam Y na estrutura (Figura 27). Também ocorre associada com muscovita manteando cristais de biotita. Inclusões são dominadas por zircão, columbita e ilmenita (Figura 26D e F). Cristais de bastnasita e de fluoreto de Y ocorrem internamente à fluorita em regiões aparentemente corroídas e substituídas (Figura 27 e Figura 28). Nas amostras de granito fortemente hidrotermalizadas, a fluorita se apresenta toda roxa e cheia de inclusões.

Topázio (traço a 1\%) é subédrico a anédrico, apresenta-se bastante fraturado e corroído, sendo manteado por muscovita pleocróica (Figura 25A). Alguns poucos cristais ocorrem inclusos em quartzo e feldspatos (Figura 26B). Quando o grau de hidrotermalismo é alto no granito, o topázio é bastante corroído e substituído por sericita (Figura 25B),

Zircão (traço) se apresenta subédrico a anédrico (Figura 25E), com coloração marrom escura (metamítico - Figura 25E e F) e comumente associado com columbita e fluorita em suas bordas (Figura 26E). Também ocorre sendo parcial ou totalmente substituído por massas de bastnasita, fluorita e columbita (Figura 29). Alguns cristais pequenos inclusos nas micas geram halos pleocróicos.

Ilmenita (traço) é anédrica a subédrica, raramente disseminada na mesostase, ocorre principalmente inclusa nas micas e em fluorita (Figura 24B).

Columbita (traço) ocorre como cristais muito finos, anedrais arredondados (Figura 25E) a localmente subédricos (Figura 25F). Comumente ocorre inclusa em fluorita e biotita ou associada a cristais de zircão metamítico. Normalmente apresentam finas lamelas de exsolução de tantalita (Figura 26E). 
Bastnasita-Parisita (traço) forma aglomerados de pequenos cristais aciculares a fibrosos, em aspecto de rede trançada. Ocorre inclusa em fluorita e substituindo cristais de zircão.
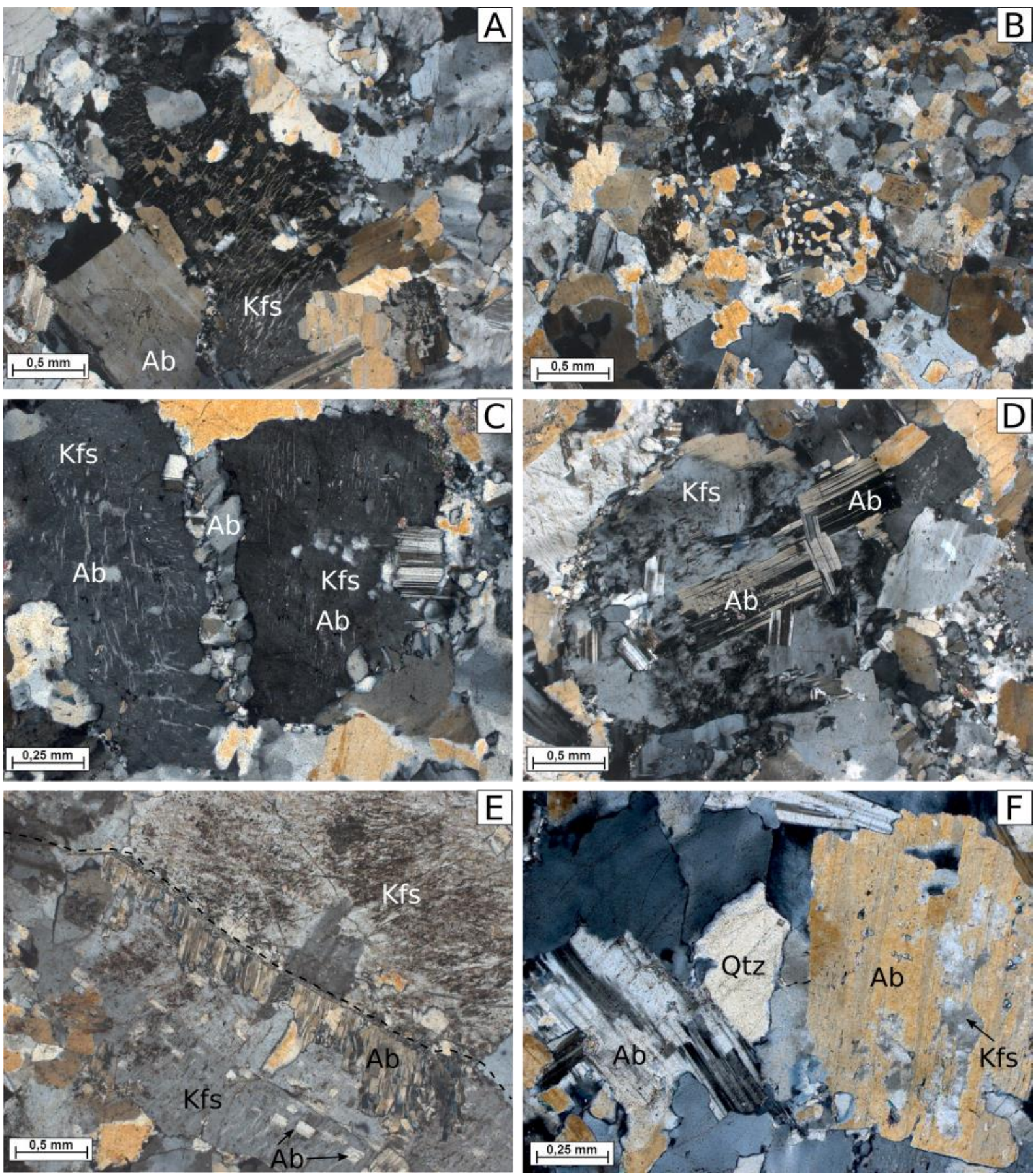

Figura 23: (A) IPV-35A - Feldspato potássico pertítico com lamelas finas e inclusões de albita e quartzo. Ao lado ocorre cristal de albita euédrica homogênea. Polarizadores cruzados. (B) IPV-35N - Intercrescimento de quartzo vermiforme com os feldspatos da mesostase. Polarizadores cruzados. (C) IPV-35A - Feldspato potássico pertítico com bordas albíticas trocadas. Polarizadores cruzados. (D) IPV-35A - Feldspato potássico manchado com inclusão de albita euédrica em diversas orientações. Polarizadores cruzados. (E) IPV-35D - Cristais de albita hidrotermal crescendo a partir de vênula (linha tracejada) sobre feldspato potássico com inclusões orientadas de albita, mas não sobre cristal de feldspato potássico turvo. Polarizadores Cruzados. (F) IPV-35A - Cristal subédrico de albita com manchas irregulares de feldspato potássico ao lado de cristal de albita limpa intersticial. Polarizadores cruzados. Siglas utilizadas: Kfs - feldspato potássico, Ab - albita, Qtz - quartzo. 

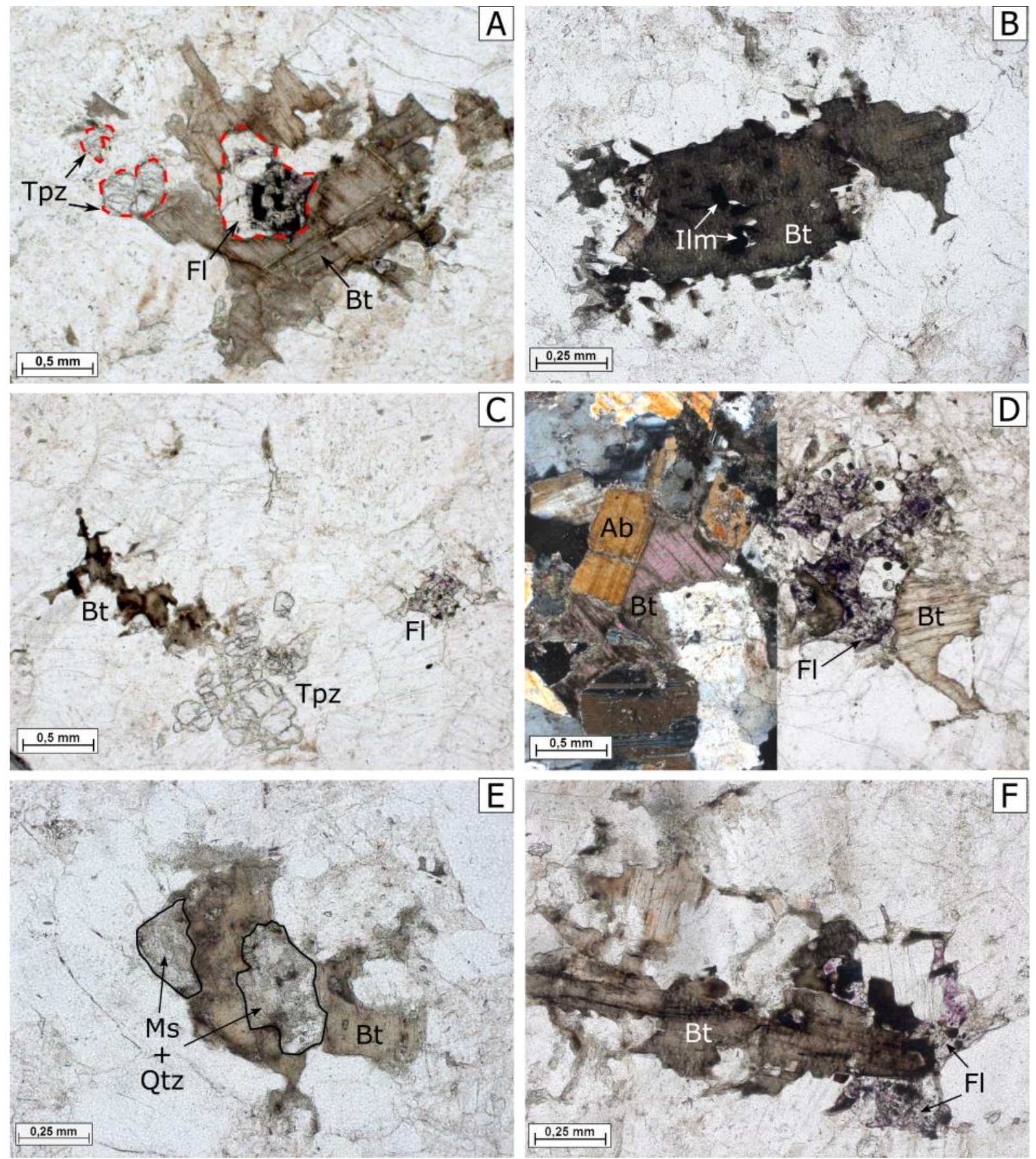

Figura 24: (A) IPV-35A - Biotita anédrica de pleocroísmo forte, associada com fluorita zonada cheia de inclusões (linha tracejada) e topázio anédrico fraturado. Polarizadores paralelos. (B) IPV-35AD - Cristal de biotita anédrica com inclusões anédricas de ilmenita. Polarizadores paralelos. (C) IPV-35A - Biotita anédrica associada a topázio subédrico fraturado e ao lado de fluorita com inclusões. Polarizadores paralelos. (D) IPV-35C - Biotita anédrica intersticial associada a fluorita cheia de inclusões também intersticial. A biotita envolve cristal de albita euédrica. Polarizadores cruzados na esquerda e paralelos na direita. (E) IPV-35AD - Biotita anédrica parcialmente substituída por intercrescimento de quartzo vermiforme e muscovita. Polarizadores paralelos. (F) IPV-35A - Biotita intersticial sendo envolta por fluorita, também intersticial. Polarizadores paralelos. Siglas utilizadas: Bt - biotita, FI - fluorita, Tpz - topázio, Ilm - ilmenita, Ab - albita, Qtz - quartzo, Ms - muscovita. 

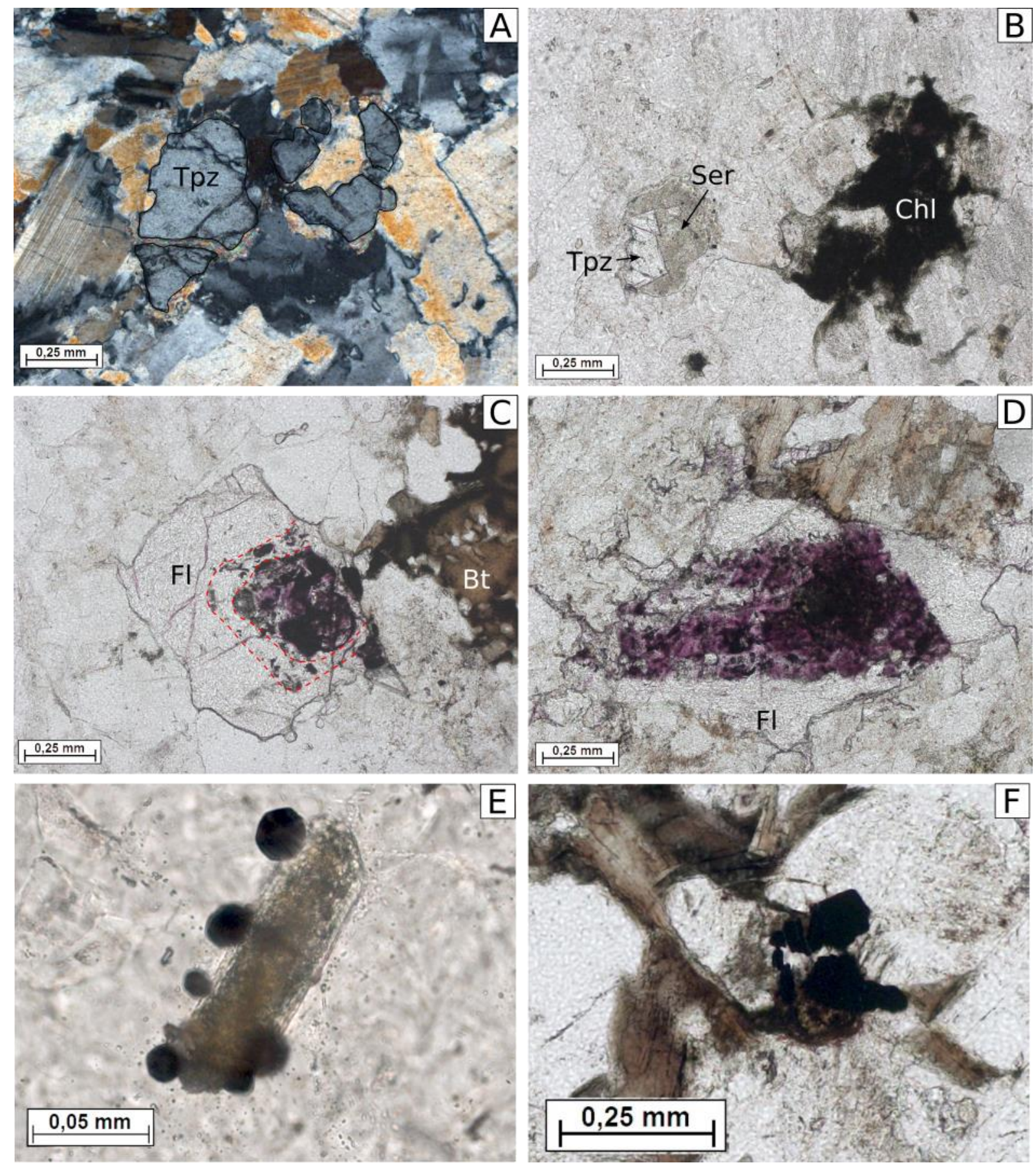

Figura 25: (A) IPV-35A - Topázio anédrico a subédrico, fraturado e corroído, com manteamento de sericita. Polarizadores cruzados. (B) IPV-35N - Topázio parcialmente substituído por massa fina de sericita. Ao lado de pseudomorfo de biotita cloritizado. Polarizadores paralelos. (C) IPV-35AD - Cristal subédrico de fluorita zonada, mostrando núcleo roxo cheio de incluões, zona intermediária (linha vermelha tracejada) incolor com poucas inclusões e borda incolor límpida. Polarizadores paralelos. (D) IPV-35M - Fluorita intersticial zonada, com inclusões contornadas por coloração arroxeada. Polarizadores paralelos. (E) Cristal subédrico de zircão altamente fraturado e de cor marrom escuro, sendo bordejado por cristais arredondados de columbita. (F) Cristal de zircão anédrico metamítico de cor marrom escuro sendo sobrecrescido por columbita. Siglas utilizadas: Tpz - topázio, Chl - clorita, Ser - sericita, FI - fluorita, Bt - biotita. 

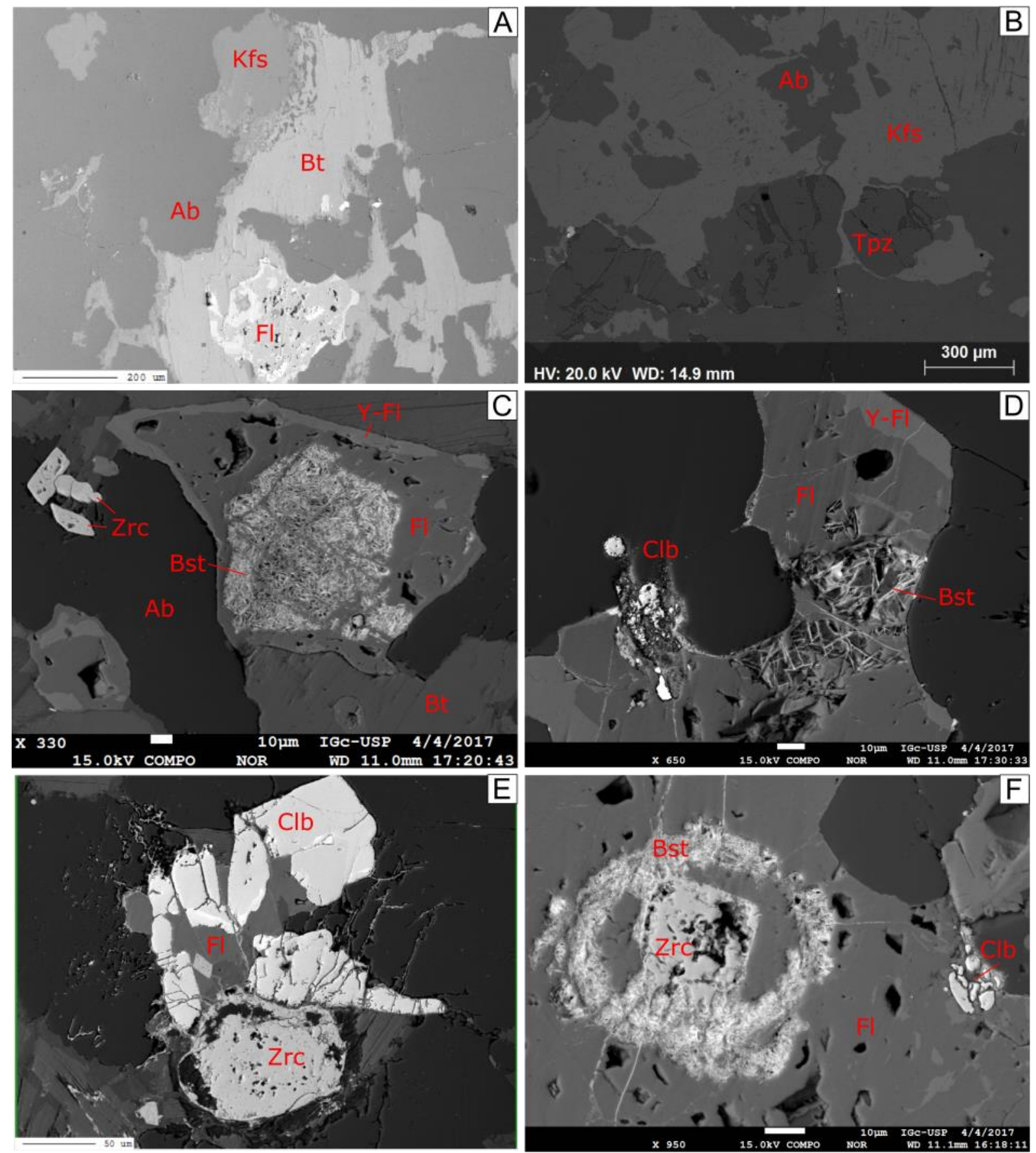

Figura 26: Prancha de imagens BSE para o TAG. (A) Biotita anédrica ao lado de fluorita zonada, mostrando borda de reação entre feldspatos. Quando em contato com feldspato potássico ocorre formação de intercrescimento entre quartzo e muscovita, e no contato com albita forma apenas muscovita. (B) Cristal subédrico de topázio parcialmente envolto por feldspato potássico interstitical. (C) Cristal de fluorita zonada apresentando núcleo de composição normal substituído por bastnasita trançada e fina borda rica em Y. (D) Cristal de fluorita zonada apresentando inclusão de columbita anédrica e sendo parcialmente substituída por bastnasita. (E) Cristal de zircão anédrico e corroído sobrecrescido por columbita intercrescida com fluorita. Notar a presença de finas lamelas de tantalita exsolvidas da columbita (linhas brancas), que, devido ao peso atômico maior apresentam reposta mais brilhante na imagem de elétrons retro-espalhados. Mesmo cristal da Figura 25F. (F) Cristal de zircão corroído circundado por halo de bastnasita trançada, inclusas em fluorita zonada. Siglas utilizadas: Kfs - feldspato potássico, Ab - albita, Bt - biotita, FI - fluorita, Tpz - topázio, Zrc - zircão, Y-FI - fluorita com ítrio, Bst - bastnasita, Clb columbita. 


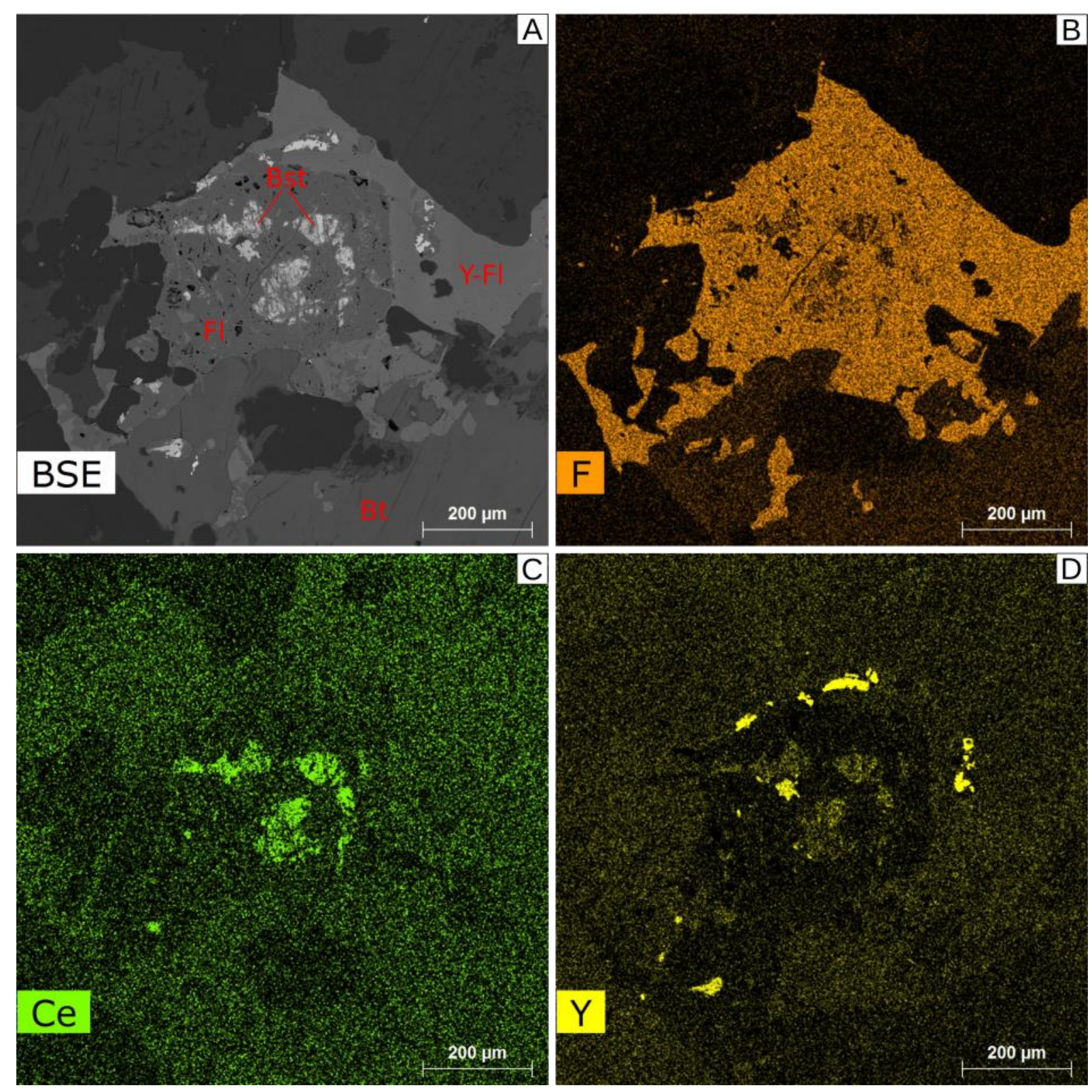

Figura 27: Mapas composicionais de EDS obtidos em MEV para cristal de fluorita zonada e com inclusões, amostra IPV-35A do TAG. (A) Imagem de elétrons retro-espalhados (BSE) correspondente à área dos mapas. (B) Mapa de distribuição de F. (C) Mapa de distribuição de Ce. (D) Mapa de distribuição de Y. Siglas utilizadas: Bt biotita, FI - fluorita, Y-FI - fluorita com ítrio, Bst - bastnasita. 


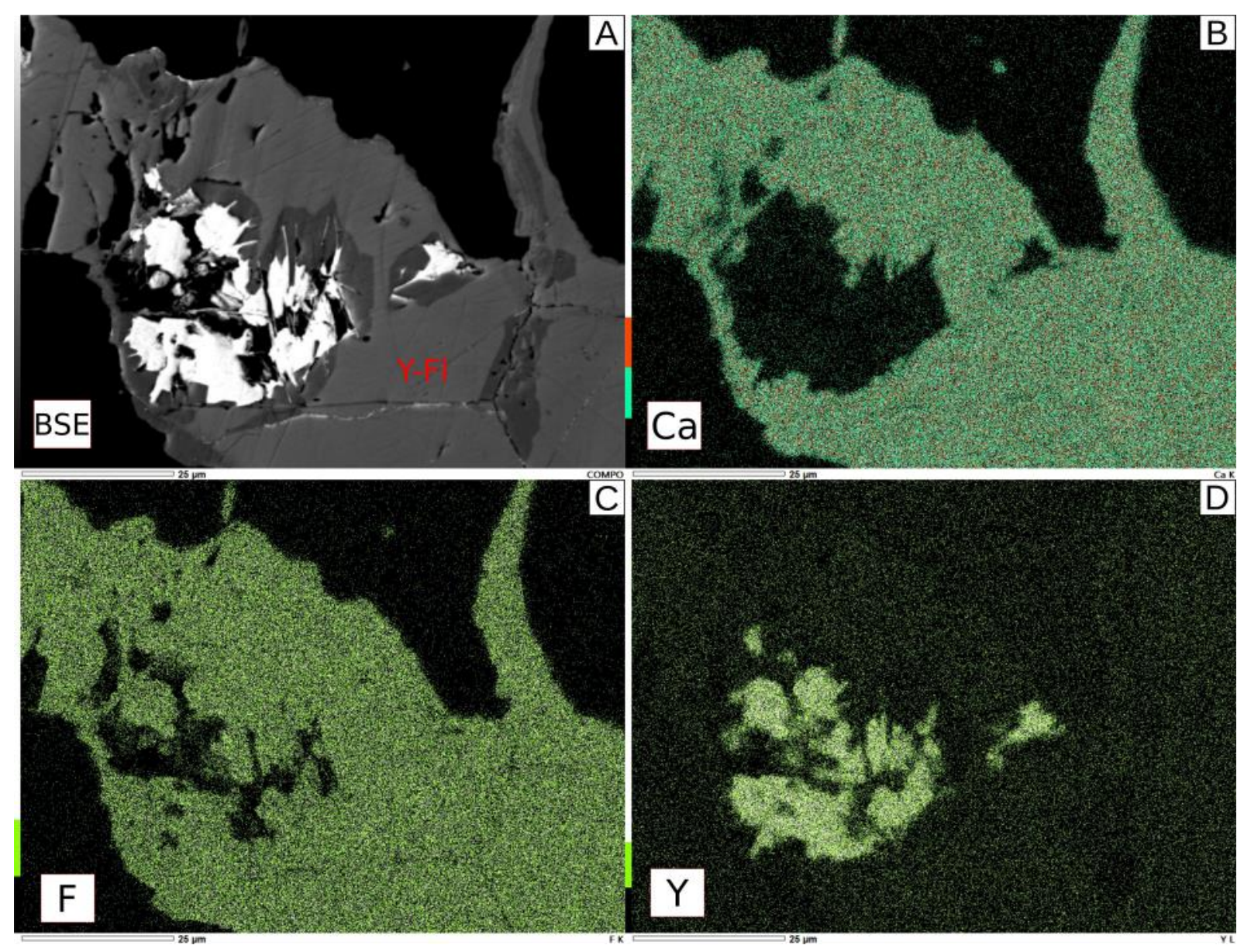

Figura 28: Mapas composicionais de EDS obtidos em FE-EPMA para cristal de fluorita zonada com inclusão de fluoreto de Y, amostra IPV-35A do TAG. (A) Imagem de elétrons retro-espalhados (BSE) correspondente à área dos mapas. (B) Mapa de distribuição de Ca. (C) Mapa de distribuição de F. (D) Mapa de distribuição de Y. 


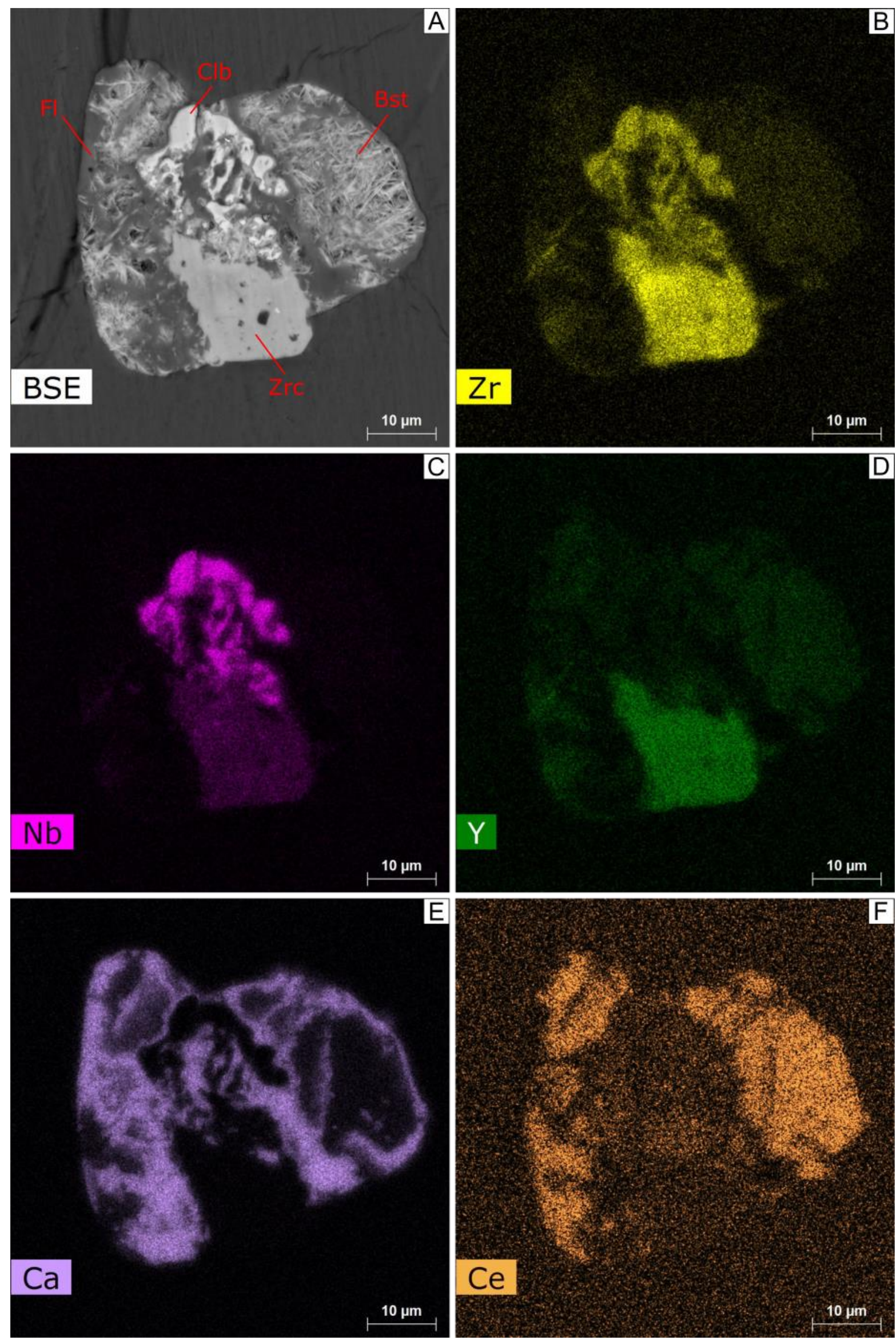

Figura 29: Mapas composicionais de EDS obtidos em MEV para cristal de zircão parcialmente substituído, amostra IPV-35A do TAG. (A) Imagem de elétrons retro-espalhados (BSE) correspondente à área dos mapas. (B) Mapa de distribuição de Zr. (C) Mapa de distribuição de Nb. (D) Mapa de distribuição de Y. (E) Mapa de distribuição de Ca. (F) Mapa de distribuição de Ce. Siglas utilizadas: Fl - fluorita, Zrc - zircão, Bst - bastnasita, Clb - columbita. 


\section{II.2 ALTERAÇÃO HIDROTERMAL NO LEUCOGRANITO INHANDJARA E GNAISSES ASSOCIADOS}

As rochas da área de estudo registram zonas de alteração hidrotermal associadas à intrusão e exsolução de fluidos dos corpos graníticos, sendo o metassomatismo alcalino e a greisenização os eventos mais expressivos regionalmente. A silicificação é importante, mas bastante restrita espacialmente.

Os gnaisses encaixantes também se encontram fortemente greisenizados e é comum a presença de veios de quartzo e topázio (variando de alguns milímetros até cerca de $50 \mathrm{~cm}$ ). Grande parte dos veios é estéril, mas alguns destes, principalmente quando possuem grande proporção de topázio apresentam cristais de wolframita e cassiterita.

Nesta sessão serão abordados os processos hidrotermais registrados diretamente no Leucogranito Inhandjara (interpretadas como auto-metassomatismo) e os presentes nos gnaisses encaixantes adjacentes, que hospedam a mineralização lavrada na antiga mina de Inhandjara.

\section{II.2.1 Metassomatismo Alcalino (Na e K?)}

A quase totalidade dos pontos visitados e amostras coletadas apresentam certa influência de metassomatismo alcalino pervasivo. Este é marcado macroscopicamente pelo aumento geral da granulação da rocha (majoritariamente pelo crescimento dos feldspatos) e coloração dos feldspatos desde tons rosados até intensamente vermelhos (Figura 13A). Localmente ocorre o consumo dos minerais máficos, tornando a rocha ainda mais hololeucocrática (chegando a $\mathrm{M}^{\prime}=0$ ).

Microscopicamente o processo se caracteriza pela oxidação e turbidez de ambos os feldspatos (plagioclásio e K-feldspato - Figura 14B), dando um aspecto sujo aos cristais devido a ocorrências de microinclusões nestes (muitas destas inclusões devem corresponder à hematita oxidada - Putnis et al., 2007).

O processo de formação dos feldspatos hidrotermais é dominado pela dissolução dos cristais ígneos em presença do fluido e posterior reprecipitação na forma de lamelas ou bandas albíticas irregulares (Figura 14E) e bordas albíticas trocadas sobre os feldspatos potássicos (Figura 17D); sobrecrescimento anedral de albita límpida sobre núcleos euédricos de plagioclásio turvo (Figura 17C); e também o crescimento de albitas intergranulares (Figura 14D) e massas de cristais finos sobre os feldspatos primários (Figura 23E). 
A presença de alguns cristais de plagioclásio com manchas de feldspato potássico (Figura 14F e Figura 23F) podem ser indicativos da ocorrência de metassomatismo potássico. Porém texturas como estas são bastante raras e a falta de biotita ou outras fases potássicas em paragênese dificulta a classificação da alteração. Portanto neste trabalho fica estabelecido o termo genérico metassomatismo alcalino, tendo maior influência do $\mathrm{Na}^{+}$, e subordinadamente de $\mathrm{K}^{+}$no processo hidrotermal.

A ocorrência de sienito encontrada em meio ao Biotita Granito (Figura 30A) pode ser produto desse metassomatismo (Costi et al., 2002; Suikkanen and Rämö, 2017). Apresenta granulação grossa, coloração avermelhada forte e nenhum mineral máfico, em contrapartida o granito logo ao lado possui granulação média, coloração bege clara e M' próximo a 4\%. Este tipo de rocha, também chamada de episienitos (Cathelineau, 1986), apresenta cristais de feldspato potássico intensamente recristalizados para albita tanto em porções centrais, como lamelas e também nas bordas. $E$ todas as fases encontram-se totalmente turvas, muitas vezes até dificultando sua identificação.

\section{II.2.2 Greisenização}

Este processo está presente em dois estilos: pervasivo, principalmente no Biotita Granito formando grandes bolsões irregulares de matriz quartzo-muscovítica fina (Figura 30B) substituindo o granito; e fissural com halos externos de reação, neste caso dominando no TAG (Figura 31D).

Durante a greisenização, os feldspatos e micas primárias são totalmente (ou em poucos casos parcialmente) substituídos principalmente por muscovita e quartzo. Clorita está sempre presente em proporções variadas; sulfetos (pirita, calcopirita, esfalerita e galena - Figura 32A e B) ocorrem nas porções mais internas dos greisens e fluorita é menos frequente, mas ocorre incolor a levemente roxa disseminadas pelo greisen ou compondo borda de veios filossilicáticos (Figura 32E).

Amostras greisenizadas tendem a diminuir um pouco na granulação quando comparadas aos granitos originais, e a coloração se torna bastante esverdeada (Figura 31A). A muscovita é a única mica presente nos endogreisens (quando ocorrem no granito) e apresenta coloração esverdeada junto com pleocroísmo fraco, desde tons incolores a verde claro.

Comumente amostras ocorrem zonadas (Figura 31B e D), com um halo externo de consumo seletivo das fases máficas, seguido por uma zona intermediária de substituição dos feldspatos por quartzo e filossilicatos ( \pm pirita e calcopirita 
disseminadas), e uma região interna de granulação muito fina (Figura 31F) dominada por muscovita e clorita ( \pm fluorita e megacristais de pirita associados a esfalerita verde subédrica cheia de inclusões e galena arroxeada intersticial - Figura 33 e 34). Algumas amostras podem apresentar zonação nos sulfetos também (Figura 31E), com regiões dominadas por megacristais que envolvem uma área central com os filossilicatos.

Localmente a greisenização ocorre associada a regiões de brecha (Figura 31C), neste caso aparece com matriz esverdeada composta por muscovita e clorita (Figura 32C) associada a topázio mais grosso nas bordas (Figura 32D) e molibdenita disseminada. Quando próximos à estas brechas, os cristais de esfalerita apresentam aumento na granulação e adquirem coloração vermelha escura (Figura 32F).

Neste trabalho, as amostras onde o Leucogranito Inhandjara é encontrado fortemente greisenizado, este passou a ser identificado como Greisen I.

\section{II.2.3 Silicificação}

Ocorre de forma fissural (veios e stockworks de quartzo, às vezes como enxames Figura 30D) envolvendo fragmentos parcialmente substituídos do granito (Figura 30E), mas em certos locais devido à alta profusão de veios ocorre substituição completa da rocha original por quartzo maciço muito fino (Figura 30F). A silicificação apresenta quartzo como paragênese quase que unicamente, com presença esparsa de óxidos e hidróvidos de ferro disseminados.

Esta alteração é mais abundante no BG, especialmente em sua porção sul. Mas também ocorre no TAG, onde os veios de quartzo comumente desenvolvem franjas micáceas de maior granulação.

Algumas amostras do BG apresentam vênulas tardias de quartzo e clorita (Figura 30C), formando stockworks que cortam todas as outras estruturas. Estas vênulas também podem apresentar cristais muito finos de fluorita.

\section{II.2.4 Cloritização e outras alterações subordinadas}

A cloritização é pervasiva, mas possui caráter seletivo, pois é marcada apenas pela substituição das micas ígneas. Forma pseudomorfos da biotita primária, que é completamente transformada em associação de clorita, minerais opacos (principalmente ilmenita), muscovita, argilominerais de Al e Si (e.g., caulinita) e rara fluorita. Comumente os pseudomorfos apresentam borda mais externa composta por muscovita fina. 
Alteração propilítica está presente na porção sul do Biotita Granito, mas de forma muito restrita espacialmente. Possui caráter pervasivo com paragênese de epidoto, clorita, titanita e raro carbonato, substituindo os feldspatos e micas ígneas.

Algumas amostras na Pedreira Viracopos, onde aflora o TAG, apresentam intensa fluoritização, com fluorita preenchendo fraturas e faces estriadas ou compondo a matriz de vênulas milimétricas de brecha hidrotermal. Esta fluorita apresenta granulação bem fina e coloração roxa bem forte. E nestes casos ocorre fase única, possivelmente de caráter mais tardio, pois corta o granito albitizado.

Sericitização está presente de forma fissural em algumas amostras do TAG. São vênulas milimétricas de coloração verde clara que cortam o granito. Locais com muitas vênulas associadas podem sofrer substituição da matriz na região entre as fissuras.

A porção central da Pedreira Viracopos apresenta alguns escassos veios milimétricos de calcita (2-5 mm). Esta apresenta coloração bem esbranquiçada, com aspecto quase opaco e contatos internos sub-poligonais. O contato para o granito é brusco, porém levemente ondulado e nenhuma textura de reação entre ambos foi identificado.

Algumas amostras ocorrem com grande proporção de argilominerais substituindo feldspatos e micas cloritizadas. Porém são ocorrências bastante restritas e não foi possível definir se sua origem é hidrotermal ou intempérica. 

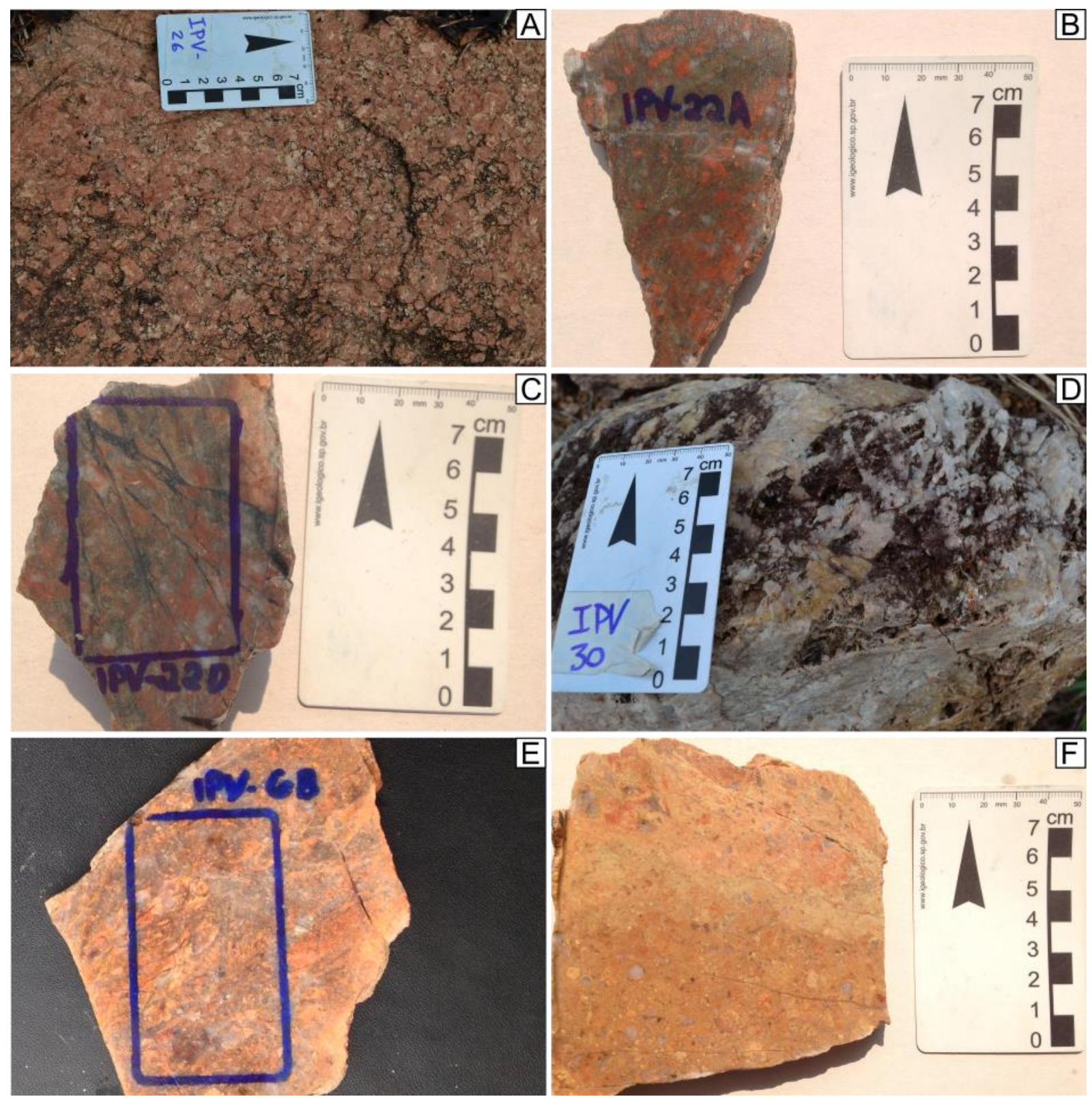

Figura 30: (A) Aspecto de campo do sienito grosso encontrado em meio ao Biotita Granito. Pode ser indicativo de intenso metassomatismo alcalino, lixiviando o quartzo e aumentando a granulação dos feldspatos. (B) Amostra do Biotita Granito inequigranular fortemente albitizado e brechado, com matriz sericítica e clorítica envolvendo fragmentos do granito alterado. (C) Amostra do Biotita Granito inequigranular mostrando as vênulas tardias de quartzo e clorita que cortam o granito albitizado e brechado. (D) Amostra de enxame de veios de quartzo sobrepostos, que substituem totalmente o granito original. (E) Amostra de Biotita Granito porfirítico parcialmente silicificado, mostrando clastos do granito fortemente albitizado envoltos por matriz de quartzo fino. (F) Biotita Granito porfirítico fortemente silicificado, que oblitera totalmente a estrutura e mineralogia primária, restando apenas alguns cristais arredondados de quartzo grosso em meio a matriz quartzosa muito fina. 

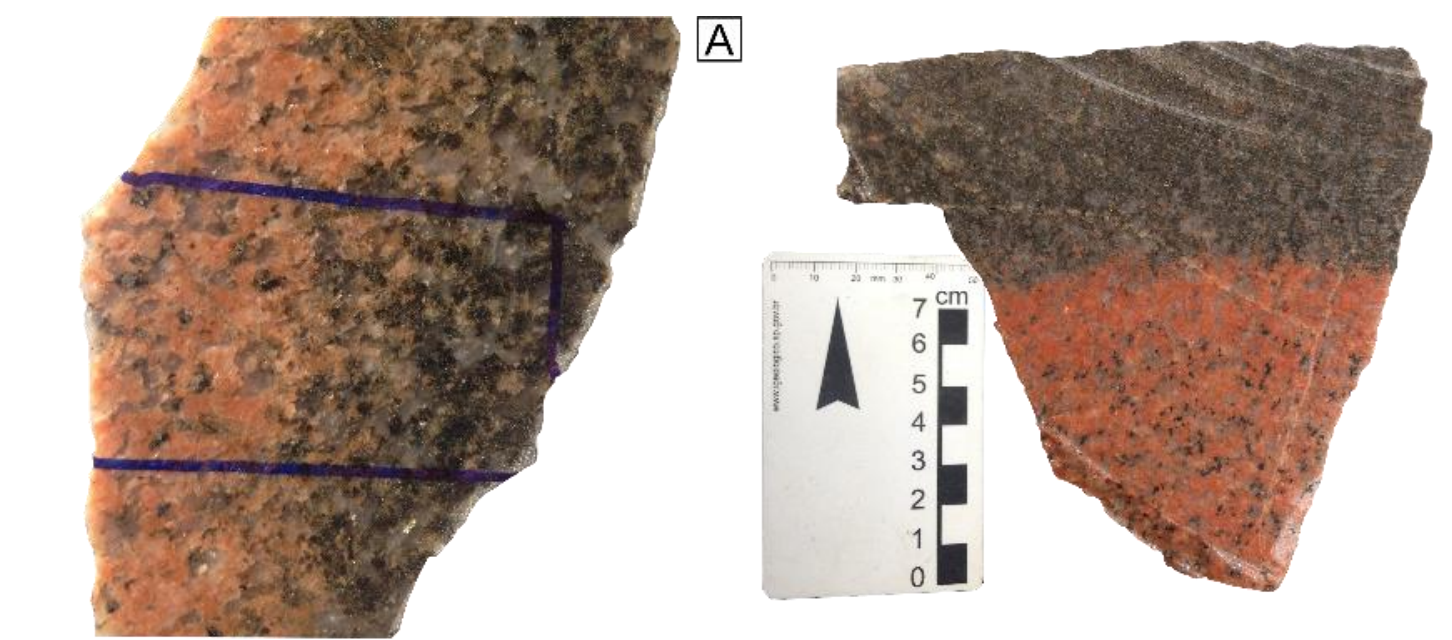

B

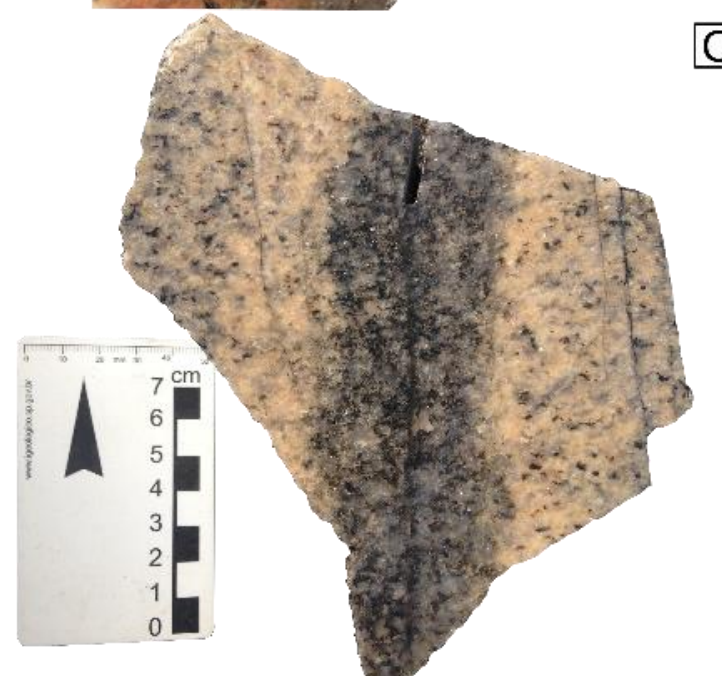

C
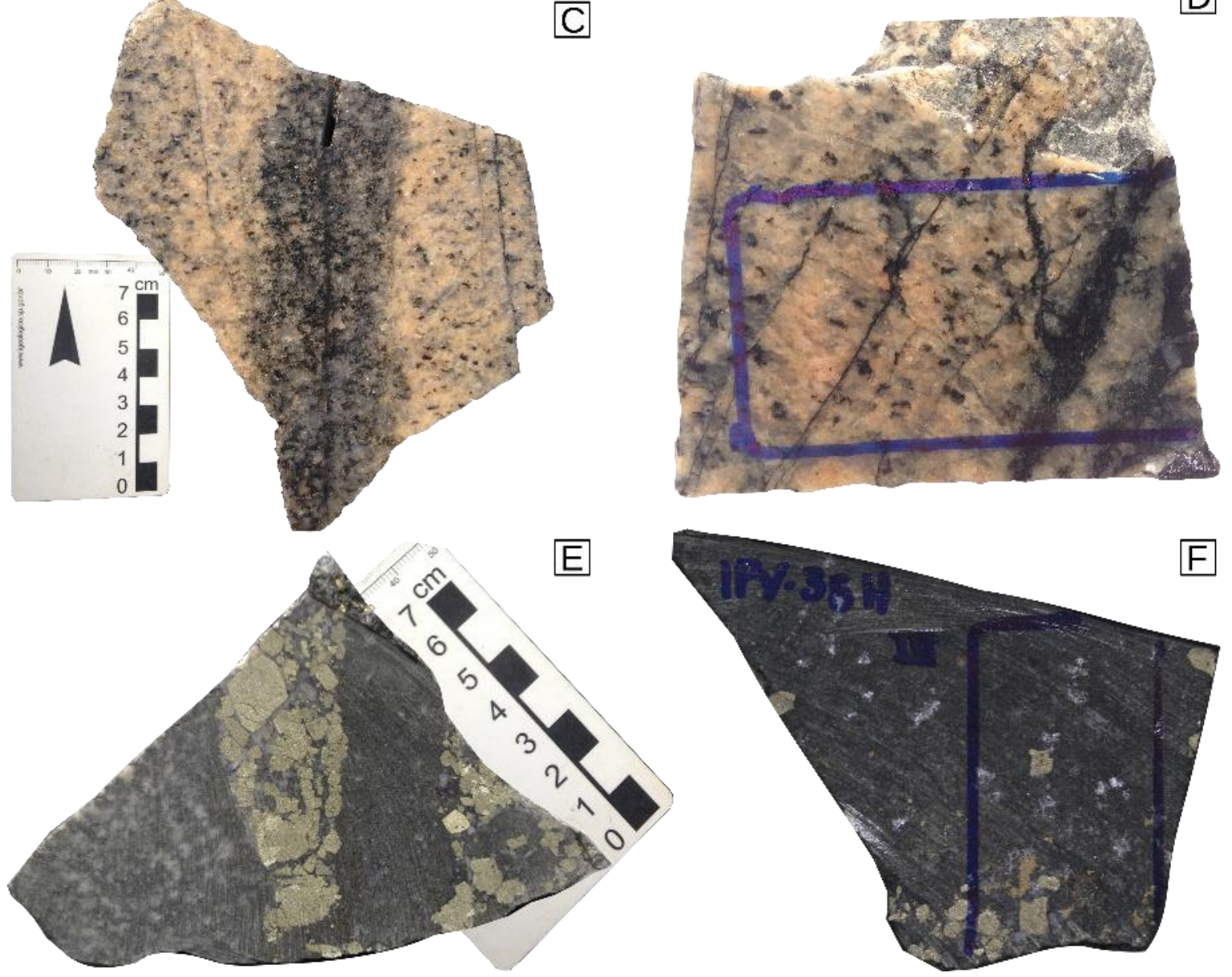

Figura 31: (A) Amostra do Topázio Granito albitizado à esquerda e greisenizado à direita, com passagem gradual entre as alterações. (B) Amostra representativa da passagem hidrotermal entre o metassomatismo alcalino oxidante pervasivo na porção inferior, transicionando para halo intermediário de albitização extrema com consumo de fases máficas e aumento da granulação dos feldspatos, seguido de halo de greisenização com formação de Limuscovita, quartzo e um pouco de clorita e por fim região de veio composto por Li-muscovita, clorita e sulfetos disseminados no topo da amostra. (C) Amostra de brecha hidrotermal associada à greisenização com formação de topázio hidrotermal na porção direita entre as vênulas de greisen. (D) Amostra zonada com veio interno maciço com Li-muscovita, clorita e sulfetos, halo intermediário de greisenização e halo externo de albitização e consumo de máficos. (E) Amostra de veio hidrotermal no TAG da Pedreira Viracopos. Notar estrutura zonada com zona interna marcada por região maciça de muscovita com Li e clorita muito finas, seguida por região com alta densidade de megacristais de pirita euédrica e, por fim, envoltas pela granito greisenizado. (F) Detalhe de amostra da porção interna do veio maciço de muscovita com Li e clorita, juntamente com sulfetos disseminados e alguma fluorita. 

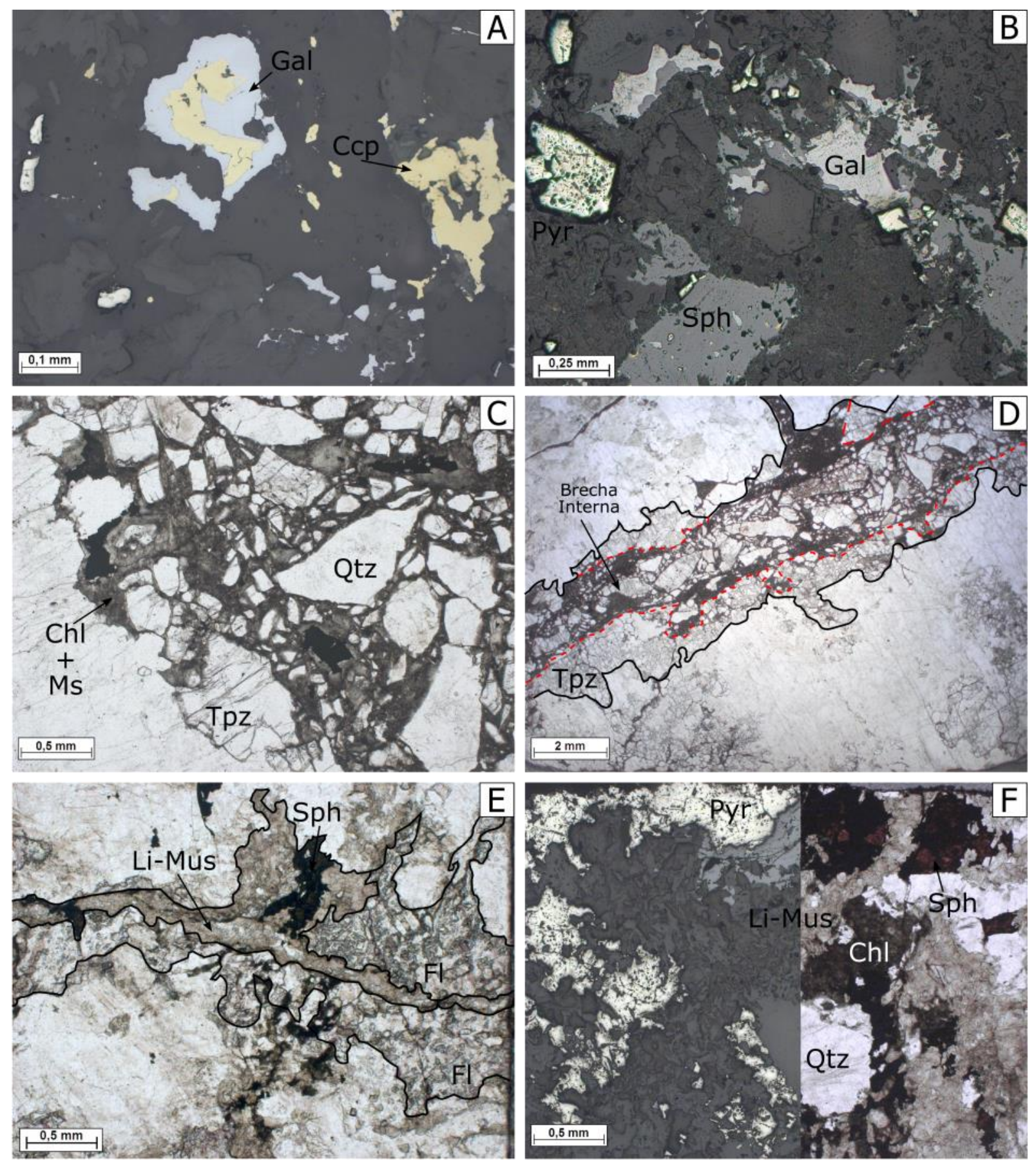

Figura 32: (A) IPV-35H - Galena manteando calcopirita em veio maciço de Li-muscovita e clorita. Luz refletida. (B) IPV-35H - Relação entre sulfetos no veio maciço de Li-muscovita e clorita. Pirita euédrica, esfalerita euédrica a subédrica com inclusões de pirita e calcopirita, e galena anedral intersticial. Luz refletida. (C) IPV-35AC - Brecha hidrotermal associada a topázio, com matriz de muscovita e clorita com sulfetos disseminados envolvendo clastos do TAG. Polarizadores paralelos. (D) IPV-35AC - Visão geral da brecha hidrotermal (linha vermelha tracejada) bordejada por banda de topázio hidrotermal (linha preta contínua). Polarizadores paralelos. (E) IPV-35G - Veio de greisen (Li-muscovita + quartzo) associado com esfalerita e sendo bordejado por fluorita poiquiloblástica. Polarizadores paralelos. (F) IPV-35AG - Amostra de greisen com pirita anédrica e esfalerita vermelha subédrica disseminadas, localmente formando aglomerados em meio a matriz de Li-muscovita e quartzo ( \pm clorita e fluorita). Luz refletida à esquerda e luz transmitida, polarizadores paralelos, à direita. Siglas utilizadas: Gal - galena, Ccp calcopirita, Pyr - pirita, Sph - esfalerita, Ms - muscovita, Chl - clorita, Qtz - quartzo, Tpz - topázio, Fl - fluorita. 


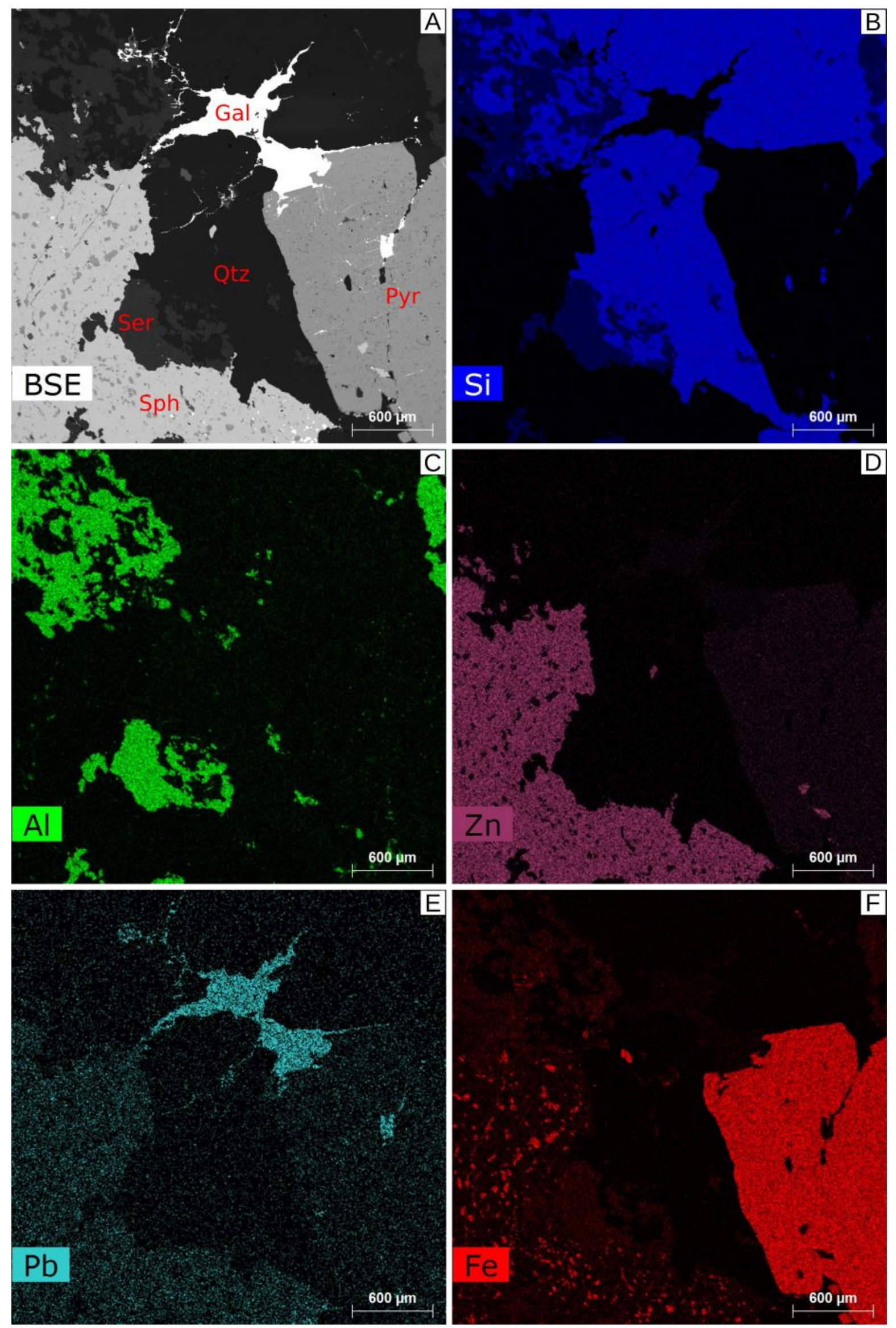

Figura 33: Mapas composicionais de EDS obtidos em MEV para sulfetos de greisen I, amostra IPV-35H do TAG. (A) Imagem de elétrons retro-espalhados (BSE) correspondente à área dos mapas. (B) Mapa de distribuição de Si. (C) Mapa de distribuição de Al. (D) Mapa de distribuição de Zn. (E) Mapa de distribuição de Pb. (F) Mapa de distribuição de Fe. 


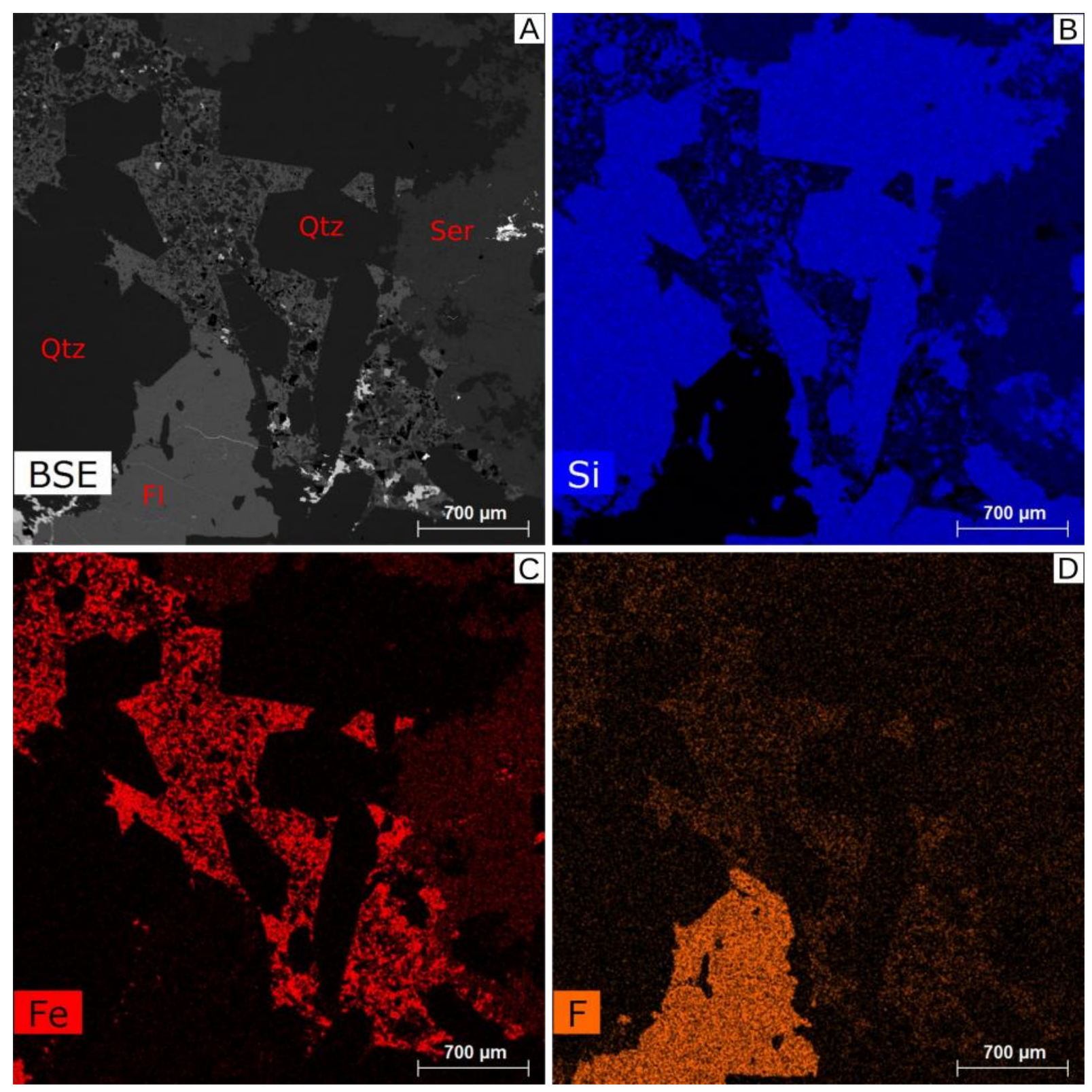

Figura 34: Mapas composicionais de EDS obtidos em MEV para matriz de greisen I, amostra IPV-35H do TAG. (A) Imagem de elétrons retro-espalhados (BSE) correspondente à área dos mapas. (B) Mapa de distribuição de Si. (C) Mapa de distribuição de Fe. (D) Mapa de distribuição de F.

\section{II.2.5 Rochas Encaixantes}

Esta unidade é composta pelos gnaisses encaixantes do Leucogranito Inhandjara (migmatitos paraderivados da unidade superior da Nappe Socorro-Guaxupé - Campos Neto e Caby, 2000) que sofreram forte alteração hidrotermal. A rocha apresenta bandamento milimétrico $(1-15 \mathrm{~mm})$ e intercala lentes quartzosas de textura granoblástica fina com bandas lepidoblásticas, compostas por biotita e muscovita finas. É comum o gnaisse ocorrer intensamente intemperizado, o que dificulta sua caracterização e amostragem em campo, mas por outro lado acaba ressaltando os diversos veios hidrotermais que cortam a rocha (Figura 35D). 
A alteração presente é caracterizada por intensa greisenização pervasiva do gnaisse, intimamente associada a veios de quartzo e topázio com micas (Figura 35A). Estes gnaisses greisenizados, e principalmente os veios que o cortam, hospedam a mineralização de W-Sn que foi explotada durante as décadas de 40 e 60 na antiga Mina de Inhandjara (Figura 3B - Figura 35B).

Localmente a região de contraste composicional entre as bandas do gnaisse pode servir como armadilha para a deposição dos minerais de minério (Figura 36F).

A greisenização é pervasiva (neste trabalho amostras com essa alteração foram identificadas como Greisen II), marcada pela substituição completa da mineralogia metamórfica pela associação de quartzo, Li-micas e topázio (Figura 35F) e outras fases acessórias esporádicas (Figura 38A).

Quartzo é sempre médio, com hábito anedral (Figura 36A) e repleto de inclusões fluidas. Muscovita varia desde cristais finos até grossos quando próxima aos veios (Figura 36E), é subédrica a euédrica, com coloração marrom claro cinzenta e leve pleocroísmo. Comumente apresenta muitas inclusões finas aciculares ou anédricas de minerais opacos (principalmente ilmenita-rutilo - Figura 36D). Topázio é subédrico, ocorrendo como cristais médios a finos dispersos na mesostase ou formando aglomerados (Figura 36B). Biotita é euédrica, ocorrendo com granulação média a fina (localmente grossa nas bordas dos veios). Apresenta coloração marrom cinzenta e forte pleocroísmo (de aspecto petrográfico muito similar às biotitas encontradas no TAG) e comumente possui diversas inclusões aciculares ou irregulares de óxidos (ilmenita-rutilo), localmente desenvolvendo textura sagenítica (inclusões aciculares orientadas em $60^{\circ}$ - Figura 36C).

Alguns pseudomorfos de granada podem ser observados (Figura 35F) sendo completamente substituídos por massas finas de micas e minerais opacos, porém alguns raros cristais preservam pequenos pedaços completamente corroídos na região central dos pseudomorfos.

O segundo produto hidrotermal identificado é a ocorrência de veios centimétricos (2 a $\sim 50 \mathrm{~cm}$ ) espaçados de quartzo e topázio com micas, wolframita e cassiterita (Figura 35C e E). Apresenta caráter fissural, mas está comumente associado a bordas micáceas (Figura 36E) mais grossas e halos externos com greisenização mais intensa que nas porções mais distantes aos veios (Figura 35A e C). 
As amostras apresentam certa variação na proporção entre quartzo e topázio e esta característica reflete diretamente a presença da mineralização de $\mathrm{W}$-Sn, onde veios quartzosos possuem poucos metais (sendo estéreis quando compostos somente por quartzo) e alcançam os maiores teores quando topázio é o mineral dominante (alguns veios são caraterizados por topazitos com wolframita e cassiterita - Figura 37A).

Quartzo é comumente grosso com fraca extinção ondulante. Ocorre como cristais subédricos alongados e orientados perpendicularmente às bordas do veio.

Topázio é euédrico a subédrico e varia de granulação grossa a média (Figura 37B). Alguns cristais podem apresentar alta densidade de inclusões fluidas, fornecendo um aspecto turvo, mas ocorrem lado a lado com cristais límpidos de hábito muito similar.

Wolframita usualmente está presente nas regiões mais internas dos veios (principalmente os que apresentam maiores teores de topázio - Figura 35E). Apresenta coloração preta totalmente opaca, ocorrendo como cristais euédricos grossos a localmente médios. Alguns cristais apresentam certo zoneamento sob luz refletida, marcado por linhas de crescimento sub-paralelas às bordas dos grãos (Figura $37 \mathrm{C}$ ). Raramente possuem inclusões irregulares de stolzita $\left(\mathrm{PbWO}_{4}\right)$. Também podem aparecer brechadas sendo envoltas por matriz micácea (Figura 38D). Sua composição foi identificada in situ por EDS, sendo majoritariamente manganesífera ( $20 \%$ de peso em óxido) e com pouco ferro ( $5 \%)$. Portanto é classificada como da variedade hübnerita.

Cassiterita ocorre principalmente nas bordas dos veios, bem no contato com a rocha encaixante, porém também aparece manteando alguns cristais de wolframita ou brechada nas bordas dos veios (Figura 38C). É euédrica com granulação média a grossa. Possui coloração castanha a vermelha (Figura 37D), com intenso pleocroísmo (especialmente nas porções mais avermelhadas), sendo comumente zonada nas cores e com linhas de crescimento paralelas às faces. Apesar da variação petrográfica, as zonas não possuem diferenças químicas (ao menos para elementos maiores), com os cristais apresentando tons de cinza homogêneos nas imagens BSE (Figura 38B) e valores similares em análises pontuais por EDS, sendo composta apenas por $\mathrm{SnO}_{2}$, sem impurezas detectáveis por EPMA. Raramente possuem inclusões subédricas de quartzo.

Quando presentes, cristais de muscovita são muito finos e compõe uma matriz que envolve fragmentos das outras fases (Figura 37E), fornecendo um aspecto brechado 
à amostra (Figura 39). Apresentam-se incolores a castanho claro, com pleocroísmo muito leve. Localmente ocorrem como cristais euédricos um pouco maiores preenchendo parcialmente das bordas para o centro algumas cavidades presentes na matriz (Figura 37F).

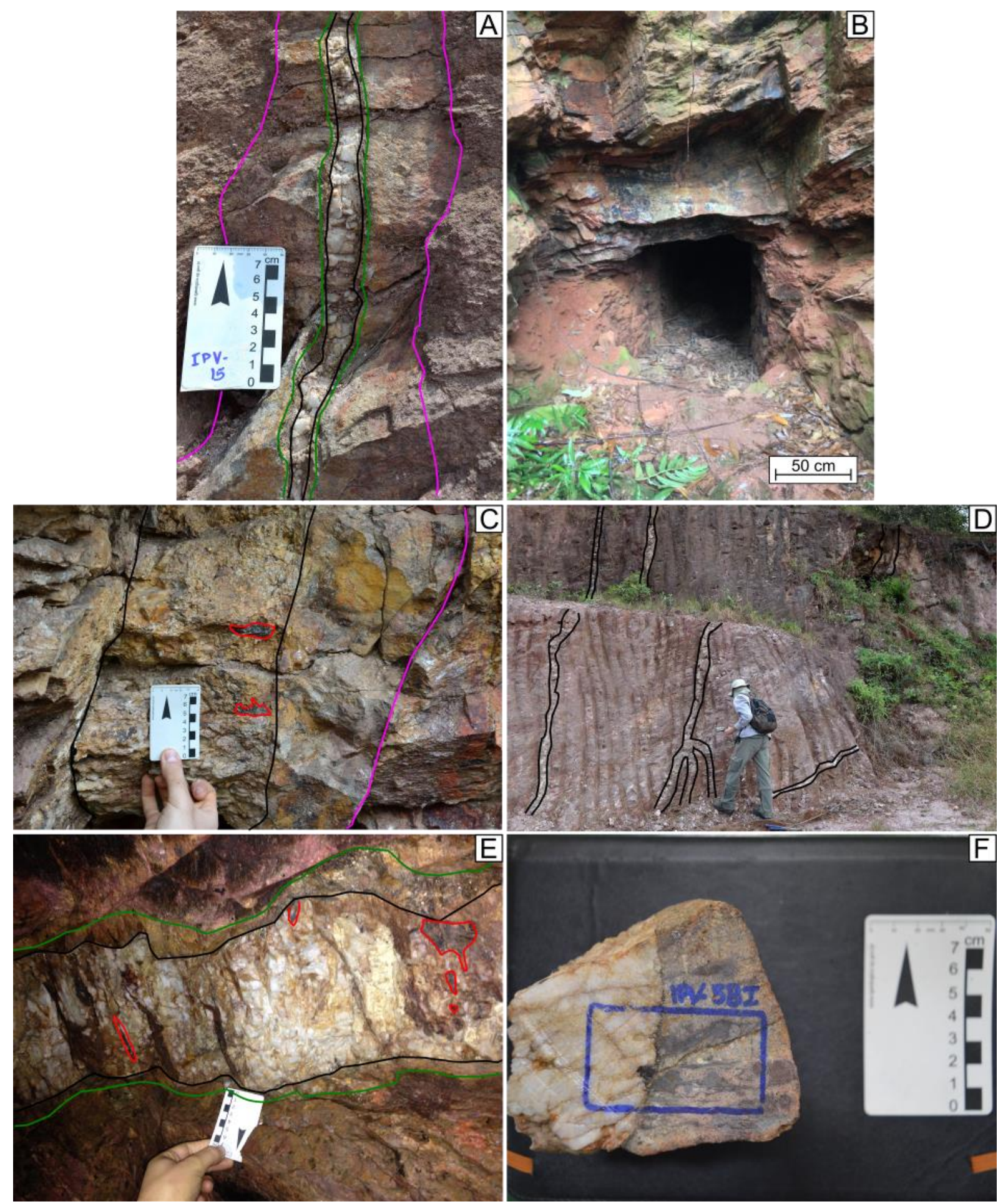

Figura 35: (A) Veio de quartzo em gnaisse (linha preta) sendo bordejado por franja micácea (linha verde) e intensa greisenização adjacente (linha rosa). (B) Entrada de um dos túneis da antiga Mina de Inhandjara. A altura da passagem é de cerca de $1 \mathrm{~m}$. (C) Veio de topazito mineralizado em wolframita (contorno vermelho) e cassiterita, sendo bordejado por greisenização intensa (linha rosa). (D) Veios de quartzo no gnaisse (linhas pretas) ocorrendo com diversas orientações. (E) Veio de quartzo-topázio (linha preta) mineralizado em wolframita (contorno vermelho), sendo bordejado por espessa franja micácea (linha verde). (F) Amostra de veio quartzo em gnaisse fortemente greisenizado. Está mineralizado em cassiterita em sua borda, associado a franja micácea. 

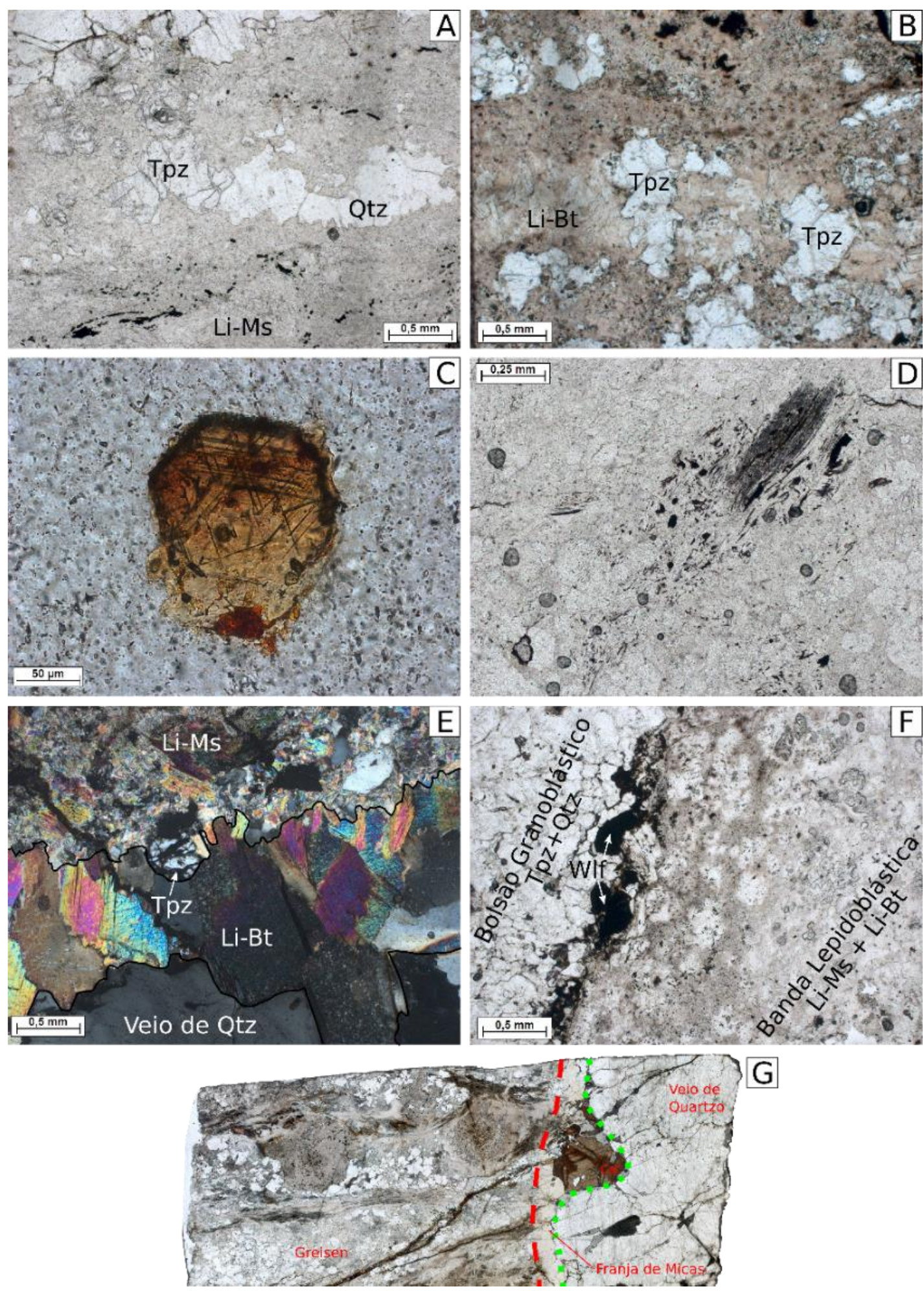

Figura 36: (A) IPV-12 - Amostra de greisen em gnaisse encaixante, dominado por Li-muscovita, quartzo e topázio com alguns minerais opacos alinhados. Polarizadores paralelos. (B) IPV-15C - Amostra de greisen ao lado de topazito mineralizado, sendo dominado por Li-biotita e topázio, com quartzo quase ausente. Notar que aglomerados de topázio aparentemente cortam bandas de biotita mais grossa. Polarizadores paralelos. (C) IPV-07A - Cristal de biotita euédrica sagenítica, com inclusões aciculares orientadas em ângulos de $60^{\circ}$, em gnaisse greisenizado. Polarizadores paralelos. (D) IPV-12 - Cristal de muscovita grossa associada a diversas inclusões anédricas de minerais opacos. Polarizadores paralelos. (E) IPV-5B(I) - Veio de quartzo (linha contínua grossa) bordejado por franja micácea associada a topázio fraturado. Notar que a granulação da franja diminui levemente em direção ao greisen (linha fina). Polarizadores cruzados. (F) IPV-15C - Amostra de gnaisse greisenizado mineralizado em wolframita no contato entre banda granoblástica (topázio e quartzo) e banda lepidoblástica (Li-muscovita e Li-biotita) Polarizadores paralelos. Siglas utilizadas: Tpz - topázio, Qtz - quartzo, Ms - muscovita, Bt - biotita, WIf - wolframita. (G) Mosaico de fotomicrografias de seção delgada mostrando veio de quartzo em greisen II. Zona de contato (linhas tracejada e pontilhada) é marcada por franja micácea de mais granulação que o greisen encaixante e hospeda cristal de cassiterita euédrica. 

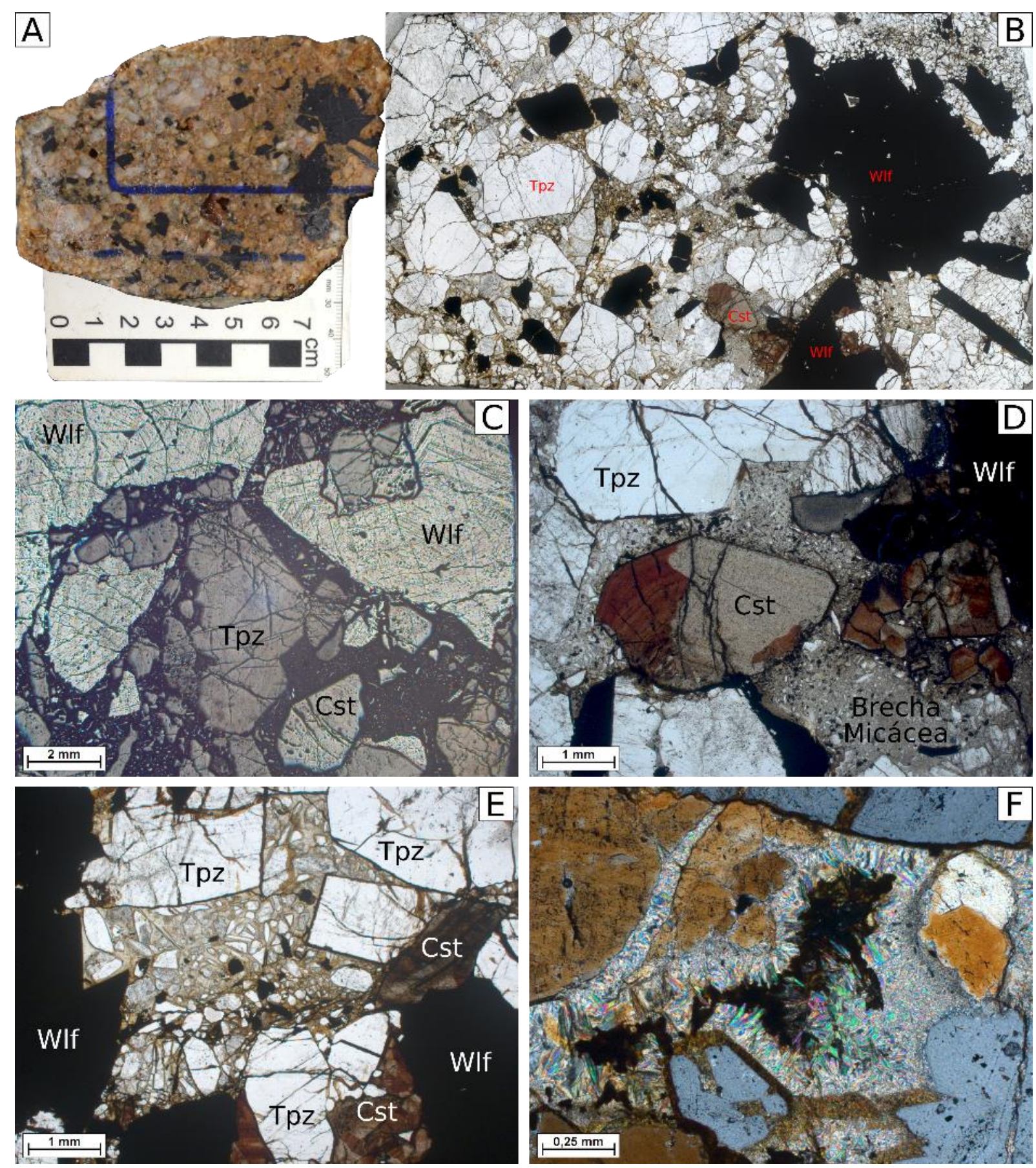

Figura 37: (A) Amostra de mão de veio de topazito com wolframita e cassiterita. (B) Mosaico de fotomicrografias de seção delgada mostrando veio de topazito mineralizado. (C) IPV-15D - Cristais euédricos de wolframita podem apresentar linhas de crescimento sub-paralelas às suas bordas. Luz refletida. (D) IPV-15D Cristal euédrico de cassiterita mostrando zonação de cor. Polarizadores paralelos. (E) IPV-15D - Wolframita euédrica bordejada por cassiterita euédrica e envolvendo topázio euédrico, ao lado de matriz brechada preenchida por sericita. Polarizadores paralelos. (F) IPV-15D - Detalhe de cavidade parcialmente preenchida por muscovita pleocróica crescendo das bordas para núcleo. Polarizadores cruzados. Siglas utilizadas: Tpz - topázio, WIf wolframita, Cst - cassiterita. 

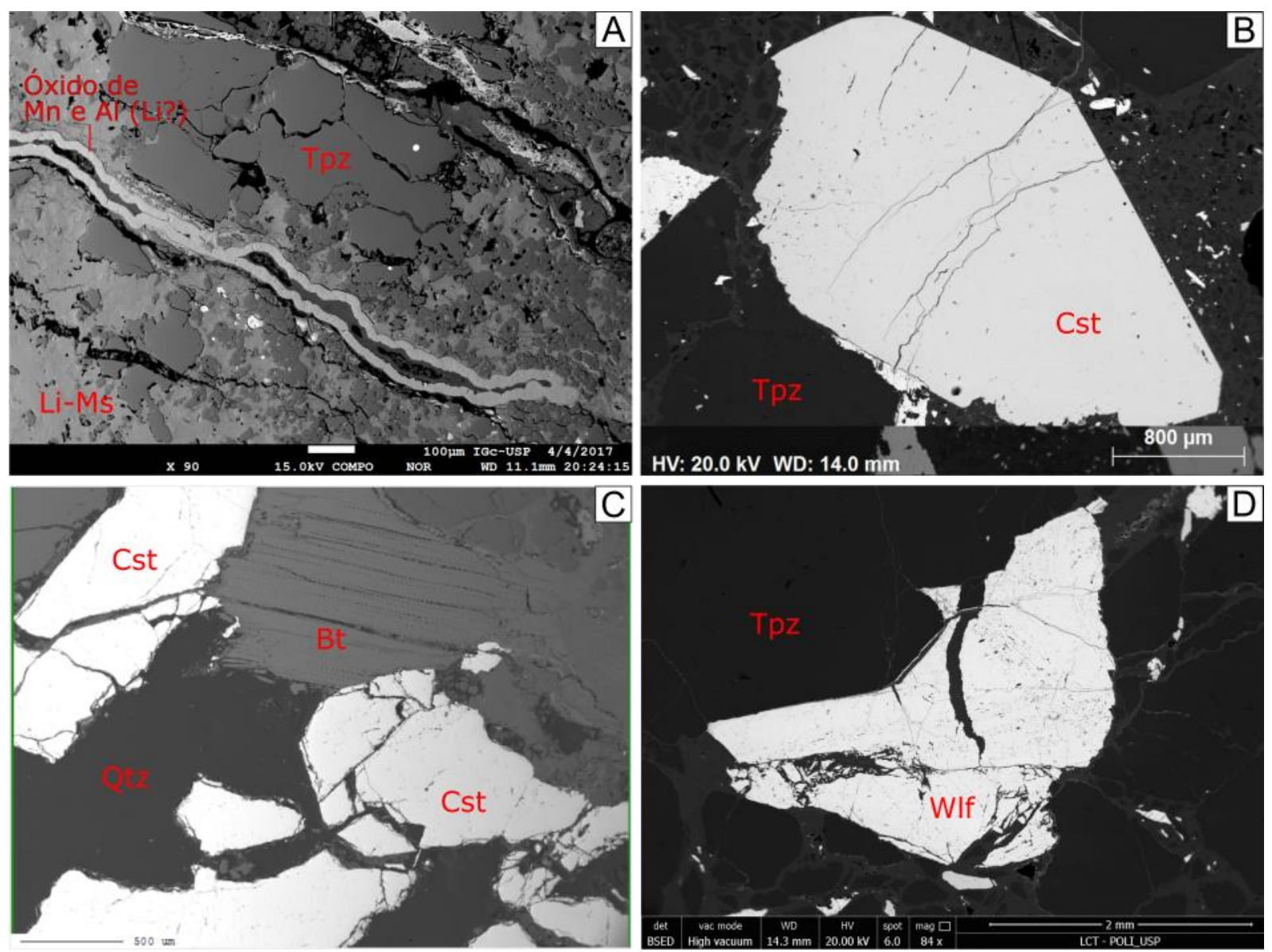

Figura 38:Prancha de imagens BSE dos greisen II e veio de topazito mineralizados. (A) Imagem BSE de greisen II, composto por com aglomerados cristalinos de topázio envoltos por massas de Li-muscovita fina. Notar presença de fratura preenchida por óxido de manganês e alumínio (+Li?). (B) Cristal de cassiterita em veio de topazito, mostrando sua resposta homogênea em imagens BSE, apesar de apresentar forte zonação de cor na análise ótica. (C) Cristais fraturados de cassiterita entre veio de quartzo e greisen II, margeado por franja micácea grossa. (D) Cristal de wolframita brechada, sendo preenchido por matriz filossilicática fina. 


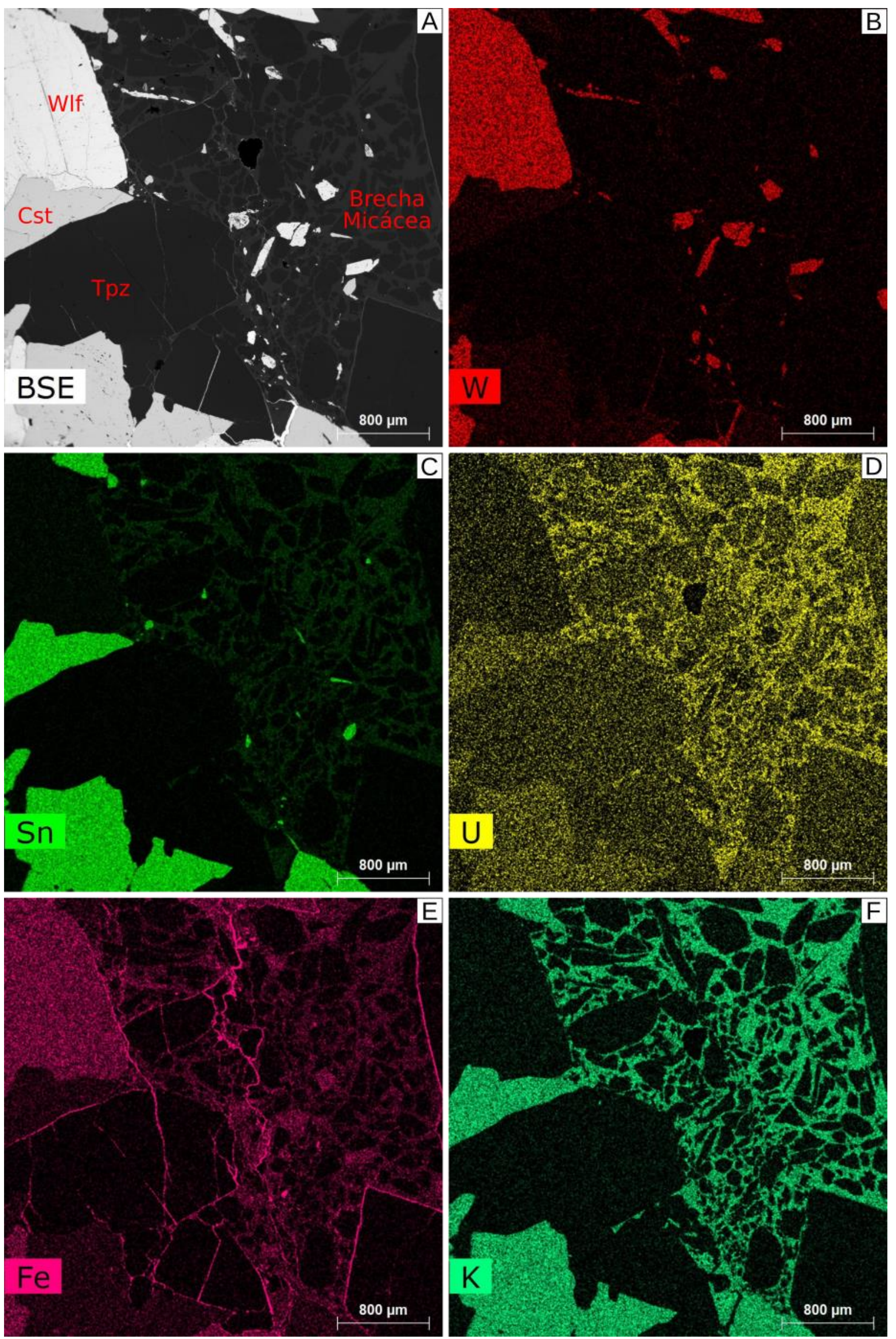

Figura 39: Mapas composicionais de EDS obtidos em MEV para veios de topazito mineralizado, amostra IPV15D. (A) Imagem de elétrons retro-espalhados (BSE) correspondente à área dos mapas. (B) Mapa de distribuição de W. (C) Mapa de distribuição de Sn. (D) Mapa de distribuição de U. (E) Mapa de distribuição de Fe. (F) Mapa de distribuição de $\mathrm{K}$. 


\section{II.3 GEOQUÍMICA DE ROCHA TOTAL}

O batólito como um todo se encontra bastante hidrotermalizado, por isso buscouse apenas as amostras menos alteradas, que fossem representativas de cada fácies, para obtenção das análises químicas. Análises químicas representativas das diferentes fácies são apresentadas na Tabela 5 e os dados completos no Anexo III

\section{II.3.1 Elementos Maiores}

Os diagramas binários tipo Harker, sílica como discriminante, são apresentados nas Figura 40,Figura 41 e Figura 42. A fácies porfirítica do Biotita Granito (BG) apresenta valores em torno de $73 \%$, enquanto as demais amostras variam de 75 a $77 \%$. Considerando os elementos maiores (Figura 40), o Biotita Granito (fácies porfirítica e inequigranular) é bastante homogêneo, com teores de $\mathrm{TiO}_{2}(\sim 0,2 \%), \mathrm{Fe}_{2} \mathrm{O}_{3}$ total $(1,0$ - 2\%), $\mathrm{MgO}(\sim 0,2 \%), \mathrm{CaO}(0,5-0,7 \%), \mathrm{Na}_{2} \mathrm{O}(3,5-4,5 \%)$ e $\mathrm{P}_{2} \mathrm{O}_{5}(0,05-0,07 \%)$ muito próximos, mas apresenta variações em $\mathrm{Al}_{2} \mathrm{O}_{3}$ (13-14\% e $11-12 \%$, respectivamente) e $\mathrm{K}_{2} \mathrm{O}$ (5-6\% e $\left.4,5 \%\right)$. O Topázio Granito (TAG) apresenta composição bem distinta, sendo bastante empobrecido em $\mathrm{TiO}_{2}(<0,08 \%), \mathrm{Fe}_{2} \mathrm{O}_{3}{ }^{\top}$ $(0,8-0,9 \%), \mathrm{MgO}(<0,03 \%), \mathrm{CaO}(0,4-0,6 \%)$ e $\mathrm{P}_{2} \mathrm{O}_{5}(<0,01 \%)$, com teores intermediários de $\mathrm{Al}_{2} \mathrm{O}_{3}(12-13 \%)$ e $\mathrm{K}_{2} \mathrm{O}(4-5 \%)$, e enriquecido apenas em $\mathrm{Na}_{2} \mathrm{O}$ ( $5 \%)$ quando comparado ao BG.

$\mathrm{O}$ número de magnésio ( $\mathrm{MgO} /[\mathrm{FeO}+\mathrm{MgO}]_{\text {moleculares})}$ é o principal diferenciador geoquímico entre as rochas estudadas (Figura 42A), onde o TAG sempre apresenta valores menores que 5 (atingindo valor próximo a zero na amostra-tipo IPV-35A), enquanto o BG apresenta valores próximos a 10 nos granitos e de 17 a 20 nas amostras mais hidrotermalizadas. 0 número de magnésio baixo é um distintivo dos leucogranitos de Inhandjara, especialmente da fácies evoluída, para o restante do Batólito Itu, que sempre apresenta valores maiores que 10 .

A razão $1 / \mathrm{TiO}_{2}$, relacionado ao comportamento compatível do titânio, tende a aumentar progressivamente entre as amostras de Inhandjara (Figura 42B). Esta varia gradualmente da fácies porfirítica, com valores próximos a 10, para a fácies inequigranular (cerca de 12). E apresenta um aumento pronunciado no TAG ( 90).

Por fim, a razão $\mathrm{K}_{2} \mathrm{O} / \mathrm{Na}_{2} \mathrm{O}$ mais baixa no TAG $(0,85-0,95)$ do que no $\mathrm{BG}(1,17$ $1,45)$, indica o caráter enriquecido em sódio da fácies mais evoluída, que quando 
comparada com o teor de $\mathrm{CaO}$ (Figura 42F) reproduz a relação petrográfica observada, onde essa fácies apresenta albita como fase magmática.

\section{II.3.2 Elementos menores e traços}

Para os elementos menores e traço (Figura 41), o Biotita Granito, considerando ambas fácies, possui valores mais elevados de $\mathrm{Ba}(400-650$ ppm), $\mathrm{Sr}(20$ - 90 ppm) e $\operatorname{Zr}(90-210 \mathrm{ppm})$ e é mais pobre em $\mathrm{F}(2200-2600 \mathrm{ppm}), \mathrm{Cs}(6.8-8.3 \mathrm{ppm})$, Nb (30 - 50 ppm), Ta (3 - 5 ppm), Rb (400 - 415 ppm) e Y (35 - 70 ppm).

Por outro lado, o Topázio Granito é enriquecido em F (3000 - 3800 ppm), Cs ( 15 ppm), Nb (60 - 80 ppm), Ta (7 - 9 ppm), Rb (650 - 780 ppm) e Y (80 - 130 ppm) e empobrecido em Ba ( 2), Sr (4,3 - 8) e Zr ( 80).

Ao considerar algumas razões de interesse, o par K/Rb (Figura 42C) separa muito bem as fácies, diminuindo desde a porfirítica (120 - 150), inequigranular ( 90) até o TAG ( 50). Assim como a razão Zr/Hf também diminui, sendo respectivamente de 24, 22 e 10 (Figura 42D) para as fácies estudadas.

A razão $\mathrm{Rb} / \mathrm{Sr}$ apresenta grande aumento nos valores com a evolução magmática (respectivamente $3,5-5,5$, 20 e $95-180$ ), enquanto a razão $\mathrm{Ba} / \mathrm{Sr}$ apresenta variação gradual do Biotita Granito (4,5 - 6) para o Topázio Granito (0,4 - 4). Essa relação entre Rb-Ba-Sr fica evidente do diagrama ternário de El Bouselly e El Sokkary (1975), onde o Topázio Granito plota no extremo mais enriquecido em Rb (Figura 41G).

A razão $\mathrm{Nb} / \mathrm{Ti}$ (Figura 42E) segue a mesma tendência da razão $1 / \mathrm{TiO}_{2}$, com os menores valores na fácies porfirítica $(0,03$ a 0,05$)$, seguida pela inequigranular $(\sim 0,09)$ e com a fácies equigranular no extremo de maior valor $(0,7$ a 0,96$)$, indicando teores similares para Nb e Ti no Topázio Granito (63 e 66 ppm, respectivamente).

Nos diagramas de elementos traço normalizados por condritos (Figura 43B), as amostras apresentam padrões muito similares, com maiores concentrações de $\mathrm{Cs}, \mathrm{Rb}$, Th, U, Nb, Ta, Y, W, Yb e Ga quando comparados aos outros plutons do Batólito Itu. Porém dentro do stock, o BG se destaca pelo maior enriquecimento em Th e $U$, sendo depletado em Mo em relação ao condrito, enquanto o TAG possui maiores teores de $\mathrm{Cs}, \mathrm{Rb}, \mathrm{Ta}, \mathrm{Y}, \mathrm{W}$ e Yb, e é depletado em $\mathrm{Sr}$ e Ba. 


\section{II.3.3 Elementos terras raras (ETR)}

Considerando os conteúdos dos elementos terras raras (ETR) para o Leucogranito Inhandjara, temos que os teores totais são pouco variáveis, entre 190 e 140 ppm para todas as amostras do stock.

Particularmente, as fácies do Biotita Granito possuem maior valor dos ETR leves (120 a 150 ppm) do que dos ETR pesados (20 a 35 ppm), enquanto o Topázio Granito apresenta menor conteúdo nos ETRL ( $\sim 90 \mathrm{ppm}$ ) e maior nos ETRP ( $\sim 60 \mathrm{ppm})$ quando comparado ao Biotita Granito.

Para os padrões de ETR normalizados pelo condrito (Figura 43A) é possível observar que as amostras do BG apresentam padrão similar, sendo levemente fracionados $\left((\mathrm{La} / \mathrm{Yb})_{\mathrm{N}}\right.$ de 3 a 8,2). A principal diferença entre as amostras é a anomalia negativa de Eu mais pronunciada para a fácies inequigranular que na porfirítica $\left(\mathrm{Eu} / \mathrm{Eu}^{*}=\right.$ $\sim 0,145$ e 0,370, respectivamente). O Biotita Granito apresenta padrões similares aos dos outros plutons do Batólito Itu. Já o TAG apresenta um padrão menos fracionado $\left((\mathrm{La} / \mathrm{Yb})_{\mathrm{N}}\right.$ entre 0,6 e 1,2), com valores de ETRL menores e ETRP maiores do que 0 restante do batólito, além de anomalia negativa de Eu fortemente pronunciada $\left(\mathrm{Eu} / \mathrm{Eu}^{*}=\sim 0,003\right)$.

\section{II.3.1 Diagramas Discriminantes}

Seguindo as classificações geoquímicas de Frost et al. (2001), os granitos estudados apresentam caráter metaluminoso (Figura 44A), mas com leve tendência a peraluminoso (ASI $=0,9-1,0$ e A/NK $=1,0-1,1$ ), são ferroanos (fe* $=0,9-1,0$ Figura 44B) e plotam na transição entre os campos álcali-cálcico a calci-alcálico (MALI = 8 - 10), com uma amostra da fácies porfirítica plotando no campo alcálico (Figura 44C). As fácies inequigranular e equigranular são calci-alcalinas de alto $K$, enquanto a fácies porfirítica plota no campo shoshonítico no diagrama $\mathrm{K}_{2} \mathrm{O}$ vs. $\mathrm{SiO}_{2}$ (Peccerillo e Taylor, 1976). Utilizando os diagramas de Dall'Agnol e de Oliveira (2007), os leucogranitos se encaixam no campo dos granitos tipo-A reduzidos.

Nos diagramas de Whalen et al. (1987), o Leucogranito Inhandjara é sempre definido como do tipo-A, em acordo com o caráter geral da Província Itu. E são classificados como do tipo A-2 conforme Eby (1992). 
Tabela 5: Análises químicas de elementos maiores em rocha total representativas das fácies do Stock de Inhandjara.

\begin{tabular}{|c|c|c|c|}
\hline Fácies & BG Porfirítico & $\begin{array}{c}\text { BG } \\
\text { Inequigranular }\end{array}$ & $\begin{array}{c}\text { TAG } \\
\text { Equigranular }\end{array}$ \\
\hline Amostra & IPV-14 & IPV-30C & IPV-35A \\
\hline $\mathrm{SiO}_{2}$ (wt\%) & 73,13 & 76,76 & 76,18 \\
\hline $\mathrm{TiO}_{2}$ & 0,098 & 0,085 & 0,011 \\
\hline $\mathrm{Al}_{2} \mathrm{O}_{3}$ & 14,33 & 12,02 & 12,96 \\
\hline $\mathrm{Fe}_{2} \mathrm{O}_{3}(\mathrm{~T})$ & 1,02 & 0,95 & 0,85 \\
\hline $\mathrm{MnO}$ & 0,024 & 0,02 & 0,064 \\
\hline $\mathrm{MgO}$ & 0,06 & 0,05 & 0,00 \\
\hline $\mathrm{CaO}$ & 0,68 & 0,53 & 0,44 \\
\hline $\mathrm{Na}_{2} \mathrm{O}$ & 4,57 & 3,83 & 4,73 \\
\hline $\mathrm{K}_{2} \mathrm{O}$ & 5,81 & 4,51 & 4,45 \\
\hline $\mathrm{P}_{2} \mathrm{O}_{5}$ & 0,021 & 0,012 & 0,008 \\
\hline P.F. & 0,59 & 0,65 & 0,45 \\
\hline Total (wt\%) & 100,33 & 99,42 & 100,14 \\
\hline $\mathrm{F}(\mathrm{ppm})$ & 2212 & 2606 & 3003 \\
\hline $\mathrm{Cl}$ (ppm) & $<500$ & $<500$ & $<500$ \\
\hline S (ppm) & $<550$ & $<550$ & $<550$ \\
\hline La (ppm) & 25,3 & 34,5 & 12,7 \\
\hline $\mathrm{Ce}$ & 57,1 & 71,4 & 37,3 \\
\hline $\mathrm{Pr}$ & 7,44 & 9,96 & 6,08 \\
\hline $\mathrm{Nd}$ & 24,6 & 32,5 & 24,2 \\
\hline $\mathrm{Sm}$ & 5,26 & 7,39 & 9,83 \\
\hline $\mathrm{Eu}$ & 0,57 & 0,34 & 0,01 \\
\hline $\mathrm{Gd}$ & 4,22 & 7 & 11,1 \\
\hline $\mathrm{Tb}$ & 0,73 & 1,29 & 2,19 \\
\hline Dy & 4,51 & 8,3 & 14,1 \\
\hline $\mathrm{Ho}$ & 1,08 & 2,04 & 3,37 \\
\hline $\mathrm{Er}$ & 3,18 & 6,04 & 10,2 \\
\hline $\mathrm{Tm}$ & 0,56 & 1,08 & 1,92 \\
\hline $\mathrm{Yb}$ & 4,04 & 7,67 & 14,5 \\
\hline Lu & 0,62 & 1,17 & 2,18 \\
\hline $\mathrm{Ba}$ & 390 & 90,6 & 1,92 \\
\hline Cs & 6,74 & 8,33 & 15,4 \\
\hline $\mathrm{Hf}$ & 3,55 & 5,17 & 8,09 \\
\hline Mo & 0,1 & 0,3 & 2 \\
\hline $\mathrm{Nb}$ & 29,6 & 47,8 & 63,3 \\
\hline $\mathrm{Pb}$ & 35,4 & 32,5 & 49,3 \\
\hline $\mathrm{Rb}$ & 404 & 415 & 783 \\
\hline $\mathrm{Sr}$ & 74,2 & 20 & 4,35 \\
\hline $\mathrm{Ta}$ & 3,3 & 4,7 & 9,1 \\
\hline Th & 40,2 & 58,8 & 35,3 \\
\hline $\mathrm{U}$ & 4,34 & 13,8 & 8,19 \\
\hline W & 3,9 & 1,2 & 2,6 \\
\hline$Y$ & 35 & 69,7 & 122 \\
\hline $\mathrm{Zr}$ & 86,2 & 113 & 79,4 \\
\hline $\mathrm{Ga}$ & 22 & 21 & 29 \\
\hline $\mathrm{Zn}$ & 17 & 21 & 37 \\
\hline ETR (ppm) & 139,2 & 190,7 & 149,7 \\
\hline ETRL (ppm) & 119,7 & 155,7 & 90,1 \\
\hline ETRP (ppm) & 19,5 & 34,9 & 59,6 \\
\hline $\mathrm{mg} \#$ & 10,4 & 9,4 & 0 \\
\hline $\mathrm{A} / \mathrm{CNK}$ & 0,95 & 0,99 & 0,96 \\
\hline Eu/Eu* & 0,37 & 0,14 & 0,003 \\
\hline$(\mathrm{La} / \mathrm{Yb})_{\mathrm{N}}$ & 4,22 & 3,03 & 0,59 \\
\hline
\end{tabular}



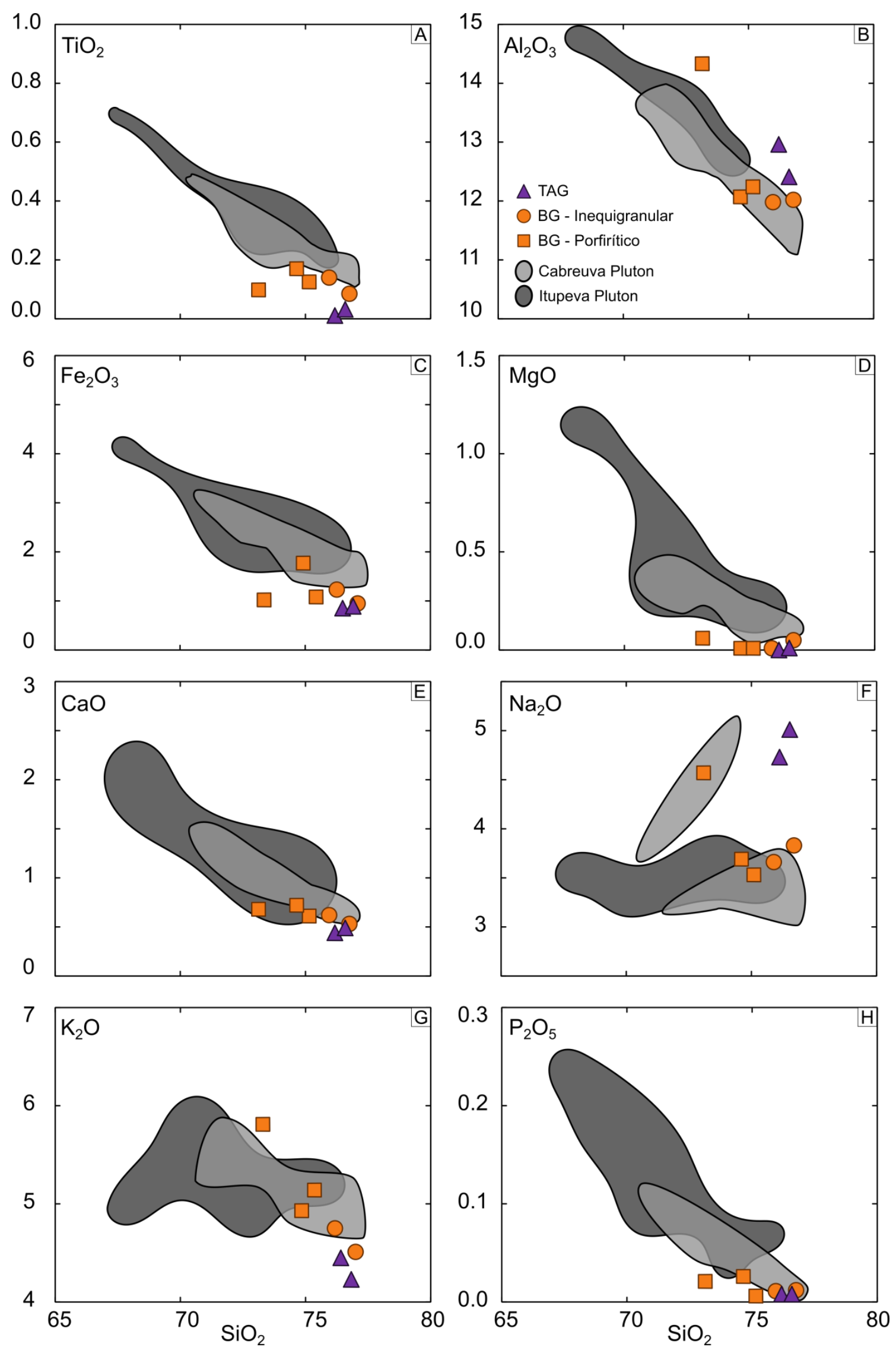

Figura 40: Diagramas de elementos maiores vs. sílica (porcentagem em peso) para as amostras de Inhandjara. Campos dos plutons do Batólito Itu a partir de dados de Galembeck (1997); Janasi et al. (2009); e dados inéditos do grupo de pesquisa. 

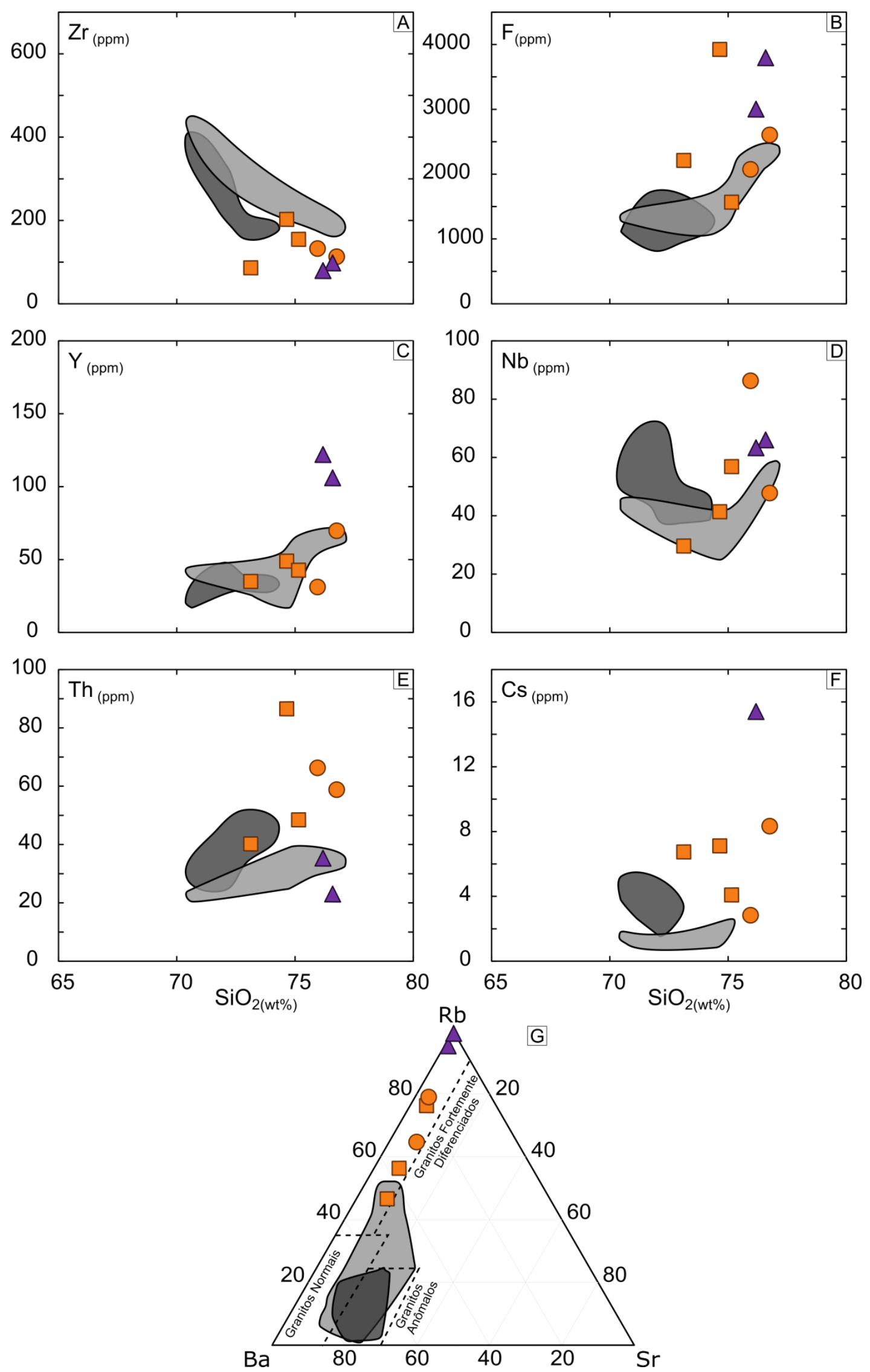

Figura 41: (A, B, C, D, E e F) Diagramas de elementos menores e traços (ppm) vs. sílica (porcentagem em peso) destacando as análises das amostras de Inhandjara. (G) Diagrama ternário Rb-Ba-Sr com campos para granitos evoluídos de El Bouselly e El Sokkary (1975). Campos dos plutons do Batólito Itu a partir de dados de Galembeck (1997); Janasi et al. (2009); e dados inéditos do grupo de pesquisa. Símbolos conforme Figura 40. 

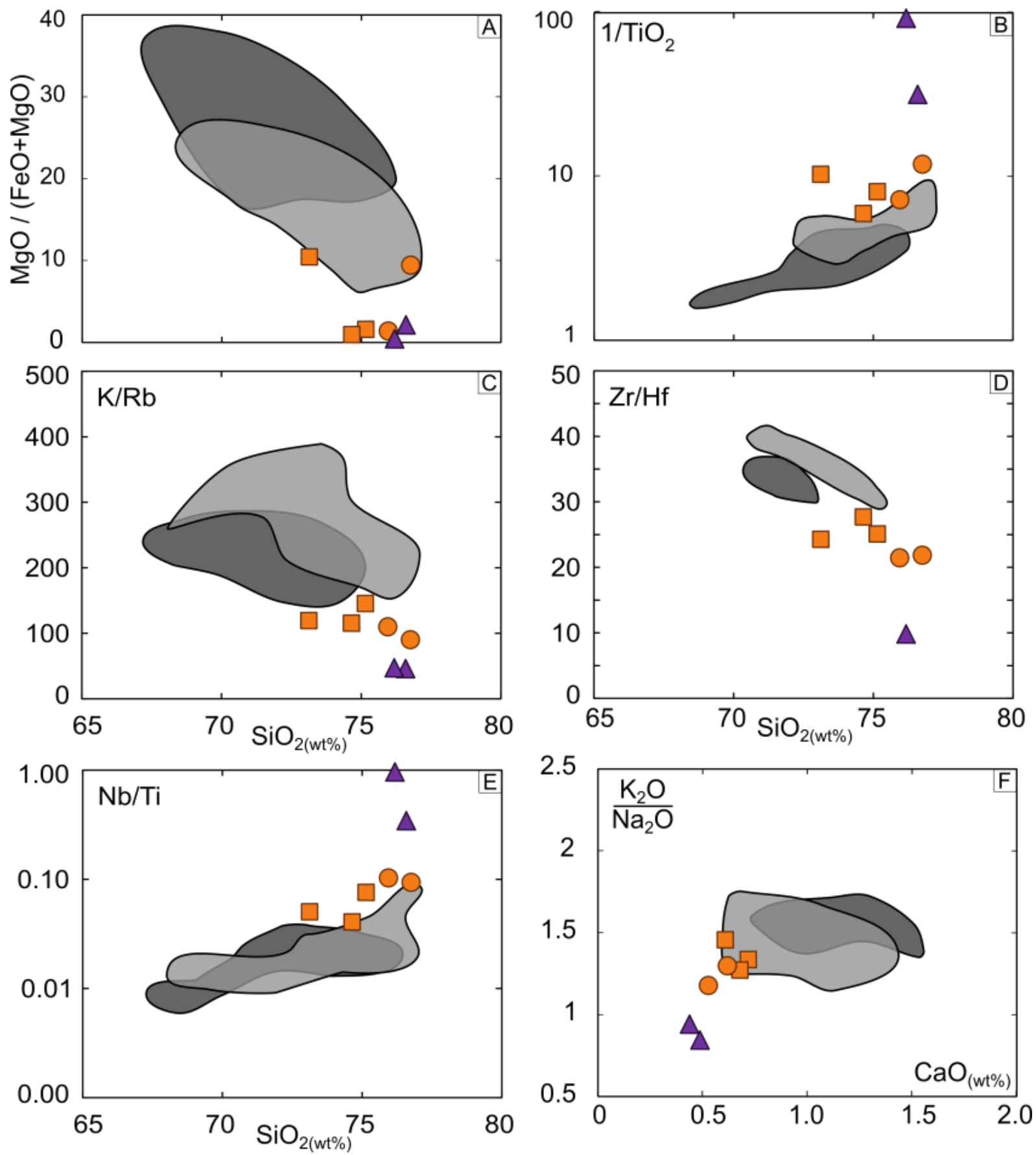

Figura 42: (A, B, C, D e E) Diagramas de razões geoquímicas de interesse vs. sílica (porcentagem em peso) ou vs. $\mathrm{CaO}$ (porcentagem em peso) para as amostras de Inhandjara. Campos dos plutons do Batólito Itu a partir de dados de Galembeck (1997); Janasi et al. (2009); e dados inéditos do grupo de pesquisa. Símbolos conforme Figura 40. 

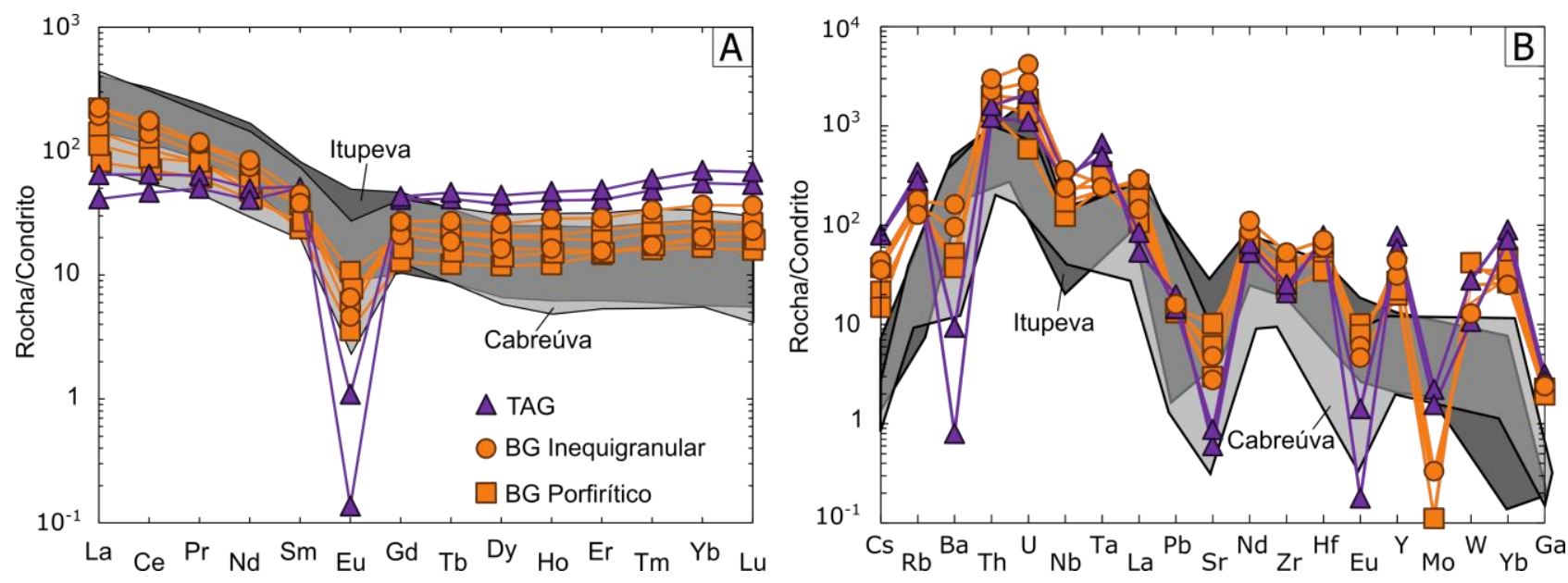

Figura 43: (A) Diagrama de elementos terras-rara (ETR) e (B) de elementos traços normalizados pelo condrito CI (McDonough \& Sun, 1995). Símbolos representam as análises deste projeto. Campos dos plutons do Batólito Itu a partir de dados de Galembeck (1997); Janasi et al. (2009); e dados inéditos do grupo de pesquisa.

\section{II.3.2 Isotopia Sm-Nd}

Amostras do Biotita Granito apresentam menores teores de $\mathrm{Sm}$ e maiores de $\mathrm{Nd}$ (respectivamente, 5,1 e 24,8 ppm), fornecendo as menores razões do conjunto e valores similares para razão ${ }^{143} \mathrm{Nd} /{ }^{144} \mathrm{Nd}$ e $\varepsilon N d$ (Tabela 6 - utilizando a idade média do granito Inhandjara em 570 Ma, apresentada no item II.5), que neste caso são bastante negativos $(\varepsilon N d=-11,73)$. Já o TAG apresenta os maiores valores de $\mathrm{Sm}(9,4 \mathrm{ppm})$, porém os menores de $\mathrm{Nd}(23,6)$, fornecendo razões muito elevadas e diferentes das obtidas para o Biotita Granito. O valor de $\varepsilon N d$ (a $570 \mathrm{Ma}$ ) é bem mais negativo que no caso anterior $(\varepsilon N d=-12,64)$, alcançando os mais baixos valores para todo o batólito (Figura 45A).

Comparando os valores de $\varepsilon N d$ obtidos para o Leucogranito Inahndjara com algumas razões e teores geoquímicos, é possível observar que o TAG, com عNd mais negativo, também apresenta maiores valores de Cs, Y e da razão Nb/Ti (Figura 45B, C e D). Enquanto para a razão $\mathrm{Zr} / \mathrm{Hf}$ é menor no TAG com $\varepsilon N d$ mais negativo (Figura 45E). Essas relações não são claras para os outros plutons do Batólito.

Tabela 6: Dados isotópicos Sm/Nd em rocha total das amostras de Inhandjara.

\begin{tabular}{|c|c|c|c|c|c|c|c|c|c|c|}
\hline Amostra & Fácies & $\begin{array}{c}\mathrm{Sm} \\
(\mathrm{ppm})\end{array}$ & $\begin{array}{c}\mathrm{Nd} \\
(\mathrm{ppm})\end{array}$ & ${ }^{147} \mathrm{Sm} /{ }^{144} \mathrm{Nd}$ & ${ }^{143} \mathrm{Nd} /{ }^{144} \mathrm{Nd}$ & $\varepsilon(0)$ & $\mathrm{fSm} / \mathrm{Nd}$ & $\mathrm{TDM}(\mathrm{Ma})$ & $\varepsilon\left(\mathrm{TD}_{\mathrm{DM}}\right)$ & $\begin{array}{c}\varepsilon \mathrm{Nd} \\
(570 \mathrm{Ma})\end{array}$ \\
\hline IPV-14 & BG Porf & 5,073 & 24,779 & 0,1238 & 0,511765 & $-17,03$ & $-0,37$ & 2171,2 & 3,16 & $-11,73$ \\
\hline IPV-30C & BG Ineq & 7,038 & 32,304 & 0,1318 & 0,511795 & $-16,45$ & $-0,33$ & 2330,7 & 2,86 & $-11,73$ \\
\hline IPV-35A & TAG & 9,371 & 23,624 & 0,2399 & 0,512151 & $-9,50$ & 0,22 & & & $-12,64$ \\
\hline
\end{tabular}



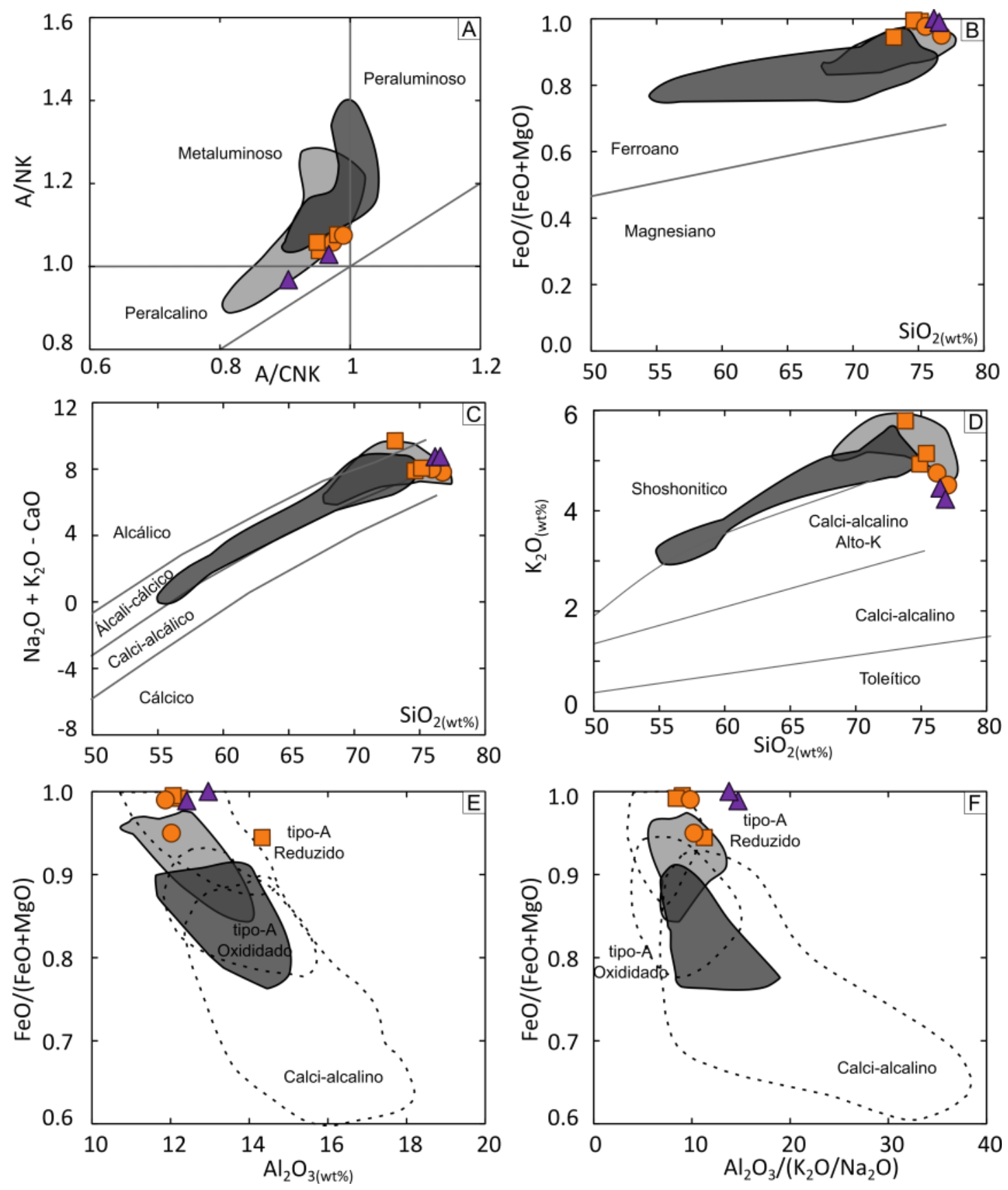

Figura 44: (A) Diagrama de proporções molares $\mathrm{Al}_{2} \mathrm{O}_{3} /\left(\mathrm{N}_{2} \mathrm{O}+\mathrm{K}_{2} \mathrm{O}\right)$ vs. $\mathrm{Al}_{2} \mathrm{O}_{3} /\left(\mathrm{CaO}+\mathrm{N}_{2} \mathrm{O}+\mathrm{K}_{2} \mathrm{O}\right)$ indicando a relação entre álcalis e alumina para as amostras de Inhandjara. (B) Diagrama Fe* vs. $\mathrm{SiO}_{2}$ (porcentagem em peso) de Frost et al. (2001) para relação entre Fe e Mg. (C) Diagrama $\mathrm{N}_{2} \mathrm{O}+\mathrm{K}_{2} \mathrm{O}-\mathrm{CaO}$ vs. $\mathrm{SiO}_{2}$ de Frost et al. (2001) indicando a alcalinidade das amostras. (D) Diagrama $\mathrm{K}_{2} \mathrm{O}$ vs $\mathrm{SiO}_{2}$ (porcentagem em peso) de Peccerillo e Taylor (1976) mostrando a afinidade de $\mathrm{K}$ nas amostras. (E) Diagrama Fe* $\mathrm{vs} \mathrm{Al}_{2} \mathrm{O}_{3}$ de Dall'Agnol e de Oliveira (2007) indicando o grau de oxidação das amostras. (F) Diagrama Fe* vs $\mathrm{Al}_{2} \mathrm{O}_{3} /\left(\mathrm{K}_{2} \mathrm{O} / \mathrm{Na}_{2} \mathrm{O}\right)$ de Dall'Agnol e de Oliveira (2007) indicando o grau de oxidação das amostras. Campos dos plutons do Batólito Itu a partir de dados de Galembeck (1997); Janasi et al. (2009); e dados inéditos do grupo de pesquisa. Símbolos conforme Figura 40. 

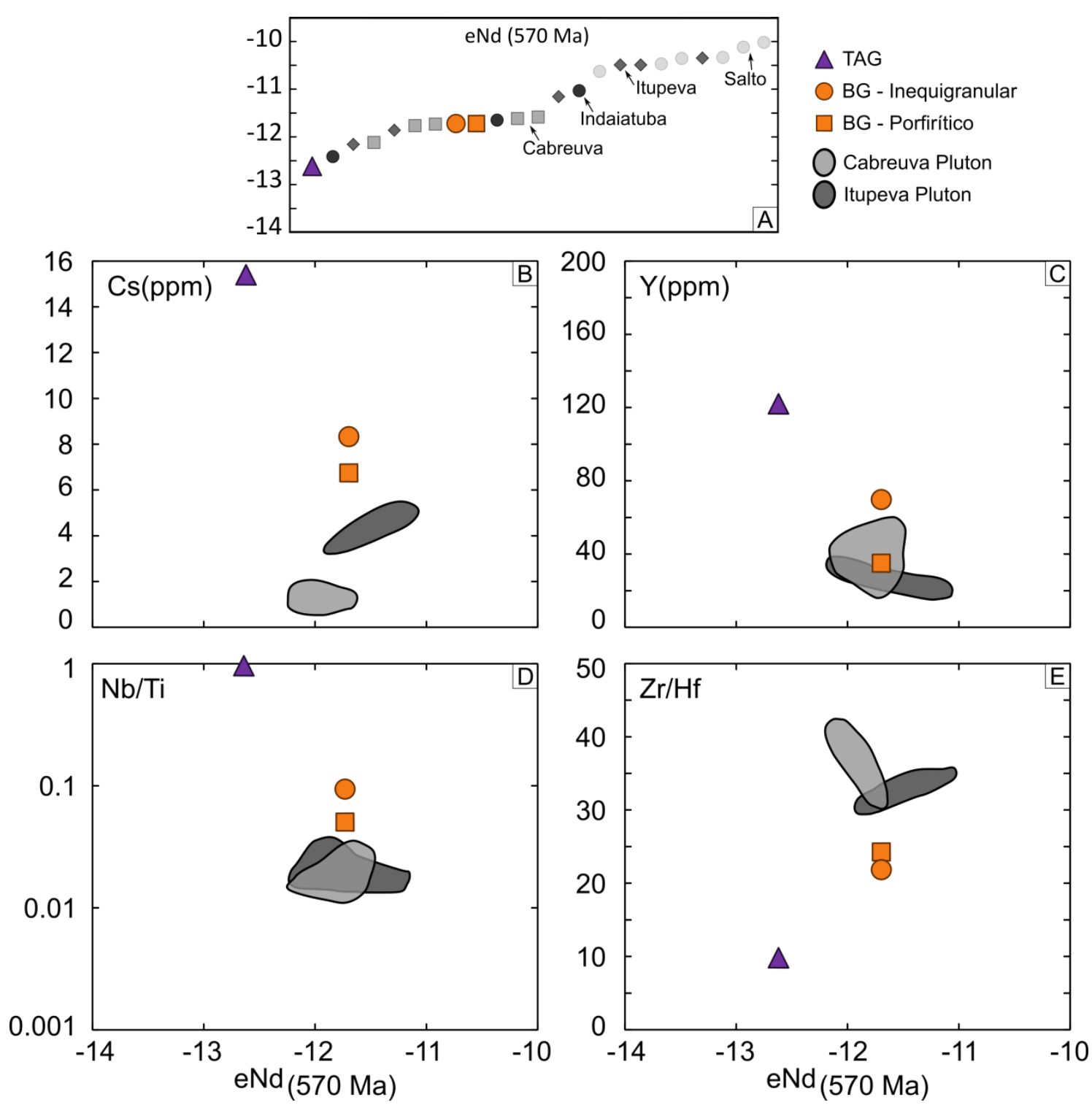

Figura 45: (A) Diagrama comparando a diminuição progressiva dos valores de $\varepsilon$ Nd das amostras de Inhandjara dentro do Batólito Itu. (B, C, D e E) Diagramas binários comparando o valor de $\varepsilon N d$ com alguns elementos e rachões geoquímicas de interesse. Análises dos outros plutons do Batólito Itu e campos definidos a partir de dados inéditos do grupo de pesquisa.

\section{II.3.1 Variação química do processo hidrotermal}

Quanto à variação química do processo hidrotermal, é possível observar que alguns elementos como $\mathrm{SiO}_{2}, \mathrm{CaO}, \mathrm{Na}_{2} \mathrm{O}, \mathrm{P}_{2} \mathrm{O}_{5}$ e ETRL, assim como o número de magnésio $\left(\mathrm{mg} \#=[\mathrm{MgO} /(\mathrm{MgO}+\mathrm{FeO})]_{\text {molar }}\right)$ tendem a apresentar menores teores com a passagem para o greisen, apesar de se manterem relativamente constantes durante 0 metassomatismo alcalino (representado indiretamente pela mudança de cor do granito dos diagramas). Já elementos como $\mathrm{Al}_{2} \mathrm{O}_{3}, \mathrm{FeO}, \mathrm{MnO}, \mathrm{K}_{2} \mathrm{O}, \mathrm{F}, \mathrm{Ba}, \mathrm{Nb}$, $\mathrm{U}$, além de razões como $\mathrm{Ba} / \mathrm{Sr}, \mathrm{Rb} / \mathrm{Sr}$ e $\mathrm{K}_{2} \mathrm{O} / \mathrm{Na}_{2} \mathrm{O}$ tendem a aumentar em proporção com a greisenização. 
Ao analisar os diagramas geoquímicos, aparentemente 0 processo de metassomatismo alcalino apresenta pouca variação nos elementos maiores entre as amostras pouco e intensamente alteradas. É, portanto, representado majoritariamente por alterações mineralógicas, marcadas pela dissolução das fases primárias e reprecipitação em minerais hidrotermais em presença da fase fluida.

Tabela 7: Dados químicos comparando amostras pouco e muito hidrotermalizadas das fácies de Inhandjara.

\begin{tabular}{|c|c|c|c|c|c|c|}
\hline Fácies & $\begin{array}{c}\text { BG } \\
\text { Porfirítico } \\
\end{array}$ & $\begin{array}{l}\text { Porfirítica } \\
\text { Alterada }\end{array}$ & $\begin{array}{c}\text { BG } \\
\text { Inequigranular } \\
\end{array}$ & $\begin{array}{l}\text { Inequigranular } \\
\text { Alterada }\end{array}$ & $\begin{array}{c}\text { TAG } \\
\text { Equigranular }\end{array}$ & $\begin{array}{c}\text { Equigranular } \\
\text { Alterada }\end{array}$ \\
\hline Amostra & IPV-14 & IPV-16B & IPV-30C & IPV-22A & IPV-35A & IPV-35D \\
\hline $\mathrm{SiO}_{2}(\mathrm{wt} \%)$ & 73,13 & 73,62 & 76,76 & 76,14 & 76,18 & 76,51 \\
\hline $\mathrm{TiO}_{2}$ & 0,098 & 0,197 & 0,085 & 0,256 & 0,011 & 0,075 \\
\hline $\mathrm{Al}_{2} \mathrm{O}_{3}$ & 14,33 & 12,14 & 12,02 & 11,09 & 12,96 & 12,32 \\
\hline $\mathrm{Fe}_{2} \mathrm{O}_{3}(\mathrm{~T})$ & 1,02 & 1,72 & 0,95 & 1,63 & 0,85 & 0,82 \\
\hline $\mathrm{MnO}$ & 0,024 & 0,038 & 0,02 & 0,045 & 0,064 & 0,034 \\
\hline $\mathrm{MgO}$ & 0,06 & 0,20 & 0,05 & 0,21 & 0,00 & 0,03 \\
\hline $\mathrm{CaO}$ & 0,68 & 1,32 & 0,53 & 0,66 & 0,44 & 0,54 \\
\hline $\mathrm{Na}_{2} \mathrm{O}$ & 4,57 & 3,42 & 3,83 & 3,61 & 4,73 & 4,14 \\
\hline $\mathrm{K}_{2} \mathrm{O}$ & 5,81 & 5,17 & 4,51 & 4,44 & 4,45 & 4,33 \\
\hline $\mathrm{P}_{2} \mathrm{O}_{5}$ & 0,021 & 0,046 & 0,012 & 0,072 & 0,008 & 0,019 \\
\hline $\mathrm{P}, \mathrm{F}$, & 0,59 & 0,76 & 0,65 & 0,52 & 0,45 & 0,46 \\
\hline Total (wt\%) & 100,33 & 98,63 & 99,42 & 98,67 & 100,14 & 99,28 \\
\hline $\mathrm{F}(\mathrm{ppm})$ & 2212 & 2701 & 2606 & 1220 & 3003 & 3262 \\
\hline $\mathrm{Cl}$ (ppm) & $<500$ & $<500$ & $<500$ & $<500$ & $<500$ & $<500$ \\
\hline $\mathrm{S}(\mathrm{ppm})$ & $<550$ & $<550$ & $<550$ & $<550$ & $<550$ & $<550$ \\
\hline La (ppm) & 25,3 & 80 & 34,5 & 69,3 & 12,7 & 20 \\
\hline $\mathrm{Ce}$ & 57,1 & 129 & 71,4 & 126 & 37,3 & 52,4 \\
\hline $\mathrm{Pr}$ & 7,44 & & 9,96 & 13,9 & 6,08 & 7,73 \\
\hline $\mathrm{Nd}$ & 24,6 & 48 & 32,5 & 44,7 & 24,2 & 29,9 \\
\hline Sm & 5,26 & & 7,39 & 7,35 & 9,83 & 10,1 \\
\hline $\mathrm{Eu}$ & 0,57 & & 0,34 & 0,78 & 0,01 & 0,08 \\
\hline Gd & 4,22 & & 7 & 5,45 & 11,1 & 10,5 \\
\hline $\mathrm{Tb}$ & 0,73 & & 1,29 & 0,88 & 2,19 & 1,95 \\
\hline Dy & 4,51 & & 8,3 & 5,23 & 14,1 & 12 \\
\hline Ho & 1,08 & & 2,04 & 1,17 & 3,37 & 2,87 \\
\hline Er & 3,18 & & 6,04 & 3,28 & 10,2 & 8,48 \\
\hline $\mathrm{Tm}$ & 0,56 & & 1,08 & 0,52 & 1,92 & 1,56 \\
\hline $\mathrm{Yb}$ & 4,04 & & 7,67 & 3,49 & 14,5 & 11,5 \\
\hline Lu & 0,62 & & 1,17 & 0,51 & 2,18 & 1,73 \\
\hline $\mathrm{Ba}$ & 390 & 524 & 90,6 & 650 & 1,92 & 22,5 \\
\hline Cs & 6,74 & & 8,33 & 1,81 & 15,4 & 15,1 \\
\hline $\mathrm{Hf}$ & 3,55 & & 5,17 & 6,22 & 8,09 & 6,77 \\
\hline Mo & 0,1 & & 0,3 & 5,2 & 2 & 1,4 \\
\hline $\mathrm{Nb}$ & 29,6 & 30 & 47,8 & 32,8 & 63,3 & 75,9 \\
\hline $\mathrm{Pb}$ & 35,4 & 2 & 32,5 & 10,1 & 49,3 & 35,9 \\
\hline $\mathrm{Rb}$ & 404 & 297 & 415 & 223 & 783 & 650 \\
\hline $\mathrm{Sr}$ & 74,2 & 173 & 20 & 95,2 & 4,35 & 6,34 \\
\hline $\mathrm{Ta}$ & 3,3 & & 4,7 & 1,9 & 9,1 & 6,7 \\
\hline Th & 40,2 & 45 & 58,8 & 43,5 & 35,3 & 46,5 \\
\hline U & 4,34 & 6 & 13,8 & 6,69 & 8,19 & 15,6 \\
\hline W & 3,9 & & 1,2 & 0,1 & 2,6 & 1 \\
\hline $\mathrm{Y}$ & 35 & 50 & 69,7 & 37 & 122 & 91,2 \\
\hline $\mathrm{Zr}$ & 86,2 & 193 & 113 & 203 & 79,4 & 97 \\
\hline $\mathrm{Ga}$ & 22 & 19 & 21 & 16 & 29 & 25 \\
\hline $\mathrm{Zn}$ (ppm) & 17 & 28 & 21 & 29 & 37 & 26 \\
\hline
\end{tabular}


Tabela 8: Dados químicos relacionando a variação na intensidade do metassomatismo no Topázio Granito aflorante na Pedreira Viracopos,

\begin{tabular}{|c|c|c|c|c|c|c|}
\hline $\begin{array}{c}\text { Grau de } \\
\text { Alteração }\end{array}$ & Incipiente & Leve & Moderado & Intenso & $\begin{array}{c}\text { Granito } \\
\text { Greisenizado }\end{array}$ & $\begin{array}{l}\text { Greisen I - } \\
\text { Veio maciço }\end{array}$ \\
\hline Amostra & IPV-35A & IPV-35B & IPV-35C & IPV-35D & IPV-35F & IPV-35H \\
\hline $\mathrm{SiO}_{2}(\mathrm{wt} \%)$ & 76,18 & 76,59 & 75,95 & 76,51 & 74,59 & 61,28 \\
\hline $\mathrm{TiO}_{2}$ & 0,011 & 0,032 & 0,032 & 0,075 & 0,02 & 0,045 \\
\hline $\mathrm{Al}_{2} \mathrm{O}_{3}$ & 12,96 & 12,41 & 12,41 & 12,32 & 13,55 & 19,44 \\
\hline $\mathrm{Fe}_{2} \mathrm{O}_{3}{ }^{(\mathrm{T})}$ & 0,85 & 0,89 & 0,83 & 0,82 & 2,85 & 4,79 \\
\hline $\mathrm{MnO}$ & 0,064 & 0,048 & 0,035 & 0,034 & 0,22 & 0,350 \\
\hline $\mathrm{MgO}$ & 0,00 & 0,01 & 0,02 & 0,03 & 0,030 & 0,01 \\
\hline $\mathrm{CaO}$ & 0,44 & 0,49 & 0,55 & 0,54 & 0,18 & 0,29 \\
\hline $\mathrm{Na}_{2} \mathrm{O}$ & 4,73 & 5,01 & 4,51 & 4,14 & 0,15 & 0,26 \\
\hline $\mathrm{K}_{2} \mathrm{O}$ & 4,45 & 4,23 & 4,39 & 4,33 & 5,66 & 6,95 \\
\hline $\mathrm{P}_{2} \mathrm{O}_{5}$ & 0,008 & 0,008 & 0,008 & 0,019 & 0,005 & 0,006 \\
\hline $\mathrm{P}, \mathrm{F}_{1}$ & 0,45 & 0,54 & 0,51 & 0,46 & 1,91 & 3,10 \\
\hline Total (wt\%) & 100,14 & 100,26 & 99,24 & 99,28 & 99,17 & 96,52 \\
\hline $\mathrm{F}(\mathrm{ppm})$ & 3003 & 3795 & 3625 & 3262 & 2149 & 2437 \\
\hline $\mathrm{Cl}(\mathrm{ppm})$ & $<500$ & $<500$ & $<500$ & $<500$ & $<500$ & $<500$ \\
\hline $\mathrm{S}(\mathrm{ppm})$ & $<550$ & $<550$ & $<550$ & $<550$ & 2809 & 4006 \\
\hline La (ppm) & 12,7 & 28 & 20 & 20 & $<28$ & 7,83 \\
\hline $\mathrm{Ce}$ & 37,3 & 62 & 46 & 52,4 & 41 & 25,1 \\
\hline $\mathrm{Pr}$ & 6,08 & & & 7,73 & & 4,23 \\
\hline $\mathrm{Nd}$ & 24,2 & 30 & 31 & 29,9 & 15 & 17,7 \\
\hline Sm & 9,83 & & & 10,1 & & 7,15 \\
\hline $\mathrm{Eu}$ & 0,01 & & & 0,08 & & 0,03 \\
\hline $\mathrm{Gd}$ & 11,1 & & & 10,5 & & 8,28 \\
\hline $\mathrm{Tb}$ & 2,19 & & & 1,95 & & 1,63 \\
\hline Dy & 14,1 & & & 12 & & 11 \\
\hline Ho & 3,37 & & & 2,87 & & 2,64 \\
\hline $\mathrm{Er}$ & 10,2 & & & 8,48 & & 7,81 \\
\hline $\mathrm{Tm}$ & 1,92 & & & 1,56 & & 1,4 \\
\hline $\mathrm{Yb}$ & 14,5 & & & 11,5 & & 9,95 \\
\hline Lu & 2,18 & & & 1,73 & & 1,49 \\
\hline $\mathrm{Ba}$ & 1,92 & 30 & 39 & 22,5 & 70 & 83,6 \\
\hline Cs & 15,4 & & & 15,1 & & 35 \\
\hline $\mathrm{Hf}$ & 8,09 & & & 6,77 & & 7,37 \\
\hline Mo & 2 & & & 1,4 & & 0,4 \\
\hline $\mathrm{Nb}$ & 63,3 & 66 & 67 & 75,9 & 77 & 116 \\
\hline $\mathrm{Pb}$ & 49,3 & 9 & 12 & 35,9 & 2018 & 11145 \\
\hline $\mathrm{Rb}$ & 783 & 762 & 648 & 650 & 895 & 1268 \\
\hline $\mathrm{Sr}$ & 4,35 & 8 & 11 & 6,34 & 8 & 2,87 \\
\hline $\mathrm{Ta}$ & 9,1 & & & 6,7 & & 9 \\
\hline Th & 35,3 & 23 & 31 & 46,5 & 26 & 47,4 \\
\hline U & 8,19 & $<3$ & 10 & 15,6 & 13 & 17,2 \\
\hline$W$ & 2,6 & & & 1 & & 5.9 \\
\hline $\mathrm{Y}$ & 122 & 106 & 106 & 91.2 & 133 & 102 \\
\hline $\mathrm{Zr}$ & 79.4 & 98 & 120 & 97 & 106 & 96 \\
\hline $\mathrm{Ga}$ & 29 & 27 & 25 & 25 & 34 & 70 \\
\hline $\mathrm{Zn}(\mathrm{ppm})$ & 37 & 40 & 29 & 26 & 3361 & 7517 \\
\hline
\end{tabular}




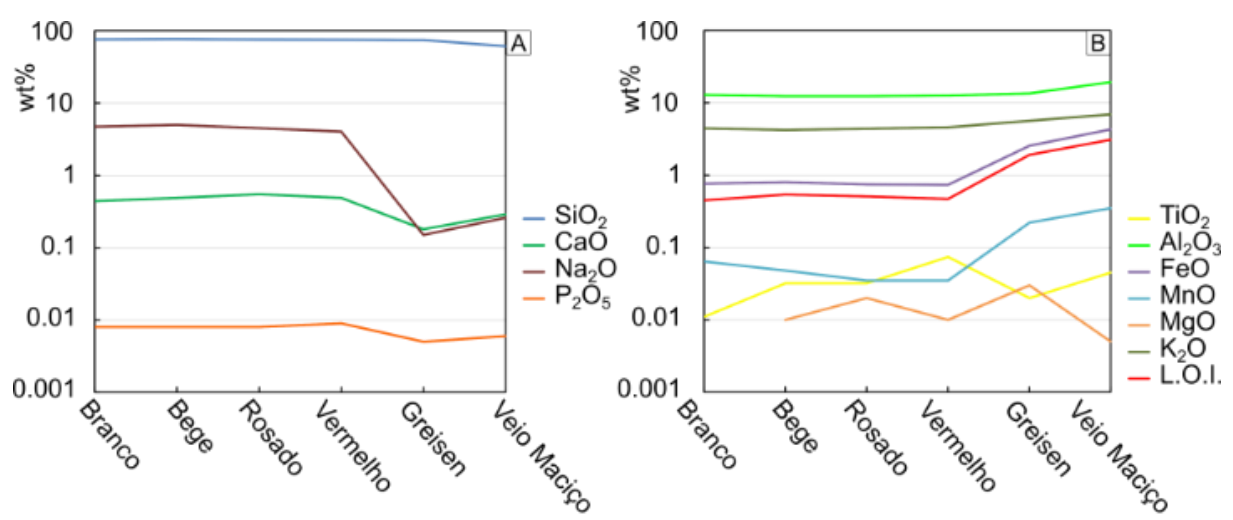

Figura 46: Variação química para elementos maiores (porcentagem em peso) com a progressão hidrotermal presente no Topázio Granito da Pedreira Viracopos. (A) Óxidos que diminuem ou se mantém relativamente constantes com o processo. (B) Óxidos que aumentam em proporção durante a evolução do sistema hidrotermal.

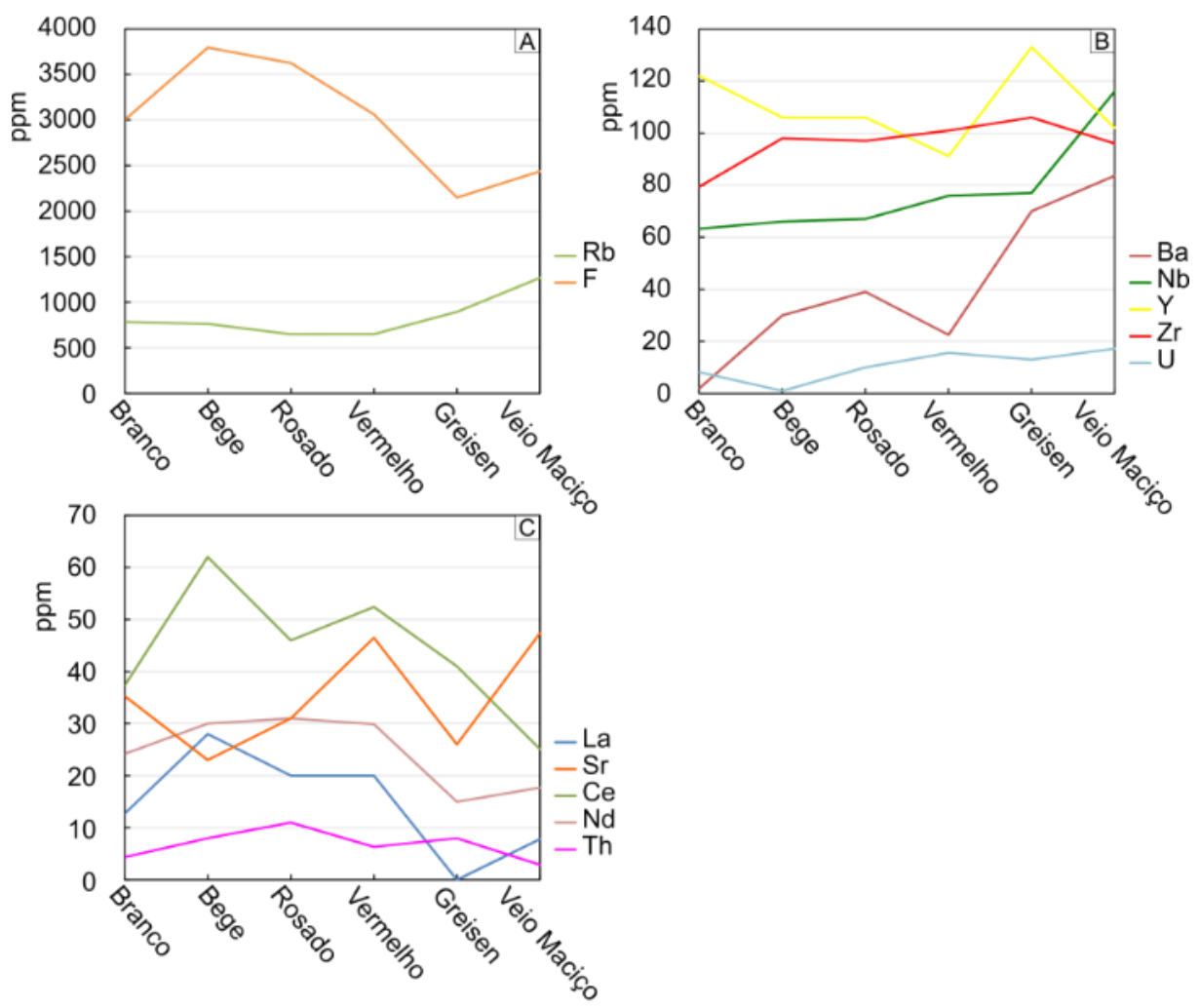

Figura 47: Variação química para elementos menores e alguns traços (ppm) com a progressão hidrotermal presente no Topázio Granito da Pedreira Viracopos. (A) Variação de Rb e F, elementos que apresentam teores muito maiores que os demais. (B) Elementos que tendem a aumentar em teor durante a evolução do sistema hidrotermal. (C) Elementos que diminuem ou se mantém relativamente constantes com o processo.
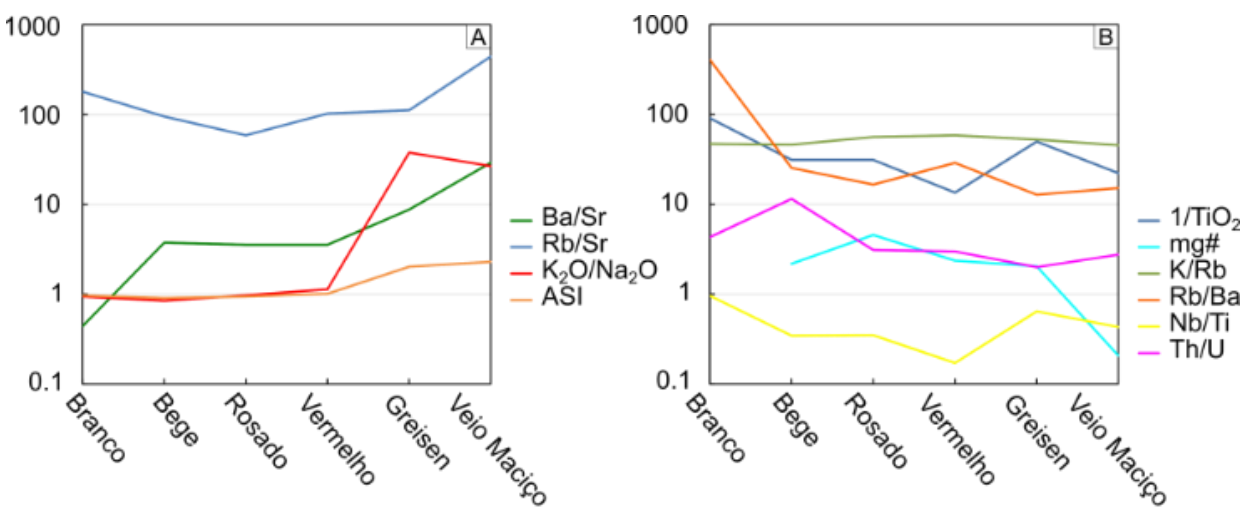

Figura 48: Variação química para algumas razões geoquímicas com a progressão hidrotermal presente no Topázio Granito da Pedreira Viracopos. (A) Razões que tendem a aumentar durante a evolução do sistema hidrotermal. (B) Razões que diminuem ou se mantém relativamente constantes com o processo. 


\section{II.4 QUÍMICA MINERAL}

Os dados completos das análises químicas de feldspato, micas, zircão e óxidos e clorita são apresentados no Anexo IV.

\section{II.4.1 Feldspatos}

Os feldspatos analisados foram classificados a partir das composições químicas e proporção dos membros finais em três categorias (Figura 49): feldspato potássico (Or $>90 \%$ ), albita (Ab > 90\%) e plagioclásio ( $\mathrm{An}>5 \%$ ); com algumas análises que plotam no campo do anortoclásio sendo agrupadas como albita.
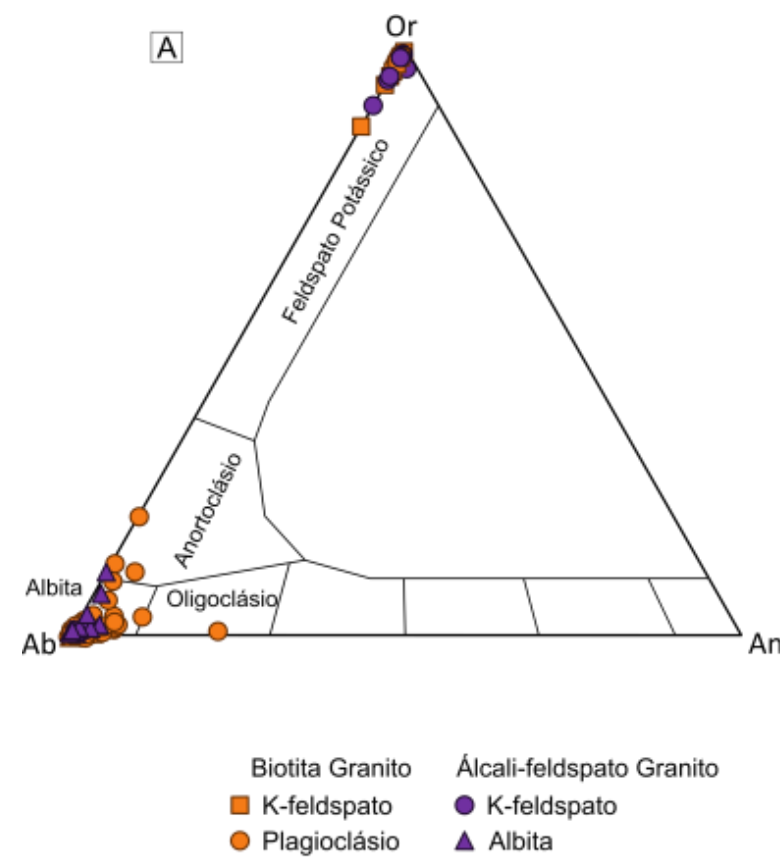
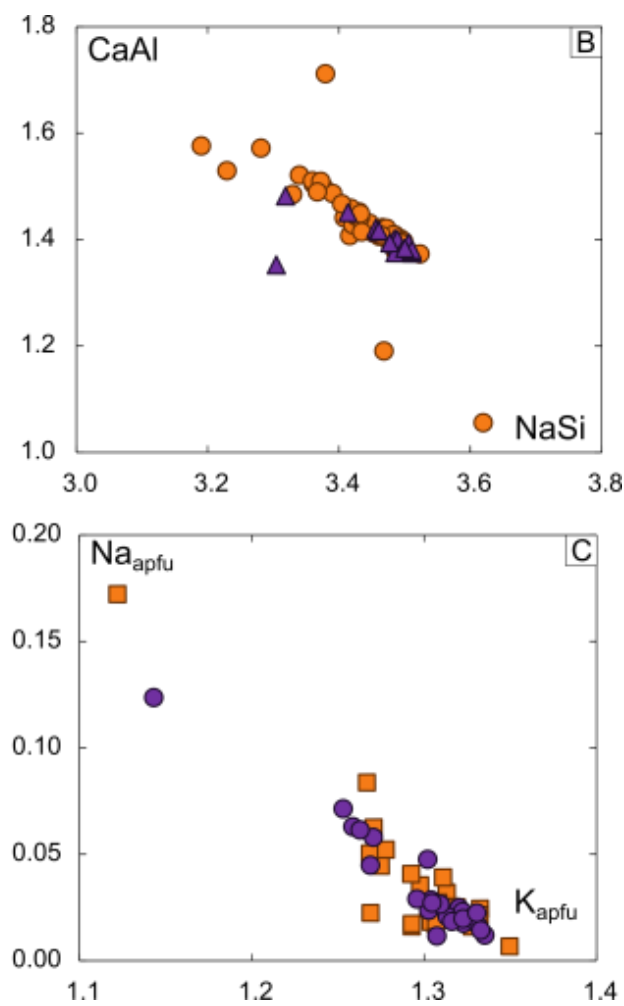

Figura 49: (A) Diagrama ternário Or-Ab-An classificatório de feldspatos com análises realizadas. (B) Diagrama binário mostrando a principal troca catiônica nos plagioclásios. (C) Diagrama binário mostrando a principal troca catiônica nos feldspatos alcalinos.

Tabela 9: Análises químicas representativas de feldspato potássico do Leucogranito Inhandjara.

\begin{tabular}{|c|c|c|c|c|c|c|}
\hline Fácies & Porfirítico & Inequigranular & Inequigranular & Inequigranular & Equigranular & Equigranular \\
\hline Análise & 5.5 & 4.2 & 21.4 & Mica5.3 & 5.2 & 7.1 \\
\hline $\mathrm{SiO}_{2}(w t \%)$ & 65,29 & 64,92 & 65,57 & 63,99 & 65,59 & 65,28 \\
\hline $\mathrm{Al}_{2} \mathrm{O}_{3}$ & 18,98 & 18,84 & 19,01 & 19,09 & 19,03 & 19,17 \\
\hline $\mathrm{Fe}_{2} \mathrm{O}_{3}$ & 0,12 & 0,00 & 0,04 & 0,21 & 0,04 & 0,00 \\
\hline $\mathrm{K}_{2} \mathrm{O}$ & 16,84 & 16,83 & 16,41 & 16,90 & 17,01 & 16,30 \\
\hline $\mathrm{CaO}$ & 0,00 & 0,03 & 0,02 & 0,00 & 0,00 & 0,01 \\
\hline $\mathrm{SrO}$ & 0,04 & 0,00 & 0,05 & 0,00 & 0,05 & 0,04 \\
\hline $\mathrm{BaO}$ & 0,00 & 0,01 & 0,04 & 0,32 & 0,05 & 0,00 \\
\hline $\mathrm{Na}_{2} \mathrm{O}$ & 0,26 & 0,24 & 0,67 & 0,25 & 0,23 & 0,74 \\
\hline Total (wt\%) & 101,55 & 100,95 & 101,80 & 100,75 & 102,00 & 101,60 \\
\hline
\end{tabular}


Tabela 9: (Continuação)

\begin{tabular}{|c|c|c|c|c|c|c|}
\hline Fácies & Porfirítico & Inequigranular & Inequigranular & Inequigranular & Equigranular & Equigranular \\
\hline Análise & 5.5 & 4.2 & 21.4 & Mica5.3 & 5.2 & 7.1 \\
\hline $\begin{array}{c}\text { Contexto } \\
\text { Textural }\end{array}$ & $\begin{array}{c}\text { nucleo } \\
\text { lamelado }\end{array}$ & $\begin{array}{c}\text { manteamento } \\
\text { borda }\end{array}$ & $\begin{array}{c}\text { nucleo } \\
\text { lamelado }\end{array}$ & $\begin{array}{c}\text { lamelas em bt } \\
\text { alterada }\end{array}$ & $\begin{array}{c}\text { nucleo } \\
\text { subédrico }\end{array}$ & $\begin{array}{c}\text { nucleo } \\
\text { pertitico }\end{array}$ \\
\hline $\mathrm{Or}$ & 98,48 & 98,54 & 96,04 & 98,57 & 98,69 & 95,62 \\
\hline $\mathrm{Ab}$ & 1,52 & 1,39 & 3,92 & 1,43 & 1,31 & 4,36 \\
\hline $\mathrm{An}$ & 0,00 & 0,07 & 0,05 & 0,00 & 0,00 & 0,02 \\
\hline $\begin{array}{c}\text { Formula } \\
\text { Estrutural }\end{array}$ & & & & & & \\
\hline $\mathrm{Si}$ & 2,55 & 2,55 & 2,55 & 2,52 & 2,55 & 2,54 \\
\hline $\mathrm{Al} \mathrm{II}^{\mathrm{V}}$ & 1,45 & 1,45 & 1,45 & 1,48 & 1,45 & 1,46 \\
\hline $\mathrm{Al}$ & 0,03 & 0,03 & 0,03 & 0,02 & 0,03 & 0,04 \\
\hline $\mathrm{Ca}$ & 0,00 & 0,00 & 0,00 & 0,00 & 0,00 & 0,00 \\
\hline $\mathrm{Na}$ & 0,02 & 0,02 & 0,05 & 0,02 & 0,02 & 0,06 \\
\hline $\mathrm{K}$ & 1,31 & 1,32 & 1,28 & 1,33 & 1,32 & 1,27 \\
\hline $\mathrm{Al}{ }^{\top}$ & 1,48 & 1,48 & 1,48 & 1,50 & 1,48 & 1,49 \\
\hline
\end{tabular}

Tabela 10: Análises químicas representativas de albita do Leucogranito Inhandjara.

\begin{tabular}{|c|c|c|c|c|c|c|c|}
\hline Fácies & Porfirítica & Porfirítica & Inequigranular & Inequigranular & Equigranular & Equigranular & Equigranular \\
\hline Análise & 5.6 & 10.1 & 3.2 & 3.4 & 12.2 & 16.2 & Bt10.3 \\
\hline $\mathrm{SiO}_{2}(\mathrm{wt} \%)$ & 68,51 & 68 & 66,73 & 67,8 & 68,67 & 68,98 & 70,87 \\
\hline $\mathrm{Al}_{2} \mathrm{O}_{3}$ & 20,17 & 20,95 & 21,4 & 20,23 & 20,34 & 20,33 & 19,87 \\
\hline $\mathrm{Fe}_{2} \mathrm{O}_{3}$ & 0,06 & 0,10 & 0,18 & 0,02 & 0 & 0,03 & 0,76 \\
\hline $\mathrm{K}_{2} \mathrm{O}$ & 0,18 & 0,10 & 0,71 & 0,04 & 0,12 & 0,20 & 0,68 \\
\hline $\mathrm{CaO}$ & 0,27 & 0,86 & 0,68 & 0,33 & 0,26 & 0,14 & 0,29 \\
\hline $\mathrm{SrO}$ & 0,04 & 0 & 0,03 & 0,07 & 0,02 & 0,10 & 0 \\
\hline $\mathrm{BaO}$ & 0,02 & 0,05 & 0,09 & 0 & 0,02 & 0 & 0 \\
\hline $\mathrm{Na}_{2} \mathrm{O}$ & 11,41 & 11,15 & 10,35 & 11,47 & 11,57 & 11,81 & 8,61 \\
\hline Total (wt\%) & 100,69 & 101,24 & 100,17 & 99,99 & 101,09 & 101,59 & 101,13 \\
\hline $\begin{array}{l}\text { Contexto } \\
\text { Textural }\end{array}$ & lamela & nucleo & $\begin{array}{l}\text { borda em } \\
\text { contato } \mathrm{Fl}\end{array}$ & $\begin{array}{c}\text { nucleo } \\
\text { alterado }\end{array}$ & manteamento & $\begin{array}{l}\text { lamelas } \\
\text { grossas }\end{array}$ & $\begin{array}{c}\text { borda em bt } \\
\text { alterada }\end{array}$ \\
\hline Or & 1,54 & 0,85 & 6,24 & 0,35 & 1,06 & 1,68 & 7,25 \\
\hline$A b$ & 97,3 & 95,45 & 90,76 & 98,24 & 97,85 & 97,75 & 91,24 \\
\hline An & 1,16 & 3,70 & 2,99 & 1,40 & 1,09 & 0,57 & 1,51 \\
\hline \multicolumn{8}{|l|}{$\begin{array}{l}\text { Formula } \\
\text { Estrutural }\end{array}$} \\
\hline $\mathrm{Si}$ & 2,61 & 2,57 & 2,54 & 2,60 & 2,61 & 2,61 & 2,66 \\
\hline $\mathrm{Al}^{\mathrm{IV}}$ & 1,39 & 1,43 & 1,46 & 1,40 & 1,39 & 1,39 & 1,34 \\
\hline $\mathrm{Al}^{\mathrm{VI}}$ & 0,15 & 0,16 & 0,17 & 0,16 & 0,16 & 0,15 & 0,15 \\
\hline $\mathrm{Ca}$ & 0,01 & 0,03 & 0,03 & 0,01 & 0,01 & 0,01 & 0,01 \\
\hline $\mathrm{Na}$ & 0,87 & 0,84 & 0,79 & 0,88 & 0,88 & 0,89 & 0,65 \\
\hline $\mathrm{K}$ & 0,01 & 0,01 & 0,05 & 0,00 & 0,01 & 0,02 & 0,05 \\
\hline $\mathrm{Al}^{\top}$ & 1,54 & 1,59 & 1,63 & 1,55 & 1,55 & 1,54 & 1,49 \\
\hline
\end{tabular}

Tabela 11: Análises químicas representativas de plagioclásio do Leucogranito Inhandjara.

\begin{tabular}{|c|c|c|c|c|}
\hline Fácies & Porfirítica & Inequigranular & Inequigranular & Inequigranular \\
\hline Análise & 10.2 & Mica14.4 & Mica14.5 & 18.1 \\
\hline $\mathrm{SiO}_{2}(w t \%)$ & 67,15 & 66,71 & 67,47 & 63,43 \\
\hline $\mathrm{Al}_{2} \mathrm{O}_{3}$ & 21,32 & 21,95 & 21,1 & 18,86 \\
\hline $\mathrm{Fe}_{2} \mathrm{O}_{3}$ & 0,10 & 0,15 & 0,10 & 0,27 \\
\hline $\mathrm{K}_{2} \mathrm{O}$ & 0,26 & 0,41 & 0,31 & 0,06 \\
\hline $\mathrm{CaO}$ & 1,44 & 2,16 & 1,316 & 5,92 \\
\hline $\mathrm{SrO}$ & 0,025 & 0,018 & 0,007 & 0,001 \\
\hline $\mathrm{BaO}$ & 0,032 & 0,064 & 0 & 0 \\
\hline $\mathrm{Na}{ }_{2} \mathrm{O}$ & 10,76 & 10,26 & 10,63 & 10,75 \\
\hline Total (wt\%) & 101,11 & 101,75 & 100,94 & 99,33 \\
\hline $\begin{array}{c}\text { Contexto } \\
\text { Textural }\end{array}$ & borda neo & nucleo & borda & $\begin{array}{c}\text { nucleo } \\
\text { alterado }\end{array}$ \\
\hline
\end{tabular}


Tabela 12: (Continuação)

\begin{tabular}{|c|c|c|c|c|}
\hline Or & 2,24 & 3,52 & 2,71 & 0,42 \\
\hline $\mathrm{Ab}$ & 91,63 & 87,29 & 91,62 & 78,08 \\
\hline $\mathrm{An}$ & 6,13 & 9,19 & 5,67 & 21,50 \\
\hline $\begin{array}{c}\text { Formula } \\
\text { Estrutural }\end{array}$ & & & & \\
\hline $\mathrm{Si}$ & 2,54 & 2,51 & 2,56 & 2,52 \\
\hline $\mathrm{Al}^{\mathrm{IV}}$ & 1,46 & 1,49 & 1,44 & 1,48 \\
\hline $\mathrm{Al}^{\mathrm{VI}}$ & 0,16 & 0,16 & 0,16 & 0,02 \\
\hline $\mathrm{Ca}$ & 0,05 & 0,08 & 0,05 & 0,24 \\
\hline $\mathrm{Na}$ & 0,82 & 0,77 & 0,81 & 0,86 \\
\hline $\mathrm{K}$ & 0,02 & 0,03 & 0,02 & 0,00 \\
\hline $\mathrm{Al}^{\top}$ & 1,62 & 1,65 & 1,60 & 1,50 \\
\hline
\end{tabular}

Os feldspatos apresentam pouca variação, com composições químicas e texturas similares. Ocorrem principalmente como feldspato potássico e albita, sendo os demais tipos restritos volumetricamente.

Feldspato potássico é a fase principal. De forma geral, não há variações químicas consideráveis na escala analisada, apresentando valor mediano do teor de Or igual a 98,2. A pequena oscilação no teor de $\mathrm{Al}^{\top}$ (de 0,00 a 0,22 a.p.f.u) está relacionada principalmente à substituição do $\mathrm{Al}^{\mathrm{IV}}$ por Fe. Nas imagens de elétrons retroespalhados (BSE), comumente exibe tons de cinza homogêneos por todo o cristal, e mesmo quando em diferentes contextos texturais, ainda possui composição similar.

Albita é a outra fase dominante, apresentando uma leve variação composicional, a depender do contexto textural em que ocorre (teores de An variam entre 0,3 e 3,8), seja como núcleos com teor de anortita pouco maior (variando entre $A n_{5}$ e $A n_{9}$, com uma única análise sendo classificada como oligoclásio, $A n_{21,5}$ ) ou então com maior proporção de Or quando ocorre como lamelas ou inclusões dentro dos cristais de feldspato potássico.

Os valores mais altos de An correlacionam-se texturalmente com os núcleos euédricos sericitizados, e diminuem em direção às bordas no BG, enquanto que no TAG o teor de An é homogêneo (máximo $A n_{3.8}$ ), independentemente do contexto textural. Al ${ }^{\top}$ varia de 1,1 a 1,7 no BG, sendo diretamente proporcional ao teor de An, e para o Topázio Granito mantém-se constante em 1,55 $( \pm 0,05)$. Esta relação entre o teor de $\mathrm{Al}^{\top}$ e a molécula de An é melhor expressa no sítio tetraédrico, uma vez que $\mathrm{Al}^{\mathrm{IV}}$ é praticamente igual nos cristais, aumentando somente quando Si diminui. Apesar destas diferenças, os cristais costumam apresentar tons de cinza homogêneos nas imagens BSE, sem uma zonação química intracristalina bem definida na escala analisada. 
Tabela 13: Fórmula estrutural calculado para os feldspatos de Inhandjara a partir de análises in situ

\begin{tabular}{|c|c|c|c|}
\hline & BG Porfirítico & BG Inequigranular & TAG Equigranular \\
\hline Feldspato Potássico & $\mathrm{K}_{1,25} \mathrm{Al}_{1,49} \mathrm{Si}_{2,55} \mathrm{O}_{8}$ & $\mathrm{~K}_{1,31} \mathrm{Al}_{1,48} \mathrm{Si}_{2,6} \mathrm{O}_{8}$ & $\mathrm{~K}_{1,31} \mathrm{Al}_{1,48} \mathrm{Si}_{2,55} \mathrm{O}_{8}$ \\
\hline Albita & $\mathrm{Na}_{0,83} \mathrm{Al}_{1,49} \mathrm{Si}_{2,66} \mathrm{O}_{8}$ & $\mathrm{Na}_{0,86} \mathrm{Al}_{1,55} \mathrm{Si}_{2,6} \mathrm{O}_{8}$ & $\mathrm{Na}_{0,87} \mathrm{Al}_{1,54} \mathrm{Si}_{2,61} \mathrm{O}_{8}$ \\
\hline Plagioclásio & $\mathrm{Na}_{0,82} \mathrm{Ca}_{0,05} \mathrm{Al}_{1,61} \mathrm{Si}_{2,55} \mathrm{O}_{8}$ & $\mathrm{Na}_{0,81} \mathrm{Ca}_{0,12} \mathrm{Al}_{1,58} \mathrm{Si}_{2,53} \mathrm{O}_{8}$ & - \\
\hline
\end{tabular}

\section{II.4.2 Micas Trioctaédricas}

Esta fase é bastante restrita, ocorre principalmente no Topázio Granito equigranular e apenas na fácies inequigranular do Biotita Granito. Na fácies porfirítica não foi encontrado nenhum cristal preservado, seja nas análises óticas ou por microscopia eletrônica, sendo totalmente substituída para associações de clorita e outros minerais.

Quando presente é representada por biotita, classificada como siderofilita segundo o diagrama de $\mathrm{Al}^{\top}$ vs. $\mathrm{Fe} /(\mathrm{Fe}+\mathrm{Mg})$. Conforme a classificação de Tischendorf (1997) a biotita do Topázio Granito equigranular é classificada como protolitionita, já no Biotita Granito inequigranular é classificada como siderofilita (Figura 50A). Pela classificação de Tischendorf et al. (2007) a biotita da fácies equigranular é classificada na transição entre annita e siderofilita, enquanto da fácies inequigranular são classificadas como annita (Figura 50B).

As amostras da fácies equigranular, possuem pequena variação composicional e textural (Si $i_{\text {apfu }} \sim 5,7 ; \mathrm{Al}^{\mathrm{VI}}$ entre 1,66 e 1.9; $\mathrm{Al}^{\top} \sim 4,1 ; \mathrm{Ti}_{\text {apfu }}<0,05 ;$ Fe $\mathrm{e}_{\text {apfu }}$ entre 2,5 e 2,9; $\mathrm{Mg}_{\text {apfu }}<0,03$; Li iapfu de 0,5 a 0,9).

Para a fácies inequigranular, o cristal observado não apresenta grandes variações composicionais entre borda e núcleo, exibindo aspecto homogêneo na imagem BSE e análises pontuais (Si $\mathrm{i}_{\text {apfu }} \sim 5,5 ; \mathrm{Al}{ }^{\mathrm{VI}} \sim 1,1 ; \mathrm{Al}^{\top} \sim 3,5 ;$ Ti apfu $~ 0,25 ; \mathrm{Fe}_{\text {apfu }} \sim 3,4 ; \mathrm{Mg}_{\mathrm{apfu}}$ 0,36; Liapfu de 0,4 a 0,5).

Em geral, a tendência em diagramas binários (Figura 51) é aumentar as proporções de $\mathrm{Si}, \mathrm{F}, \mathrm{Li}, \mathrm{Al}^{\top}$ (estimulado pelo enriquecimento em $\mathrm{Al}^{\mathrm{VI}}$ ) e $\mathrm{Mn}$ das amostras das fácies porfirítica e equigranular, associadas à diminuição de $\mathrm{Al}^{\mathrm{IV}}$, $\mathrm{Fe}, \mathrm{Mg}$ e Ti. $\mathrm{K}$ apresenta valores ligeiramente dispersos, de 1,8 a 2,1 a.p.f.u., mas não há correlação com as variações dos outros elementos analisados. 
Tabela 14: Análises químicas in situ representativas de micas trioctaédricas de Inhandjara

\begin{tabular}{|c|c|c|}
\hline Fácies & Inequigranular & Equigranular \\
\hline Amostra & IPV-30C & IPV-35A \\
\hline Análise & 13,1 & 10,2 \\
\hline $\mathrm{SiO}_{2}(\mathrm{wt} \%)$ & 36,16 & 37,77 \\
\hline $\mathrm{TiO}_{2}$ & 2,17 & 0,34 \\
\hline $\mathrm{Al}_{2} \mathrm{O}_{3}$ & 19,87 & 22,77 \\
\hline $\mathrm{FeO}$ & 26,08 & 21,51 \\
\hline $\mathrm{MnO}$ & 0,81 & 1,81 \\
\hline $\mathrm{MgO}$ & 1,54 & 0,08 \\
\hline $\mathrm{CaO}$ & 0,03 & 0,02 \\
\hline $\mathrm{Na}_{2} \mathrm{O}$ & 0,12 & 0,08 \\
\hline $\mathrm{K}_{2} \mathrm{O}$ & 9,69 & 10,23 \\
\hline $\mathrm{Nb}_{2} \mathrm{O}_{5}$ & 0,03 & 0,06 \\
\hline $\mathrm{ZnO}$ & 0,17 & 0,17 \\
\hline $\mathrm{Cl}$ & 0,03 & 0,006 \\
\hline $\mathrm{F}$ & 0,05 & 0,58 \\
\hline $\mathrm{Li}_{2} \mathrm{O}^{*}$ & 0,79 & 1,26 \\
\hline $\mathrm{H}_{2} \mathrm{O} *$ & 3,88 & 3,68 \\
\hline Total (wt\%) & 101,39 & 100,06 \\
\hline \multicolumn{3}{|l|}{ APFU } \\
\hline $\mathrm{Si}$ & 5,5 & 5,7 \\
\hline $\mathrm{Al}^{\mathrm{IV}}$ & 2,5 & 2,3 \\
\hline $\mathrm{Al}_{\mathrm{VI}}$ & 1,1 & 1,8 \\
\hline $\mathrm{Al}^{\top}$ & 3,6 & 4,1 \\
\hline $\mathrm{Ti}$ & 0,2 & 0,04 \\
\hline $\mathrm{Fe}$ & 3,3 & 2,7 \\
\hline $\mathrm{Mn}$ & 0,1 & 0,2 \\
\hline $\mathrm{Mg}$ & 0,3 & 0,02 \\
\hline Li* & 0,5 & 0,8 \\
\hline $\mathrm{Na}$ & 0,04 & 0,02 \\
\hline K & 1,9 & 2,0 \\
\hline $\mathrm{Cl}$ & 0,007 & 0,002 \\
\hline $\mathrm{F}$ & 0,02 & 0,3 \\
\hline $\mathrm{OH}^{*}$ & 4,0 & 3,7 \\
\hline $\mathrm{Fe} / \mathrm{Fe}+\mathrm{Mg}$ & 0,90 & 0,99 \\
\hline $\begin{array}{l}\text { Contexto } \\
\text { Textural }\end{array}$ & $\begin{array}{c}\text { Subédrica na } \\
\text { mesostase }\end{array}$ & Anédrica intersticial \\
\hline
\end{tabular}



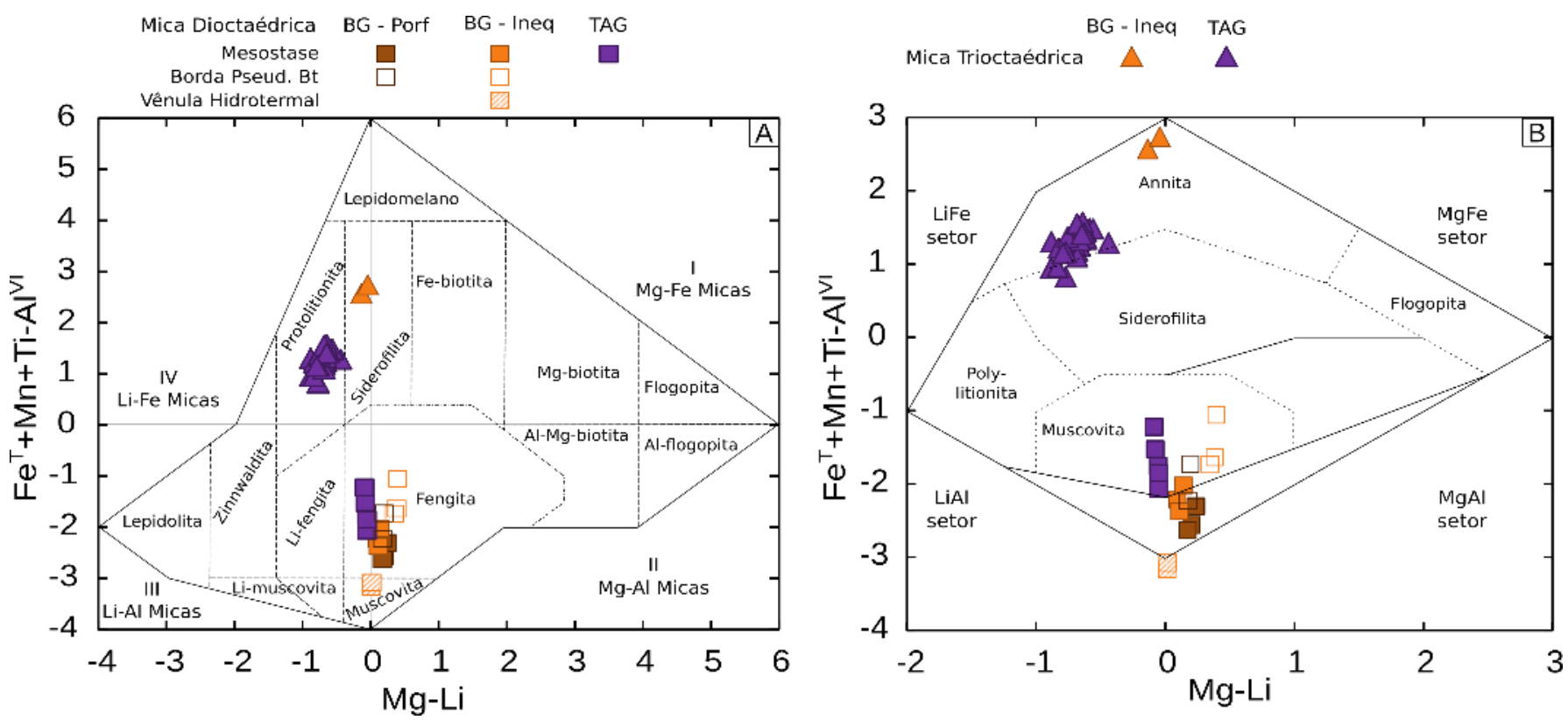

Figura 50: Comparação entre as classificações de (A) Tischendorf (1997) e (B) Tischendorf et al. (2007) para as análises de micas de Inhandjara.
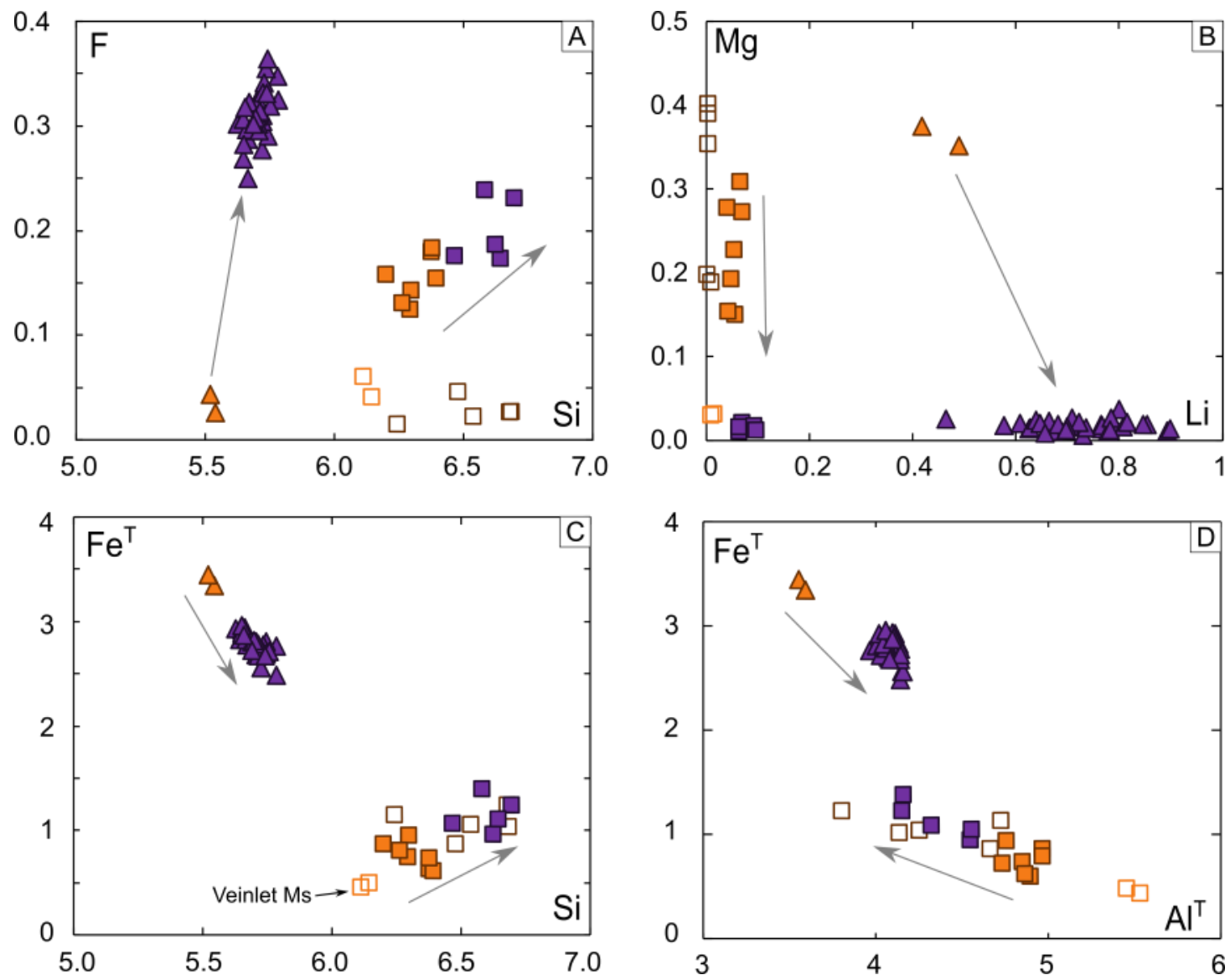

Figura 51: (A, B, C e D) Diagramas binários com proporções catiônicas das análises de micas. Vetores indicam a variação química conforme diferenciação. Legenda conforme Figura 50. 


\section{II.4.3 Micas Dioctaédricas}

As análises de micas dioctaédricas plotam na porção inferior dos diagramas de classificação (Figura 50), e correspondem a fengita, (conforme classificação de Tischendorf (1997) - Figura 50A) ou a muscovita (conforme Tischendorf et al. (2007) - Figura 50B). Apresentam leve deslocamento para cima nos diagramas quando presentes em pseudomorfos de biotita, mas comumente são homogêneas dentro de cada fácies e contexto que ocorrem. Análises de cristais em vênulas hidrotermais são bem distintas das demais e tendem ao vértice da muscovita "ideal" nos diagramas.

$\mathrm{Na}$ fácies porfirítica a fengita pode ocorrer como cristais euédricos intercrescidos com clorita na mesostase ou preenchendo bolsões. Ou então ocorre anédrica associada com clorita e opacos nos pseudomorfos de biotita.

$\mathrm{Na}$ fácies inequigranular ocorre em três grupos composicionais relacionados a contextos texturais distintos. Fengitas euédricas a subédricas na mesostase, possuem contatos retos a serrilhados com fases ígneas. Fengita anédrica, ocorre intercrescida com clorita e manteando pseudomorfos de biotita. Muscovita euédrica, aparece apenas inclusa em quartzo próximo a vênulas hidrotermais.

Para a fácies equigranular, todas análises ocorrem no mesmo contexto textural, manteando e preenchendo fraturas dos cristais de biotita ou interstícios na mesostase, porém apresentam uma leve dispersão química contínua nas proporções atômicas.

Os contextos texturais observados na petrografia também puderam ser separados por suas características químicas (Figura 51). A fengita euédrica, que ocorre na mesostase ou bolsões, geralmente se correlaciona bem com vetores de diferenciação, aumentando a proporção catiônica de $\mathrm{Si}, \mathrm{F}, \mathrm{Fe}, \mathrm{Mn}$ e Li, e diminuindo a proporção de $M g$ e $\mathrm{Al}^{\top}$ (incluindo $\mathrm{Al}^{\mathrm{IV}}$ e $\mathrm{Al}^{\mathrm{VI}}$ ) do Biotita Granito para o Topázio Granito. A fengita presente nos pseudomorfos de biotita plota ligeiramente separada dos cristais da mesostase, e possuem menor conteúdo de $\mathrm{F}, \mathrm{Al}^{\top}$ e Li, com maior teor de $\mathrm{Si}$, $\mathrm{Fe}$ e $\mathrm{Ti}$ quando comparadas à fengita da mesostase (Figura 51). Análises em muscovita de vênula hidrotermal mostram que esta possui menos $\mathrm{Fe}, \mathrm{Mg}$, $\mathrm{Si}$ e $\mathrm{Ti}$, com maior conteúdo de $\mathrm{Al}^{\top}$ em relação às fengitas no granito. 
Tabela 15: Análises químicas in situ representativas de micas dioctaédricas de Inhandjara

\begin{tabular}{|c|c|c|c|c|c|c|}
\hline Fácies & Porfirítica & Porfirítica & Inequigranular & Inequigranular & Inequigranular & Equigranular \\
\hline Amostra & IPV-14 & IPV-14 & IPV-30C & IPV-30C & IPV-30C & IPV-35A \\
\hline Análise & 21.2 & 13.2 & 14.2 & 3.1 & 16b.1 & 13.2 \\
\hline $\mathrm{SiO}_{2}(\mathrm{wt} \%)$ & 46,19 & 47,05 & 45,26 & 47,38 & 45,22 & 48,11 \\
\hline $\mathrm{TiO}_{2}$ & 0,30 & 0,17 & 0,33 & 1,42 & 0,00 & 0,31 \\
\hline $\mathrm{Al}_{2} \mathrm{O}_{3}$ & 29,01 & 28,67 & 28,95 & 22,81 & 34,64 & 27,41 \\
\hline $\mathrm{FeO}$ & 6,29 & 7,50 & 8,12 & 10,45 & 3,91 & 8,26 \\
\hline $\mathrm{MnO}$ & 0,30 & 0,20 & 0,37 & 0,21 & 0,17 & 0,17 \\
\hline $\mathrm{MgO}$ & 1,50 & 0,91 & 0,93 & 1,91 & 0,15 & 0,10 \\
\hline $\mathrm{Na}_{2} \mathrm{O}$ & 0,24 & 0,16 & 0,32 & 0,03 & 0,48 & 0,09 \\
\hline $\mathrm{K}_{2} \mathrm{O}$ & 10,80 & 10,52 & 10,74 & 10,85 & 10,79 & 10,83 \\
\hline $\mathrm{F}$ & 0,41 & 0,10 & 0,32 & 0,058 & 0,14 & 0,43 \\
\hline $\mathrm{Cl}$ & 0,03 & 0,01 & 0,00 & 0,00 & 0,00 & 0,01 \\
\hline $\mathrm{Li}_{2} \mathrm{O} *$ & 0,12 & 0,02 & 0,09 & 0,01 & 0,03 & 0,13 \\
\hline $\mathrm{H}_{2} \mathrm{O} *$ & 4,14 & 4,3 & 4,16 & 4,23 & 4,37 & 4,15 \\
\hline Total (wt\%) & 99,33 & 99,59 & 99,54 & 99,43 & 99,87 & 100,06 \\
\hline \multicolumn{7}{|l|}{ APFU } \\
\hline $\mathrm{Si}$ & 6,4 & 6,5 & 6,3 & 6,7 & 6,1 & 6,6 \\
\hline $\mathrm{AIIV}^{\mathrm{IV}}$ & 1,6 & 1,5 & 1,7 & 1,3 & 1,9 & 1,4 \\
\hline $\mathrm{AlVI}^{\mathrm{VI}}$ & 3,1 & 3,1 & 3,05 & 2,5 & 3,6 & 3,1 \\
\hline $\mathrm{Al}^{\top}$ & 4,7 & 4,6 & 4,7 & 3,8 & 5,5 & 4,4 \\
\hline $\mathrm{Ti}$ & 0,03 & 0,02 & 0,03 & 0,1 & 0,0 & 0,03 \\
\hline $\mathrm{Fe}$ & 0,7 & 0,9 & 0,9 & 1,2 & 0,4 & 0,9 \\
\hline $\mathrm{Mn}$ & 0,03 & 0,02 & 0,04 & 0,02 & 0,02 & 0,02 \\
\hline $\mathrm{Mg}$ & 0,3 & 0,2 & 0,2 & 0,4 & 0,03 & 0,02 \\
\hline Li* & 0,07 & 0,01 & 0,05 & 0,005 & 0,02 & 0,07 \\
\hline $\mathrm{Na}$ & 0,06 & 0,04 & 0,09 & 0,01 & 0,1 & 0,02 \\
\hline $\mathrm{K}$ & 1,9 & 1,8 & 1,9 & 1,9 & 1,9 & 1,9 \\
\hline $\mathrm{Cl}$ & 0,006 & 0,002 & 0,1 & 0,03 & 0,06 & 0,002 \\
\hline $\mathrm{F}$ & 0,2 & 0,04 & 0,0 & 0,0 & 0,0 & 0,2 \\
\hline $\mathrm{OH}^{*}$ & 3,8 & 3,9 & 3,8 & 4,0 & 3,9 & 3,8 \\
\hline $\mathrm{Fe} / \mathrm{Fe}+\mathrm{Mg}$ & 0,70 & 0,82 & 0,83 & 0,75 & 0,93 & 0,98 \\
\hline $\begin{array}{l}\text { Contexto } \\
\text { Textural }\end{array}$ & $\begin{array}{l}\text { Euédrica } \\
\text { em bolsão }\end{array}$ & $\begin{array}{c}\text { Pseudomorfo } \\
\text { de biotita }\end{array}$ & $\begin{array}{l}\text { Euédrica na } \\
\text { mesostase }\end{array}$ & $\begin{array}{c}\text { Pseudomorfo de } \\
\text { biotita }\end{array}$ & $\begin{array}{l}\text { Em vênula } \\
\text { hidrotermal }\end{array}$ & $\begin{array}{l}\text { Borda de biotita } \\
\text { e intersticial }\end{array}$ \\
\hline
\end{tabular}

\section{II.4.4 Micas no greisen II (gnaisse encaixante)}

As micas do greisen II, cristais do grupo trioctaédrico são caracterizados como Febiotita, siderofilita e protolitionita segundo classificação de Tischendorf (1997), Figura $52 \mathrm{~A}$, e como annita a siderofilitas tendendo a polilitionitas conforme Tischendorf et al. (2007), Figura 52B. Porém no segundo caso, muitas análises caem fora dos campos estabelecidos, indicando um possível problema nos recálculos ou na própria classificação.

As micas dioctaédricas são classificadas como fengitas (Tischendorf, 1997) ou muscovitas (Tischendorf et al., 2007), tendo o mesmo problema de parte das análises plotarem fora dos campos delimitados. 
Em diagramas binários (Figura 53), as micas do greisen II apresentam grande correlação com as análises realizadas no TAG. Formam alguns trends de enriquecimento em Si e F, associados a empobrecimento em Fe.

\section{II.4.5 Óxidos}

Cristais de óxidos analisados foram divididos conforme a proporção elementar entre $\mathrm{Fe}$, Ti e Nb. Assim, foram classificados como ilmenita, presente em todas as amostras, e rutilo rico em ferro (presente no Biotita Granito) ou columbita (presente no TAG).

Comumente, amostras do Biotita Granito apresentam cristais zonados (Figura 16E e F), com núcleos irregulares de ilmenita ( $\mathrm{Ti}$ e $\mathrm{Fe}$ iguais) manteados por rutilo (principalmente $\mathrm{Ti}$, com presença de $\mathrm{Fe}$ e alguns cristais com certa quantidade de $\mathrm{Nb}$ ). Isto indica uma diminuição gradual da proporção de Fe em relação aos outros elementos para as bordas dos cristais, que se apresentam corroídas e porosas, manteando núcleos mais homogêneos (Figura 20E).

\section{II.4.6 Clorita}

A clorita é um mineral secundário e compõe a grande maioria dos filossilicatos presentes no Biotita Granito, sendo restrita no Topázio Granito.

Os cristais analisados (Tabela 16) correspondem a chamosita em todas as amostras, sendo classificados na variedade dafinita $\left[(\mathrm{Fe}, \mathrm{Mg})_{5} \mathrm{Al}(\mathrm{Si}, \mathrm{Al})_{4} \mathrm{O}_{10}(\mathrm{OH})_{8}\right]$ conforme divisão de Hey (1954) - Figura 54A. As análises mostram pouca variação dentro de cada unidade (TAG e BG), com única exceção no teor de Mn, que apresenta maiores valores no Biotita Granito inequigranular do que no porfirítico (Figura 54B, C, D e E).

A principal variação se dá entre a clorita do TAG e do BG. Onde no primeiro

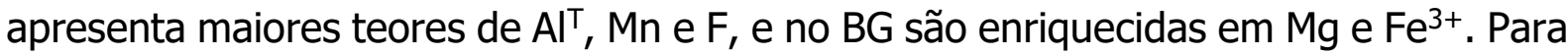
o restante dos elementos, não há grande variação entre os cristais analisados. 

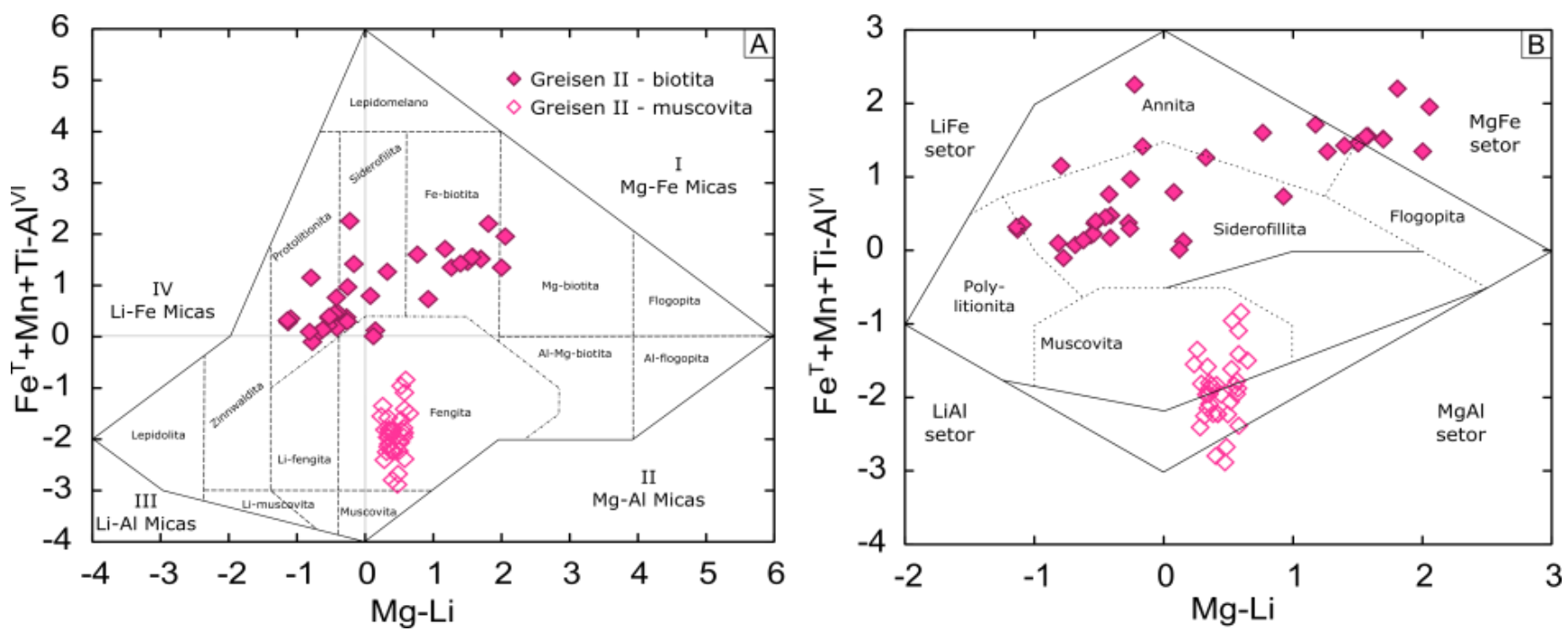

Figura 52: Comparação entre as classificações de (A) Tischendorf (1997) e (B) Tischendorf et al. (2007) para as análises de micas dos greisens II, nos gnaisses encaixantes de Inhandjara.
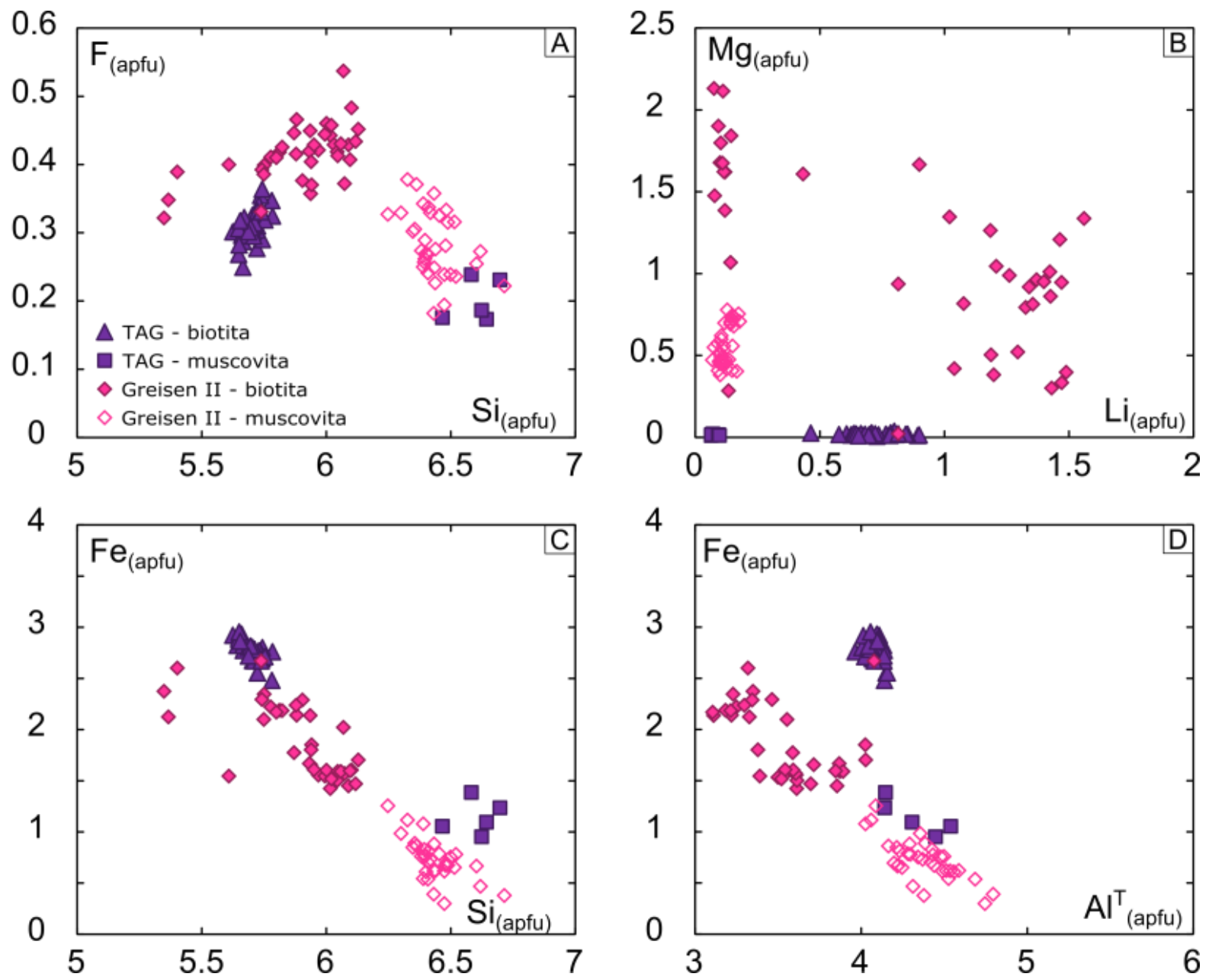

Figura 53: (A, B, C e D) Diagrama binários com proporções catiônicas comparando as análises de micas do TAG com micas do greisen II em amostras de Inhandjara. 
Tabela 16: Análises químicas in situ representativas de cloritas de Inhandjara

\begin{tabular}{|c|c|c|c|}
\hline Fácies & BG Porfirítico & BG Inequigranular & TAG Equigranular \\
\hline Amostra & IPV-14 & IPV-30C & IPV-35A \\
\hline Análise & 1.2 & 9.1 & 13.1 \\
\hline $\mathrm{SiO}_{2}$ & 24,27 & 23,34 & 22,23 \\
\hline $\mathrm{TiO}_{2}$ & 0,2 & 0,006 & 0,04 \\
\hline $\mathrm{Al}_{2} \mathrm{O}_{3}$ & 20,24 & 20,89 & 20,58 \\
\hline $\mathrm{Fe}_{2} \mathrm{O}_{3}$ & 1,0 & 0,54 & 0,41 \\
\hline $\mathrm{FeO}$ & 38,9 & 40,51 & 42,02 \\
\hline $\mathrm{MnO}$ & 0,79 & 1,03 & 2,98 \\
\hline $\mathrm{MgO}$ & 3,81 & 2,91 & 0,05 \\
\hline $\mathrm{CaO}$ & 0,03 & 0,04 & 0,02 \\
\hline $\mathrm{K}_{2} \mathrm{O}$ & 0,09 & 0,04 & 0,1 \\
\hline $\mathrm{F}$ & 0 & 0,001 & 0,05 \\
\hline $\mathrm{Cl}$ & 0,008 & 0,02 & 0 \\
\hline $\mathrm{H}_{2} \mathrm{O} *$ & 10,65 & 10,55 & 10,17 \\
\hline Total & 100,06 & 100,07 & 98,93 \\
\hline \multicolumn{4}{|l|}{ APFU } \\
\hline $\mathrm{Si}$ & 5,4 & 5,3 & 5,2 \\
\hline $\mathrm{Al}^{\mathrm{IV}}$ & 2,5 & 2,7 & 2,8 \\
\hline $\mathrm{Al}^{\mathrm{VI}}$ & 2,8 & 2,9 & 2,9 \\
\hline $\mathrm{Al}^{\top}$ & 5,4 & 5,6 & 5,7 \\
\hline $\mathrm{Ti}$ & 0,03 & 0,001 & 0,007 \\
\hline $\mathrm{Fe}^{3+}$ & 0,2 & 0,09 & 0,07 \\
\hline $\mathrm{Fe}^{2+}$ & 7,3 & 7,7 & 8,2 \\
\hline $\mathrm{Mn}$ & 0,1 & 0,2 & 0,6 \\
\hline $\mathrm{Mg}$ & 1,3 & 1,0 & 0,02 \\
\hline $\mathrm{K}$ & 0,05 & 0,02 & 0,06 \\
\hline $\mathrm{Cl}$ & 0,006 & 0,01 & 0,0 \\
\hline $\mathrm{F}$ & 0,0 & 0,001 & 0,08 \\
\hline $\mathrm{OH}^{*}$ & 16,0 & 16,0 & 15,9 \\
\hline $\mathrm{Fe} / \mathrm{Fe}+\mathrm{Mg}$ & 0,87 & 0,89 & 1,00 \\
\hline $\begin{array}{c}\text { Contexto } \\
\text { Textural }\end{array}$ & $\begin{array}{c}\text { Nucleo de } \\
\text { psudomorfo }\end{array}$ & $\begin{array}{c}\text { Borda de } \\
\text { pseudomorfo }\end{array}$ & $\begin{array}{c}\text { Borda de } \\
\text { pseudomorfo }\end{array}$ \\
\hline
\end{tabular}



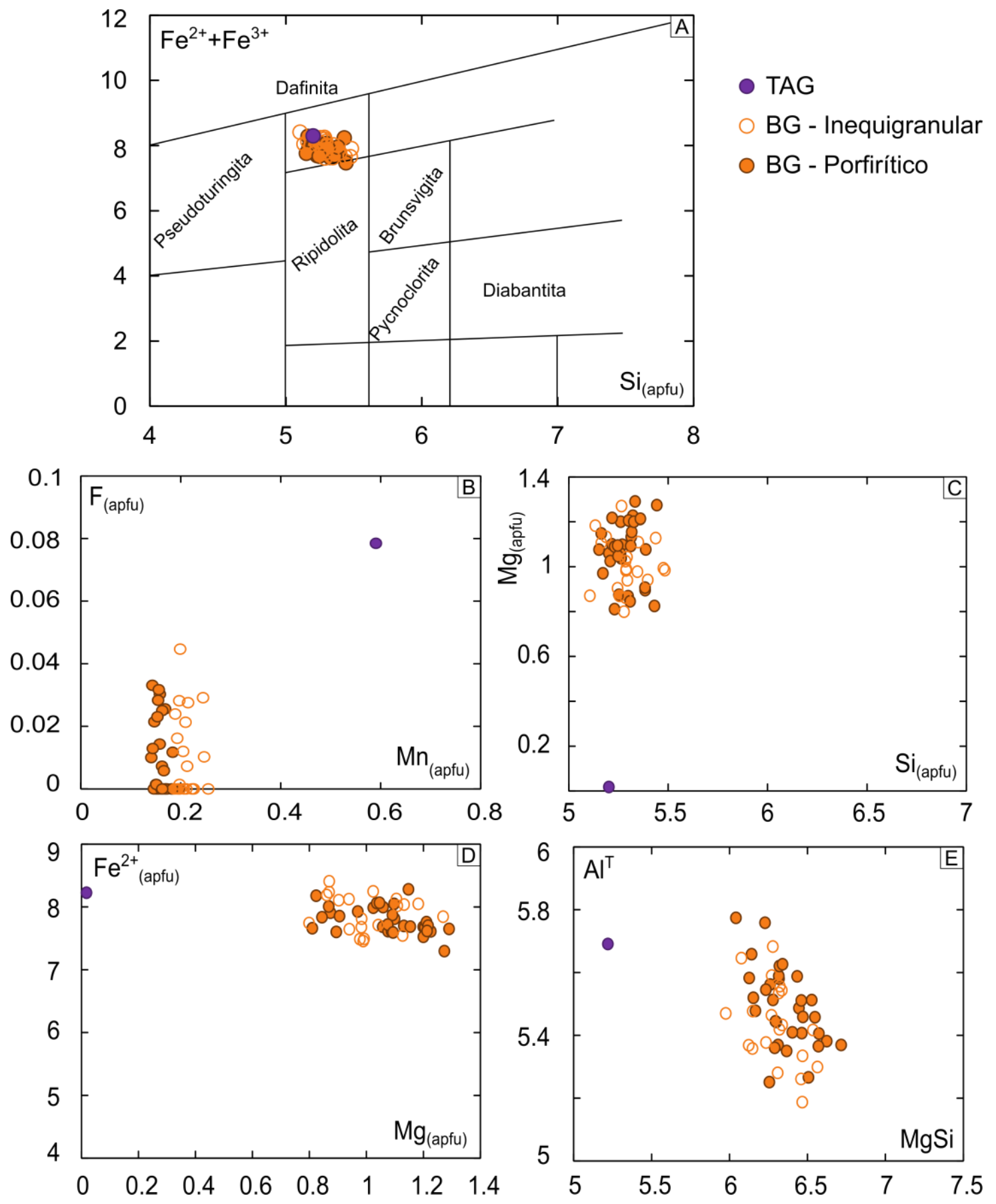

Figura 54: (A) Diagrama classificatório de Hey (1954) para análises de clorita de Inhandjara. (B, C, D e E) Diagramas binários com proporções atômicas de elementos de interesse para análises de clorita.

\section{II.4.7 Zircão}

Cristais de zircão do Biotita Granito (IPV-14 e 30C) se apresentam prismáticos, alguns com terminações bipiramidadas, comumente incolores a levemente castanhos e com poucas fraturas. Imagens de catodoluminescência (CL) apresentam zoneamento oscilatório bem marcado, com tons progressivamente mais escuros do centro para as bordas, e sobrecrescimento de horizontes mais homogêneos de coloração bem escura. Alguns grãos possuem núcleos arredondados e truncados pelo zoneamento, comumente são mais escuros e com textura interna indicando alteração (Anexo V). 
Cristais do TAG (IPV-35A) são subédricos, podendo ser euédricos a anédricos, e comumente apresentam coloração marrom escura, com diversas fraturas e inclusões (columbita, fluorita e bastnasita, também presentes sobrecrescendo as bordas). Apresentam características similares com os zircões magmáticos descritos por Rubin et al. (1989), com forma ameboide local, muitas inclusões e textura porosa. Em imagens $\mathrm{CL}$, são completamente escuros e predominantemente homogêneos, com alguns cristais apresentando leve zoneamento oscilatório (Anexo X).

O comportamento químico varia dentre as amostras de uma mesma fácies e entre as fácies, mostrando clara correlação com o processo de diferenciação magmatohidrotermal nos diagramas binários (Tabela 17 - Figura 55A a F). Nos diagramas as amostras foram agrupadas de acordo com as texturas internas dos cristais (zoneamento oscilatório vs. homogêneo e escuro). Os domínios com tons cinza claro nas imagens $\mathrm{CL}$ apresentam maior proporção catiônica de $\mathrm{Si}$ e $\mathrm{Zr}$, enquanto os domínios escuros, sem resposta $\mathrm{CL}$, são enriquecidos em $\mathrm{Y}, \mathrm{F}, \mathrm{ETR}, \mathrm{Nb}, \mathrm{Hf}$, Th e U.

Entre as fácies do Leucogranito Inhandjara, o zircão mostra diminuição da razão $\mathrm{Zr} / \mathrm{Hf}$ e aumento nos elementos incompatíveis com a diferenciação. Esse padrão também é reproduzido dos núcleos para as bordas dos cristais do BG. No TAG essa variação núcleo-borda não é observada, pois os cristais são homogêneos, sempre com altos teores de elementos incompatíveis. A razão Th/U aumenta do BG para o TAG; apesar dos valores $\mathrm{U}$ e Th nas zonas escuras de ambas fácies apresentarem teor semelhante. O conteúdo de $\mathrm{Y}_{2} \mathrm{O}_{3}$ é bastante elevado no TAG, variando de 6-12\%, pouco comuns na literatura, enquanto o BG apresenta teores de 0 a $9 \%$.

Em diagramas normalizados pelo condrito, amostras do Biotita Granito (Figura 55G, $\mathrm{H}$ e I) apresentam grande variação nos teores de ETR totais, com enriquecimento dos ETRP em relação aos ETRL ( $\left(a_{N} / Y_{N}\right.$ entre 0,003 e 0,14) e anomalia negativa de Eu (Eu/Eu* de 0,07 a 0,30). Zonas de tons mais claros nas imagens de $\mathrm{CL}$ comumente possuem os menores de ETR totais, com anomalias positivas de $\mathrm{Ce}(\mathrm{Ce} / \mathrm{Ce} *$ de 0,97 a 16,35). Zonas mais escuras em cristais das mesmas amostras apresentam teores maiores de ETR totais, especialmente os leves, e neste caso, não possuem anomalia de Ce $(0,92$ a 2,38). Já o TAG apresenta padrões de ETR normalizados pelo condrito sem variação, com os maiores valores de ETR totais, especialmente os ETRP, razão $\mathrm{LaN}_{N} / \mathrm{Yb}_{\mathrm{N}}$ entre 0.002 e 0.004 , intensa anomalia negativa de $\mathrm{Eu}(\mathrm{Eu} / \mathrm{Eu} *<0.002)$ e sem anomalia de $\mathrm{Ce}(1,35$ a 1,61). 
Tabela 17: Análises químicas in situ representativas dos zircões de Inhandjara

\begin{tabular}{|c|c|c|c|c|c|}
\hline Fácies & Porfirítica & Porfirítica & Inequigranular & Inequigranular & Equigranular \\
\hline Amostra & IPV-14 & IPV-14 & IPV-30C & IPV-30C & IPV-35A \\
\hline Análise & 13_núcleo & 17_borda & 11_núcleo & 20_borda & 06_borda \\
\hline $\mathrm{SiO}_{2}(\mathrm{wt} \%)$ & 32,5 & 30,21 & 32,31 & 28,13 & 26,04 \\
\hline $\mathrm{ZrO}_{2}$ & 65,99 & 61,93 & 65,58 & 57,13 & 38,49 \\
\hline $\mathrm{HfO}_{2}$ & 1,03 & 1,62 & 0,86 & 1,34 & 3,00 \\
\hline $\mathrm{TiO}_{2}$ & 0,06 & 0,08 & 0 & 0,12 & 0,23 \\
\hline $\mathrm{Al}_{2} \mathrm{O}_{3}$ & 0,01 & 0,29 & 0 & 0,66 & 2,06 \\
\hline $\mathrm{FeO}$ & 0,17 & 0,53 & 0,02 & 1,65 & 1,65 \\
\hline $\mathrm{CaO}$ & 0,01 & 0,09 & 0,008 & 0,41 & 0,46 \\
\hline $\mathrm{P}_{2} \mathrm{O}_{5}$ & 0 & 0 & 0 & 0,61 & 0,23 \\
\hline $\mathrm{UO}_{2}$ & 0 & 0,03 & 0,02 & 0,05 & 0,24 \\
\hline $\mathrm{ThO}_{2}$ & 0 & 0,64 & 0,05 & 0,59 & 1,46 \\
\hline $\mathrm{Nb}_{2} \mathrm{O}_{5}$ & 0 & 0,15 & 0 & 0,02 & 1,97 \\
\hline $\mathrm{Gd}_{2} \mathrm{O}_{3}$ & 0,01 & 0,17 & 0,003 & 0,36 & 0,45 \\
\hline $\mathrm{Dy}_{2} \mathrm{O}_{3}$ & 0 & 0,23 & 0,09 & 0,43 & 0,90 \\
\hline $\mathrm{Yb}_{2} \mathrm{O}_{3}$ & 0,07 & 0,38 & 0,19 & 0,57 & 1,96 \\
\hline $\mathrm{Y}_{2} \mathrm{O}_{3}$ & 0,08 & 1,48 & 0,59 & 2,86 & 8,93 \\
\hline $\mathrm{F}$ & 0 & 0,21 & 0 & 0,97 & 1,57 \\
\hline Total (wt\%) & 99,94 & 98,03 & 99,72 & 95,92 & 90,22 \\
\hline \multicolumn{6}{|l|}{ APFU } \\
\hline $\mathrm{Si}$ & 3,99 & 3,85 & 3,98 & 3,65 & 3,64 \\
\hline $\mathrm{Zr}$ & 3,95 & 3,85 & 3,94 & 3,61 & 2,62 \\
\hline $\mathrm{Hf}$ & 0,04 & 0,06 & 0,03 & 0,05 & 0,12 \\
\hline $\mathrm{Ti}$ & 0,006 & 0,007 & 0 & 0,01 & 0,02 \\
\hline $\mathrm{Al}$ & 0,002 & 0,04 & 0 & 0,1 & 0,34 \\
\hline $\mathrm{Fe}$ & 0,02 & 0,06 & 0,001 & 0,18 & 0,19 \\
\hline $\mathrm{Ca}$ & 0,002 & 0,01 & 0,001 & 0,056 & 0,07 \\
\hline$P$ & 0 & 0 & 0 & 0,07 & 0,03 \\
\hline$U$ & 0 & 0,0009 & 0,0006 & 0,001 & 0,007 \\
\hline Th & 0 & 0,01 & 0,001 & 0,01 & 0,03 \\
\hline $\mathrm{Nb}$ & 0 & 0,008 & 0 & 0,001 & 0,12 \\
\hline $\mathrm{Gd}$ & 0,0005 & 0,007 & 0,0001 & 0,02 & 0,02 \\
\hline Dy & 0 & 0,009 & 0,003 & 0,02 & 0,04 \\
\hline $\mathrm{Yb}$ & 0,003 & 0,01 & 0,007 & 0,02 & 0,08 \\
\hline$Y$ & 0,005 & 0,1 & 0,04 & 0,2 & 0,66 \\
\hline $\mathrm{F}$ & 0 & 0,08 & 0 & 0,4 & 0,69 \\
\hline $\mathrm{Zr} / \mathrm{Hf}$ & 55,68 & 33,37 & 66,6 & 37,22 & 11,2 \\
\hline Th/U & - & 20,18 & 2,50 & 11,13 & 6,08 \\
\hline Sn (ppm) & 5,32 & 1265,24 & 108,96 & 595,74 & 62,36 \\
\hline ETR (ppm) & 620,84 & 31169,05 & 11105,93 & 27107,46 & 47367,09 \\
\hline ETRL (ppm) & 48,35 & 7304,83 & 2484,11 & 6266,85 & 1973,76 \\
\hline ETRP (ppm) & 572,49 & 23864,22 & 8621,82 & 20840,61 & 45393,33 \\
\hline
\end{tabular}


Biotita Granito Porfiritico

Biotita Granito Inequigranular

Alcali-feldspato granito com topázio

Zonas escuras zonamento fraco

Zonas escuras zonamento fraco

$\Delta$ Zonas escuras zonamento fraco

$\square$ Zonas claras zonamento fino

O Zonas claras zonamento fino
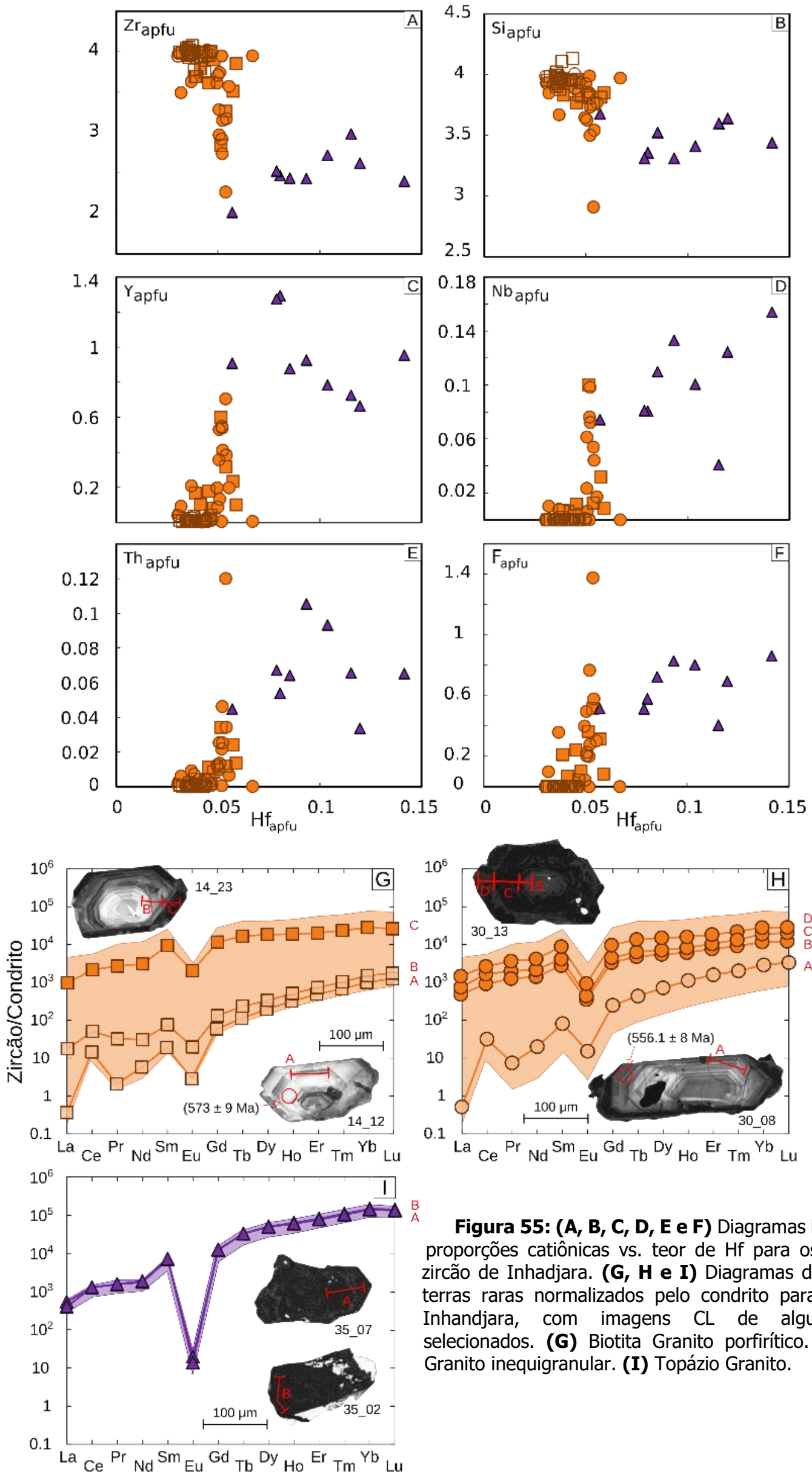

Figura 55: (A, B, C, D, E e F) Diagramas binários com proporções catiônicas vs. teor de Hf para os cristais de zircão de Inhadjara. (G, H e I) Diagramas de elementos terras raras normalizados pelo condrito para zircões de Inhandjara, com imagens $\mathrm{CL}$ de alguns cristais selecionados. (G) Biotita Granito porfirítico. (H) Biotita Granito inequigranular. (I) Topázio Granito. 

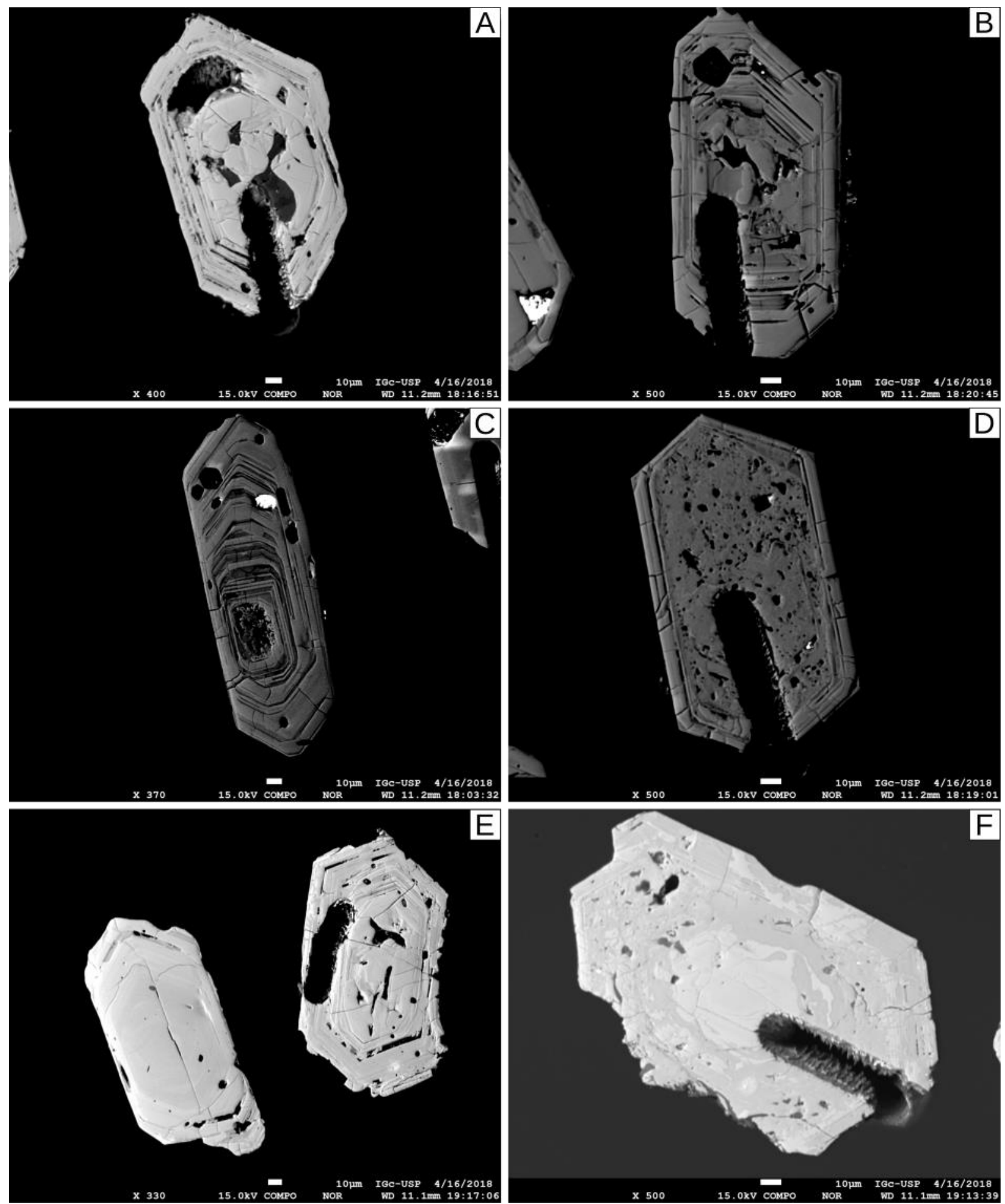

Figura 56: Imagens BSE para zircões do Biotita Granito. (A) Fácies Porfirítica (IPV-14) - cristal 2. (B) Fácies Porfirítica (IPV-14) - cristal 12. (C) Fácies Porfirítica (IPV-14) - cristal 28. (D) Fácies Porfirítica (IPV-14) - cristal 7. (E) Fácies Inequigranular (IPV-30C) - cristal 10 à esquerda e cristal 2 à direita. (F) Fácies Inequigranular (IPV30C) - cristal 5. 

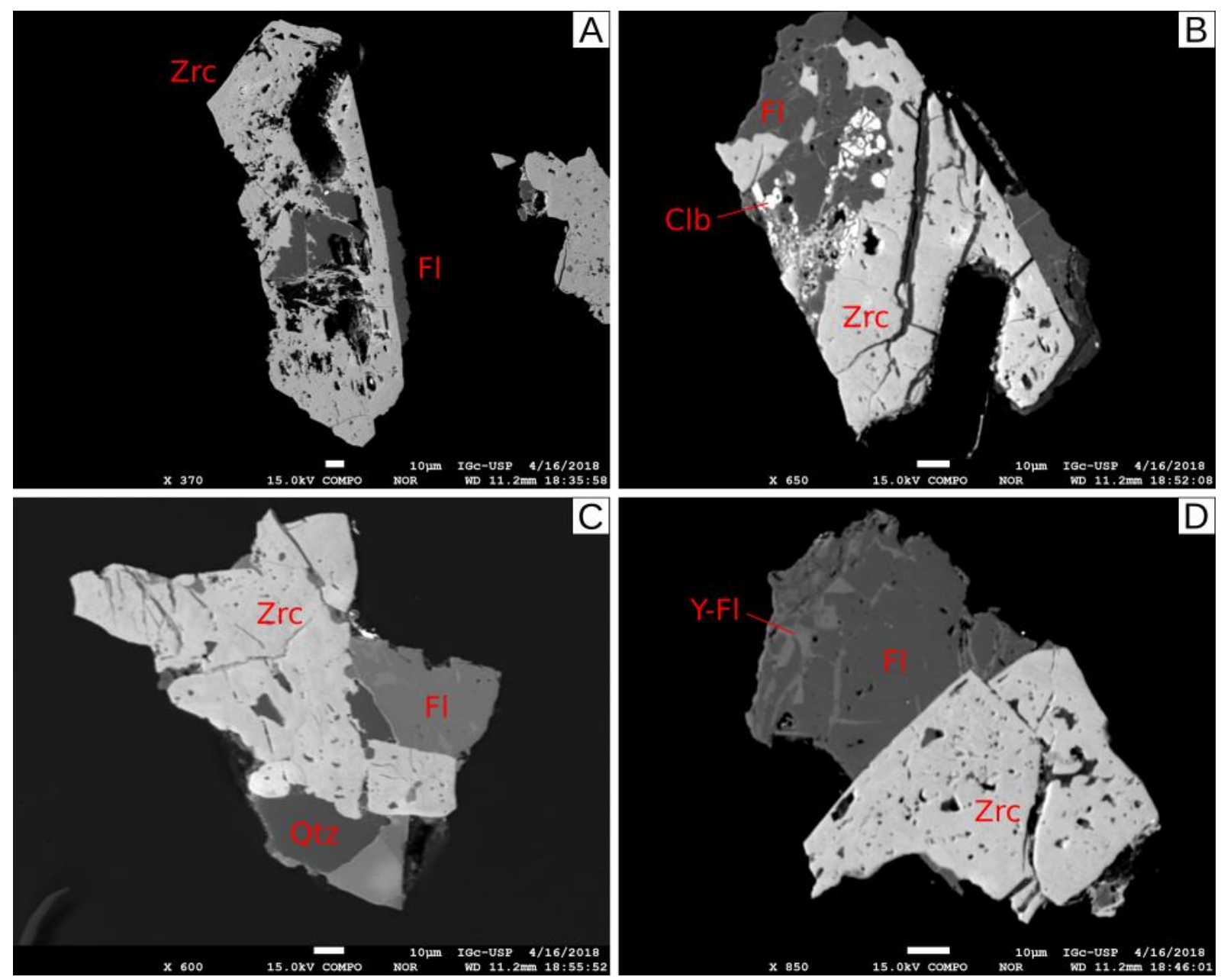

Figura 57: Imagens BSE para zircões do Topázio Granito. (A) IPV-35A - cristal 01, poroso com fluorita internamente e nas bordas. (B) IPV-35A - cristal 02, fraturadoe parcialmnte substituído por fluorita e columbita. (C) IPV-35A - cristal 16, cristal anédrico associado com fluorita rica em Y e quartzo. (D) IPV-35A - cristal 15, subédrico e fraturado, associado a fluorita com manchas de Y-fluorita.

\section{II.5 DATAÇÃO U-PB EM ZIRCÃO}

Amostras representativas de cada fácies, as mesmas utilizadas para a obtenção das análises químicas, foram selecionadas para datação U-Pb por microssonda iônica de alta resolução (SHRIMP), porém apenas as das fácies do Biotita Granito puderam ser analisadas. A amostra do granito com topázio apresenta zircão fortemente alterado (ou metamítico), com hábito subédrico, diversas fraturas, coloração acastanhada na lupa e cor preta nas imagens de catodoluminescência, decorrentes da alta concentração de $\mathrm{U}$, que impossibilitou a análise deste grupo (Figura 58).

No Biotita Granito as análises se concentraram em especial nas bordas dos cristais, com domínio cinza médio nas imagens de $\mathrm{CL}$, visando obtenção da idade de cristalização do granito (Figura 59 e Figura 61). Os teores de Th e U da fácies porfirítica são bem variados, com valores respectivamente entre 120 - 760 ppm e 55 - 620 ppm, enquanto a razão Th/U varia de 0,79 a 2,08. A idade concórdia obtida para o Biotita 
Granito porfirítico é de $576 \pm 6 \mathrm{Ma}$ (Figura 60), considerando apenas os dados concordantes da população central. Porém, algumas idades ${ }^{206} \mathrm{~Pb} / 238 \mathrm{U}$ isoladas mais antigas foram encontradas, e apresentam valores concordantes em torno de 640, 750 e $1140 \mathrm{Ma}$, indicando possíveis heranças nessa fácies.

Para a fácies inequigranular os teores de Th dos cristais analisados variam entre 120 e 570 ppm, com dois valores fora desse intervalo, de 75 e 1600 ppm; enquanto o U varia menos, entre 80 e 260 ppm, com três teores bem mais altos, de 830, 1010 e 2645 ppm. Já a razão Th/U varia bastante, desde 0,16 até 2,24. O Biotita Granito Inequigranular apresenta idades pontuais sistematicamente mais jovens que a fácies anterior, e sua idade concórdia obtida é de $565 \pm 6 \mathrm{Ma}$ (Figura 62). Algumas análises apresentaram idades mais jovens, porém discordantes, e foram interpretadas como resultantes da perda de $\mathrm{Pb}$ do zircão após a cristalização.

Considerando as diferenças de idade entre as duas amostras analisadas, observase que são semelhantes dentro do erro do método, e assim, foi definido que a cristalização do Biotita Granito se deu no intervalo entre 575 e 565 Ma.

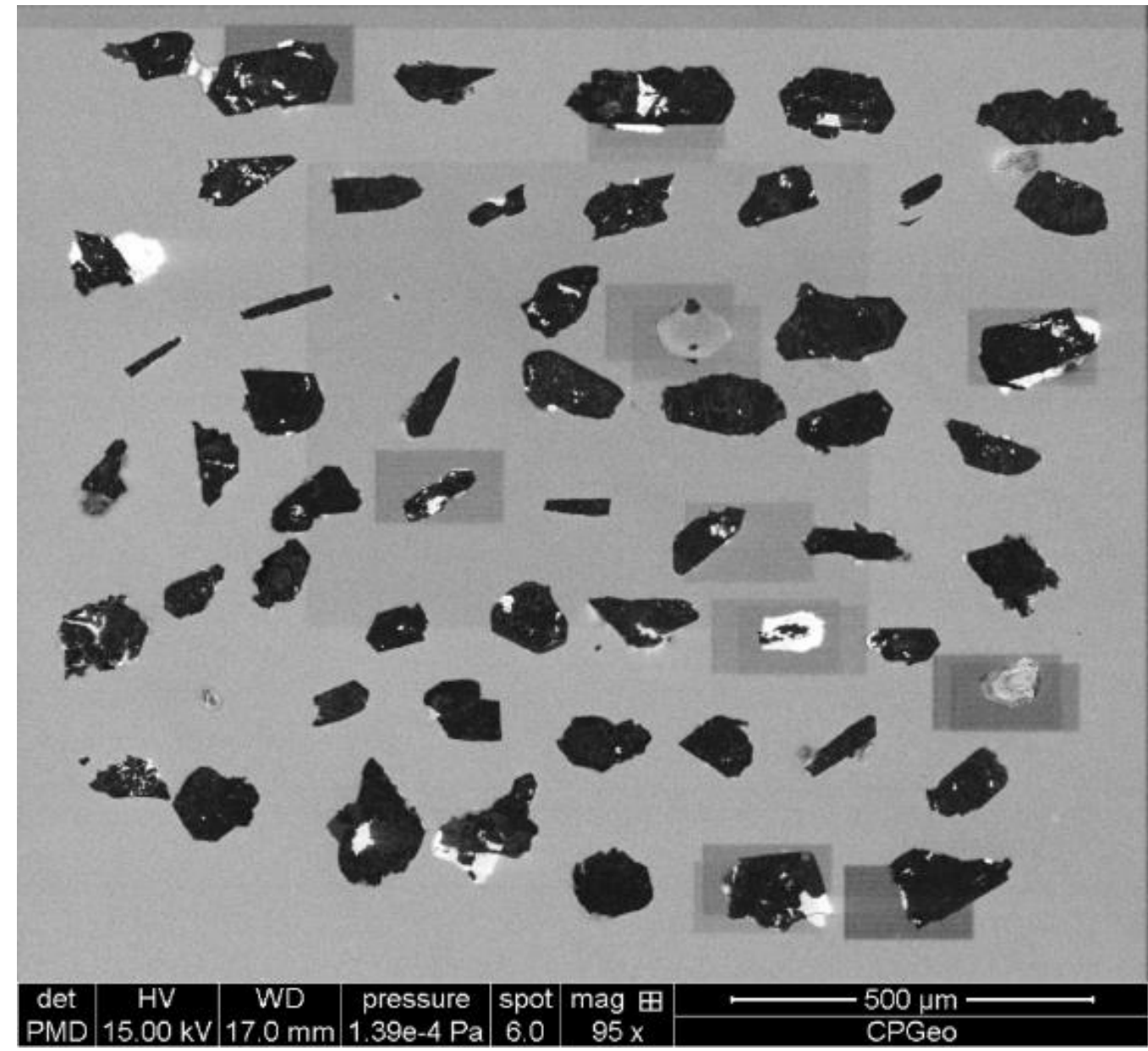

Figura 58: Imagem de catodoluminêscencia dos cristais de zircão da amostra IPV-35A (TAG). 
Tabela 18: Dados geocronológicos U-Pb obtidos em cristais de zircão de Inhandjara por SHRIMP.

\begin{tabular}{|c|c|c|c|c|c|c|c|c|}
\hline Fácies & Cristal & Análise & Th & $U$ & $\begin{array}{c}\text { Idade } \\
\left(206 \mathrm{~Pb} /{ }^{238} \mathrm{U}\right)\end{array}$ & $\begin{array}{c}\text { erro } \\
(2 \sigma)\end{array}$ & $\begin{array}{c}\text { Idade } \\
\left({ }^{207} \mathrm{~Pb} /{ }^{206} \mathrm{~Pb}\right)\end{array}$ & $\begin{array}{c}\text { erro } \\
(2 \sigma)\end{array}$ \\
\hline Porfiritica & 1 & 1 & 120,65 & 84,83 & 567,27 & 18 & 581 & 24 \\
\hline Porfiritica & 2 & 1 & 136,68 & 104,26 & 747,96 & 25 & 742 & 32 \\
\hline Porfiritica & 3 & 1 & 235,85 & 113,17 & 596,41 & 21 & 665 & 32 \\
\hline Porfiritica & 4 & 1 & 293,39 & 173,76 & 562,29 & 17 & 571 & 24 \\
\hline Porfiritica & 5 & 1 & 158,62 & 140,35 & 590,59 & 18 & 617 & 22 \\
\hline Porfiritica & 6 & 1 & 135,62 & 97,08 & 537,61 & 17 & 543 & 22 \\
\hline Porfiritica & 7 & 1 & 324,81 & 371,24 & 643,02 & 19 & 657 & 22 \\
\hline Porfiritica & 8 & 1 & 253,62 & 176,04 & 580,09 & 17 & 591 & 22 \\
\hline Porfiritica & 9 & 1 & 548,79 & 532,44 & 1143,79 & 65 & 1058 & 82 \\
\hline Porfiritica & 10 & 1 & 81,87 & 53,16 & 575,95 & 20 & 580 & 26 \\
\hline Porfiritica & 11 & 1 & 230,58 & 162,92 & 556,69 & 16 & 566 & 22 \\
\hline Porfiritica & 12 & 1 & 167,59 & 125,24 & 573,47 & 17 & 583 & 22 \\
\hline Porfiritica & 13 & 1 & 128,69 & 137,91 & 589,70 & 18 & 612 & 22 \\
\hline Porfiritica & 14 & 1 & 415,43 & 526,57 & 588,86 & 17 & 589 & 20 \\
\hline Porfiritica & 14 & 2 & 149,73 & 112,96 & 583,60 & 24 & 601 & 34 \\
\hline Porfiritica & 15 & 1 & 759,10 & 616,93 & 577,31 & 18 & 593 & 24 \\
\hline Inequig & 1 & 1 & 119,91 & 81,22 & 355,79 & 18 & 498 & 630 \\
\hline Inequig & 2 & 1 & 131,01 & 88,50 & 551,68 & 18 & 617 & 166 \\
\hline Inequig & 2 & 2 & 224,91 & 239,87 & 567,75 & 17 & 623 & 70 \\
\hline Inequig & 3 & 1 & 164,71 & 166,68 & 559,11 & 17 & 570 & 94 \\
\hline Inequig & 3 & 2 & 286,89 & 232,12 & 501,25 & 15 & 629 & 228 \\
\hline Inequig & 4 & 1 & 536,04 & 238,74 & 455,04 & 14 & 1027 & 340 \\
\hline Inequig & 5 & 1 & 573,68 & 256,58 & 552,25 & 16 & 643 & 154 \\
\hline Inequig & 6 & 1 & 74,97 & 95,34 & 581,26 & 18 & 556 & 150 \\
\hline Inequig & 7 & 1 & 1601,39 & 1008,82 & 579,39 & 16 & 589 & 52 \\
\hline Inequig & 8 & 1 & 321,58 & 376,62 & 556,06 & 16 & 558 & 174 \\
\hline Inequig & 9 & 1 & 422,72 & 2644,22 & 621,08 & 17 & 562 & 20 \\
\hline Inequig & 9 & 2 & 366,32 & 830,48 & 567,89 & 16 & 553 & 72 \\
\hline
\end{tabular}




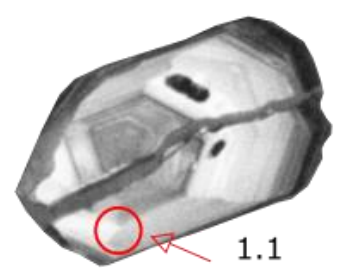

5.1

$(567 \pm 9 \mathrm{Ma})$

$(591 \pm 9 \mathrm{Ma})$

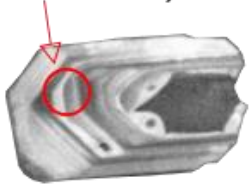

9.1

6.1

$(538 \pm 8 \mathrm{Ma})$

10.1

$(576 \pm 10 \mathrm{Ma})$
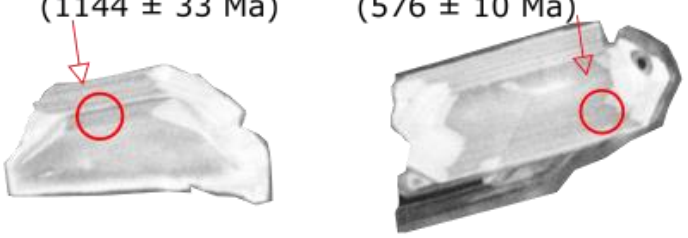

$(596 \pm 11 \mathrm{Ma})$
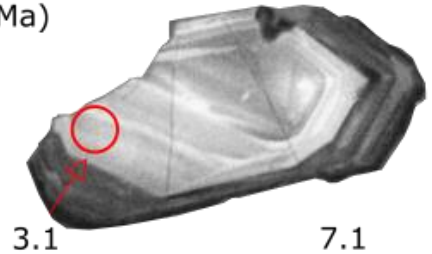

7.1

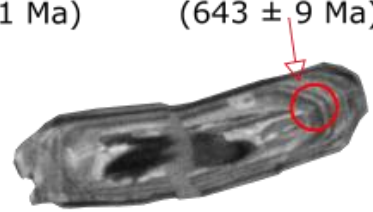

11.1 $(557 \pm 8 \mathrm{Ma}) \quad(573 \pm 9 \mathrm{Ma})$
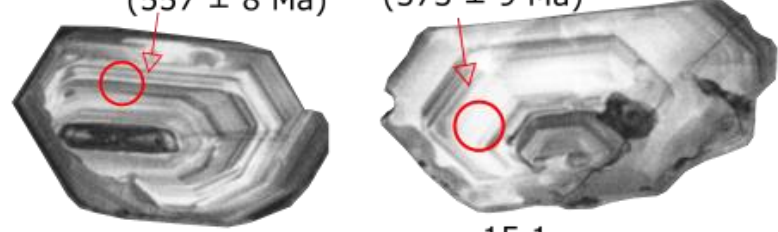

$(577 \pm 9 \mathrm{Ma})$
15.1

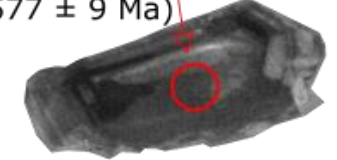

4.1
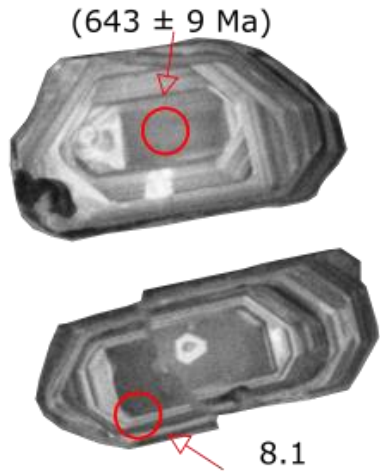

$(580 \pm 9 \mathrm{Ma})$

$300 \mu \mathrm{m}$

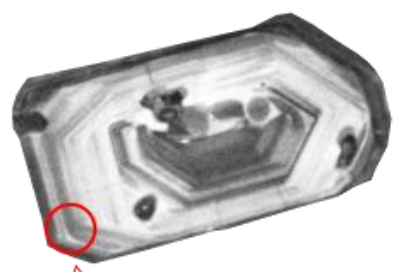

13.1

$(590 \pm 9 \mathrm{Ma})$

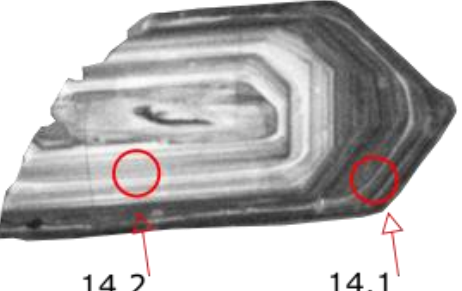

$(584 \pm 12 \mathrm{Ma}) \quad(589 \pm 8 \mathrm{Ma})$

Figura 59: Imagem de catodoluminêscencia dos cristais de zircão datados da amostra IPV-14 (BG porfirítico) com posição dos spots e idade pontuais ${ }^{206} \mathrm{~Pb} /{ }^{238} \mathrm{U}$ por SHRIMP.

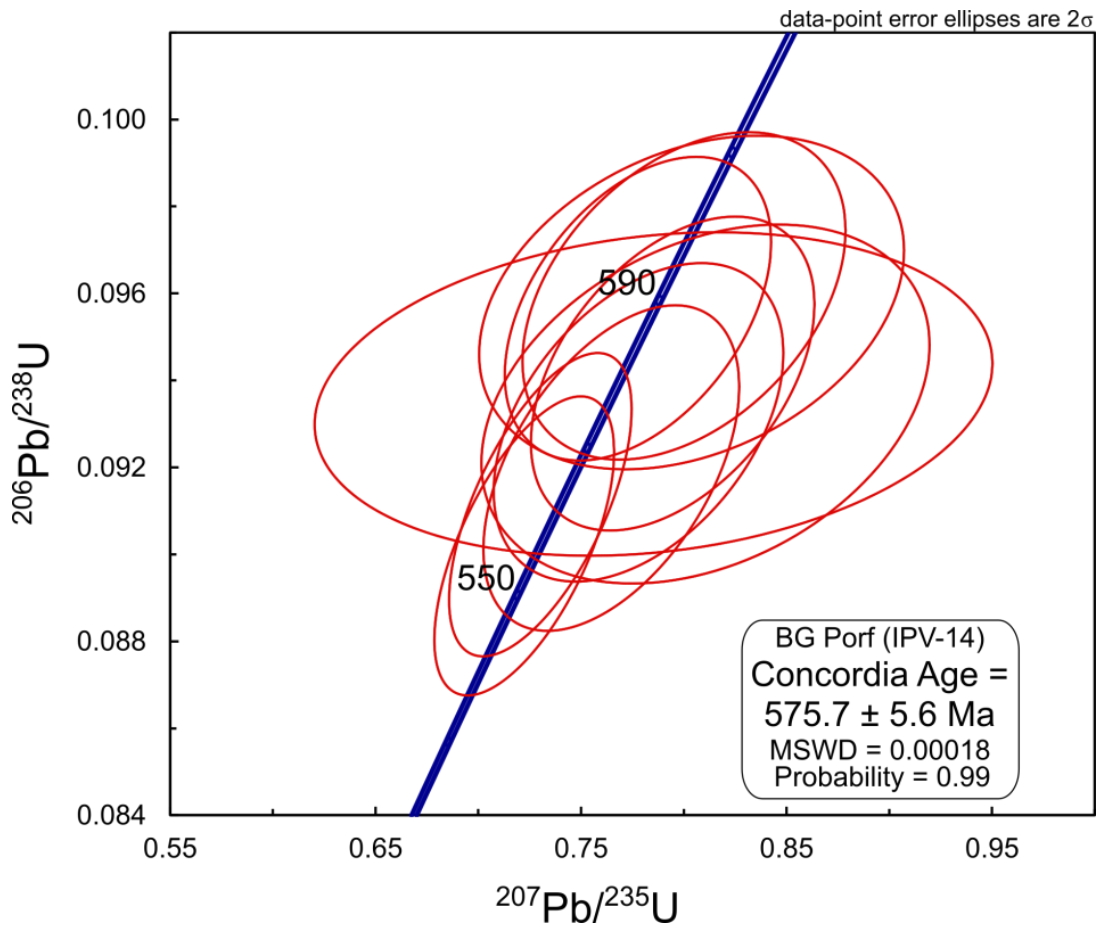

Figura 60: Diagrama concordia obtido para dados concordantes do BG porfirítico. 

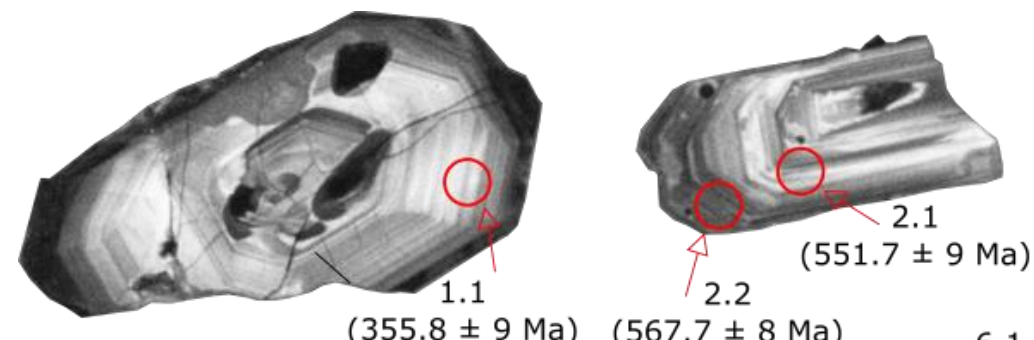

$(355.8 \pm 9 \mathrm{Ma}) \quad(567.7 \pm 8 \mathrm{Ma})$

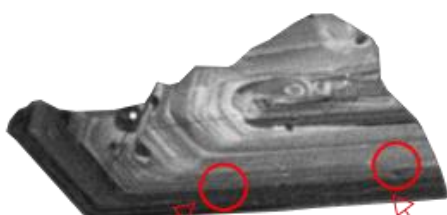

3.1

$(559.1 \pm 8 \mathrm{Ma})$

3.2

$(501.2 \pm 8 \mathrm{Ma})$

6.1

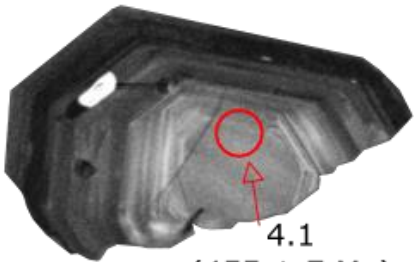

$(455 \pm 7 \mathrm{Ma})$

8.1

$(556.1 \pm 8 \mathrm{Ma})$

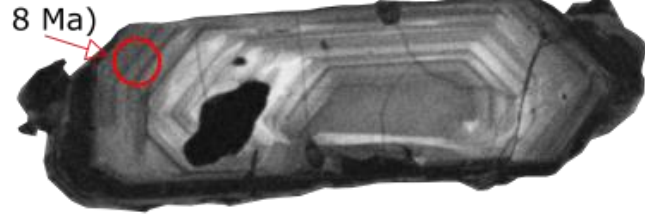

$(581.3 \pm 9 \mathrm{Ma})$

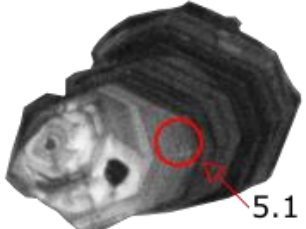

$(552.2 \pm 8 \mathrm{Ma})$
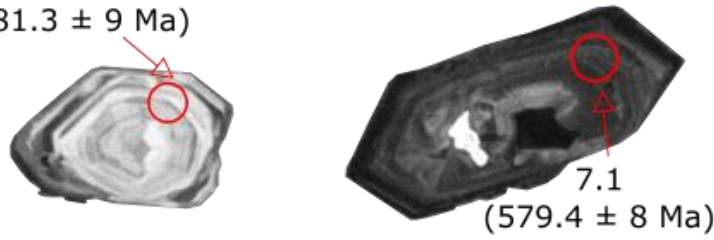

9.1

$(621.1 \pm 9 \mathrm{Ma})$

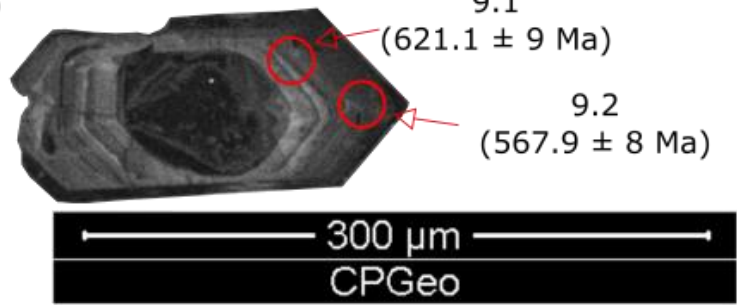

Figura 61: Imagem de catodoluminêscencia dos cristais de zircão datados da amostra IPV-30C (BG inequigranular) com posição dos spots e idade pontuais ${ }^{206} \mathrm{~Pb} / 238 \mathrm{U}$ por SHRIMP.

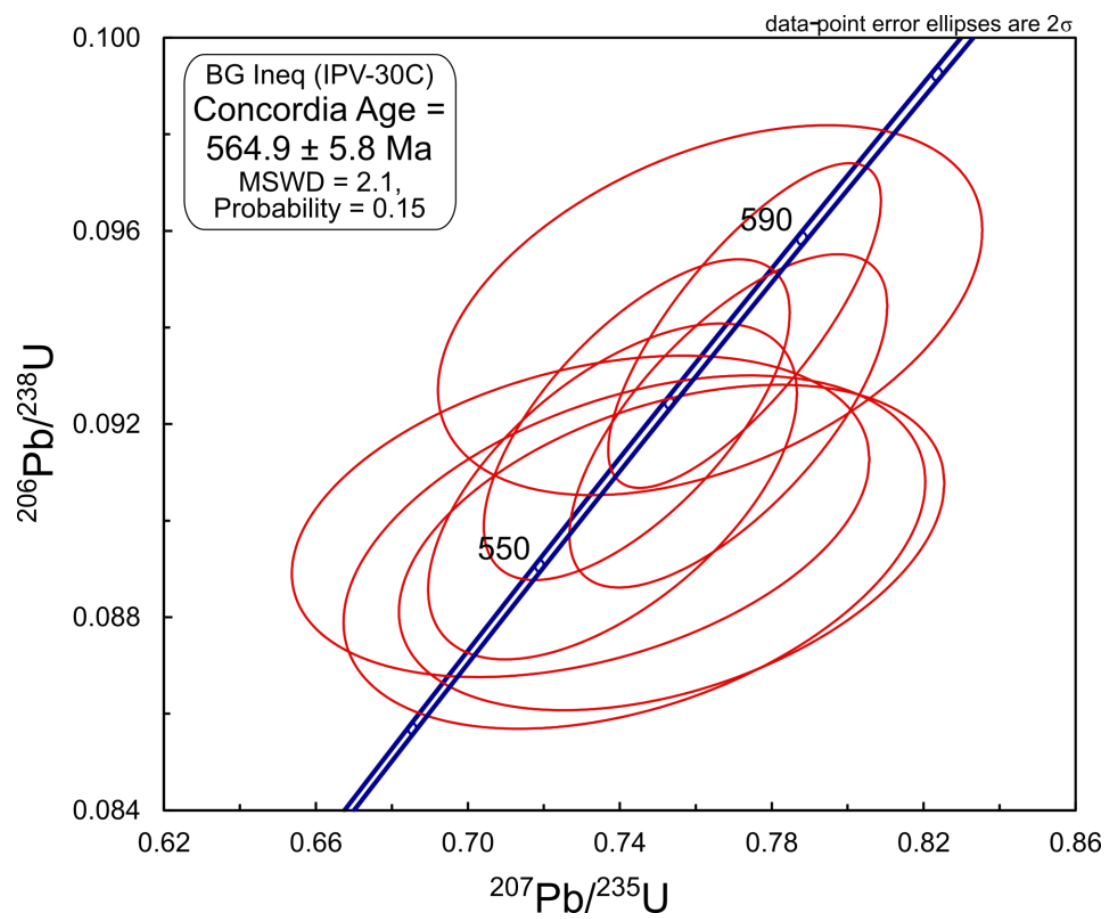

Figura 62: Diagrama concordia obtido para dados concordantes do BG inequigranular. 


\section{CAPÍTULO III - DISCUSSÃO E CONCLUSÕES}

\section{III.1 DISCUSSÃO}

Estudos prévios no Batólito Itu incluem a região de Inhandjara majoritariamente como parte do Pluton Itupeva (Pascholati, 1990; Ribeiro et al., 1994), com sua porção sul (aproximadamente metade do BG) correspondendo ao Pluton Cabreúva (Galembeck, 1997; Janasi et al., 2009). Neste trabalho, os litotipos magmáticos estudados foram interpretados como componentes do Leucogranito Inhandjara, um stock satélite distinto dos demais plutons do Batólito Itu e mais evoluído.

O stock é subdividido em duas unidades principais: Biotita Granito (BG) e Topázio Granito (TAG). As amostras do BG apresentam grande variação textural, mas, devido às diversas semelhanças mineralógicas, suas fortes afinidades químicas e razões isotópicas Sm-Nd muito próximas, as fácies porfirítica e inequigranular foram interpretadas como cristalizadas diretamente do mesmo magma nos estágios iniciais.

Em comparação, o TAG é um pouco distinto das demais amostras nas análises petrográficas e químicas, e foi interpretado como representante do magma residual, uma fase mais tardia e evoluída do sistema Inhandjara. Assim, o TAG é comparável aos topázio granitos da série de baixo-P definida por Taylor (1992).

\section{III.1.1 Geoquímica de Rocha Total}

O caráter bastante evoluído do Leucogranito Inhandjara pode ser observado em diagramas geoquímicos (Figura 40, Figura 41 e Figura 42), nos quais as amostras estudadas apresentam elevados conteúdos de $\mathrm{SiO}_{2}$, álcalis (especialmente $\mathrm{Na}_{2} \mathrm{O}$ ) e $\mathrm{Al}_{2} \mathrm{O}_{3}$, juntamente com os menores conteúdos de $\mathrm{TiO}_{2}, \mathrm{MgO}, \mathrm{CaO}, \mathrm{P}_{2} \mathrm{O}_{5}$. Isto é consistente com as observações de campo e mineralógicas. Considerando os elementos traço, o Biotita Granito já demonstra um caráter geoquímico diferenciado, porém os elevados teores de $\mathrm{F}, \mathrm{Y}, \mathrm{Rb}, \mathrm{Cs}, \mathrm{Nb}$, Ta e Ga do TAG indicam uma concentração ainda maior dos elementos incompatíveis na fácies evoluída, inclusive com alguns valores muito acima dos encontrados para o restante do Batólito Itu.

Os baixos teores de $\mathrm{CaO}, \mathrm{FeO}, \mathrm{MgO}, \mathrm{TiO}_{2}, \mathrm{P}_{2} \mathrm{O}_{5}, \mathrm{Ba}, \mathrm{Sr}, \mathrm{Zr}$ e Eu do magma podem refletir retenção de palgioclásio, minerais máficos, zircão e fosfatos na fonte ou concentração em cumulatos graníticos, em profundidade. Tais processos levariam à formação de um magma residual com composição mais sódica, possibilitando a cristalização de albita magmática. Outra possível interpretação, é de que esse caráter 
químico indique uma fonte já diferenciada para o magma que deu origem ao Leucogranito Inhandjara.

$O$ alto teor de $Y$ é consistente com os padrões de ETR normalizados pelo condrito, onde o TAG apresenta padrões sub-horizontais com leve enriquecimento nos ETRP $\left(0,6<\mathrm{La}_{N} / \mathrm{Yb}_{N}<1,1\right)$, enquanto o Biotita Granito já apresenta valores um pouco mais enriquecidos em ETRL $\left(3<\mathrm{La}_{N} / \mathrm{Yb}_{N}<4\right)$, porém ainda muito abaixo das razões para os plutons Itupeva e Cabreúva, com padrões muito mais fracionados, conforme dados de Janasi et al. (2009), respectivamente $15<L a_{N} / Y_{N}<35$ e $L a_{N} / Y b_{N} \sim 17$. A forte anomalia de Eu também é um forte indicativo do comportamento diferenciado das amostras; assim como o efeito tetrad (Masuda et al., 1987- comportamento diferente dentre os ETR) apresentado pelos ETR padronizados pelo condrito, onde os granitos mostram valor de $\mathrm{TE}_{1,3}$ (Irber, 1999) maior que 1,0, chegando a 1,1 no Topázio Granito.

Algumas razões geoquímicas, tais como $\mathrm{Rb} / \mathrm{Sr}$, $\mathrm{Rb} / \mathrm{Ba}$ e $\mathrm{K} / \mathrm{Rb}$, ajudam a identificar o caráter altamente diferenciado de rochas graníticas, conforme Wu et al. (2017).

$\mathrm{O}$ Leucogranito Inhandjara mostrou razões $\mathrm{Rb} / \mathrm{Sr}$ e $\mathrm{Rb} / \mathrm{Ba}$ bastante elevadas especialmente no granito com topázio (respectivamente, 180 e 408), em especial, devido aos altos teores de $\mathrm{Rb}$. Assim, quando utilizamos o diagrama ternário $\mathrm{Rb}-\mathrm{Ba}-\mathrm{Sr}$ de El Bouselly e El Sokkary (1975), observamos que as amostras do Biotita Granito estão no campo dos granitos diferenciados, com o Topázio Granito plotando no extremo mais evoluído (Figura 41G), enquanto as amostras do Batólito Itu plotam no campo dos granitos normais.

As razões $\mathrm{Zr} / \mathrm{Hf}$ e $\mathrm{Nb} / \mathrm{Ta}$ também são ótimos indicadores para o processo de diferenciação (Figura 63B), pois relacionam pares de afinidade geoquímica muito parecida e tendem a se manter constantes quando em sistema fechado. Para alterar estas razões é necessário um forte evento de fracionamento (Wu et al., 2017) ou então a influência de processos tardi-magmáticos-hidrotermais (Raimbault et al., 1995; Wang et al., 2000). Estas razões mostram grande variação entre o Biotita Granito $(22<\mathrm{Zr} / \mathrm{Hf}<27$ e $9<\mathrm{Nb} / \mathrm{Ta}<10)$ e o Topázio Granito ( $\mathrm{Zr} / \mathrm{Hf} \sim 10$ e Nb/Ta 7). Assim, de acordo com os trabalhos anteriormente citados, foi necessário um intenso fracionamento magmático associado a posterior interação com uma fase fluida para a formação do Topázio Granito (Figura 63A), sendo este de mesma fonte que o Biotita Granito. De acordo com Ballouard et al. (2016), a razão Nb/Ta = 5 é um bom marcador para discriminar granitos especializados (Figura 63B). As amostras do Leucogranito 
Inhandjara são deslocadas dos campos definidos pelos autores devido à alta razão $\mathrm{Nb} / \mathrm{Ta}$, pois apresentam razão $\mathrm{Zr} / \mathrm{Hf}$ com valores semelhantes aos granitos mineralizados em metais raros. A razão $\mathrm{Nb} / \mathrm{Ta}$ mais elevada pode indicar que houve concentração de $\mathrm{Nb}$ nos estágios finais de cristalização do magma, em relação aos menores conteúdos de Ta, exemplificada pela presença de columbita com finas lamelas de tantalita no Topázio Granito.
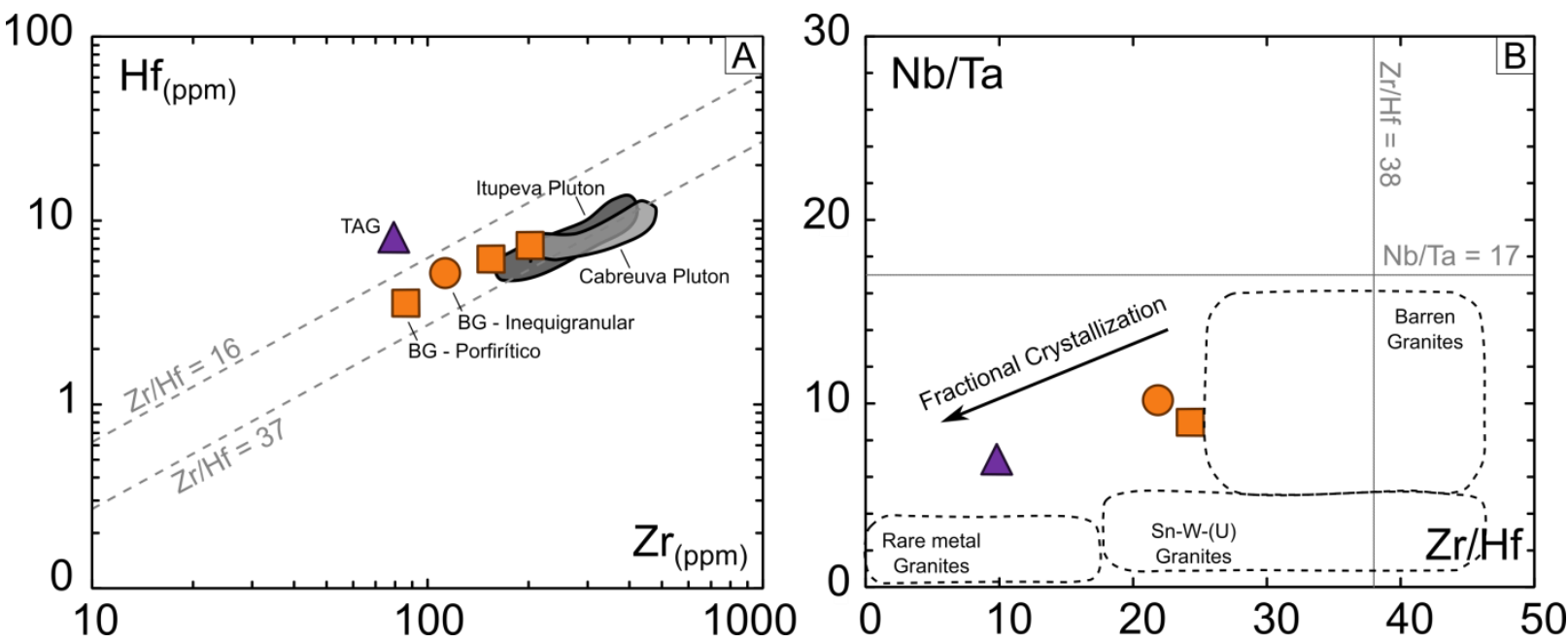

Figura 63: (A) Diagrama $\mathrm{Hf}$ vs. Zr para as amostras rocha total de Inhandjara e campos dos plutons adjacentes. Valores de referência para razão $\mathrm{Zr} / \mathrm{Hf}$ são fornecidos como balizadores. (B) Diagrama Nb/Ta vs. Zr/Hf com linhas de referência conforme Wu et al. (2017) e campos para granitos mineralizados de Ballouard et al. (2016).

\section{III.1.1 Química Mineral}

O plagioclásio das amostras do Biotita Granito é em geral sódico (teor máximo da molécula de An de 21,5$)$, porém a presença de albita $(A n<5)$ nesta unidade é provável resultado da substituição pós-magmática (Haapala, 1997; Pirajno, 2013). Esta alteração dissolveu o plagioclásio ígneo e o reprecipitou, em seguida albita hidrotermal pura, remobilizada das lamelas de exsolução dos feldspatos pertíticos, sobrecresce os núcleos alterados, formando as bordas límpidas e cristais intergranulares. No Topázio Granito, o teor de anortita sistematicamente baixo (An máximo de 3,8 ) e os cristais homogêneos sem indicativos texturais de reprecipitação subsolidus caracterizam a albita como feldspato alcalino ígneo. Isto sugere a cristalização da albita em granito subsolvus, diretamente do magma enriquecido em $\mathrm{Na}_{2} \mathrm{O}$.

A composição química da biotita, assim como os outros minerais do grupo da mica, pode ser um bom indicador do processo de fracionamento magmático (Berni et al., 2017). No Biotita Granito esse mineral não preserva a variação, pois grande parte dos 
cristais já foram completamente substituídos para clorita hidrotermal. No Topázio Granito, onde a biotita está bem preservada, os baixos teores de $\mathrm{Mg}$ e os valores consideráveis de $\mathrm{F} \mathrm{e} \mathrm{Li}$ indicam um caráter diferenciado.

O zircão é um ótimo indicador da evolução magmática em granitos (Pupin, 1980; Breiter and Škoda, 2017), sendo a fase que melhor registra o processo de diferenciação, com diversas referências para sua aplicação em granitos tipo-A ou especializados em metais raros (Wang et al., 2000; Kempe et al., 2004; Breiter et al., 2014, 2016; Lamarão et al., 2018).

O Leucogranito Inhandjara possui cristais de zircão com composição química que segue as mesmas tendências observadas para outros granitos especializados em metais raros (Lamarão et al., 2018); onde as rochas mais diferenciadas apresentam cristais com menor teor de $\mathrm{Zr}$ e enriquecidos em Hf, Y, ETR, Th, U, Nb e Ta (Figura $64 \mathrm{~A}$ e B). As texturas observadas nos cristais de zircão do Leucogranito Inhandjara também são típicas de rochas diferenciadas (Lamarão et al., 2018), onde cristais precoces são euédricos e com zoneamento oscilatório fino bem marcado (núcleos de zircão do Biotita Granito), enquanto cristais tardios (bordas do zircão do Biotita Granito e grãos inteiros do Topázio Granito; ainda magmáticos?) são mais anédricos, sem zoneamento bem definido, e associados a outras fases acessórias (e.g. fluorita e columbita).

Os baixos conteúdos de $\mathrm{Zr}$ e alto de $\mathrm{Hf}$ no magma gerador do Leucogranito Inhandjara, em especial do Topázio Granito, é responsável pela composição química fora do padrão do zircão (Figura 64C). A falta de Zr no magma faz com que outros elementos em excesso (e.g. $\mathrm{Hf}, \mathrm{Y}, \mathrm{Nb}, \mathrm{Th}, \mathrm{U}$ ) ocupem o sítio deste elemento na estrutura do zircão (Wang et al., 2000). Desse modo, fácies altamente evoluídas em sistemas graníticos tendem a apresentar zircão com composição química que se desvia da composição ideal (Wang et al., 2000; Breiter et al., 2014; Lamarão et al., 2018).

Composição química de zircão fora do padrão, como as observadas nas amostras de Inhandjara, pode estar diretamente relacionada com diferenciação magmática e especialização metálica de magmas graníticos, mas também podem ser uma resposta à alteração hidrotermal em estágios tardi-magmáticos (Rubin et al., 1989; Kempe et al., 2004). 
Breiter e Škoda (2017) definiram que a razão Zr/Hf do zircão não é alterada durante os processos hidrotermais ou com a metamictização, e que esta razão reflete diretamente o grau de fracionamento do magma, tendendo a diminuir durante sua evolução (Raimbault et al., 1995; Wang et al., 2000). A razão Zr/Hf obtida para os cristais de zircão das amostras de Inhandjara colocam suas fácies dentro dos campos definidos por Breiter et al. (2014), de $25<\mathrm{Zr} / \mathrm{Hf}<55$ para granitos moderadamente evoluídos, onde plota o Biotita Granito; e $\mathrm{Zr} / \mathrm{Hf}<25$ para granitos altamente evoluídos onde o Topázio Granito se encaixa, indicando cristalização a partir de um magma evoluído, que se diferenciou ainda mais posteriormente (Figura 64D).
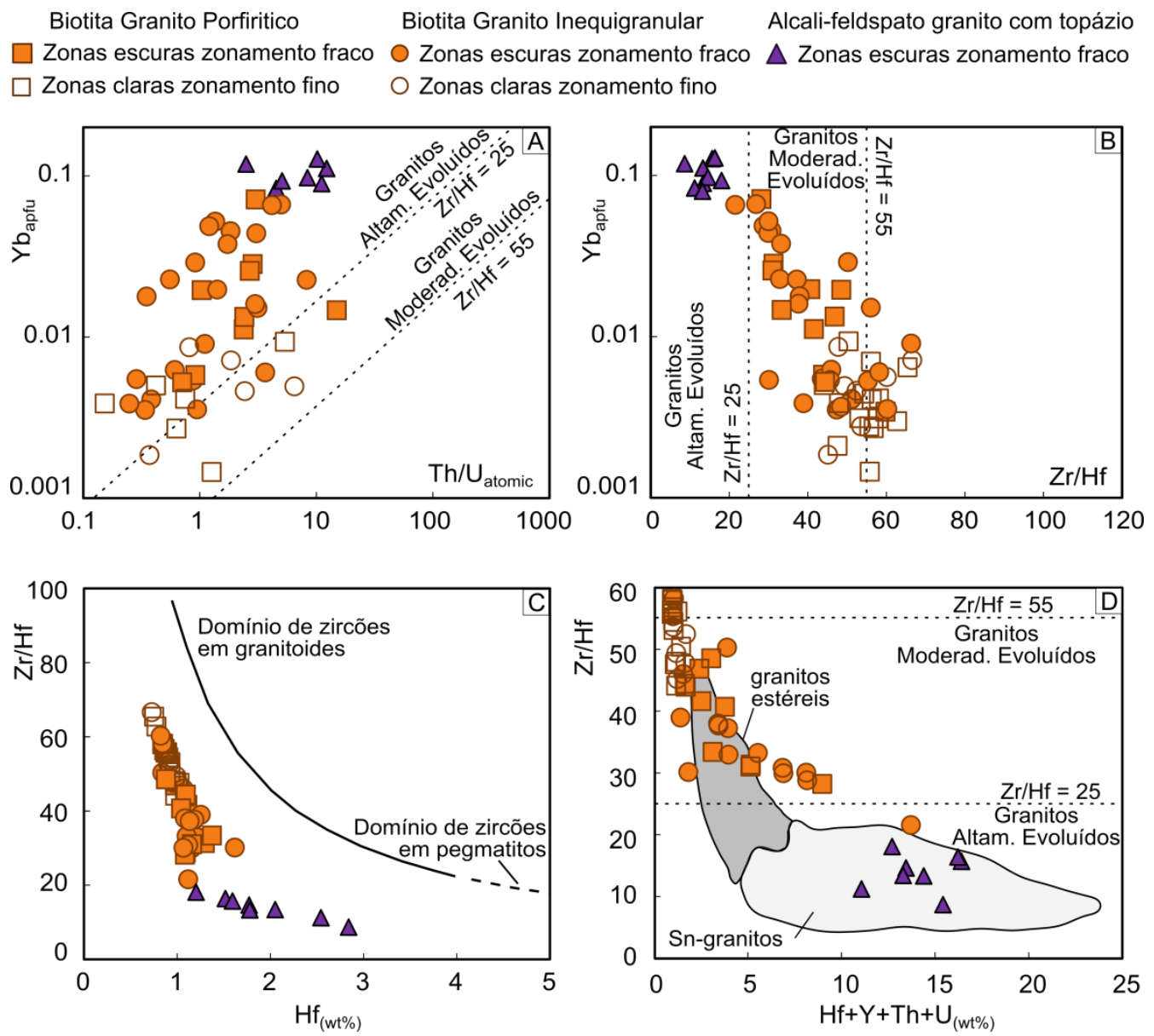

Figura 64: Diagramas para dados de química in situ para zircões de Inhandjara (A) Diagrama Yb vs. Th/U para os zircões de Inhandjara com os campos dos granitos moderadamente e altamente evoluídos definidos por Breiter et al. (2014) demarcados. (B) Diagrama Yb vs. Zr/Hf com os campos dos granitos moderadamente e altamente evoluídos de Breiter et al. (2014) demarcados. (C) Diagrama Zr/Hf vs. Hf (porcentagem em peso) com os domínios de zircões delimitados conforme Raimbault et al., (1995) e Wang et al. (2000) (D) Diagrama Zr/Hf vs. $\mathrm{HF}+\mathrm{Y}+\mathrm{Th}+\mathrm{U}$ com os campos de granitos estéreis e estaníferos definidos por Lamarão et al. (2018). 
A composição normativa do Biotita Granito, representada no diagrama Q-Ab-Or para o sistema haplogranítico (Figura 65), indica uma composição próxima ao mínimo granítico normal. No Topázio Granito a composição normativa é deslocada em direção ao vértice da $\mathrm{Ab}$ e representa o mínimo granítico para um magma com cerca de $1 \%$ de F (conforme parâmetros de Manning, 1981). Durante a cristalização do granito, tal conteúdo de $\mathrm{F}$ foi exsolvido juntamente com outros voláteis e formou uma fase fluida livre, apesar de parte do $\mathrm{F}$ ser incorporado na estrutura de fases magmáticas evoluídas (e.g., biotita, topázio, fluorita e Y-fluorita). Isto corrobora com a hipótese de fracionamento magmático, realçado pelo fracionamento tardio da fácies evoluída em presença de uma fase fluida rica em $\mathrm{F}$.

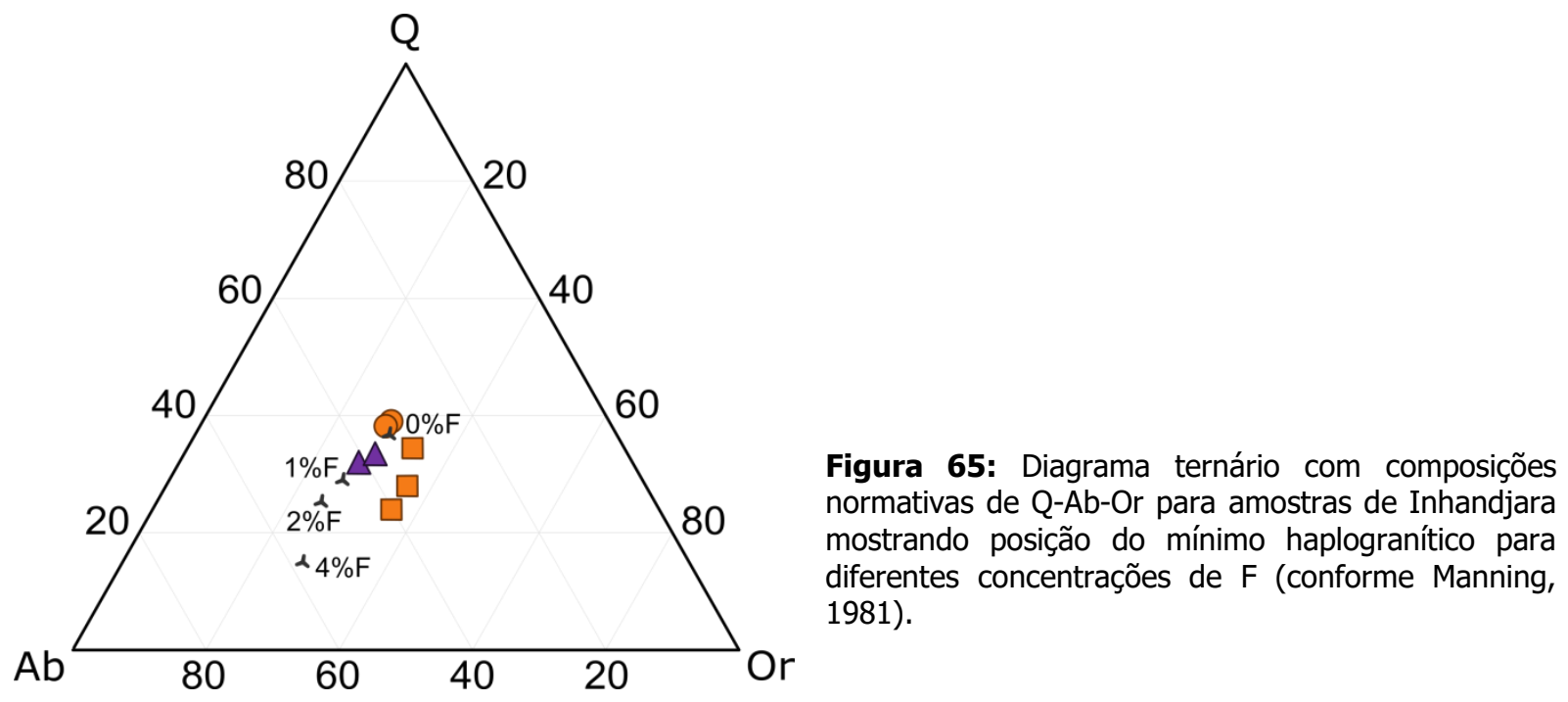

\section{III.1.1 Geoquímica isotópica Sm-Nd e de ETR}

Os valores de $\varepsilon \mathrm{Nd}_{(570 \text { м.а.) }}$ bastante negativos para as amostras de Inhandjara (-11.7 para BG e -12.6 para TAG) indicam uma fonte predominantemente crustal para os magmas, e que apesar de ter valores similares com os observados para o restante do Batólito Itu (entre -10 e -13), o عNd do Leucogranito é dos mais baixos encontrados.

Este resultado, somado a outros dados, indica prováveis processos de interação dos magmas geradores dos plutons do batólito em câmaras profundas (Alves et al. 2018, em preparação).

Considerando apenas as amostras de Inhandjara, temos que o Biotita Granito, com valores idênticos de $\varepsilon N d$ para as duas fácies, pode representar a cristalização de um mesmo magma sob diferentes condições físicas. Já a amostra do Topázio Granito, com os valores de $\varepsilon N d$ mais negativos, apresenta um desacoplamento entre os teores de $\mathrm{Sm}$ e $\mathrm{Nd}$, sendo enriquecido no primeiro e empobrecido no segundo, quando 
comparado ao Biotita Granito. O esperado para sistemas magmáticos é que os ETR apresentem comportamento similar (e.g., (Rollinson, 1994). Assim, o desacoplamento de Sm e Nd pode indicar mistura com reservatórios enriquecidos apenas em Sm ou fracionamento diferencial nos ETR durante sua evolução magmática. O Topázio Granito é crustal e raso e nenhuma fonte mais enriquecida em Sm é encontrada na região. Assim, é possível que este comportamento químico seja resultado da interação com fluidos hidrotermais ricos em F exsolvidos do magma (Peretyazhko and Savina, 2010). Esse tipo de interação com fluidos hidrotermais pode levar ao efeito tetrad nos padrões de ETR (Lottermoser, 1992), observado de forma leve nas amostras de Inhandjara ( $\mathrm{TE}_{1,3} \sim 1,1$ no Topázio Granito). Esse efeito pode estar associado a mineralizações de metais raros (e.g., Nardi et al., 2012). Isto indica um magma inicialmente rico em $\mathrm{F}$ para a geração do granito Inhandjara, que reflete na cristalização de fases magmáticas portadoras deste elemento (e.g. fluorita, topázio e micas).

\section{III.1.2 Associação com Mineralizações de Metais Raros}

De acordo com os dados obtidos neste trabalho, o Leucogranito Inhandjara representa o termo mais evoluído do Batólito Itu, e é semelhante petrologicamente a granitos especializados em metais raros descritos na literatura (Sawka et al., 1990; Haapala, 1997; Audétat et al., 2000; Lenharo et al., 2003; Haapala and Lukkari, 2005; Bettencourt et al., 2005; Lamarão et al., 2012).

Leite e Zanardo (1994) já haviam indicado o caráter evoluído do leucogranito que estudaram e, assim como Saldanha (1946), relacionam a mineralização de Inhandjara diretamente com a evolução do granito.

A associação entre granitos altamente diferenciados e mineralizações de metais raros é comumente descrita na literatura (Lehmann, 1990). Onde esses granitos evoluídos hospedam grande parte das ocorrências de Sn e W (Lenharo et al., 2002; Haapala, 1995; Botelho and Moura, 1998; Moura et al., 2014; Lamarão et al., 2012).

Processos hidrotermais, como albitização e greisenização, também estão intimamente associados a estes depósitos de minerais raros (Haapala, 1997).

O Leucogranito Inhandjara apresenta albitização, greisenização e intima relação com mineralizações de metais raros. Columbita(-tantalita) e Y-fluorita ocorrem como fases magmáticas; enquanto minerais de ETR (bastnasita), substituem cristais de mica e fluorita, e principalmente os sulfetos (pirita, esfalerita, galena, calcopirita e molibdenita) representam fases hidrotermais. Estes últimos ocorrem disseminados nos 
greisens ou como aglomerados lenticulares nos veios mais grossos de muscovita com Li e clorita presentes no Topázio Granito. Molibdenita e galena também ocorrem em bolsões pegmatíticos associados ao leucogranito.

Wolframita e cassiterita, minerais de minério presentes em veios de topázio e quartzo nos gnaisses encaixantes, não foram observadas no Leucogranito Inhandjara, mesmo quando greisenizado. Estas fases ocorrem apenas quando o topázio é presente nos veios hidrotermais, alcançando os maiores teores nos veios de topazito.

A ausência de mineralizações de Sn e W internamente ao Leucogranito Inhandjara e seus endogreisens (greisen I) pode ser explicada de duas formas: pela ausência destes metais na fonte do magma; ou estavam presentes no magma, mas foram remobilizados pela fase fluida exsolvida e disseminadas pelo sistema.

Lehmann (1982) demonstrou que não há necessidade de uma fonte enriquecida em Sn para formar depósitos, sendo a diferenciação magmática e as condições físicoquímicas na crosta rasa (especialmente fugacidade de oxigênio) os principais fatores que controlam a mineralização.

No entanto, Romer and Kroner (2016) e Wolf et al. (2018) indicam que a existência de uma fonte enriquecida em Sn é fator importante para a formação de depósitos de metais raros, fato corroborado pelo maior número de depósitos jovens (Fanerozóicos) em relação a terrenos pré-cambrianos. Porém, este resultado pode ser consequência do intenso retrabalhamento de terrenos antigos.

Breiter et al. (2017) reconhece que existe certa dependência de fontes enriquecidas em metais para formar depósitos, mas define que processos locais de concentração magmática e concentração em estruturas preferenciais são de grande importância para mineralizações de Sn-W. Sendo estas especialmente dependentes da fase fluida, que tende a concentrar esses metais. Já a ocorrência de $\mathrm{Nb}$ e Ta está diretamente ligada com processos magmáticos, sendo o caráter mineralizante herdado deste estágio e concentrado pela diferenciação.

Como existem depósitos de metais raros na região de Inhandjara, a falta de mineralizações de W-Sn nos leucogranitos deve estar relacionada com a remobilização destes metais por processos hidrotermais tardios e não à falta dos metais no sistema magmático. Onde o caráter altamente redutor no sistema granítico (presença de diversos sulfetos no greisen I) manteve alta a solubilidade de W e Sn (Linnen et al., 1995) e impossibilitou a precipitação de wolframita e cassiterita. 
Estudando a mineralização na Mina de Inhandjara, Saldanha (1946) constatou que o enriquecimento em topázio se correlaciona com o aumento da proporção de wolframita e cassiterita, sendo oposta à ocorrência de quartzo, e atinge ausência completa dos metais nas porções silicificadas. Os dados obtidos neste trabalho corroboram esta interpretação, onde muitos dos veios encontrados são silicosos e estéreis, enquanto os veios mineralizados apresentam topázio. Isto indica que a presença de $\mathrm{F}$ na fase fluida é de extrema importância para gerar depósitos de Sn-W, pois estes devem se ligar formando complexos fluoretados que transportam os metais.

Assim, os metais possivelmente foram carregados para fora do sistema magmático remobilizados pela fase fluida rica em $\mathrm{F}$ exsolvida do magma e a precipitação dos metais só foi possível nas rochas encaixantes, possivelmente por armadilhas físicoquímicas, como diminuição da temperatura, oxidação pela reação com a mineralogia do gnaisse e mistura com fluidos externos não magmáticos (Hulsbosch et al., 2016). Este último processo foi definido por Audétat et al. (2008) como o principal mecanismo para a precipitação das fases de Sn-W. Esses autores demonstraram que mineralizações de Sn e W estão relacionadas com granitos evoluídos e especializados, porém a deposição dos metais necessita de interação com fluidos externos (possivelmente meteóricos) para ocorrer. Isto poderia explicar a presença dos minérios apenas nas rochas encaixantes, em porções distais dos granitos, onde os fluidos já perderam parte do calor inicial e possuem maior chance de mistura com fluidos nãomagmáticos. 


\section{III.1.3 Evolução Magmato-Hidrotermal do Sistema}

O modelo proposto para a formação do Leucogranito Inhandjara é o seguinte (Figura 66): em primeiro estágio, mais profundo, ocorreu a extração do magma de Inhandjara das câmaras relacionadas ao Batólito Itu. Este magma inicial começou a se cristalizar como o Biotita Granito (porfirítico nas bordas e inequigranular para o centro); Após considerável cristalização do Biotita Granito, o magma residual (enriquecido em elementos incompatíveis, voláteis e metais) migrou para uma região mais rasa da crosta, se cristalizou como o Topázio Granito e exsolveu os voláteis dissolvidos no magma durante este processo. A fase fluida liberada causou a brechação e o fraturamento do Topázio Granito e se dissipou pelo sistema, remobilizando grande parte do conteúdo metalífero concentrado pelo magma. Durante sua circulação estes fluidos alteraram os granitos já cristalizados (auto-metassomatismo), com intenso metassomatismo alcalino (principalmente albitização) e greisenização do Leucogranito Inhandjara. Ao migrarem para as rochas encaixantes, os fluidos magmáticos reagiram com os gnaisses (causando sua greisenização) e precipitaram os metais nos veios de quartzo-topázio.

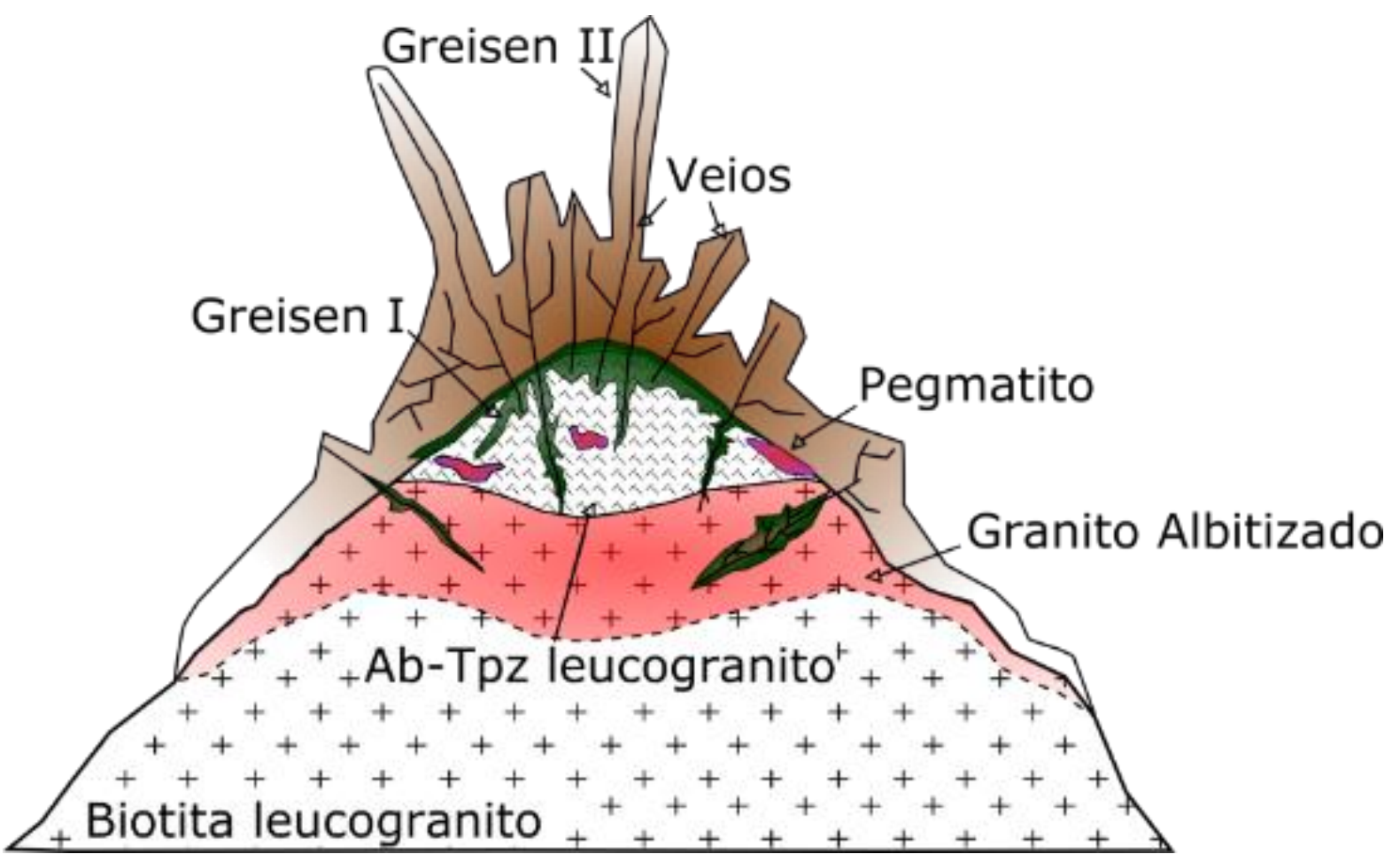

Figura 66: Modelo esquemático para o Stock Inhandjara, com os litotipos e alterações hidrotermais definidos. Conforme Lehmann (1990) e Pirajno (2013). 


\section{2 CONCLUSÕES}

O Leucogranito Inhandjara foi definido neste trabalho como um stock satélite ao Batólito Itu, com afinidades geoquímicas e geocronológicas ao Batólito e à Província Itu, mas sem vinculação direta com os plutons Itupeva e Cabreúva adjacentes, nos quais a área de estudo era incluída previamente (Pascholati, 1990; Galembeck, 1997; Janasi et al., 2009).

De acordo com os dados obtidos, o Leucogranito Inhandjara representa um magma residual altamente diferenciado e evoluído, extraído de uma câmara mais profunda do sistema que possivelmente gerou o Batólito Itu, e se colocou em sua borda.

O stock Inhandjara é Neoproterozóico, com idade de cristalização ca. 570 Ma, similar dentro do erro às idades obtidas para os Plutons adjacentes (ca. $580 \mathrm{Ma}$ ).

O Leucogranito Inhandjara é caracterizado por dois litotipos principais, o Biotita Granito (porfirítico e inequigranular) e o Topázio Granito, geoquimicamente caracterizados como granitos tipo-A reduzidos e predominantemente metaluminosos, representando o subtipo "baixo-P" de granitos com topázio (Taylor, 1992).

As características petrológicas do Leucogranito Inhandjara, como a diminuição do teor de elementos compatíveis e aumento de alguns incompatíveis, baixa proporção de fases máficas e a cristalização de minerais típicos de granitos evoluídos (e.g. zircão com elevado conteúdo de Hf, albita, micas litiníferas, topázio, fluorita e columbita), indicam que a diferenciação magmática foi um processo de extrema importância na formação do Stock de Inhandjara.

Estas características mostram que o Leucogranito Inhandjara se assemelha aos granitos especializados em metais raros (Sn-W-Nb-Ta-ETR) e portanto deve representar a fonte principal desses metais para as mineralizações presentes na região.

Assim, neste trabalho nós reforçamos a ideia de Saldanha (1946), de que a mineralização de Sn e W em Inhandjara está intimamente ligada a evolução do granito local, que foi fonte dos metais e fluidos hidrotermais, servindo de motor termal para a formação do sistema mineralizante de wolframita e cassiterita, explotadas na área da antiga Mina de Inhandjara. 


\section{CAPÍTULO IV - REFERÊNCIAS CITADAS}

Abreu, S.F., 1945, Fundamentos geográficos da mineração brasileira: Revista Brasileira de Geografia, v. 7, p. 3-137.

Van Achterbergh, E., Ryan, C.G., and Griffin, W.L., 2001, GLITTER on-line interactive data reduction for the LA-ICPMS microprobe:

Alves, A., Janasi, V. de A., Pereira, G. de S., and Araujo, F.P. Unraveling the hidden evidences of magma mixing processes via combination of in situ $\mathrm{Sr}$ isotopes and trace elements analyses on plagioclase crystals: Unpublished data, .

Alves, A., Pereira, G. de S., Janasi, V. de A., Higgins, M., Polo, L.A., Juriaans, O.S., and Ribeiro, B.V., 2015, The origin of felsic microgranitoid enclaves: Insights from plagioclase crystal size distributions and thermodynamic models: Lithos, v. 239, p. 33-44, doi: 10.1016/j.lithos.2015.09.027.

Amaral, G., and Pascholati, E.M., 1990, Aspectos Metalogenéticos da Suíte Intrusiva de Itu, in Sociedade Brasileira De Geologia ed., Anais do 36 Congresso Brasileiro de Geologia, Natal - RN, p. 12751280, http://books.google.com/books?id=nlOOAAAAIAAJ\&pgis $=1$.

Audétat, A., Günther, D., and Heinrich, C.A., 2000, Magmatic-hydrothermal evolution in a fractionating granite: A microchemical study of the Sn-W-F-mineralized mole granite (Australia): Geochimica et Cosmochimica Acta, v. 64, p. 3373-3393, doi: 10.1016/S0016-7037(00)00428-2.

Audétat, A., Pettke, T., Heinrich, C.A., and Bodnar, R.J., 2008, The Composition of MagmaticHydrothermal Fluids in Barren and Mineralized Intrusions: Economic Geology, v. 103, p. 877-908, doi: 10.2113/gsecongeo.103.5.877.

Ballouard, C., Poujol, M., Boulvais, P., Branquet, Y., Tartèse, R., and Vigneresse, J.L., 2016, Nb-Ta fractionation in peraluminous granites: A marker of the magmatic-hydrothermal transition: Geology, v. 44, p. 231-234, doi: 10.1130/G37475.1.

Berni, G. V., Wagner, T., Fusswinkel, T., and Wenzel, T., 2017, Magmatic-hydrothermal evolution of the Kymi topaz granite stock, SE Finland: Mineral chemistry evidence for episodic fluid exsolution: Lithos, v. 292-293, p. 401-423, doi: 10.1016/j.lithos.2017.09.015.

Bettencourt, J.S., Leite, W.B., Goraieb, C.L., Sparrenberger, I., Bello, R.M.S., and Payolla, B.L., 2005, Sn-polymetallic greisen-type deposits associated with late-stage rapakivi granites, Brazil: Fluid inclusion and stable isotope characteristics: Lithos, v. 80, p. 363-386, doi: 10.1016/j.lithos.2004.03.060.

Botelho, N.F., and Moura, M.A., 1998, Granite-ore deposit relationships in Central Brazil: Journal of South American Earth Sciences, v. 11, p. 427-438, doi: 10.1016/S0895-9811(98)00026-1.

El Bouselly, A.M., and El Sokkary, A.A., 1975, The Relation Between Rb, Ba and Sr in Granitic Rocks: Chemical Geology, v. 16, p. 207-219, doi: 10.1016/0009-2541(75)90029-7.

Bowden, P., 1981, Uranium in the Niger-Nigeria Younger Granite Province: Mineralogical Magazine, v. 44, p. 379-389, doi: 10.1180/minmag.1981.044.336.03.

Breiter, K., Durišová, J., Hrstka, T., Korbelová, Z., Hložková Vaňková, M., Vašinová Galiová, M., Kanický, V., Rambousek, P., Knésl, I., Dobeš, P., and Dosbaba, M., 2017, Assessment of magmatic vs. metasomatic processes in rare-metal granites: A case study of the Cínovec/Zinnwald Sn-W-Li deposit, Central Europe: Lithos, v. 292-293, p. 198-217, doi: 10.1016/j.lithos.2017.08.015.

Breiter, K., Lamarão, C.N., Borges, R.M.K., and Dall'Agnol, R., 2014, Chemical characteristics of zircon from A-type granites and comparison to zircon of S-type granites: Lithos, v. 192-195, p. 208-225, doi: 10.1016/j.lithos.2014.02.004.

Breiter, K., Müller, A., Shail, R., and Simons, B., 2016, Composition of zircons from the Cornubian Batholith of SW England and comparison with zircons from other European Variscan rare-metal granites: Mineralogical Magazine, v. 80, p. 1273-1289, doi: 10.1180/minmag.2016.080.071.

Breiter, K., and Škoda, R., 2017, Zircon and whole-rock Zr/Hf ratios as markers of the evolution of granitic magmas: Examples from the Teplice caldera (Czech Republic/Germany): Mineralogy and Petrology, v. 111, p. 435-457, doi: 10.1007/s00710-017-0509-z.

Campos Neto, M.D.C., Basei, M.A.S., Vlach, S.R.F., Caby, R., Szabó, G.A.J., and Vasconcelos, P.M., 2004, Migração de Orógenos e Superposição de Orogêneses: Um Esboço da Colagem Brasiliana no Sul do Cráton do São Francisco, SE - Brasil: Geologia USP - Serie Cientifica, v. 4, p. 13-40, doi: 10.5327/S1519-874X2004000100002.

Campos Neto, M.D.C., and Caby, R., 2000, Terrane accretion and upward extrusion of high-pressure granulites in the neoproterozoic nappes of Southeast Brazil: Petrologic and structural constraints: Tectonics, v. 19, p. 669-687, doi: 10.1029/1999TC900065.

Candela, P.A., 1997, A review of shallow, ore-related granites: Textures, volatiles, and ore metals: 
Journal of Petrology, v. 38, p. 1619-1633, doi: 10.1093/petroj/38.12.1619.

Cathelineau, M., 1986, The hydrothermal alkali metasomatism effects on granitic rocks: Quartz dissolution and related subsolidus changes: Journal of Petrology, v. 27, p. 945-965, doi: 10.1093/petrology/27.4.945.

Costi, H.T., Dall'Agnol, R., Borges, R.M.K., Minuzzi, O.R.R., and Teixeira, J.T., 2002, Tin-Bearing Sodic Episyenites Associated with the Proterozoic, A-Type Água Boa Granite, Pitinga Mine, Amazonian Craton, Brazil: Gondwana Research, v. 5, p. 435-451, doi: 10.1016/S1342-937X(05)70734-6.

Dall'Agnol, R., and de Oliveira, D.C., 2007, Oxidized, magnetite-series, rapakivi-type granites of Carajás, Brazil: Implications for classification and petrogenesis of A-type granites: Lithos, v. 93, p. 215233, doi: 10.1016/j.lithos.2006.03.065.

Deer, W.A., Howie, R.A., and Zussman, J., 1992, An Introduction to the Rock-forming Minerals: Hong Kong, Longman Scientific \& Technical, 558 p.

Derre, C., Lecolle, M., Roger, G., and Tavares de Freitas Carvalho, J., 1986, Tectonics, magmatism, hydrothermalism and sets of flat joints locally filled by SnW aplite-pegmatite and quartz veins; southeastern border of the Serra de Estrela granitic massif (Beira Baixa, Portugal): Ore Geology Reviews, v. 1, p. 43-56, doi: 10.1016/0169-1368(86)90004-1.

Eby, G.N., 1992, Chemical subdivision of the A-type granitoids:Petrogenetic and tectonic implications: Geology, v. 20, p. 641, doi: 10.1130/0091-7613(1992)020<0641:CSOTAT>2.3.CO;2.

Exley, C.S., 1958, Magmatic Differentiation and Alteration in the St. Austell Granite: Quarterly Journal of the Geological Society, v. 114, p. 197-230, doi: 10.1144/gsjgs.114.1.0197.

Ferreira, F.J.F., 1991, Aerogamaespectrometria e Aeromagnetometria de um Trato Ocidental do PréCambriano Paulista: Universidade de São Paulo, $150 \mathrm{p}$.

Frost, B.R., Barnes, C.G., Collins, W.J., Arculus, R.J., Ellis, D.J., and Frost, C.D., 2001, A Geochemical Classification for Granitic Rocks: Journal of Petrology, v. 42, p. 2033-2048, doi: 10.1093/petrology/42.11.2033.

Galembeck, T.M.B., 1997, O Complexo Múltiplo, Centrado e Plurisserial Itu - SP: Universidade Estadual Paulista, $374 \mathrm{p}$.

Gill, R., 2010, Igneous Rocks and Processes. A practical guide:, doi: 10.1017/CBO9781107415324.004.

Gu, L.X., Zhang, Z.Z., Wu, C.Z., Gou, X.Q., Liao, J.J., and Yang, H., 2011, A topaz- and amazonitebearing leucogranite pluton in eastern Xinjiang, NW China and its zoning: Journal of Asian Earth Sciences, v. 42, p. 885-902, doi: 10.1016/j.jseaes.2010.12.010.

Haapala, I., 1997, Magmatic and postmagmatic processes in tin-mineralized granites: Topaz-bearing leucogranite in the Eurajoki rapakivi granite stock, Finland: Journal of Petrology, v. 38, p. 16451659, doi: 10.1093/petroj/38.12.1645.

Haapala, I., 1995, Metallogeny of the Rapakivi granites: Mineralogy and Petrology, v. 54, p. 149-160, doi: $10.1007 / B F 01162858$.

Haapala, I., Frindt, S., and Kandara, J., 2007, Cretaceous Gross Spitzkoppe and Klein Spitzkoppe stocks in Namibia: Topaz-bearing A-type granites related to continental rifting and mantle plume: Lithos, v. 97, p. 174-192, doi: 10.1016/j.lithos.2006.12.002.

Haapala, I., and Lukkari, S., 2005, Petrological and geochemical evolution of the Kymi stock, a topaz granite cupola within the Wiborg rapakivi batholith, Finland: Lithos, v. 80, p. 347-362, doi: 10.1016/j.lithos.2004.05.012.

Hannah, J.L., and Stein, H.J., 1990, Magmatic and hydrothermal processes in ore-bearing systems: Special Paper of the Geological Society of America, v. 246, p. 1-10, doi: 10.1130/SPE246-p1.

Heilbron, M., Valeriano, C.M., Tassinari, C.C.G., Almeida, J., Tupinambá, M., Siga, O., and Trouw, R.A.J., 2008, Correlation of Neoproterozoic terranes between the Ribeira Belt, SE Brazil and its African counterpart: comparative tectonic evolution and open questions: Geological Society, London, Special Publications, v. 294, p. 211-237, doi: 10.1144/SP294.12.

Hey, M.H., 1954, A New Review of the Chlorites: Mineralogical Magazine, v. 30, p. 277-292, doi: 10.1180/minmag.1954.030.224.01.

Hulsbosch, N., Boiron, M.C., Dewaele, S., and Muchez, P., 2016, Fluid fractionation of tungsten during granite-pegmatite differentiation and the metal source of peribatholitic $W$ quartz veins: Evidence from the Karagwe-Ankole Belt (Rwanda): Geochimica et Cosmochimica Acta, v. 175, p. 299-318, doi: 10.1016/j.gca.2015.11.020.

Irber, W., 1999, The lanthanide tetrad effect and its correlation with K / Rb , Eu / Eu *, Sr / Eu , Y / Ho , and $\mathrm{Zr} / \mathrm{Hf}$ of evolving peraluminous granite suites: Geochimica et Cosmochimica Acta, v. 63, p. 489-508.

Ishihara, S., and Murakami, H., 2006, Fractionated ilmenite-series granites in southwest Japan: Source magma for REE-Sn-W mineralizations: Resource Geology, v. 56, p. 245-256, doi: 10.1111/j.17513928.2006.tb00282.x. 
Janasi, V.D.A., Vlach, S.R.F., Campos Neto, M.D.C., and Ulbrich, H.H.G.J., 2009, Associated A-type subalkaline and high-K calc-alkaline granites in the Itu Granite Province, southeastern Brazil: Petrological and tectonic significance: Canadian Mineralogist, v. 47, p. 1505-1526, doi: 10.3749/canmin.47.6.1505.

Kempe, U., Gruner, T., Renno, A.D., Wolf, and René, M., 2004, Discussion on Wang et al. (2000) "Chemistry of Hf-rich zircons from the Laoshan I- and A-type granites, Eastern China", Mineralogical Magazine, 64, 867 - 877: Mineralogical Magazine, v. 68, p. 669-675, doi: $10.1180 / 0026461046840211$.

Lamarão, C.N., Cordovil Pinho, S.C., de Paiva, A.L., and Galarza, M.A., 2012, Mineralogy and geochemistry of the Paleoproterozoic, tin-mineralized Bom Jardim granite of the Velho Guilherme Suite, Eastern Amazonian craton: Journal of South American Earth Sciences, v. 38, p. 159-173, doi: 10.1016/j.jsames.2012.05.004.

Lamarão, C.N., Marques, G.T., de Oliveira, D.C., Costi, H.T., Borges, R.M.K., and Dall'Agnol, R., 2018, Morphology and composition of zircons in rare metal granites from Brazilian tin provinces: Journal of South American Earth Sciences, v. 84, p. 1-15, doi: 10.1016/j.jsames.2018.03.003.

Lehmann, B., 1990, Lecture Notes in Earth Sciences. Metallogeny of Tin: Springer-Verlag, 206 p.

Lehmann, B., 1982, Metallogeny of tin: magmatic differentiation versus geochemical heritage.: Economic Geology, v. 77, p. 50-59, doi: 10.2113/gsecongeo.77.1.50.

Leite, W.B., and Zanardo, A., 1994, O Albita Granito de Inhandjara, Complexo Granitoide Itu (SP), in Anais do 38 Congresso Brasileiro de Geologia, Balneário Camboriú, SC, Sociedade Brasileira de Geologia, p. 109.

Lenharo, S.L.R., Moura, M.A., and Botelho, N.F., 2002, Petrogenetic and mineralization processes in Paleo- to Mesoproterozoic rapakivi granites: Examples from Pitinga and Goiás, Brazil: Precambrian Research, v. 119, p. 277-299, doi: 10.1016/S0301-9268(02)00126-2.

Lenharo, S.L.R., Pollard, P.J., and Born, H., 2003, Petrology and textural evolution of granites associated with tin and rare-metals mineralization at the Pitinga mine, Amazonas, Brazil: Lithos, v. 66, p. 3761, doi: 10.1016/S0024-4937(02)00201-3.

Linnen, R.L., Pichavant, M., Holtz, F., and Burgess, S., 1995, The effect of fo2 on the solubility, diffusion, and speciation of tin in haplogranitic melt at $850^{\circ} \mathrm{C}$ and 2 kbar: Geochimica et Cosmochimica Acta, v. 59, p. 1579-1588, doi: 10.1016/0016-7037(95)00064-7.

Loios, V.A.P., 2009, MÉTODOS DE PREPARAÇÃO E SEPARAÇÃO DE MINERAIS NO CPGeo-IGc-USP, in Boletim de Resumos Expandidos Simpósio 45 Anos de Geocronologia no Brasil, v. 10, p. 107-109.

Lottermoser, B.G., 1992, Rare earth elements and hydrothermal ore formation processes: Ore Geology Reviews, v. 7, p. 25-41, doi: 10.1016/0169-1368(92)90017-F.

Lukkari, S., Thomas, R., and Haapala, I., 2009, Crystallization of the kymi topaz granite stock within the wiborg rapakivi granite batholith, Finland: Evidence from melt inclusions: Canadian Mineralogist, v. 47, p. 1359-1374, doi: 10.3749/canmin.47.6.1359.

Le Maitre, R.W., Streckeisen, A., Zanettin, B., Le Bas, M.J., Bonin, B., Bateman, P., Bellieni, G., Dudek, A., Efremova, S., Keller, J., Lameyre, J., Sabine, P.A., Schmid, R., SØrensen, H., et al., 2002, Igneous Rocks. A Classification and Glossary of Terms: v. 44, 447-678 p., doi: 10.1017/CBO9781107415324.004.

Manning, D.A.C., 1986, Contrasting styles of Sn-W mineralisation in peninsular Thailand and SW England: Mineralium Deposita, v. 21, p. 44-52.

Manning, D. a. C., 1981, The effect of fluorine on liquidus phase relationships in the system Q-Ab-Or with excess water at 1 kb.: Contrib. Mineral. Petrol., v. 76, p. 205-215.

Masuda, A., Kawakami, O., Dohmoto, Y., and Takenaka, T., 1987, Lanthanide tetrad effects in nature: Two mutually opposite types, W and M: Geochemical Journal, v. 21, p. 119-124, doi: 10.2343/geochemj.21.119.

Mori, P.E., Correia, C.T., Reeves, S., and Haukka, M., 1999, Development of a fused glass disc XRF facility and comparison with the pressed powder pellet technique at Instituto de Geociencias, Sao Paulo University, Brazil: Revista Brasileira de Geociências, v. 29, p. 441-446.

Moura, M.A., and Botelho, N.F., 2000, The Topaz-Albite granite and related rocks from the Sn-In mineralized zone of Mangabeira Granitic Massif (GO, Brasil): Revista Brasileira de Geociências, v. 30 , p. $270-273$.

Moura, M.A., Botelho, N.F., and Carvalho de Mendonça, F., 2007, The indium-rich sulfides and rare arsenates of the Sn-In-mineralized Mangabeira a-type granite, central Brazil: Canadian Mineralogist, v. 45, p. 485-496, doi: 10.2113/gscanmin.45.3.485.

Moura, M.A., Botelho, N.F., Olivo, G.R., Kyser, K., and Pontes, R.M., 2014, Genesis of the Proterozoic Mangabeira tin-indium mineralization, Central Brazil: Evidence from geology, petrology, fluid inclusion and stable isotope data: Ore Geology Reviews, v. 60, p. 36-49, doi: 
10.1016/j.oregeorev.2013.12.010.

Nardi, L.V.S., Formoso, M.L.L., Jarvis, K., Oliveira, L., Bastos Neto, A.C., and Fontana, E., 2012, REE, Y, $\mathrm{Nb}, \mathrm{U}$, and Th contents and tetrad effect in zircon from a magmatic-hydrothermal F-rich system of Sn-rare metal-cryolite mineralized granites from the Pitinga Mine, Amazonia, Brazil: Journal of South American Earth Sciences, v. 33, p. 34-42, doi: 10.1016/j.jsames.2011.07.004.

Navarro, M.S., Andrade, S., Ulbrich, H.H.G.J., Gomes, C.B., and Girardi, V.A.V., 2008, The direct determination of rare earth elements in basaltic and related rocks using ICP-MS: Testing the efficiency of microwave oven sample decomposition procedures: Geostandards and Geoanalytical Research, v. 32, p. 167-180, doi: 10.1111/j.1751-908X.2008.00840.x.

Neves, B.B.D.B., Fuck, R.A., and Pimentel, M.M., 2014, The Brasiliano collage in South America: a review: Brazilian Journal of Geology, v. 44, p. 493-518, doi: 10.5327/Z2317-4889201400030010.

Pascholati, E.M., 1990, Caracterização Geofísica da Suíte Intrusiva de Itu: Universidade de São Paulo, $135 \mathrm{p}$.

Pascholati, E.M., Amaral, G., Hiodo, F.Y., Okuno, E., Yoshimura, E.M., and Yukihara, E.G., 1997, SURVEY OF ENVIRONMENTAL GAMMA RADIATION AROUND ITU (SP), in XI ENFIR/IV ENAN Joint Nuclear Conferences. Annals, Poços de Caldas (MG).

Peccerillo, A., and Taylor, S.R., 1976, Geochemistry of eocene calc-alkaline volcanic rocks from the Kastamonu area, Northern Turkey: Contributions to Mineralogy and Petrology, v. 58, p. 63-81, doi: $10.1007 / \mathrm{BF} 00384745$.

Pereira, G. de S., 2013, O significado dos enclaves microgranulares félsicos na evolução de magmas graníticos: petrologia dos enclaves do Pluton Salto, Batólito Itu, SP: Universidade de São Paulo, 109 p., doi: 10.11606/D.44.2013.tde-13112013-151042.

Pereira, R.M., Neumann, R., Ávila, C.A., and Castro, C., 2008, Determinação da gênese da cassiterita com base na sua composição química e inclusões minerais: ocorrências no sul e sudeste brasileiro: Revista Brasileira de Geociências, v. 38, p. 246-252.

Peretyazhko, I.S., and Savina, E. a., 2010, Tetrad effects in the rare earth element patterns of granitoid rocks as an indicator of fluoride-silicate liquid immiscibility in magmatic systems: Petrology, v. 18, p. 514-543, doi: 10.1134/S086959111005005X.

Perrotta, M.M., Salvador, E.D., Lopes, R.., D'Agostino, L.Z., Peruffo, N., Gomes, S.D., Sachs, L.L.B., Meira, V.T., Garcia, M. da G.M., and Lacerda Filho, J.V., 2005, Mapa geológico do estado de SP. Escala 1:750.000: , p. 1.

Petronilho, L.., 2009, Método Sm-Nd no CPGeo_IGc-USP: Procedimentos Analíticos Atualmente em Rotina, in Boletim de Resumos Expandidos Simpósio 45 Anos de Geocronologia no Brasil, v. 8, p. $116-118$.

Pirajno, F., 2013, Effects of Metasomatism on Mineral Systems and Their Host Rocks: Alkali Metasomatism, Skarns, Greisens, Tourmalinites, Rodingites, Black-Wall Alteration and Listvenites, in Harlov, D.E. and Austrheim, H. eds., Metasomatism and the Chemical Transformation of Rock, Berlin Heidelberg, Springer, p. 203-251.

Pitfield, P.E.J., Teoh, L.H., and Cobbing, E.J., 1990, Textural variation and tin mineralization in granites from the main range province of the Southeast Asian Tin Belt: Geological Journal, v. 25, p. 419429, doi: $10.1002 / g j .3350250324$.

Pollard, P.J., 1995, A special issue devoted to the geology of rare metal deposits: an introduction and overview: Economic Geology, v. 90, p. 489-494, doi: 10.2113/gsecongeo.90.3.489.

Pupin, J.P., 1980, Zircon and granite petrology: Contributions to Mineralogy and Petrology, v. 73, p. 207-220, doi: 10.1007/BF00381441.

Putnis, A., Hinrichs, R., Putnis, C. V., Golla-Schindler, U., and Collins, L.G., 2007, Hematite in porous red-clouded feldspars: Evidence of large-scale crustal fluid-rock interaction: Lithos, v. 95, p. 1018, doi: $10.1016 /$ j.lithos.2006.07.004.

Raimbault, L., Cuney, M., Azencott, C., Duthou, J.L., and Joron, J.L., 1995, Geochemical evidence for a multistage magmatic genesis of Ta-Sn-Li mineralization in the granite at Beauvoir, French Massif Central: Economic Geology, v. 90, p. 548-576, doi: 10.2113/gsecongeo.90.3.548.

Ribeiro, E. dos S.C. 1994, ANÁLISE VARIOGRÁFICA E PROCESSAMENTO DIGITAL DE IMAGENS APLICADOS À AREA DA SUÍTE INTRUSIVA DE ITU (SP): Universidade Estadual de Campinas UNICAMP, $136 \mathrm{p}$.

Ribeiro, E. dos S.C., Pascholati, E.M., and Amaral, G., 1994, Mineralização sulfetada na parte norte do granito Itupeva, Suíte Intrusiva Itu, SP.pdf, in Anais do 38 Congresso Brasileiro de Geologia, Balneário Camboriú, SC, Sociedade Brasileira de Geologia, p. 174-175.

Rollinson, H., 1994, Using Geochemical Data: Evaluation, Presentation, Interpretation: 375 p., doi: 10.1180/minmag.1994.058.392.25.

Romer, R.L., and Kroner, U., 2016, Phanerozoic tin and tungsten mineralization-Tectonic controls on 
the distribution of enriched protoliths and heat sources for crustal melting: Gondwana Research, v. 31, p. 60-95, doi: 10.1016/j.gr.2015.11.002.

Rubin, J.N., Henry, C.D., and Price, J.G., 1989, Hydrothermal zircons and zircon overgrowths, Sierra Blanca Peaks, Texas: American Mineralogist, v. 74, p. 865-869.

Saad, A.R., Etchebehere, M.L. de C., Pressinotti, P.C., Silva, R.B. da, and Campanha, V.A., 1996, Potencialidade Mineral do Estado de São PAulo: Revista Universidade Guarulhos - Série Geociências, v. 1, p. 5-17.

Saldanha, R., 1946, O Estudo da Jazida de Wolframita de Inhandjara: Boletim da Faculdade de Filosofia, Ciências e Letras da Universidade de São Paulo, v. LX, p. 5-93.

Sato, K., Tassinari, C.C.G., Basei, M.A.S., Siga, O., Onoe, A.T., and De Souza, M.D., 2014, Sensitive High Resolution Ion Microprobe (SHRIMP IIe/MC) of the Institute of Geosciences of the University of São Paulo, Brazil: Analytical method and first results: Geologia USP - Serie Cientifica, v. 14, p. 3-18, doi: 10.5327/Z1519-874X201400030001.

Sawka, W.N., Kistler, R.W., and Chappell, B.W., 1990, Geochemistry of highly fractionated I- and S-type granites from the tin-tungsten province of western Tasmania: GSA Special Paper, v. 246.

Souza, S.., 2009, Métodos Radiométricos Rb-Sr e Sm-Nd no CPGeo-IGc-USP, in Boletim de Resumos Expandidos Simpósio 45 Anos de Geocronologia no Brasil, p. 137-139.

Štemprok, M., Pivec, E., and Langrová, A., 2005, The petrogenesis of a wolframite-bearing greisen in the Vykmanov granite stock, Western Krušné hory pluton (Czech Republic): Bulletin of Geosciences, v. 80, p. 163-184.

Suikkanen, E., and Rämö, O.T., 2017, Metasomatic alkali-feldspar syenites (episyenites) of the Proterozoic Suomenniemi rapakivi granite complex, southeastern Finland: Lithos, v. 294-295, p. 1-19, doi: https://doi.org/10.1016/j.lithos.2017.09.017.

Suwimonprecha, P., Cerny, P., and Friedrich, G., 1995, Rare Metal Mineralization Related to Granites and Pegmatites, Phuket, Thailand: Economic Geology, v. 90, p. 603-615.

Tassinari, C.C.G., 1988, As idades das rochas e dos eventos metamórficos da porção sudeste do estado de são paulo e sua evolução crustal.

Taylor, R.P., 1992, Petrological and geochemical characteristics of the Pleasant Ridge zinnwaldite-topaz granite, southern New Brunswick, and comparisons with other topaz-bearing felsic rocks: Canadian Mineralogist, v. 30, p. 895-921.

Tindle, A.G., and Webb, P.C., 1990, Estimation of lithium contents in trioctahedral micas using microprobe data: application to micas from granitic rocks: European Journal of Mineralogy, v. 2, p. 595-610, doi: 10.1127/ejm/2/5/0595.

Tischendorf, G., Förster, H.J., Gottesmann, B., and Rieder, M., 2007, True and brittle micas: composition and solid-solution series: Mineralogical Magazine, v. 71, p. 285-320, doi: 10.1180/minmag.2007.071.3.285.

Tischendorf, G., Gottesmann, B., Förster, H.J., and Trumbull, R.B., 1997, On Li-Bearing Micas: Estimating $\mathrm{Li}$ from Electron Microprobe Analyses and an Improved Diagram for Graphical Representation: Mineralogical Magazine, v. 61, p. 809-834, doi: 10.1180/minmag.1997.061.409.05.

Trouw, R.A.J., Peternel, R., Ribeiro, A., Heilbron, M., Vinagre, R., Duffles, P., Trouw, C.C., Fontainha, M., and Kussama, H.H., 2013, A new interpretation for the interference zone between the southern Brasília belt and the central Ribeira belt, SE Brazil: Journal of South American Earth Sciences, v. 48, p. 43-57, doi: 10.1016/j.jsames.2013.07.012.

Vlach, S.R.F., Janasi, V. de A., and Vasconcellos, A.C.B.C., 1991, O Magmatismo Granitoide Tardi- a pós-orogênico de Idade Brasiliana no Estado de São Paulo: Boletim IG-USP, Publicacao Especial, v. 9, p. 99-101, doi: 10.1017/CBO9781107415324.004.

Wang, R.C., Zhao, G.T., Chen, X.M., Xu, S.J., and Wang, D.Z., 2000, Chemistry of Hf-rich zircons from the Laoshan I- and A-type granites, Eastern China: Mineralogical Magazine, v. 64, p. 867-877, doi: Doi 10.1180/002646100549850.

Wernick, E., 2000, Arc-Related Rapakivi Granites From the Ribeira Fold Belt, Se Brazil .*: Revista Brasileira de Geociências, v. 30, p. 20-24.

Wernick, E., 1992, Rapakivi granites related to the post-collision relaxing stage: the Itu province (Late Precambrian) of SE/S Brazil, in International geological congress,.

Whalen, J.B., Currie, K.L., and Chappell, B.W., 1987, A-type granites: geochemical characteristics, discrimination and petrogenesis: Contributions to Mineralogy and Petrology, v. 95, p. 407-419, doi: $10.1007 / B F 00402202$.

White, M.G., 1974, Tungsten Resourcers of Brazil.:

Whitney, D.L., and Evans, B.W., 2010, Abbreviations for names of rock-forming minerals: American Mineralogist, v. 95, p. 185-187, doi: 10.2138/am.2010.3371. 
Wiedenbeck, M., Allé, P., Corfu, F., Griffin, W.L., Meier, M., Oberli, F., Von Quadt, A., Roddick, J.C., and Spiegel, W., 1995, Three natural zircon standards for U-Th-Pb, Lu-Hf, trace element and REE analyses: Geostandards Newsletter, v. 19, p. 1-23.

Wolf, M., Romer, R.L., Franz, L., and López-Moro, F.J., 2018, Tin in granitic melts: The role of melting temperature and protolith composition: Lithos, v. 310-311, p. 20-30, doi: 10.1016/j.lithos.2018.04.004.

Wu, F.Y., Liu, X.C., Ji, W.Q., Wang, J.M., and Yang, L., 2017, Highly fractionated granites: Recognition and research: Science China Earth Sciences, v. 60, p. 1201-1219, doi: 10.1007/s11430-016-51391. 



\begin{tabular}{|c|c|c|c|}
\hline IPV-03 & IPV-02 & IPV-01 & 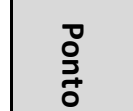 \\
\hline 291364 & 290970 & 289969 & $\underset{\substack{\frac{x}{N} \\
\frac{\omega}{幺}}}{x}$ \\
\hline \multirow[t]{2}{*}{7440408} & 7439967 & 7438887 & 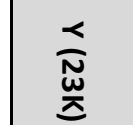 \\
\hline & & & N \\
\hline $\begin{array}{c}\text { Saprólito do paragnaisse } \\
\text { bandado, com diversos } \\
\text { veios centimátricos de } \\
\text { Qtz leitoso. }\end{array}$ & $\begin{array}{l}\text { Saprólito de gnaisse bandado } \\
\text { (micaceo e quartzo-feldspatico) } \\
\text { de granulacao fina-media. } \\
\text { Textura milonitica com fol. } \\
\text { anastomosada e minerais } \\
\text { estirados. Localmente com } \\
\text { veios de Qtz e bolsões } \\
\text { pegmatíticos ao redor. }\end{array}$ & $\begin{array}{l}\text { Saprólito Granito(?), aparent. } \\
\text { maciço, hololeucocratico } \\
\text { esbranquiçado, inequi. fino- } \\
\text { medio. Aspecto brechado } \\
\text { localmente e com veios de Qtz } \\
\text { fino cinzento ressaltados pelo } \\
\text { intemperismo }\end{array}$ & 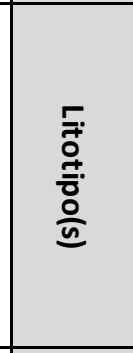 \\
\hline \multirow[t]{10}{*}{$\begin{array}{l}\text { Afloramento em chão de } \\
\text { estrada próxima à Mina } \\
\text { Abandonada }\end{array}$} & $\begin{array}{l}\text { Afloramento em barranco ao } \\
\text { lado da Estrada da Mina }\end{array}$ & $\begin{array}{l}\text { Afloramento em barranco ao } \\
\text { lado da Estrada da Mina }\end{array}$ & 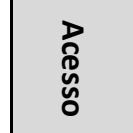 \\
\hline & & $\begin{array}{l}\text { Veio silicificado em saprólito } \\
\text { Qtz-Feldsp. }\end{array}$ & $\frac{\delta}{\frac{\rho}{\alpha}}$ \\
\hline & & & 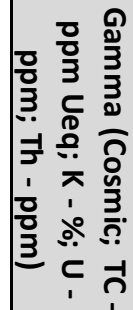 \\
\hline & & & 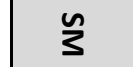 \\
\hline & Fol.: 145/30; 145/60 & & $\begin{array}{l}3 \\
\frac{1}{0} \\
\frac{0}{2} \\
\frac{0}{2}\end{array}$ \\
\hline & & & 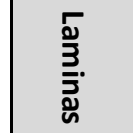 \\
\hline & & & 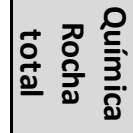 \\
\hline & & & 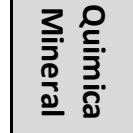 \\
\hline & & & $\begin{array}{l}\overline{\bar{a}} \\
\stackrel{+}{+} \\
\frac{0}{0} \\
\frac{0}{\bar{v}}\end{array}$ \\
\hline & & & 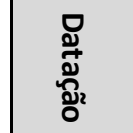 \\
\hline
\end{tabular}




\begin{tabular}{|c|c|c|c|}
\hline IPV-06 & IPV-05 & IPV-04 & 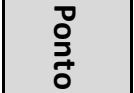 \\
\hline 287904 & 291256 & 291265 & $\underset{\frac{x}{N}}{\frac{x}{X}}$ \\
\hline \multirow[t]{2}{*}{7439079} & 7440318 & 7440279 & $\underset{\substack{\underline{w} \\
\frac{\omega}{幺}}}{\swarrow}$ \\
\hline & & & $\mathbf{N}$ \\
\hline $\begin{array}{l}\text { Granito hololeucocratico levemente } \\
\text { foliado (micas e matriz orientadas), } \\
\text { inequigranular medio-grosso e textura } \\
\text { xenomorfica. Presença de veios de Qtz } \\
\text { centimétricos paralelos à foliação, } \\
\text { localmente a encaixante ocorre } \\
\text { silicificada ao redor dos veios. }\end{array}$ & $\begin{array}{l}\text { Gnaisse bandado de granulacao } \\
\text { fina-media. Presença de veios } \\
\text { submétricos de Qtz com } \\
\text { mineralização de sulfetos e } \\
\text { outros minerais. Grande } \\
\text { concentração de muscovita nas } \\
\text { paredes dos veios (greisen?) }\end{array}$ & $\begin{array}{l}\text { Gnaisse bandado } \\
\text { (micaceo e quartzo- } \\
\text { feldspatico) de } \\
\text { granulacao fina-media. } \\
\text { Bastante intemperizado. }\end{array}$ & 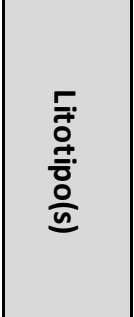 \\
\hline $\begin{array}{l}\text { Corte de barranco em rua de terra que } \\
\text { dá acesso ao Cond. Inhandjara }\end{array}$ & $\begin{array}{c}\text { Mina abandonada ao lado do } \\
\text { Hotel ITR-Spa }\end{array}$ & $\begin{array}{l}\text { Trincheira abandonada } \\
\text { ao lado do Hotel ITR-Spa }\end{array}$ & 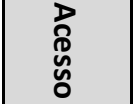 \\
\hline $\begin{array}{l}\text { A: granito fort. hidrotermalizado; B: } \\
\text { veio de Qtz com pedaço da encaixante } \\
\qquad(+225 / 65)\end{array}$ & Veio de Qtz mineralizado & & $\frac{8}{\frac{0}{9}}$ \\
\hline & 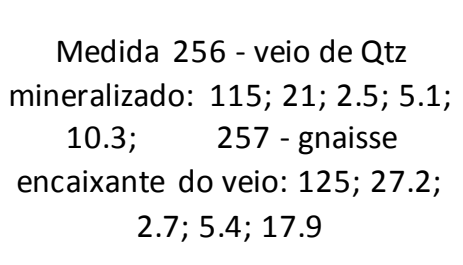 & & 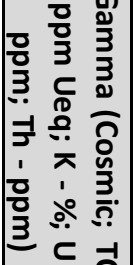 \\
\hline & & & $\underline{3}$ \\
\hline Fol. 080/40; 110/50; 090/45 & Fol.: 095/20; 090/40; 188/20 & & $\begin{array}{l}3 \\
\frac{1}{0} \\
\frac{2}{20} \\
\frac{2}{4}\end{array}$ \\
\hline$X(A, B)$ & $X(A, B)$ & & $\frac{5}{3}$ \\
\hline & $X(B)$ & & 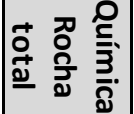 \\
\hline & $X(B)$ & & 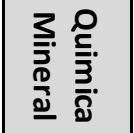 \\
\hline & & & $\begin{array}{l}\overline{\bar{g}} \\
\stackrel{0}{0} \\
\frac{0}{\overline{0}}\end{array}$ \\
\hline & & & 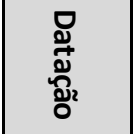 \\
\hline
\end{tabular}




\begin{tabular}{|c|c|c|c|c|}
\hline IPV-10 & IPV-09 & IPV-08 & IPV-07 & $\begin{array}{l}\text { Do } \\
\stackrel{0}{7} \\
\stackrel{0}{0}\end{array}$ \\
\hline 291090 & 290822 & 290772 & 291029 & 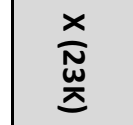 \\
\hline 7440834 & 7440681 & 7440647 & 7440415 & $\underset{\substack{N \\
\frac{\omega}{幺}}}{<}$ \\
\hline 719 & 688 & 686 & 706 & $N$ \\
\hline \multirow[t]{5}{*}{$\begin{array}{l}\text { Veio de quartzo } \\
\text { de } \sim 50 \mathrm{~cm} \text {; veio } \\
\text { de quartzo leitoso } \\
+ \text { cinza + fino no } \\
\text { gnaisse }\end{array}$} & $\begin{array}{l}\text { Veio de quartzo e } \\
\text { óxido de } \\
\text { manganês } \\
\text { misturado ao solo }\end{array}$ & $\begin{array}{l}\text { Veio } \\
\text { paraleo à } \\
\text { foliação do } \\
\text { gnaisse }\end{array}$ & $\begin{array}{l}\text { Veio de quartzo em estrada de terra; dez metros distante } \\
\text { temos gnaisse intemperizado cortado por veios de } \\
\text { quartzo concordantes e discordantes da foliação principal } \\
\text { (bandamento) }\end{array}$ & 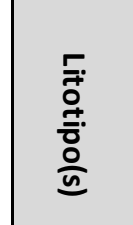 \\
\hline & No alto do morro & & $\begin{array}{l}\text { Afloramento em chão de estrada próxima à entrada da } \\
\text { mina }\end{array}$ & 勇 \\
\hline & $\begin{array}{l}\text { Veio de material } \\
\text { brechado e com } \\
\text { matriz preta }\end{array}$ & & $\begin{array}{l}\text { A: veio composto discordante, na zona de falha }(+ \\
\text { 180/60); B: veio na zona de falha inflectada }(+155 / 32) \text {; C: } \\
\text { veio de quartzo mais fino e escuro, discordante }(+125 / 45)\end{array}$ & 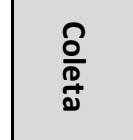 \\
\hline & & & & 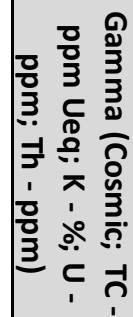 \\
\hline & & & & $\underline{3}$ \\
\hline \multirow[t]{6}{*}{$\begin{array}{l}\text { Orientação do } \\
\text { veio: } 196 / 80\end{array}$} & & $\begin{array}{l}\text { Foliação: } \\
354 / 58 \\
355 / 52\end{array}$ & $\begin{array}{l}\text { Fol. gnaisse: } 127 / 30,113 / 35,110 / 35 \text {; Veios de Qtz grosso } \\
\text { concordante: 090/30, 090/50; Zona de Falha: } 182 / 67 \\
\text { 185/65, 187/80, 154/30; deslocamento horiz. de } 80 \mathrm{~cm} \text { de } \\
\text { aplito pela falha }\end{array}$ & $\begin{array}{l}3 \\
\frac{3}{0} \\
\frac{2}{20} \\
\frac{9}{4}\end{array}$ \\
\hline & & & $X(A)$ & 离. \\
\hline & & & & 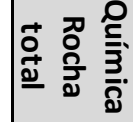 \\
\hline & & & & 疍: \\
\hline & & & & $\begin{array}{l}\overline{\underline{g}} \\
\stackrel{0}{+} \\
\stackrel{0}{\overline{0}}\end{array}$ \\
\hline & & & & 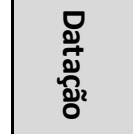 \\
\hline
\end{tabular}




\begin{tabular}{|c|c|c|c|}
\hline IPV-13 & IPV-12 & IPV-11 & 帝 \\
\hline 288683 & 291137 & 291037 & $\underset{\substack{\underline{w} \\
\frac{w}{x}}}{x}$ \\
\hline 7437892 & 7440657 & 7440877 & $\underset{\substack{\underline{\omega} \\
\text { 玄 }}}{<}$ \\
\hline 708 & 744 & 706 & N \\
\hline $\begin{array}{l}\text { Granito rosado bastante fraturado, } \\
\text { com quartzo arredondado, } \\
\text { inequigranular médio }\end{array}$ & $\begin{array}{l}\text { Veio de quartzo cinza } \\
\text { associado com leitoso de } \\
\sim 50 \mathrm{~cm} \text { na estrada (acaba } \\
\text { em uma trincheira) no } \\
\text { gnaisse intemperizado ; }\end{array}$ & $\begin{array}{l}\text { gnaisse intemperizado sendo cortado por } \\
\text { veios de quartzo acinzentado bandados } \\
\text { (discordantes), zona de falha; também temos } \\
\text { veios de quartzo leitoso na foliação }\end{array}$ & 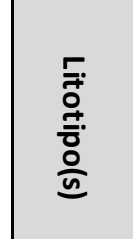 \\
\hline Dentro da cidade & & Afloramento no chão da estrada & 空 \\
\hline $\begin{array}{l}\text { A: granito rosado inequi. médio; B: } \\
\text { granito com forte alteração } \\
\text { hidrotermal e matriz fina verde escura }\end{array}$ & $\begin{array}{l}\text { veio Qtz cinzento + fino } \\
\text { bandado com leitoso (+ } \\
215 / 55)\end{array}$ & $\begin{array}{l}\text { A: veio Qtz discordante bandado (+ 154/40); } \\
\text { B: veio Qtz leitoso concordante; C: veio Qtz c/ } \\
\text { máfico prismático (bloco solto do chão) }\end{array}$ & $\frac{\delta}{\frac{\delta}{d}}$ \\
\hline $\begin{array}{l}\text { Medida } 260 \text { - granito: } 752 ; 60.5 ; 5.1 ; \\
12.7 ; 52.3 ; 261 \text { - granito: } 689 ; 59.4 ; \\
\text { 5.7; } 9.9 ; 52.9 ; 262 \text { - granito com forte } \\
\text { alt. Hidrot. e matriz esverdeada: } 728 \text {; } \\
\qquad 65.2 ; 5.3 ; 15 ; 53.2\end{array}$ & & & 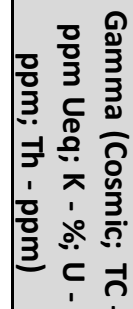 \\
\hline \multirow[t]{2}{*}{$\begin{array}{c}\text { SM: (A) } 0.033 \pm 0.016 ; \text { (B) } 0.094 \pm \\
0.022\end{array}$} & & & $\underline{3}$ \\
\hline & $\begin{array}{l}\text { Orientação do veio: } \\
211 / 55,209 / 65\end{array}$ & $\begin{array}{l}\text { Direção dos veios leitosos N020; Zona de } \\
\text { falha } 185 / 60 \text {; veio de quartzo cinza } \\
\text { bandado } 196 / 55\end{array}$ & $\begin{array}{l}3 \\
\frac{0}{0} \\
\frac{0}{2} \\
\frac{0}{3}\end{array}$ \\
\hline \multirow[t]{5}{*}{$X(A, B)$} & $\mathrm{x}$ & & 产. \\
\hline & & & 节总 \\
\hline & & & 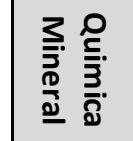 \\
\hline & & & $\begin{array}{l}\overline{\bar{o}} \\
\stackrel{0}{0} \\
\frac{0}{\overline{0}}\end{array}$ \\
\hline & & & 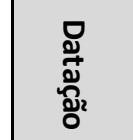 \\
\hline
\end{tabular}




\begin{tabular}{|c|c|c|}
\hline IPV-15 & IPV-14 & $\stackrel{0}{\stackrel{0}{2}}$ \\
\hline 291466 & 288980 & $\underset{\substack{\underline{w} \\
\frac{\omega}{幺}}}{x}$ \\
\hline 7439758 & 7438067 & $\underset{\substack{\underline{\omega} \\
\text { \} }}{<}} \\
{\hline 684} &{690} &{N} \\
{\hline \begin{array}{l}\text { Morro do paragnaisse bandado intemperizado. Diversos veios Qtzosos de espessura variável. Na } \\
\text { subida, perto das bananeiras ocorre veio de Qtz leitoso. No descampado onde tem a uma boca } \\
\text { (sem saída, com animal morto, e com veio métrico de Qtz com sulfetos e outros), vários veios } \\
\text { centimétricos subverticais, alguns com bordas de reação na encaixante e/ou bandamento com o } \\
\text { Qtz fino cinzento. Veios leitosos paralelos à foliação, com porç̃̃es de alteração avermelhada e } \\
\text { pontos pretos. Também ocorrem porç̃es com intensa alteração intempérica para material } \\
\text { argiloso e caulinitico. E diversos blocos de material brechado, muito denso, com matriz de } \\
\text { minerais escuros (minério?) }\end{array}} &{\begin{array}{l}\text { Granito rosado com } \\
\text { sulfeto e fluorita (IC } \\
\sim 8 \% \text { ), inequigranular } \\
\text { médio, com } \\
\text { feldspatos } \\
\text { avermelhados/ovala } \\
\text { dos (parece o } \\
\text { Itupeva) } \\
\end{array}} &{\text { 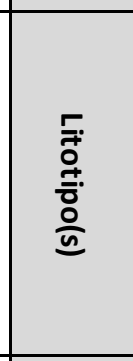 }} \\
{\hline \begin{array}{l}\text { Ruínas do local de escoamento do minério da Antiga Mina, gruta da santa, mercadinha } \\
\text { João Bosco }\end{array}} &{\begin{array}{l}\text { Morrote de granito } \\
\text { no alto da cidade }\end{array}} &{\text { 勇 }} \\
{\hline \text { Foram coletadas várias amostras. }} &{\begin{array}{l}\text { Granito levem. } \\
\text { Hidrotermalizado } \\
\text { com fluorita }\end{array}} &{\frac{2}{\frac{2}{9}}} \\
{\hline} &{\begin{array}{l}\text { Medida } 263- \\
\text { granito: } 742 ; 58.6 \\
5.5 ; 12.4 ; 46.2\end{array}} &{\text { 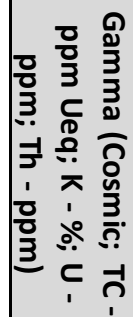 }} \\
{\hline} &{\text { SM: } 0.028 \pm 0.027} &{\text { కs }} \\
{\hline \begin{array}{l}\text { Fol. Gnaisse: } 163 / 35,172 / 25,182 / 25,165 / 24,178 / 12 \text {; Veios subvert.: 027/90, 038/85, } \\
\text { 021/83, 035/87, 024/86; Veios discordantes: 198/25, 208/35, 275/80, 115/87 }\end{array}} &{ } &{\begin{array}{l}3 \\
\frac{1}{0} \\
\frac{0}{2} \\
\frac{0}{0}\end{array}} \\
{\hline X(C, D)} &{\mathrm{x}} &{\text { 㞼. }} \\
{\hline \multirow[t]{4}{*}{X(C)}X ( C )} &{\mathrm{x}} &{\text { 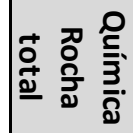 }} \\
{\hline} &{\mathrm{x}} &{\text { 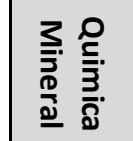 }} \\
{\hline} &{\mathrm{x}} &{\begin{array}{l}\bar{\pi} \\
\stackrel{0}{0} \\
\frac{0}{0} \\
\frac{0}{0}\end{array}} \\
{\hline} &{\mathrm{x}} &{\text { 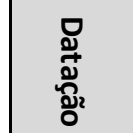 }} \\
$\hline
\end{tabular}




\begin{tabular}{|c|c|c|c|}
\hline IPV-18 & IPV-17 & IPV-16 & 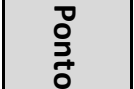 \\
\hline 288030 & 288002 & 288064 & 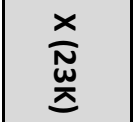 \\
\hline 7439503 & 7439311 & 7439271 & 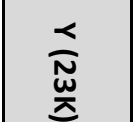 \\
\hline 720 & 734 & 727 & $N$ \\
\hline $\begin{array}{l}\text { Fragmentos e poucos blocos de } \\
\text { Qtz (com aspecto de enxame de } \\
\text { venulas) em meio a blocos de } \\
\text { granito (alguns fortemente } \\
\text { silicificados). }\end{array}$ & $\begin{array}{l}\text { Veio centimétrico Qtzoso com } \\
\text { argilominerais rosados a } \\
\text { alaranjados associados, } \\
\text { cortando barranco de granito } \\
\text { bem intemperizado. }\end{array}$ & $\begin{array}{l}\text { Granito maciço, inequi. médio- } \\
\text { grosso, IC } \sim 5-8 \% \text {, bem } \\
\text { avermelhado e com qtz } \\
\text { esbranquiçado arredondado } \\
\text { (fort. alt. hidrotermal). } \\
\text { Localmente com matriz escura } \\
\text { esverdeada, pouco Qtz e felds } \\
\text { brechado. } \\
\end{array}$ & 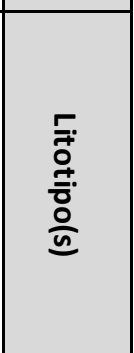 \\
\hline & $\begin{array}{l}\text { Estradinha secundária à rua } \\
\text { subindo o morro de acesso ao } \\
\text { Cond. Inhandjara. }\end{array}$ & $\begin{array}{l}\text { Rua subindo o morro para } \\
\text { acesso do Cond. Inhandjara. } \\
\text { Ponto da mata queimada. }\end{array}$ & 䞻 \\
\hline $\begin{array}{l}\text { Bloco de granito fortemente } \\
\text { silicificado (presença do } \\
\text { enxame de vênulas) }\end{array}$ & & $\begin{array}{l}\text { Amostra A: granito } \\
\text { avermelhado; B: porção com } \\
\text { matriz escura verde. }\end{array}$ & $\underset{\frac{\delta}{0}}{\frac{\delta}{d}}$ \\
\hline & & $\begin{array}{c}\text { SM: (A) } 1.07 \pm 0.25 \text { e } 2.32 \pm \\
0.102 \text { (B): } 0.06 \pm 0.03\end{array}$ & $\underline{3}$ \\
\hline & $\begin{array}{c}\text { Veio Qtz: } 330 / 80,314 / 80 \\
330 / 75\end{array}$ & & $\begin{array}{l}3 \\
0 \\
\frac{0}{2} \\
\frac{0}{2}\end{array}$ \\
\hline \multirow[t]{5}{*}{$x$} & & $X(A, B)$ & 产. \\
\hline & & $X(A, B)$ & 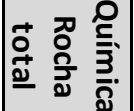 \\
\hline & & & 疍: \\
\hline & & & $\begin{array}{l}\overline{\underline{0}} \\
\text { 0े } \\
\frac{0}{\overline{0}}\end{array}$ \\
\hline & & & 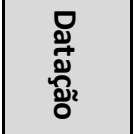 \\
\hline
\end{tabular}




\begin{tabular}{|c|c|c|c|}
\hline IPV-21 & IPV-20 & IPV-19 & 일 \\
\hline 288050 & 288028 & 288024 & $\underset{\frac{x}{N}}{\frac{x}{幺}}$ \\
\hline 7439344 & 7439396 & 7439449 & $\underset{\substack{\underline{w} \\
\frac{\omega}{x}}}{\prec}$ \\
\hline 735 & 730 & 723 & $N$ \\
\hline \multirow[t]{2}{*}{$\begin{array}{l}\text { Última ocorrência } \\
\text { dos Blocos de Qtz } \\
\text { antes de voltar a } \\
\text { aflorar o granito. }\end{array}$} & $\begin{array}{l}\text { Blocos de } \\
\text { Qtz na } \\
\text { porção de } \\
\text { topo de } \\
\text { morrote. }\end{array}$ & Diversos blocos de Qtz espalhados entre a mata. & 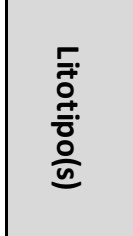 \\
\hline & & & 离 \\
\hline \multirow[t]{9}{*}{$\begin{array}{l}\text { Amostra dos } \\
\text { veios de Qtz. }\end{array}$} & & $\begin{array}{l}\text { A: veio com cavidades e cristais prismáticos de Qtz; B: veio de Qtz associado com } \\
\text { argilominerais; C: pedaço de bloco métrico que apresenta duas porções (fina } \\
\text { rosada e branca de granulação média); D: Qtz muito fino e de aspecto alterado. }\end{array}$ & $\frac{\delta}{\frac{\delta}{\infty}}$ \\
\hline & & & 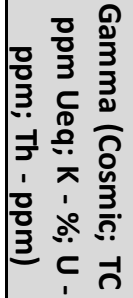 \\
\hline & & & $\underline{3}$ \\
\hline & & & $\begin{array}{l}3 \\
\frac{1}{0} \\
\frac{0}{20} \\
\frac{9}{n}\end{array}$ \\
\hline & & & 章. \\
\hline & & & 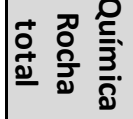 \\
\hline & & & 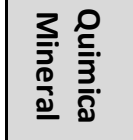 \\
\hline & & & $\begin{array}{l}\overline{\underline{0}} \\
\stackrel{+}{+} \\
\stackrel{0}{\overline{0}}\end{array}$ \\
\hline & & & 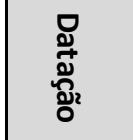 \\
\hline
\end{tabular}




\begin{tabular}{|c|c|c|c|}
\hline IPV-23 & IPV-22.2 & IPV-22 & $\begin{array}{l}\text { Do } \\
\stackrel{0}{\overparen{T}} \\
\text { Oे }\end{array}$ \\
\hline 288797 & 289090 & 289025 & $\underset{\substack{\underline{w} \\
\frac{w}{x}}}{x}$ \\
\hline 7440237 & 7440679 & 7440637 & 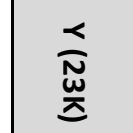 \\
\hline 820 & 843 & 836 & N \\
\hline \multirow[t]{11}{*}{$\begin{array}{l}\text { Milonito, não } \\
\text { parece estar in } \\
\text { situ }\end{array}$} & $\begin{array}{l}\text { Blocos do granito brechado } \\
\text { sendo cortados por vênulas } \\
\text { milimétricas de Qtz, localmente } \\
\text { com estrutura stockwork. }\end{array}$ & $\begin{array}{l}\text { Blocos diversos de granito de aparência brechada, felds. } \\
\text { bem avermelhados e pouco Qtz, redondo e esbranquiçado. } \\
\text { Inequi. Médio-grosso, IC } 5-7 \% \text {, presença de matriz mais } \\
\text { fina verde escura. Localmente grada para porções com } \\
\text { aspecto milonítico, dominado pela matriz fina foliada e de } \\
\text { cor verde escura, Qtz ausente e felds anedrais. Raros blocos } \\
\text { de material silicificado e um único bloco de diorito fino. }\end{array}$ & 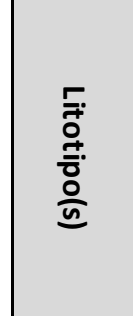 \\
\hline & $\begin{array}{l}\text { Cerca de } 50 \mathrm{~m} \text { do ponto } \\
\text { anterior. }\end{array}$ & Condomínio Colinas de Inhandjara & 知 \\
\hline & $\begin{array}{l}\text { D: granito com stockwork de } \\
\text { Qtz; E: bloco com Qtz } \\
\text { criptocristalino esverdeado }\end{array}$ & $\begin{array}{l}\text { A: granito de aspecto brechado; B: milonito de matriz fina } \\
\text { verde; C: diorito fino }\end{array}$ & $\frac{\delta}{\frac{\delta}{a}}$ \\
\hline & $\begin{array}{l}\text { Medida } 296 \text { - granito com } \\
\text { veios em rede: } 791,37.6,2.9 \text {, } \\
7.6,35.3 ; 297 \text { - solo cheio de } \\
\text { grãos soltos: } 827,35.4,1.1,8.1 \text {, } \\
\text { 45; } 298 \text { - solo: } 813,40.6,1.2 \text {, } \\
\text { 9.1, } 52.6 ; 299 \text { - veio de quartzo: } \\
755,21.3,0.8,4.1,27.4\end{array}$ & $\begin{array}{l}\text { Medida } 295 \text { - granito com aspeco brechado: } 802 ; 40.6 ; 3.0 ; \\
\text { 7.0; } 42.0\end{array}$ & 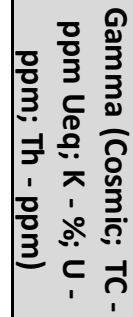 \\
\hline & & & $\underline{3}$ \\
\hline & & & $\begin{array}{l}3 \\
\frac{0}{0} \\
\frac{0}{2} \\
\frac{0}{3}\end{array}$ \\
\hline & $X(D)$ & $X(A, B, C)$ & 永. \\
\hline & & $X(A)$ & 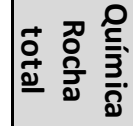 \\
\hline & & & 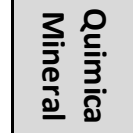 \\
\hline & & & $\begin{array}{l}\overline{\bar{n}} \\
\stackrel{+}{0} \\
\frac{0}{\overline{0}}\end{array}$ \\
\hline & & & 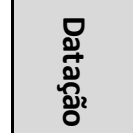 \\
\hline
\end{tabular}




\begin{tabular}{|c|c|c|c|c|}
\hline IPV-27 & IPV-26 & IPV-25 & IPV-24 & 롱 \\
\hline 289008 & 288972 & 288933 & 288849 & 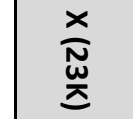 \\
\hline 7440095 & 7440054 & 7439953 & 7440030 & $\underset{\substack{\underline{w} \\
\text { 玄 }}}{\underline{x}}$ \\
\hline 840 & 833 & 829 & 818 & $N$ \\
\hline $\begin{array}{l}\text { Granito maciço, inequigranular médio- } \\
\text { grosso, IC } 5 \% \text {, com Kfs vermelho } \\
\text { subhedral e Qtz leitoso anedral. } \\
\text { Localmente com feldsp. orientados e } \\
\text { com manteamento branco. Alguns } \\
\text { bolsões de material sienitico estão } \\
\text { presentes com contatos bruscos e não- } \\
\text { retilíneos para o granito. } \\
\end{array}$ & $\begin{array}{l}\text { Sienito maciço, bastante } \\
\text { avermelhado, } \\
\text { hololeucocrático e inequi. } \\
\text { grosso(episienito?). } \\
\text { Localmente apresenta } \\
\text { feldsp. com manteamento } \\
\text { branco (albita?) }\end{array}$ & $\begin{array}{l}\text { Granito } \\
\text { idêntico ao } \\
\text { do ponto } \\
\text { IPV-24 }\end{array}$ & $\begin{array}{l}\text { Granito inequigranular } \\
\text { médio-grosso, com } \\
\text { feldspato manteado } \\
\text { (rapakivi?),não está } \\
\text { hidrotermalizado. }\end{array}$ & 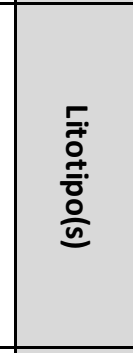 \\
\hline & & & & 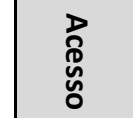 \\
\hline Granito & Sienito & & $\begin{array}{l}\text { Granito fracamente } \\
\text { hidrotermalizado com } \\
\text { feldsp. Manteado. }\end{array}$ & $\frac{\delta}{\frac{\delta}{d}}$ \\
\hline $\begin{array}{c}\text { Medida } 306 \text { - granito: } 770,44.7,4.4, \\
\text { 5.9, 43.9; } 307 \text { - porção + sienítica: } 849 \text {, } \\
62.4,5.8,11.7,56.8 ; 308 \text { - granito com } \\
\text { veios: } 822,48.7,4.1,8.7,48.8 ; 309 \text { - } \\
\text { granito: } 792,49.2,4.2,8.0,48.9\end{array}$ & $\begin{array}{c}\text { Medida } 304: 752,79.2,6.6 \\
\text { 13.6, } 76.4 ; 305: 752 ; 79.2 \\
6.6 ; 13.6 ; 76.4\end{array}$ & $\begin{array}{l}\text { Medida } \\
303- \\
\text { granito: } \\
621,66.3 \\
5.9,9.8 \\
66.4\end{array}$ & $\begin{array}{c}\text { Medida } 300 \text { - granito menos } \\
\text { intemperizado: } 761,51.1 \\
4.5,7.3,50 ; 301 \text { - granito } \\
\text { com capa de intemperismo: } \\
7.0 ? ? ?, 48.1,4.3,9.1,46 \\
302 \text { - solo: } 775,42.3,2.5 \\
8.3,46.3\end{array}$ & 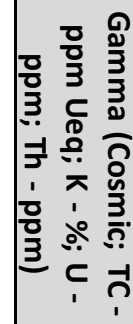 \\
\hline & SM: $1.61 \times 10-3 \mathrm{SI}$ & $\begin{array}{c}\text { SM: } 1.28 \mathrm{x} \\
10-3 \mathrm{SI}\end{array}$ & $\begin{array}{c}\mathrm{SM} \text { :granito pouco } \\
\text { intemperizado } 1.44 \times 10-3 \mathrm{SI}\end{array}$ & $\tilde{3}$ \\
\hline $\begin{array}{c}\text { Feldsp. Orient.: aprox. N-S Fraturas: } \\
\text { 215/65, 210/60 Veio Qtz: 185/75, } \\
\text { 190/70, 192/70 }\end{array}$ & & & & $\begin{array}{l}3 \\
\frac{1}{0} \\
\frac{2}{2} \\
\frac{2}{4}\end{array}$ \\
\hline $\mathrm{x}$ & $x$ & & & 产. \\
\hline & & & & 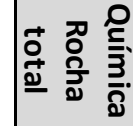 \\
\hline & & & & 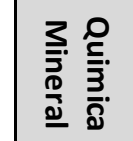 \\
\hline & & & & $\begin{array}{l}\bar{\pi} \\
\stackrel{0}{\circ} \\
\text { ㅎ․ }\end{array}$ \\
\hline & & & & 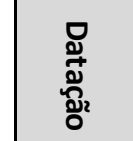 \\
\hline
\end{tabular}




\begin{tabular}{|c|c|c|c|}
\hline IPV-30 & IPV-29 & IPV-28 (CAB-15- ) & $\underset{0}{\stackrel{0}{\partial}}$ \\
\hline 289020 & 289139 & 289083 & $\underset{\substack{x \\
\text { 玄 }}}{x}$ \\
\hline 7439348 & 7440029 & 7439631 & 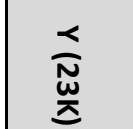 \\
\hline 848 & 848 & 849 & N \\
\hline $\begin{array}{l}\text { Veio espesso, granito } \\
\text { inequigranular médio- } \\
\text { grosso (próximo da } \\
\text { portaria), granito } \\
\text { stockwork }\end{array}$ & $\begin{array}{l}\text { Granito equigranular grosso } \\
\text { cortado por diques de aplito, } \\
\text { afetados por fraturas E-W }\end{array}$ & $\begin{array}{l}\text { granito maciço, inequi. grosso-médio } \\
\text { avermelhado e IC } 5 \% \text {, do outro lado da } \\
\text { rua aparece granito mais fino e coloração } \\
\text { mais rosada. Presença de alguns veios de } \\
\text { Qtz leitoso e manchas de alteração com } \\
\text { aspecto de sais brancos e azuis, também } \\
\text { dendritos de MnO }\end{array}$ & 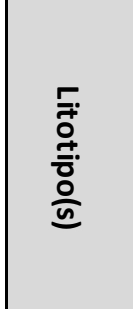 \\
\hline $\begin{array}{l}\text { coletadas várias } \\
\text { amostras }\end{array}$ & $\begin{array}{l}\text { amostra pequena do dique } \\
\text { aplitico avermelhado }\end{array}$ & $\begin{array}{l}\text { A: granito grosso mod. hidrot. B: granito } \\
\text { mais fino e mais claro, levem. hidrotermal }\end{array}$ & 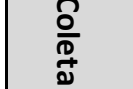 \\
\hline Medidas 315-318 & $\begin{array}{c}\text { Medida } 312 \text { - granito: } 834 ; 54.7 \\
4.4 ; 7.9 ; 59.3 ; \quad 313 \text { - granito } \\
789 ; 50.2 ; 4.0 ; 7.2 ; 53.2 ; \quad 314 \text { - }\end{array}$ & $\begin{array}{c}\text { Medida } 310 \text { - granito: } 739,45.9,3.6,8.4 \\
\text { 46.3; } 311 \text { - granito mais fino com veios de } \\
\text { Qtz: } 801 ; 52 ; 3.7 ; 13.2 ; 48\end{array}$ & 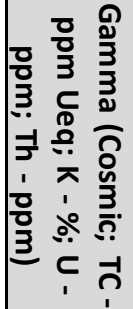 \\
\hline & & & $\underline{\xi}$ \\
\hline $\begin{array}{c}\text { Veio espesso de Qtz: } \\
325 / 84,320 / 75,150 / 87 \\
155 / 55,150 / 70\end{array}$ & $\begin{array}{l}\text { Aplitos: } 050 / 50,065 / 85,340 / 60 \\
\text { Fraturas no Aplito: } 315 / 50 \text { e } \\
\text { 180/60 Fraturas Granito: } \\
\text { 190/80, 172/65, 180/65 }\end{array}$ & Veios Qtz leitoso: 005/85, 182/80, 192/85 & $\begin{array}{l}3 \\
\frac{1}{0} \\
\frac{0}{2} \\
\frac{0}{0}\end{array}$ \\
\hline$X(A, B, C, E)$ & $\mathrm{x}$ & $X(A, B)$ & 永. \\
\hline$X(C)$ & & & 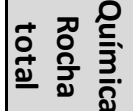 \\
\hline$X(C)$ & & & 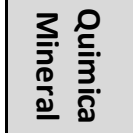 \\
\hline$X(C)$ & & & $\begin{array}{l}\overline{\overline{0}} \\
\stackrel{0}{0} \\
\frac{0}{2}\end{array}$ \\
\hline$X(C)$ & & & 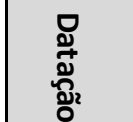 \\
\hline
\end{tabular}




\begin{tabular}{|c|c|c|c|}
\hline IPV-33 & IPV-32 & IPV-31 & $\begin{array}{l}\text { Do } \\
\stackrel{0}{\overparen{T}} \\
\text { Oे }\end{array}$ \\
\hline 288038 & 288094 & 288445 & $\underset{\substack{\underline{w} \\
\frac{\omega}{x}}}{x}$ \\
\hline 7439057 & 7439361 & 7439553 & 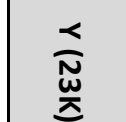 \\
\hline 710 & 734 & 762 & $N$ \\
\hline \multirow[t]{11}{*}{$\begin{array}{l}\text { Granito maciço, inequi. Médio- } \\
\text { grosso, IC } 5 \% \text {, com felds } \\
\text { vermelho, Qtz leitoso } \\
\text { arredondado e Plg raro. } \\
\text { Localmente comfraturas } \\
\text { preenchidas por material fino } \\
\text { verde escuro. }\end{array}$} & $\begin{array}{l}\text { Granito maciço, inequi. Médio- } \\
\text { grosso, IC } 5 \% \text {, com felds } \\
\text { vermelho, Qtz leitoso } \\
\text { arredondado e Plg raro. } \\
\text { Localmente com matriz fina } \\
\text { verde escuro. }\end{array}$ & $\begin{array}{l}\text { Granito inequigranular } \\
\text { médio grosso, IC } 3 \% \text {. } \\
\text { Presença de fraturas } \\
\text { preenchidas por material } \\
\text { fino verde escuro, } \\
\text { localmente brechando o } \\
\text { granito. }\end{array}$ & $\begin{array}{l}\text { 둘 } \\
\text { 호. } \\
\text { 흠 }\end{array}$ \\
\hline & & $\begin{array}{l}\text { Afloramento de blocos de } \\
\text { granito ao lado da rua de } \\
\text { acesso ao Cond. Inhandjara }\end{array}$ & 㤐 \\
\hline & & & $\frac{\delta}{\infty}$ \\
\hline & $\begin{array}{c}\text { Medida } 320 \text { - granito: } 772 ; \\
51.8 ; 4.5 ; 8.9 ; 50.1\end{array}$ & $\begin{array}{c}\text { Medida } 319 \text { - granito: } 770 ; \\
58.5 ; 4.5 ; 10.0 ; 59.2\end{array}$ & 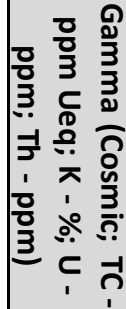 \\
\hline & & & 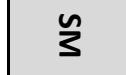 \\
\hline & & $\begin{array}{c}\text { Fraturas preenchidas por } \\
\text { material verde escuro fino: } \\
\text { 050/80, 055/90, 260/70, } \\
270 / 70\end{array}$ & $\begin{array}{l}3 \\
\frac{1}{0} \\
\frac{2}{20} \\
\frac{9}{4}\end{array}$ \\
\hline & & & ב⿱艹 \\
\hline & & & 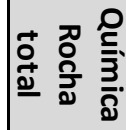 \\
\hline & & & 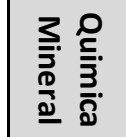 \\
\hline & & & $\begin{array}{l}\overline{\bar{g}} \\
\stackrel{+}{0} \\
\stackrel{0}{\frac{0}{2}}\end{array}$ \\
\hline & & & 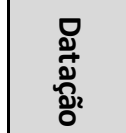 \\
\hline
\end{tabular}




\begin{tabular}{|c|c|c|}
\hline IPV-35 & IPV-34 & 蒿 \\
\hline 290555 & 287808 & $\frac{x}{\underset{N}{\frac{\omega}{幺}}}$ \\
\hline 7444856 & 7439240 & $\underset{\substack{\tilde{\omega} \\
\text { 玄 }}}{<}$ \\
\hline 756 & 677 & $N$ \\
\hline $\begin{array}{l}\text { Granito maciço, coloração rosada, inequi. médio-fino a localmente equi. } \\
\text { médio, moderadamente hidrotermalizado. Paredão intensamente fraturado, } \\
\text { com preenchimento por material fino verde claro. Presença de blackwalls } \\
\text { centimétricos a métricos de material muito fino, verde bem escuro e com } \\
\text { sulfetos e fluorita disseminados. Localmente os veios ocorrem } \\
\text { anastomosados e formam estruturas tipo "par S-C" envolvendo o granito } \\
\text { encaixante. Âs vezes os BW mostram borda de reação no contato com o } \\
\text { granito, formando camadas centimétricas de matriz verde escura, seguida de } \\
\text { porções bem avermelhadas, pouco Qtze sem máficos (episienito?), passando } \\
\text { para o granito. Contatos são bruscos, mas nem sempre retilíneos. }\end{array}$ & $\begin{array}{c}\text { Granito bem intemperizado, maciço, inequigranular } \\
\text { médio-grosso, com felds. rosado e Qtz esbranquiçado. } \\
\text { Localmente grada para porções mais pegmatoides, } \\
\text { bem qtzosas e com minerais escuros intersticiais. Alta } \\
\text { densidade de veios de Qtz em várias direções, alguns } \\
\text { com cavidades e cristais prismáticos, minerais pretos } \\
\text { ou minerais incolores levem. arroxeados e com } \\
\text { clivagem. }\end{array}$ & $\begin{array}{l}\text { 둘 } \\
\frac{0}{0} \\
\frac{+}{\bar{\sigma}} \\
\frac{0}{n}\end{array}$ \\
\hline Pedreira Viracopos, porção C & $\begin{array}{l}\text { Corte de barranco em rua de terra que dá acesso } \\
\text { ao Cond. Inhandjara }\end{array}$ & 勇 \\
\hline $\begin{array}{c}\text { Amostra E: granito F: passagem BW-matriz verde-episienito- } \\
\text { granito }\end{array}$ & $\begin{array}{l}\text { A: veio fino com minerais escuros (+ 195/80); B: } \\
\text { veio de Qtz com cavidades e cristais prismáticos } \\
\qquad(+228 / 70) \text {; C: granito silicificado }\end{array}$ & $\frac{\delta}{\frac{\delta}{\alpha}}$ \\
\hline $\begin{array}{l}\text { Medida } 331 \text { - granito comum da pedreira: } 651 ; 62.8 ; 4.4 ; \\
\text { 18.5; } 36.8 ; 332 \text { - blackwall: } 605 ; 90.1 ; 4.5 ; 35.3 ; 28.8 ; 333 \text { - } \\
\text { granito entre } 2 \text { BW: } 558 ; 75.3 ; 4.2 ; 26.7 ; 28.3\end{array}$ & & 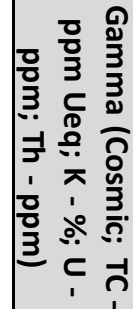 \\
\hline & & $\underline{\xi}$ \\
\hline $\begin{array}{l}\text { Fraturas: } 033 / 80,17 / 90,022 / 84,330 / 71,090 / 76,036 / 85 \\
\quad 014 / 80,353 / 70 ; \mathrm{BW}: 032 / 76,027 / 87,010 / 75\end{array}$ & $\begin{array}{l}\text { Veios de Qtz: 225/80, 358/72, 218/75, 205/70, } \\
\text { 040/87, 195/80 }\end{array}$ & 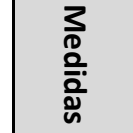 \\
\hline $\mathrm{X}$ (varias) & $X(C)$ & 产. \\
\hline$X(E, F, H)$ & & 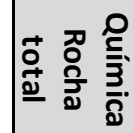 \\
\hline & & 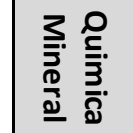 \\
\hline & & $\begin{array}{l}\overline{\bar{o}} \\
\stackrel{0}{0} \\
\stackrel{0}{0}\end{array}$ \\
\hline & & 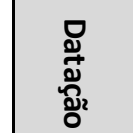 \\
\hline
\end{tabular}




\begin{tabular}{|c|c|c|c|}
\hline IPV-35.4 & IPV-35.3 & IPV-35.2 & $\begin{array}{l}\stackrel{0}{0} \\
\stackrel{\partial}{\not}\end{array}$ \\
\hline 290444 & 290509 & 290476 & $\underset{\substack{\underline{w} \\
\text { 文 }}}{x}$ \\
\hline 7444734 & 7444673 & 7444678 & $\underset{\substack{\underline{w} \\
\text { 玄 }}}{<}$ \\
\hline 788 & 783 & 781 & N \\
\hline $\begin{array}{l}\text { Granito maciço, rosado, inequi. } \\
\text { Médio-fino, IC } 5-7 \% \text {, moderada } \\
\text { alteração hidrotermal. Localmente } \\
\text { ocorrem enclaves migrogranulares } \\
\text { félsicos de aspecto semelhante à } \\
\text { encaixante, exceto pelo } \\
\text { granulação (Autoenclave?) }\end{array}$ & $\begin{array}{l}\text { Granito maciço, branco, } \\
\text { IC 7-10\%, inequi. fino- } \\
\text { médio, alteração } \\
\text { hidrotermal apenas } \\
\text { fissural. }\end{array}$ & $\begin{array}{l}\text { Granito maciço, bege a levem. } \\
\text { rosado, IC } 6 \% \text {, inequi. médio- } \\
\text { fino, moderad. } \\
\text { Hidrotermalizado. Presença de } \\
\text { BW similares ao do ponto } \\
\text { anterior, mas com sulfetos e } \\
\text { fluorita mais finos. }\end{array}$ & $\begin{array}{l}\frac{5}{\overline{0}} \\
\stackrel{+}{\bar{*}} \\
\frac{0}{\underline{0}}\end{array}$ \\
\hline Pedreira Viracopos, porção A & $\begin{array}{l}\text { Pedreira Viracopos, } \\
\text { porção A }\end{array}$ & Pedreira Viracopos, porção A & 离 \\
\hline $\begin{array}{c}\text { Amostra C: granito G: granito } \\
\text { com enclave }\end{array}$ & Amostra A & Amostra B & $\frac{\delta}{\infty}$ \\
\hline & & & 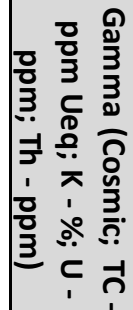 \\
\hline & & & 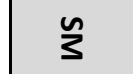 \\
\hline Fraturas: $004 / 80,017 / 72,013 / 74$ & $\begin{array}{c}\text { BW: 038/88, 225/80, } \\
031 / 85,083 / 90,014 / 60 \\
012 / 76,010 / 70,355 / 70 \\
001 / 65,000 / 70\end{array}$ & $\begin{array}{c}\text { Fraturas: } 045 / 045,044 / 87 \\
\text { 040/90, } 035 / 90,035 / 90 \\
040 / 90\end{array}$ & $\begin{array}{l}3 \\
\frac{1}{0} \\
\frac{2}{20} \\
\text { थั }\end{array}$ \\
\hline $\mathrm{X}$ (varias) & $X(A)$ & X (varias) & 产. \\
\hline \multirow[t]{4}{*}{$X(C)$} & $X(A)$ & $X(B)$ & 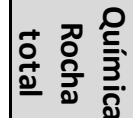 \\
\hline & $X(A)$ & & 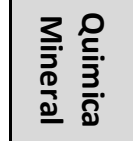 \\
\hline & $X(A)$ & & $\begin{array}{l}\bar{\pi} \\
\stackrel{0}{\circ} \\
\text { 음. }\end{array}$ \\
\hline & & & 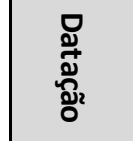 \\
\hline
\end{tabular}




\begin{tabular}{|c|c|c|c|}
\hline IPV-35.7 & IPV-35.6 & IPV-35.5 & $\begin{array}{l}\text { Do } \\
\stackrel{2}{Z}\end{array}$ \\
\hline 290584 & 290584 & 290447 & 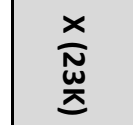 \\
\hline \multirow[t]{2}{*}{7444692} & 7444692 & 7444795 & 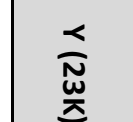 \\
\hline & & 789 & $N$ \\
\hline $\begin{array}{l}\text { Granito fino } \\
\text { rosado }\end{array}$ & $\begin{array}{l}\text { Granito branco a bege. } \\
\text { Presenca de dois conjuntos de } \\
\text { fraturas obliquas, não } \\
\text { mineralizadas e preenchidas } \\
\text { por greisen. }\end{array}$ & $\begin{array}{l}\text { Granito maciço, avermelhado, inequi médio- } \\
\text { grosso a localmente equi. médio. Presença de } \\
\text { fluorita roxa disseminada na rocha ou formando } \\
\text { vênulas no granito. Presença de vênulas de } \\
\text { material verde claro distribuídas por todas a } \\
\text { pedreira, localmente nesta porção, associada } \\
\text { com cristais incolores a esbranquiçados com } \\
\text { clivagem e dureza menor que } 6 \text { (carbonatos?) }\end{array}$ & 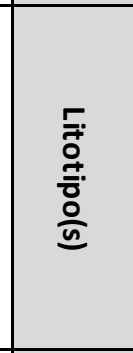 \\
\hline \multirow[t]{3}{*}{$\begin{array}{c}\text { Pedreira } \\
\text { Viracopos, } \\
\text { porção A }\end{array}$} & Pedreira Viracopos, porção A & Pedreira Viracopos, porção B & 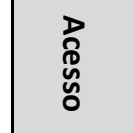 \\
\hline & & Amostra D & $\frac{\delta}{\frac{\delta}{a}}$ \\
\hline & & & 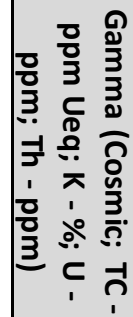 \\
\hline \multirow[t]{2}{*}{$0.07 \pm 0.017$} & $\begin{array}{c}\text { Branco: } 0.04 \pm 0.018 \\
\text { Bege: } 0.039 \pm 0.017\end{array}$ & & un \\
\hline & $\begin{array}{c}\text { Fraturas: } 358 / 60,356 / 50 \\
020 / 50,345 / 40,000 / 65\end{array}$ & & $\begin{array}{l}3 \\
\frac{3}{0} \\
\frac{2}{2} \\
\text { की }\end{array}$ \\
\hline$X(N, A D)$ & $\mathrm{X}$ (varias) & $\mathrm{X}$ (varias) & 㞼. \\
\hline \multirow[t]{4}{*}{$X(A D)$} & & $X(D)$ & . \\
\hline & & & 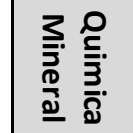 \\
\hline & & & 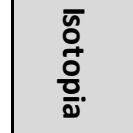 \\
\hline & & & 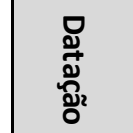 \\
\hline
\end{tabular}




\begin{tabular}{|c|c|c|c|}
\hline IPV-35.10 & IPV-35.9 & IPV-35.8 & $\begin{array}{l}\text { Do } \\
\stackrel{0}{7} \\
\text { Oे }\end{array}$ \\
\hline 290672 & 290584 & 290584 & 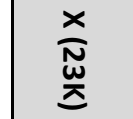 \\
\hline \multirow[t]{2}{*}{7444600} & 7444692 & 7444692 & 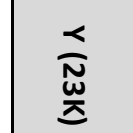 \\
\hline & & & $N$ \\
\hline $\begin{array}{l}\text { Presença de rocha encaixante aflorando no chão e barrancos } \\
\text { inferiores. Gnaisse xistoso de estrutura bandada intercalando } \\
\text { camadas milimétricas lepidoblasticas com granoblásticas. } \\
\text { Elevado grau de intemperismo, mostrando coloração ocre e } \\
\text { avermelhada. Contato com granito é abrupto e } \\
\text { subarredondado, levemente paraleloá foliação, porém as vezes } \\
\text { discordante. Ognaisse também ocorre comoxenólitos métricos } \\
\text { dentro do corpo granítico, ocorrendo mais bem preservados } \\
\text { neste caso. Ocorrem veios centimétricos de quartzo } \\
\text { concordantes e discordantes a foliacao. }\end{array}$ & Greisen & $\begin{array}{l}\text { Granito rosado a vermelho. } \\
\text { Ocorrencias de bolsoes centimetricos } \\
\text { de pegmatitos com Qtz branco, Kfs } \\
\text { rosado e bt cinza escurto (intersticial), } \\
\text { além de cristais finos de sulfetos } \\
\text { cinzentos (galena) nas bordas. O } \\
\text { contato superior para o granito é } \\
\text { marcado por borda de aplito. }\end{array}$ & $\begin{array}{l}\text { 훌 } \\
\stackrel{+}{+} \\
\text { 움 }\end{array}$ \\
\hline \multirow[t]{4}{*}{ Pedreira Viracopos, porção D } & $\begin{array}{l}\text { Pedreira Viracopos, } \\
\text { porção B }\end{array}$ & Pedreira Viracopos, porção B & 勇 \\
\hline & & & $\frac{\delta}{\frac{\delta}{\alpha}}$ \\
\hline & & & 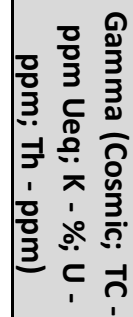 \\
\hline & $\begin{array}{l}\text { Chao: } 0.109 \pm 0.035 \\
\text { Bloco: } 0.06 \pm 0.018\end{array}$ & $\begin{array}{c}\text { Rosado: } 0.049 \pm 0.018 \text { Vermelho: } \\
0.058 \pm 0.019\end{array}$ & us \\
\hline $\begin{array}{l}\text { Fol.: } 125 / 55,130 / 65,098 / 60,086 / 63 \text {. Veio de Qtz } \\
\text { ortogonal a fol: } 215 / 80,215 / 83\end{array}$ & $\begin{array}{c}\text { BW: 010/85, } \\
\text { 005/90, 005/88 } \\
\text { Veio: } 215 / 60 \\
\text { 045/85, 221/85 }\end{array}$ & & $\begin{array}{l}3 \\
\frac{1}{0} \\
\frac{2}{2} \\
\frac{2}{0}\end{array}$ \\
\hline \multirow[t]{5}{*}{$X(A M)$} & & $\mathrm{X}$ (varias) & 可 \\
\hline & & & 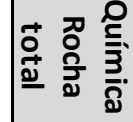 \\
\hline & & & 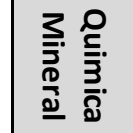 \\
\hline & & & $\begin{array}{l}\overline{0} \\
\stackrel{+}{0} \\
\text { o․ } \\
\text { ㅇ. }\end{array}$ \\
\hline & & & 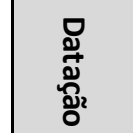 \\
\hline
\end{tabular}




\begin{tabular}{|c|c|c|}
\hline IPV-37 & IPV-36 & $\begin{array}{l}7 \\
\stackrel{0}{7} \\
\text { ᄅे }\end{array}$ \\
\hline 287922 & 288081 & 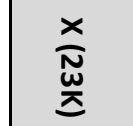 \\
\hline 74371413 & 7437553 & 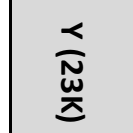 \\
\hline 745 & & $N$ \\
\hline $\begin{array}{l}\text { Afloramento de blocos no pasto, de granito bem } \\
\text { alterado, com coloracao avermelhada. Estrutura } \\
\text { macica a levemente foliada (brechado) com textura } \\
\text { inequigranular grossa-media. IC }=3-4 \% \text {, com bt como } \\
\text { mafico, já bastante cloritizada (esverdeadas). Aspecto } \\
\text { similar ao ponto anterior e ao IPV- } 16\end{array}$ & $\begin{array}{l}\text { Afloramento de lajedo de granito em meio a pasto com bloquinhos } \\
\text { ao redor. Grau de intemperismo variado, de baixo a moderado, com } \\
\text { coloracao rosada a avermelhada. Estrutura macica a localmente } \\
\text { brechada, textura é inequigranular grossa-media (porfiroide?) e IC = } \\
\text { 3-4\%. Bt como mafico principal, ja bastante cloritizada. Presenca de } \\
\text { porcoes muito finas e avermelhadas, proximas aos termos mais } \\
\text { deformados. Ocorrem minerais secundarios muito finos em zonas de } \\
\text { falha estriadas, com coloraao amarelada, ocre e roxo. Presenca de } \\
\text { bolsoes de sericita verde claro. }\end{array}$ & 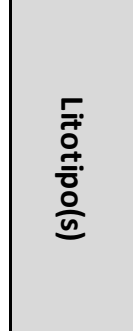 \\
\hline Pasto as margens da cidade de Itupeva & Pasto as margens da cidade de Itupeva & 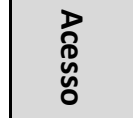 \\
\hline & & $\frac{\delta}{\frac{\delta}{0}}$ \\
\hline $836 ; 53.5 ; 4.8 ; 10.0 ; 49.1$ & & 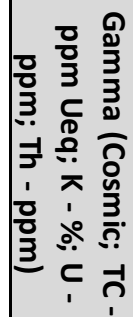 \\
\hline $1.56 \pm 0.612$ & $1.39 \pm 0.812$ & $\tilde{3}$ \\
\hline & & $\begin{array}{l}3 \\
\frac{1}{0} \\
\frac{0}{20} \\
\frac{9}{4}\end{array}$ \\
\hline & $\mathrm{x}$ & 离. \\
\hline & & 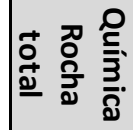 \\
\hline & & 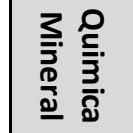 \\
\hline & & 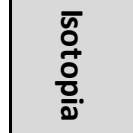 \\
\hline & & 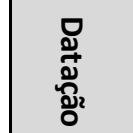 \\
\hline
\end{tabular}


ANEXO II - TABELA DE GAMAESPECTROMETRIA DE CAMPO 

Gamaespectrometria - IPV

\begin{tabular}{|c|c|c|c|c|c|c|c|c|}
\hline \multirow[t]{2}{*}{ Ponto } & \multicolumn{2}{|c|}{ Coordenadas UTM } & \multirow{2}{*}{ Altitude (m) } & \multirow{2}{*}{ Local de Medição } & \multirow{2}{*}{ K_\% } & \multirow{2}{*}{ U_ppm } & \multirow{2}{*}{ Th_ppm } & \multirow{2}{*}{$\mathrm{Th} / \mathrm{U}$} \\
\hline & $x$ & Y & & & & & & \\
\hline IPV13 & 288682 & 7437892 & 708 & lajedo Granito Itupeva & 5,1 & 12,7 & 52,3 & 4,1 \\
\hline IPV13 & 288682 & 7437892 & 708 & Granito com cobertura de musgo & 5,7 & 9,9 & 52,9 & 5,3 \\
\hline IPV13 & 288682 & 7437892 & 708 & Granito muito hidrotermalizado & 5,3 & 15 & 53,2 & 3,5 \\
\hline IPV34 & 287808 & 7439240 & 677 & Granito Itupeva & 4,4 & 4,8 & 34,7 & 7,2 \\
\hline IPV34 & 287808 & 7439240 & 677 & Granito Itupeva & 6,1 & 5,9 & 33,8 & 5,7 \\
\hline IPV14 & 288980 & 7438067 & 690 & Granito Itupeva & 5,5 & 12,4 & 46,2 & 3,7 \\
\hline IPV22.2 & 289090 & 7440679 & 843 & solo Granito Inhandjara & 1,1 & 8,1 & 45 & 5,6 \\
\hline IPV22.2 & 289090 & 7440679 & 843 & solo Granito Inhandjara & 1,2 & 9,1 & 52,6 & 5,8 \\
\hline IPV22.2 & 289090 & 7440679 & 843 & solo quartzoso & 0,8 & 4,1 & 27,4 & 6,7 \\
\hline IPV24 & 288849 & 7440030 & 818 & solo Granito Inhandjara & 2,5 & 8,3 & 46,3 & 5,6 \\
\hline IPV22 & 289025 & 7440637 & 836 & bloco alterado Granito Inhandjara & 3 & 7 & 42 & 6 \\
\hline IPV22.2 & 289090 & 7440679 & 843 & stockwork Granito Inhandjara & 2,9 & 7,6 & 35,3 & 4,6 \\
\hline IPV30 & 289020 & 7439348 & 847 & venulação em Granito Inhandjara & 2,6 & 9,8 & 33,7 & 3,4 \\
\hline IPV30 & 289020 & 7439348 & 847 & bloco alterado Granito Inhandjara & 2,9 & 8,3 & 37,1 & 4,5 \\
\hline IPV30 & 289020 & 7439348 & 847 & bloco alterado Granito Inhandjara & 3,3 & 8,5 & 54,9 & 6,5 \\
\hline IPV25 & 288933 & 7439953 & 829 & Granito Itupeva & 5,9 & 9,8 & 66,4 & 6,8 \\
\hline IPV24 & 288849 & 7440030 & 818 & Granito Inhandjara & 4,5 & 7,3 & 50 & 6,8 \\
\hline IPV24 & 288849 & 7440030 & 818 & Granito Inhandjara & 4,3 & 7 & 50,6 & 7,2 \\
\hline IPV27 & 289008 & 7440095 & 840 & Granito Inhandjara & 4,4 & 5,9 & 43,9 & 7,4 \\
\hline IPV27 & 289008 & 7440095 & 840 & Granito Inhandjara & 4,1 & 8,7 & 48,8 & 5,6 \\
\hline IPV27 & 289008 & 7440095 & 840 & Granito Inhandjara & 4,2 & 8 & 48,9 & 6,1 \\
\hline IPV28 & 289083 & 7439631 & 849 & bloco alterado Granito Inhandjara & 3,6 & 8,4 & 46,3 & 5,5 \\
\hline IPV28 & 289083 & 7439631 & 849 & bloco alterado Granito Inhandjara & 3,7 & 13,3 & 48 & 3,6 \\
\hline IPV29 & 289139 & 7440029 & 848 & Granito Inhandjara & 4,4 & 7,9 & 59,3 & 7,5 \\
\hline IPV29 & 289139 & 7440029 & 848 & Granito Inhandjara & 4 & 7,2 & 53,2 & 7,4 \\
\hline IPV29 & 289139 & 7440029 & 848 & Granito Inhandjara & 4,3 & 7,4 & 58,2 & 7,9 \\
\hline IPV30 & 289020 & 7439348 & 847 & lajedo Granito Inhandjara & 3,7 & 9,6 & 51 & 5,3 \\
\hline IPV31 & 288445 & 7439553 & 762 & Granito Inhandjara & 4,5 & 10 & 50,1 & 5 \\
\hline IPV32 & 288094 & 7439361 & 734 & Granito Inhandjara & 4,5 & 8,9 & 59,2 & 6,7 \\
\hline IPV26 & 288972 & 7440054 & 833 & Episienito & 6,2 & 10,3 & 69,7 & 6,8 \\
\hline IPV26 & 288972 & 7440054 & 833 & Episienito & 6,6 & 13,6 & 76,4 & 5,6 \\
\hline IPV27 & 289008 & 7440095 & 840 & Episienito & 5,8 & 11,7 & 56,8 & 4,9 \\
\hline IPV35.2 & 290476 & 7444678 & 781 & Granito Pedreira bege a roseo & 3,7 & 16,7 & 24,4 & 1,5 \\
\hline IPV35.3 & 290509 & 7444673 & 783 & Granito Pedreira branco & 2,7 & 16,4 & 17,3 & 1,1 \\
\hline IPV35 & 290555 & 7444856 & 756 & Granito Pedreira roseo a vermelho & 4,4 & 18,5 & 36,8 & 2 \\
\hline IPV35 & 290555 & 7444856 & 756 & veio de alteracao hidrotermal & 4,5 & 35,3 & 28,8 & 0,8 \\
\hline IPV35 & 290555 & 7444856 & 756 & Granito Pedreira entre 2 veios & 4,2 & 2,7 & 28,3 & 10,5 \\
\hline IPV35.4 & 290444 & 7444734 & 788 & Granito Pedreira roseo a vermelho & 4,4 & 20,1 & 38,4 & 1,9 \\
\hline IPV35.5 & 290447 & 7444795 & 789 & Granito Pedreira vermelho & 4 & 18,1 & 32,3 & 1,8 \\
\hline
\end{tabular}


ANEXO III - TABELA DE GEOQUÍMICA DE ROCHA TOTAL 



\begin{tabular}{|c|c|c|c|c|c|c|c|c|c|}
\hline \multirow{2}{*}{$\begin{array}{c}\text { Fácies } \\
\text { Amostra }\end{array}$} & \multicolumn{4}{|c|}{ Porfirítica } & \multicolumn{3}{|c|}{ Inequigranular } & \multicolumn{2}{|c|}{ Equigranular } \\
\hline & IPV-14 & IPV-16A & CAB-04 & CAB-42 & IPV-30C & CAB-41 & CAB-30 & IPV-35A & IPV-35B \\
\hline \multicolumn{10}{|c|}{ Maiores (wt\%) } \\
\hline $\mathrm{SiO} 2$ & 73,13 & 73,56 & 75,15 & 74,65 & 76,76 & 75,95 & 75,89 & 76,18 & 76,59 \\
\hline TiO2 & 0,098 & 0,212 & 0,125 & 0,17 & 0,085 & 0,14 & 0,04 & 0,011 & 0,032 \\
\hline $\mathrm{Al} 2 \mathrm{O} 3$ & 14,33 & 12,93 & 12,24 & 12,07 & 12,02 & 11,98 & 12,8 & 12,96 & 12,41 \\
\hline Fe2O3t & 1,02 & 1,66 & 1,08 & 1,77 & 0,95 & 1,23 & 0,67 & 0,85 & 0,89 \\
\hline $\mathrm{MnO}$ & 0,02 & 0,04 & 0,04 & 0,06 & 0,02 & 0,09 & 0,01 & 0,06 & 0,05 \\
\hline $\mathrm{MgO}$ & 0,06 & 0,18 & 0,01 & 0,01 & 0,05 & 0,01 & 0,01 & 0,00 & 0,01 \\
\hline $\mathrm{CaO}$ & 0,68 & 0,58 & 0,61 & 0,72 & 0,53 & 0,62 & 0,36 & 0,44 & 0,49 \\
\hline $\mathrm{Na} 2 \mathrm{O}$ & 4,57 & 4,02 & 3,53 & 3,69 & 3,83 & 3,66 & 2,79 & 4,73 & 5,01 \\
\hline $\mathrm{K} 2 \mathrm{O}$ & 5,81 & 5,79 & 5,14 & 4,93 & 4,51 & 4,75 & 6,17 & 4,45 & 4,23 \\
\hline P2O5 & 0,02 & 0,05 & 0,01 & 0,03 & 0,01 & 0,01 & 0,00 & 0,01 & 0,01 \\
\hline $\mathrm{PF}$ & 0,59 & 0,61 & 0,74 & 0,53 & 0,65 & 0,44 & 0,6 & 0,45 & 0,54 \\
\hline Total & 100,33 & 99,63 & 98,67 & 98,62 & 99,42 & 98,88 & 99,34 & 100,14 & 100,26 \\
\hline \multicolumn{10}{|c|}{ Menores e Traço (ppm) } \\
\hline $\mathrm{F}$ & 2212 & 1410 & 1567 & 3924 & 2606 & 2073 & 277 & 3003 & 3795 \\
\hline $\mathrm{Cl}$ & $<500$ & $<500$ & $<500$ & $<500$ & $<500$ & $<500$ & $<500$ & $<500$ & $<500$ \\
\hline$S$ & $<550$ & $<550$ & $<550$ & $<550$ & $<550$ & $<550$ & $<550$ & $<550$ & $<550$ \\
\hline La & 25,30 & 79,00 & 60,94 & 68,77 & 34,50 & 43,99 & 3,88 & 12,70 & 28,00 \\
\hline $\mathrm{Ce}$ & 57,10 & 129,00 & 112,02 & 141,50 & 71,40 & 82,91 & 16,23 & 37,30 & 62,00 \\
\hline $\mathrm{Pr}$ & 7,44 & & 11,75 & 14,31 & 9,96 & 9,91 & 0,66 & 6,08 & \\
\hline $\mathrm{Nd}$ & 24,60 & 51,00 & 40,10 & 50,43 & 32,50 & 28,64 & 1,84 & 24,20 & 30,00 \\
\hline $\mathrm{Sm}$ & 5,26 & & 7,54 & 8,80 & 7,39 & 4,61 & 0,35 & 9,83 & \\
\hline $\mathrm{Eu}$ & 0,57 & & 0,48 & 0,45 & 0,34 & 0,26 & 0,26 & 0,01 & \\
\hline Gd & 4,22 & & 6,42 & 6,16 & 7,00 & 3,31 & 0,24 & 11,10 & \\
\hline $\mathrm{Tb}$ & 0,73 & & 1,01 & 1,06 & 1,29 & 0,58 & 0,06 & 2,19 & \\
\hline Dy & 4,51 & & 6,45 & 6,72 & 8,30 & 3,83 & 0,38 & 14,10 & \\
\hline $\mathrm{Ho}$ & 1,08 & & 1,41 & 1,51 & 2,04 & 0,87 & 0,09 & 3,37 & \\
\hline $\mathrm{Er}$ & 3,18 & & 3,99 & 4,86 & 6,04 & 3,07 & 0,32 & 10,20 & \\
\hline $\mathrm{Tm}$ & 0,56 & & 0,71 & 0,82 & 1,08 & 0,56 & 0,06 & 1,92 & \\
\hline $\mathrm{Yb}$ & 4,04 & & 4,71 & 5,64 & 7,67 & 4,23 & 0,55 & 14,50 & \\
\hline Lu & 0,62 & & 0,67 & 0,85 & 1,17 & 0,73 & 0,11 & 2,18 & \\
\hline $\mathrm{Ba}$ & 390,00 & 514,00 & 125,91 & 231,50 & 90,60 & 90,36 & 317,87 & 1,92 & 30,00 \\
\hline Co & $<6$ & $<6$ & $<6$ & $<6$ & $<6$ & $<6$ & $<6$ & $<6$ & $<6$ \\
\hline $\mathrm{Cr}$ & $<13$ & $<13$ & $<13$ & $<13$ & $<13$ & 15,00 & $<13$ & $<13$ & $<13$ \\
\hline Cs & 6,74 & & 4,09 & 7,12 & 8,33 & 2,83 & 3,72 & 15,40 & \\
\hline $\mathrm{Hf}$ & 3,55 & & 6,17 & 7,31 & 5,17 & 6,18 & 7,40 & 8,09 & \\
\hline Mo & 0,10 & & & & 0,30 & & & 2,00 & \\
\hline $\mathrm{Nb}$ & 29,60 & 30,00 & 56,88 & 41,38 & 47,80 & 86,27 & 7,53 & 63,30 & 66,00 \\
\hline $\mathrm{Ni}$ & $<5$ & $<5$ & $<5$ & $<5$ & $<5$ & $<5$ & $<5$ & $<5$ & $<5$ \\
\hline $\mathrm{Pb}$ & 35,40 & 15,00 & 39,56 & 35,30 & 32,50 & 35,65 & 28,92 & 49,30 & 9,00 \\
\hline $\mathrm{Rb}$ & 404,00 & 314,00 & 293,19 & 354,39 & 415,00 & 358,62 & 240,33 & 783,00 & 762,00 \\
\hline Sc & $<14$ & $<14$ & $<14$ & & $<14$ & $<14$ & $<14$ & $<14$ & $<14$ \\
\hline $\mathrm{Sr}$ & 74,20 & 89,00 & 34,66 & 44,03 & 20,00 & 21,63 & 112,77 & 4,35 & 8,00 \\
\hline $\mathrm{Ta}$ & 3,30 & & & & 4,70 & & & 9,10 & \\
\hline Th & 40,20 & 52,00 & 48,49 & 86,52 & 58,80 & 66,29 & 35,78 & 35,30 & 23,00 \\
\hline$U$ & 4,34 & 3,00 & 10,03 & 30,96 & 13,80 & 20,39 & 9,78 & 8,19 & $<3$ \\
\hline
\end{tabular}




\begin{tabular}{|c|c|c|c|c|c|c|c|c|c|}
\hline Fácies & \multicolumn{4}{|c|}{ Porfirítica } & \multicolumn{3}{|c|}{ Inequigranular } & \multicolumn{2}{|c|}{ Equigranular } \\
\hline Amostra & IPV-14 & IPV-16A & CAB-04 & CAB-42 & IPV-30C & CAB-41 & CAB-30 & IPV-35A & IPV-35B \\
\hline V & $<9$ & $<9$ & $<9$ & $<9$ & $<9$ & $<9$ & $<9$ & $<9$ & $<9$ \\
\hline W & 3,90 & & & & 1,20 & & & 2,60 & \\
\hline$Y$ & 35,00 & 40,00 & 42,69 & 48,88 & 69,70 & 31,14 & 3,27 & 122,00 & 106,00 \\
\hline $\mathrm{Zr}$ & 86,20 & 210,00 & 154,83 & 202,45 & 113,00 & 132,50 & 122,64 & 79,40 & 98,00 \\
\hline $\mathrm{Cu}$ & 18,00 & $<5$ & 8,00 & $<5$ & $<5$ & $<5$ & $<5$ & $<5$ & $<5$ \\
\hline Ga & 22,00 & 18,00 & 19,00 & 20,00 & 21,00 & 18,00 & 20,00 & 29,00 & 27,00 \\
\hline $\mathrm{Zn}$ & 17,00 & 31,00 & 12,00 & 43,00 & 21,00 & 19,00 & 8,00 & 37,00 & 40,00 \\
\hline LREE & 119,70 & & 232,35 & 283,81 & 155,75 & 170,06 & 22,97 & 90,11 & \\
\hline HREE & 19,51 & & 25,87 & 28,07 & 34,93 & 17,44 & 2,09 & 59,57 & \\
\hline REE & 139,21 & & 258,22 & 311,89 & 190,68 & 187,50 & 25,05 & 149,68 & \\
\hline & & & & Raz & & & & & \\
\hline 1/TiO2 & 10,20 & 4,72 & 8,00 & 5,88 & 11,76 & 7,14 & 25,00 & 90,91 & 31,25 \\
\hline mg\# & 10,44 & 17,69 & 1,62 & 1,00 & 9,45 & 1,43 & 2,59 & 0,00 & 2,18 \\
\hline$f e^{*}$ & 0,94 & 0,90 & 0,99 & 0,99 & 0,95 & 0,99 & 0,99 & 1,00 & 0,99 \\
\hline $\mathrm{K} / \mathrm{Rb}$ & 119,35 & 153,02 & 145,49 & 115,45 & 90,19 & 109,92 & 213,05 & 47,16 & 46,07 \\
\hline $\mathrm{Ba} / \mathrm{Sr}$ & 5,26 & 5,78 & 3,63 & 5,26 & 4,53 & 4,18 & 2,82 & 0,44 & 3,75 \\
\hline $\mathrm{Rb} / \mathrm{Sr}$ & 5,44 & 3,53 & 8,46 & 8,05 & 20,75 & 16,58 & 2,13 & 180,00 & 95,25 \\
\hline $\mathrm{Zr} / \mathrm{Hf}$ & 24,28 & & 25,08 & 27,70 & 21,86 & 21,44 & 16,58 & 9,81 & \\
\hline $\mathrm{Nb} / \mathrm{Ta}$ & 8,97 & & & & 10,17 & & & 6,96 & \\
\hline $\mathrm{Th} / \mathrm{U}$ & 9,26 & 17,33 & 4,83 & 2,79 & 4,26 & 3,25 & 3,66 & 4,31 & 11,50 \\
\hline $\mathrm{Nb} / \mathrm{Ti}$ & 0,05 & 0,02 & 0,08 & 0,04 & 0,09 & 0,10 & 0,03 & 0,96 & 0,34 \\
\hline $\mathrm{Eu} / \mathrm{Eu}^{*}$ & 0,37 & & 0,21 & 0,18 & 0,14 & 0,20 & 2,72 & 0,00 & \\
\hline$(\mathrm{La} / \mathrm{Sm}) \mathrm{N}$ & 3,00 & & 5,04 & 4,88 & 2,92 & 5,96 & 6,88 & 0,81 & \\
\hline$(\mathrm{La} / \mathrm{Yb}) \mathrm{N}$ & 4,25 & & 8,78 & 8,28 & 3,06 & 7,07 & 4,75 & 0,59 & \\
\hline K2O/Na2O & 1,27 & 1,44 & 1,46 & 1,34 & 1,18 & 1,30 & 2,21 & 0,94 & 0,84 \\
\hline ANK & 1,04 & 1,00 & 1,08 & 1,06 & 1,07 & 1,07 & 1,14 & 1,03 & 0,97 \\
\hline ACNK & 0,95 & 0,93 & 0,98 & 0,95 & 0,99 & 0,97 & 1,07 & 0,97 & 0,91 \\
\hline MALI & 9,70 & 9,23 & 8,06 & 7,90 & 7,81 & 7,79 & 8,60 & 8,74 & 8,75 \\
\hline ASI & 0,95 & 0,93 & 0,98 & 0,95 & 0,99 & 0,98 & 1,07 & 0,97 & 0,91 \\
\hline $10000 * \mathrm{Ga} / \mathrm{Al}$ & 2,90 & 2,63 & 2,93 & 3,13 & 3,30 & 2,84 & 2,95 & 4,23 & 4,11 \\
\hline TSatZr & 724,6 & 797,8 & 781,5 & 800,8 & 757,1 & 768,3 & 770,9 & 724,3 & 734,5 \\
\hline
\end{tabular}




\begin{tabular}{|c|c|c|c|c|c|c|c|}
\hline Fácies & $\begin{array}{l}\text { Porfirítica } \\
\text { Alterada }\end{array}$ & $\begin{array}{c}\text { Inequigranular } \\
\text { Alterada }\end{array}$ & \multicolumn{2}{|c|}{ Equigranular Alterada } & \multirow{2}{*}{$\begin{array}{c}\begin{array}{c}\text { Equigranular } \\
\text { muito } \\
\text { alterada }\end{array} \\
\text { IPV-35D }\end{array}$} & \multirow{2}{*}{$\begin{array}{l}\text { Greisen I } \\
\text { IPV-35H }\end{array}$} & \multirow{2}{*}{$\begin{array}{c}\text { Greisen II } \\
\text { IPV-15C }\end{array}$} \\
\hline Amostra & IPV-16B & IPV-22A & IPV-35C & IPV-35E & & & \\
\hline \multicolumn{8}{|c|}{ Maiores (wt\%) } \\
\hline $\mathrm{SiO} 2$ & 73,62 & 76,14 & 75,95 & 75,12 & 75,43 & 61,28 & 58,1 \\
\hline $\mathrm{TiO} 2$ & 0,197 & 0,256 & 0,032 & 0,018 & 0,074 & 0,045 & 0,513 \\
\hline Al2O3 & 12,14 & 11,09 & 12,41 & 12,48 & 12,66 & 19,44 & 19,43 \\
\hline Fe2O3t & 1,72 & 1,63 & 0,83 & 1,02 & 0,82 & 4,79 & 7,52 \\
\hline $\mathrm{MnO}$ & 0,04 & 0,05 & 0,04 & 0,06 & 0,04 & 0,35 & 1,32 \\
\hline $\mathrm{MgO}$ & 0,20 & 0,21 & 0,02 & 0,02 & 0,01 & 0,01 & 1,52 \\
\hline $\mathrm{CaO}$ & 1,32 & 0,66 & 0,55 & 0,57 & 0,49 & 0,29 & 0,05 \\
\hline $\mathrm{Na} 2 \mathrm{O}$ & 3,42 & 3,61 & 4,51 & 4,27 & 4,05 & 0,26 & 0,29 \\
\hline $\mathrm{K} 2 \mathrm{O}$ & 5,17 & 4,44 & 4,39 & 4,63 & 4,59 & 6,95 & 7,28 \\
\hline P2O5 & 0,05 & 0,07 & 0,01 & 0,01 & 0,01 & 0,01 & 0,03 \\
\hline $\mathrm{PF}$ & 0,76 & 0,52 & 0,51 & 0,57 & 0,47 & 3,1 & 2,94 \\
\hline Total & 98,63 & 98,67 & 99,25 & 98,76 & 98,64 & 96,52 & 98,99 \\
\hline \multicolumn{8}{|c|}{ Menores e Traço (ppm) } \\
\hline $\mathrm{F}$ & 2701 & 1220 & 3625 & 3556 & 3062 & 2437 & 22229 \\
\hline $\mathrm{Cl}$ & $<500$ & $<500$ & $<500$ & $<500$ & $<500$ & $<500$ & $<500$ \\
\hline $\mathrm{S}$ & $<550$ & $<550$ & $<550$ & $<550$ & $<550$ & 4006 & $<550$ \\
\hline La & 80,00 & 69,30 & 20,00 & 20,00 & 20,00 & 7,83 & 29,00 \\
\hline $\mathrm{Ce}$ & 129,00 & 126,00 & 46,00 & 44,00 & 52,40 & 25,10 & 84,00 \\
\hline $\mathrm{Pr}$ & & 13,90 & & & 7,73 & 4,23 & \\
\hline $\mathrm{Nd}$ & 48,00 & 44,70 & 31,00 & 21,00 & 29,90 & 17,70 & 35,00 \\
\hline $\mathrm{Sm}$ & & 7,35 & & & 10,10 & 7,15 & \\
\hline $\mathrm{Eu}$ & & 0,78 & & & 0,08 & 0,03 & \\
\hline $\mathrm{Gd}$ & & 5,45 & & & 10,50 & 8,28 & \\
\hline $\mathrm{Tb}$ & & 0,88 & & & 1,95 & 1,63 & \\
\hline Dy & & 5,23 & & & 12,00 & 11,00 & \\
\hline Ho & & 1,17 & & & 2,87 & 2,64 & \\
\hline $\mathrm{Er}$ & & 3,28 & & & 8,48 & 7,81 & \\
\hline $\mathrm{Tm}$ & & 0,52 & & & 1,56 & 1,40 & \\
\hline $\mathrm{Yb}$ & & 3,49 & & & 11,50 & 9,95 & \\
\hline $\mathrm{Lu}$ & & 0,51 & & & 1,73 & 1,49 & \\
\hline $\mathrm{Ba}$ & 524,00 & 650,00 & 39,00 & 30,00 & 22,50 & 83,60 & 339,00 \\
\hline Co & $<6$ & $<6$ & $<6$ & $<6$ & $<6$ & $<6$ & 10,00 \\
\hline $\mathrm{Cr}$ & $<13$ & $<13$ & $<13$ & $<13$ & $<13$ & $<13$ & 82,00 \\
\hline Cs & & 1,81 & & & 15,10 & 35,00 & \\
\hline $\mathrm{Hf}$ & & 6,22 & & & 6,77 & 7,37 & \\
\hline Mo & & 5,20 & & & 1,40 & 0,40 & \\
\hline $\mathrm{Nb}$ & 30,00 & 32,80 & 67,00 & 76,00 & 75,90 & 116,00 & 24,00 \\
\hline $\mathrm{Ni}$ & $<5$ & $<5$ & $<5$ & $<5$ & $<5$ & 6,00 & 36,00 \\
\hline $\mathrm{Pb}$ & 2,00 & 10,10 & 12,00 & 50,00 & 35,90 & 11145,00 & 36,00 \\
\hline $\mathrm{Rb}$ & 297,00 & 223,00 & 648,00 & 692,00 & 650,00 & 1268,00 & 3163,00 \\
\hline Sc & $<14$ & $<14$ & $<14$ & $<14$ & $<14$ & $<14$ & 19,00 \\
\hline $\mathrm{Sr}$ & 173,00 & 95,20 & 11,00 & 6,00 & 6,34 & 2,87 & 14,00 \\
\hline $\mathrm{Ta}$ & & 1,90 & & & 6,70 & 9,00 & \\
\hline Th & 45,00 & 43,50 & 31,00 & 28,00 & 46,50 & 47,40 & $<7$ \\
\hline
\end{tabular}




\begin{tabular}{|c|c|c|c|c|c|c|c|}
\hline \multirow{2}{*}{$\begin{array}{c}\text { Fácies } \\
\text { Amostra }\end{array}$} & \multirow{2}{*}{$\begin{array}{c}\begin{array}{c}\text { Porfirítica } \\
\text { Alterada }\end{array} \\
\text { IPV-16B }\end{array}$} & \multirow{2}{*}{$\begin{array}{c}\begin{array}{c}\text { Inequigranular } \\
\text { Alterada }\end{array} \\
\text { IPV-22A }\end{array}$} & \multicolumn{2}{|c|}{ Equigranular Alterada } & \multirow{2}{*}{$\begin{array}{c}\begin{array}{c}\text { Equigranular } \\
\text { muito } \\
\text { alterada }\end{array} \\
\text { IPV-35D }\end{array}$} & \multirow{2}{*}{$\begin{array}{l}\text { Greisen I } \\
\text { IPV-35H }\end{array}$} & \multirow{2}{*}{$\begin{array}{c}\text { Greisen II } \\
\text { IPV-15C }\end{array}$} \\
\hline & & & IPV-35C & IPV-35E & & & \\
\hline $\mathrm{U}$ & 6,00 & 6,69 & 10,00 & 7,00 & 15,60 & 17,20 & $<3$ \\
\hline $\mathrm{V}$ & $<9$ & 9,00 & $<9$ & $<9$ & $<9$ & $<9$ & 59,00 \\
\hline W & & 0,10 & & & 1,00 & 5,90 & \\
\hline$Y$ & 50,00 & 37,00 & 106,00 & 128,00 & 91,20 & 102,00 & 23,00 \\
\hline $\mathrm{Zr}$ & 193,00 & 203,00 & 120,00 & 106,00 & 97,00 & 96,00 & 142,00 \\
\hline $\mathrm{Cu}$ & $<5$ & $<5$ & $<5$ & $<5$ & $<5$ & 132,00 & 7,00 \\
\hline Ga & 19,00 & 16,00 & 25,00 & 27,00 & 25,00 & 70,00 & 58,00 \\
\hline $\mathrm{Zn}$ & 28,00 & 29,00 & 29,00 & 48,00 & 26,00 & 7517,00 & 333,00 \\
\hline LREE & & 261,25 & & & 120,13 & 62,01 & \\
\hline HREE & & 21,31 & & & 50,67 & 44,23 & \\
\hline REE & & 282,56 & & & 170,80 & 106,24 & \\
\hline \multicolumn{8}{|c|}{ Razões } \\
\hline $1 / \mathrm{TiO} 2$ & 5,08 & 3,91 & 31,25 & 55,56 & 13,51 & 22,22 & 1,95 \\
\hline mg\# & 18,73 & 20,34 & 4,56 & 3,74 & 2,36 & 0,21 & 28,60 \\
\hline$f e^{*}$ & 0,90 & 0,89 & 0,98 & 0,98 & 0,99 & 1,00 & 0,83 \\
\hline $\mathrm{K} / \mathrm{Rb}$ & 144,46 & 165,23 & 56,22 & 55,52 & 58,60 & 45,49 & 19,10 \\
\hline $\mathrm{Ba} / \mathrm{Sr}$ & 3,03 & 6,83 & 3,55 & 5,00 & 3,55 & 29,13 & 24,21 \\
\hline $\mathrm{Rb} / \mathrm{Sr}$ & 1,72 & 2,34 & 58,91 & 115,33 & 102,52 & 441,81 & 225,93 \\
\hline $\mathrm{Zr} / \mathrm{Hf}$ & & 32,64 & & & 14,33 & 13,03 & \\
\hline $\mathrm{Nb} / \mathrm{Ta}$ & & 17,26 & & & 11,33 & 12,89 & \\
\hline $\mathrm{Th} / \mathrm{U}$ & 7,50 & 6,50 & 3,10 & 4,00 & 2,98 & 2,76 & 3,00 \\
\hline $\mathrm{Nb} / \mathrm{Ti}$ & 0,03 & 0,02 & 0,35 & 0,70 & 0,17 & 0,43 & 0,01 \\
\hline $\mathrm{Eu} / \mathrm{Eu}^{*}$ & & 0,38 & & & 0,02 & 0,01 & \\
\hline$(\mathrm{La} / \mathrm{Sm}) \mathrm{N}$ & & 5,89 & & & 1,24 & 0,68 & \\
\hline$(\mathrm{La} / \mathrm{Yb}) \mathrm{N}$ & & 13,49 & & & 1,18 & 0,53 & \\
\hline $\mathrm{K} 2 \mathrm{O} / \mathrm{Na} 2 \mathrm{O}$ & 1,51 & 1,23 & 0,97 & 1,08 & 1,13 & 26,73 & 25,10 \\
\hline ANK & 1,08 & 1,03 & 1,02 & 1,04 & 1,09 & 2,45 & 2,33 \\
\hline ACNK & 0,89 & 0,93 & 0,94 & 0,95 & 1,01 & 2,29 & 2,30 \\
\hline MALI & 7,27 & 7,39 & 8,35 & 8,33 & 8,15 & 6,92 & 7,52 \\
\hline ASI & 0,89 & 0,93 & 0,94 & 0,96 & 1,01 & 2,29 & 2,30 \\
\hline $10000 * \mathrm{Ga} / \mathrm{Al}$ & 2,96 & 2,73 & 3,81 & 4,09 & 3,73 & 6,80 & 5,64 \\
\hline TSatZr & 787,9 & 801 & 755,4 & 746,3 & 743,8 & 789,4 & 824,7 \\
\hline
\end{tabular}


ANEXO IV - TABELAS DE QUÍMICA MINERAL 



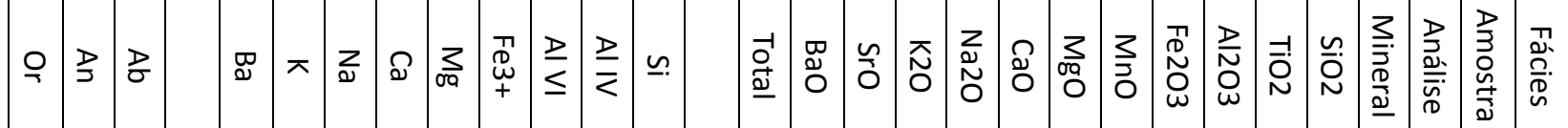

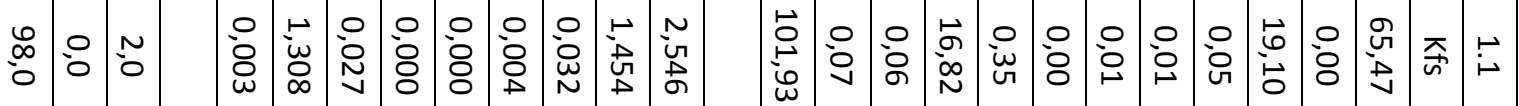

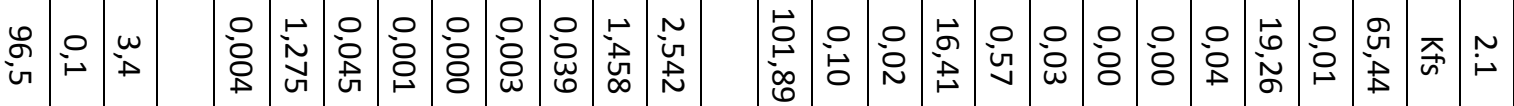

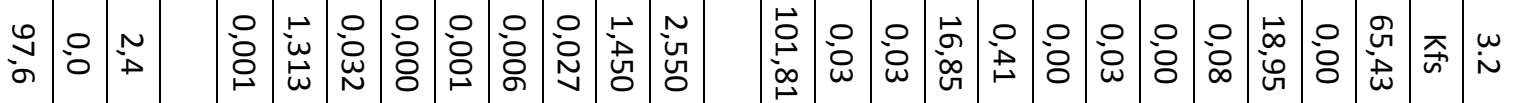

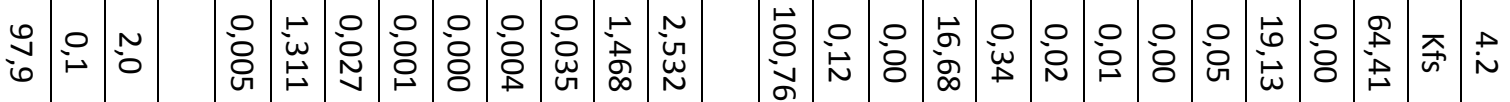

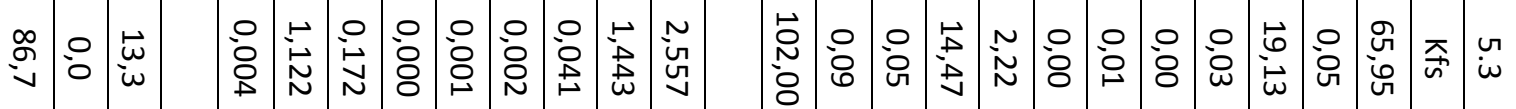

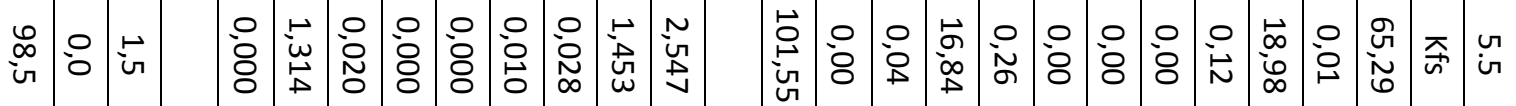

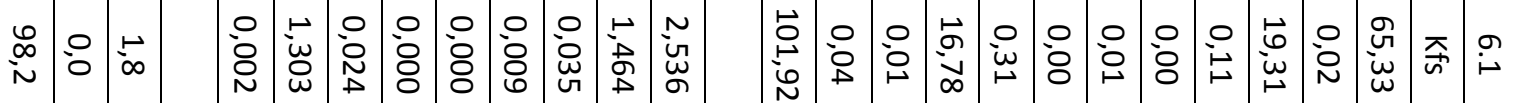

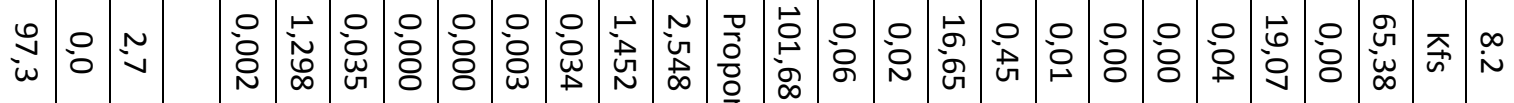

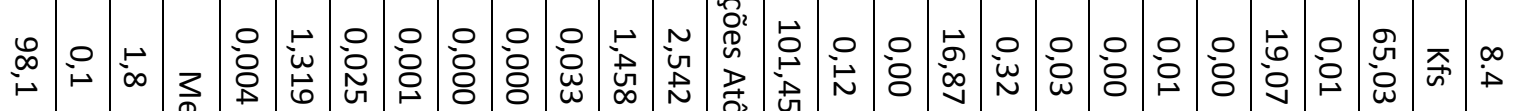

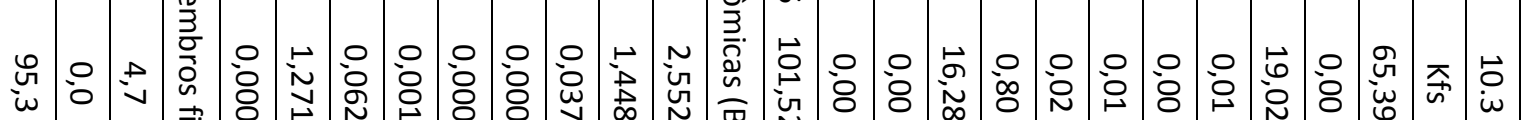
w

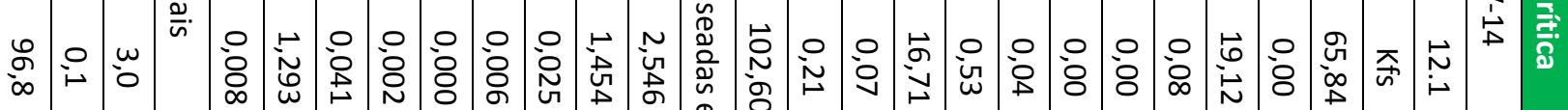

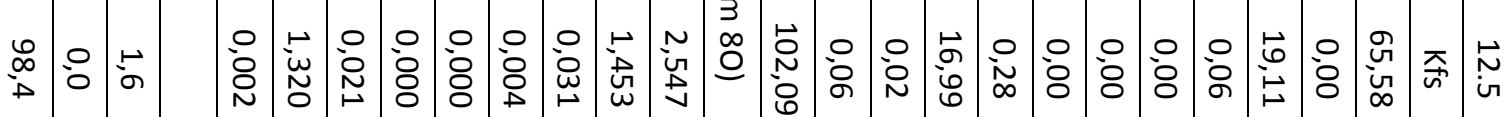

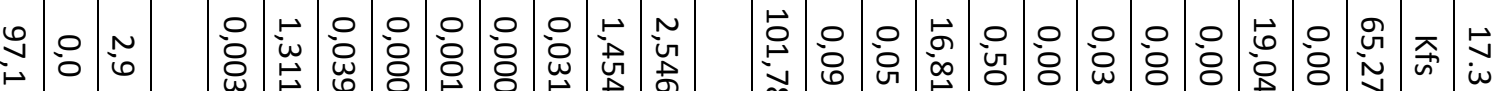

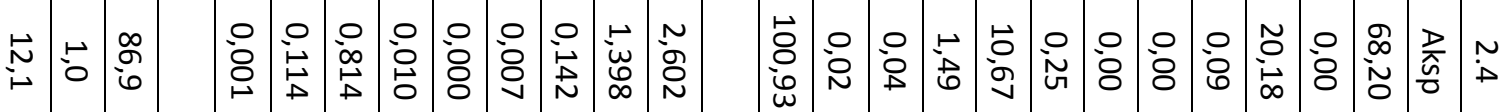

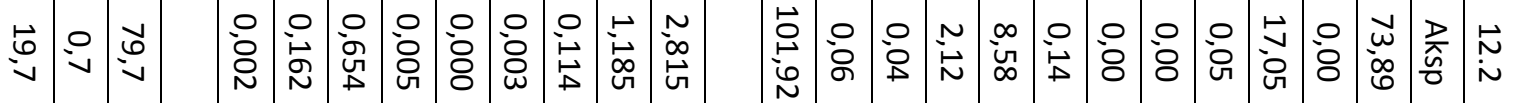

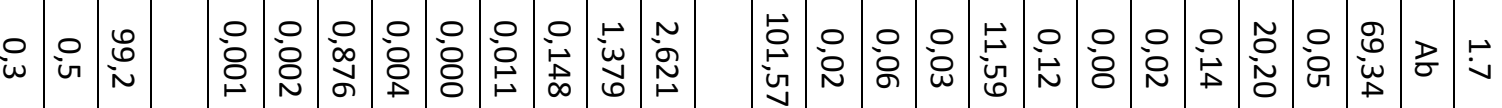

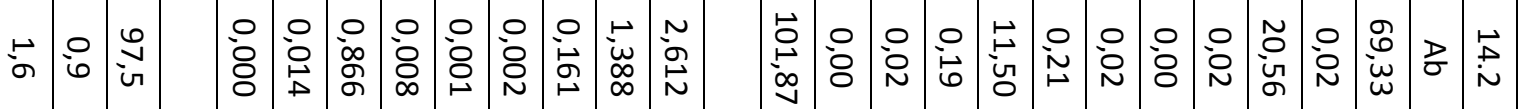

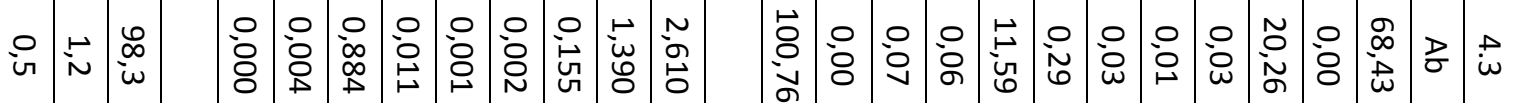

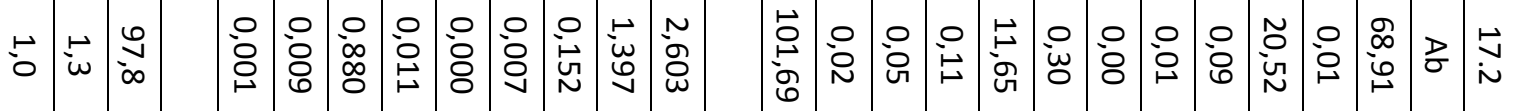

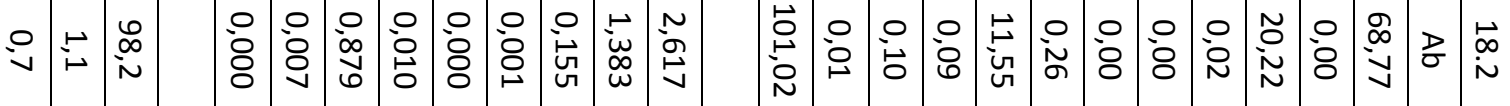




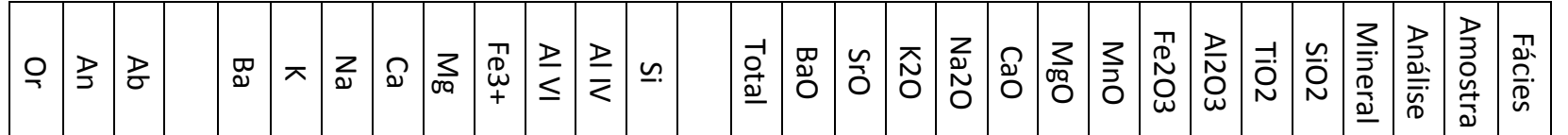

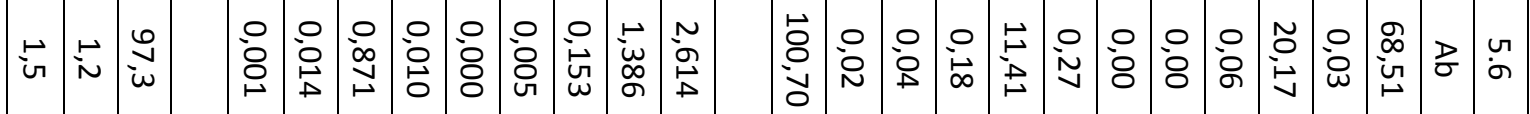

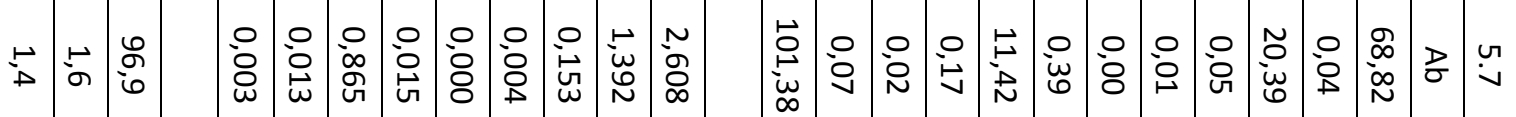

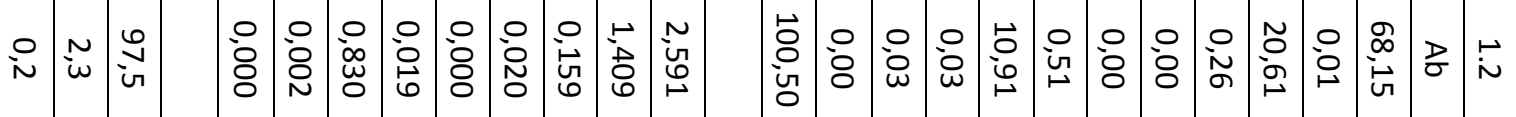

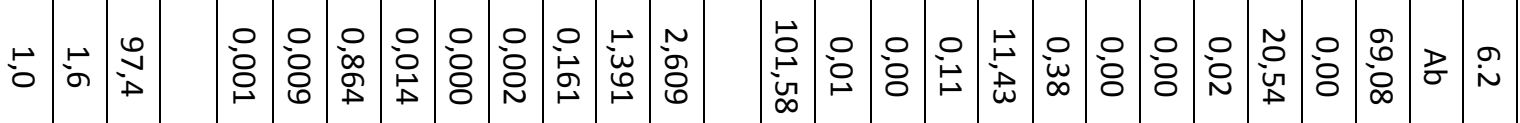

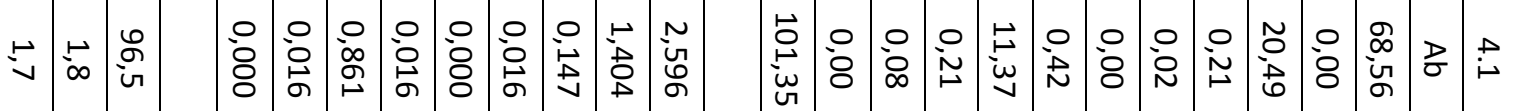

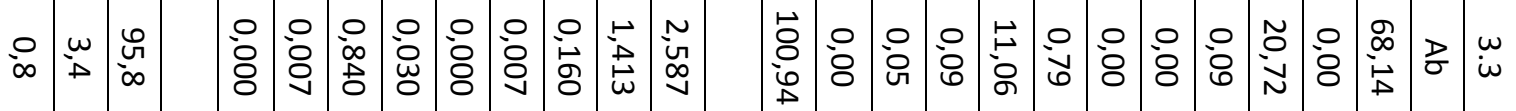

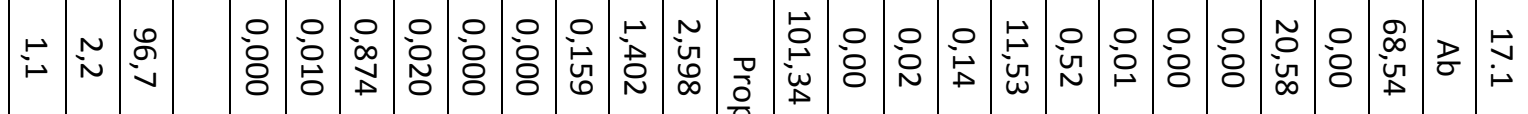

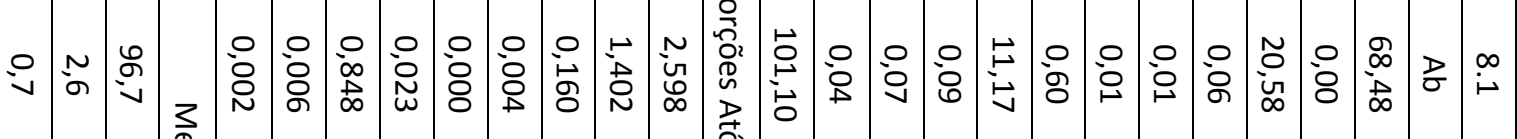

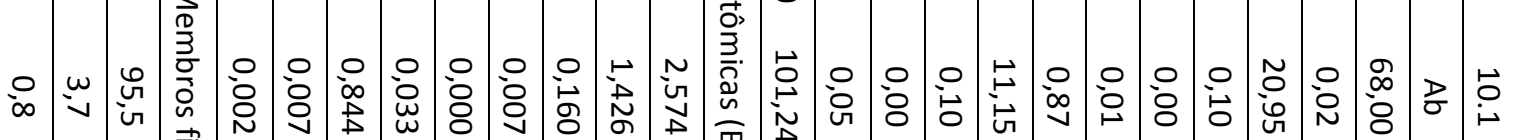

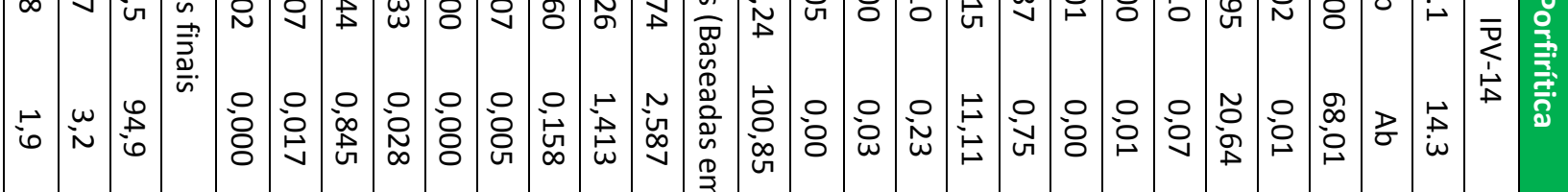

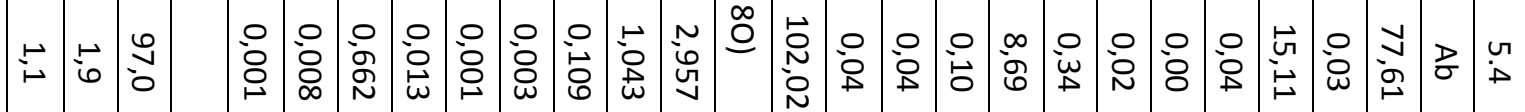

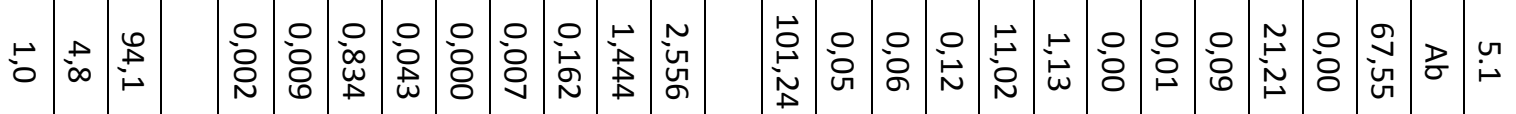

芯点慈

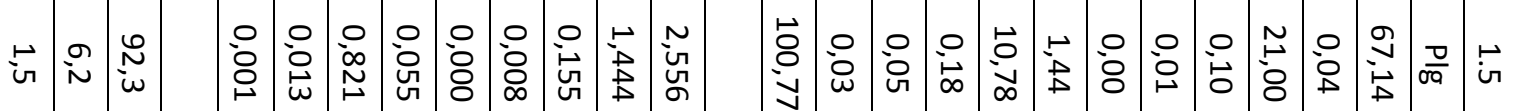

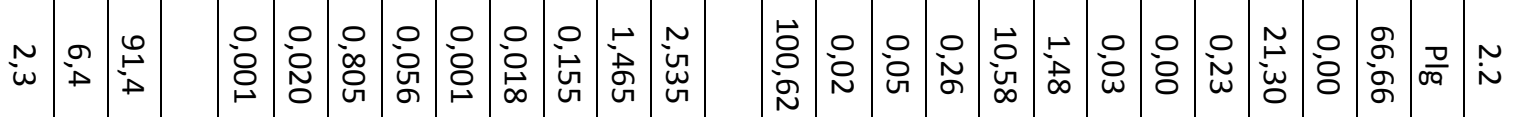

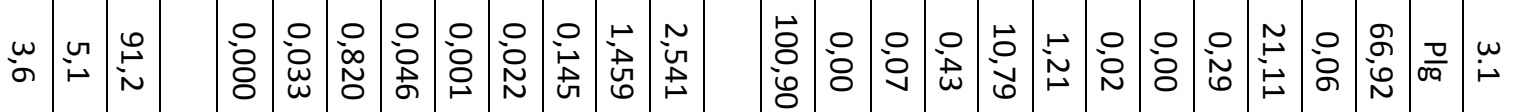

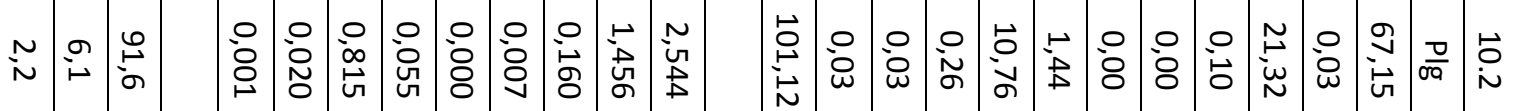

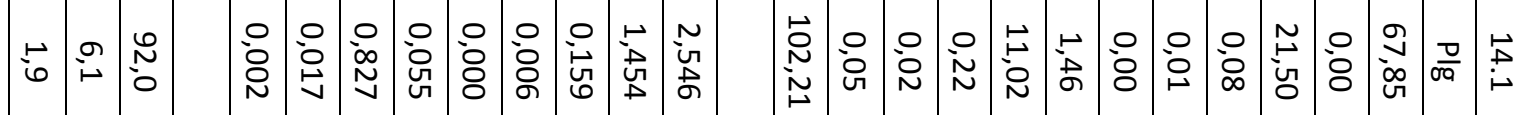


으 고

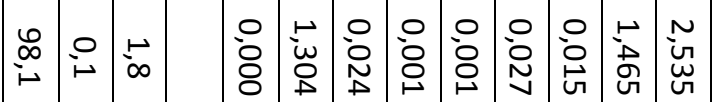

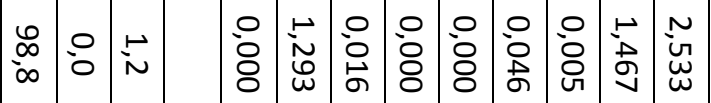

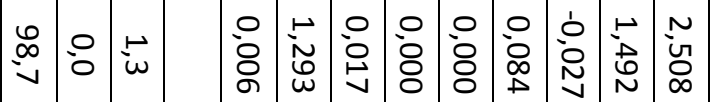

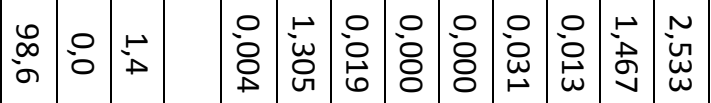

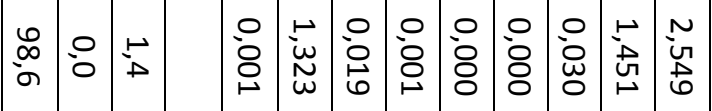

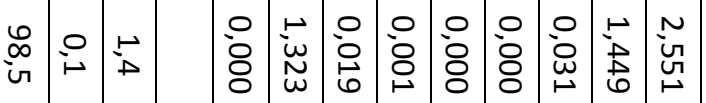

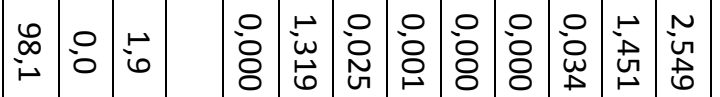

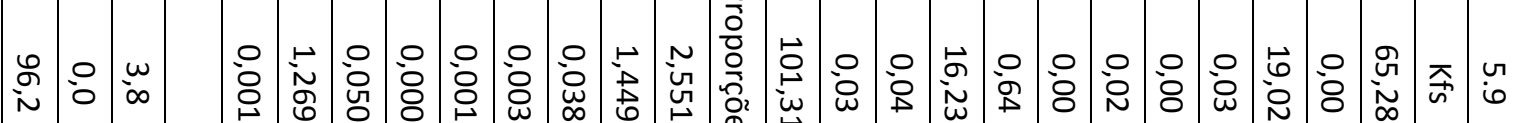

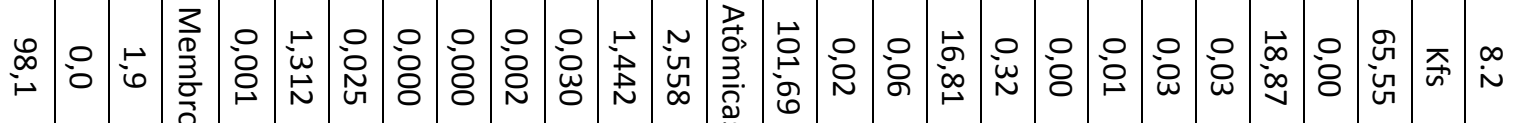

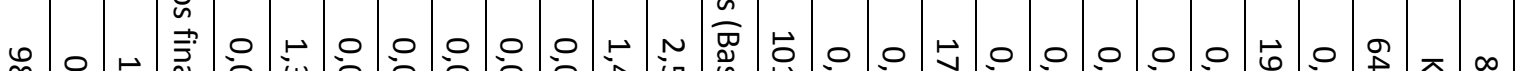

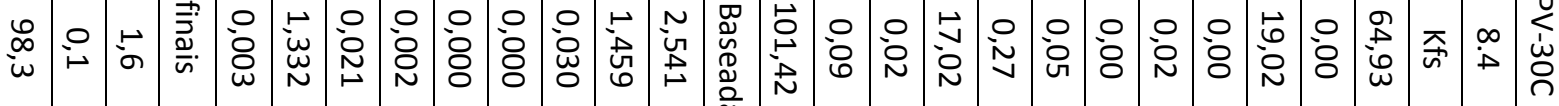

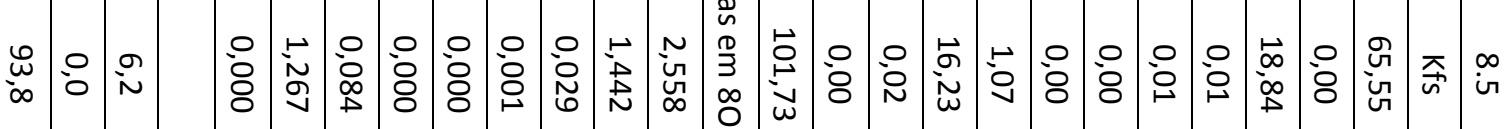

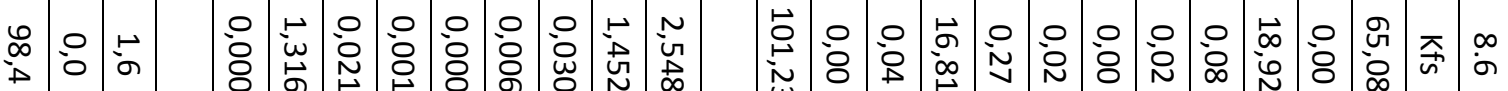

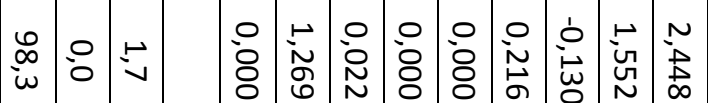

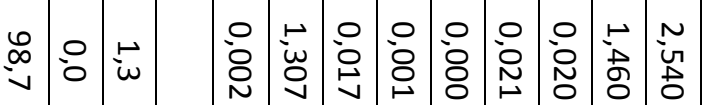

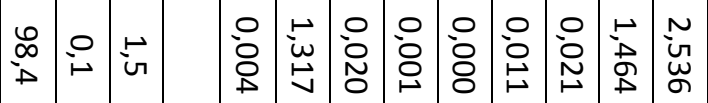

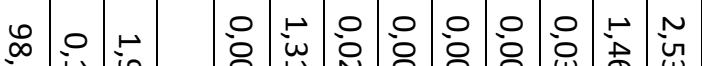

○

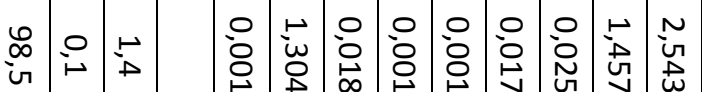

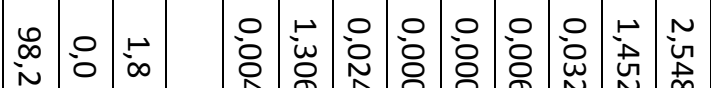

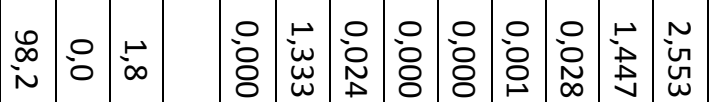

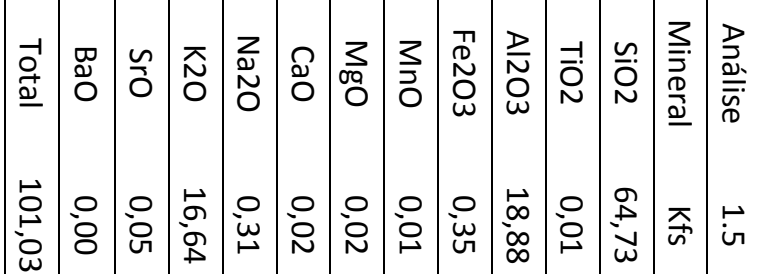

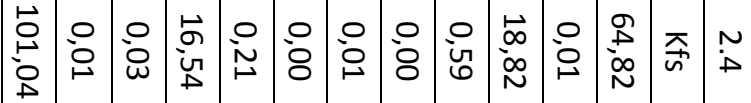

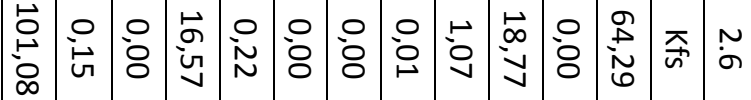

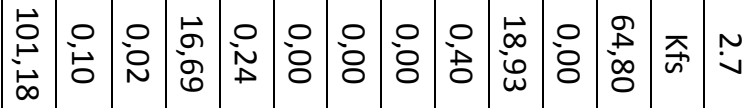

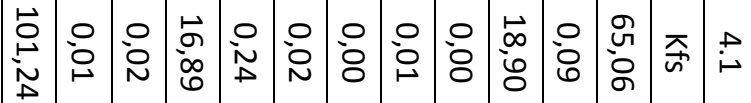

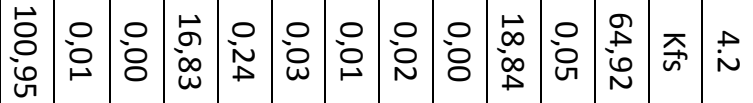

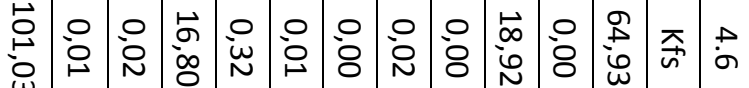

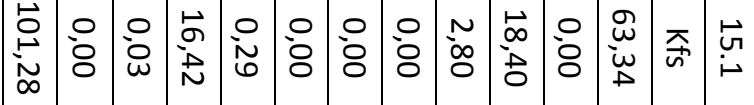

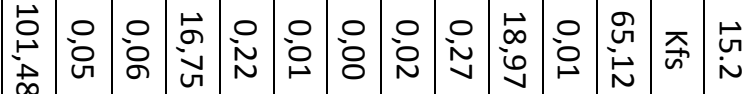

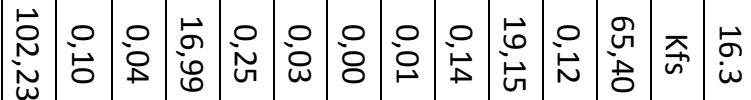

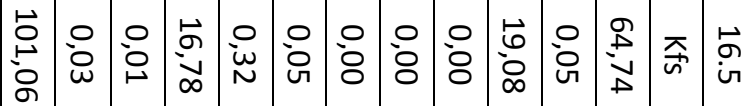

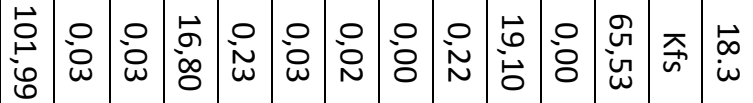

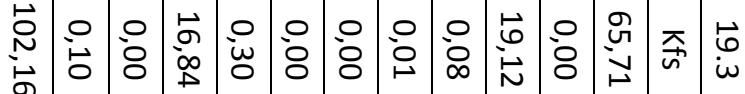

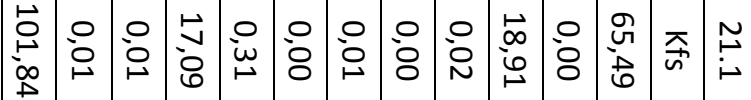




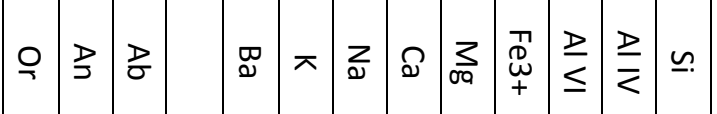

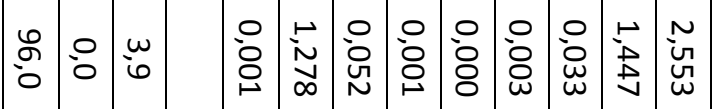

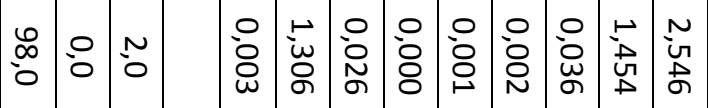

$\left.\begin{array}{l}\infty \\ \infty\end{array}\right)$

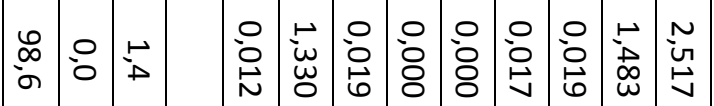

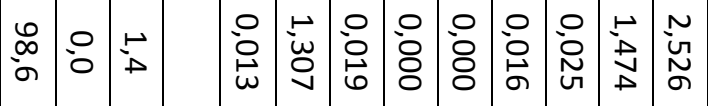

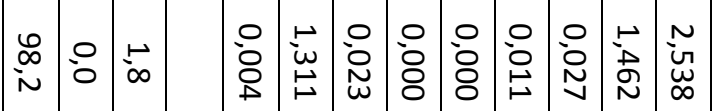

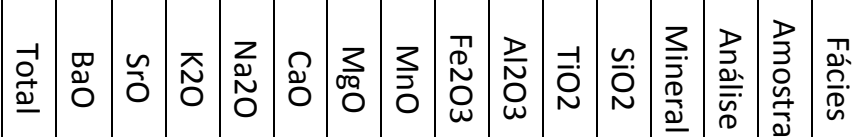

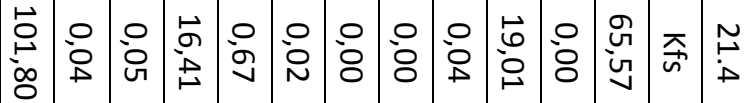

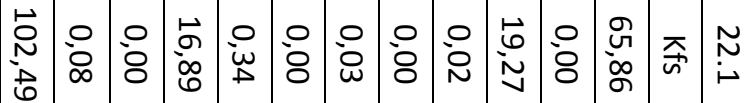

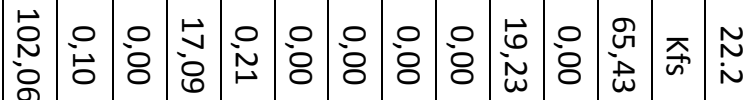

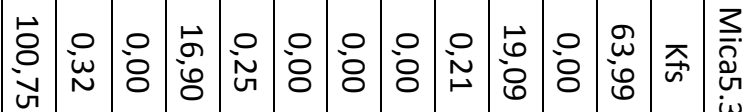

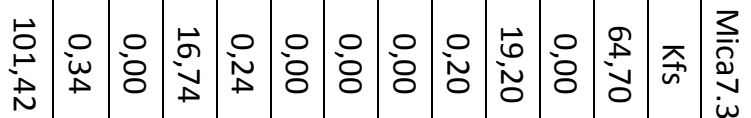

$\overrightarrow{0}$
$\dot{0}$
$\dot{0}$

i $\left.\frac{1}{3} \frac{3}{3}\right)^{\frac{3}{2}}$ N ○ N

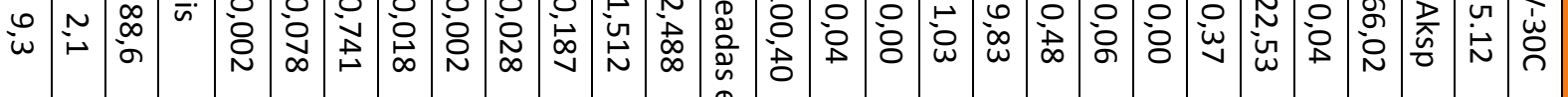

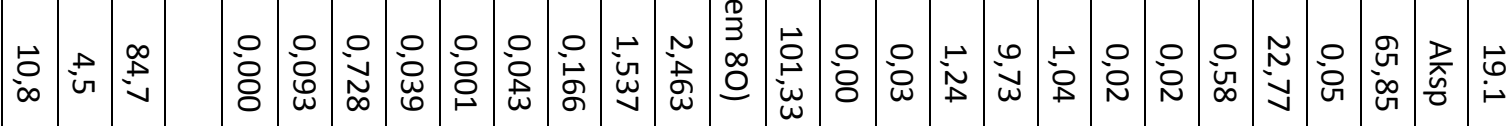

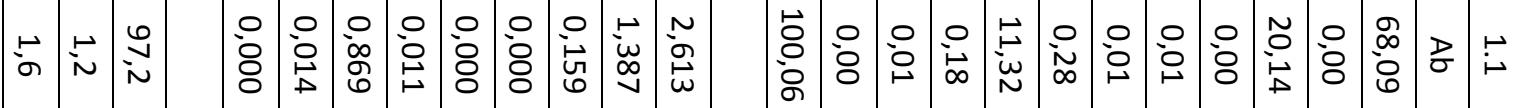

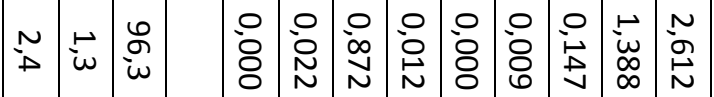

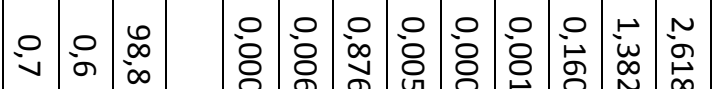

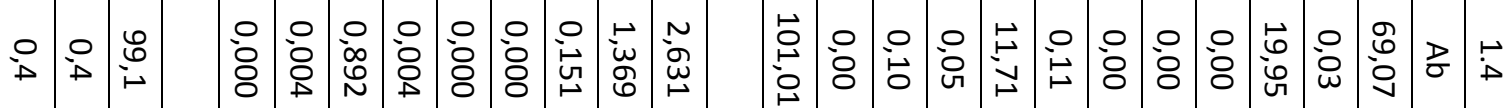

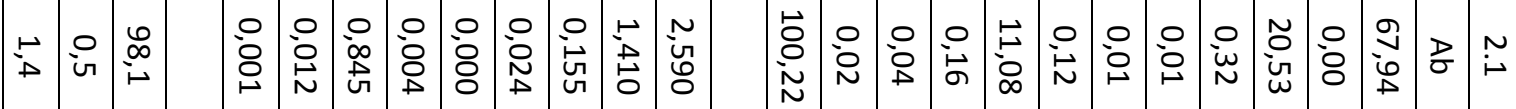

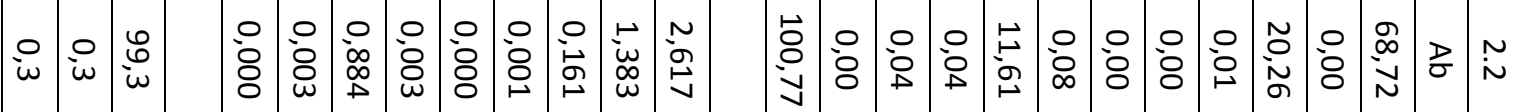

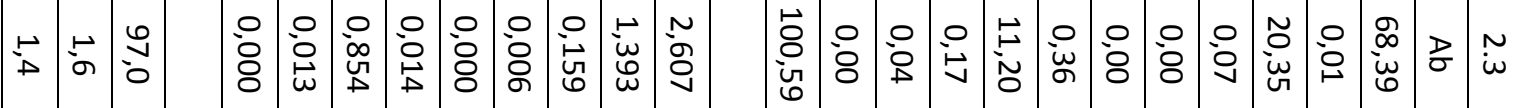

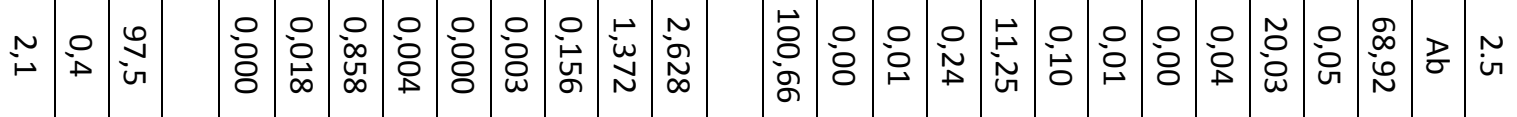




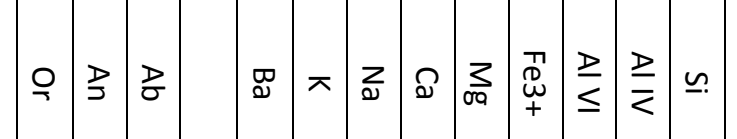

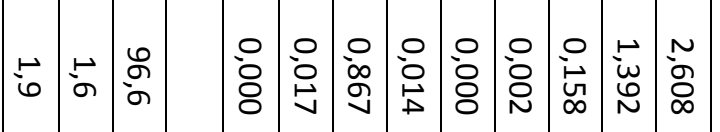

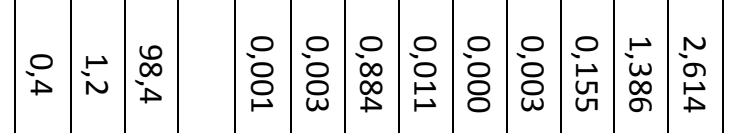

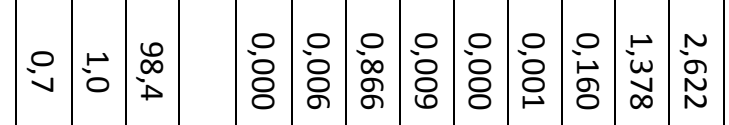

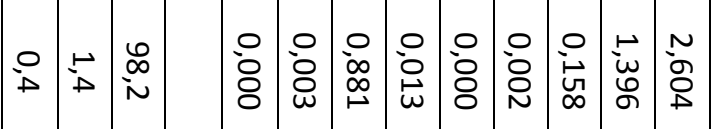

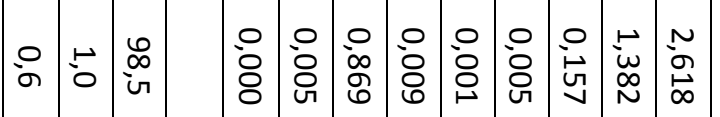

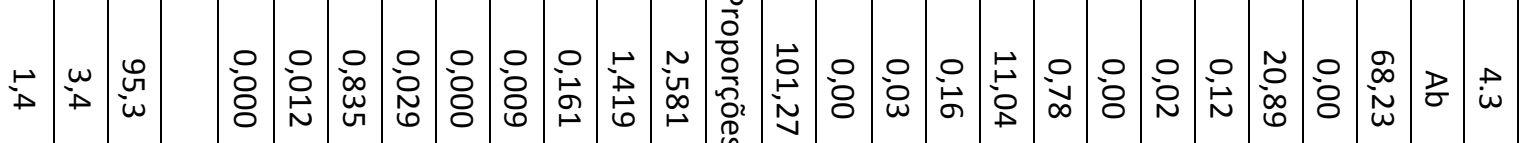

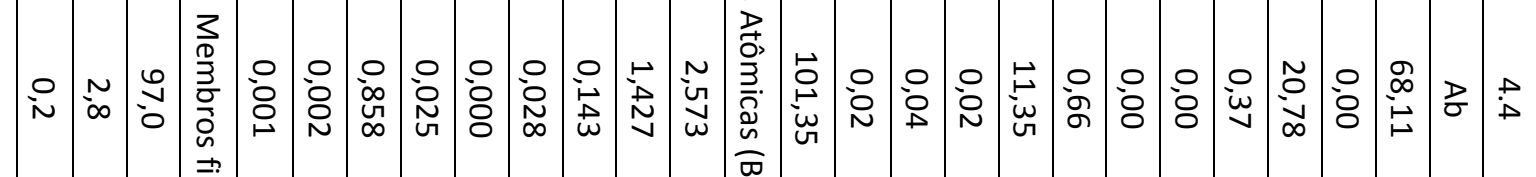

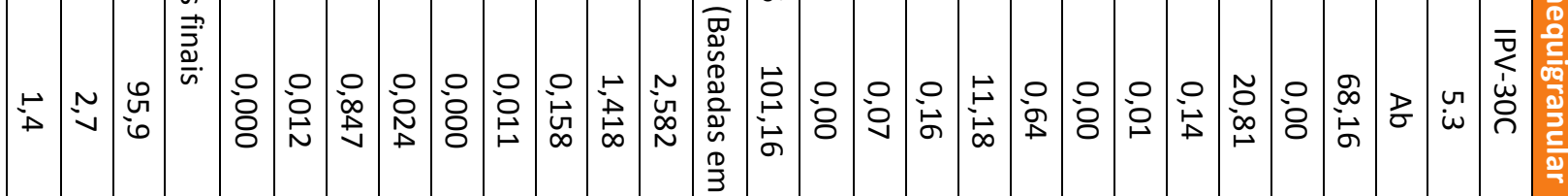

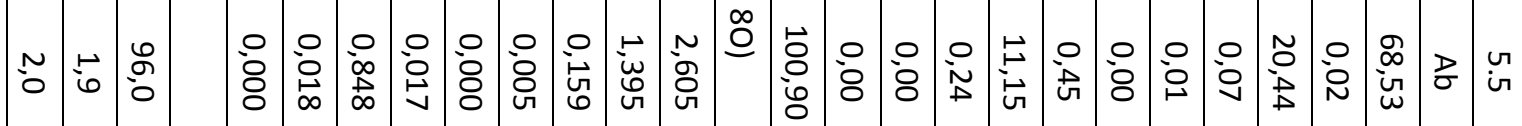

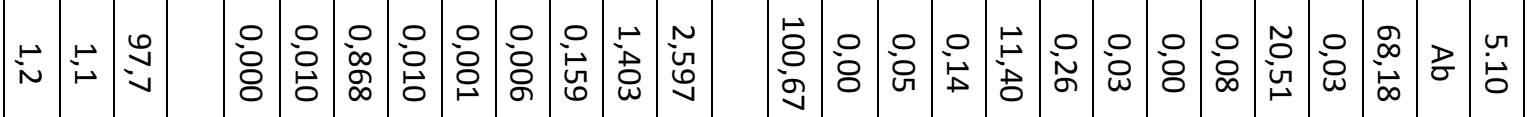

占爷总

占宏总

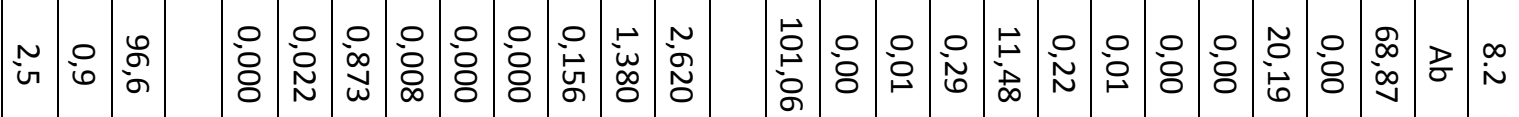

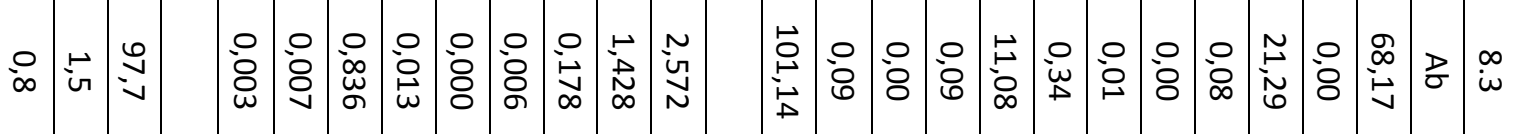

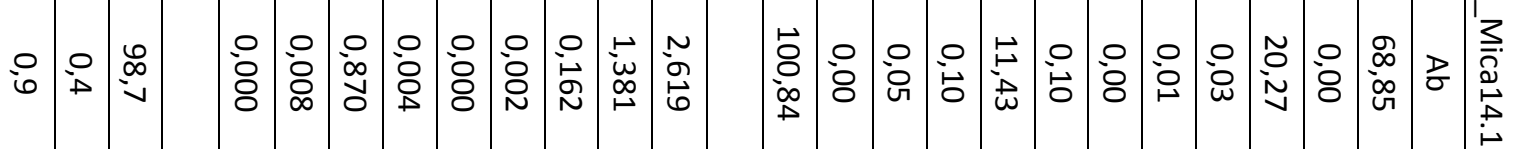




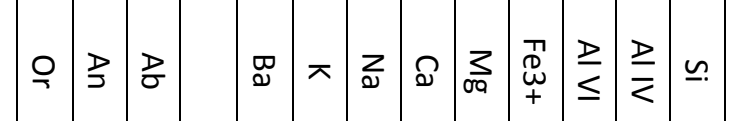

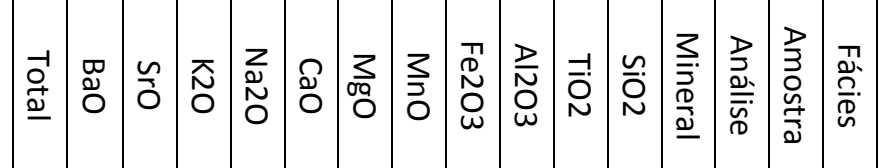

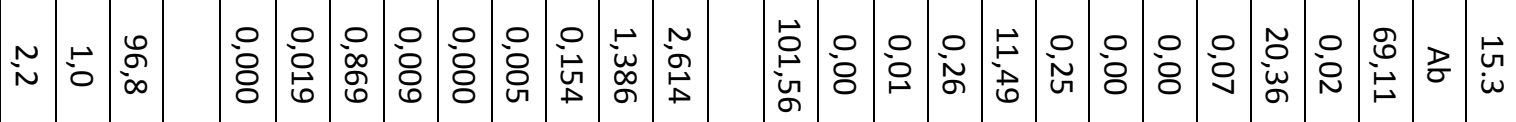

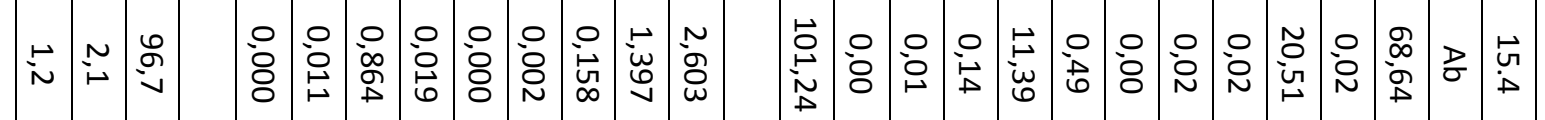

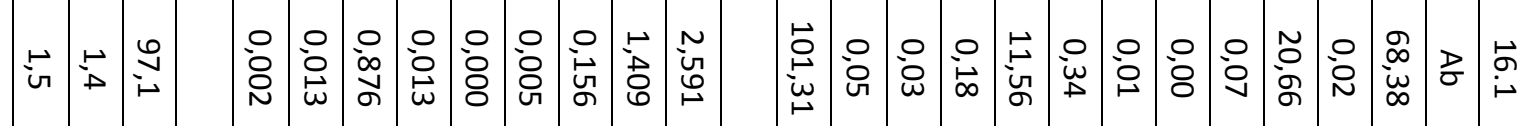

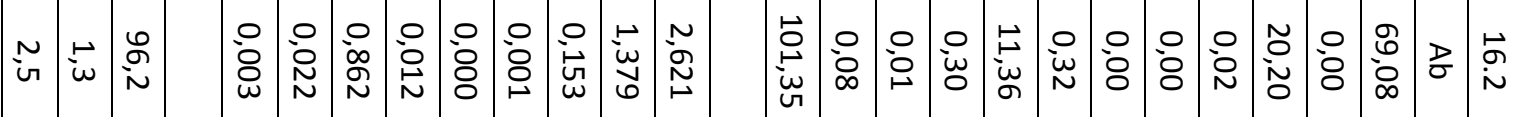

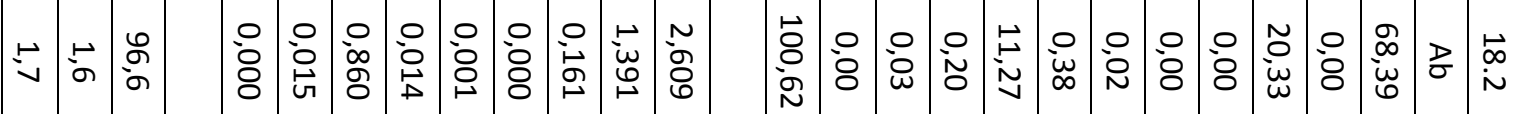

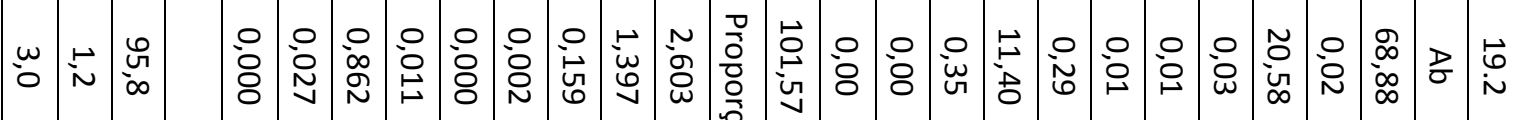

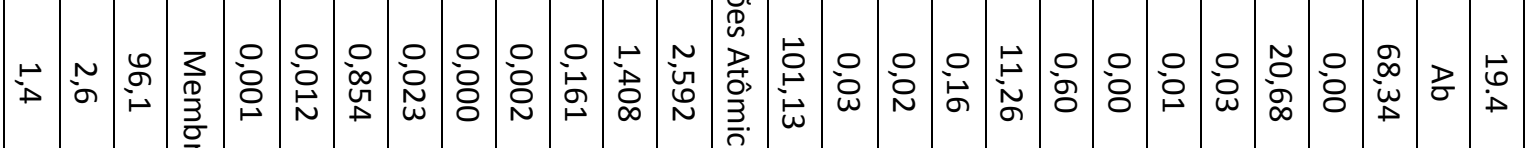

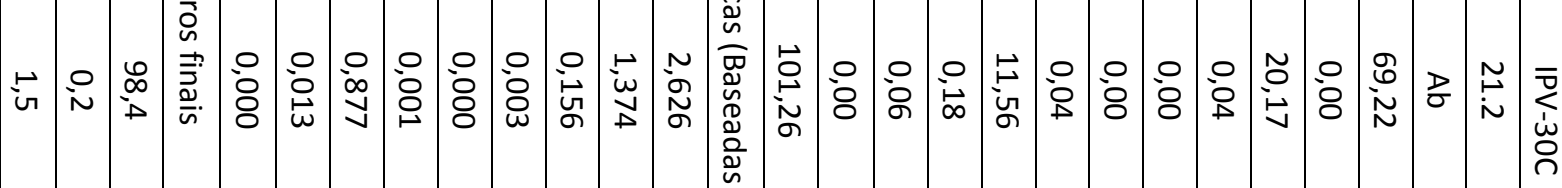

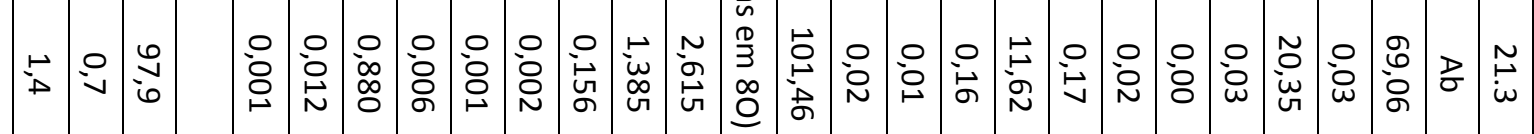

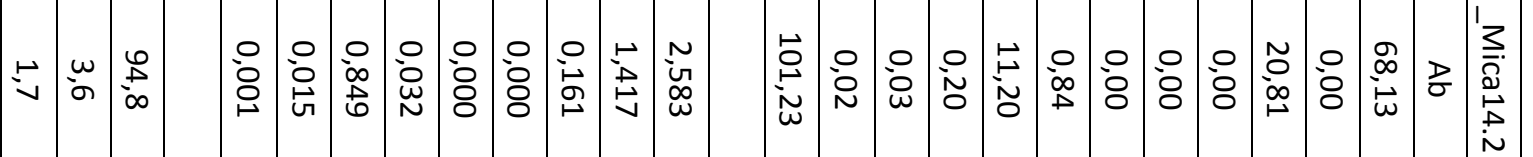

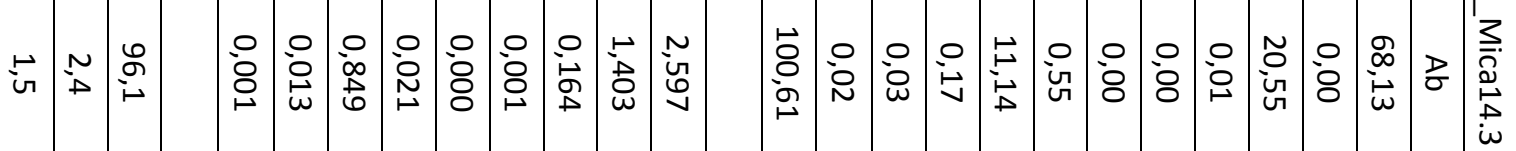

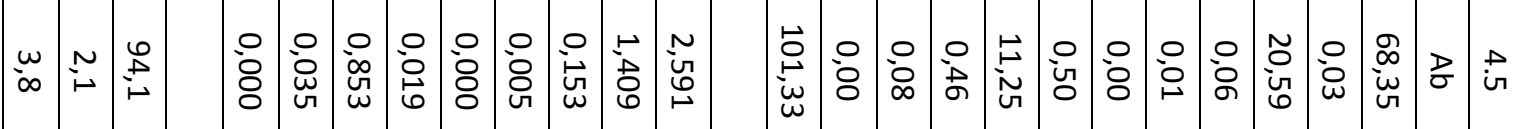

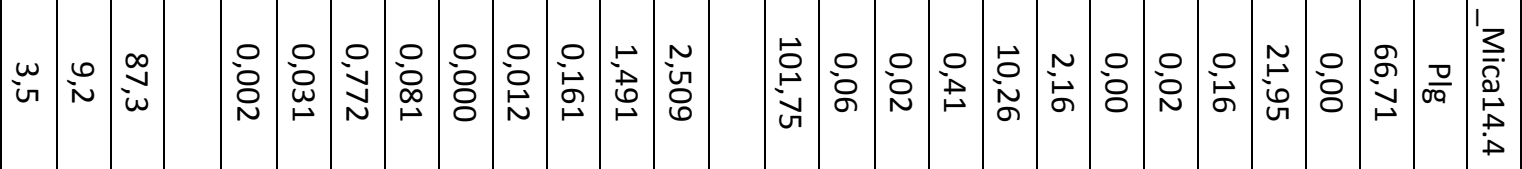

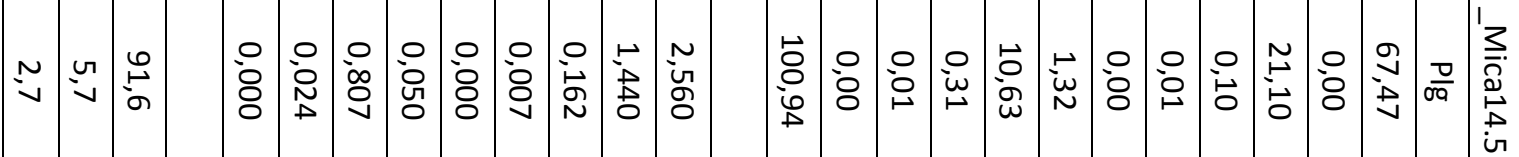

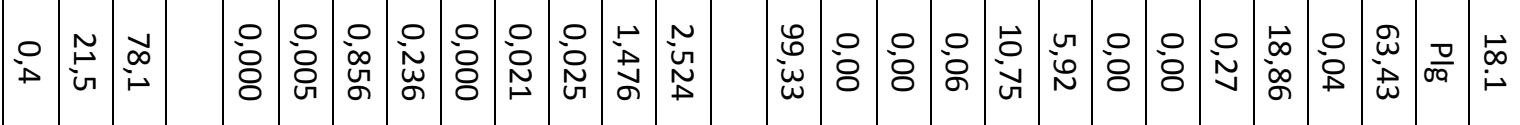




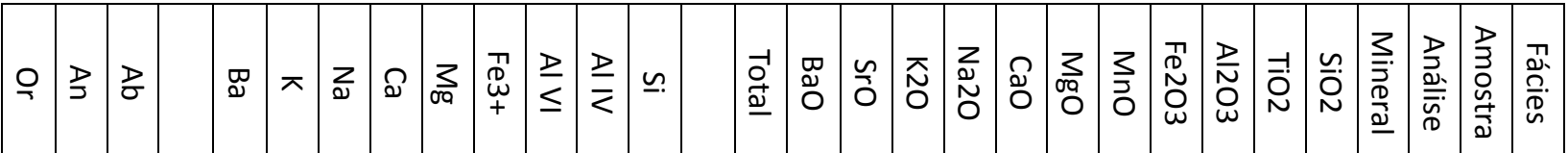

$\left.\begin{array}{l}\infty \\ 0\end{array}\right)$

兽品点

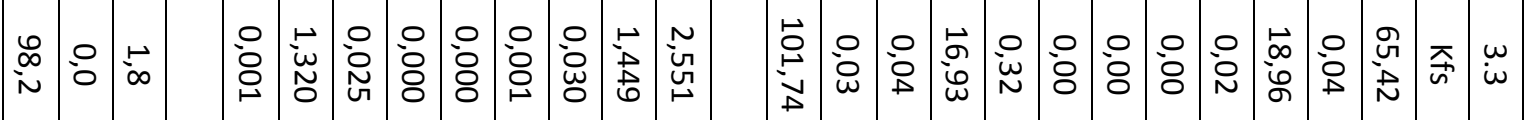

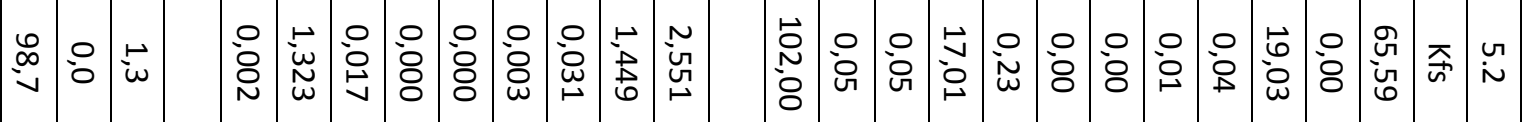

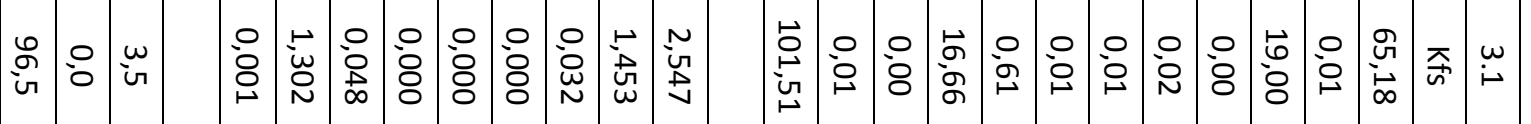

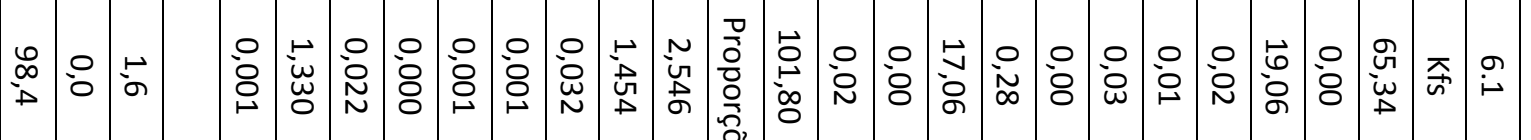

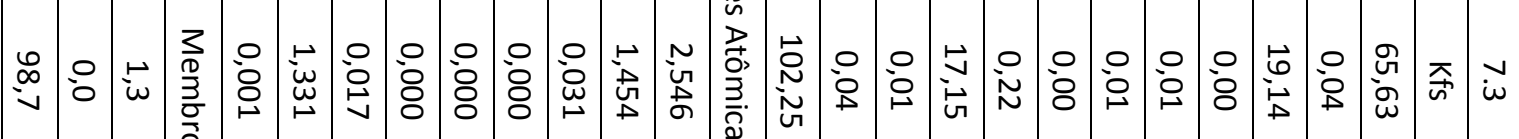

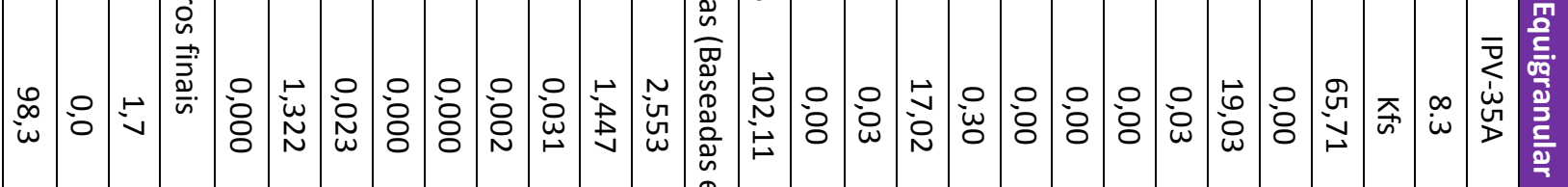

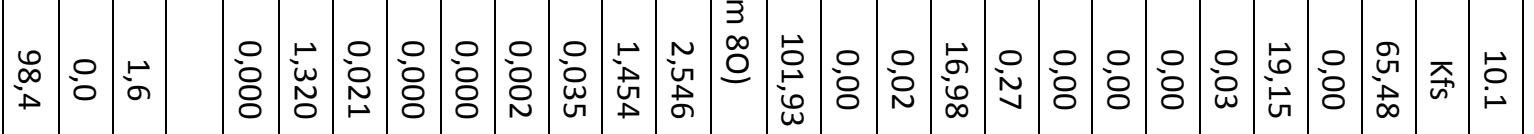

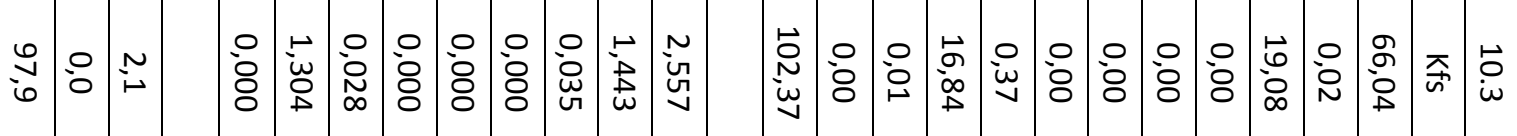

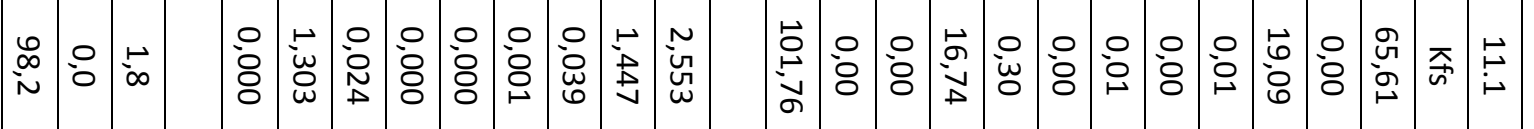

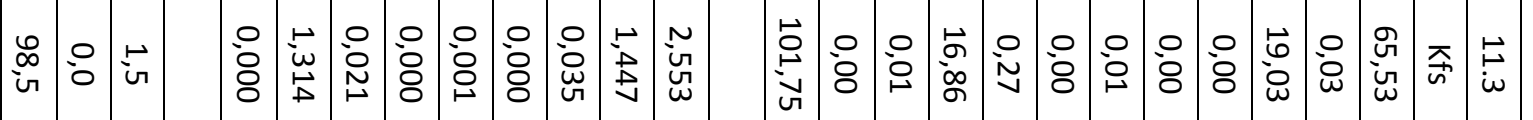

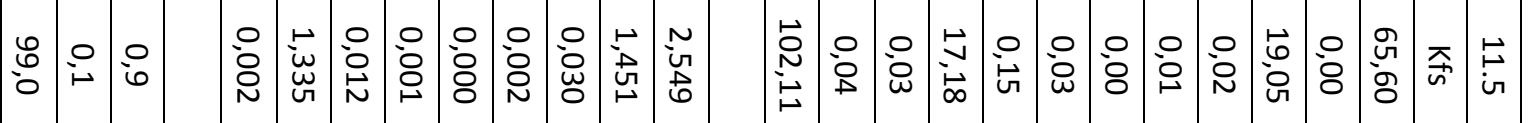

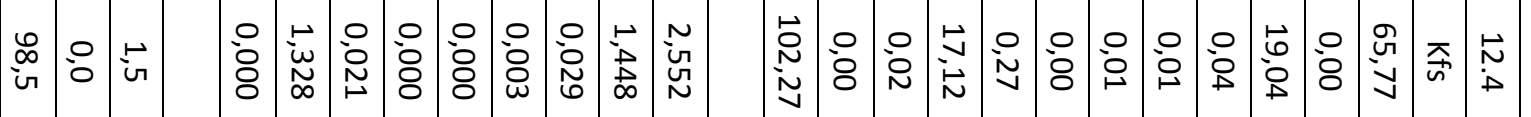

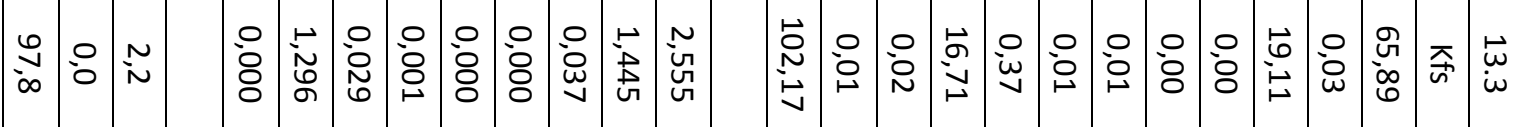




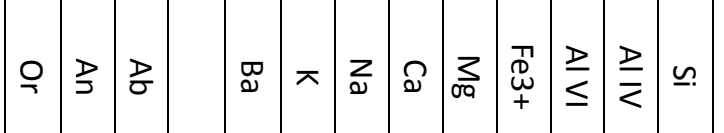

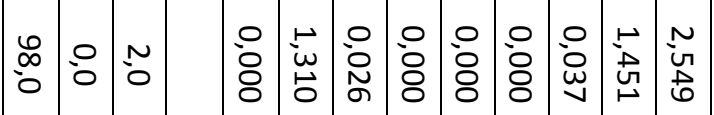

品

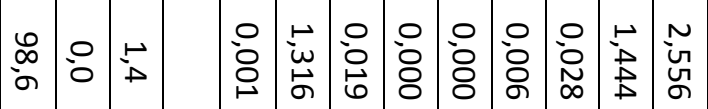

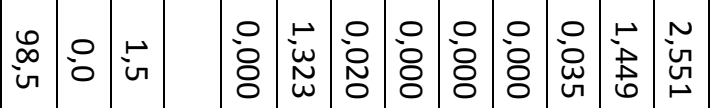

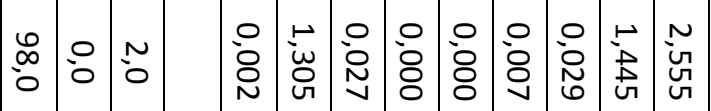

惫占占

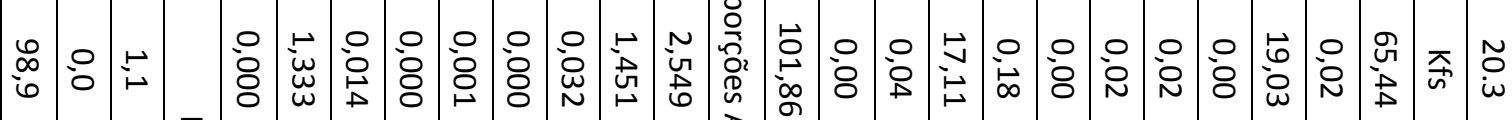

每

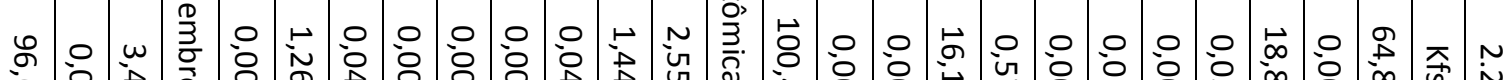

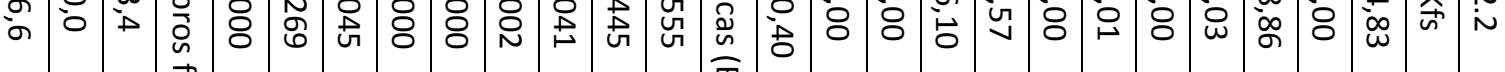

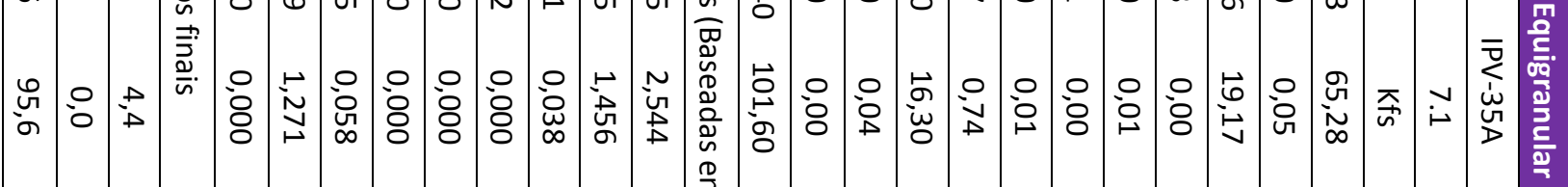

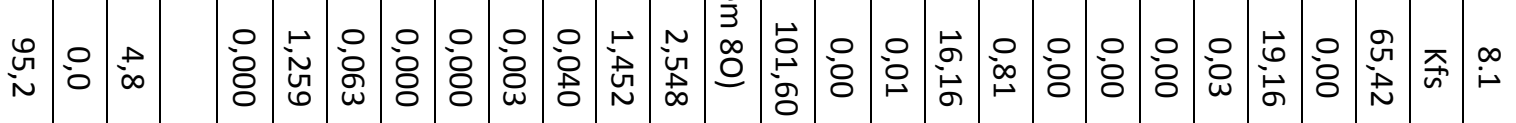

总谓点

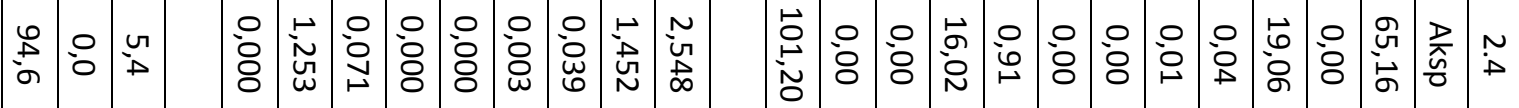

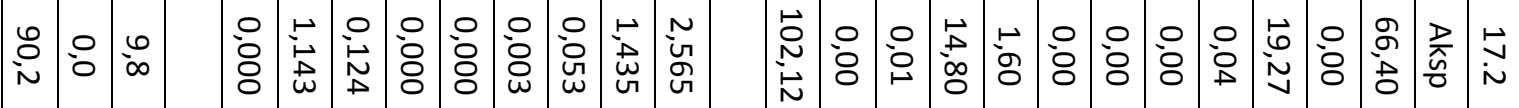

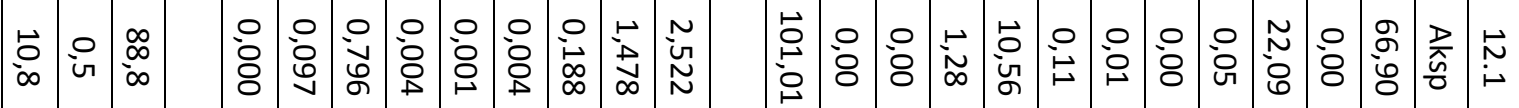

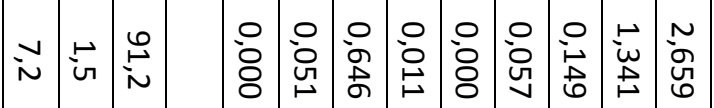

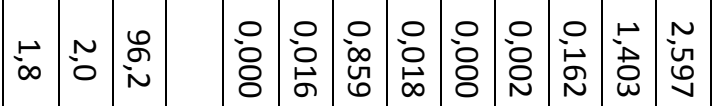

占占点至

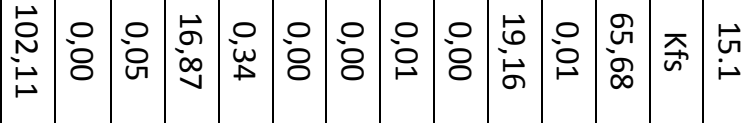

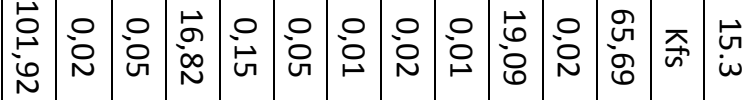

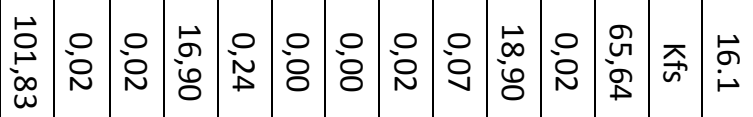

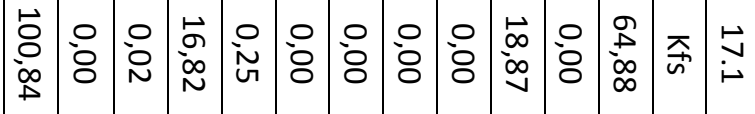

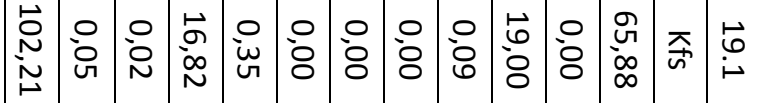

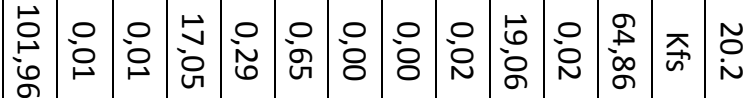




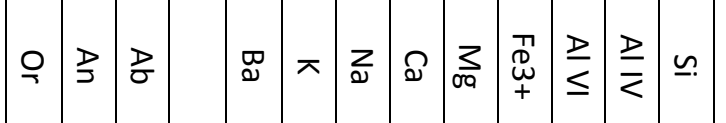

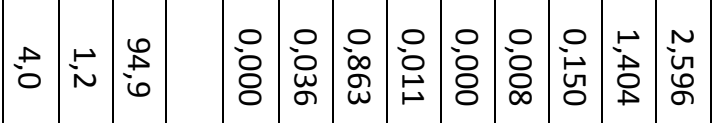

台号总

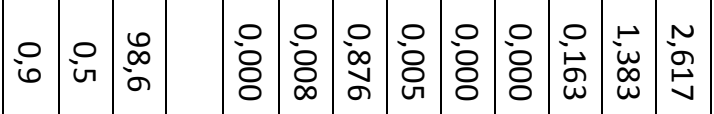

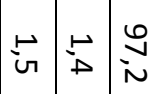

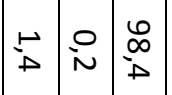

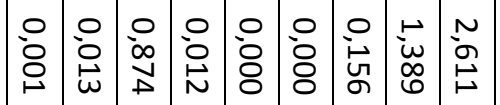

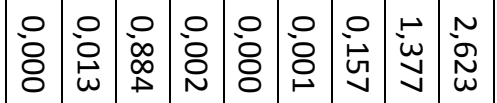

○茓空

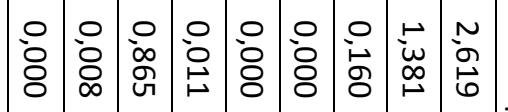

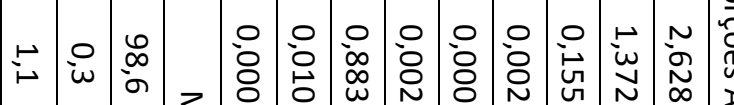

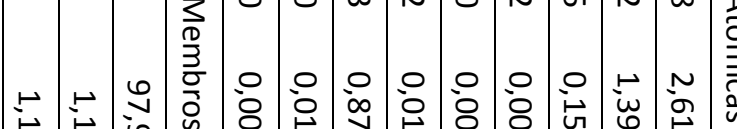

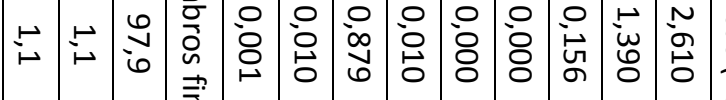

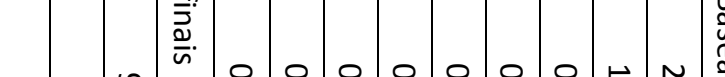

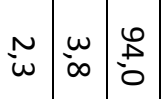

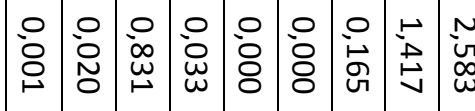

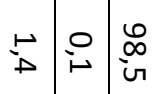

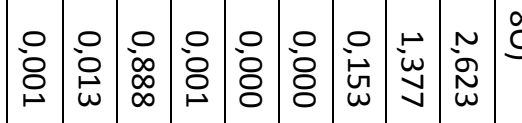

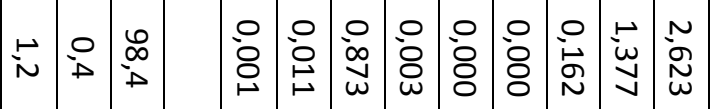

卢舟䆓

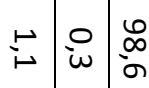

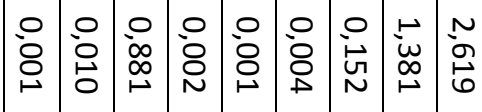

$\vec{N} \underset{\sim}{\overrightarrow{0}} \underset{\infty}{\infty}$

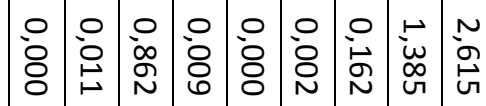

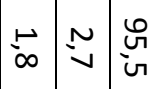

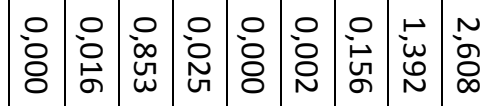

낭

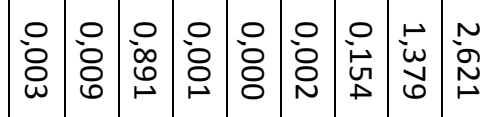

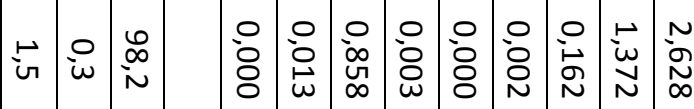

总弯

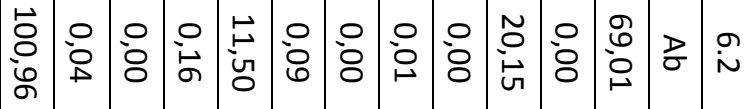

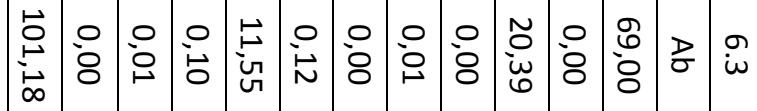

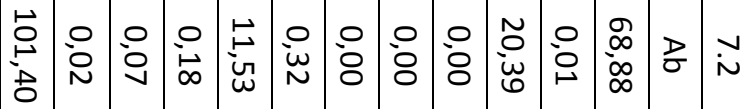

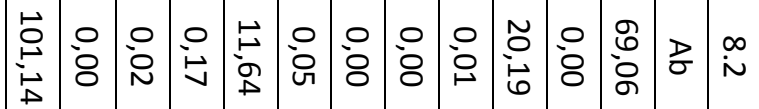

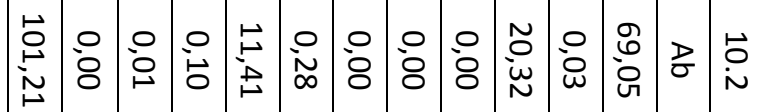

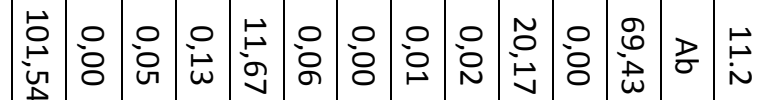

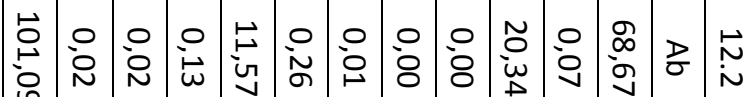

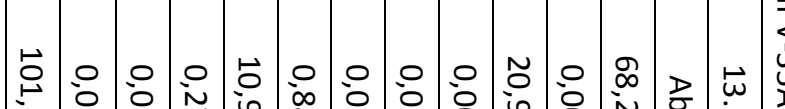

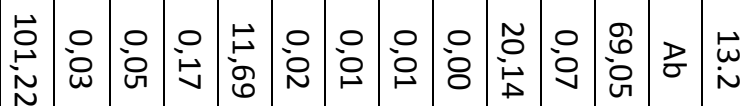

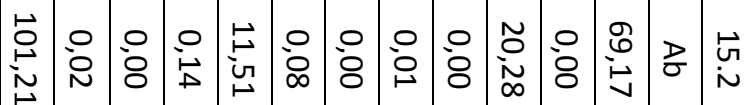

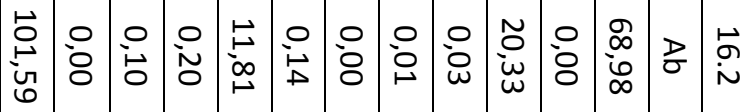

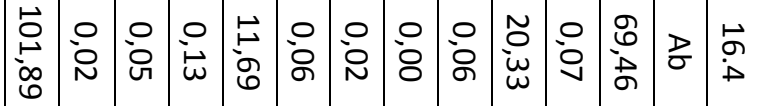

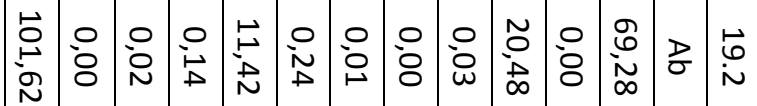

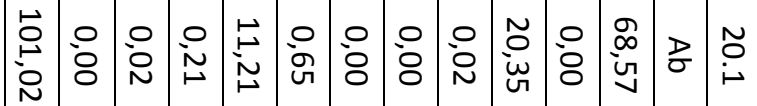

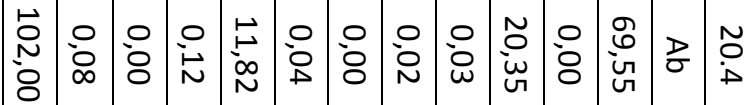

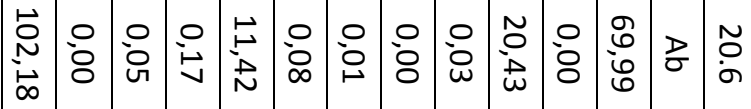




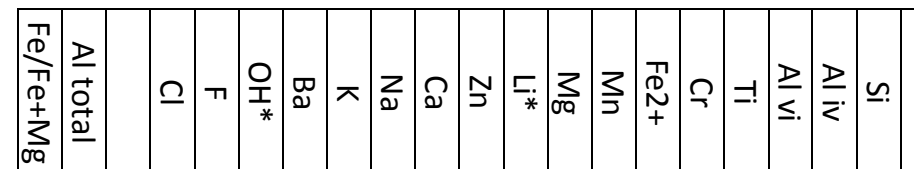

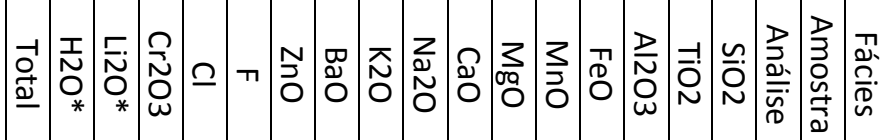

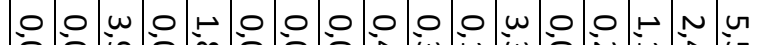

ค)

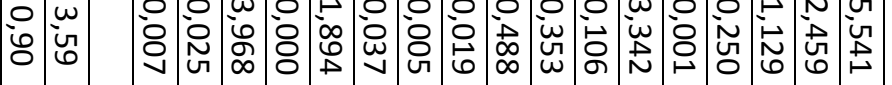

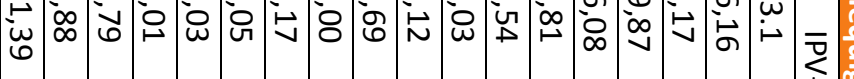

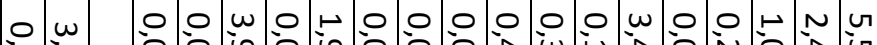

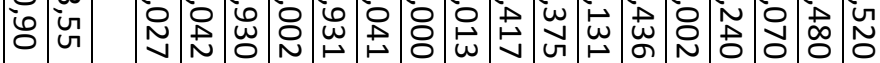

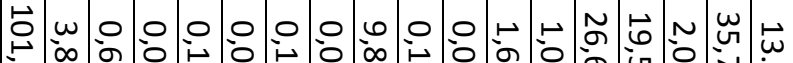
岕

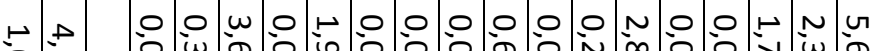

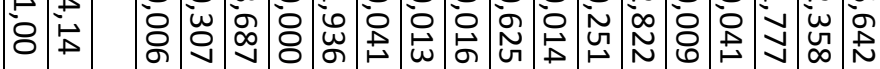

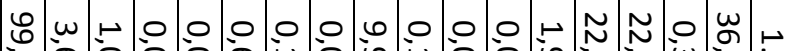
ת.

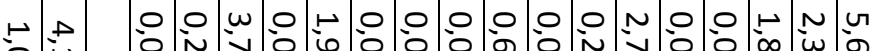

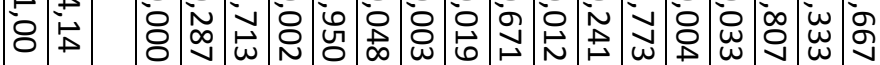

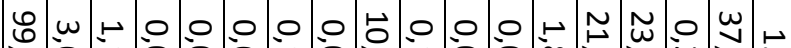

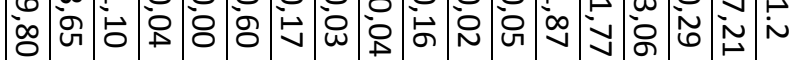

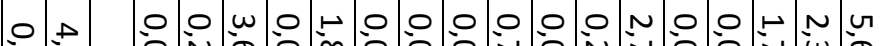

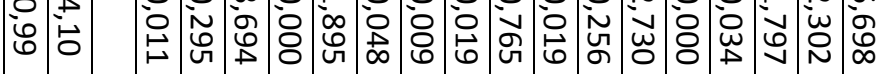

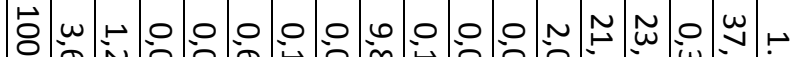
崫

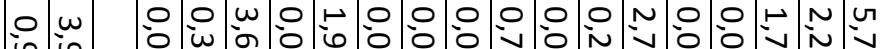

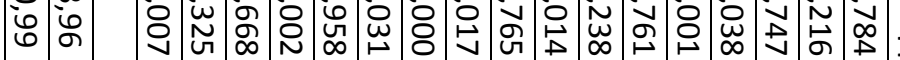

$\infty \underset{\sim}{\omega} \circ 0000$

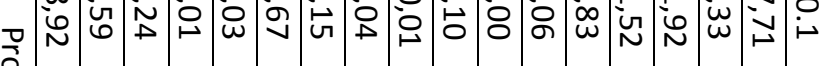

- $\quad$ a 0 w 0 .

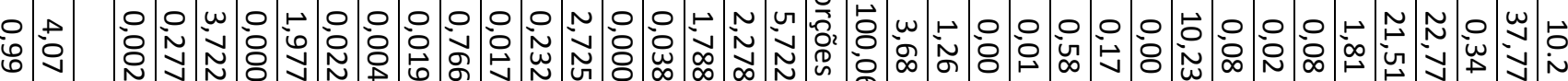

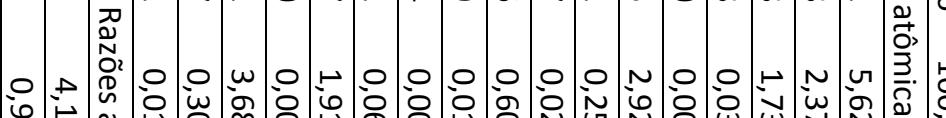

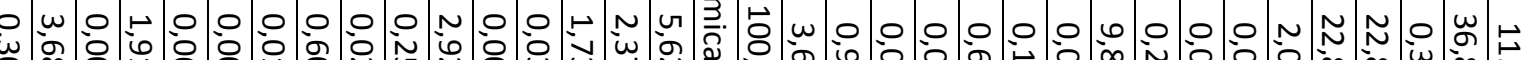

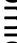

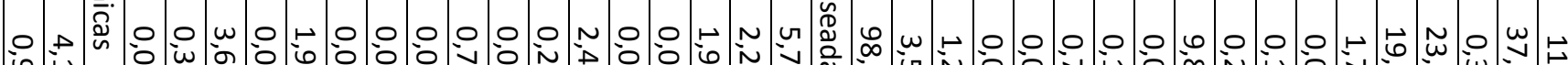

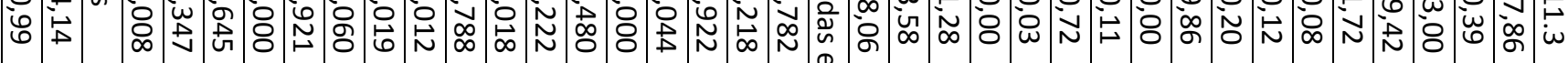

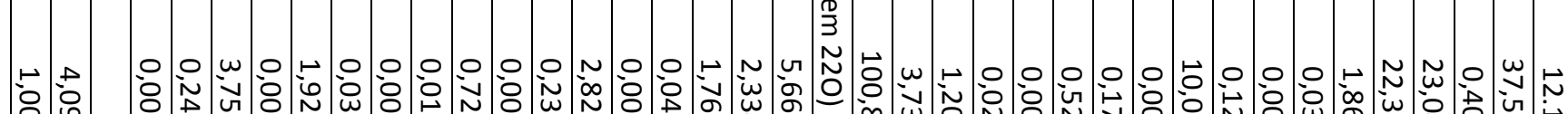

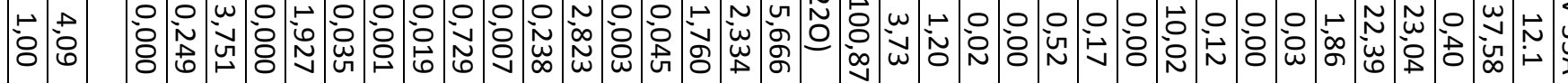

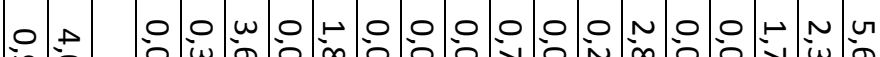

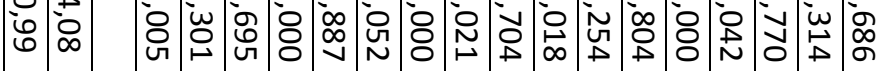

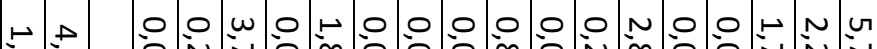

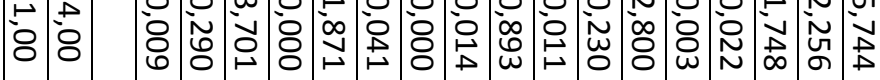

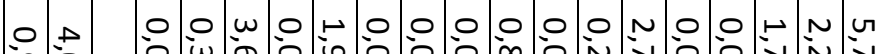

等

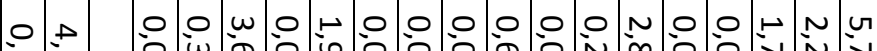

落

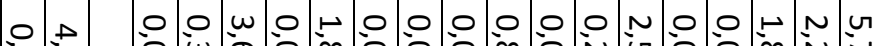

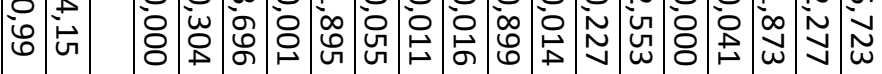

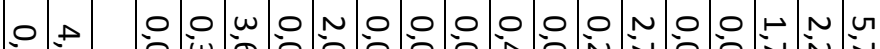

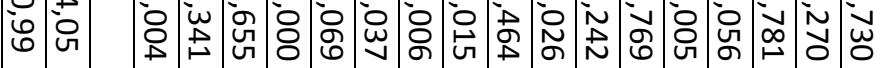

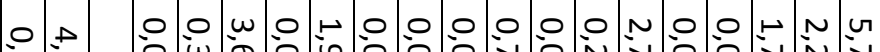

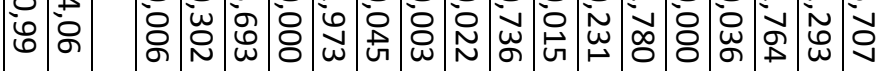

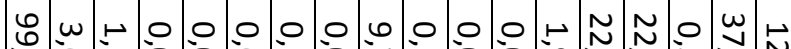

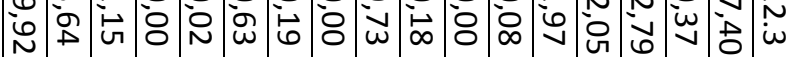

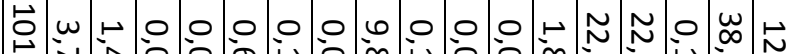
व

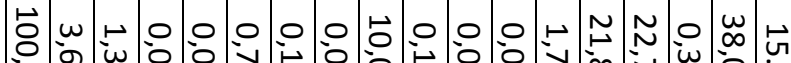
每

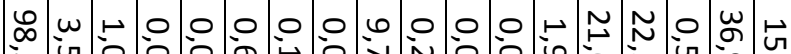

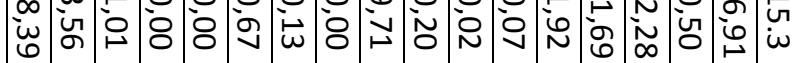

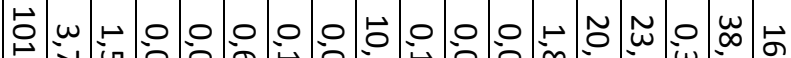
茫

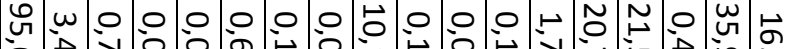

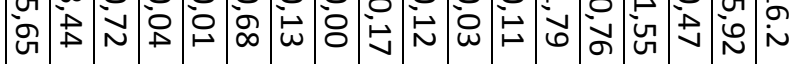

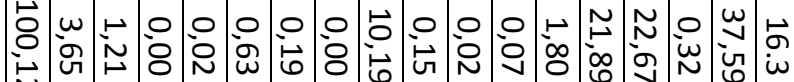




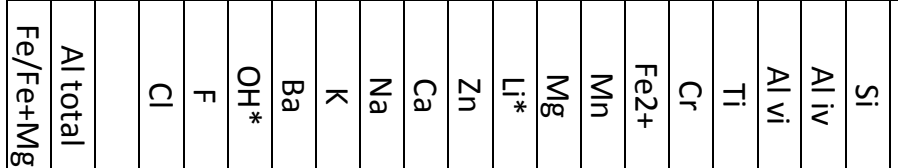

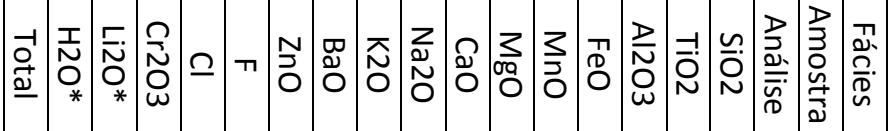

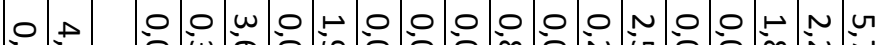

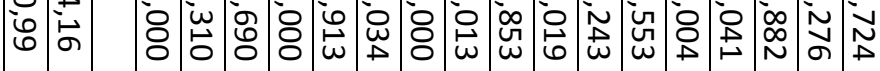

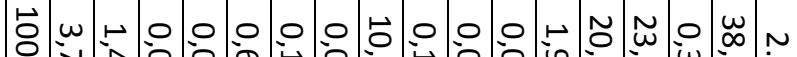

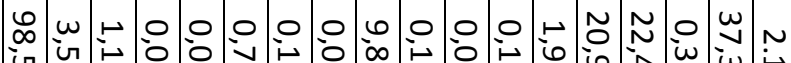

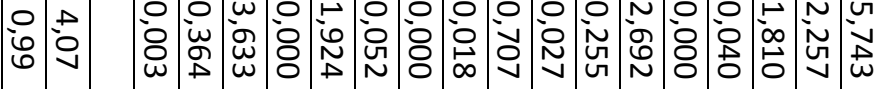
行 ज官

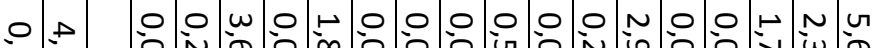

$\infty \omega 000000.0000$

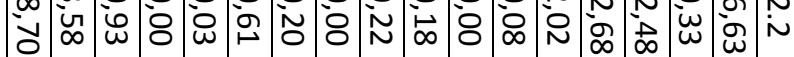
讨

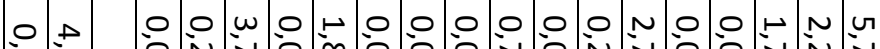

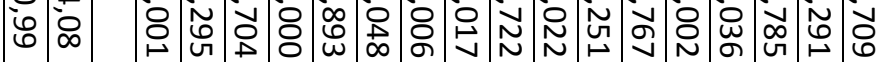

๑)

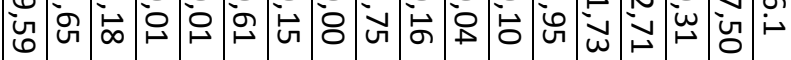

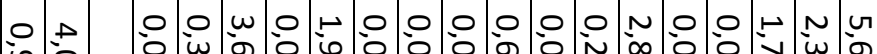

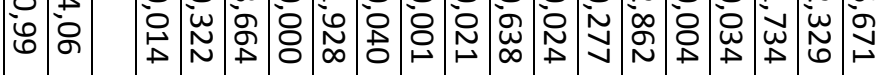

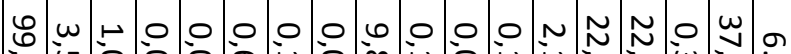

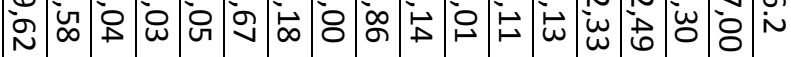

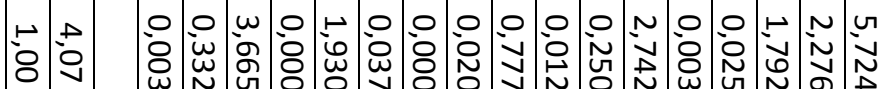

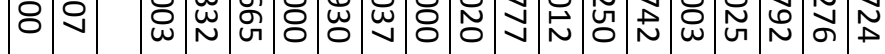

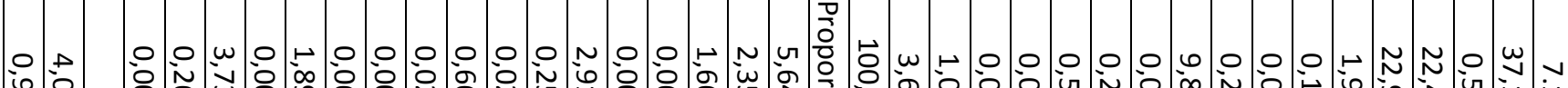

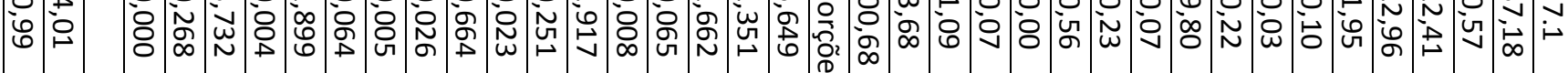
$\circ \rightarrow$ J

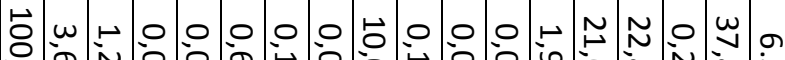

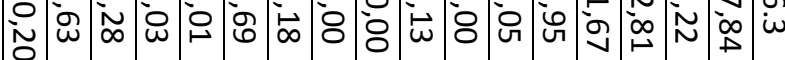

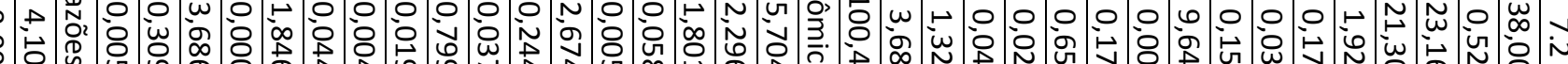

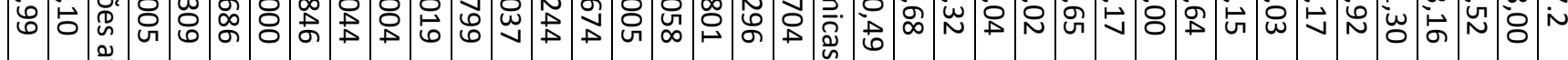

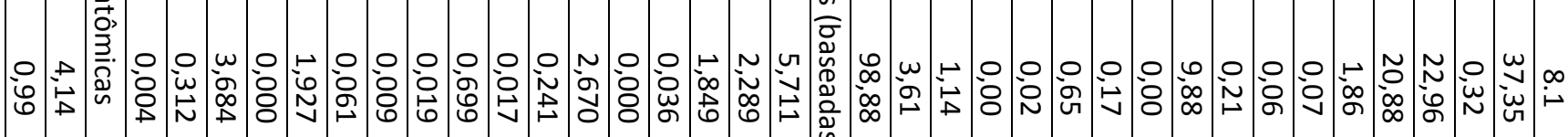
O

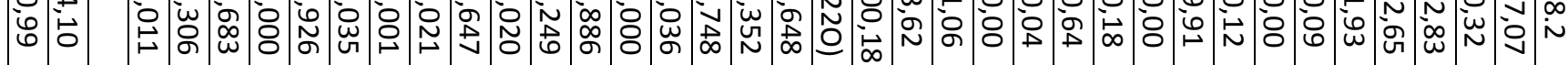

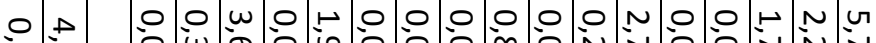

:

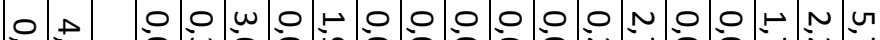

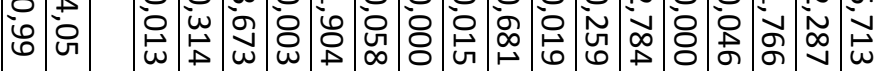

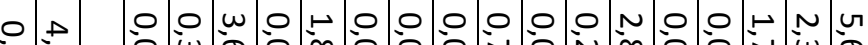

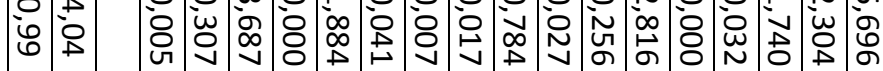

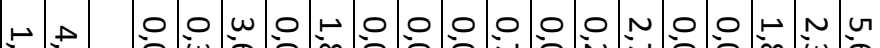

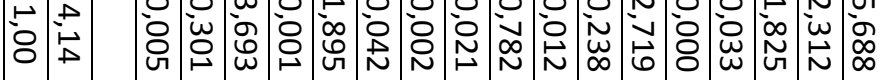

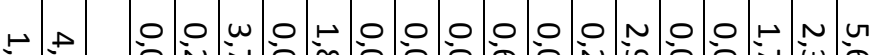

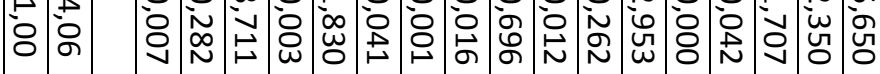

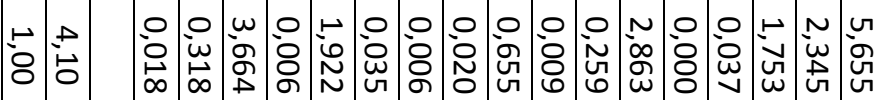

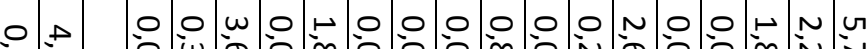

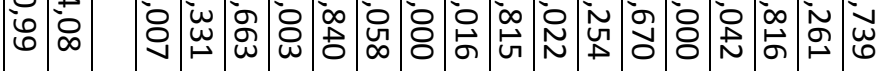

b.

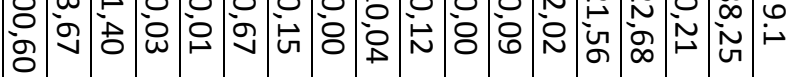

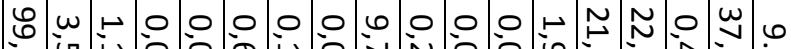

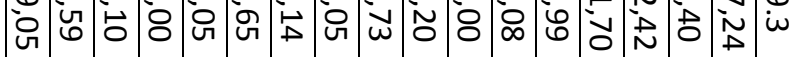

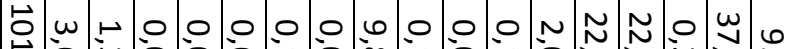

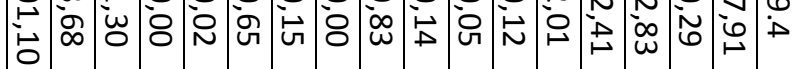

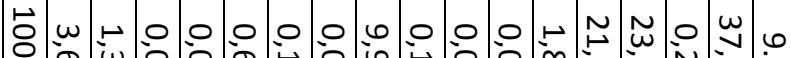
\%

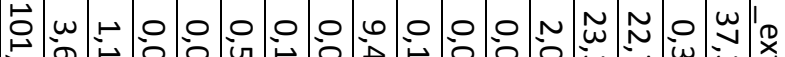

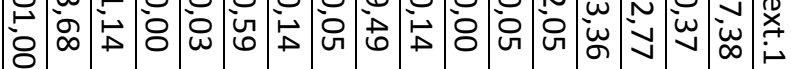

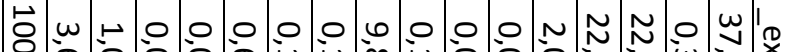

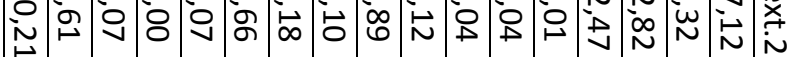

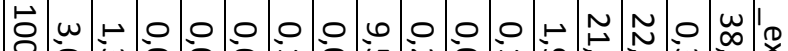

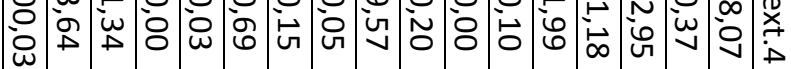




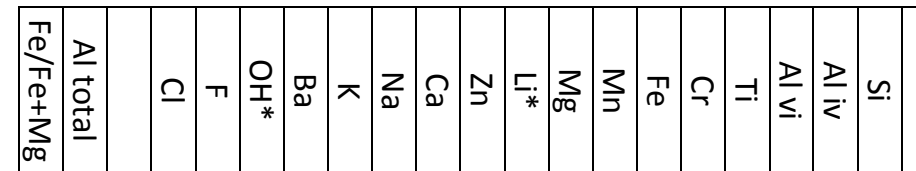

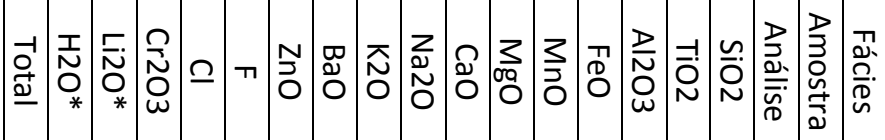

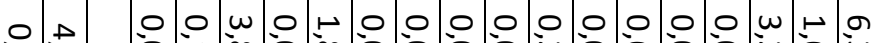

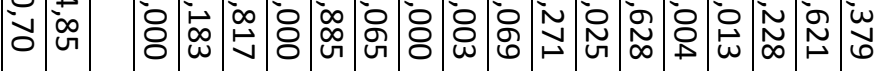

는

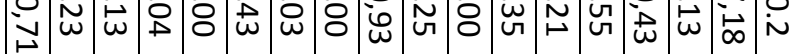

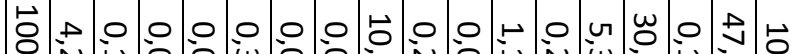
ஸ્j

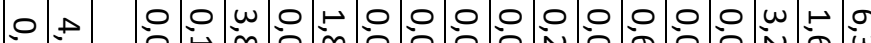

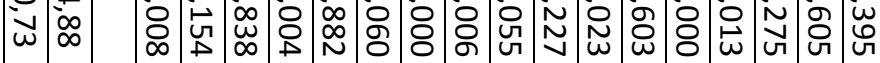

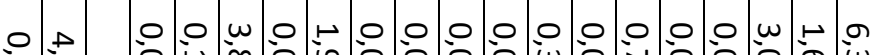

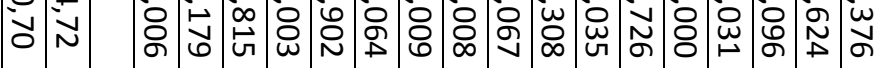

i.

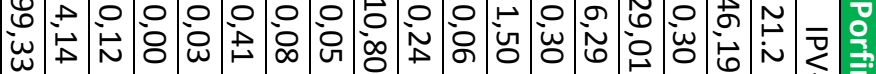

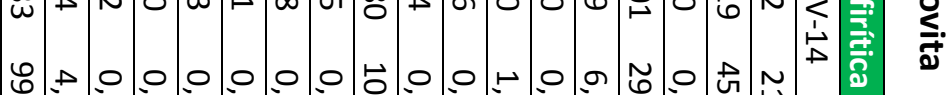

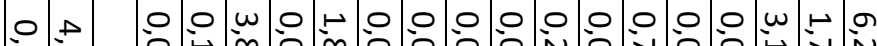

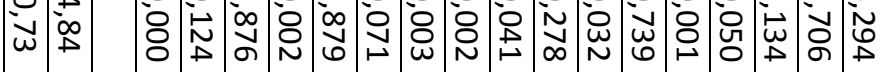

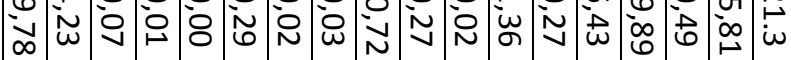

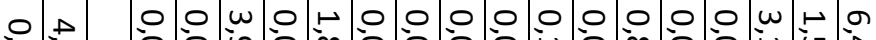

等

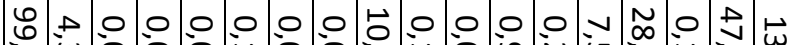

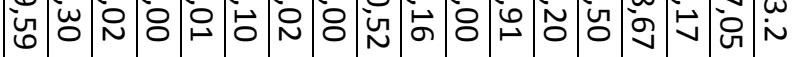

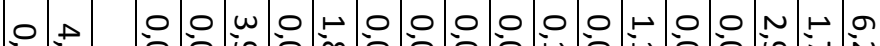

年

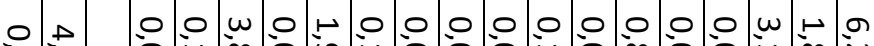

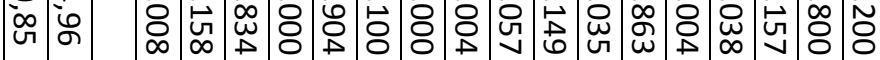

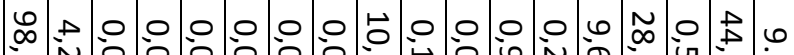

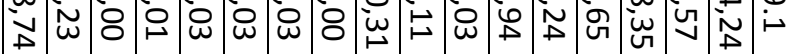

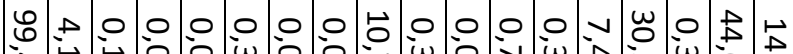

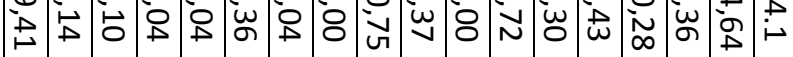

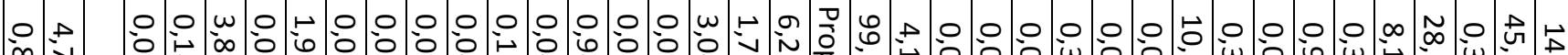

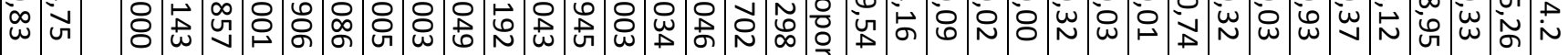

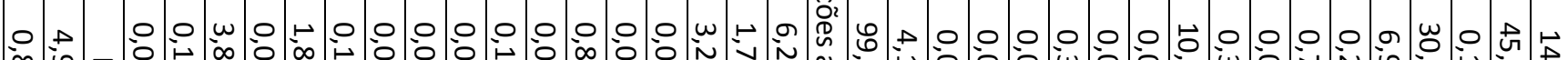

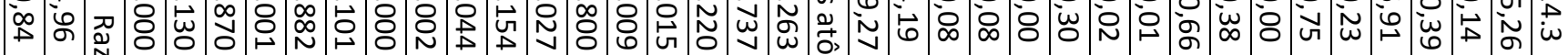
館

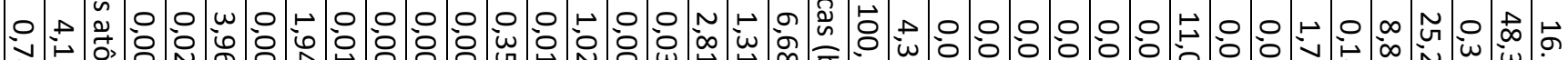

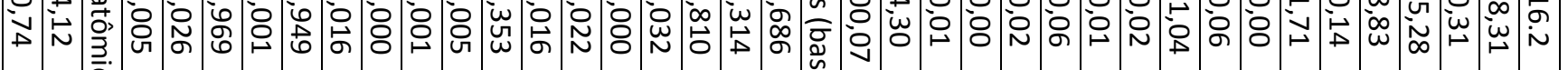

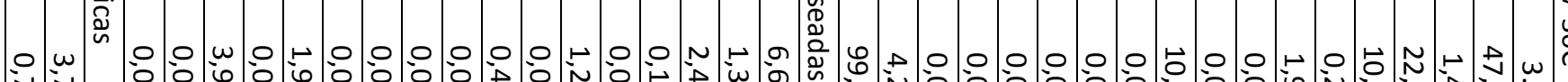

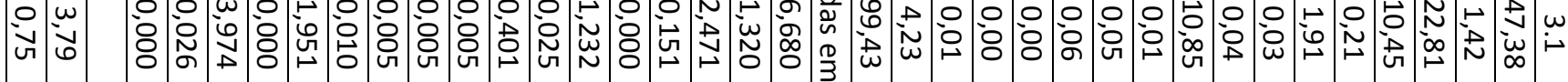

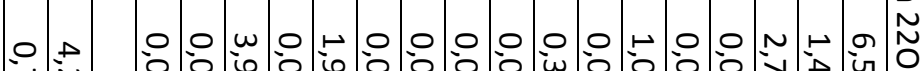

w垈

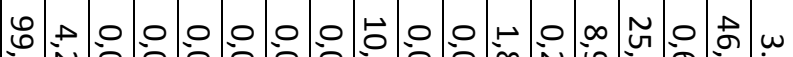

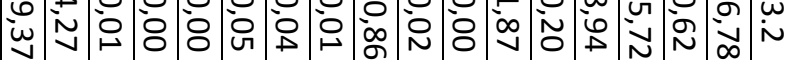

- v 0 o $w 01$

管

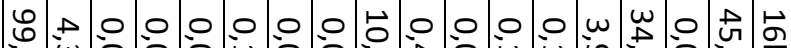

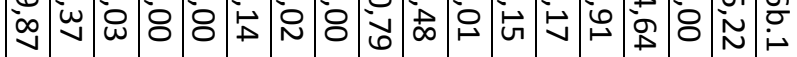

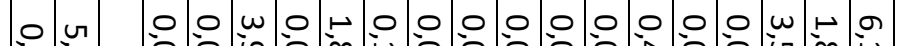

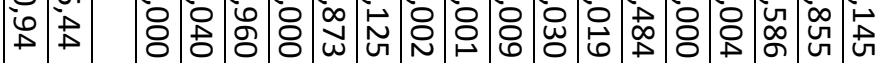

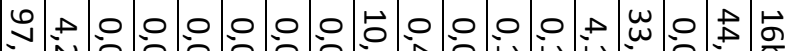

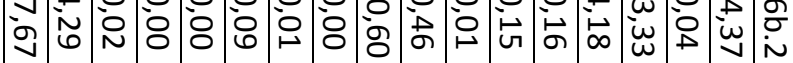

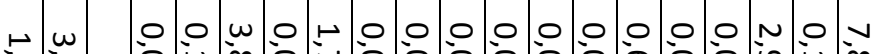

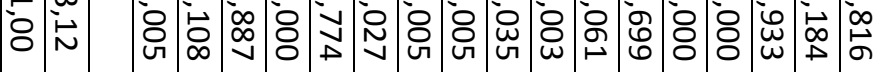

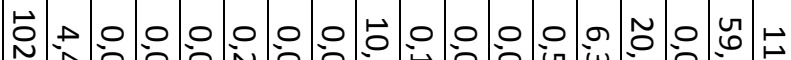

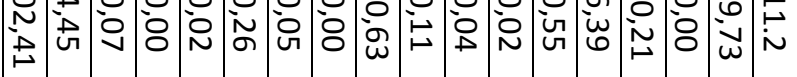

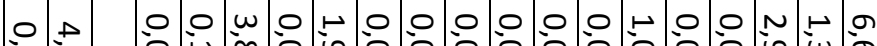

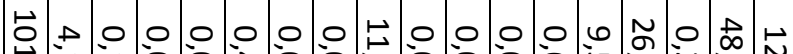

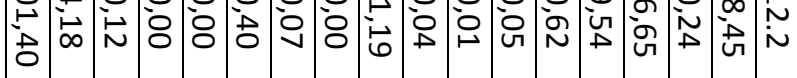

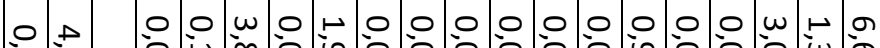

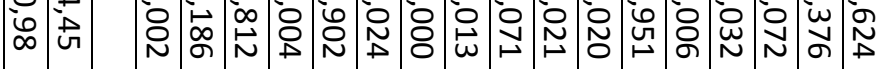

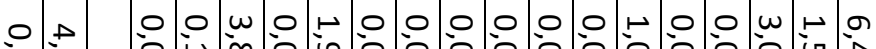

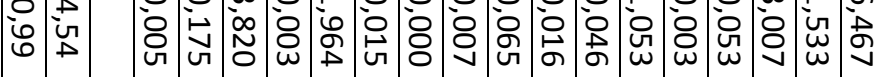

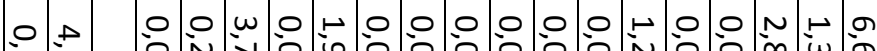

U

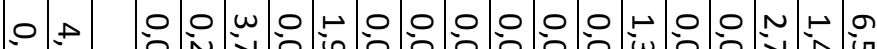

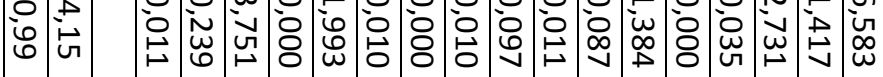

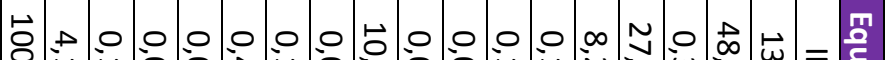
б

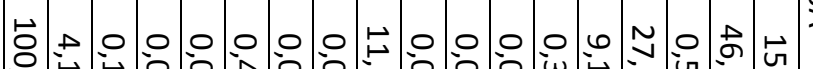
出 苟

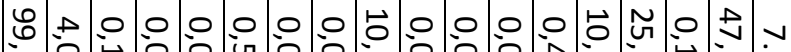

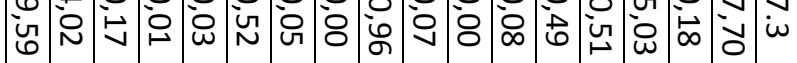

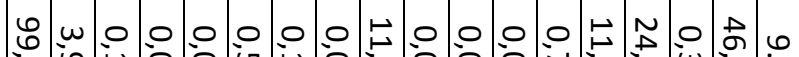
मे 


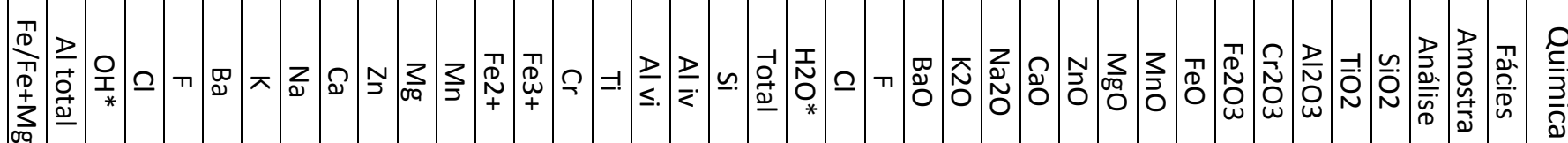

us

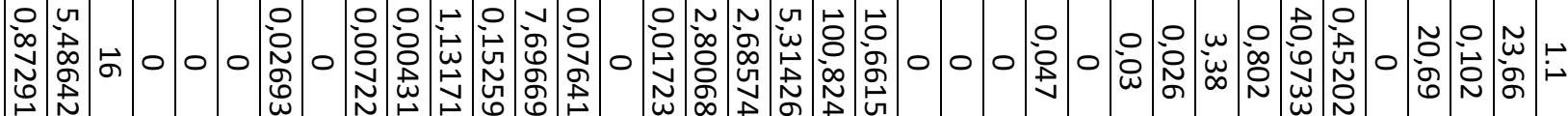

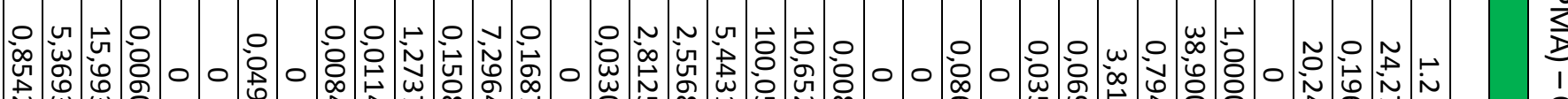

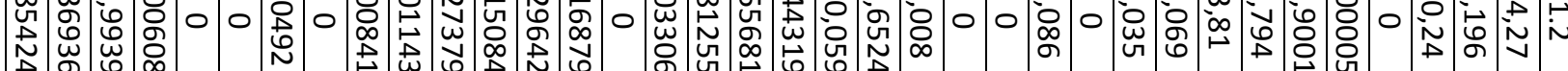

$\therefore$ u $\checkmark$ 罗 0
$\infty$

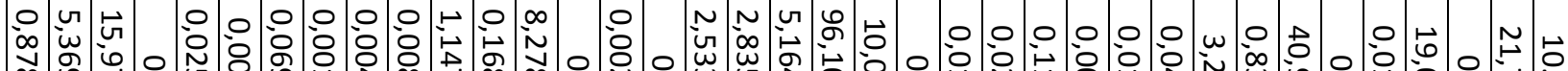

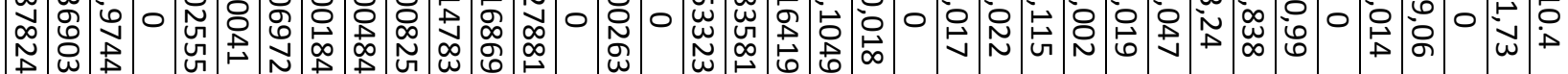

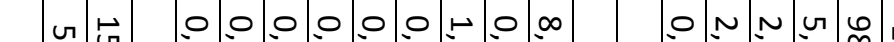

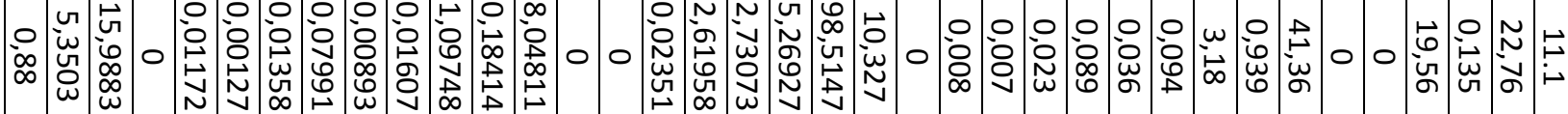

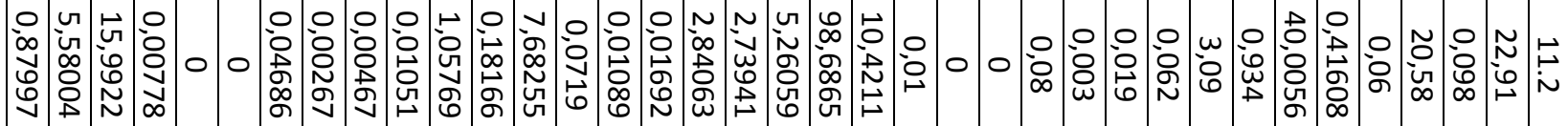

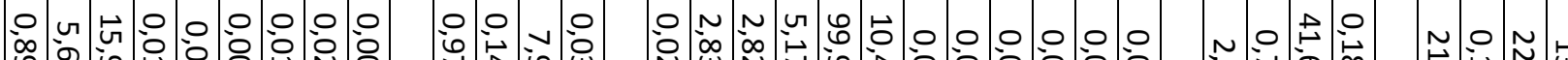

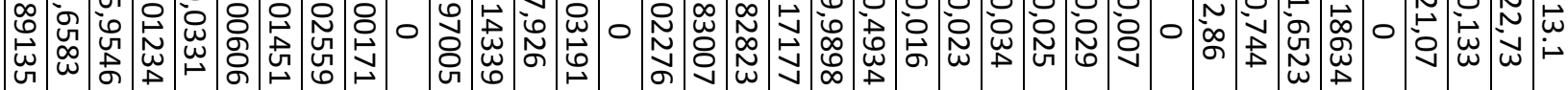

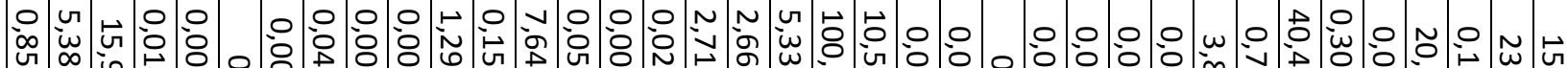

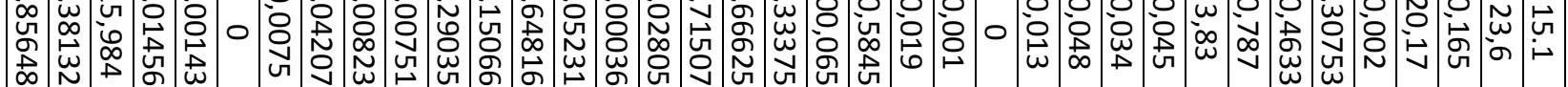

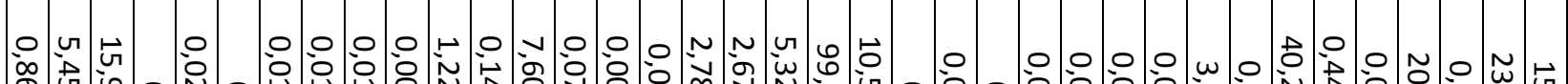

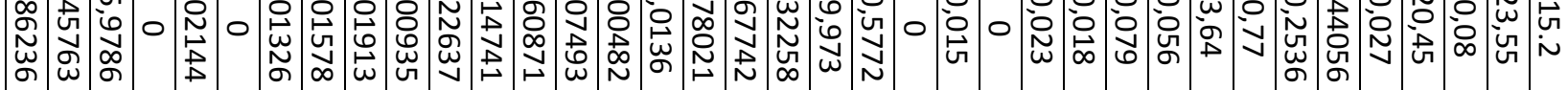

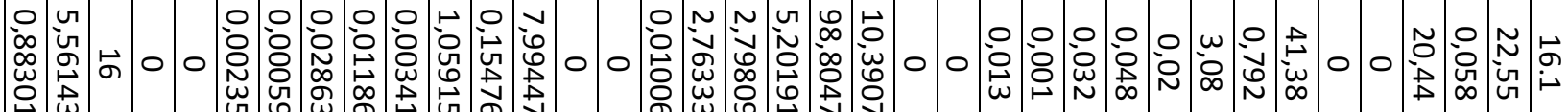

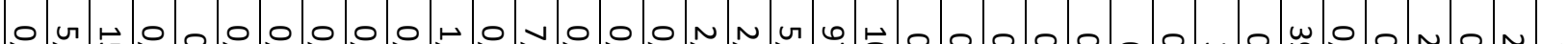

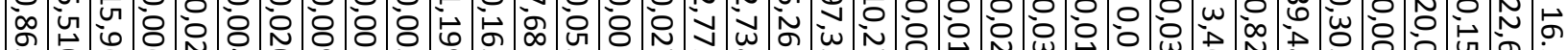

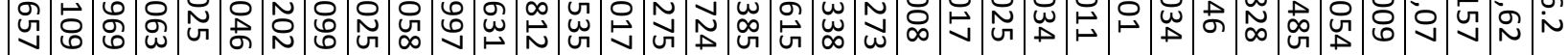

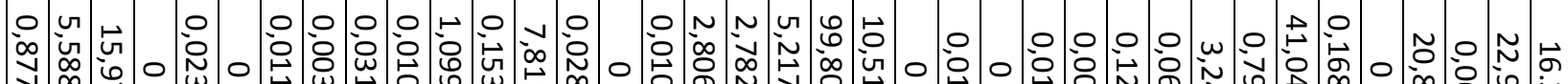

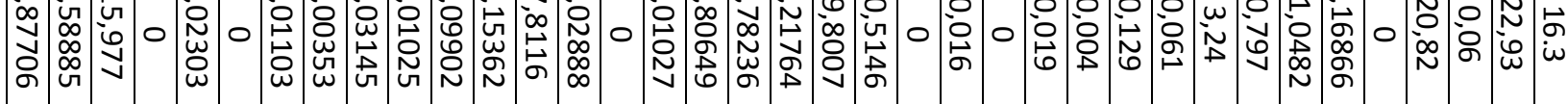

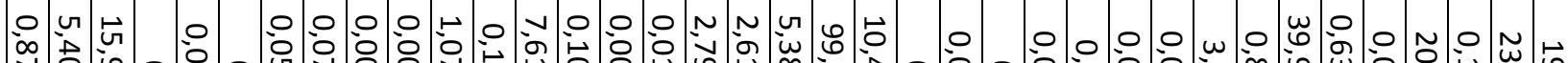

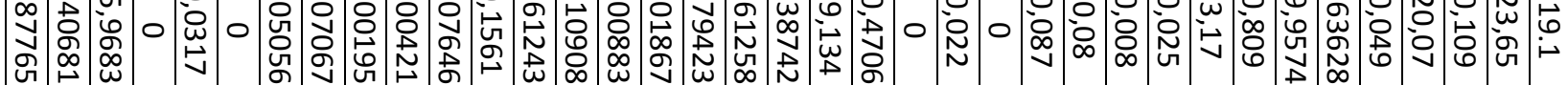

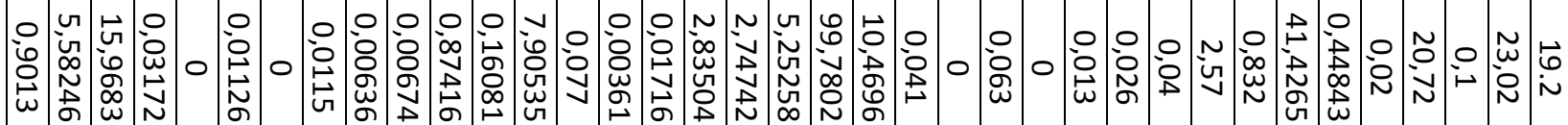

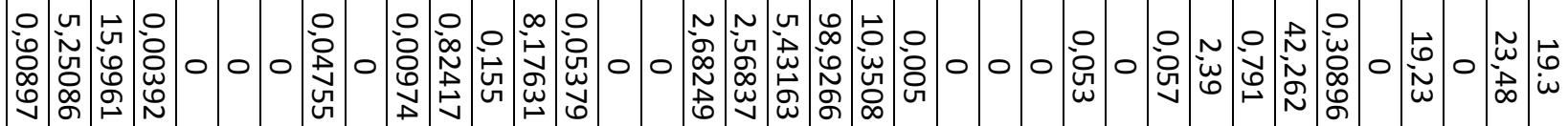

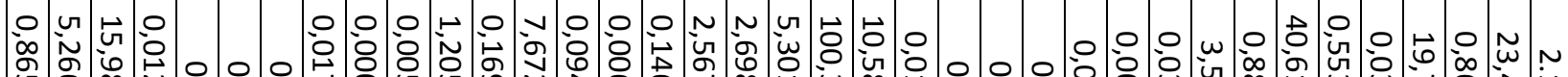

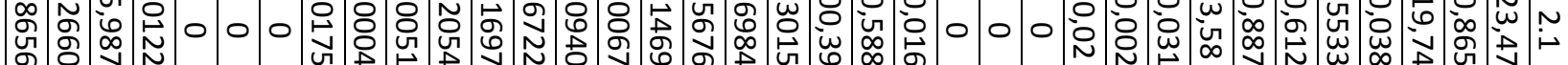
ฉ 


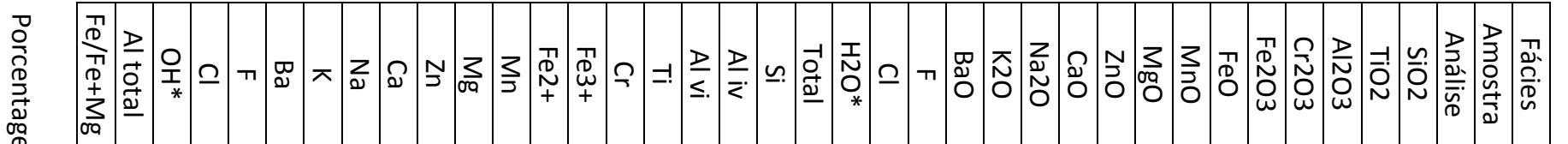

O $u$

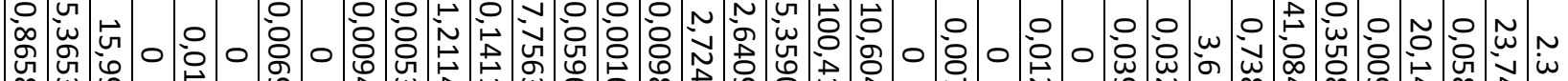

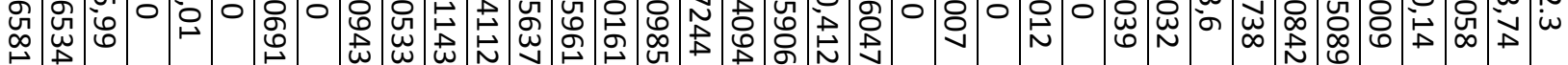

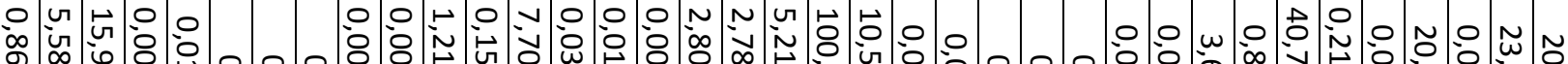

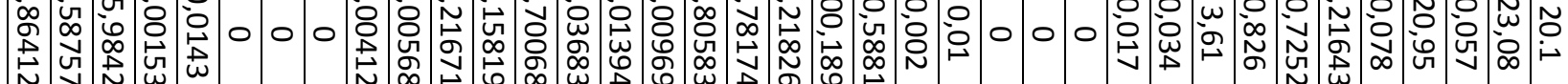
$\therefore 0$

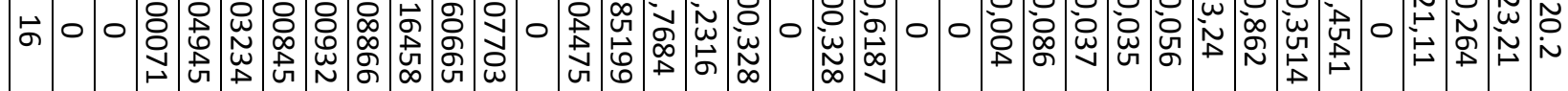

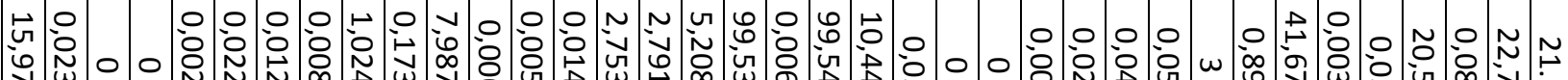

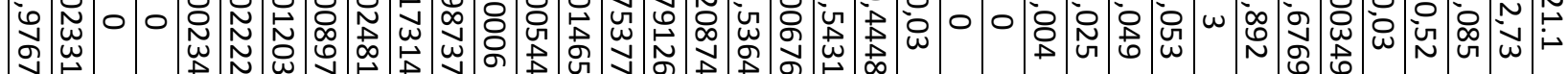

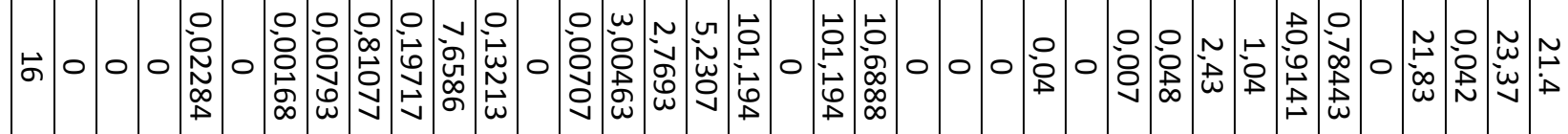

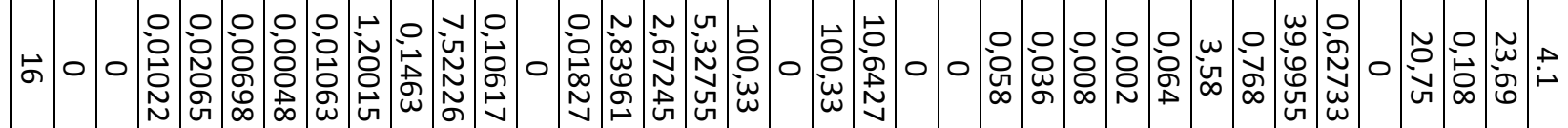

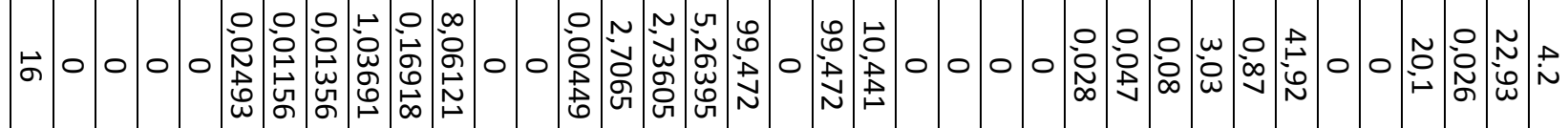

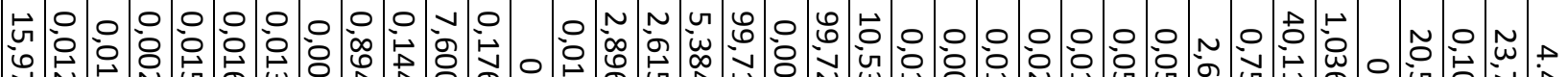

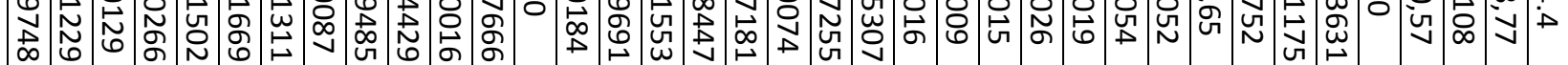

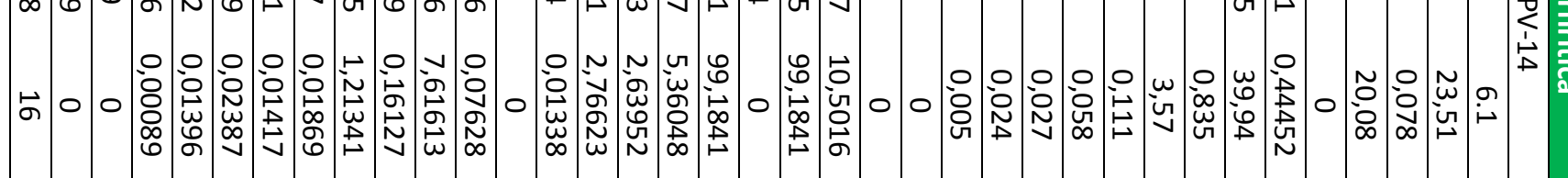

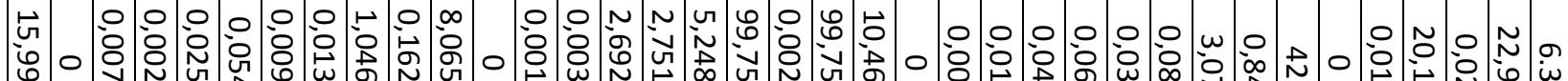

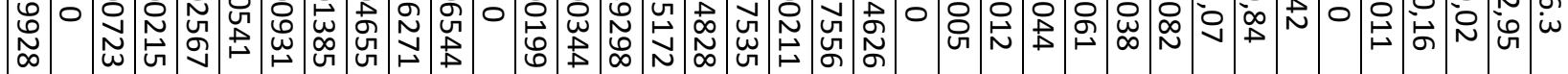

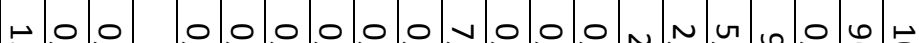

U

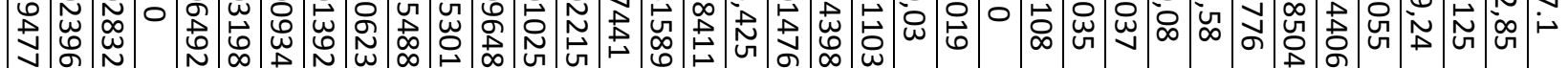

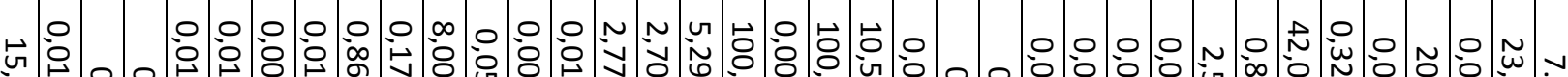

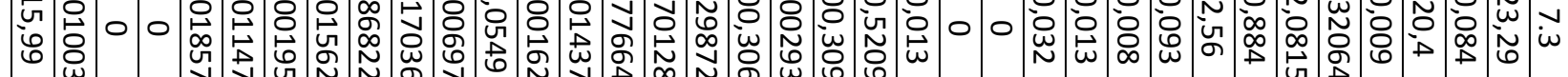

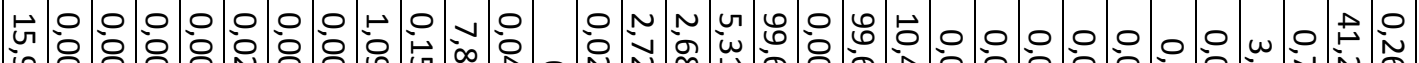

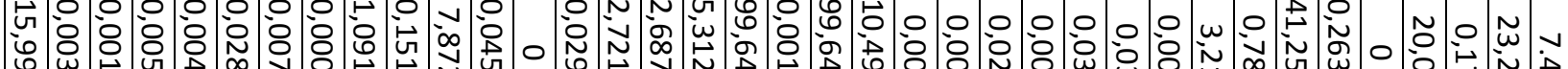
焉 으

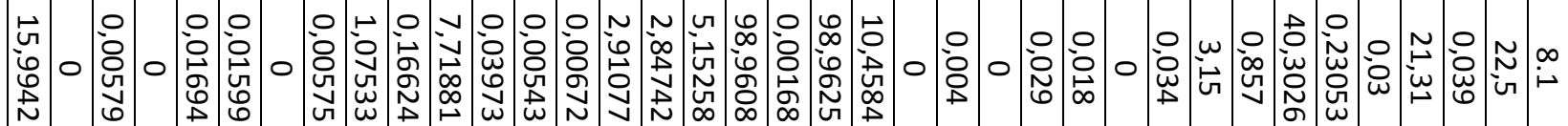

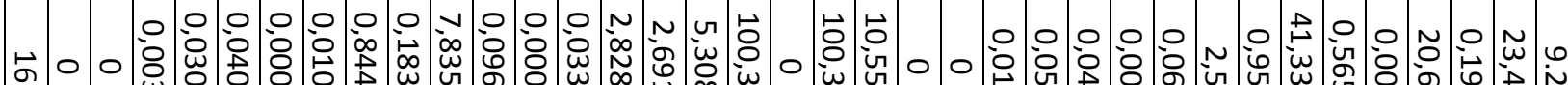

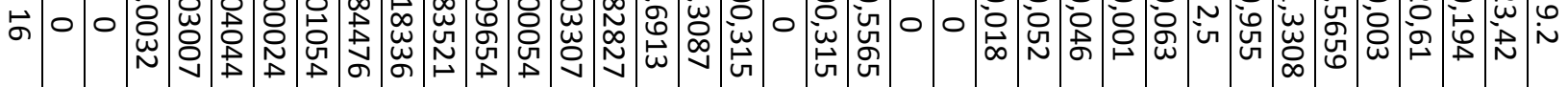

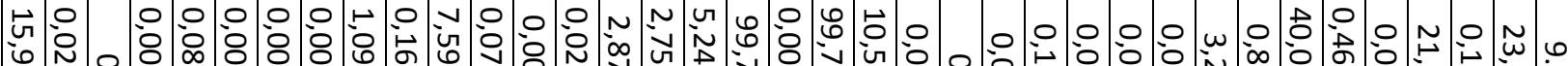

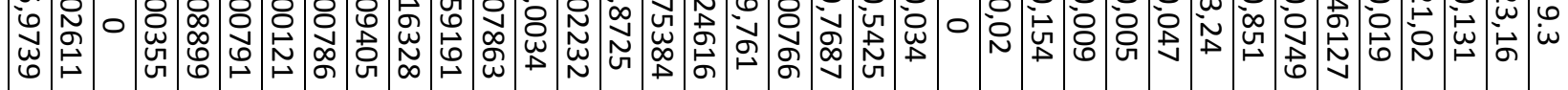




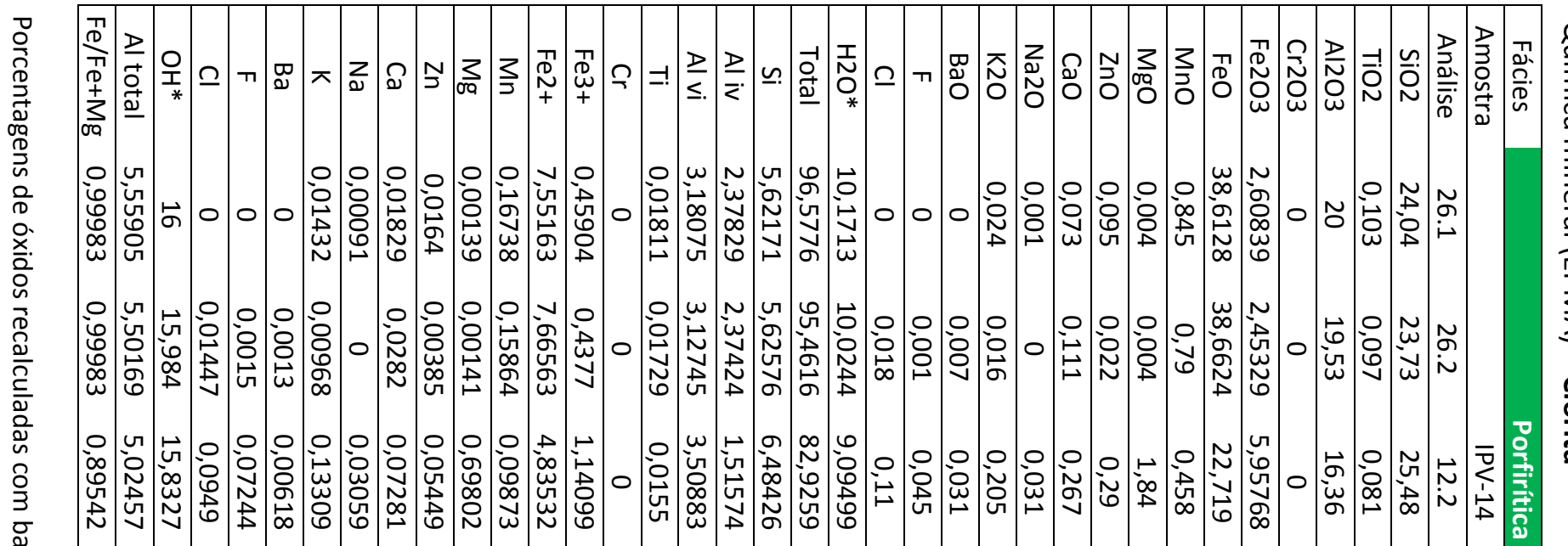

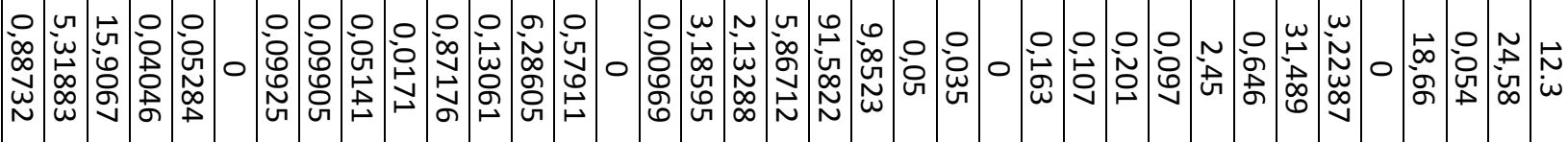

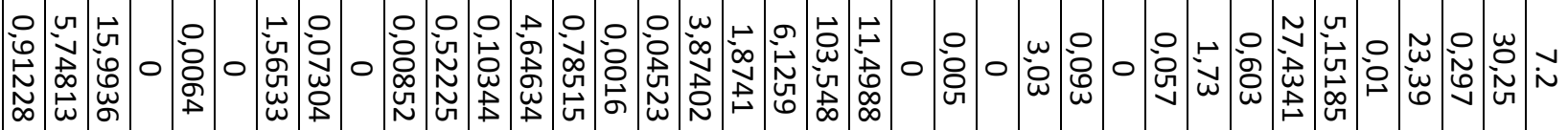

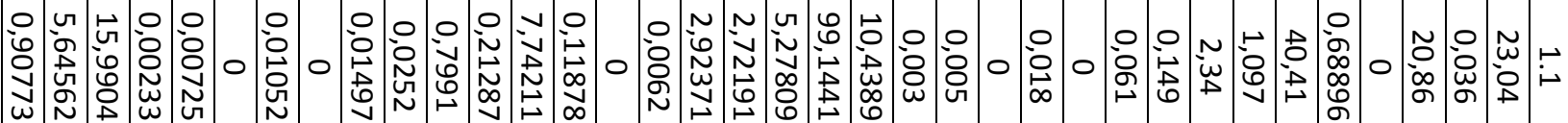

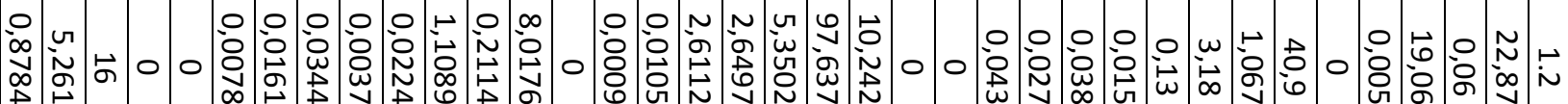

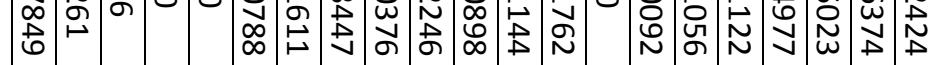

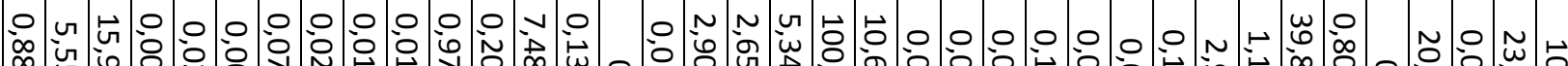

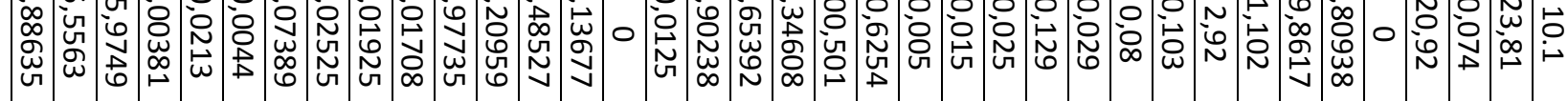

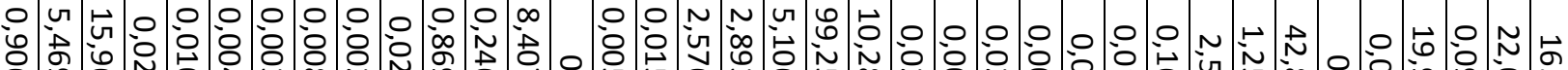

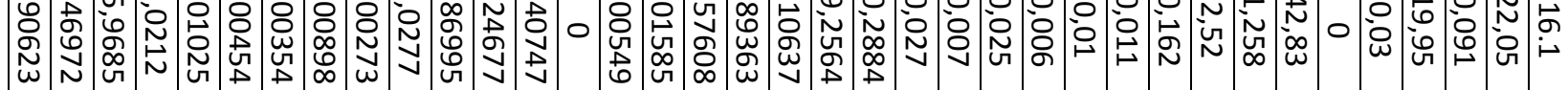

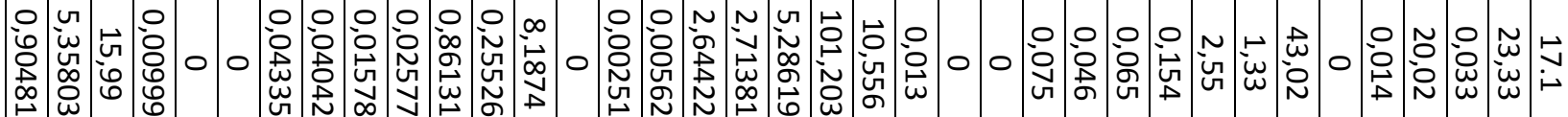

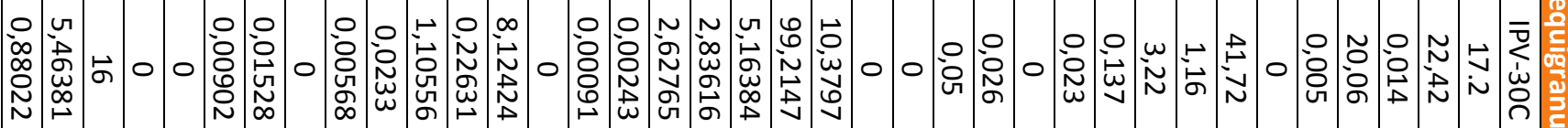

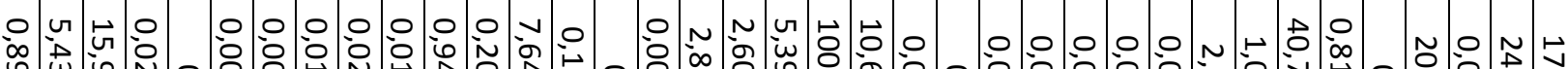

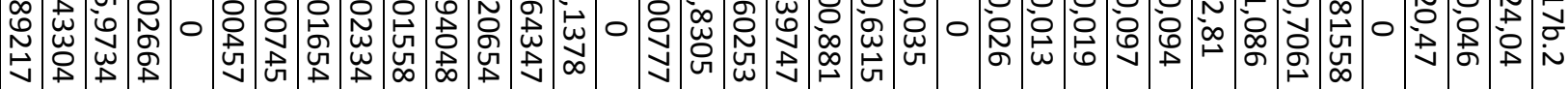

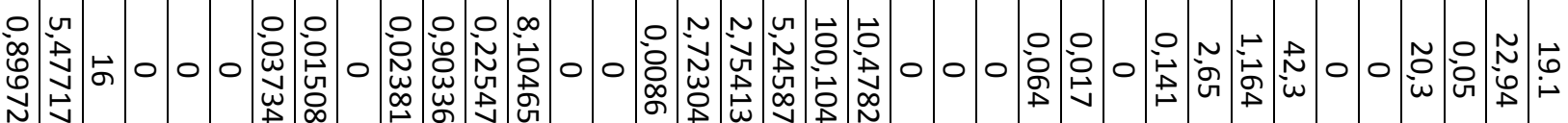

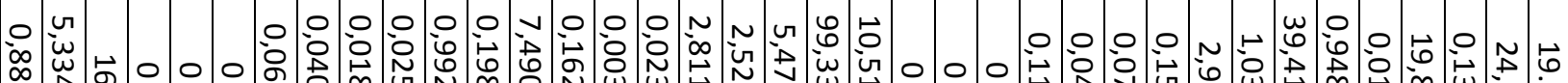

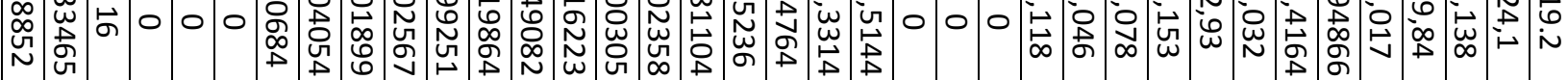

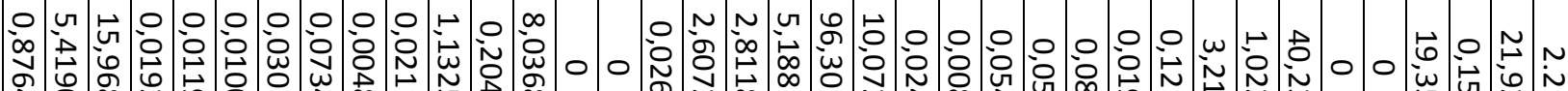

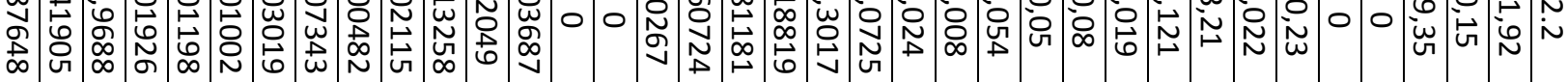

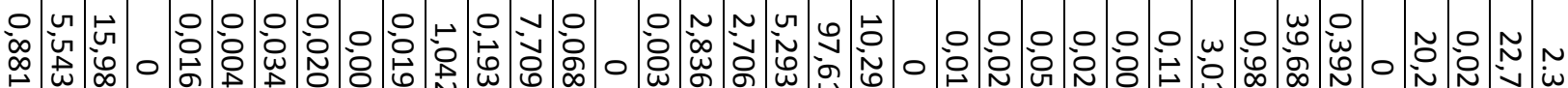

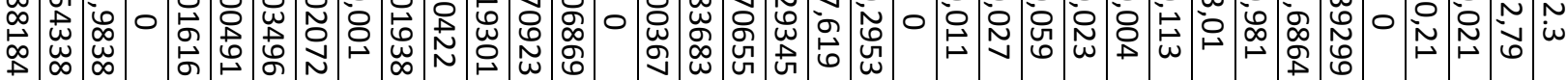




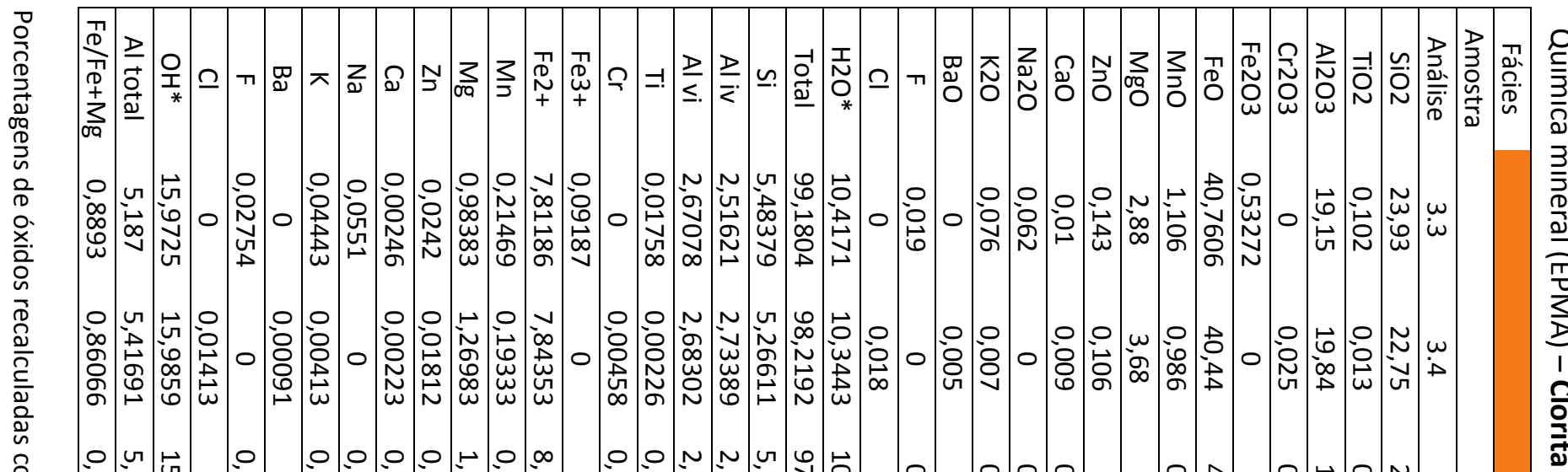

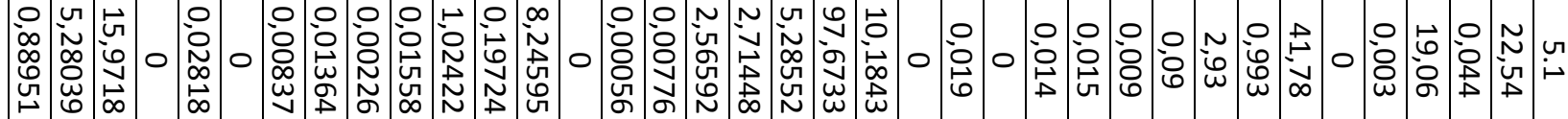

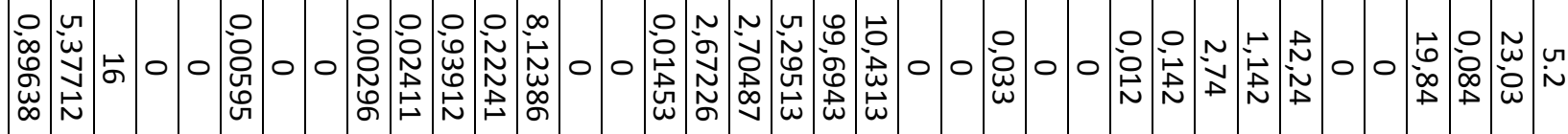

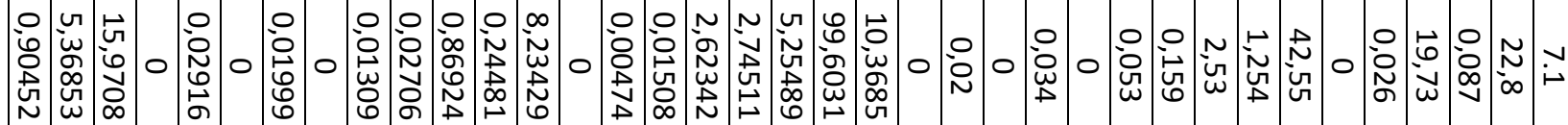

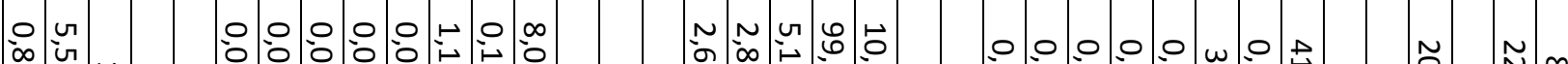

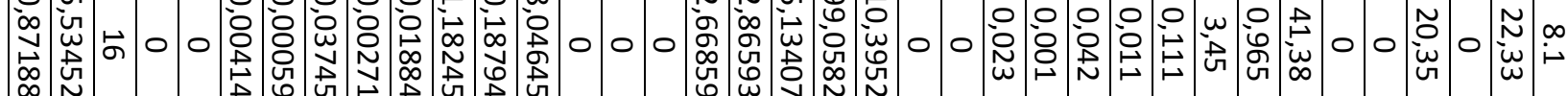

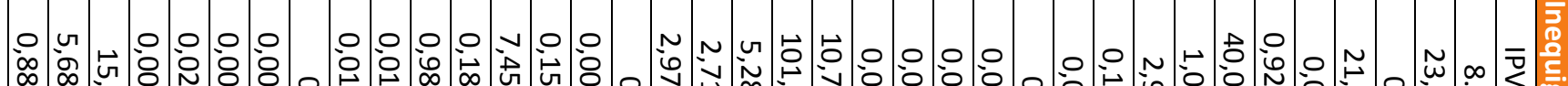

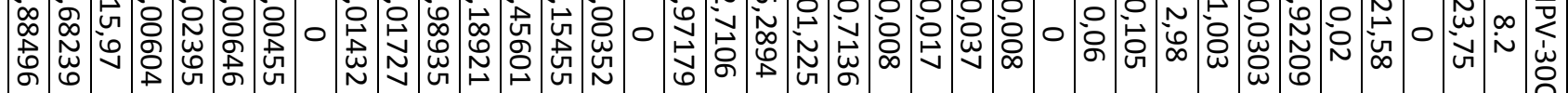

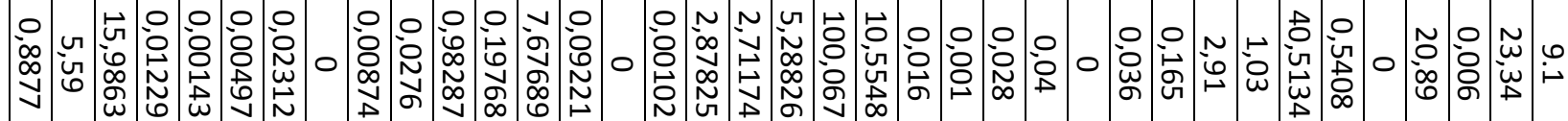

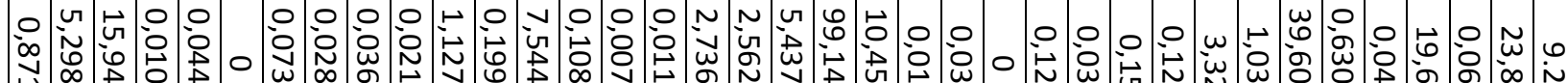

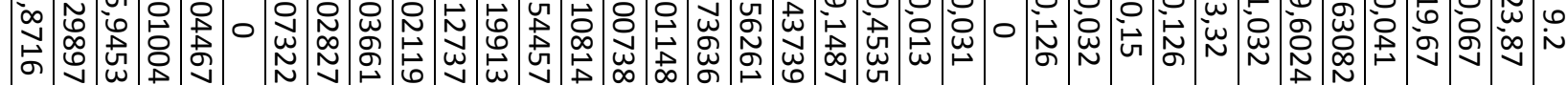

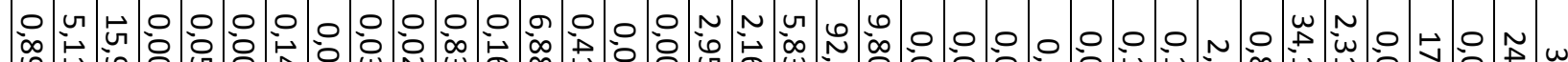

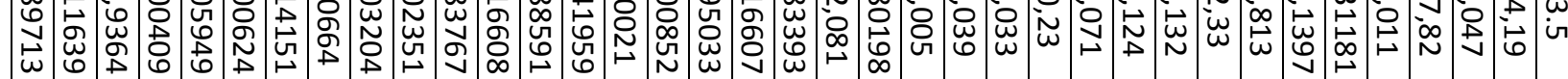

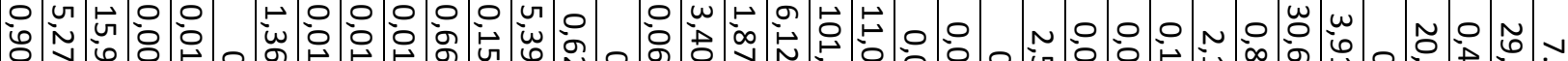

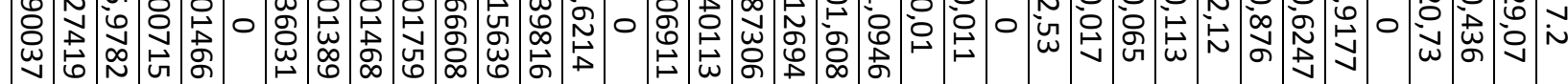

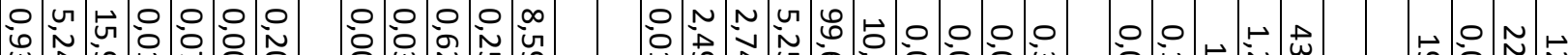

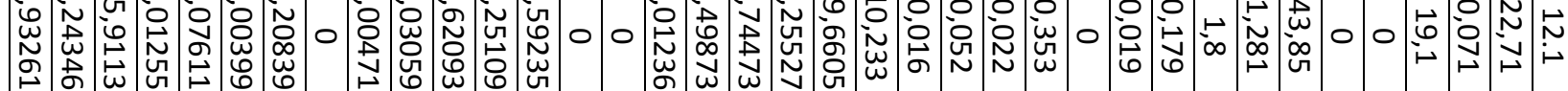

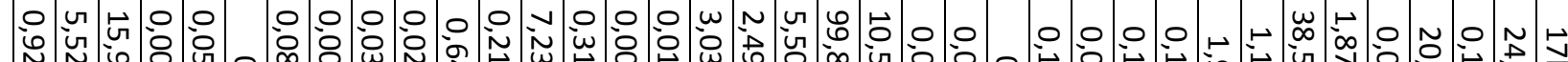

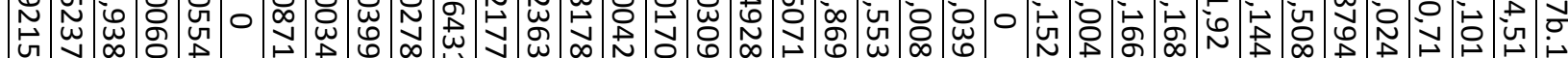

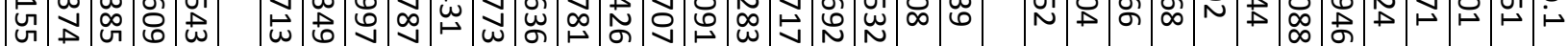

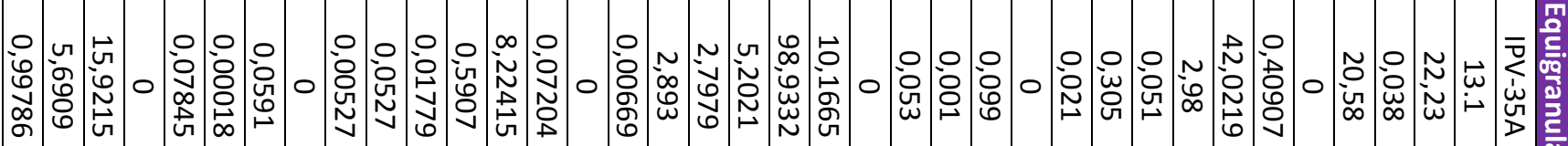

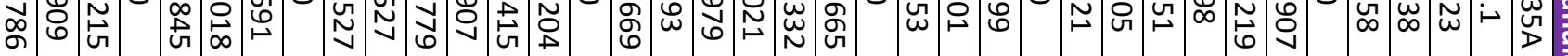




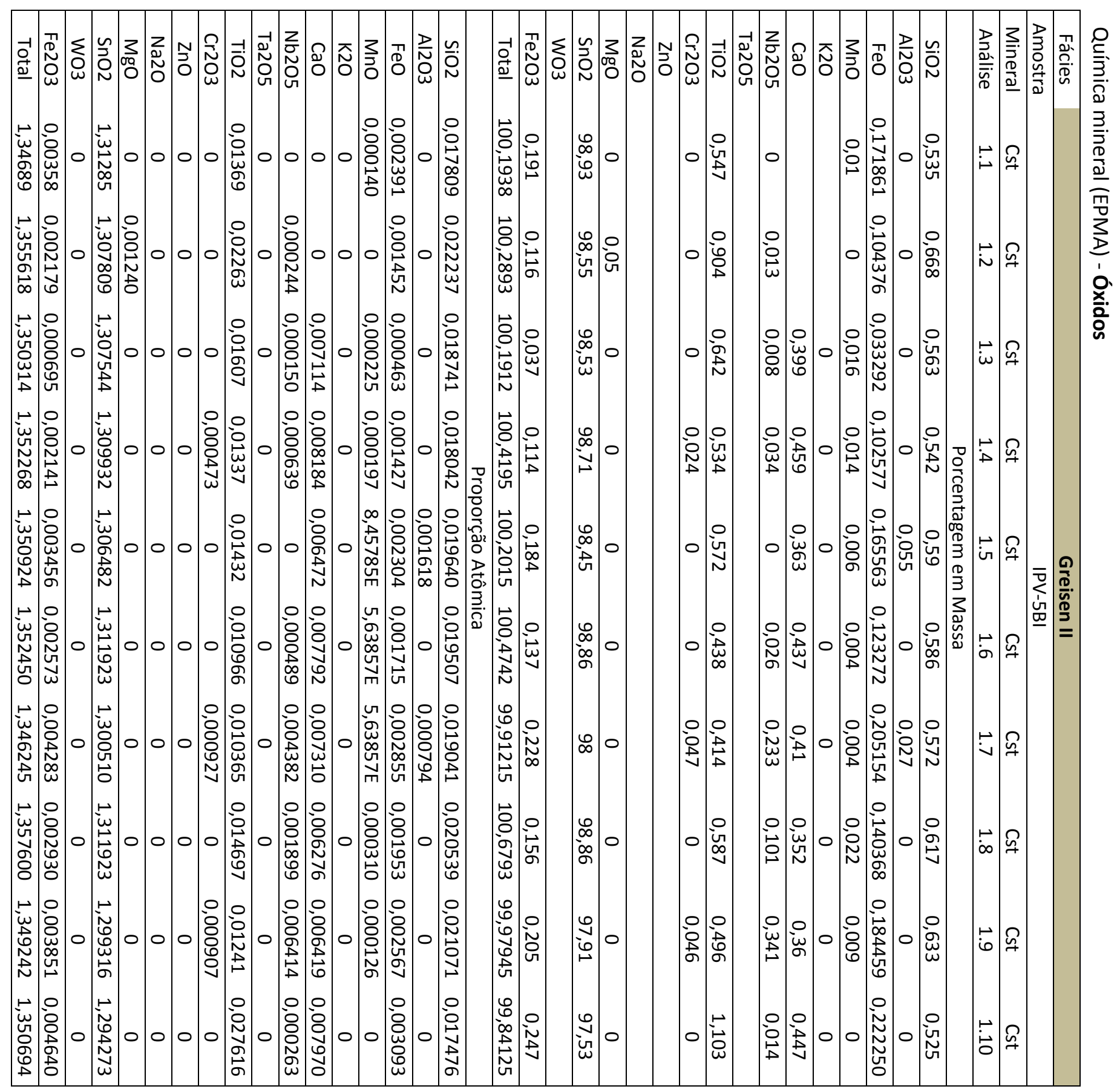




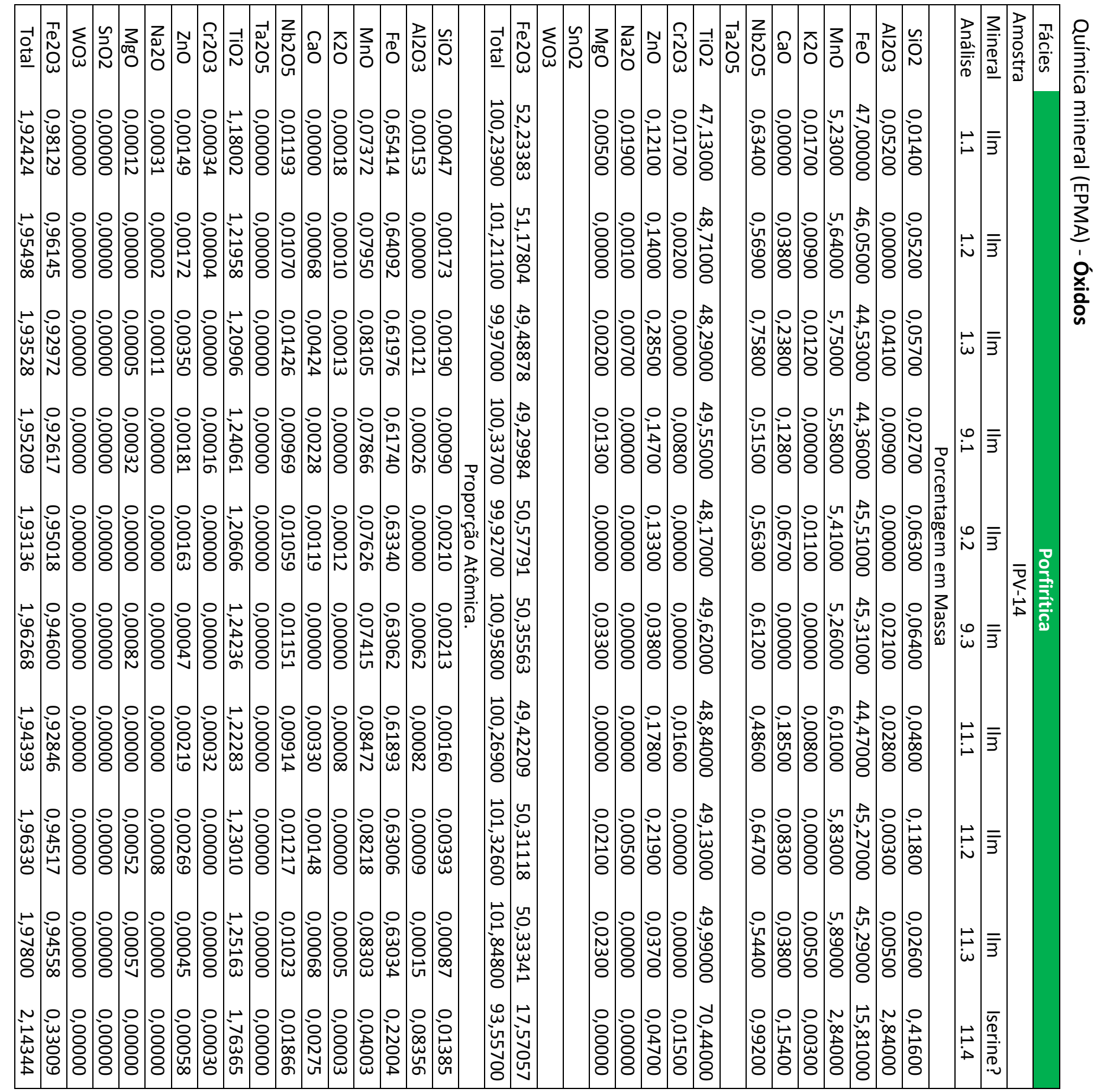




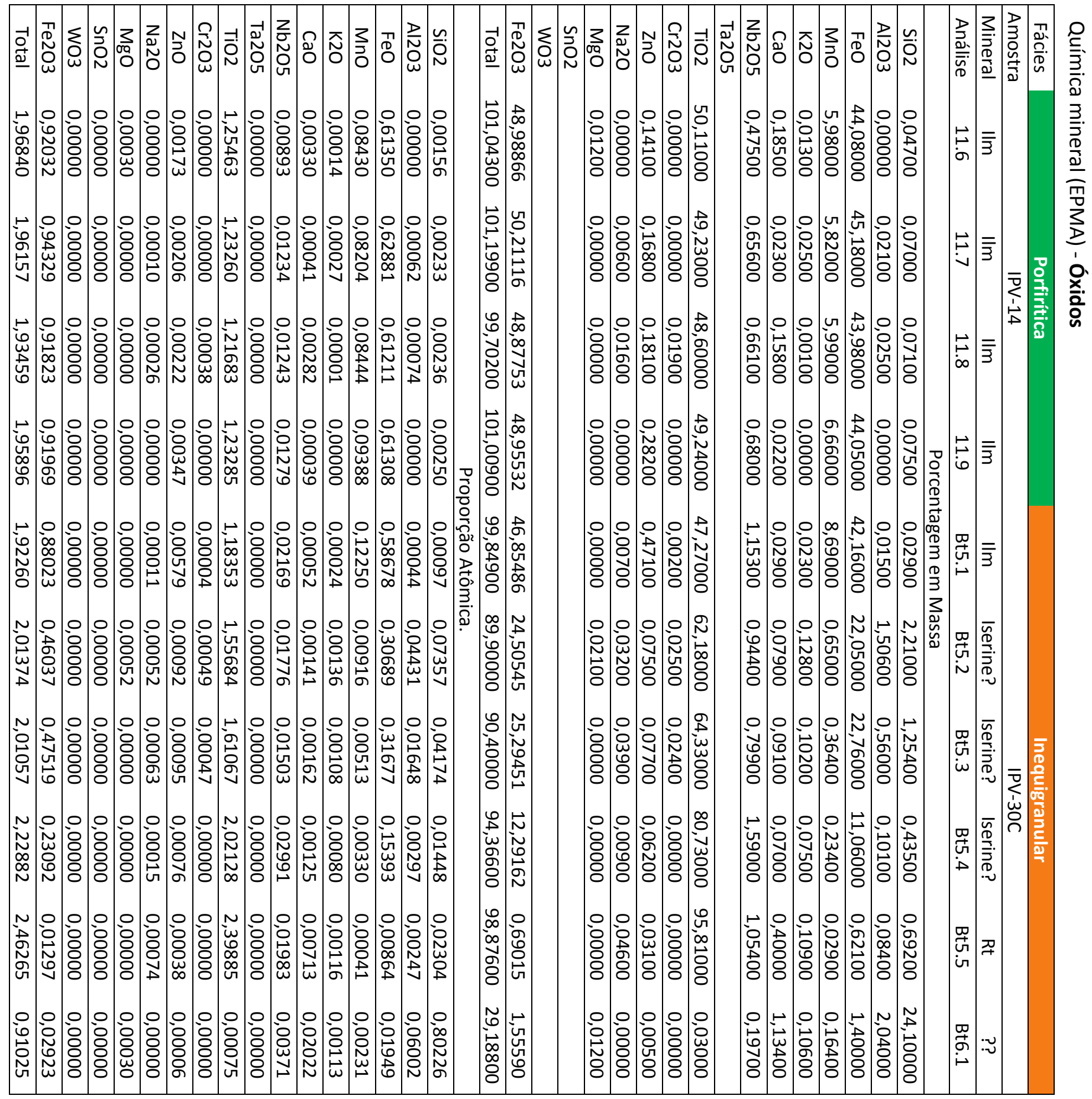




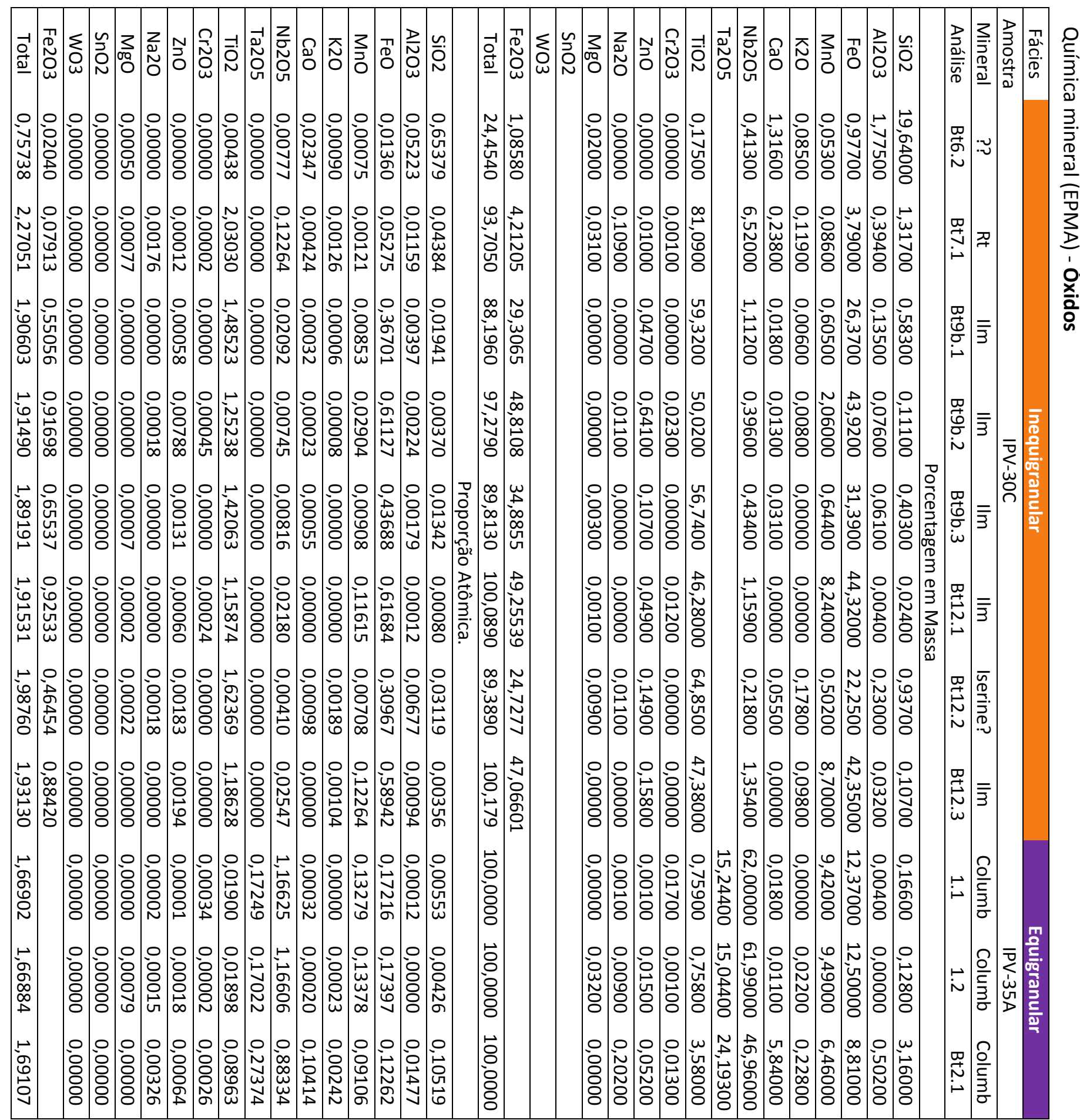




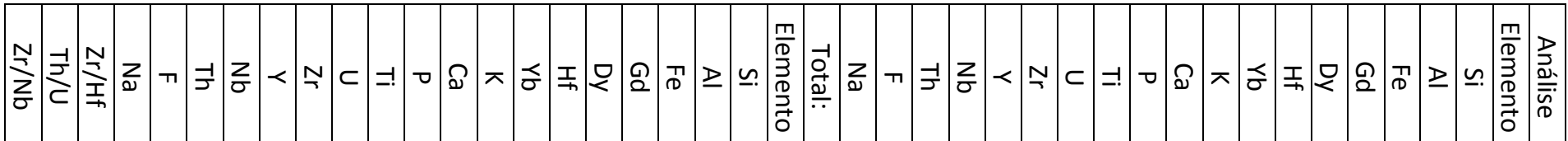

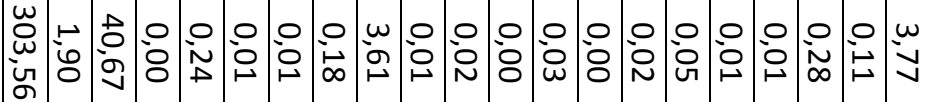

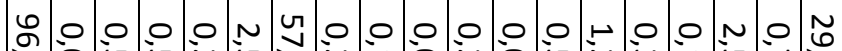

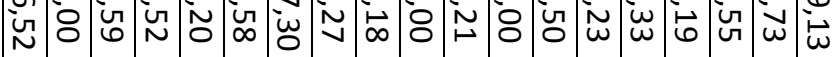

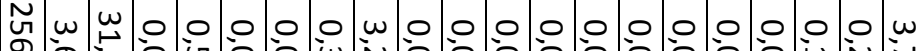

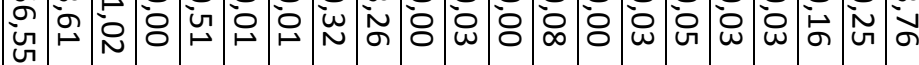

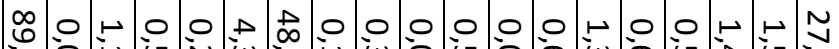

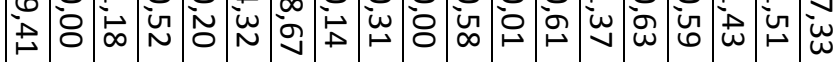

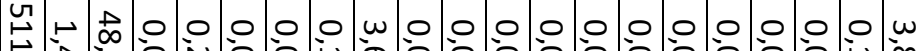

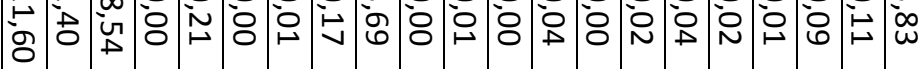

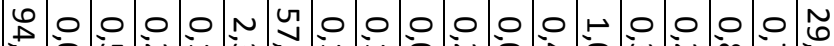

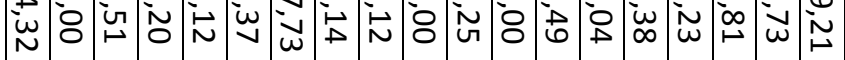

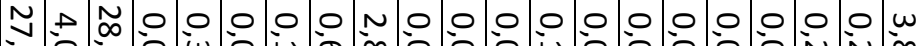
○

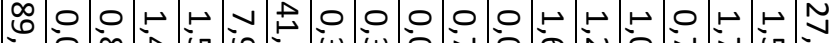
क

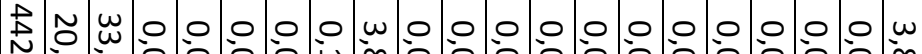
出

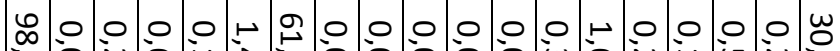

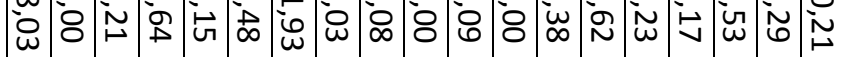

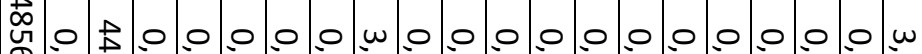

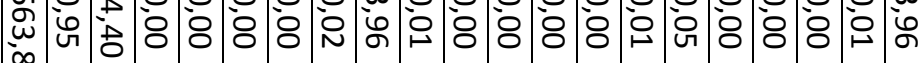
$\infty$

H

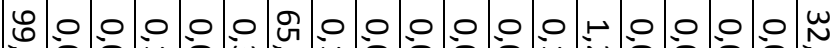

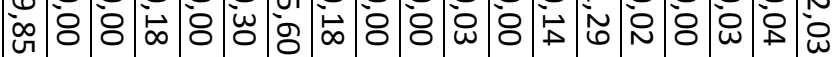

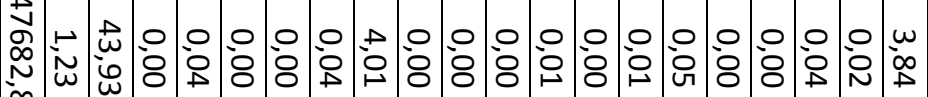

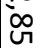

w

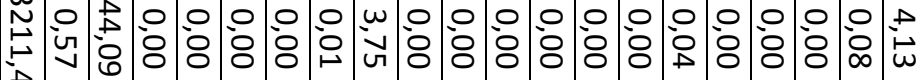
is

Dे
$\infty$ 点 $\underset{\omega}{\omega}$

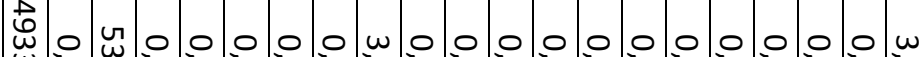

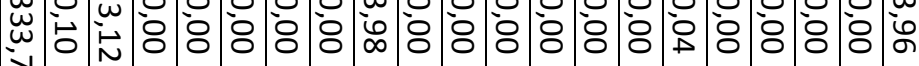
$\omega$

$\vec{\omega}$

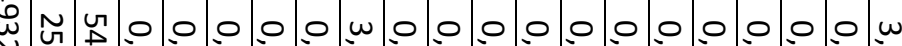
管 $\underset{\omega}{\omega}$

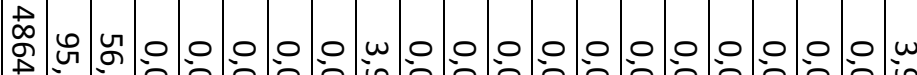

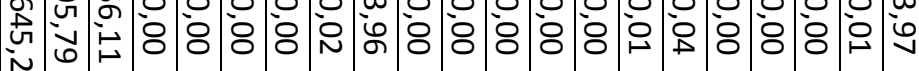
जั

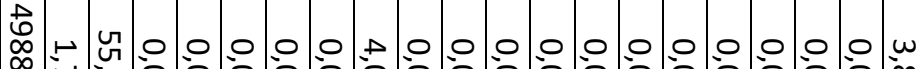

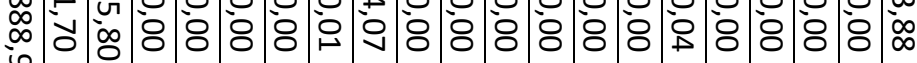
뭉

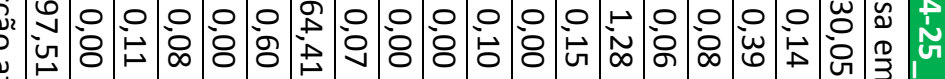

$\lim _{0}$

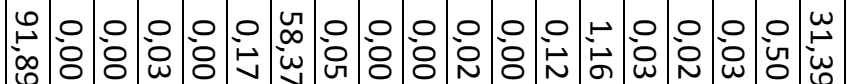

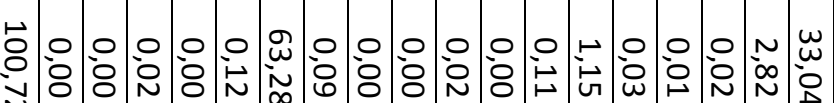

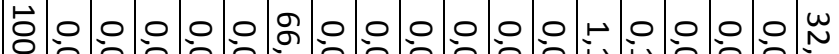

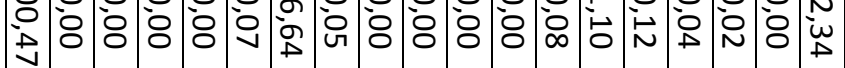

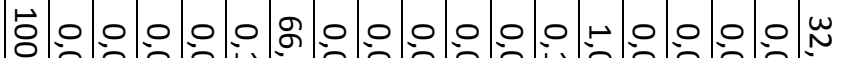
స்

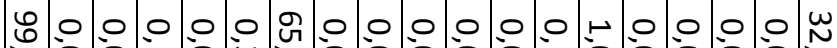
2.

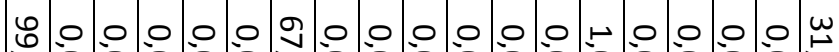
ஆ:8 


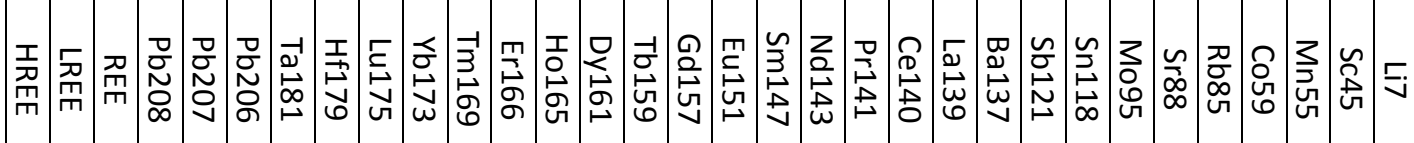

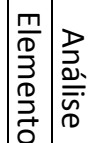

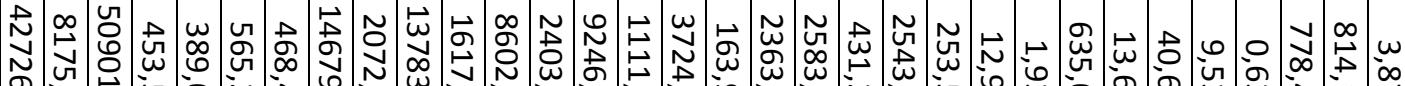
न

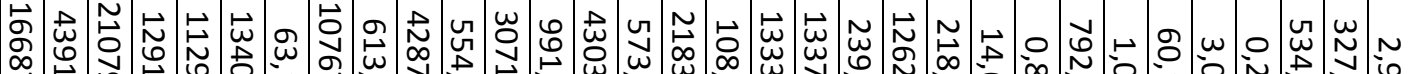

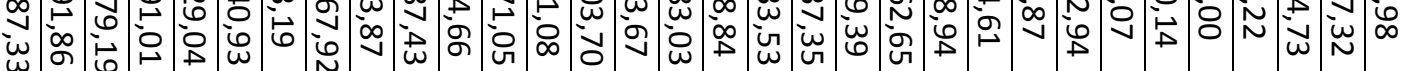

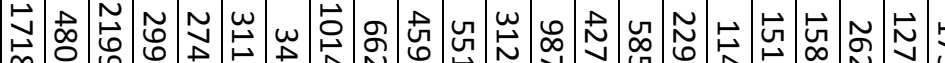

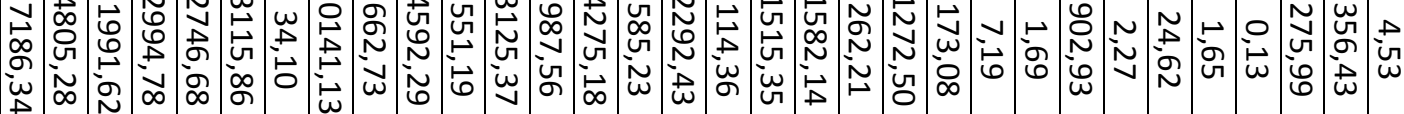

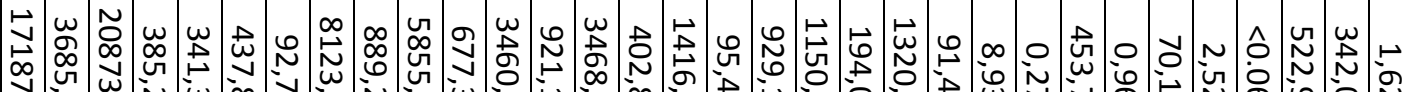

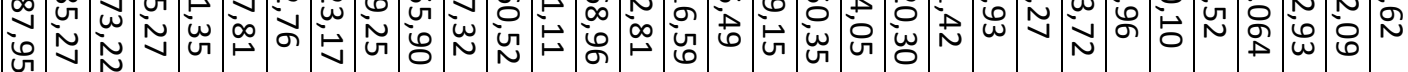

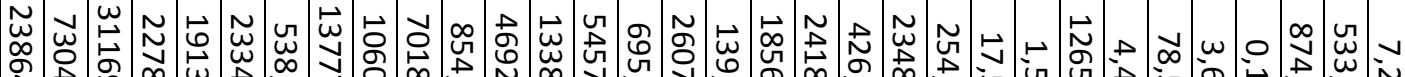

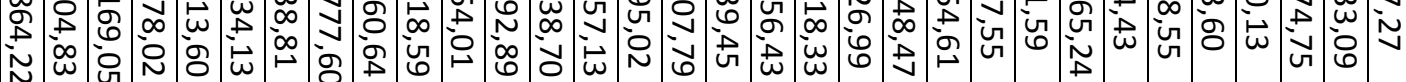

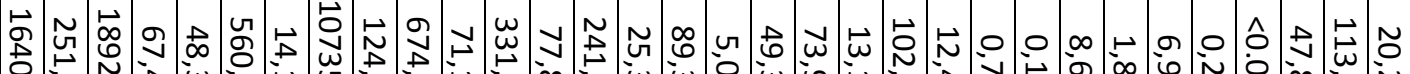

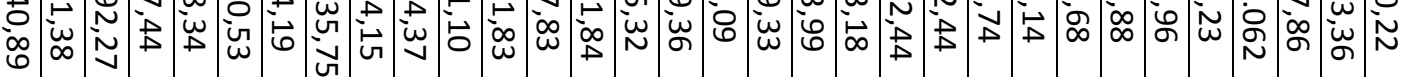

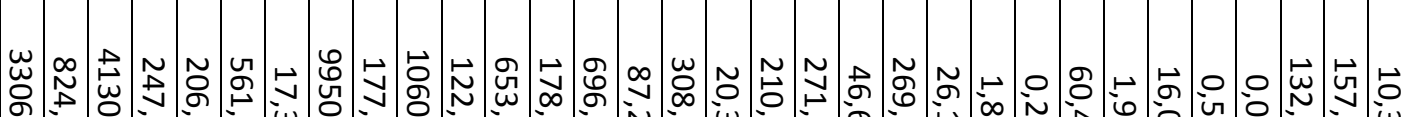

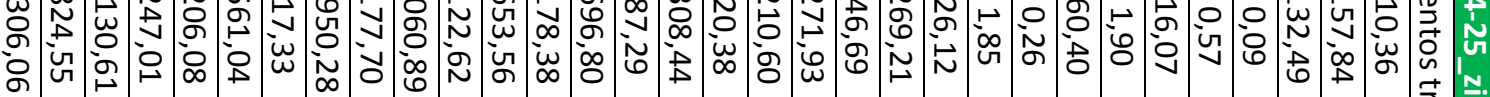

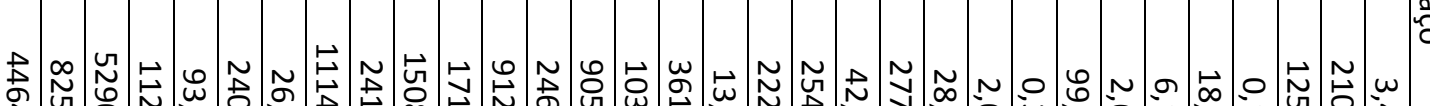

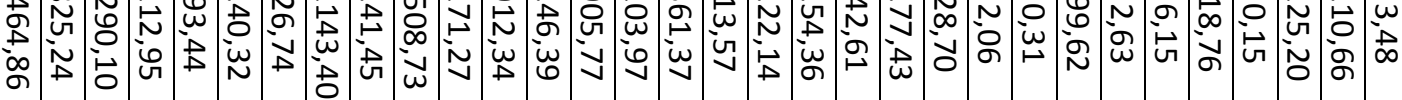

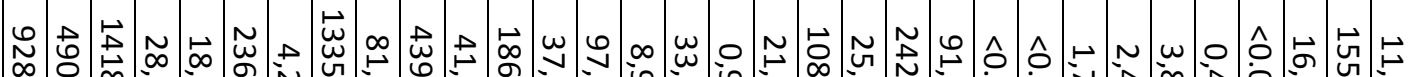

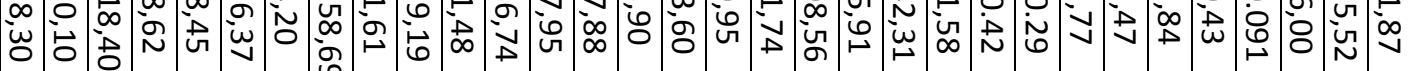

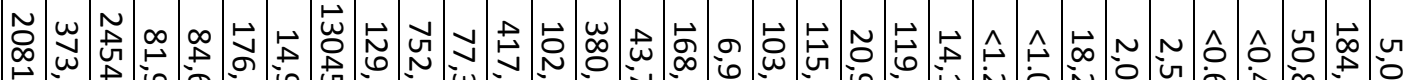

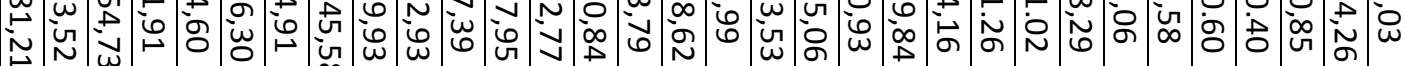

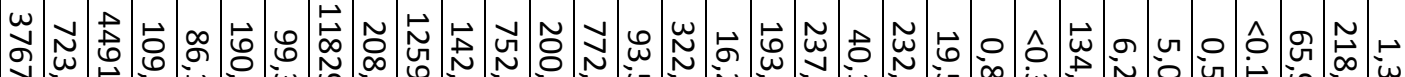

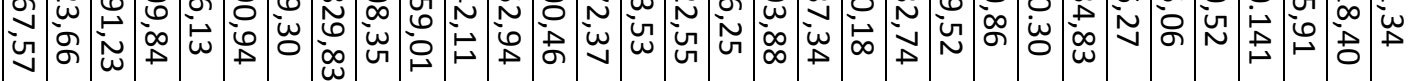

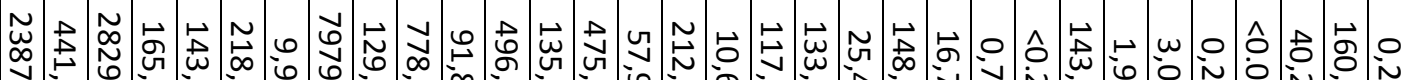

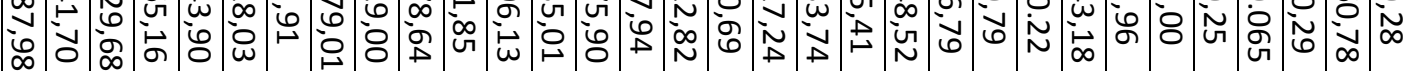

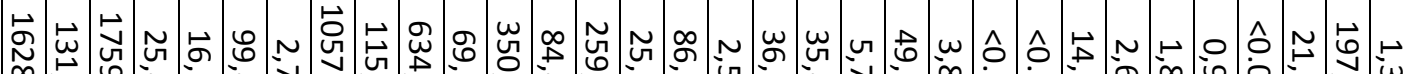

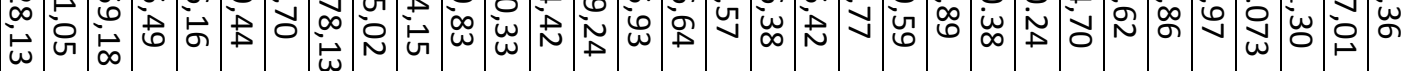




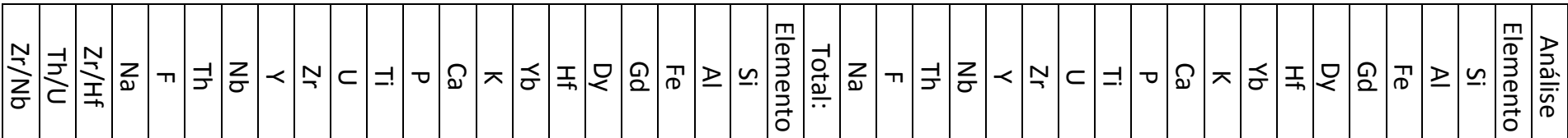

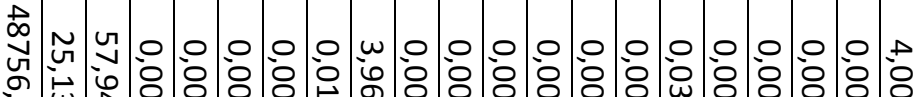

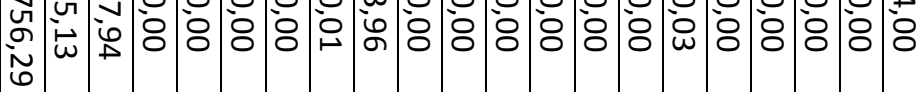

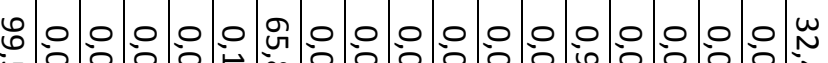
沉 :

م

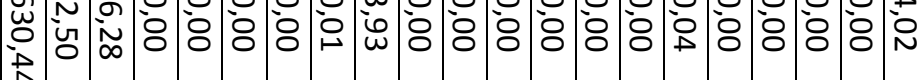

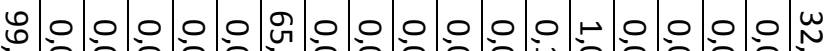
w:

芯.

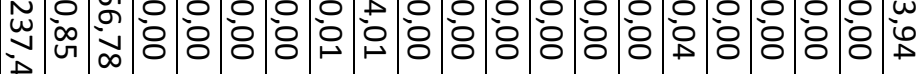
ث

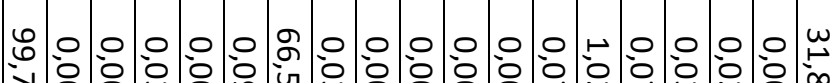
궁

怘 出 N

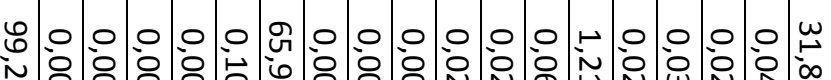

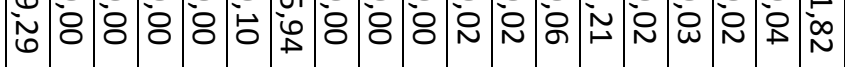

空

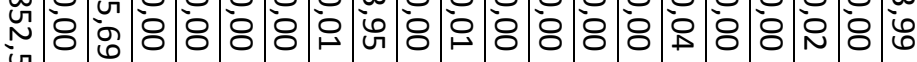
出

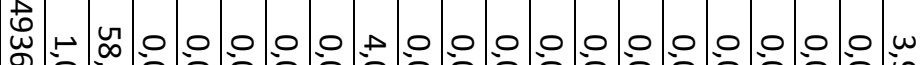

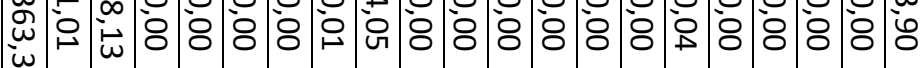
$\underset{\perp}{\omega}$

总 N

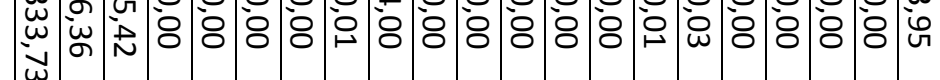

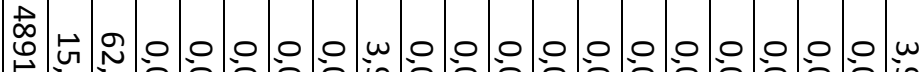

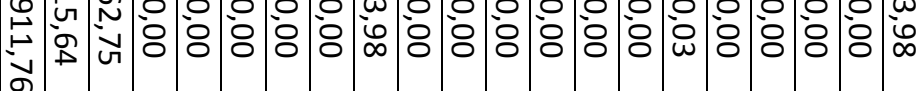
ने

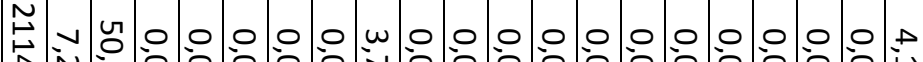
点

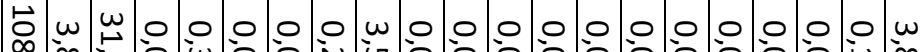

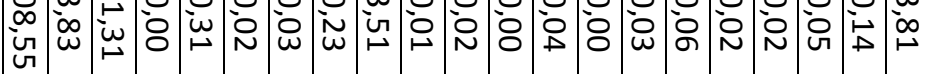

\% 年

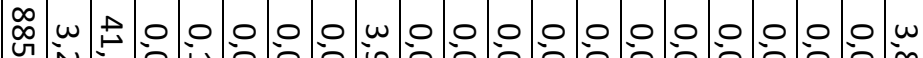

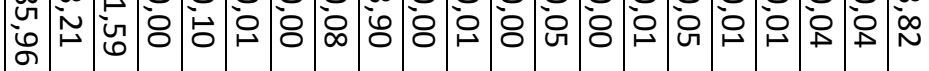

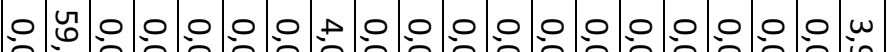

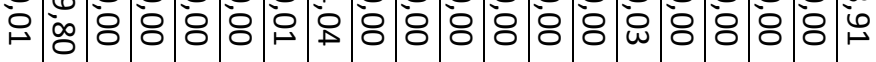

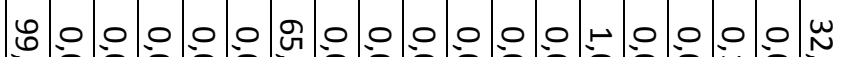
识:

焉

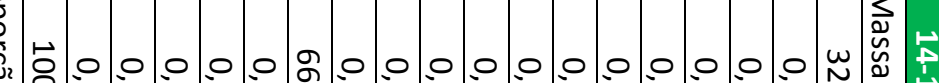

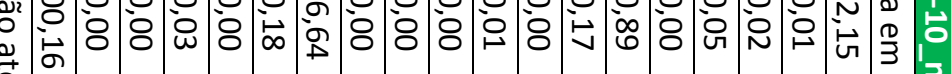
家.

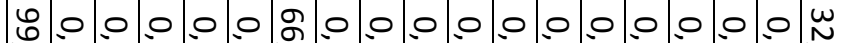
४े : :

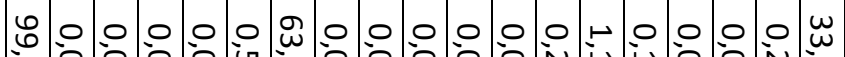

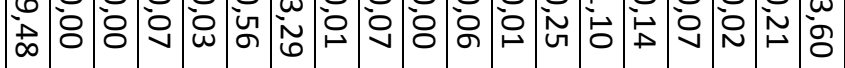

D. O 究

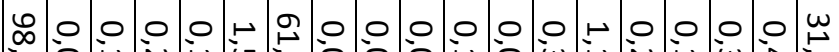

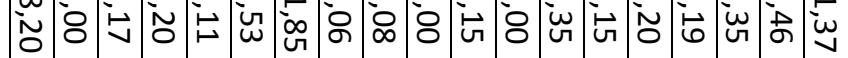

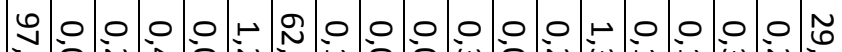

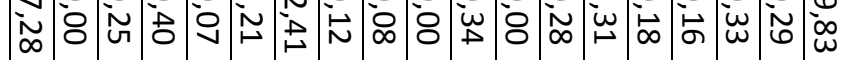

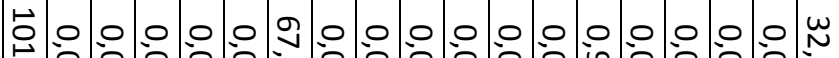

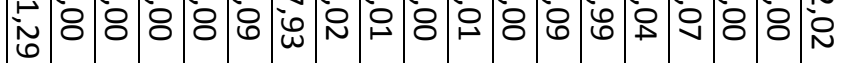




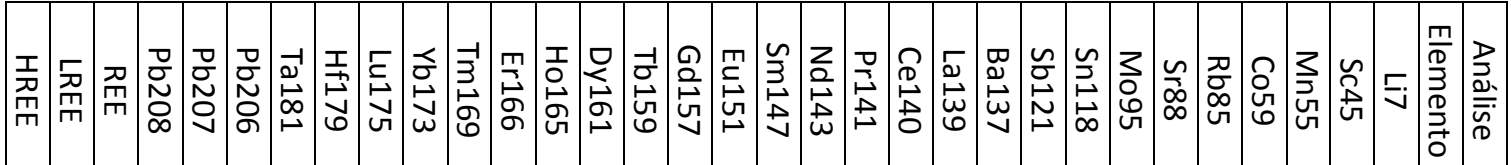

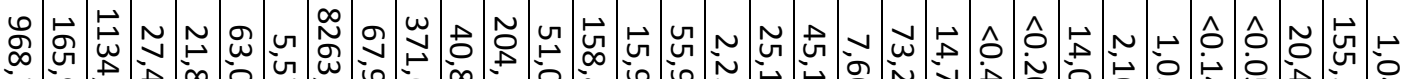

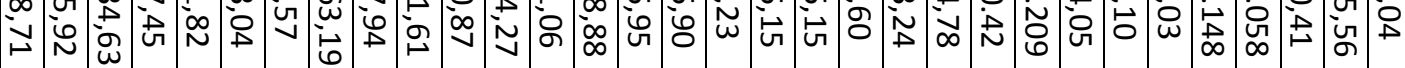

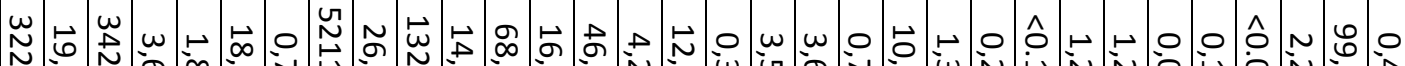

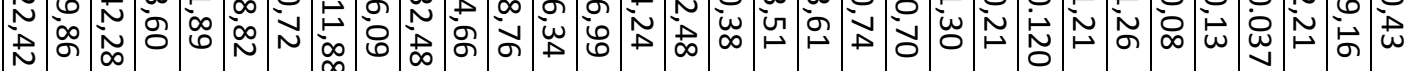

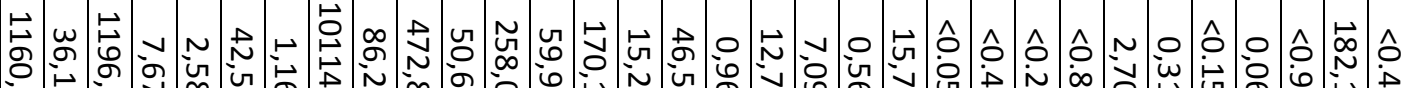

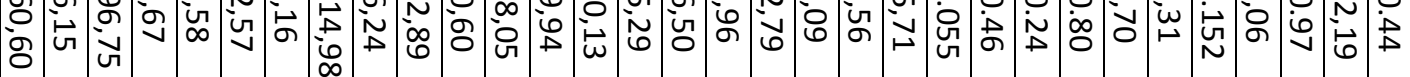

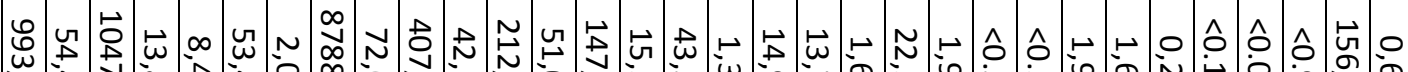

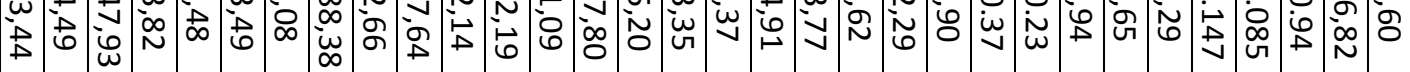

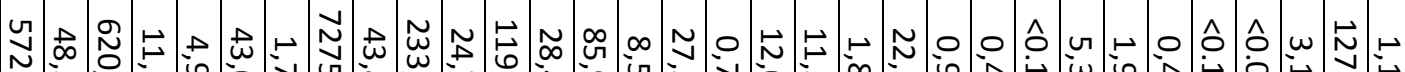
定

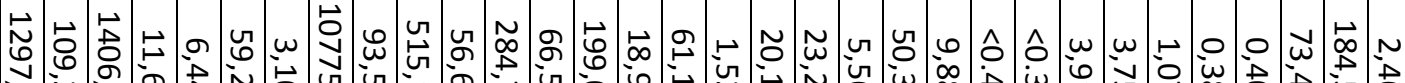

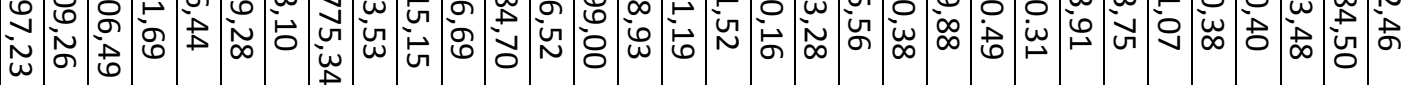

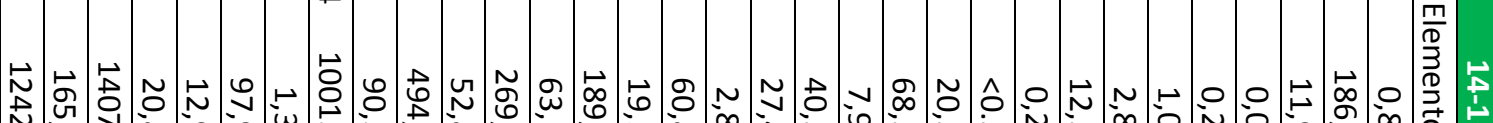

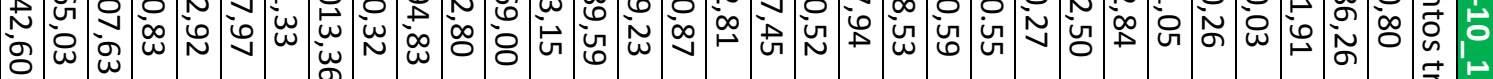

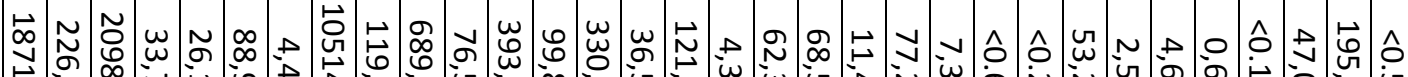

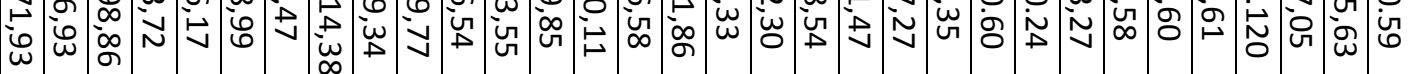

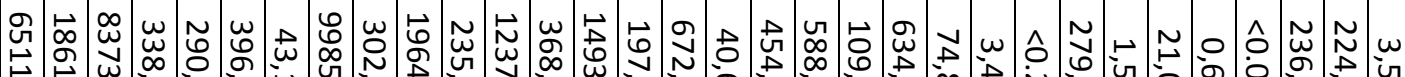

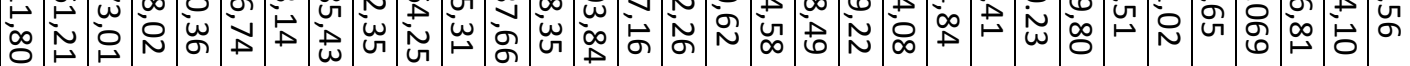

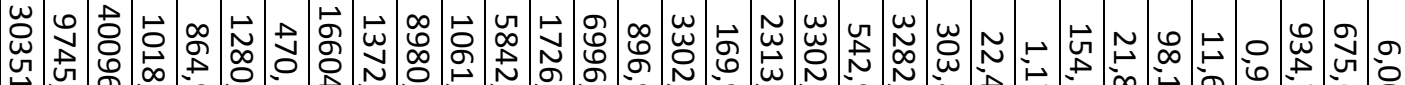

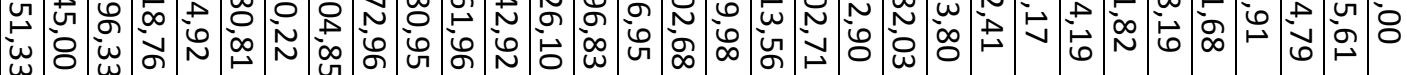

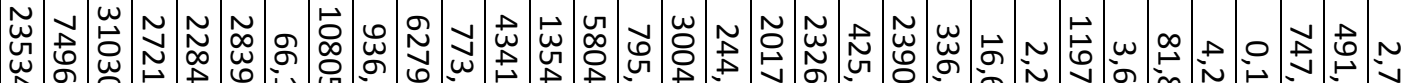

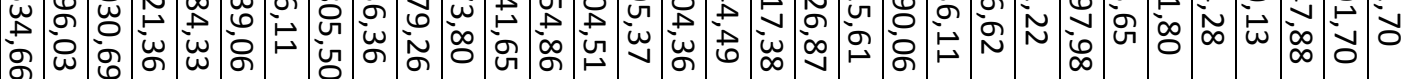

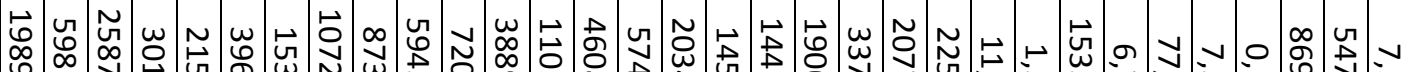

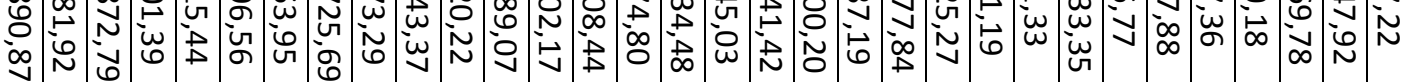




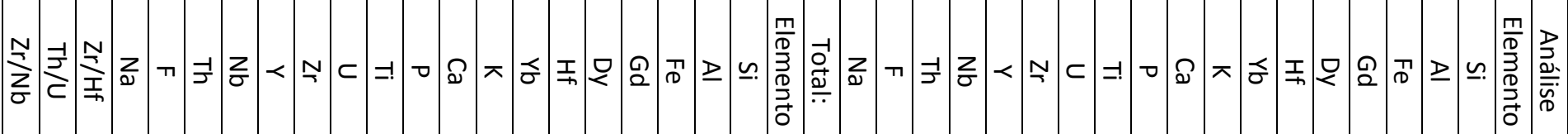

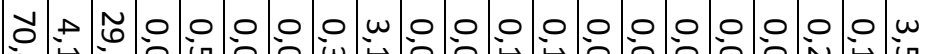
合

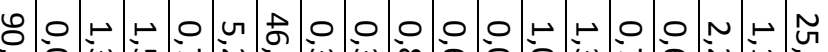

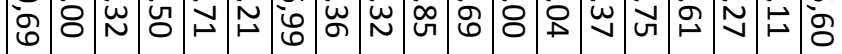

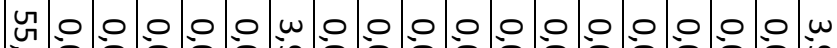
岕:

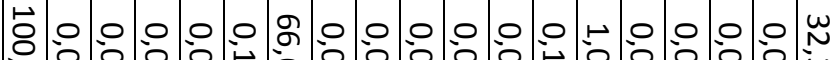

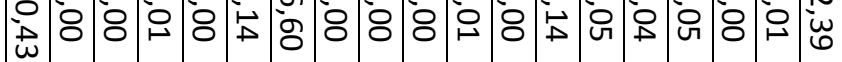

f n m 焉

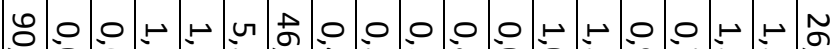

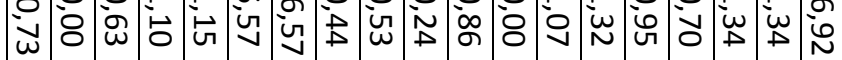

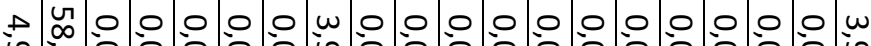

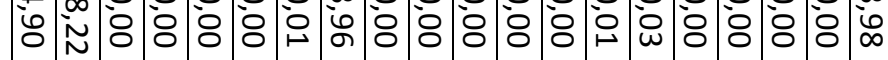

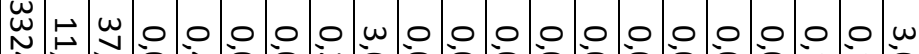

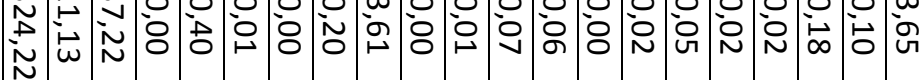

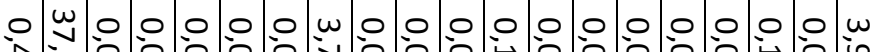

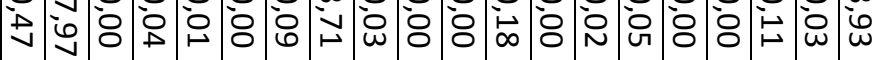

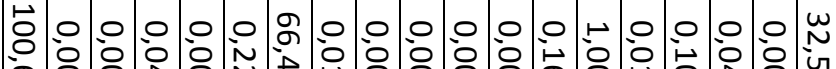

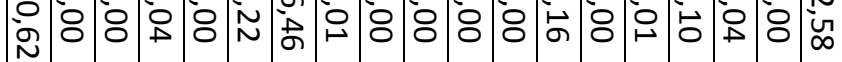

U.

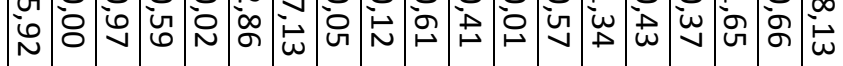

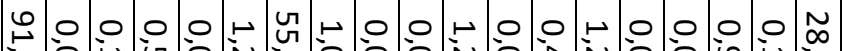
ث:

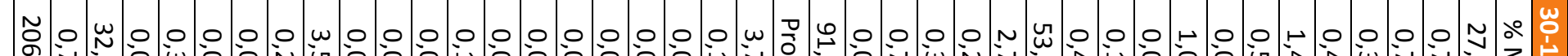

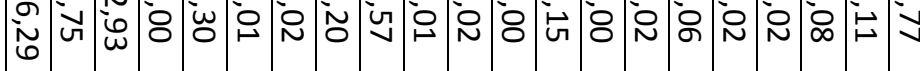

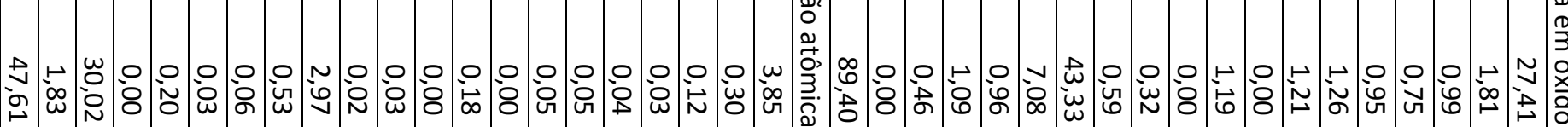

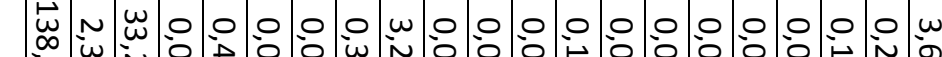
管

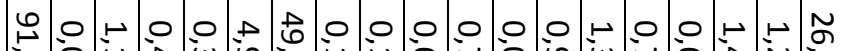
ज浣

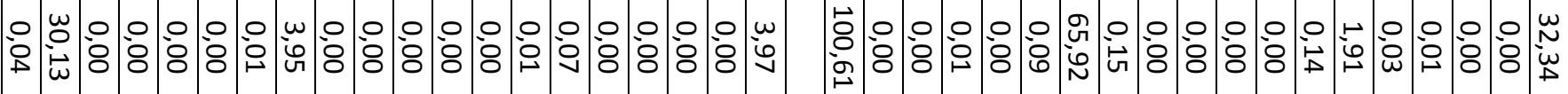
ஃ

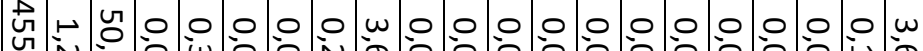

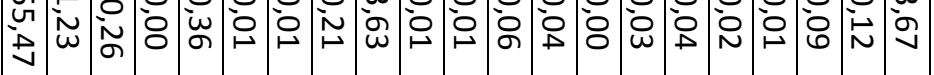

U

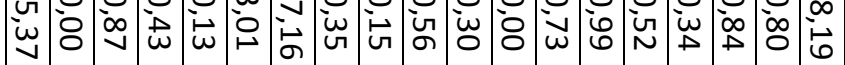

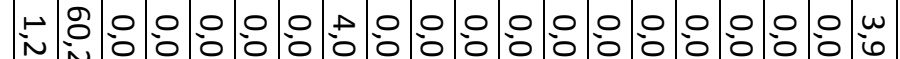

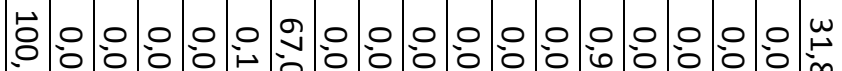
๙

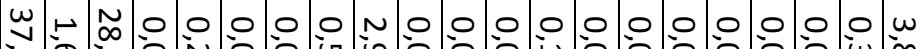

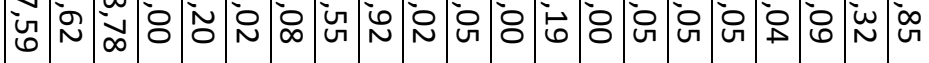

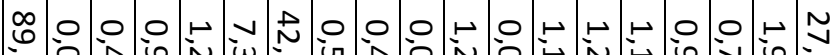

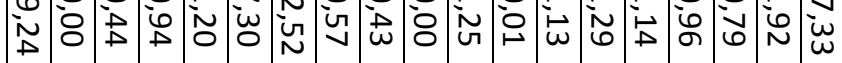

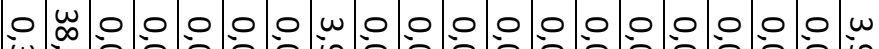

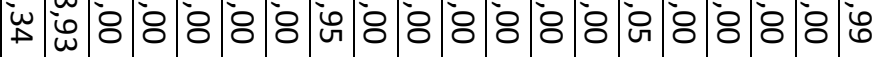

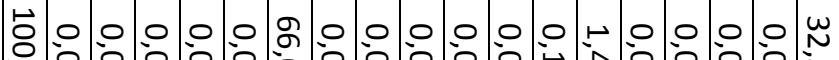
垔 


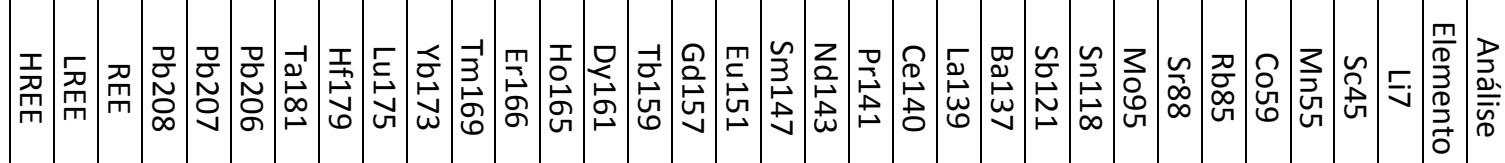

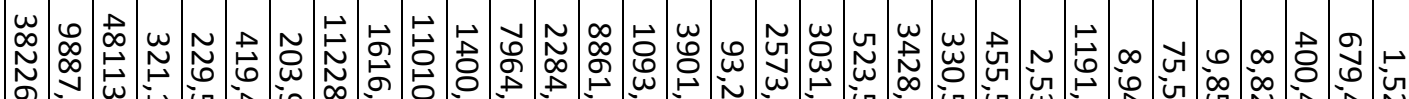

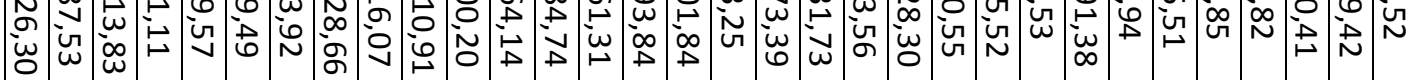

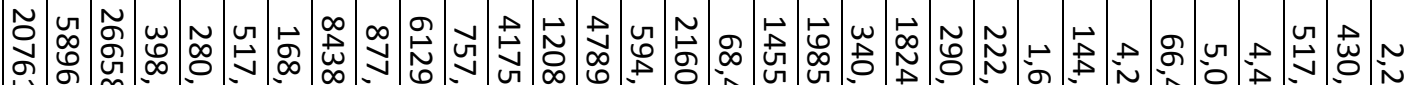

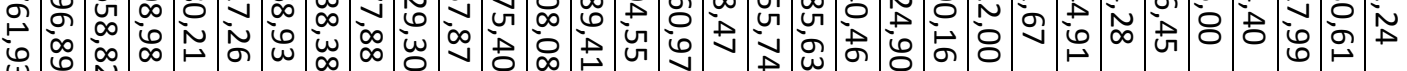

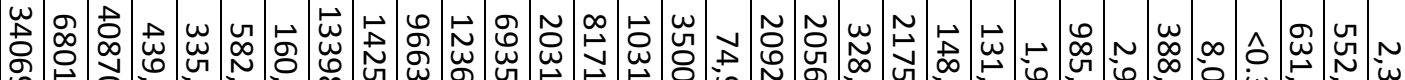

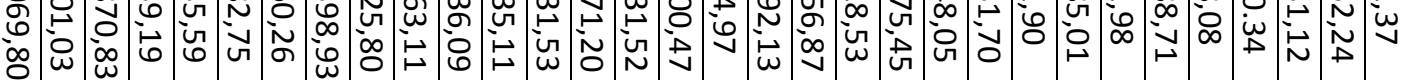

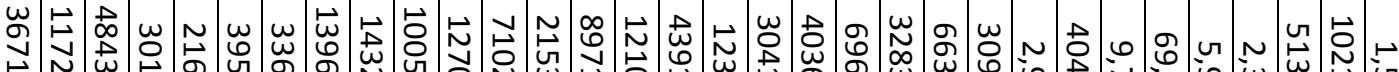

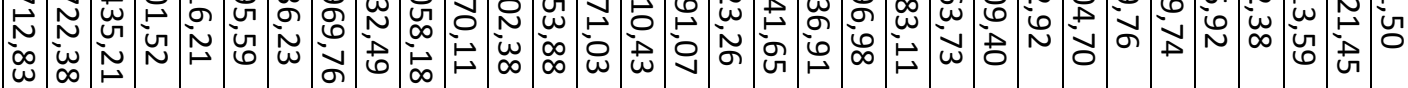

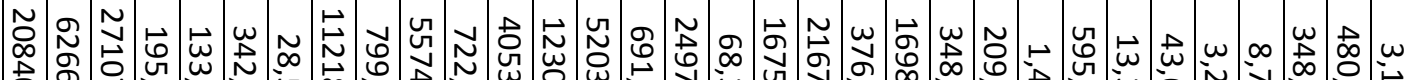

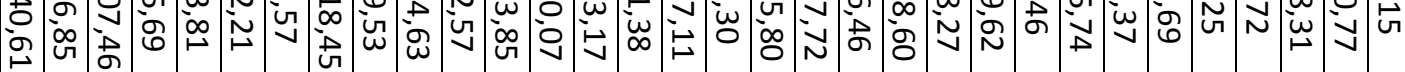

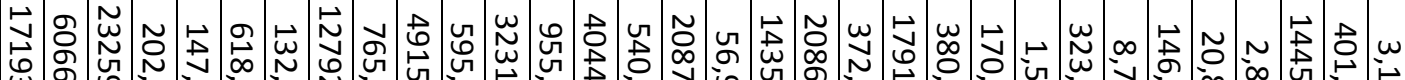

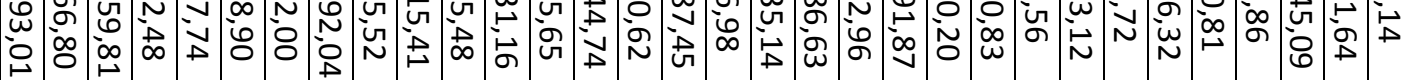

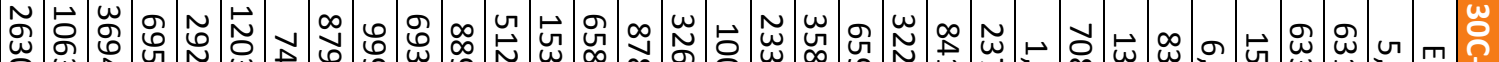

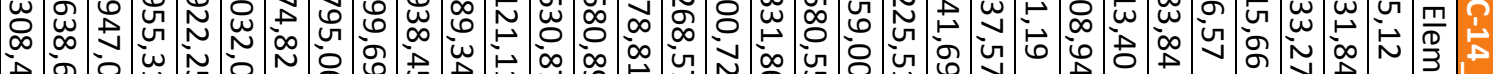

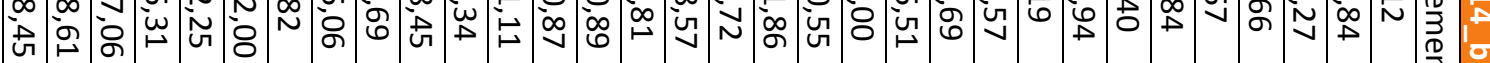

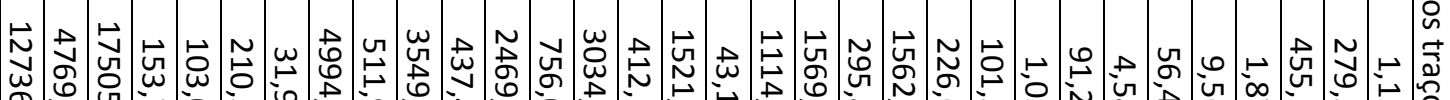

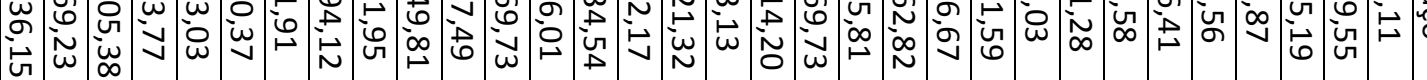

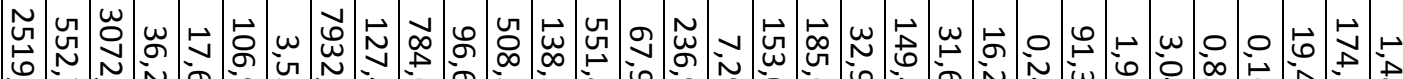

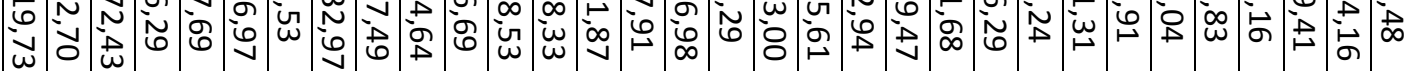

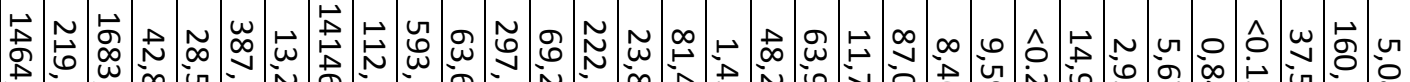

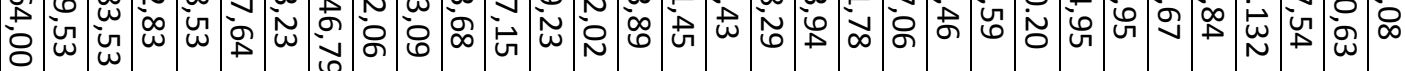

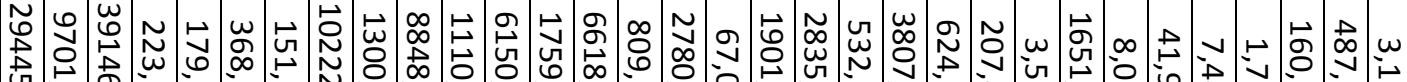

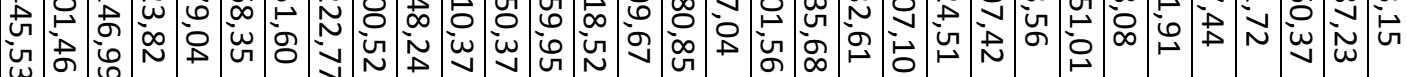

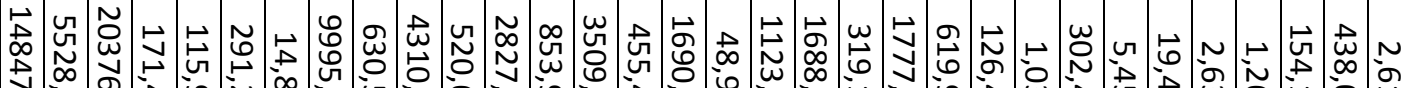

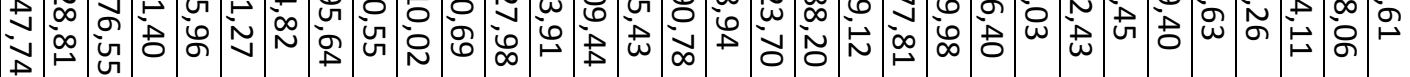

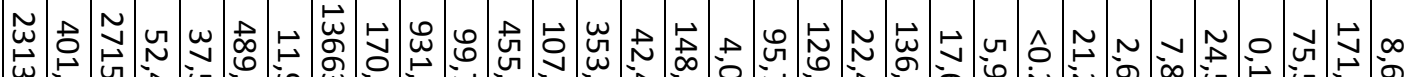

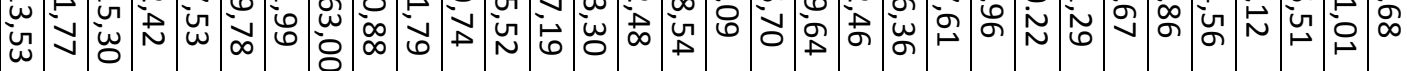

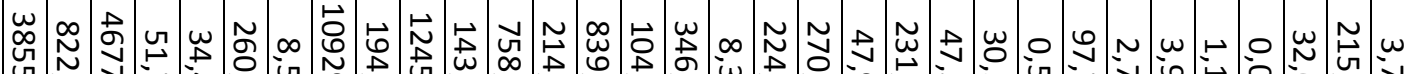

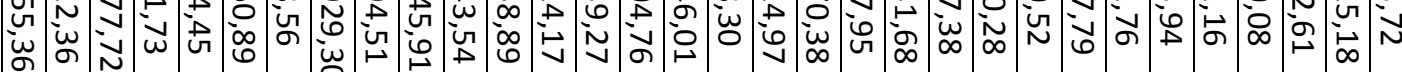




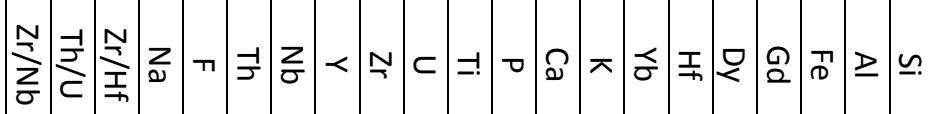

ก 留

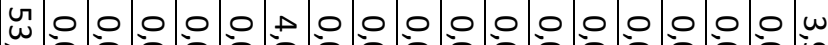
。

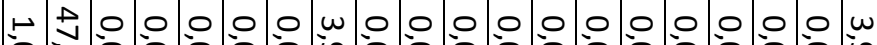
官

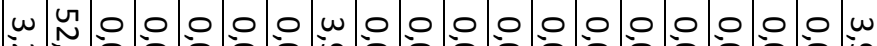
N

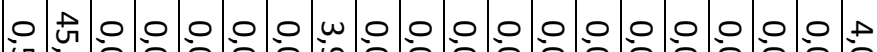

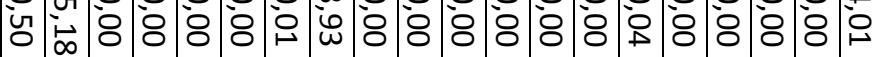

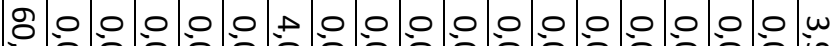
占

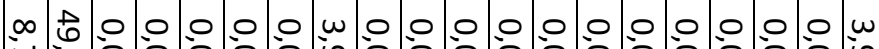
N

HUN ஸ்

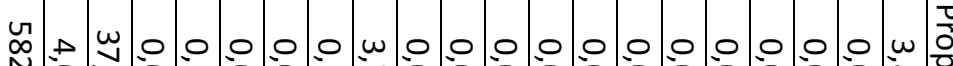
v

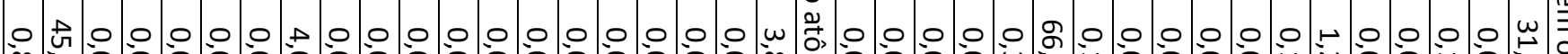
舟

เ

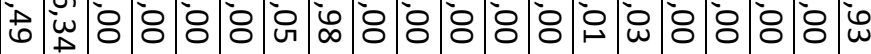

ที 嵅

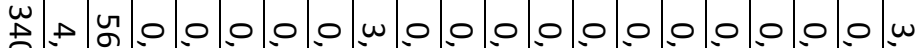
出

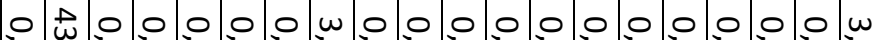
w v

1

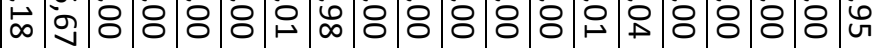

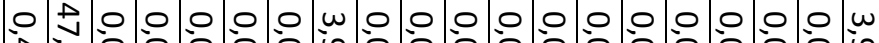
न

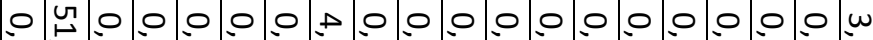
出

$\infty \circ 000.0 .000000000 \omega$ "

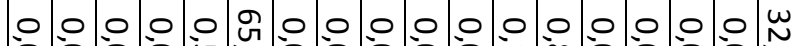
৪ 웅

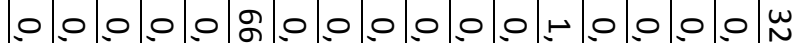
웅요

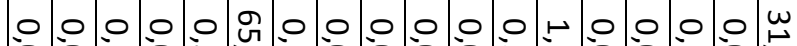
8 8 w

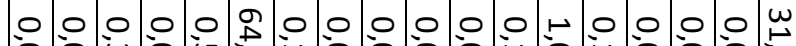

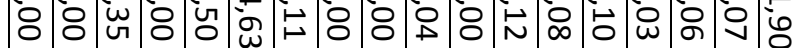

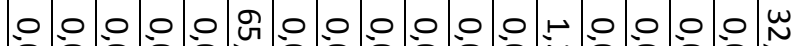

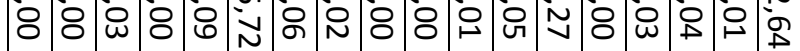

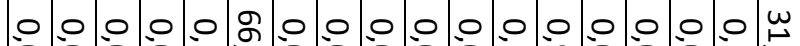

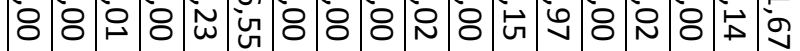

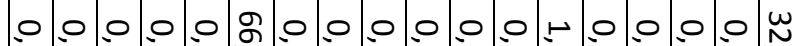
응은

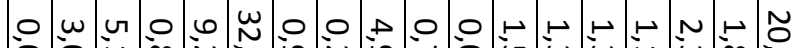
৪

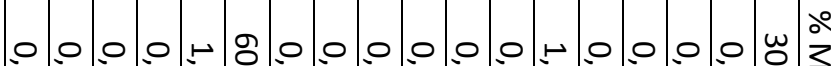
(2)

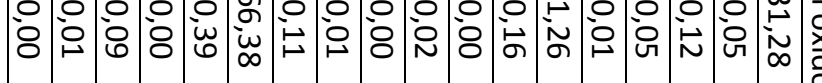

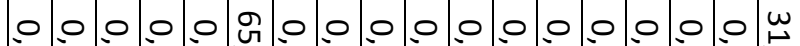

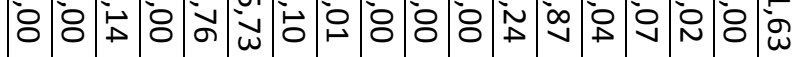

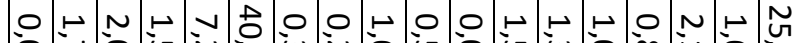
\&

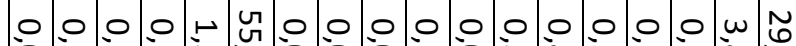
৪

- 0 - 0 o 0 G ৪ ৪

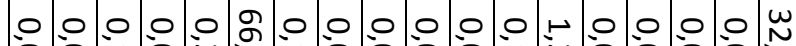

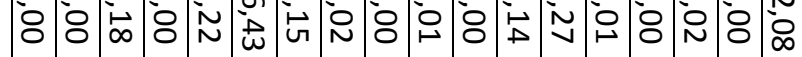

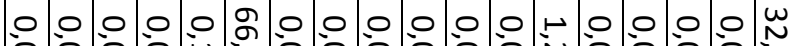
৪:

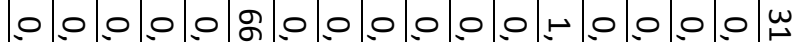
8 8 8 88 8 8 年 


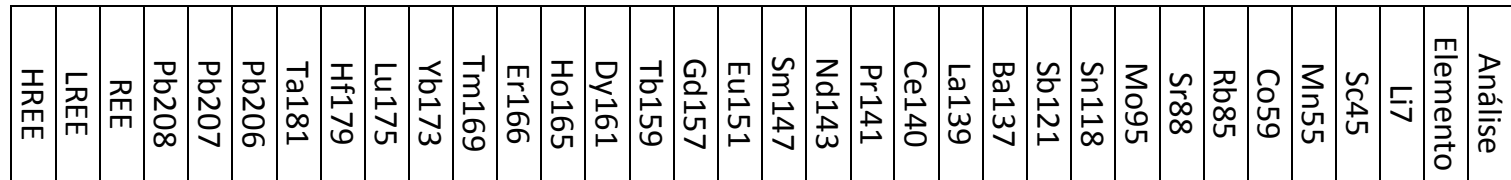

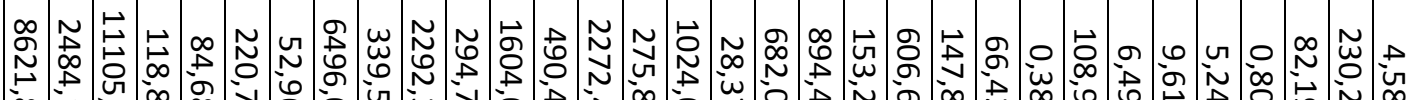

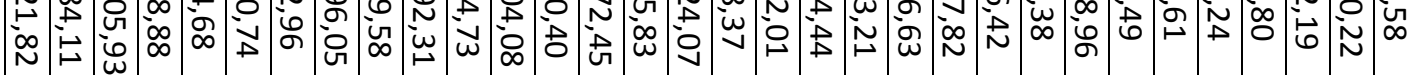

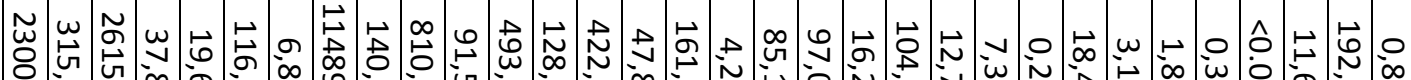

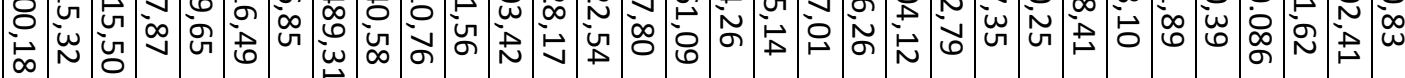

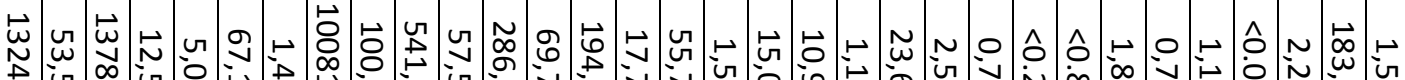

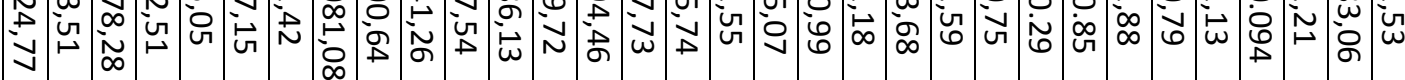

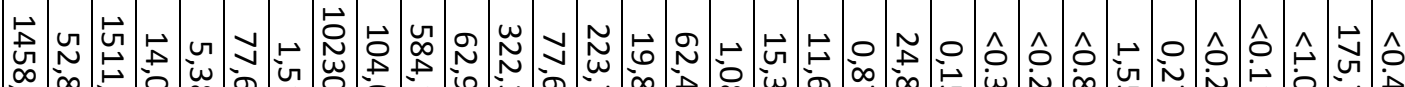

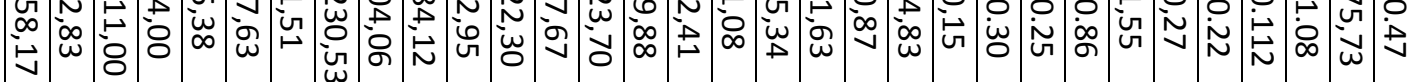

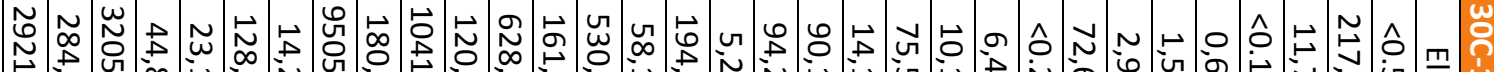

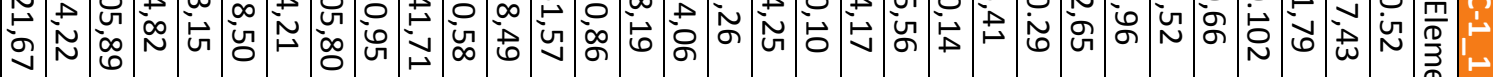

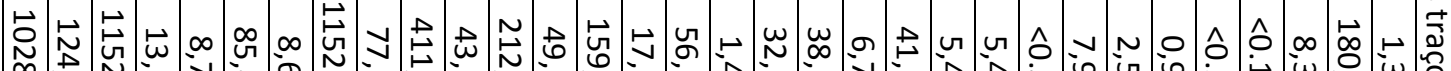

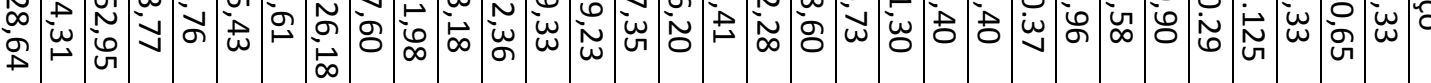

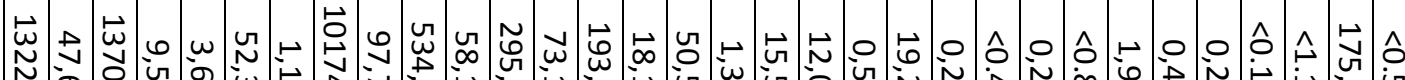

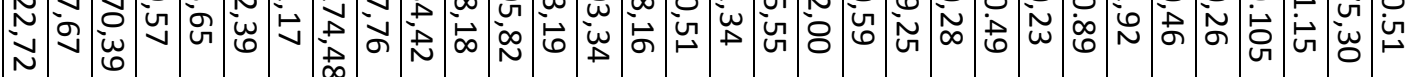

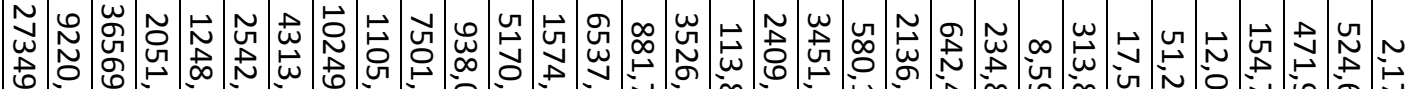

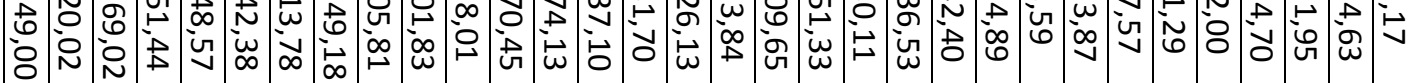

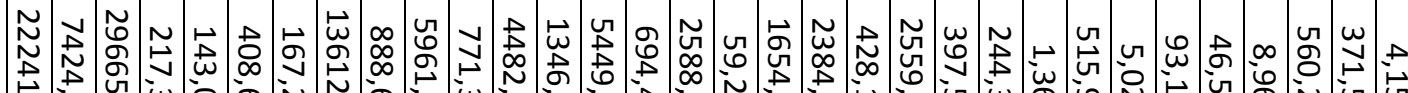

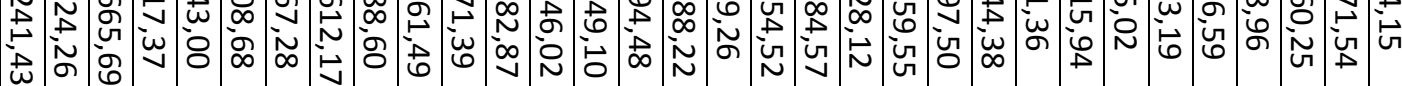

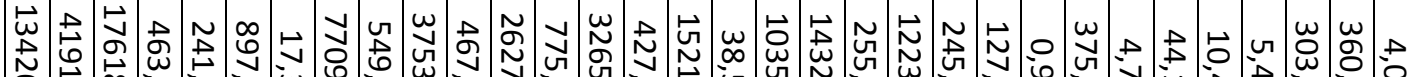

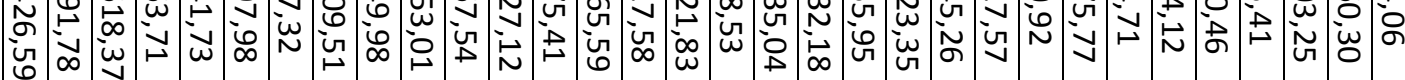




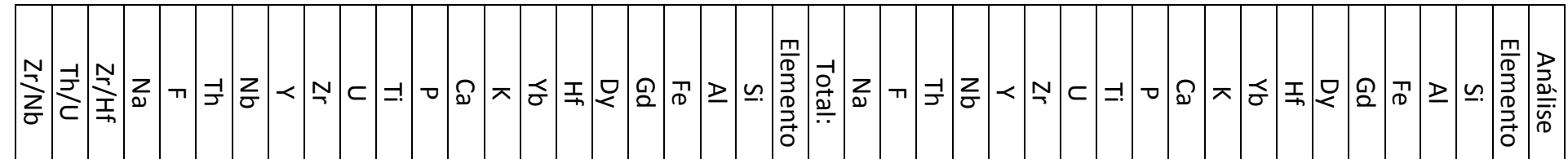

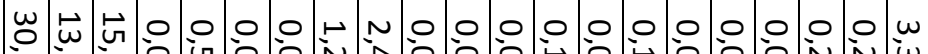

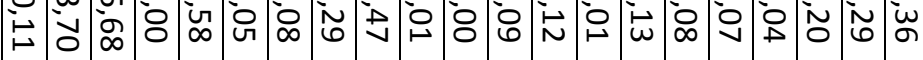

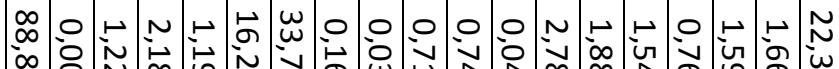

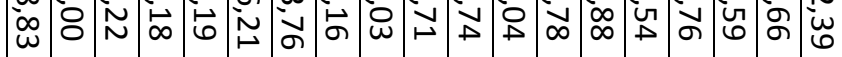

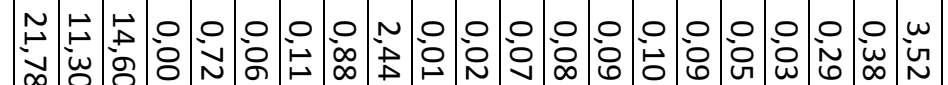

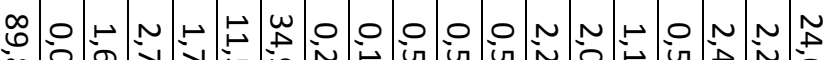

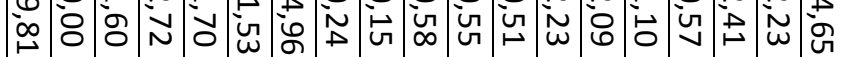

N

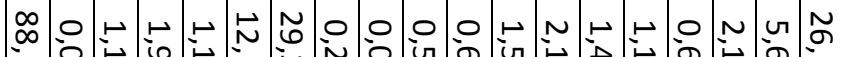

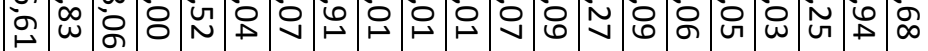

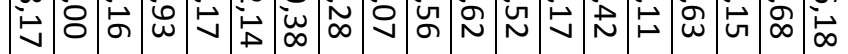

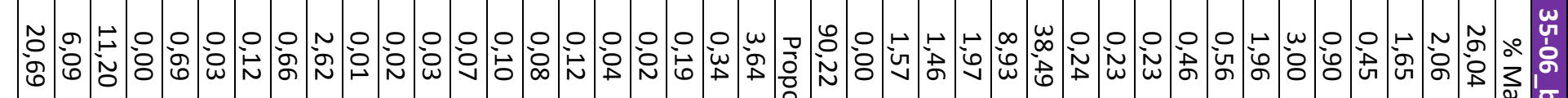

U.

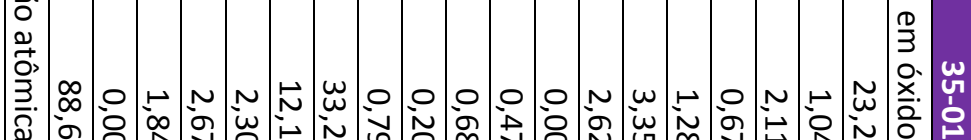
出

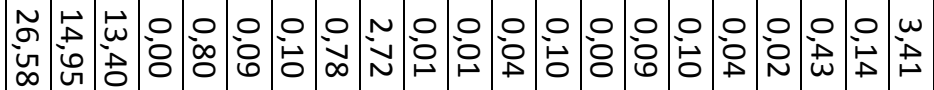

$\tilde{0}$

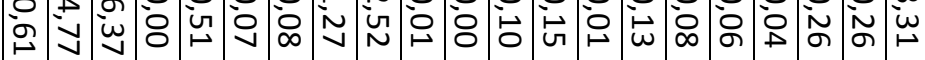

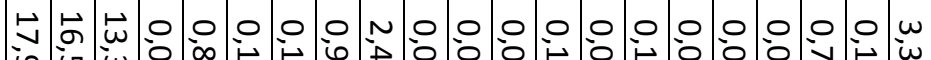

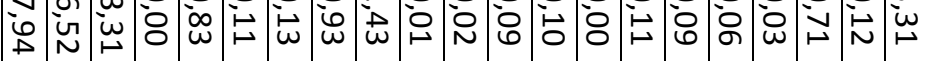

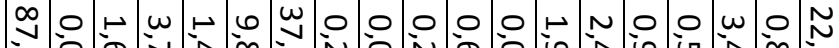

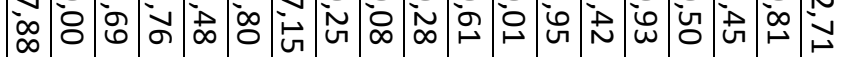

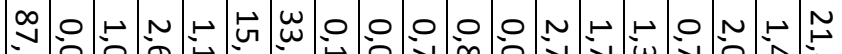

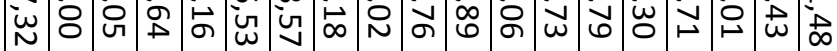

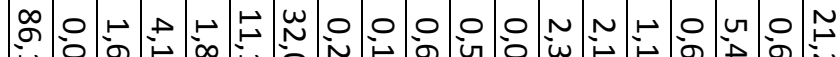
产 


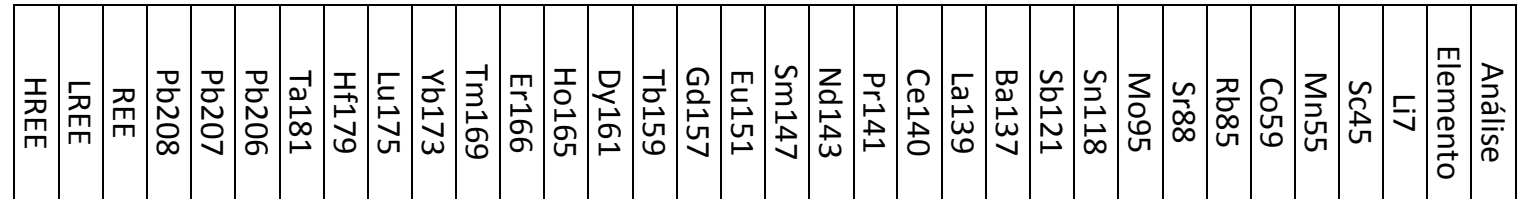

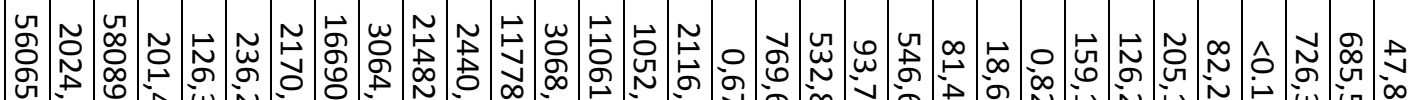

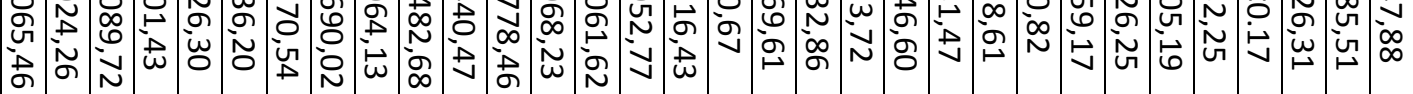

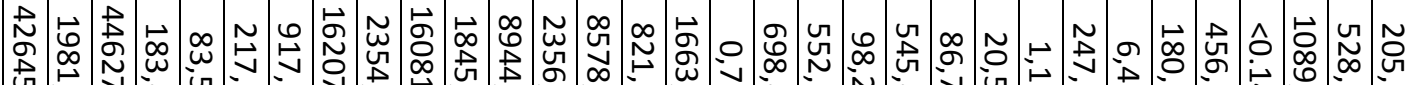

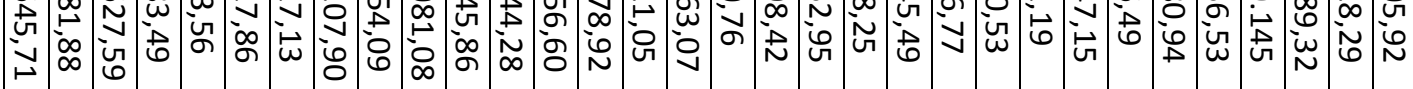

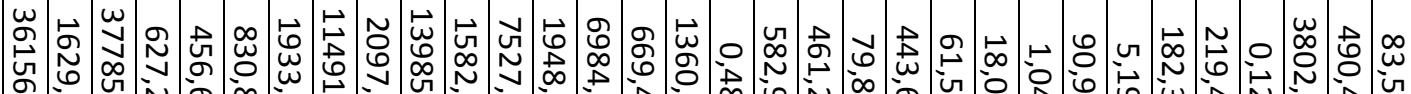

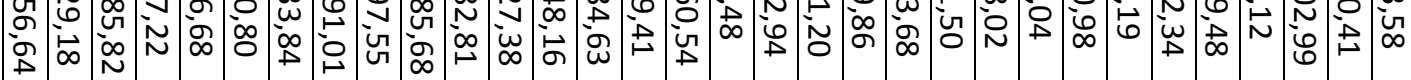

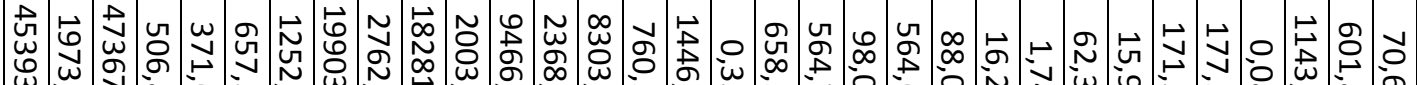
等

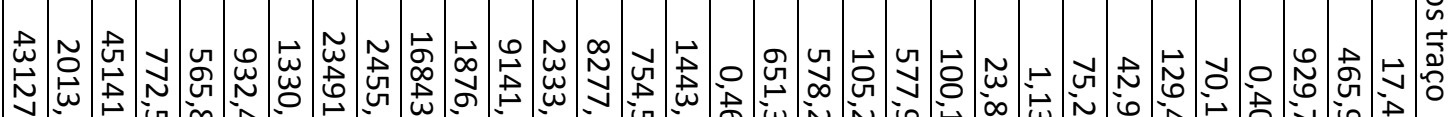

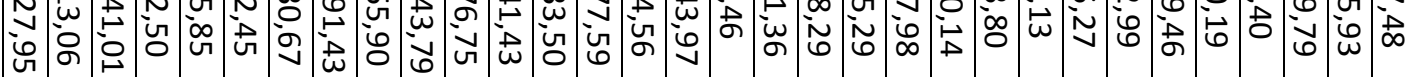

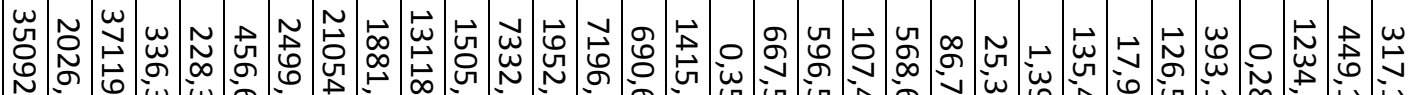

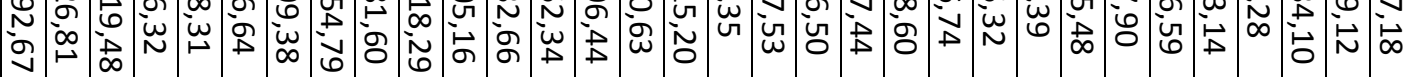

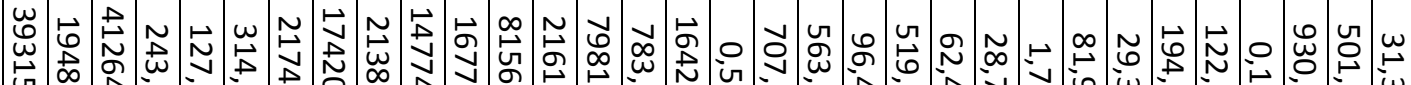

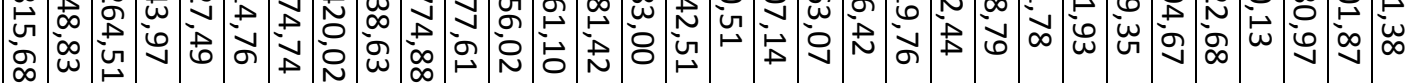

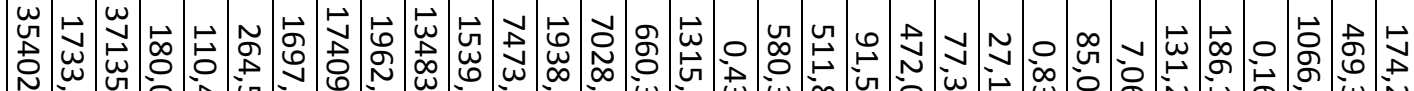

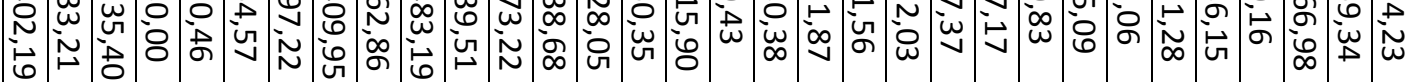


ANEXO V - TABELA DE DATAÇÃO U-PB POR SHRIMP 



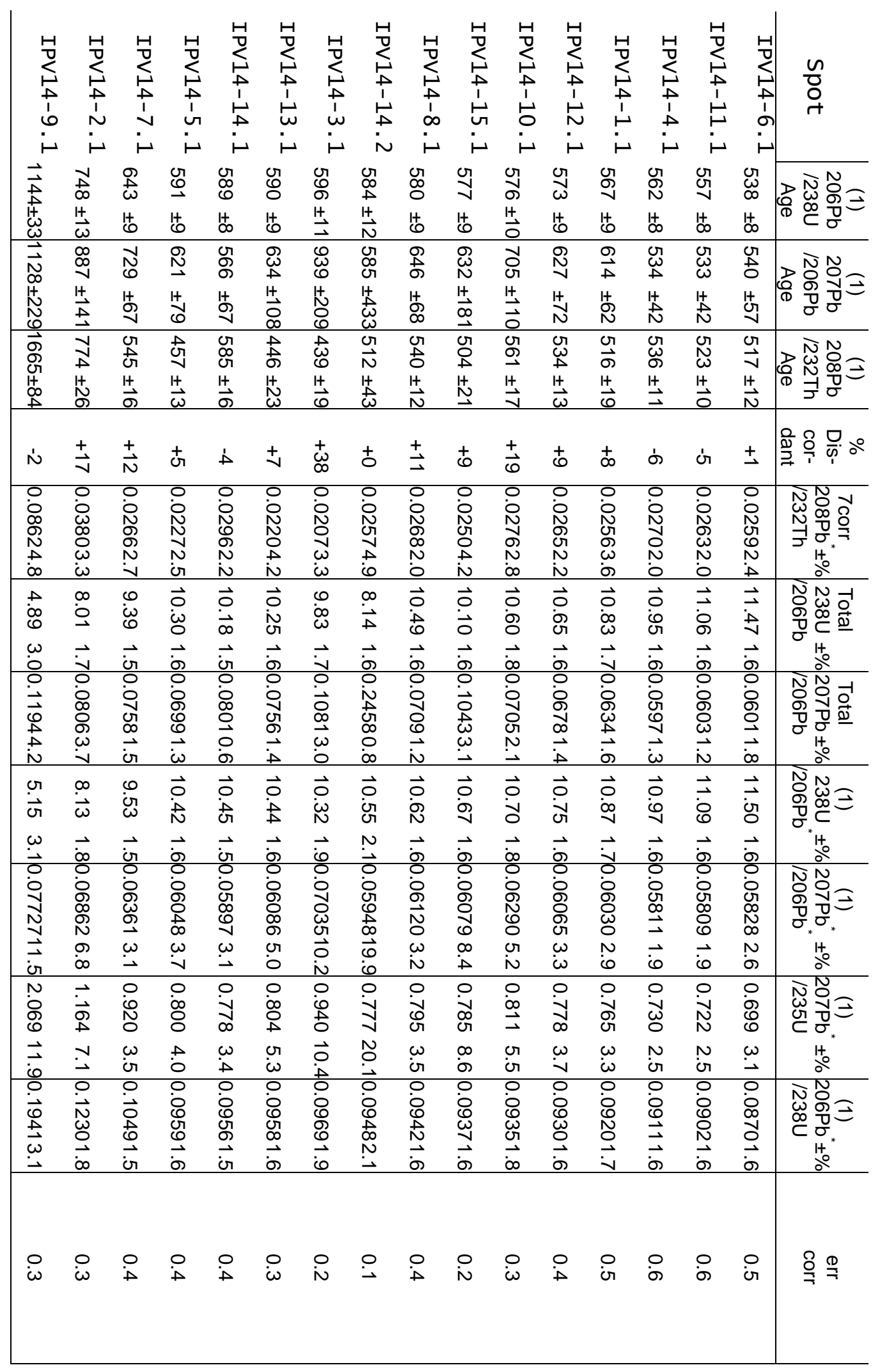




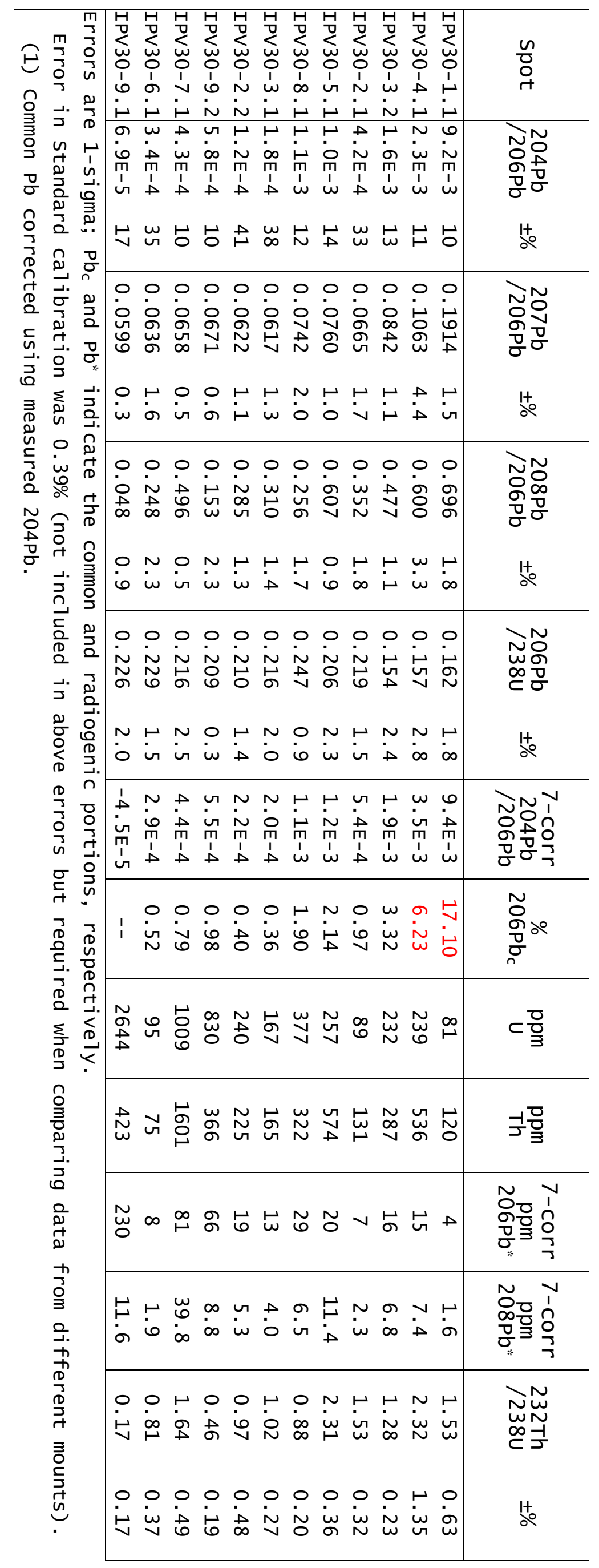




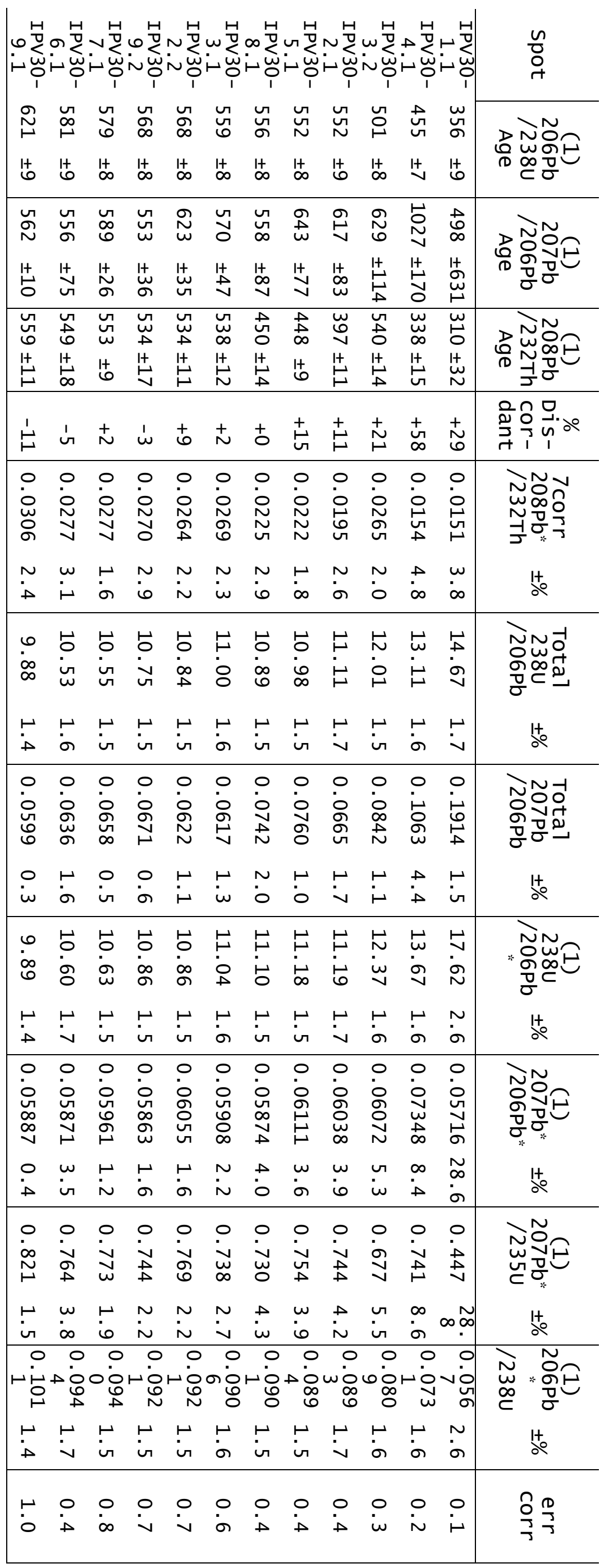


ANEXO VI - CRISTAIS DE ZIRCÃO COM PONTOS ANALISADOS POR SHRIMP, WDS E LA-ICP-MS 



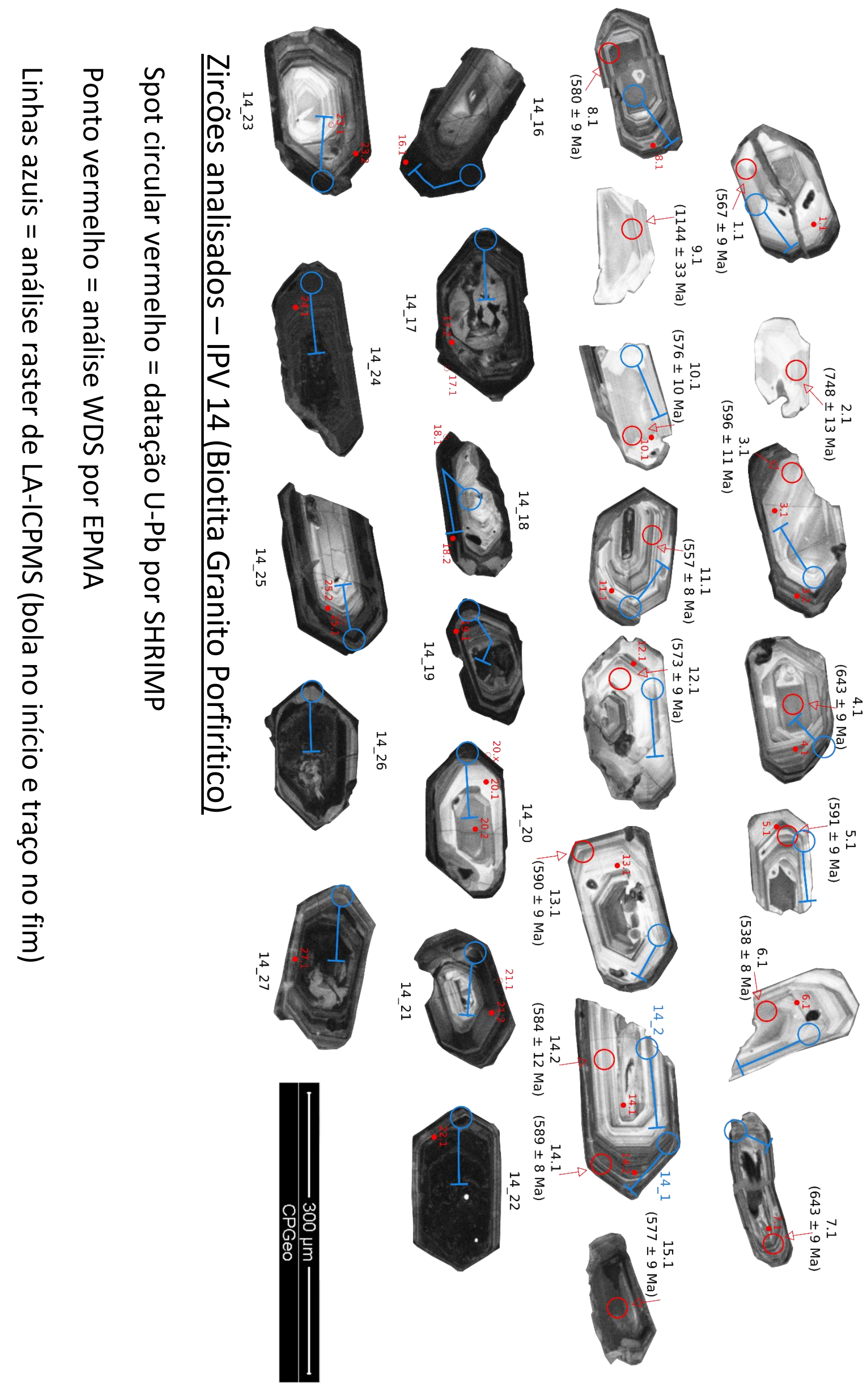




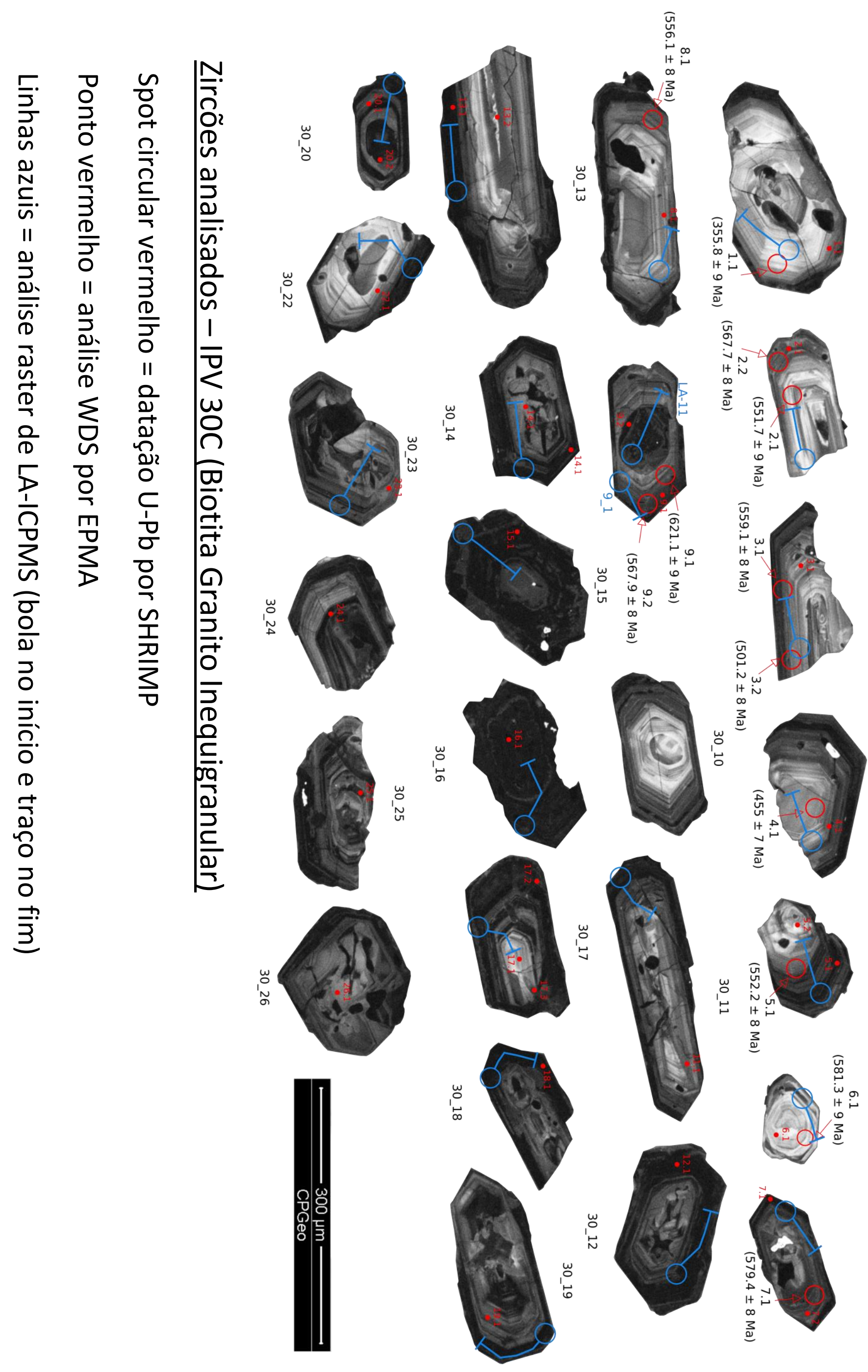



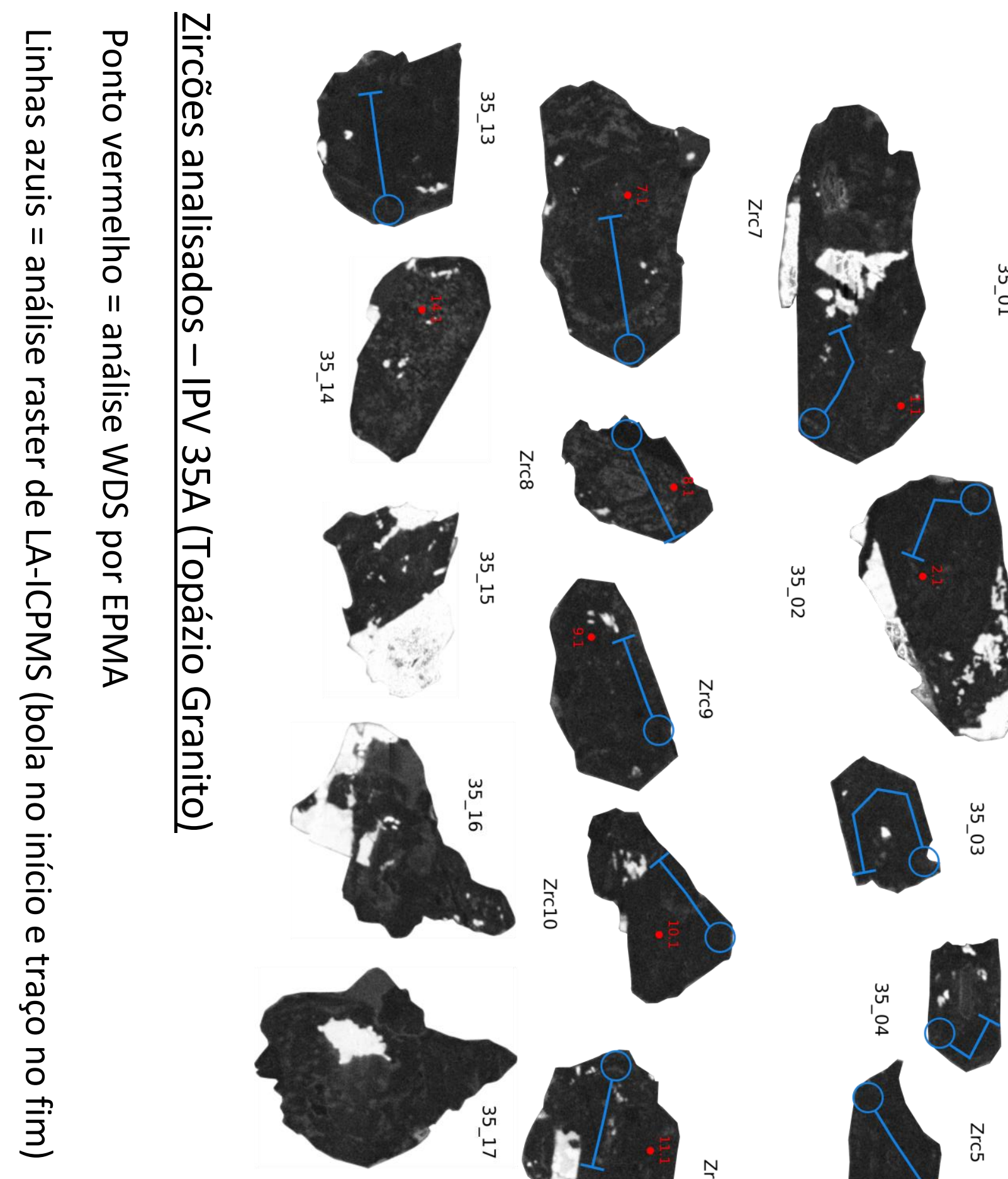

N
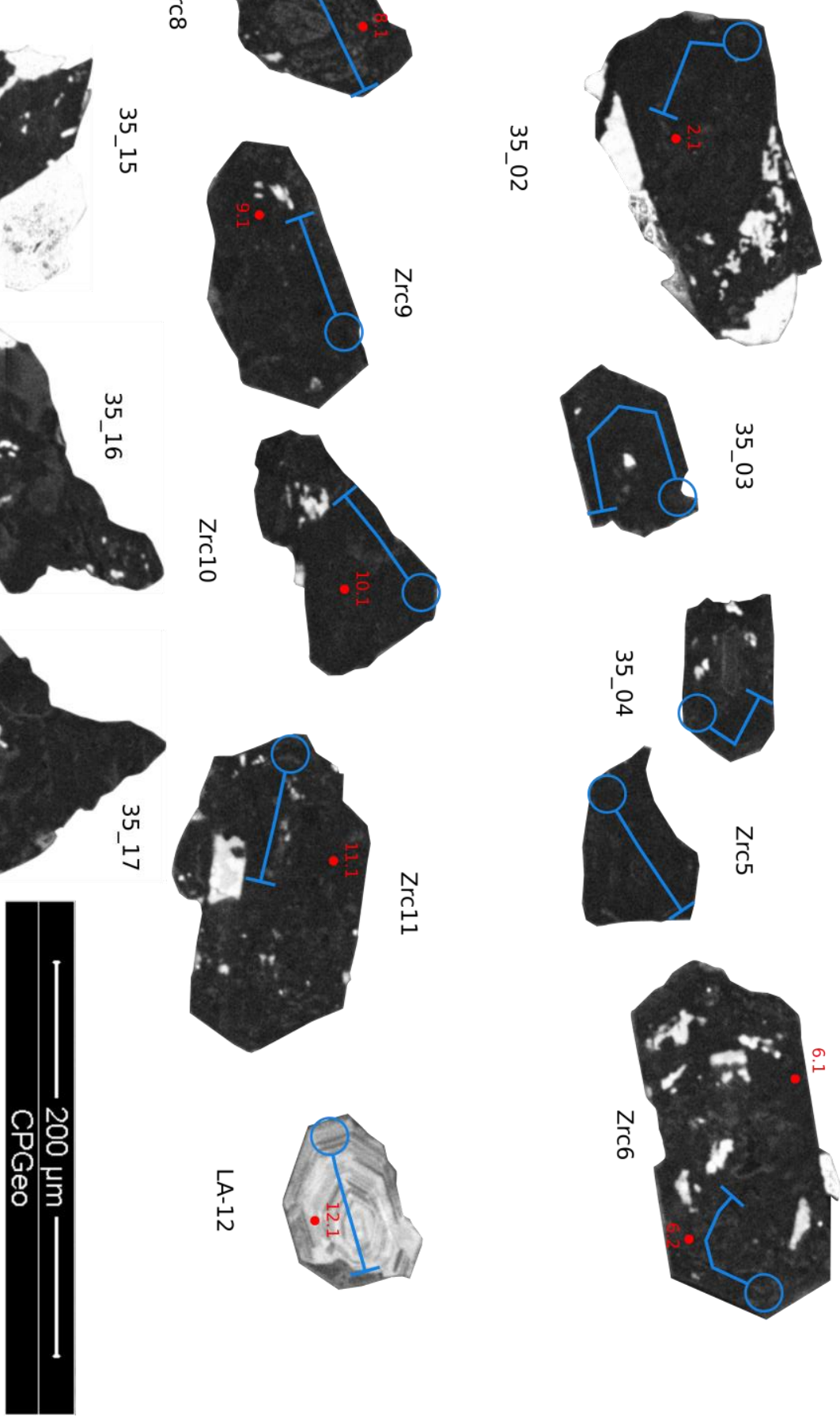